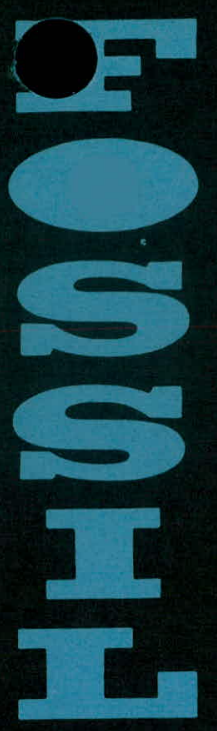

\title{
CHARACTERISTICS OF AMERICAN COALS IN RELATION TO THEIR CONVERSION INTO CLEAN ENERGY FUELS \\ Quarterly Technical Progress Report, January-March 1976
}

W. Spackman
A. Davis
P. L. Walker
H. L. Lovell

R. H. Essenhigh

F. J. Vastola

P. H. Given

May 1976

FE-2030-3

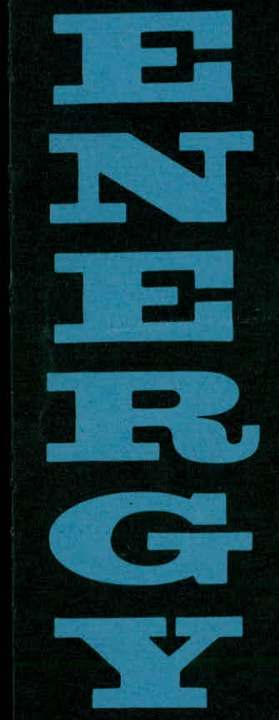

Coal Research Section

Pennsylvania State University

University Park, Pennsylvania

\section{ENERGY RESEARCH AND DEVELOPMENT ADMINISTRATION}




\section{DISCLAIMER}

This report was prepared as an account of work sponsored by an agency of the United States Government. Neither the United States Government nor any agency Thereof, nor any of their employees, makes any warranty, express or implied, or assumes any legal liability or responsibility for the accuracy, completeness, or usefulness of any information, apparatus, product, or process disclosed, or represents that its use would not infringe privately owned rights. Reference herein to any specific commercial product, process, or service by trade name, trademark, manufacturer, or otherwise does not necessarily constitute or imply its endorsement, recommendation, or favoring by the United States Government or any agency thereof. The views and opinions of authors expressed herein do not necessarily state or reflect those of the United States Government or any agency thereof. 


\section{DISCLAIMER}

Portions of this document may be illegible in electronic image products. Images are produced from the best available original document. 


\section{NOTICE}

This report was prepared as an account of work sponsored by the United States Government. Neither the United States nor the United States Energy Research and Development Administration, nor any of their employees, nor any of their contractors, subcontractors, or their employees, makes any warranty, express or implied, or assumes any legal liability or responsibility for the accuracy, completeness or usefulness of any information, apparatus, product or process disclosed, or represents that its use would not infringe privately owned rights.

This report has been reproduced directly from the best available copy.

Available from the National Technical Information Service, U. S. Department of Commerce, Springfield, Virginia 22161

Price: Paper Copy $\$ 7.50$ (domestic)

$\$ 10.00$ (foreign)

Microfiche $\$ 2.25$ (domestic)

$\$ 3.75$ (foreign) 


\section{Quarterly Technical Progress Report \\ January - March 1976}

by

W. Spackman, A. Davis, P.L. Walker, H.L. Lovell, R.H. Essenhigh, F.J. Vastola and P.H. Given

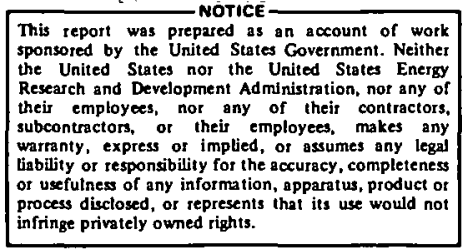

COAL RESEARCH SECTION

THE PENNSYLVANIA STATE UNIVERSITY. UNIVERSITY PARK, PENNSYLVANIA 16802 


\section{THIS PAGE}

\section{WAS INTENTIONALLY LEFT BLANK}




\section{ABSTRACT}

Responses to the questionnaire, which was distributed to determine. the extent to which the nation's coal seams have been sampled and characterized, are being received.

Early comparisons indicate a mathematical relationship between average randoil rellectance (Rapid Scan) and the mean-maximum reflectance as obtained by standard reflectance analysis.

Results obtained so far show support of a diffusion dominance mechanism in the oxidation region of a combustion pot and a chemical kinetic mechanism in the gasification region. Values of reaction rates in coke beds have been calculated from experiments with a fixed bed shaft gasifier.

Devolatilization of a North Dakota lignite in a laminar flow reactor did subsequent treatment of the resulting char has shown that weight loss is strongly dependent upon the isothermal decomposition time.

Although gasification rates increase with increase in partial pressure of oxygen, the mechanism for gasification of a given char is independent of partial pressure of oxygen. Study of the reactivity of ion-exchanged lignite chars to steam shows that increased heat treatment decreases reactivity and ion exchange increases reactivity.

Use of the DSC technique to study the thermal effects involved during chemisorption of oxygen on Saran carbon has yielded information on the activation energy ( $E$ a) of the reaction.

Work on the infinite parallel plane char combustion computer model has determined that low volatile chars and coals can be suitable fuels if adequate available internal. surface area is present. 
TABLE OF CONTENTS

ABSTRACT

$\underline{\text { Page }}$

OBJECTIVE AND SCOPE OF WORK

TASK DESCRIPTIONS

iv

SUMMARY OF PROGRESS TO DATE 1

SAMPLE COLLECTION AND SEAM CHARACTERIZATION 4 Coal Sampling and Routine Characterization 4

COAL CHARACTERIZATION 8

Rapid Scan Automated Reflectance Microscope System 8

Hot-Stage Microscopy $\quad 9$

SAMPLE BANK OPERATION, MAINTENANCE, AND DEVELOPMENT 11

Service to Other Agencies 11

PENN STATE/ERDA COAL DATA BASE 12

Coal Data Base Activity. Report 12

COAL BENEFICIATION AND PRE-USE PROCESSING 13

Coal Preparation Studies 13

REACTOR DEVELOPMENT AND OPERATION 33

Evaluation of the Gasification Potential of Coals 33

Characteristics of Chars Produced Upon Rapid Devolatilization

of North Dakota Lignite 42

COKES AND CHARS $\quad 50$

Reactivities of American Coal Chars in Air 50

Reactivities of American Coal Chars in Steam 55

Reactivity of Ion-Exchanged Lignite in Chars to Steam 60

Effect of Heat Treatment Conditions on Reactivity of

Chars to Air

67

Small Angle X-ray Studies on Coal Chars 72

DIFFERENTIAL SCANNING CALORIMETRY

Differential Scanning Calorimetry Studies on Coals

and Chars

COMBUSTION OF CHARS AND LOW VOLATILE FUELS 84

Coal Combustion Research; Low Volatile Fuels--Combustion
of Char and Anthracite Coal in Large Utility Boilers

COMBUSTION OF COAL-OIL EMULSIONS: 93

Combustion of Coal-0il Emulsions 93

CONCLUSIONS 94 
Page

REFERENCES

96

APPENDIX A - DATA FOR DRYFLO SEPARATION TESTS

99 -

APPENDIX B - SMOKE POINT AND HEAT TRANSFER CHARACTERISTICS OF OIL/WATER/AIR EMULSIONS WITHOUT AND WITH COAL

ADDITION IN A HOT WALL FURNACE 


\section{OBJECTIVE AND SCOPE OF WORK}

The primary objective of the overall program is to achieve the capability of predicting, from a knowledge of coal composition, the behavior of a coal in pre-conversion processing, coal gasification and coal liquefaction processes.

It is reasonable to ask if this goal is in fact attainable, recognizing the heterogeneity of coal seams. Clearly, it is not if one concerns oneself simply with the rank of the coal seam and its aggregate chemistry. A high volatile $B$ coal from Indiana need not react to processing in the same manner as a high volatile B coal from Utah, even though their "chemistries" may be very similar. In contrast, a coal lithotype of a specific kind, at a given level of rank, can be expected to behave consistently, whether it derives from . Alabama or Pennsylvania. Hence, the goal may very well be attainable if, as in the case of coal carbonization, we concern ourselves with the reacting entities and the properties of the important lithotypes.

The goal is to attain the same high level of predictive accuracy that is now found in the area of coal carbonization, where Penn State's collaborative work with the steel industry proved highly successful. To achieve this goal Penn State has devised an integrated program in which the success of the research is highly dependent on the effective operation of ALL of the program's Facets and Sub-facets which are as follows:

Facet I: Characterization of the Nation's Coal Resources

I-A: Sample Collection and Seam Characterization

I-B: Coal Characterization

I-C: Sainple Bank Operation, Maintenance and Development

I-D: Penn State-ERDA Coal Data Base

Facet II: Coal Beneficiation and Pre-Use Processing

Facet IV: Significance of Coal Characteristics in Gasification Processes IV-A: Reactor Development and Operation

IV-B: Cokes and Chars

IV-D: Reactivity of Coal Chars

IV-E: Catalys is Research

IV-F: Differential Scanning Calorimetry

Facet V: Coal Combustion Research

$V-A$ : Combustion of Chars and Low Volatile Fuels

$V-B$ : Combustion of Coal-0il Emulsions 
THE CHARACTERISTICS OF AMERICAN COALS IN RELATION TO THEIR CONVERSION INTO CLEAN ENERGY FUELS

\section{TASK DESCRIPTIONS}

FACET I-A Task 1

Task 2

Task 3

FACET I-B

Task 6

Task 7

$\frac{\text { FACET } I-C}{\text { Task } 8}$

Tasks 9-14

FACET I-D

Task 15

Task 16

Task 17

FACET I I Task 18

Task 19

Task 20

Task 21

Task 22

FACET IV-A Task 23

Task 24

Task 25

Task 26

FACET IV-B Task 27

Task 28

Task 29

Task 30

FACET IV-F

Task 31

FACET $V$-A

Task 32

Task 33

FACET $V$-B

Task 34
Sample Collection and Seam Characterization

Sampling Survey

Sampling Plan

Sampling

Coal Characterization

Characteristics and Use Potential of U. S. Coal Seams

Characterization of Other ERDA Contractor Samples

Automation of Microscopic Analytical Methods

Sample Bank Operation, Maintenance and Development

Maintenance of Coal Sample Bank

Provision of Samples and Data to Penn State and Other Investigators

Penn State/ERDA Coal Data Base

Computerization of Data

Evaluation of the Data Base

Structuring and Utilization of the Data Base

Coal Beneficiation and Pre-Use Processing

Washability Characterization

Physical Properties of Coal Lithotypes

Techniques for Fractionation

Beneficiation of Conversion Feedstocks

Evaluation of Dry Flo Separator

Rcactor Development and Operation

Operation of IsotherinaT Furnace

Pyrolys is of Coal Lithotypes

Operation of Pressurized Isothermal Reactor

Coal Reactivity

Cokes and Chars

Effect of Variables on Char Structures

Effect of Char Structures on Rear.tivities

Catalytic Effect of Minerals in Gasification

Effect of Catálytic Cations on Gasification

Differential Scanning Calorimetry

DSC in Evaluating Coals for Conversion

Combustion of Chars and Low Volatile Fuels

$\bar{F}$ Tame Ball Combustion Model

Plane Flame Furnace

Combustion of Coal - 0il Emulsions

Combustion of Coal - 0il Emulsions 


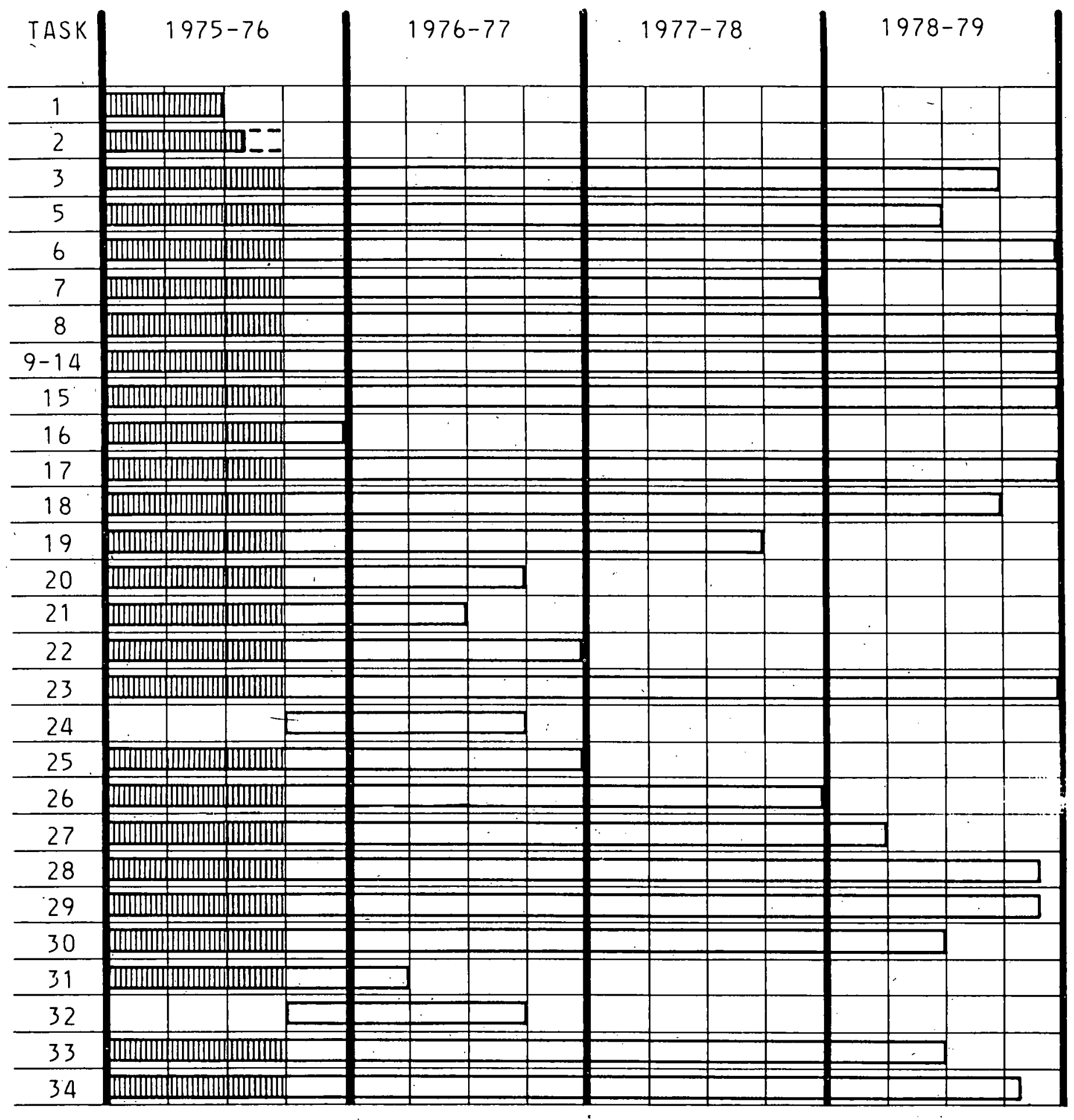

LEGEND

I-ニ-I SCHEDULE EXTENSION

EARLY START

PROJECT PLAN AND PROGRESS REPORT

Quarter Ending March 31, 1976 


\section{SUMMARY OF PROGRESS TO DATE}

A survey of state geological agencies, universities, and private research organizations engaged in coal research is being conducted to determine the extent to which the nation's coal seams have been sampled and characterized. The results of this survey will be used as a guide to plan and schedule future coal sampling trips.

Work on the automated reflectance microscope (Rapid Scan) has been directed toward system refinements and improving maceral analyses. 0ther microscopy endeavors include plans to study thermal stress using the Leitz 1350 heating stage.

During the report period, 27 characterized coal samples and 39 printouts of analytical data were sent to outside agencies; as Penn State continues providing services to others engaged in coal research.

The Penn State Coal Data Base has been structured to run on a dedicated minicomputer system. Demonstrations of the data system have been given in Allentown, Pittsburgh, and Philadelphia, Pennsylvania and Washington, D.C.

The difficulties in locating a suitable industrial feed for the DryFlo Separator have been further addressed. A possibility is being investigated at a preparation plant utilizing Super Flow Air Cleaners on a minus $1 / 2$ in. feed. The dust product from this plant, which is recovered via cyclones, appears to be a potential feed for the Dryflo studies. An effort is being made to make Dryflo tests at this location.

The final design of the pressurized laminar-flow isothermal reactor is nearly complete. A meeting to finalize the plans on March 17 indicated that Autoclave Engineers, Inc. is nearly ready to begin manufacture of components. The job planning diagram provided by Autoclave Engineers, Inc. is presented in this report.

Devolatilization of a North Dakota lignite in a laminar flow reactor and subsequent treatment of the resulting char has shown that weight loss is strongly dependent'upon the isothermal decomposition time.

Reactivity of the most reactive char (PSOC-91) has been studied at $405^{\circ} \mathrm{C}$ in different mixtures of oxygen and nitrogen. The char reactivity increases with increase in partial pressure of oxygen. Effect of particle size on char reactivity has been studied in the case of two chars: a low volatile bituminous char (PSOC-127) and a lignite char (PSOC-37). Reduction in particle size increases the reactivity of both raw and dellineralized PSOC-127 char. However, in the case of raw and dellineralized PSOC- 87 chars reactivities are almost independent of particle size. Relative reactivities of various chars in air and carbon dioxide are the same. 
Preliminary results of reactivities of chars to steam are presented in this report. The reactivity of PSOC-9l char in steam at $910^{\circ} \mathrm{C}$ is about the. same as that in air at $405^{\circ} \mathrm{C}$. Reactivity of a given char in steam at $910^{\circ} \mathrm{C}$ is independent of bed height or starting weights $\leqslant 3 \mathrm{mg}$. Reactivities of four lignite chars show appreciable decrease upon removal of mineral matter.

Reactivities of variously treated chars made from PSOC-140, a Darco Texas lignite, have been measured at three reaction temperatures. Preliminary results show 1) reactivity decreases as heat treatment temperature increases, 2) raw. coal.chars-are approximately ten times more reactive than the demineralized coal char for all reaction temperatures, and 3) reactivities of chars made from demineralized coals which had been ion exchanged with calciumt+ were ten times greater than reactivities of raw coal char at a reaction temperature of $650^{\circ} \mathrm{C}$, but were only twice as great at a reaction temperature of $700^{\circ} \mathrm{C}$, and only slightly greater at a reaction temperature of $750^{\circ} \mathrm{C}$. In addition to reactivities, helium densities, mercury densities, and carbon dioxide surface areas for some of the. coals, chars, and reacted chars have been measured. Also, ash and moisture contents have been determined.

The effect of various modes of heat treatment on char reactivity in air at $500^{\circ} \mathrm{C}$ has been studied. Reactivities have been shown to be maximized by keeping the maximum heat treatment temperature as low as possible, the heating rate as high as possible, and allowing no soak time at: the maximum temperature. It has been observed that aging of chars in dry air has little or no effect on subsequent reactivity. Heat treatment of chars in different atmospheres (nitrogen, carbon dioxide, hydrogen) to the same temperature has no significant effect on subsequent char reactivity.

The use of small angle $x$-ray scattering to characterize heat treated coals continues to show promise. Systematic variations of a primary structural parameter are noted with variations in heat treatment temperature and the rank of the parent coal. At present we are obtaining values for the volume fraction of pores in order to calculate secondary parameters such as surface area and pore dimensions.

- The differential scanning calorimetry technique has been used to study the thermal effects involved during chemisorption of oxygen on Saran carbon. In the temperature range $100-202^{\circ} \mathrm{C}$, the Saran carbon, previously activated to 63.8 percent carbon burn-off, showed the existence of different groups of active sites. The activation energy for chemisorption of oxygen increased with increasing surface coverage and ultimately attained a constant value. The unactivated Saran carbon also showed different kinetic stages in the temperature range $202-304^{\circ} \mathrm{C}$, but activation energy was independent of surface coverage. The order of chemisorption process is proportional to square root of the oxygen partial pressure. Following adsorption at a given temperature, the sample was heated to high temperatures in nitrogen. Resorption experiments were then performed to find out the 
fraction of the carbon surface regenerated. The fraction regenerated increases with increase in adsorption or desorption temperature.

A large body of experimental results indicates that low to nearly zero volatile matter fuels (coal chars and anthracite coals) can be stabilized in a laboratory-scale combustion apparatus (the plane flame furnace). Order of magnitude shifts in the distance from the watercooled inlet tube bank to the flame front can occur in switching from fuels suspected of having large accessible internal surface areas (macroporous) to fuels thought to have little readily accessible internal surface area (microporous).

Much of óur work to date has been focused on the development of computer models to analyze and explain past experiments and to design future experiments. A model which considers only the stable combustion of a pul-. verized char flame in an infinite parallel plane geometry (properties varying only along direction of flow) is a logical starting point toward further three dimensional modeling. The model permits examination of the detailed structure of pulverized char flames simply, yet realistically. Capabilities for using uneven nodal spacing and variable radiation absorption coefficient were incorporated into the infinite parallel plane mode, greatly enhancing the computational ability of the computer program. A study of hot wall ignition of a pulverized char/air mixture was conducted and an unambiguously defined ignition temperature was found for the system. Further uses of the model include a recent study to predict infinite parallel plane combustion results using the experimentally measured char kinetics. of Field. ${ }^{25}$

The results of experiments conducted during the past year on oil/ water/air emulsions with and without small coal additions have been compiled and evaluated for presentation to The Combustion Institute. 


\title{
FACET I-A: SAMPLE COLLECTION AND SEAM CHARACTERIZATION
}

\author{
COAL SAMPLING AND ROUTINE CHARACTERIZATION
}

During the last report period initial steps were taken in conducting a survey to determine the extent to which the nation's coal seams have been sampled and characterized. Questionnaires were distributed to 25 state agencies, from which 24 replies were received. As a follow-up to the questionnaire, the following geological surveys have been contacted by personal visit or telephone: USGS, Arizona, Arkansas, Illinois, Indiana, Kansas, Kentucky, Missouri, New Mexico, Oklahoma, and Texas. In addition, universities and private research organizations have now been contacted, of which 18 have responded. Upon completion of the survey, the University will use the information obtained as a guide to plan and schedule the collection of 1300 coal samples. Agencies included in the survey are listed in Table 1.

Thin sections of eight coals have been made from oriented coal blocks and Hardgrove grindability tests were run of 44 polished blocks made from PSOC samples 357 through 378. Reflectance data were generated on eight samples (PSOC-357 through 364), while fluorescence analyses were completed on eight samples (PSOC-343, 344, 346, 350, 352-355).

Coals sent to our Mineral Constitution Lab by March 1, 1976 (PSOC$230,233,235,249,272,273,279-281,286,287,290,305-321,323-334$, 336-351, 353-356) have undergone preliminary processing and are in the course of being analyzed for major, minor, and trace elements. Mineral matter will also be eventually determined.

A typical sample is split into two lots, one to be used in all analyses and the other to be saved as a possible check. From the lot to be analyzed, an $x$-ray fluorescence pellet, a high temperature ash (HTA), and a low temperature ash (LTA) are prepared.

The elements sulfur, chlorine, and phosphorus are determined directly in the whole coal via x-ray fluorescence analys is of the pellet while major and minor elements such as silicon, aluminum, iron, calcium, magnesium, manganese, sodium, potassium, titanium, zinc, and lead are determined by atomic absorption analys is of the HTA. Involatile trace elements such as boron, barium, beryllium, cobalt, chromium, germanium, lanthanum, molybdenum, niobium, nickel, selenium, strontium, vanadium, yttrium, ytterbium, zirconium, cerium, and copper are determined via emission spectrographic analys is of the HTA. Volatile elements such as arsenic, selenium, cadmium, and fluorine can be determined via special atomic absorption or wet chemical techniques on the LTA or the whole coal. Mineral content is determined on the basis of quantitative $x$-ray diffraction and infra-red analysis of the LTA. A general flow diagram of the entire analytical procedure is presented in Figure 1 (this will be modified when the new Plasma Spectrometer is obtained). 
Table 1. Agencies Included in Survey

\section{State Geological Agencies}

Al abama

Alaska

Arizona

Arkansas

Colorado

Illinois

Indiand

Iowa

Kansas

Kentucky

Maryland

Missouri

Montana

New Mexico

North Dakota

Ohio

Ok lahoma

Pennsylvania

Tennessee

Texas

Utah

Virginia

Washington

West Virginia

Wyoming
Universities and Research Organizations

University of Arizona

Batelle Columbus Labs.

Batelle Northwest

Bechtel Corporation

Bethlehem Steel

Bituminous Coal Research, Inc.

Brigham Young University

Carnegie-Mellon University

Colorado School of Mines

Combustion Engineering, Inc.

Conoco Coal Development Co.

University of Denver Research Inst.

- Dow Chemical Co.

Exxon

Fluor Engineers \& Constructors

Fluor Utah, Inc.

FMC Corp.

Gulf Research and Development

\section{IGT}

Lawrence Livermore

Arthur D. Little, Inc.

Los Alamos

Massachusetts Institute of Technology Mobil 0i]

University of Montana

State University of NY at Buffaro

University of North Dakota

Oak Ridge

Pittsburg \& Midway Coal Mining Co.

Purdue University

Shell Mining Ventures

Stanford Research Institute

United States Steel

University of Utah

University of Utah (Fuels Engineering)

Virginia Polytechnic Institute

Virginia State University

University of West Virginia

West Michigan University

Westinghouse Electric Corporation 


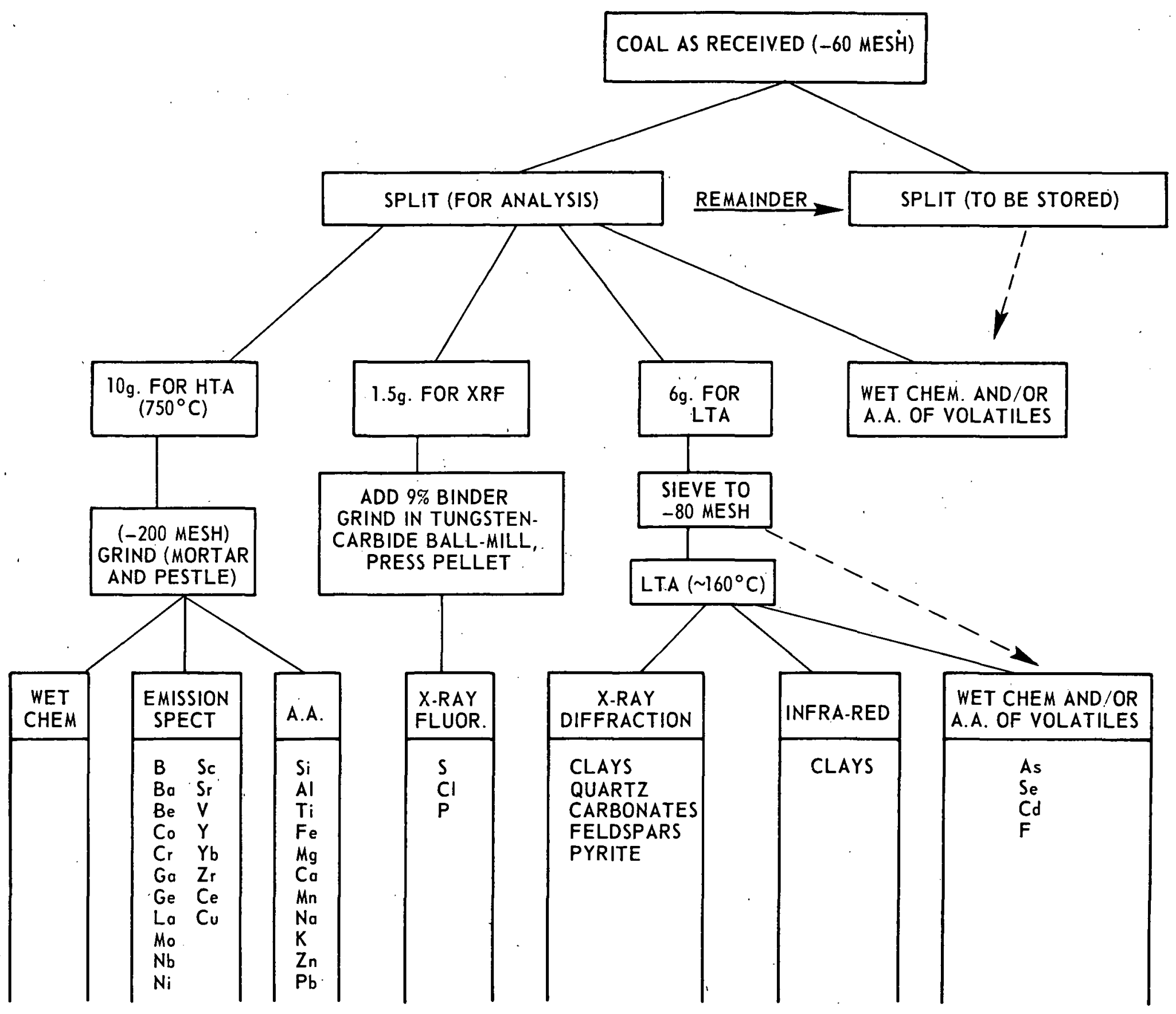

Figure 1. FLOW CHART FOR ANALYTICAL PROCEDURES 
Currently, major and minor_element data as well as percent chlorine are available for all of the samples. In addition, trace element datia is available for PSOC samples 233-310. Completion of all trace element analyses is a matter of time as is percent sulfur trioxide. While the technique for the determination of percent sulfur and percent phosphorus is ready, completion awaits the calibration of reliable standards. Such is also the case for the determination of mineral content. Here, the problem lies in what internal standard is to be employed. While previous workers in this and other labs have made use of a calcium fluoride internal standard, communications with the Illinois State. Geological Survey indicate that aluminum oxide may be more desirable. It is the aluminum oxide series of. standards which are now being tested. 
FACET I-B: COAL CHARACTERIZATION

\section{RAPID SCAN AUTOMATED REFLECTANCE MICROSCOPE SYSTEM}

Work on the automated reflectance microscope (Rapid Scan) has been directed toward system refinements and improving maceral analyses. Both the system electronics and the computer based programming were modified in order to reduce inherent system noise. A variable gain, low noise amplifier was added to the system immediately prior to the computer input. This allowed the photomultiplier potential voltage to be set at an optimum, constant level, independent of system standardization. The result was a minor improvement of the signal to noise ratio. A more sophisticated computer program was also developed to minimize the effect of noise on the coal reflectogram.

A study was conducted to visually check data recorded by the Rapid Scan from a known scan line. A photomosaic of a traverse (approximately $2000 \mu$ in length) was made and then compared to the digital data recorded by the Rapid Scan while passing over the same line. When the effects of scale were equalized, a one to one comparison showed the Rapid Scan to be completely accurate.

Many times however, it is difficult to distinguish the lower reflecting coal constituents as the translucent epoxy binder allows particles below the surface to reflect anomalously low readings. This distorts the lower portion of the reflectogram. In order to correct this problem, several dyes were mixed with the epoxy to make it opaque. Two of the dyes, which were particle dyes, proved unsatisfactory because they raised the reflectance of the resin into the coal region of the reflectogram. However, the third dye, a special pigment dye, has been successful in significantly lessening this effect.

Studies were conducted to test the reproducibility of the maceral analysis on a single pellet. A coal was selected and several analyses, consisting of 100,000 data pts each, were run covering different areas of the pellet. Good precision was obtained when the results were plotted on an $x-y$ graphic plotter.

A suite of 11 coals was then analyzed. These coals varied in rank from lignite to anthracite and all had a high vitrinite content. The purpose of this study was to compare average random reflectance as recorded by the Rapid Scan to the mean-maximum reflectance as obtained by standard reflectance analysis. Early comparisons indicate a mathematical relationship between these two values.

Future work will be directed toward better quantifying this relationship. This will entail analyzing additional suites of coals of 
varying rank and graphically comparing the two values. Emphas is will also be directed toward distinguishing between the various minor macerals in the coal reflectogram.

\section{HOT-STAGE MICROSCOPY}

\section{Introduction}

The purpose of this investigation is to characterize the behavior and optical properties of selected coal components subjected to thermal stress in atmospheres of nitrogen, steam, carbon dioxide, and hydrogen by direct observation using the Leitz 1350 heating stage.

Heating stages facilitate the dynamic investigation of physical conditions and reactions of small particles at elevated temperatures. Although the hot-stage microscope is a well-known tool in the fields of metallography and ceramic science, little has been done to apply hotstage microscopic technique to the study of coal.

Berry ${ }^{1}, 2$ first applied heating stage technique to coal research in his investigation of thermal properties of bituminous coal components in an inert atmosphere using the Leitz 1000 model hot-stage. Walsh and Dutcher ${ }^{3}$ investigated the properties of anthracite lithotypes, and Dutcher ${ }^{4}$ briefly reviewed reactions of coal constituents under the hotstage microscope. Rau and Robertson ${ }^{5}$ briefly discussed the potential and several applications of hot-stage microscopy in coal research. $\mathrm{Nandi}$ and Montgomery ${ }^{6}$ studied the thermal reactivity of the maceral semifusinite from some coals of western Canada.

\section{Experimenta?}

All of the above investigations were conducted in an inert atmosphere. Furthermore, the older investigations utilized coal petrographic terminology, which has since become obsolete following the institution of the standardized nomenclature of the International Commission for Coal Petrology. ${ }^{7}$

Presented here, in outline form, are proposals for investigations. using the Leitz 1350 hot-stage and appropriate photographic and thermal monitoring accessories and controls:

1. Observe the reactions of vitrinite macerals in "pure" concentrations under the hot-stage microscope using modern vitrinoid group nomenclature.

2. Conduct the above study using a nitrogen atmosphere as an experimental control and then introduce the variables of: 
a. rank

b. ambient atmospheres of:

(1) steam

(2) carbon dioxide

(3) hydrogen

c. heating rate

d. sample preoxidation

e. sample size

$f$. addition of mineral matter

3. Study macerals and combinations of macerals (microlithotypes) from coal of various rank under the conditions outlined in 2 .
a. exinite
b. semifusinite
c. pesudovitrinite

4. Study petrographically, particle residues at various stages of thermal treatment and compare them to char and filter cake residues of coal liquefaction and gasification processes.

5. Monitor evolved gases during thermal treatment in nitrogen atmospheres using either:

a. on-line gas chromatography or residual gas analysis

b. room-temperature chromatography

6. Correlate the observed properties and reactions with the calculated or measured basic analytical parameters of:
a. $\operatorname{rank}$ (reflectivity)
b. Vicker microhardness
c. Hardgrove grindability
d. Geiseler plasticity
e. Free-Swelling Index and/or Gray-King Coke Type
$f$. Proximate and ultimate analyses

7. Produce time-lapse motion pictures, visually demonstrating the reactions of coal macerals and microlithotypes when subjected to thermal stress, for distribution to interested consumers. 
FACET I-C: SAMPLE BANK OPERATION, MAINTENANCE, AND DEVELOPMENT

\section{SERVICE TO OTHER AGENCIES}

During the report period, 27 characterized coal samples were sent to outside agencies engaged in coal research. In addition, 39 printouts of analytical data were dispatched.

Fourteen sampies containing large quantities of organic and total sulfur were provided the General Electric Space Center for desulfurization studies; five samples were selected for the Penn State Materials Research Laboratory for use in work to improve the efficiency of grinding processes; seven coal pellets of different ranks were sent to the University of Southern California; and one coal sample was sent to E. Soehngen and Associates for use in ultra-fine grinding.

Maceral data was generated on eight washability fractions each from PSOC-296 and 297, from 21 sized samples sent by IGT, and on eight coal samples sent by other ERDA contracting agencies and numbered POC-280 through 287. Both maceral and reflectance analyses were performed on two samples from Calgon and four samples sent by Alcoa and numbered PSCS-1 through 4. 
FACET I-D: PENN STATE/ERDA COAL DATA BASE

\author{
COAL DATA BASE ACTIVITY REPORT
}

The Penn State Coal Data Base has been structured to run on a dedicated minicomputer system. The implementation of this system has enabled on-line searches and manipulations of the data base to be made through the use of remote terminals. Demonstrations of the data system have been given in Allentown, Pittsburgh, and Philadelphia, Pennsylvania and Washington, D.C.

The computer system used for this project is a PDP-8/A with $16 \mathrm{~K}$ core memory. The bulk storage used for the data base is a dual IBM type floppy disc system. For remote operation the computer is interfaced to a 300 Band modern.

Two independent data files have been established. One file is structured according to each coal, listing all the characteristics of each coal. The second file is structured according to each characteristic, listing the values of that characteristic for all coals.

The development of programs for use with the data base is an ongoing process. In order to make them transportable, the programs have been written in Fortran-IV. In addition, they have been designed so that an untrained operator can use them in a prompting question-answer mode. Four modes of operation are now on-line:

1. Search mode - in this mode the operator can search the data base for those coals that fall within selected value ranges for variables such as composition, location, etc.

2. Map mode - in this mode coals are mapped according to selected ranges of two variables.

3. Combined - in this option coals screened by the search program can be selectively mapped.

4. Calculation mode - this mode enables parameters such as coke strength, which can be calculated from data within the base, to be obtained for any coal or blend of coal. 
FACET II: COAL BENEFICIATION AND PRE-USE PROCESSING

COAL PREPARATION STUDIES

\section{Computerization of Coal Fractionalion Data}

The petrographic analytical details of the fractions previously developed for PSOC-306 (a high volatile A coal from the Ohio No. 12 seam, Yorkville, Ohio) were incorporated into the coal preparation data bank. These new data show the following variations between fractions, and in comparison with the as received analysis:

\begin{tabular}{lrr} 
& \multicolumn{2}{c}{ Volume, \% } \\
\cline { 2 - 3 } & \multicolumn{1}{c}{ Range } & Feed \\
\cline { 2 - 3 } Vitrinite & $91.3-55.70$ & 61.9 \\
Exinite & $5.6-0.10$ & 7.5 \\
Micrinite & $9.8-2.30$ & 9.0 \\
Fusinite & $34.4-4.60$ & 21.6
\end{tabular}

\section{Fractionation of Coal Samples}

The studies in Task 18 include the fractionation of three samples described in the July-September 1975 Quarterly Technical Progress Report (PSOC-325, 337, and 184), four additional samples that are now completed including chemical analys is (PSOC-329, 317, 183, and 349), and PSOC-357 which is neariy fractionated. The identification of the recently completed samples are shown in Table 2, and their basic preparation characteristics in Table 3. In suminary, seven seams representing four ranks have been fractionated.

Development of Plans for Pilot Plant Test of the Dryflo Separator

The difficulties in locating a suitable industrial feed for the Dryflo Separator have been further addressed. Sampling was made of raw coal which had been deep-mined from a Lower Kittanning seam and subsequently sized at $3 / 8 \mathrm{in.}$ The coal from this location had had a history of constant and relatively low moisture contents. However, when tested, the moisture content was unacceptably high and a field pilot screen test gave unacceptable yields.

Another potential is being investigated at a preparation plant utilizing Super Flow Air Cleaners on a minus $1 / 2$ in. feed froml the $B$ and $D$ seams. This large plant $(270 \mathrm{ton} / \mathrm{hr}$ ) was inefficient because its feed was too wet. Test samples were taken and analyzed from this plant 
Table 2. Identification of Coals Fractionated

\begin{tabular}{|c|c|c|c|}
\hline PSOC No. & $\begin{array}{l}\text { ASTM } \\
\text { Rank }\end{array}$ & $\begin{array}{l}\text { Parr Volatile } \\
\text { Matter, \% }\end{array}$ & Seam - Location \\
\hline 329 & High Volatile $A$ & 42.6 & $\begin{array}{l}\text { Brookville } \\
\text { Pennsylvania }\end{array}$ \\
\hline 317 & Low Volatile & 17.7 & $\begin{array}{l}\text { Lower Freeport } \\
\text { Pennsylvania }\end{array}$ \\
\hline 183 & High Volatile B & 42.4 & $\begin{array}{l}\text { Upper Block } \\
\text { Indiana }\end{array}$ \\
\hline 349 & - High Volatile A & 42.5 & $\begin{array}{l}\text { Lower Clarion } \\
\text { Pennsylvania }\end{array}$ \\
\hline 357 & High Volatile A & 34.3 & $\begin{array}{l}\text { Lower Elkhorn } \\
\text { Kentucky }\end{array}$ \\
\hline
\end{tabular}

as shown in Tables 4 and 5 . The dust product from this plant, which is recovered via cyclones, appears to be a potential feed for the DryFlo studies, although it does not adequately represent the ROM coal, has a somewhat small size distribution, and has higher than desirable moisture content. An effort is being made to make Dryflo tests at this location.

\section{Review Statement Describing the Dryflo Separator ${ }^{8}$}

Mechanized mining systems now being used in deep mines are producing greater levels of fine particle sizes which characteristically include more mineral matter and higher moisture contents than coal extracted by conventional methods. ${ }^{9}$ These mined coal properties are contraproductive in conventional coal beneficiation, inclúding higher processing costs, although most coal now consumed (for combustion and carbonization) is finally crushed to at least.minus $1 / 4$ in. Most advanced coal conversion and fluidized bed combustion processes being developed will also use fine sized coal particles. Most fine coal is currently beneficiated by "wet" processes that require costly unit operations to remove the process. water from levels as high as 35 weight percent. The need to beneficiate coal (especially fine sizes) to control and reduce ash and sulfur. content, as well as to manage organic composition, is evidenced by the current all-time high level of activity in this study area. Accordingly, any development capable of fine coal beneficiation without using water, especially with low costs, has great potential in contribution to the solution of the nation's energy needs. The Dryflo system appears to offer this potential, and is worthy of further evaluation. 
Table 3. Summary of Preparation Characteristics

of Coals Fractionated

(Dry Basis)

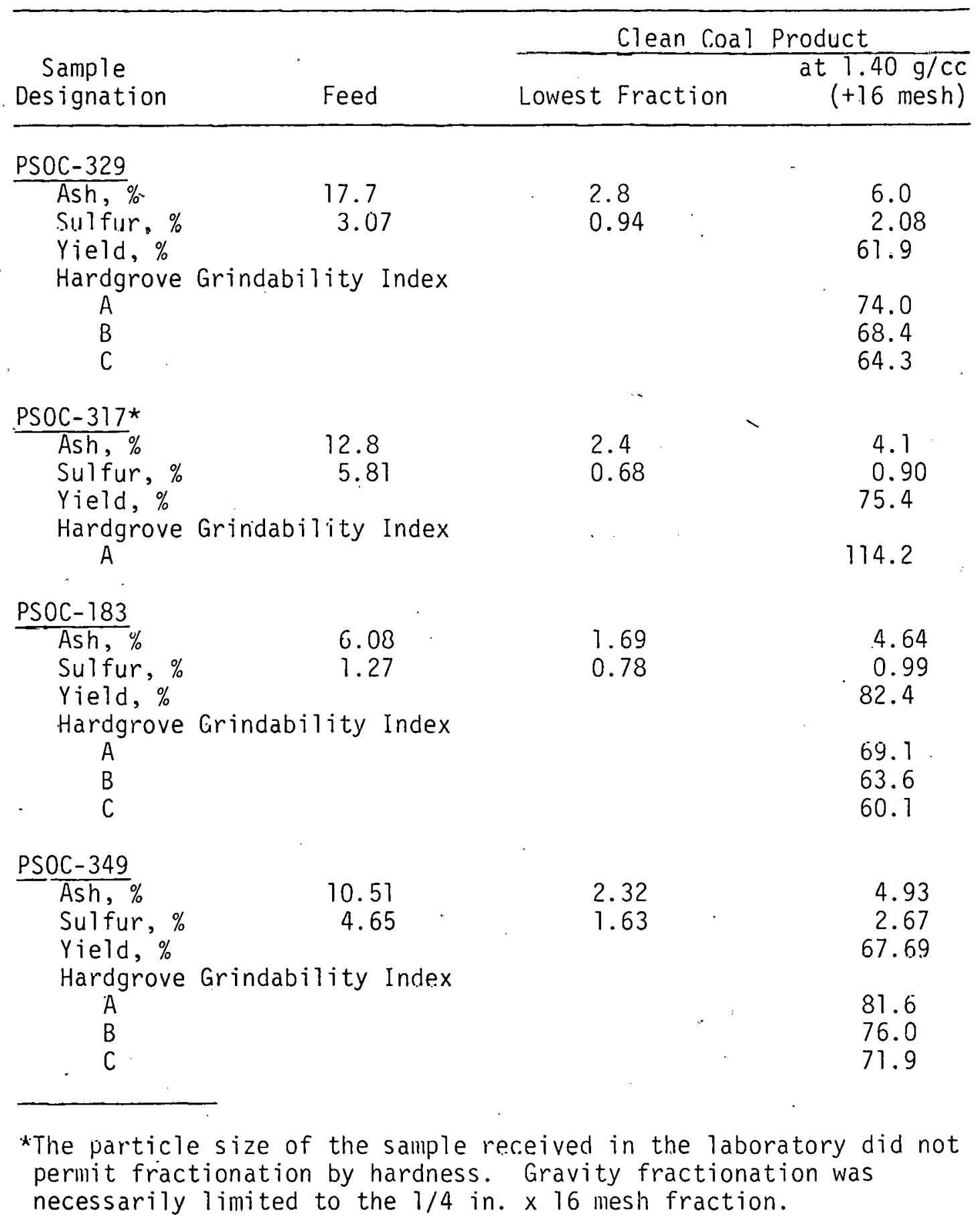


Table 4. Plant Samples Describing Performances of Superflow Air Cleaner

Treating Central Pennsylvania B and D Searns Size Analyses

Raw Coal (7.1\% Moisture)

\begin{tabular}{|c|c|c|c|c|c|c|c|}
\hline \multirow[b]{3}{*}{ Passed } & \multirow[b]{3}{*}{ Retained } & \multirow{2}{*}{\multicolumn{2}{|c|}{ Direct }} & \multicolumn{4}{|c|}{ Cumulative } \\
\hline & & & & \multicolumn{2}{|c|}{ Passed } & \multicolumn{2}{|c|}{ Retained } \\
\hline & & Wt. $\%^{1}$ & Ash $\%^{2}$ & Wt. \% & Ash $\%^{2}$ & wt. \% & Ash $\%^{2}$ \\
\hline $\begin{array}{l}1 / 4 " \\
16 M \\
30 M \\
100 M\end{array}$ & $\begin{array}{l}1 / 4 " \\
16 M \\
30 M \\
100 M\end{array}$ & $\begin{array}{l}12.9 \\
48.0 \\
13.8 \\
14.6 \\
10.6\end{array}$ & $\begin{array}{l}19.87 \\
17.29 \\
12.22 \\
12.01 \\
15.28\end{array}$ & $\begin{array}{r}12.9 \\
60.9 \\
74.7 \\
89.3 \\
100.0\end{array}$ & $\begin{array}{l}19.87 \\
17.84 \\
16.80 \\
16.02 \\
15.94\end{array}$ & $\begin{array}{r}100.0 \\
87.1 \\
39.1 \\
25.3 \\
10.7\end{array}$ & $\begin{array}{l}15.94 \\
15.35 \\
12.98 \\
13.34 \\
15.28\end{array}$ \\
\hline \multicolumn{8}{|c|}{ Clean Coal ( $7.4 \%$ Moisture) } \\
\hline $\begin{array}{l}1 / 4 " \\
16 M \\
30 M \\
100 M\end{array}$ & $\begin{array}{l}1 / 4 " \\
16 M \\
30 M \\
100 M\end{array}$ & $\begin{array}{l}11.7 \\
49.4 \\
13.8 \\
14.7 \\
10.4\end{array}$ & $\begin{array}{l}18.17 \\
14.99 \\
12.84 \\
11.43 \\
15.80\end{array}$ & $\begin{array}{r}11.7 \\
61.1 \\
74.9 \\
89.6 \\
100.0\end{array}$ & $\begin{array}{l}18.17 \\
15.60 \\
15.09 \\
14.49 \\
14.63\end{array}$ & $\begin{array}{r}100.0 \\
88.3 \\
38.9 \\
25.1 \\
10.4\end{array}$ & $\begin{array}{l}14.63 \\
14.16 \\
13.10 \\
13.24 \\
15.80\end{array}$ \\
\hline \multicolumn{8}{|c|}{ Middling ( $6.1 \%$ Moisture) } \\
\hline $\begin{array}{l}1 / 4 " \\
16 M \\
30 M \\
100 M\end{array}$ & $\begin{array}{l}1 / 4^{\prime \prime} \\
16 M \\
30 M \\
100 M\end{array}$ & $\begin{array}{r}30.3 \\
42.2 \\
8.3 \\
10.6 \\
8.6\end{array}$ & $\begin{array}{l}35.91 \\
33.88 \\
14.96 \\
12.43 \\
16.83\end{array}$ & $\begin{array}{r}30.3 \\
72.5 \\
80.8 \\
91.4 \\
100.0\end{array}$ & $\begin{array}{l}35.91 \\
34.73 \\
32.70 \\
30.35 \\
29.18\end{array}$ & $\begin{array}{r}100.0 \\
69.7 \\
27.5 \\
19.2 \\
8.6\end{array}$ & $\begin{array}{l}29.18 \\
26.26 \\
14.57 \\
14.40 \\
16.83\end{array}$ \\
\hline \multicolumn{8}{|c|}{ Reject Refuse ( $5.5 \%$ Moisture) } \\
\hline $\begin{array}{l}1 / 4^{\prime \prime} \\
16 M \\
30 M \\
100 M\end{array}$ & $\begin{array}{l}1 / 4 " \\
16 M \\
30 M \\
100 M\end{array}$ & $\begin{array}{r}31.2 \\
47.1 \\
6.0 \\
8.2 \\
7.5\end{array}$ & $\begin{array}{l}53.15 \\
35.05 \\
15.30 \\
12.52 \\
16.93\end{array}$ & $\begin{array}{r}31.2 \\
78.3 \\
84.3 \\
92.5 \\
100.0\end{array}$ & $\begin{array}{l}53.15 \\
42.26 \\
40.34 \\
37.88 \\
36.31\end{array}$ & $\begin{array}{r}100.0 \\
68.8 \\
21.7 \\
15.7 \\
7.5\end{array}$ & $\begin{array}{l}36.31 \\
16.67 \\
14.81 \\
14.63 \\
16.93\end{array}$ \\
\hline \multicolumn{8}{|c|}{ Dust (3.8\% Moisture) } \\
\hline $\begin{array}{l}1 / 4 " \\
16 M \\
30 M \\
100 M\end{array}$ & $\begin{array}{l}1 / 4^{\prime \prime} \\
16 M \\
30 M \\
100 M\end{array}$ & $\begin{array}{c}-- \\
-- \\
0.6 \\
85.6 \\
13.3\end{array}$ & $\begin{array}{c}-- \\
-- \\
13.75 \\
8.01 \\
10.37\end{array}$ & $\begin{array}{r}-. \\
-\overline{0} \\
0.6 \\
86.2 \\
100.0\end{array}$ & $\begin{array}{r}13.75 \\
8.02 \\
3.37\end{array}$ & $\begin{array}{r}100.0 \\
99.4 \\
13.8\end{array}$ & $\begin{array}{r}8.37 \\
8.34 \\
10.37\end{array}$ \\
\hline
\end{tabular}


Table 5. Plant Samples Describing Performances of Superflow Air Cleaner Treating Central Pennsylvania B and D Seams

Washability Analyses

Raw Coal

\begin{tabular}{|c|c|c|c|c|c|c|c|c|}
\hline \multirow[b]{3}{*}{ Sink } & \multirow[b]{3}{*}{ Float } & \multirow{2}{*}{\multicolumn{3}{|c|}{ Direct }} & \multicolumn{4}{|c|}{ Cumulative } \\
\hline & & & & & & & & $n k$ \\
\hline & & Wt. \% & $\mathrm{H}_{2} \mathrm{O} \%$ & Ash \%* & $\overline{\text { Wt. } \%}$ & Ash \%* & $\overline{\text { Wt. } \%}$ & Ash \%* \\
\hline $\begin{array}{l}1.30 \\
1.60\end{array}$ & $\begin{array}{l}1.30 \\
1.60\end{array}$ & $\begin{array}{l}66.8 \\
15.7 \\
18.1\end{array}$ & $\begin{array}{l}0.10 \\
0.10 \\
0.20\end{array}$ & $\begin{array}{r}5.96 \\
15.47 \\
73.50\end{array}$ & $\begin{array}{r}66.8 \\
81.9 \\
100.0\end{array}$ & $\begin{array}{r}5.96 \\
5.71 \\
19.62\end{array}$ & $\begin{array}{r}100.0 \\
33.2 \\
18.1\end{array}$ & $\begin{array}{l}19.62 \\
47.11 \\
73.50\end{array}$ \\
\hline
\end{tabular}

\section{Clean Coal}

$\begin{array}{rrrrrrrrr} & 1.30 & 55.9 & 0.10 & 3.10 & 56.9 & 3.10 & 100.0 & 14.72 \\ 1.30 & 1.60 & 29.3 & 0.10 & 10.76 & 86.2 & 5.70 & 43.1 & 30.05 \\ 1.60 & & 13.8 & 0.30 & 71.01 & 100.0 & 14.72 & 13.8 & 71.01\end{array}$

岁

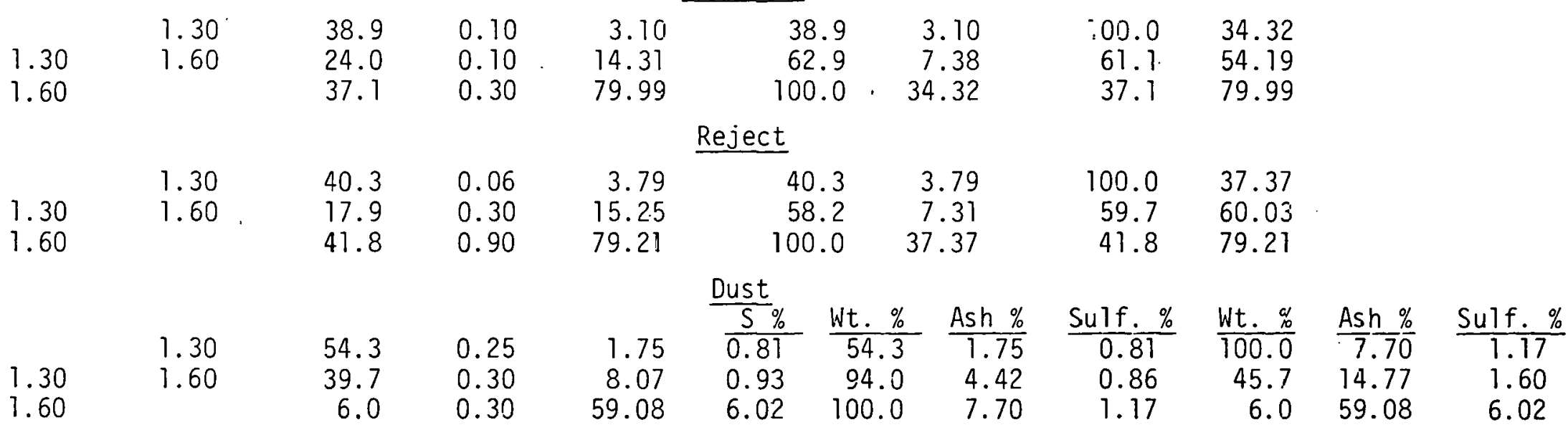

CALCULATEd RECOVERIES: Clean Coal - 90.0\%; Middling - 4.0\%; Reject - 5.9\%; Dust - 0.1\%

*Dry Bas is 
All pneumatic-cleaning approaches have feed moisture content limitations. The Dryflo Separator is not an exception. However, should the ROM feed to such a system require drying, moisture reduction from five or six percent is obviously better than from 35 percent.

The Dryfio device functions pneumatically and has the capability to process coal feeds whose top sized particles range from $1 / 4$ in. to less than 100 mesh. Its pinch sluice format transports the feed from the outer periphery by gravity to an inner gate discharge with an increasing béd depth. At the gate, the particle momentum results in a free fall trajectory defined by particle mass and shape. The particle target location permits separation of particles by composition using a splitter system. During transport down the sluice, the bed is partially fluidized by air passing through a controlled permeability bed bottom.

The Model 30 previously studied has a bed area of one square foot, with bed dimensions of $20 \mathrm{in}$. length and nine in. feed width. It has a feed capacity of about 2 ton/hr requiring $2 \mathrm{hp}$, primarily for air movement. The operating parameters are sluice bed angle $\left(12-23^{\circ}\right)$, air flow rate, splitter positions, feed rate, and feed characteristics. Dust control is critical, however can probably be achieved. Feed moisture content will have limitations and can be a process constraint.

The fundamental principal of separation relates particle mass to terminal settling velocity as applied through the equipment design. This concept is illustrated in Figure 2.

The feed material must be adequately fluidized on the Dryflo bed to allow particle segregation to occur prior to separation of the discharge plume by the splitters. The potential sensitivity of the machine to separate particles of different properties relates to plume length and the degree of horizontal segregation attained within the plume. There is a wall effect. The fluidization of the coal feed is primarily a function of coal particle size and size distribution; however, the air flow rate through the bed may be controlled (20-50 $\left.\mathrm{ft}^{3} / \mathrm{min}\right)$. The pressure drop across the bed ( $<7$ in. water) is primarily a design and maintenance factor. The plume characteristics relate to fluidization, but are associated with bed retention time and particle momentum at the discharge gate.

A unique process applicable to the Dryflo Separator permits the introduction of a dry heavy media (magnetite) into the feed to achieve beneficiation of top particle sizes between 1/4 in. and 16 mesh. Small sized feeds do not require this addition. The media is recovered by screening and recycled.

The modified Model 60 now being studied varies in bed length and in plume product separation design. These changes are described in Figure 3 . The modifications are expected to increase unit capacity, enhance bed segregation, improve separation efficiency, and minimize wall effects. 


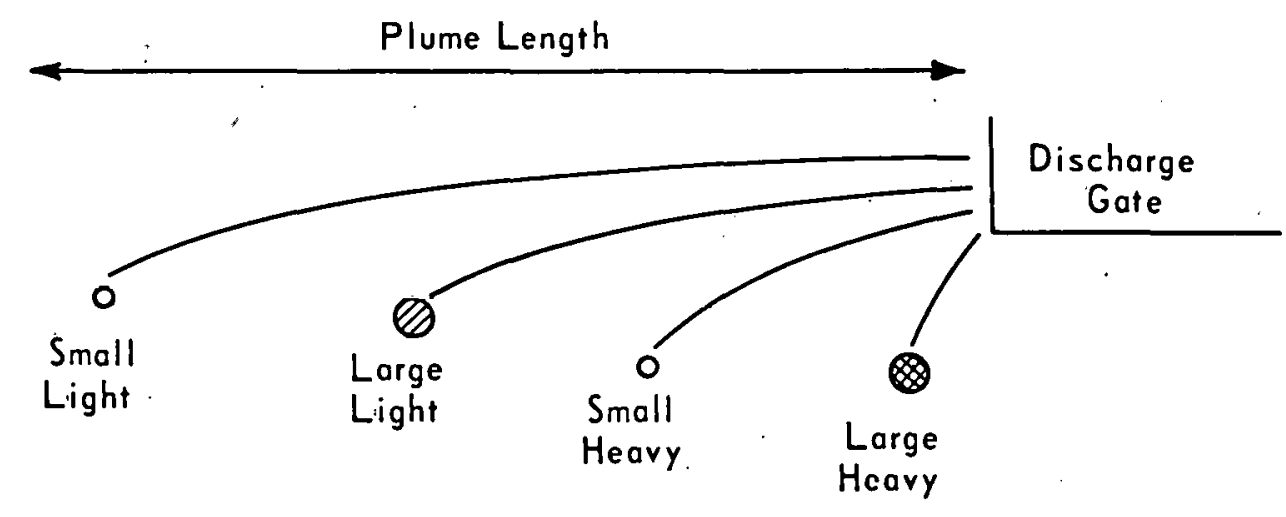

Figure 2. PARTICLE DISTRIBUTION PATTERN

FROM DRY FLOW SEPARATOR PLUME 


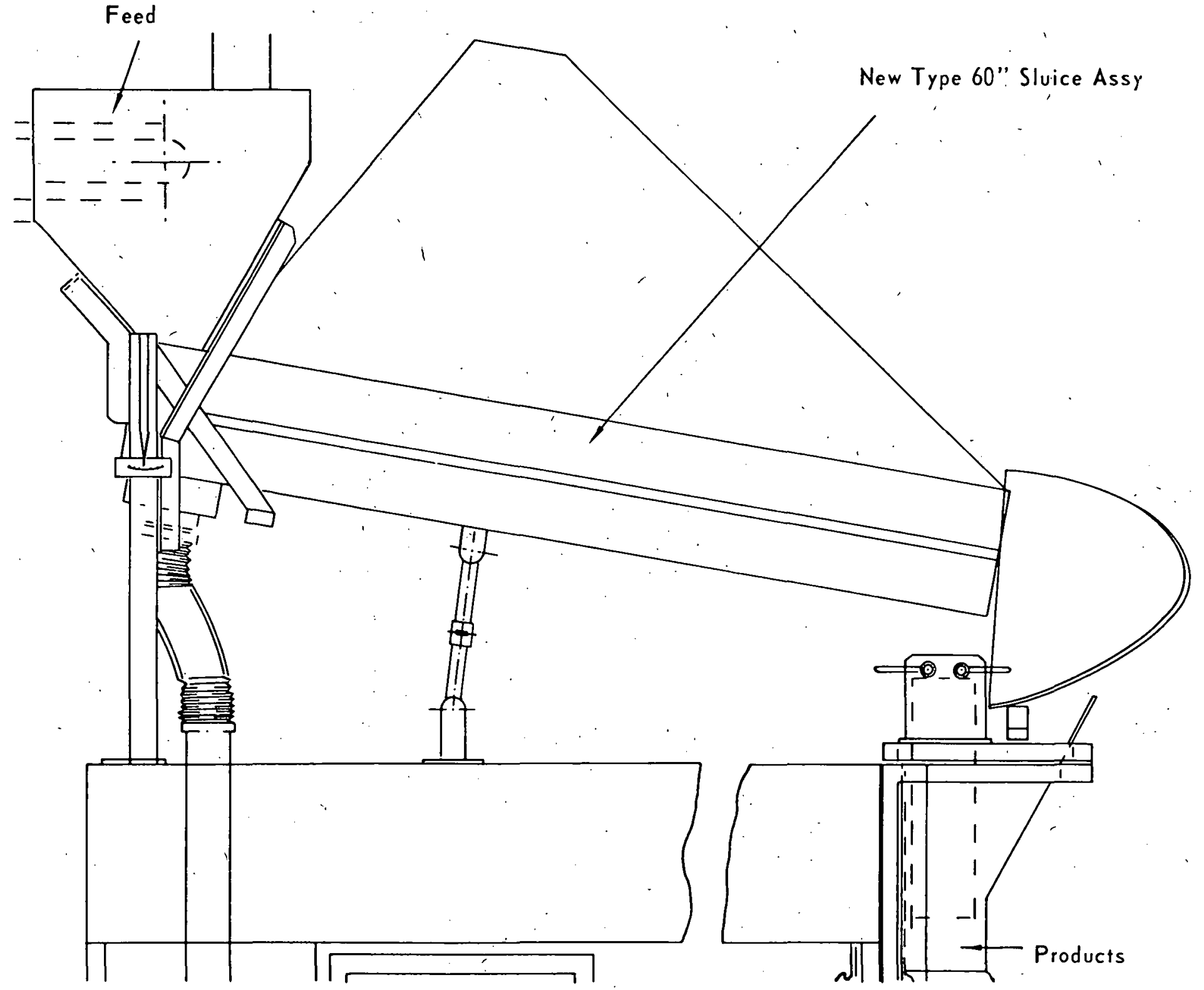

FiUit: 3. SCHEMATIC DRAWING OF MODEL 60 DRYFLO SEPARATOR 


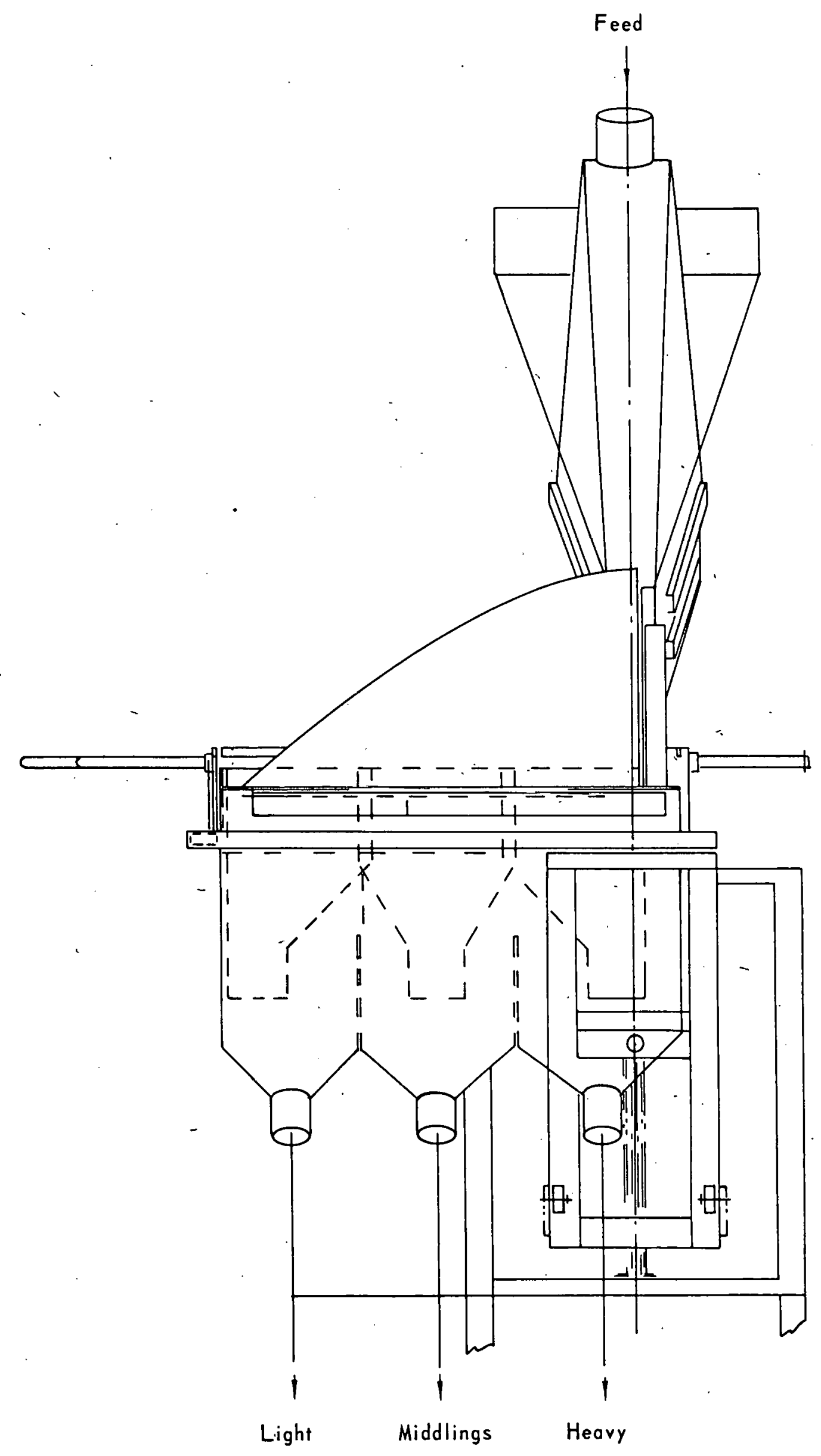

Figure 3 (Continued). SCHEMATIC DRAWING OF MODEL 60 DRYFLO SEPARATOR 
Fifty-eight runs were made using the Model 30 with nine different American coals (Table 6) of six ranks under different process parameters. These tests were short runs utilizing about 50 to 100 ib feed per test. Three product streams were developed (clean coal, middling, and refuse), which were sampled and analyzed. The ranges of coal feed characteristics were ash (4.8-14.5\%), sulfur (0.8-4.3\%), total moisture $(0.6-31.7 \%)$, and particle size ranges (1/4 in. $\times 16$ mesh, $30 \times 100$ mesh, minus 8 mesh, minus 16 mesh, minus 30 mesh, and minus 100 mesh).

The following two tables (Table 7 and 8) summarize the test conditions employed and results attained. Five tests (Nos. 3, 4, 22, 23, and 24) gave sulfur rejections from the clean coal of greater than sixty percent; while six tests (Nos. 3, 4, 22-24, and 26) gave ash rejections from the clean coal of greater than fifty-eight percent. As a specific example, Test 4 made with Brookville seam coal of minus 30 mesh resulted in a clean coal product of 68.3 weight percent. The ash was reduced from 15.3 to 9.1 percent, the sulfur from 4.25 to 2.43 percent. The corresponding ash and sulfur contents of limited size fractions having lowest levels were, respectively, 7.2 and 1.32 percent.

Another set of data showing more detailed results for the same coal is given in Table 9 .

A further attempt to analyze the data was made with Test Run 13, using an anthracite feed. The analys is of the products follow in Table 10. In this test 23.4 percent of the ash, and 11.9 percent of the sulfur were rejected from the clean coal product. An attempt to correlate the results with terminal settling velocities is illustrated in Figure 4. Reasonable agreement is indicated. However, the horizontal velocity extensively modulates the particle trajectory to achieve a physical separation by placement of the three products in different locations. The densities plotted represent an average based upon ash content as determined from washability data. The product cut was near 1.65 density, the middling in the range of 1.65 and 1.67 , while the refuse contained particles above 1.67 density.

A further evaluation was made by performing sink-float separations at the several gravities used for reference in Figure 4 . These separations are very tedious and time-consuming to perform, requiring centrifugation. The data are presented in Table 11. Although the levels of misplaced material are not equivalent to those attained by wet-coarse coal processing, substantial beneficiation did occur in a single pass. The greatest error appears to be represented by the presence of clean coal in the refuse. All separations apparently occurred at somewhat higher densities than predicted. This coal obviously contained very high levels of near gravity material, estimated to be greater than 30 percent \pm 0.1 gravity at 1.55 separation point.

The actual test data of the above are attached in Appendix A. 
Table 6. Coal Utilized.in Dryflc Separator Evaluations

\begin{tabular}{lllccccc}
\hline & \multicolumn{1}{c}{ Designation } & \multicolumn{1}{c}{ Rank } & $\begin{array}{c}\text { Moisture } \\
\%\end{array}$ & $\begin{array}{c}\text { Ash } \\
\%\end{array}$ & $\begin{array}{c}\text { Total } \\
\text { Sulfur } \\
\%\end{array}$ & $\begin{array}{c}\text { Pyritic } \\
\text { Sulfur } \\
\%\end{array}$ \\
\hline 85 & No. 8 Leader & Anthracite & & 1.25 & 8.32 & 1.05 & 0.28 \\
Bradford & Lower Kittanning & Mecium Volatile & 0.50 & 12.62 & 3.77 & \\
Elliot & Brookville & Medium Volatile & 0.59 & 14.79 & 4.15 & \\
208 & Freeport & Medium Volatile & 7.13 & 10.19 & 4.29 & 2.68 \\
102 & Pittsburgh & High Volatile A & 1.64 & 7.07 & 1.36 & 0.54 \\
5 & Elkhorn No. 3 & High Volatile A & 1.87 & 4.78 & 1.60 & 0.77 \\
105 & Indiana No. 1 Block & High Volatile B & 6.20 & 11.32 & 2.21 & 1.24 \\
233 & Wadge & High Volatile C & 6.59 & 7.55 & 0.60 & \\
86 & Zap & Lignite & 31.70 & 11.49 & 1.22 & 0.56 \\
\hline
\end{tabular}


Table 7. Test Conditions Utilized with Model 30 DryFlo Separator

\begin{tabular}{|c|c|c|c|c|c|c|c|c|c|c|c|}
\hline \multirow{2}{*}{$\begin{array}{l}\text { Test } \\
\text { No. }\end{array}$} & \multirow{2}{*}{$\begin{array}{l}\text { PSOC } \\
\text { No. }\end{array}$} & \multirow[b]{2}{*}{ Seam Name } & \multirow{2}{*}{$\begin{array}{l}\text { Coal } \\
\text { Rank }\end{array}$} & \multirow{2}{*}{$\begin{array}{c}\text { Coal Size } \\
\text { (mesh) }\end{array}$} & \multirow{2}{*}{$\begin{array}{l}\text { Coal } \\
\text { Feed Rate } \\
\text { (tons/hr) }\end{array}$} & \multirow{2}{*}{$\begin{array}{c}\text { Bed } \\
\text { Angle } \\
\text { (degrees) }\end{array}$} & \multirow{2}{*}{$\begin{array}{c}\text { Air } \\
\text { Flow Rate } \\
(\mathrm{cfm})\end{array}$} & \multicolumn{4}{|c|}{$\frac{\text { Splitter Settings }}{\text { Distance in Inches }}$} \\
\hline & & & & & & & & $\mathrm{k}_{1}$ & $k_{2}$ & $k_{3}$ & $k_{4}$ \\
\hline 1 & Elliot & Brookville & MV & -30 & 1.011 & 16 & 28 & 1.500 & 0.000 & 1.000 & 2.875 \\
\hline 2 & Elliot & Brookville & MV & -30 & 1.401 & 16 & 28 & 1.187 & 0.000 & 1.215 & 2.750 \\
\hline 3 & Elliot & Brookville & MV & -30 & 1.332 & 16 & 20 & 1.187 & 0.000 & 1.125 & 2.750 \\
\hline 4 & Elliot & Brookville & MV & -30 & 1.164 & 16 & 24 & 1.187 & 0.000 & 1.125 & 2.750 \\
\hline 5 & 233 & Wadge & HVC & -30 & 1.008 & 16 & 24 & 0.625 & 0.000 & 1.125 & 2.750 \\
\hline 6 & .233 & Wadge & HVC & -30 & 1.293 & 16 & 24 & 0.812 & 0.000 & 1.125 & 2.750 \\
\hline 7 & 233 & Wadge & HVC & $.30 \times 100$ & 2.158 & 12 & 20 & 1.000 & 0.000 & 1.125 & 2.750 \\
\hline 8 & 233 & Wadge & HVC & $30 \times 100$ & 1.506 & 12 & 24 & 1.000 & 0.000 & 1.125 & 2.750 \\
\hline 9 & 233 & Wadge & HVC & $30 \times 100$ & 2.026 & 23 & 24 & 1.343 & 0.125 & 1.250 & 2.750 \\
\hline 10 & 233 & Wadge & HVC & $30 \times 100$ & 2.067 & 23 & 20 & 1.343 & 0.125 & 1.250 & 2.750 \\
\hline 11 & 233 & Wadge & HVC & $30 \times 100$ & 1.903 & 17.5 & 20 & 1.343 & 0.125 & 1.125 & 2.875 \\
\hline 12 & 233 & Wadge & HVC & $30 \times 100$ & 1.873 & 17.5 & 24 & 1.343 & 0.125 & 1.125 & 2.875 \\
\hline 13 & 85 & \#8 Leader & AN & $30 \times 100$ & 1.740 & 16 & 20 & 1.250 & 0.000 & 1.750 & 2.656 \\
\hline 14 & 85 & \#8 Leader & AN & $30 \times 100$ & 1.680 & 16 & 24 & 1.250 & 0.000 & 1.750 & 2.656 \\
\hline $15 \mathrm{HM}$ & 102 & Pittsburgh & HVA & -30 & 1.571 & 16 & 25 & 1.062 & 0.000 & 1.656 & 2.437 \\
\hline $16 \mathrm{HM}$ & 102 & Pittsburgh & HVA & -30 & 1.861 & 16 & 30 & 1.062 & 0.000 & 1.656 & 2.437 \\
\hline $17 \mathrm{HM}$ & 102 & Pittsburgh & HVA & -30 & 1.897 & 16 & 20 & 1.062 & 0.000 & 1.656 & 2.437 \\
\hline 18RM & 102 & Pittsburgh & HVA & -30 & 1.047 & 16 & 20 & 1.062 & 0.000 & 1.656 & 2.437 \\
\hline 19RM & 102 & Pittsburgh & HVA & -30 & 1.485 & 16 & 25 & 1.062 & 0.000 & 1.656 & 2.437 \\
\hline $20 \mathrm{RM}$ & 102 & Pittsburgh & HVA & -30 & 1.647 & 16 & 30 & 1.062 & 0.000 & 1.656 & 2.437 \\
\hline 21 & Elliot & Brookville & MV & -100 & 0.624 & 16 & 20 & 0.343 & -0.250 & 1.500 & 2.125 \\
\hline 22 & Elliot & Brookville & MV & -100 & 0.894 & 16 & 20 & 0.343 & -0.250 & $1: 500$ & 2.125 \\
\hline
\end{tabular}


Table 7 (continued). Test Conditions Utilized with Model 30 Dryflo Separator

\begin{tabular}{|c|c|c|c|c|c|c|c|c|c|c|c|}
\hline \multirow{2}{*}{$\begin{array}{l}\text { Test } \\
\text { No. }\end{array}$} & \multirow{2}{*}{$\begin{array}{l}\text { PSOC } \\
\text { No. }\end{array}$} & \multirow[b]{2}{*}{. Seam Name } & \multirow{2}{*}{$\begin{array}{l}\text { Coal } \\
\text { Rank }\end{array}$} & \multirow{2}{*}{$\begin{array}{l}\text { Coal Size } \\
\text { (mesh) }\end{array}$} & \multirow{2}{*}{$\begin{array}{c}\text { Coal } \\
\text { Feed Rate } \\
\text { (tons/hr) }\end{array}$} & \multirow{2}{*}{$\begin{array}{c}\text { Bed } \\
\text { Angle } \\
\text { (degrees) }\end{array}$} & \multirow{2}{*}{$\begin{array}{l}\text { Air } \\
\text { Flow Rate } \\
\text { :cfm) }\end{array}$} & \multicolumn{4}{|c|}{$\begin{array}{l}\text { Splitter Settings } \\
\text { Distance in Inches }\end{array}$} \\
\hline & & & & & & & & $\mathrm{k}_{1}$ & $\mathrm{k}_{2}$ & $k_{3}$ & $k_{4}$ \\
\hline $23 R M$ & 5 & Elkhorn No. 3 & HVA. & -30 & $0.64 ?$ & 16 & 24 & 1.062 & 0.000 & 1.656 & 2.437 \\
\hline $24 R M$ & 5 & Elkhorn No. 3 & HVA & -30 & 0.997 & 12 & 24 & 1.062 & -0.062 & 1.406 & 2.500 \\
\hline $25 \mathrm{RM}$ & 5 & Elkhorn No. 3 & HVA & -30 & 0.535 & 23 & 24 & 1.187 & 0.062 & 1.737 & 2.406 \\
\hline $268 \mathrm{M}$ & 5 & Elkhorn No. 3 & HVA & -30 & 0.710 & 16 & 20 & 1.062 & 0.000 & 1.656 & 2.437 \\
\hline $27 \mathrm{RM}$ & 5 & Elkhorn No. 3 & HVA & -30 & 0.594 & 16 & 23 & 1.062 & 0.000 & 1.656 & 2.437 \\
\hline 28 & 105 & Indiana \#1 Block & HVB & -16 & N.A. & 16 & 24 & 1.750 & 0.625 & 1.000 & 3.000 \\
\hline $29 \mathrm{H}$ & 105 & Indiana \#1 Block & HVB & $1 / 4 " x 16$ & 0.641 & 16 & 30 & 1.4375 & 0.5372 & 1.2872 & 2.84375 \\
\hline $30 \mathrm{H}$ & 105 & Indiana \#1 Block & HVB & $1 / 4 " \times 16$ & 0.767 & 12.5 & 30 & 1.437 .5 & 0.4437 & 1.1937 & 2.84375 \\
\hline $31 \mathrm{H}$ & 105 & Indiana \#1 8lock & HVB & $1 / 4^{11} \times 16$ & 1.028 & 12.5 & 30 & 1.4375 & 0.4437 & 1.1937 & 2.84375 \\
\hline $32 \mathrm{H}$ & 105 & Indiana \#1 Block & HVB & $1 / 4^{\prime \prime} \times 16$ & 0.910 & 16 & 30 & 1.4375 & 0.5372 & 1.2872 & 2.84375 \\
\hline $33 \mathrm{H}$ & 208 & Freeport & MV & $1 / 4 " x 16$ & 0.629 & 12.5 & 30 & 1.4375 & 0.4437 & 1.1937 & 2.84375 \\
\hline $34 \mathrm{H}$ & 208 & Freeport & MV & $1 / 4^{\prime \prime} \times 16$ & 1.060 & 12.5 & 30 & 1.4375 & 0.4437 & 1.1937 & 2.84375 \\
\hline $35 \mathrm{H}$ & 208 & Freeport & MV & $1 / 4^{15} \times 16$ & 0.896 & 16 & 30 & 1.4375 & 0.5372 & 1.2872 & 2.84375 \\
\hline $36 \mathrm{H}$ & 208 & Freeport & MV & $1 / 4^{11} \times 16$ & 1.082 & $16^{\circ}$ & 30 & 1.4375 & 0.5372 & 1.2872 & 2.84375 \\
\hline$* 37 \mathrm{H}$ & 86 & Zap & Lig. & $1 / 4^{11} \times 16$ & 0.921 & 16 & 30 & 1.4375 & 0.5372 & 1.2872 & 2.84375 \\
\hline$\star 38 \mathrm{H}$ & 86 & Zap & Lig. & $1 / 4 " \times 16$ & 0.979 & 12.5 & 30 & 1.4375 & 0.4437 & 1.1937 & 2.84375 \\
\hline$\star 39 \mathrm{H}$ & Elliot & Brookville & MV & $1 / 4^{11} \times 16$ & 1.424 & 12.5 & 30 & 1.4375 & 0.4437 & 1.1937 & 2.84375 \\
\hline$\star 40 \mathrm{H}$ & Elliot & Brookville & MV & $1 / 4^{11} \times 16$ & 0.837 & 16 & 30 & 1.4375 & 0.5372 & 1.2872 & 2.84375 \\
\hline 41 & 86 & Zap & Lig. & -16 & $1.255^{\circ}$ & 16 & 30 & 1.250 & 0.375 & 1.000 & 3.000 \\
\hline 42 & 86 & Zap. & Lig. & -16 & $i .123$ & 12.5 & 30 & 1.187 & 0.375 & 0.875 & 3.000 \\
\hline 43 & 86 & Zap & Lig. & -16 & 1.169 & 12.5 & 30 & 1.187 & 0.375 & 0.875 & 3.000 \\
\hline 44 & 86 & Zap & Lig. & -16 & 1.667 & 16 & 40 & 1.250 & 0.375 & 1.000 & 3.000 \\
\hline 45 & 86 & Zap & Lig. & -16 & 1.536 & 16 & 40 & 1.125 & 0.250 . & 1.000 & 3.000 \\
\hline
\end{tabular}


Table 7 (continued). Test Conditions Utilized with Model 30 DryFlo Separator

\begin{tabular}{|c|c|c|c|c|c|c|c|c|c|c|c|}
\hline \multirow{2}{*}{$\begin{array}{l}\text { Test } \\
\text { No. }\end{array}$} & \multirow{2}{*}{$\begin{array}{l}\text { PSOC } \\
\text { No. }\end{array}$} & \multirow[b]{2}{*}{ Seam Name } & \multirow{2}{*}{$\begin{array}{l}\text { Coal } \\
\text { Rank }\end{array}$} & \multirow{2}{*}{$\begin{array}{l}\text { Coal Size } \\
\text { (mesh) }\end{array}$} & \multirow{2}{*}{$\begin{array}{l}\text { Coal } \\
\text { Feed Rate } \\
\text { (tons/hr) }\end{array}$} & \multirow{2}{*}{$\begin{array}{c}\text { Bed } \\
\text { Angle } \\
\text { (degrees) }\end{array}$} & \multirow{2}{*}{$\begin{array}{l}\text { Air } \\
\text { Flow Rate } \\
\text { (cfm) }\end{array}$} & \multicolumn{4}{|c|}{$\begin{array}{l}\text { Splitter Settings } \\
\text { Distance in Inches }\end{array}$} \\
\hline & & & & & & & & $\cdot k_{1}$ & $\mathrm{~K}_{2}$ & $\mathrm{~K}_{3}$ & $\mathrm{~K}_{4}$ \\
\hline 46 & 208 & Freeport & MV & -16 & 1.776 & 16 & 24 & 7.250 & 0.375 & 1.000 & 3.000 \\
\hline 47 & 208 & Freeport & MV & -16 & 1.822 & 16 & 24 & 1.250 & 0.375 & 1.000 & 3.000 \\
\hline 48 & 208 & Freeport & MV & -16 & 1.760 & 16 & 24 & 1.125 & 0.250 & 1.000 & 3.000 \\
\hline 49 & 208 & Freeport & MV & -16 & 1.522 & 12.5 & 30 & 1.000 & 0.187 & 0.875 & 3.000 \\
\hline 50 & 208 & Freeport & MV & -16 & 1.843 & 12.5 & 40 & 1.000 & 0.187 & 0.875 & 3.000 \\
\hline 51 & Elliot & Brookville & MV & -8 & 1.433 & 16 & 24. & 1.125 & 0.250 & 1.000 & 3.000 \\
\hline 52 & Elliot & Brookville & MV & -8 & 1.545 & 16 & 30 & 1.125 & 0.250 & 1.000 & 3.000 \\
\hline 53 & Elliot & Brookville & MV & -8 & 1.664 & 16 & 40 & 1.125 & 0.250 & 1.000 & 3.000 \\
\hline $54 \mathrm{R}$ & 105 & Indiana \#l Block & HVB & -16 & 1.582 & 16 & 40 & 0.875 & 0.3759 & 1.1259 & 2.2812 \\
\hline $55 \mathrm{R}$ & 105 & Indiana \#1. Block & HVB & -16 & 1.799 & 16 & 45 & 0.875 & 0.3759 & 1.1259 & 2.2812 \\
\hline $56 \mathrm{R}$ & 105 & Indiana \#1 Block & HVB & -16 & 1.684 & 16 & 50 & 0.875 & 0.3759 & 1.1259 & 2.2812 \\
\hline $57 \mathrm{H}$ & Bradford & Wadge & MV & $1 / 4 " \times 16$ & 0.913 & 16 & 30 & 1.4375 & 0.5372 & 1.2872 & 2.8437 \\
\hline $58 \mathrm{H}$ & Bradford & Wadge & MV & $1 / 4 " \times 16$ & 1.047 & 12.5 & 30 & 1.4375 & 0.4437 & 1.1937 & 2.8437 \\
\hline $\begin{array}{l}N . A . \\
H M \\
R M \\
H \\
R \\
\star\end{array}$ & $\begin{array}{l}=\text { Not available } \\
=\text { Sample crush } \\
=\text { Sample crush } \\
=\text { Heavy med tes } \\
=\text { Recycled reft } \\
=\text { Twin runs con }\end{array}$ & $\begin{array}{l}\text { by hammer mill } \\
\text { by roll mill } \\
\text { run } \\
\text { e from test \#28 } \\
\text { ined }\end{array}$ & & & & & - & $\begin{array}{l}k_{1}=x \\
k_{2}=y \\
k_{3}=y \\
k_{4}=x\end{array}$ & $\begin{array}{l}\text { istance } t \\
\text { istance } t \\
\text { istance } t \\
\text { istance } t\end{array}$ & $\begin{array}{l}\# 1 \text { spli } \\
\# 1 \text { spli } \\
\# 2 \text { spli } \\
\# 2 \text { spli }\end{array}$ & $\begin{array}{l}\text { ter edge } \\
\text { ter edge } \\
\text { ter edge } \\
\text { ter edge }\end{array}$ \\
\hline
\end{tabular}


Table 8. Dryflo Sepcrator Test Results

\begin{tabular}{|c|c|c|c|c|c|c|c|c|c|c|c|c|}
\hline \multirow{2}{*}{$\begin{array}{l}\text { Test. } \\
\text { Number }\end{array}$} & & \multicolumn{3}{|c|}{ Weight \% Recovery } & \multicolumn{2}{|c|}{$\begin{array}{c}\% \text { Recovered } \\
\text { in Clean Coal } \\
\end{array}$} & \multicolumn{2}{|c|}{$\begin{array}{c}\% \text { Rejected } \\
\text { from Clean Coal }\end{array}$} & \multicolumn{2}{|c|}{$\begin{array}{l}\% \text { Recovered } \\
\text { in Middling } \\
\end{array}$} & \multicolumn{2}{|c|}{$\begin{array}{c}\% \text { Recovered } \\
\text { in Refuse } \\
\end{array}$} \\
\hline & & Product & Mid & Refuse & Sulfur & & Sulfur & & Sulfur & Ash & Sulfur & Ash \\
\hline 1 & & 66.9 & 10.7 & 32.4 & 44.81 & 47.19 & 55.19 & 52.81 & 8.55 & 9.08 & 46.64 & 43.73 \\
\hline 2 & & 68.3 & 12.9 & 18.8 & 40.54 & 47.14 & 59.46 & 52.86 & 11.08 & 12.34 & 48.38 & 40.52 \\
\hline 3 & & 57.3 & 21.9 & 20.8 & 31.67 & 34.93 & 68.33 & 65.07 & 19.33 & 22.30 & 49.00 & 42.77 \\
\hline 4 & & 53.0 & 20.9 & 26.1 & 30.30 & 31.36 & 69.70 & 68.64 & 14.61 & 18.59 & 55.09 & 50.05 \\
\hline 5 & & 68.5 & 19.0 & 12.5 & 68.50 & 64.33 & 31.50 & 35.67 & 18.17 & 19.60 & 13.33 & 16.08 \\
\hline 6 & & 80.7 & 9.7 & 9.6 & 79.33 & 76.95 & 20.67 & 23.05 & 9.03 & 9.92 & 10.74 & 13.13 \\
\hline 7 & & 73.4 & 19.0 & 7.6 & 73.40 & 70.80 & 26.60 & 29.20 & 18.57 & 19.08 & 8.03. & 10.13 \\
\hline 13 & & 86.9 & 4.4 & 8.7 & 88.13 & 76.62 & 11.87 & 23.38 & $4.40^{\prime}$ & 6.41 & 7.47 & 16.97 \\
\hline 14 & & 88.2 & 3.9 & 7.9 & 89.44 & 78.50 & 10.56 & 21.50 & 3.83 & 5.14 & 6.73 & 16.36 \\
\hline 15 & & 88.2 & 5.3 & 6.5 & 86.86 & 78.54 & 13.14 & 21.46 & 5.45 & 6.93 & 7.68 & 14.53 \\
\hline 16 & & 89.8 & 4.9 & 5.3 & 89.11 & 79.42 & 10.89 & 20.58 & 4.29 & 6.75 & 6.59 & 13.82 \\
\hline 17 & & 69.1 & 22.4 & 8.5 & 68.53 & 53.24 & 31.47 & 46.76 & 21.64 & 27.10 & 9.82 & 19.66 \\
\hline 18 & & 76.1 & 14.9 & 9.0 & 74.01 & 62.10 & 25.99 & 37.90 & 15.10 & 17.46 & 10.90 & 20.44 \\
\hline 19 & & 89.2 & 5.2 & 5.6 & 87.55 & 78.98 & 12.45 & 21.02 & 5.40 & 7.70 & 7.05 & 13.32 \\
\hline 20 & & 91.0 & 3.8 & 5.2 & 89.38 & 81.66 & 10.62 & 18.34 & 3.85 & 5.23 & 6.78 & 13.11 \\
\hline 21 & & 61.7 & . & 38.3 & 53.65 & 53.08 & 46.35 & 46.92 & $0: 00$ & 0.00 & 46.42 & 46.95 \\
\hline 22 & 1 & 30.6 & & 69.4 & 25.25 & 25.63 & 74.75 & 74.37 & 0.10 & 0.00 & 74.65 & 74.37 \\
\hline 23 & & 48.5 & 26.5 & 25.0 & 39.35 & 41.03 & 60.65 & 58.97 & 21,66 & 23.24 & 38.99 & 35.73 \\
\hline 24 & & 32.0 & 45.8 & 22.2 & 27.24 & 26.87 & 72.76 & 73.13 & 38.11 & 40.99 & 34.65 & 32.14 \\
\hline 25 & & 67.4 & 4.7 & 27.9 & 56.83 & 55.81 & 43.17 & 44.19 & 4.33 & 4.43 & 38.84 & 39.76 \\
\hline 26 & & 47.5 & 28.0 & 24.5 & 40.53 & 41.36 & 59.47 & 58.64 & 25.49 & 27.20 & 33.97 & 31.45 \\
\hline
\end{tabular}


Table 8 (continued). Dryflo Separator Test Results

\begin{tabular}{|c|c|c|c|c|c|c|c|c|c|c|c|}
\hline \multirow{2}{*}{$\begin{array}{l}\text { Test } \\
\text { Number }\end{array}$} & \multicolumn{3}{|c|}{ Weight $\%$ Recovery } & \multicolumn{2}{|c|}{$\begin{array}{r}\% \text { Recovered } \\
\text { in Clean Coal } \\
\end{array}$} & \multicolumn{2}{|c|}{$\begin{array}{l}\% \text { Rejected } \\
\text { from Clean Coal }\end{array}$} & \multicolumn{2}{|c|}{$\begin{array}{l}\% \text { Recovered } \\
\text { in Middling } \\
\end{array}$} & \multicolumn{2}{|c|}{$\begin{array}{l}\% \text { Recovered } \\
\text { in Refuse }\end{array}$} \\
\hline & Product & Mid & Refuse & & & Sulfur & & Sulfur & & Sulfur & Ash \\
\hline 27 & 53.9 & 18.4 & 27.7 & 44.79 . & 45.17 & 55.21 & 54.83 & 15.61 & 16.73 & 39.60 & 38.10 \\
\hline 28 & 56.4 & & 43.6 & 54.93 & 52.61 & 45.07 & 47.39 & 0.11 & 0.03 & 44.96 & $47: 36$ \\
\hline 29 & 85.8 & 5.6 & 8.6 & 80.66 & 81.35 & 19.34 & 18.65 & 8.73 & 7.30 & 10.61 & 11.35 \\
\hline 30 & 66.9 & 22.0 & 11.1 & 56.83 & 59.70 & 43.17 & 40.30 & 26.10 & 25.31 & 17.07 & 15.00 \\
\hline 31 & 71.3 & 18.7 & 10.0 & 62.54 & 63.70 & 37.46 & 36.30 & 17.91 & 19.99 & 19.55 & 16.31 \\
\hline 32 & 87.5 & 6.0 & 6.5 & 81.47 & 83.37 & 18.53 & 16.63 & 7.03 & 7.34 & 11.51 & 9.30 \\
\hline 33 & 63.9 & 26.7 & 9.4 & 45.77 & 46.70 & 54.23 & 53.30 & 29.48 & 28.67 & 24.75 & 24.63 \\
\hline 34 & 61.8 & 26.5 & 11.7 & 41.08 & 42.90 & 58.92 & 57.10 & 26.58 & 26.89 & 32.34 & 30.20 \\
\hline 53 & 60.6 & 23.6 & 15.8 & & & & & & & & \\
\hline 54 & 44.3 & 39.4 & 16.3 & 37.64 & 33.19 & 62.36 & 66.81 & 39.40 & 38.06 & 22.96 & 26.76 \\
\hline 55 & 65.0 & 24.8 & 10.2 & 56.88 & 56.95 & 43.13 & 43.05 & 24.28 & 27.48 & 18.84 & 15.57 \\
\hline 56 & 71.9 & 19.2 & 8.9 & 64.67 & 65.13 & 35.33 & 34.87 & 20.39 & 21.87 & 14.94 & 13.00 \\
\hline 57 & 87.4 & 6.2 & 6.4 & 71.99 & 73.24 & 28.01 & 26.76 & 12.71 & 11.31 & 15.30 & 15.46 \\
\hline 58 & 72.4 & 16.1 & 11.5 & 48.82 & 50.50 & 51.18 & 49.50 & 21.63 & 19.62 & 29.55 & 29.88 \\
\hline
\end{tabular}


Table 9. Data for DryFlo Separator Test No. I

Figures from Elliot Feed Sample

Product Coal Data

This fraction $=66.9 \%$ of the feed

\begin{tabular}{|c|c|c|c|c|c|c|c|c|c|c|c|c|c|}
\hline \multirow[b]{2}{*}{ Size } & \multirow[b]{2}{*}{ Fraction } & \multicolumn{4}{|c|}{ Direct Values } & \multicolumn{4}{|c|}{ Cumulative Retained } & \multicolumn{4}{|c|}{ Cumulative Passed } \\
\hline & & $\begin{array}{c}\text { Weight } \\
\%\end{array}$ & $\begin{array}{l}\text { Ash } \\
\%\end{array}$ & $\underset{\%}{\text { Sulfur }}$ & Moisture & $\begin{array}{c}\text { Weight } \\
\%\end{array}$ & $\begin{array}{c}\text { Ash } \\
\%\end{array}$ & $\underset{\%}{\text { Sulfur }}$ & $\begin{array}{c}\text { Moisture } \\
\%\end{array}$ & $\underset{\%}{\text { Weight }}$ & $\begin{array}{c}\text { Ash } \\
\%\end{array}$ & $\underset{\substack{\alpha \\
\text { Sulfur }}}{ }$ & $\begin{array}{c}\text { Moisture } \\
\%\end{array}$ \\
\hline $\begin{array}{r}30 M \\
60 M \\
100 M\end{array}$ & $\begin{array}{r}30 M \\
60 M \\
100 M\end{array}$ & $\begin{array}{r}0.60 \\
50.50 \\
24.70 \\
24.20\end{array}$ & $\begin{array}{r}6.60 \\
8.14 \\
9.56 \\
15.31\end{array}$ & $\begin{array}{l}1.04 \\
1.51 \\
2.46 \\
5.81\end{array}$ & $\begin{array}{l}0.75 \\
0.55 \\
0.60 \\
0.75\end{array}$ & $\begin{array}{r}0.60 \\
51.10 \\
75.80 \\
100.0\end{array}$ & $\begin{array}{r}6.60 \\
8.12 \\
8.59 \\
10.22\end{array}$ & $\begin{array}{l}1.04 \\
1.50 \\
1.82 \\
2.78\end{array}$ & $\begin{array}{l}0.75 \\
0.55 \\
0.57 \\
0.61\end{array}$ & $\begin{array}{r}100.00 \\
99.40 \\
48.90 \\
24.20\end{array}$ & $\begin{array}{l}10.22 \\
10.24 \\
12.41 \\
15.31\end{array}$ & $\begin{array}{l}2.78 \\
2.79 \\
4.12 \\
5.81\end{array}$ & $\begin{array}{l}0.61 \\
0.61 \\
0.67 \\
0.75\end{array}$ \\
\hline & . & . & & - & This $f r$ & $\frac{\text { ddling } C}{\text { tion }=1}$ & $\frac{a 1 \text { Dat }}{.7 \% \text { of }}$ & the feec & t. & & & & \\
\hline $\begin{array}{r}30 \mathrm{M} \\
60 \mathrm{M} \\
.100 \mathrm{M}\end{array}$ & $\begin{array}{r}30 M \\
60 M \\
100 M\end{array}$ & $\begin{array}{r}7.50 \\
77.40 \\
12.00 \\
3.10\end{array}$ & $\begin{array}{l}10.97 \\
10.22 \\
21.49 \\
32.90\end{array}$ & $\begin{array}{r}2.21 \\
2.21 \\
7.30 \\
17.27\end{array}$ & $\begin{array}{l}0.60 \\
0.65 \\
0.65 \\
0.45\end{array}$ & $\begin{array}{r}7.50 \\
84.90 \\
96.90 \\
100.0\end{array}$ & $\begin{array}{l}10.97 \\
10.29 \\
11.67 \\
12.33\end{array}$ & $\begin{array}{l}2.21 \\
2.21 \\
2.84 \\
3.29\end{array}$ & $\begin{array}{r}0.60 \\
0.65 \\
0.65 \\
0.64\end{array}$ & $\begin{array}{r}100.00 \\
92.50 \\
15.10 \\
3.10\end{array}$ & $\begin{array}{l}12.33 \\
12.44 \\
23.83 \\
32.90\end{array}$ & $\begin{array}{r}3.29 \\
3.38 \\
9.35 \\
17.27\end{array}$ & $\begin{array}{l}0.64 \\
0.64 \\
0.61 \\
0.45\end{array}$ \\
\hline & . & & & & This fy & $\frac{\text { Refuse Co }}{\text { tion }=2}$ & $\frac{\text { Data }}{4 \% \text { of }}$ & he feec & & & & & \\
\hline $\begin{array}{r}30 \mathrm{M} \\
60 \mathrm{M} \\
100 \mathrm{M}\end{array}$ & $\begin{array}{r}30 M \\
60 M \\
100 M\end{array}$ & $\begin{array}{r}15.70 \\
74.60 \\
8.20 \\
1.50\end{array}$ & $\begin{array}{l}32.86 \\
25.43 \\
41.33 \\
51.15\end{array}$ & $\begin{array}{r}6.17 \\
834 \\
15.81 \\
10.46\end{array}$ & $\begin{array}{l}0.50 \\
0.50 \\
0.55 \\
0.30\end{array}$ & $\begin{array}{c}15.70 \\
90.30 \\
98.50 \\
100.0\end{array}$ & $\begin{array}{l}32.86 \\
26.72 \\
27.94 \\
28.29\end{array}$ & $\begin{array}{l}6.17 \\
7.96 \\
8.62 \\
8.64\end{array}$ & $\begin{array}{l}0.50 \\
0.50 \\
0.50 \\
0.50\end{array}$ & $\begin{array}{r}100.00 \\
84.30 \\
9.70 \\
1.50\end{array}$ & $\begin{array}{l}28.29 \\
27.43 \\
42.35 \\
51.15\end{array}$ & $\begin{array}{r}8.64 \\
9.10 \\
14.98 \\
10.46\end{array}$ & $\begin{array}{l}0.50 \\
0.50 \\
0.51 \\
0.30\end{array}$ \\
\hline , & & & & & This & $\frac{\text { Composit }}{\text { tion }=1}$ & $\frac{\text { Data }}{.0 \% \quad 0}$ & the $f$ & & & & & \\
\hline $\begin{array}{r}30 M \\
60 M \\
100 M\end{array}$ & $\begin{array}{r}30 M \\
60 M \\
100 M\end{array}$ & $\begin{array}{r}4.72 \\
58.78 \\
19.65 \\
16.86\end{array}$ & $\begin{array}{l}26.91 \\
13.35 \\
13.31 \\
16.37\end{array}$ & $\begin{array}{l}5.06 \\
3.55 \\
4.02 \\
6.13\end{array}$ & $\begin{array}{l}0.54 \\
0.55 \\
0.60 \\
0.74\end{array}$ & $\begin{array}{r}4.72 \\
63.50 \\
83.14 \\
100.0\end{array}$ & $\begin{array}{l}26.91 \\
14.36 \\
14.11 \\
14.49\end{array}$ & $\begin{array}{l}5.06 \\
3.66 \\
3.75 \\
4.15\end{array}$ & $\begin{array}{l}0.54 \\
0.55 \\
0.56 \\
0.59\end{array}$ & $\begin{array}{r}100.00 \\
95.28 \\
36.50 \\
16.86\end{array}$ & $\begin{array}{l}14.49 \\
13.88 \\
14.72 \\
16.37\end{array}$ & $\begin{array}{l}4.15 \\
4.10 \\
5.00 \\
6.13\end{array}$ & $\begin{array}{l}0.59 \\
0.59 \\
0.66 \\
0.74\end{array}$ \\
\hline
\end{tabular}


Table 10. Washability Data for DryFlo Separator Test No. 13

Figures from PSOC - 85 (Anthracite) Feed

Product Coal Data

This fraction $=86.9 \%$ of the feed

\begin{tabular}{|c|c|c|c|c|c|c|c|c|c|c|c|c|c|}
\hline \multirow[b]{2}{*}{ Size } & & \multicolumn{4}{|c|}{ Direct Values } & \multicolumn{4}{|c|}{ Cumulative Retained } & \multicolumn{4}{|c|}{ Cumulative Passed } \\
\hline & $\frac{\text { Fraction }}{\text { Retained }}$ & $\begin{array}{l}\text { Weight } \\
\%\end{array}$ & $\begin{array}{c}\text { Ash } \\
\%\end{array}$ & Sulfur & $\begin{array}{c}\text { Moisture } \\
\%\end{array}$ & $\underset{\%}{\text { Weight }}$ & $\begin{array}{c}\text { Ash } \\
\%\end{array}$ & $\underset{\%}{\text { Sulfur }}$ & $\begin{array}{c}\text { Moisture } \\
\%\end{array}$ & $\begin{array}{c}\text { Weight } \\
\%\end{array}$ & $\begin{array}{c}\text { Ash } \\
\%\end{array}$ & $\underset{\%}{\text { Sulfur }}$ & $\begin{array}{c}\text { Moisture } \\
\%\end{array}$ \\
\hline \multirow[t]{2}{*}{$\begin{array}{r}30 M \\
60 M \\
100 M \\
150 M \\
200 M\end{array}$} & $\begin{array}{r}30 M \\
60 M \\
100 M \\
150 M \\
200 M\end{array}$ & $\begin{array}{r}5.10 \\
47.30 \\
24.30 \\
10.40 \\
0.90 \\
12.00\end{array}$ & $\begin{array}{r}7.46 \\
8.32 \\
8.93 \\
9.89 \\
11.30 \\
14.81\end{array}$ & $\begin{array}{l}1.40 \\
1.35 \\
.1 .50 \\
1.60 \\
1.60 \\
1.45\end{array}$ & $\begin{array}{l}0.80 \\
0.80 \\
0.95 \\
0.90 \\
0.90 \\
1.05\end{array}$ & $\begin{array}{r}5.10 \\
52.40 \\
76.70 \\
87.10 \\
88.00 \\
100.00\end{array}$ & $\begin{array}{l}7.46 \\
8.24 \\
8.46 \\
8.63 \\
8.65 \\
9.39\end{array}$ & $\begin{array}{l}1.40 \\
1 . .35 \\
1.40 \\
1.42 \\
1.43 \\
1.43\end{array}$ & $\begin{array}{l}0.80 \\
0.80 \\
0.85 \\
0.85 \\
0.85 \\
0.88\end{array}$ & $\begin{array}{r}100.00 \\
94.90 \\
47.60 \\
23.30 \\
12.90 \\
12.00\end{array}$ & $\begin{array}{r}9.39 \\
9.50 \\
10.67 \\
12.48 \\
14.57 \\
14.81\end{array}$ & $\begin{array}{l}1.43 \\
1.43 \\
1.51 \\
1.52 \\
1.46 \\
1.44\end{array}$ & $\begin{array}{l}0.88 \\
0.88 \\
0.96 \\
0.98 \\
1.04 \\
1.05\end{array}$ \\
\hline & \multicolumn{9}{|c|}{$\frac{\text { Middling Coal Data }}{\text { raction }=4.4 \% \text { of the feed }}$} & & & & \\
\hline $\begin{array}{l}30 M \\
60 M \\
100 M \\
150 M \\
200 M\end{array}$ & $\begin{array}{l}30 M \\
60 M \\
100 M \\
150 M \\
200 M\end{array}$ & $\begin{array}{r}14.40 \\
68.60 \\
13.60 \\
1.70 \\
0.00 \\
1.70\end{array}$ & $\begin{array}{r}11.58 \\
16.78 \\
16.16 \\
0.00 \\
0.00 \\
0.00\end{array}$ & $\begin{array}{l}1.20 \\
1.30 \\
1.45 \\
2.20 \\
0.00 \\
2.15\end{array}$ & $\begin{array}{l}0.70 \\
0.80 \\
0.65 \\
0.00 \\
0.00 \\
0.00\end{array}$ & $\begin{array}{r}14.40 \\
83.00 \\
96.60 \\
98.30 \\
98.30 \\
100.00\end{array}$ & $\begin{array}{l}11.58 \\
15.88 \\
15.92 \\
15.64 \\
15.64 \\
15.38\end{array}$ & $\begin{array}{l}1.20 \\
1.28 \\
1.31 \\
1.32 \\
1.32 \\
1.34\end{array}$ & $\begin{array}{l}0.70 \\
0.78 \\
0.76 \\
0.75 \\
0.75 \\
0.74\end{array}$ & $\begin{array}{r}100.00 \\
85.60 \\
17.00 \\
3.40 \\
1.70 \\
1.70\end{array}$ & $\begin{array}{r}15.38 \\
16.01 \\
12.93 \\
0.00 \\
0.00 \\
0.00\end{array}$ & $\begin{array}{l}1.34 \\
1.36 \\
1.59 \\
2.17 \\
2.15 \\
2.15\end{array}$ & $\begin{array}{l}0.74 \\
0.74 \\
0.52 \\
0.00 \\
0.00 \\
0.00\end{array}$ \\
\hline \multicolumn{14}{|c|}{$\frac{\text { Refuse Coal Data }}{\text { ation }=8.7 \% \text { of the feed }}$} \\
\hline $\begin{array}{r}30 M \\
60 M \\
.100 M \\
150 M \\
200 M\end{array}$ & $\begin{array}{l}30 M \\
60 M \\
100 M \\
150 M \\
200 M\end{array}$ & $\begin{array}{r}16.20 \\
74.40 \\
8.10 \\
0.90 \\
0.00 \\
0.40\end{array}$ & $\begin{array}{r}19.38 \\
21.14 \\
23.44 \\
0.00 \\
0.00 \\
0.00\end{array}$ & $\begin{array}{l}1.10 \\
1.10 \\
1.90 \\
4.30 \\
0.00 \\
4.10\end{array}$ & $\begin{array}{l}0.65 \\
0.65 \\
0.60 \\
0.00 \\
0.00 \\
0.00\end{array}$ & $\begin{array}{r}16.20 \\
90.60 \\
98.70 \\
99.60 \\
99.60 \\
100.00\end{array}$ & $\begin{array}{l}19.38 \\
20.83 \\
21.04 \\
20.85 \\
20.85 \\
20.77\end{array}$ & $\begin{array}{l}1.10 \\
1.10 \\
1.17 \\
1.19 \\
1.19 \\
1.21\end{array}$ & $\begin{array}{l}0.65 \\
0.65 \\
0.65 \\
0.64 \\
0.64 \\
0.64\end{array}$ & $\begin{array}{r}100.00 \\
83.80 \\
9.40 \\
1.30 \\
0.40 \\
0.40\end{array}$ & $\begin{array}{r}20.77 \\
21.03 \\
20.20 \\
0.00 \\
0.00 \\
0.00\end{array}$ & $\begin{array}{l}1.21 \\
1.23 \\
2.22 \\
4.24 \\
4.10 \\
4.10\end{array}$ & $\begin{array}{l}0.64 \\
0.64 \\
0.52 \\
0.00 \\
0.00 \\
0.00\end{array}$ \\
\hline \multicolumn{14}{|c|}{$\frac{\text { Composit Data }}{\text { on }=100 . \overline{0 \%} \text { of the feed }}$} \\
\hline $\begin{array}{l}30 M \\
60 M \\
100 M \\
150 M \\
200 M\end{array}$ & $\begin{array}{r}30 M \\
60 M \\
100 M \\
150 M \\
200 M\end{array}$ & $\begin{array}{r}6.47 \\
50.59 \\
22.42 \\
9.19 \\
0.78 \\
10.54\end{array}$ & $\begin{array}{r}10.46 \\
10.46 \\
9.58 \\
9.73 \\
11.30 \\
14.66\end{array}$ & $\begin{array}{l}1.32 \\
1.32 \\
1.51 \\
1.63 \\
1.60 \\
1.46\end{array}$ & $\begin{array}{l}0.76 \\
0.78 \\
0.93 \\
0.89 \\
0.90 \\
1.04\end{array}$ & $\begin{array}{r}6.47 \\
57.07 \\
79.49 \\
88.68 \\
89.46 \\
100.00\end{array}$ & $\begin{array}{c}10.46 \\
10.46 \\
10.21 \\
10.16 \\
10.17 \\
10.65\end{array}$ & $\begin{array}{l}1.32 \\
1.32 \\
1.37 \\
1.40 \\
1.40 \\
1.41\end{array}$ & $\begin{array}{l}0.76 \\
0.78 \\
0.82 \\
0.83 \\
0.83 \\
0.85\end{array}$ & $\begin{array}{r}100.00 \\
93.53 \\
42.93 \\
20.51 \\
11.32 \\
10.54\end{array}$ & $\begin{array}{l}10.65 \\
10.66 \\
10.89 \\
12.32 \\
14.42 \\
14.66\end{array}$ & $\begin{array}{l}1.41 \\
1.41 \\
1.53 \\
1.54 \\
1.47 \\
1.46\end{array}$ & $\begin{array}{l}0.85 \\
0.86 \\
0.95 \\
0.96 \\
1.03 \\
1.04\end{array}$ \\
\hline
\end{tabular}


Table 11. Evaluation of Dryflo Separatcr Data for Test 13 (PSOC-B5 Anthracite)

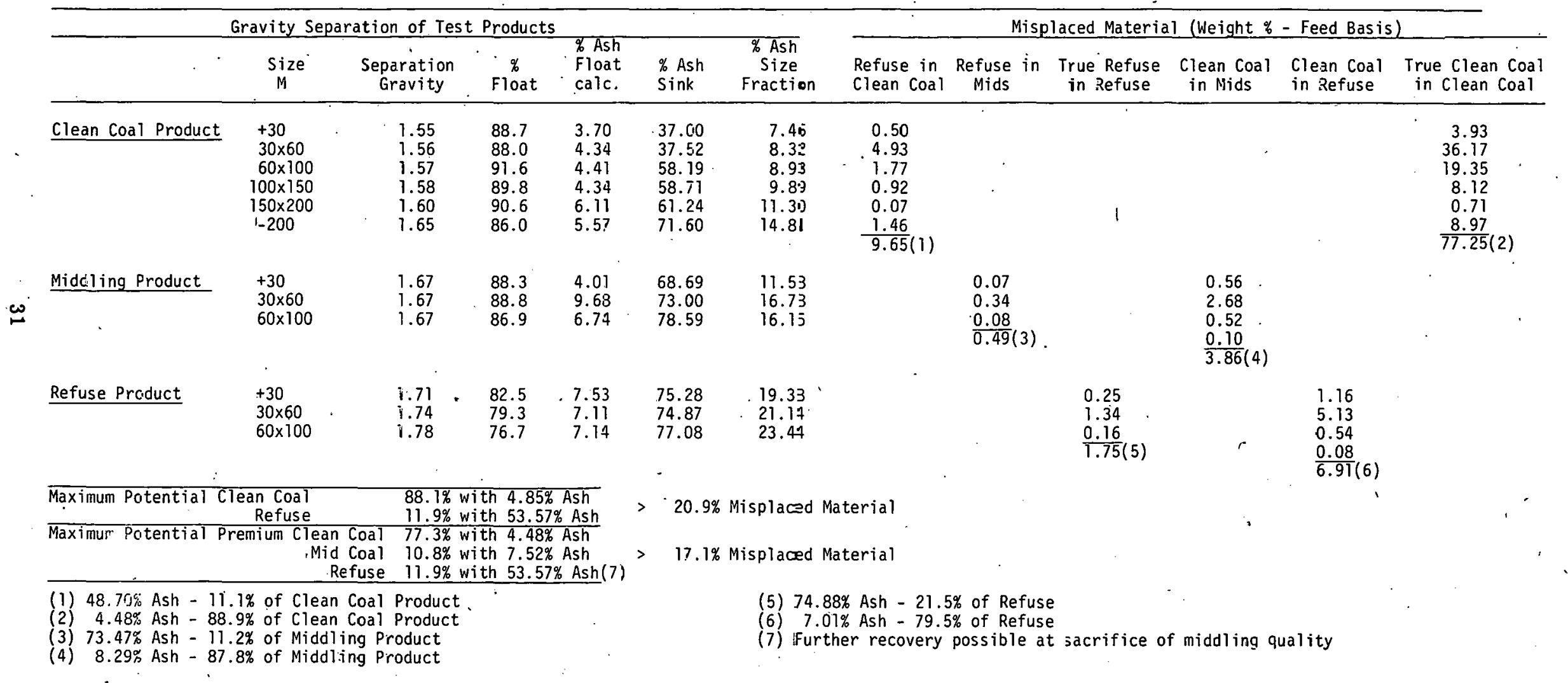




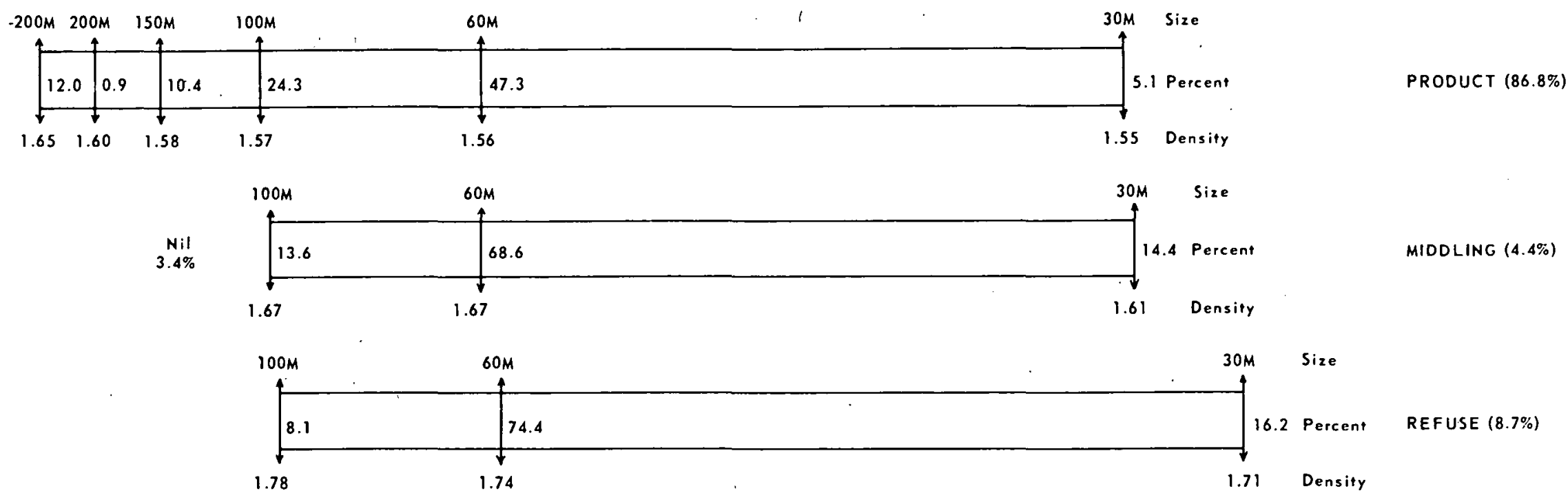

TERMINAL SETTLING VELOCITIES OF PARTICLES CONSIDERED IN DRYFLO SEPARATOR TEST 13 - PSOC.85 - SEPARATION CHARACTERISTICS

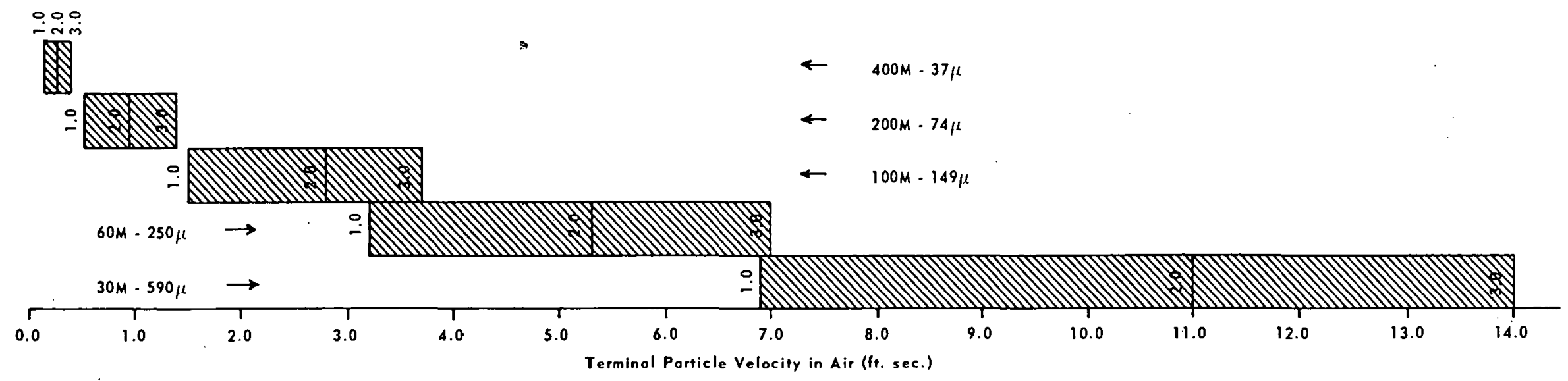

THEORETICAL TERMINAL SETTLING VELOCITIES

(Lapple, et al., "Fluid and Particle Mechanics", Univ. Delaware, 1951, p. 292)

Figure 4. TERMINAL SETTLING VELOCITIES 


\section{EVALUATION OF THE GASIFICATION POTENTIAL' OF COALS}

\section{Introduction}

The final design of the pressurized laminar-flow isothermal reactor is nearly complete, al though now two months behind schedule. Complete engineering drawings have been submitted by the subcontractor, Autoclave Engineers, Inc., for our review. A meeting to finalize the plans was held March 77 th. Immediate approval of all design aspects and components is anticipated except. for the coal feed and venturi system, and the separator vessel, both of which require further design study. Autoclave Engineers has reconfirmed the quoted date of delivery of the equipment. The job planning diagram provided by Autoclave indicates the present progress toward completion of this project (Figure 5).

\section{Experimental}

Values of reaction rates in coke beds have been calculated from experiments with a fixed bed shaft gasifier (combustion pot), assuming diffusion dominated reaction in the oxidation region and chemical kinetic controlled reaction in the gasification region.

In the second quarterly report the analysis of the bed assumed equal (diffusional) rate constants for the two heterogeneous reactions of this three-reaction sequence: carbon reacting heterogeneously with oxygen and carbon dioxide to form carbon monoxide, with carbon monoxide reacting homogeneously with oxygen in the pores of the bed to form carbon dioxide, permitting an analytical solution. However, the experimental results showed this to be less than adequate as evidence by the graph presented. Now, using different rate constants for the two heterogeneous reactions, it follows that the equation for the variation of gas composition with time in the bed is

$$
\left(Y_{1}+1 / 2 Y_{2}\right) /\left(1-1 / 2 Y_{3}\right)=A e^{-n_{1} t}+B e^{-n_{2} t}+C
$$

where $Y_{1}, Y_{2}$, and $Y_{3}$ are mole fractions of oxygen, carbon dioxide, and carbon monoxide respectively, $n_{1}$ and $n_{2}$ are modified rate constants for the two heterogeneous reactions, and $A, B$, and $C$ are constants.

Experimental verification of the developed equation is still underway, but useful conclusions have been drawn from the data collected so far in experiments using coke beds. Using this expression, we have determined the diffusional rate constants $n_{1}$ from the slopes of semilogarithmic plots (Figure 6). Data for the curves were collected at 


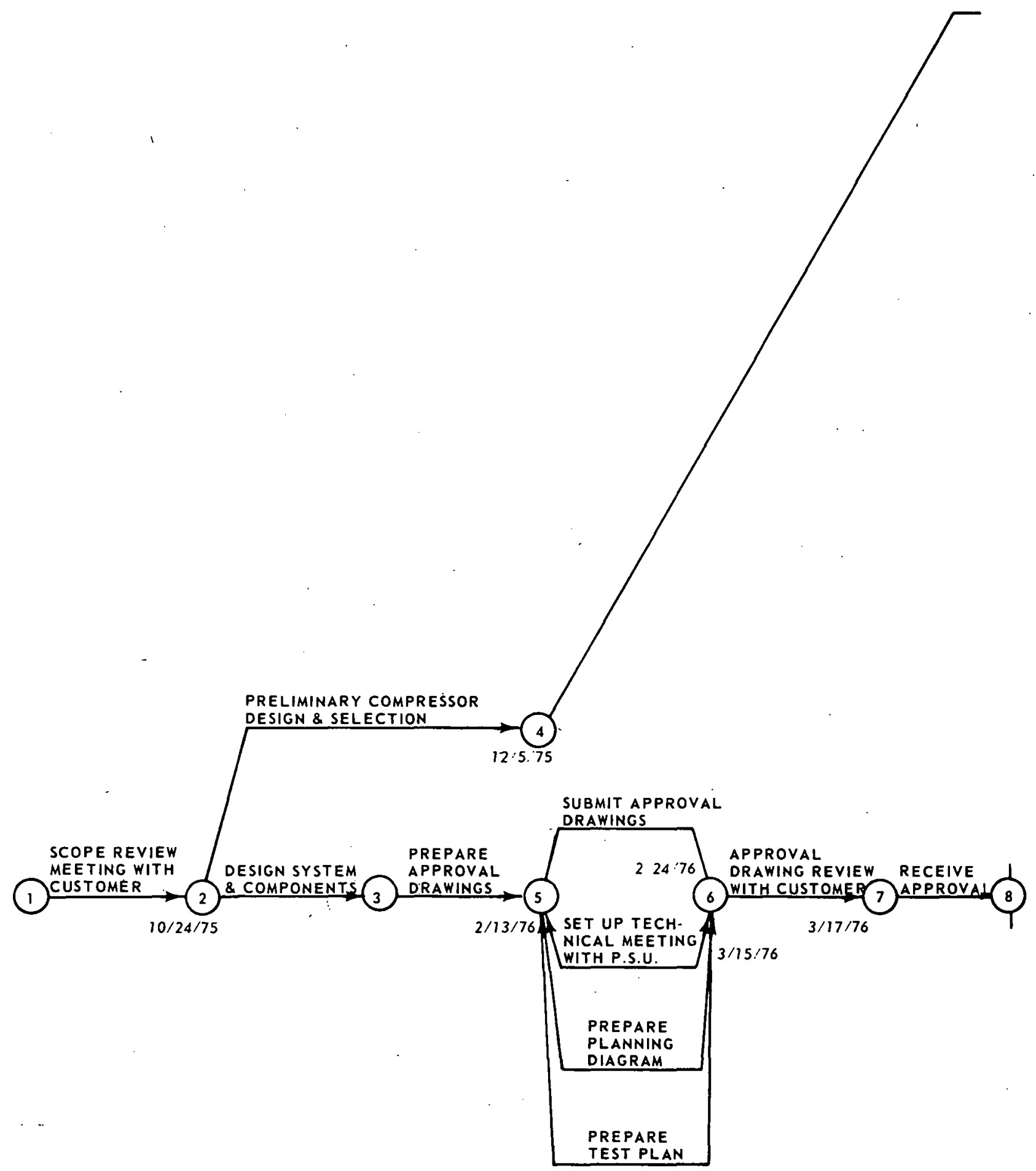

Figure 5. JOB PLANNING DIAGRAM FOR CONSTRUCTION OF ISOTHERMAL REACTOR (Autoclave Engineers, Inc.) 


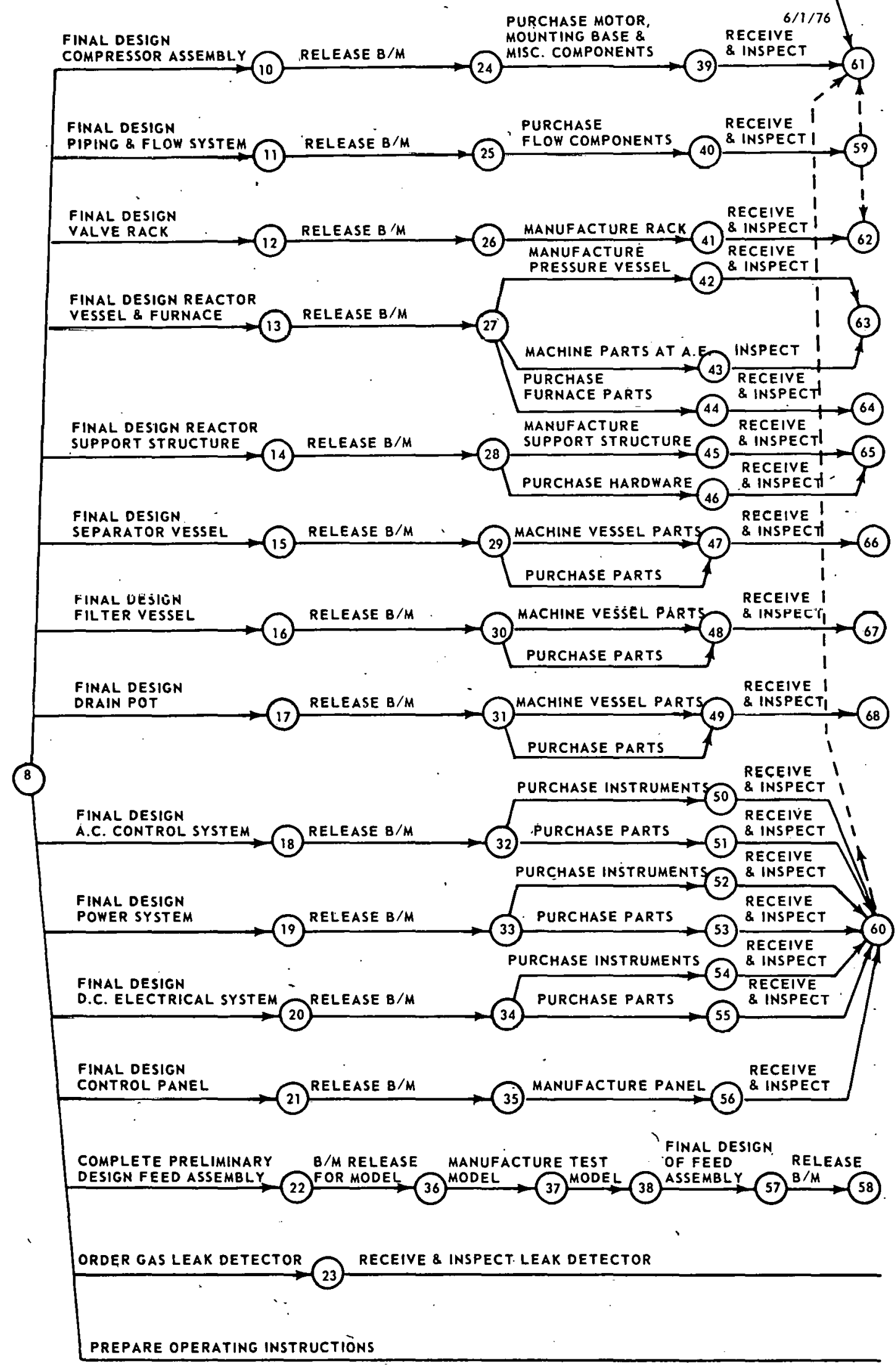




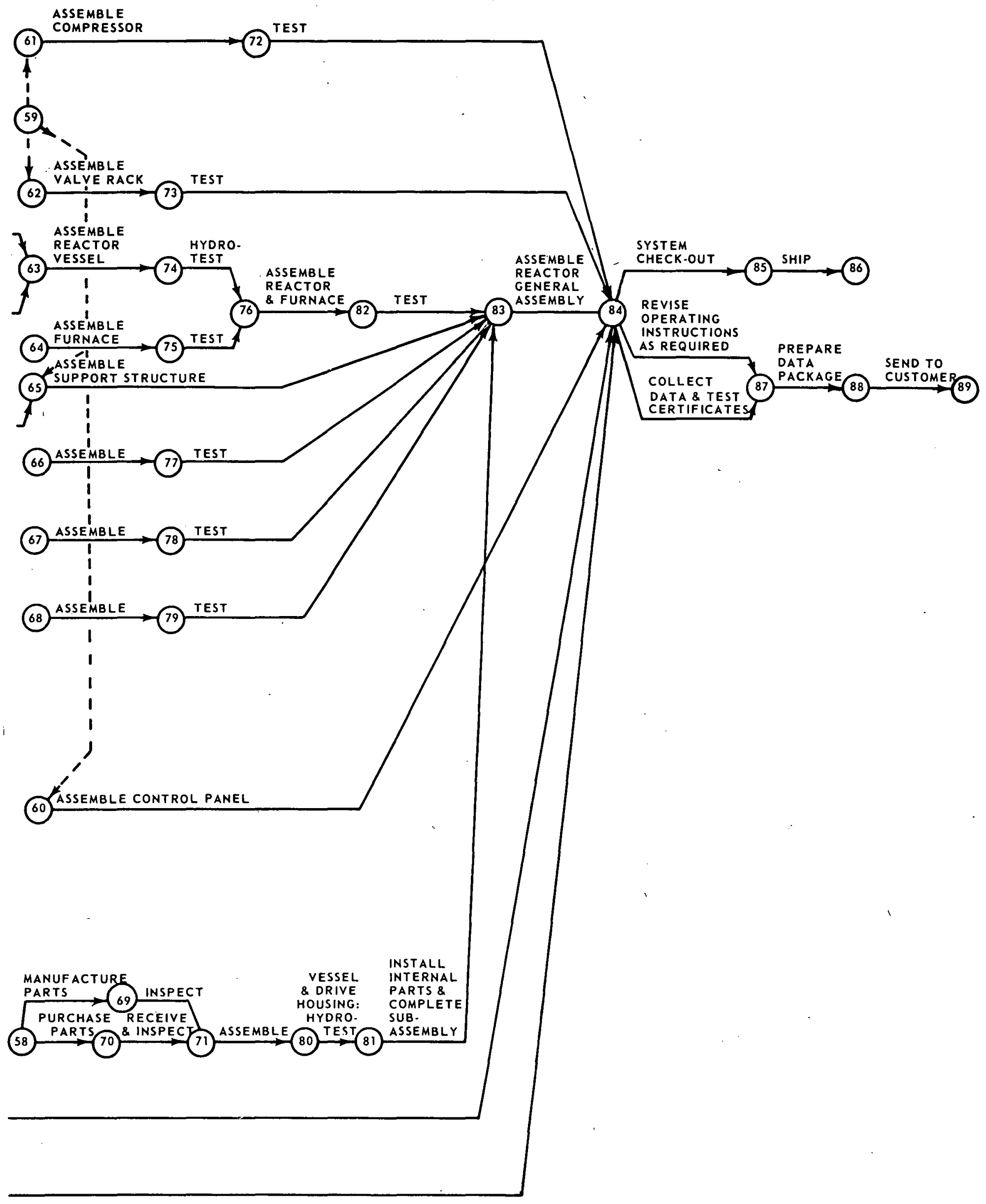




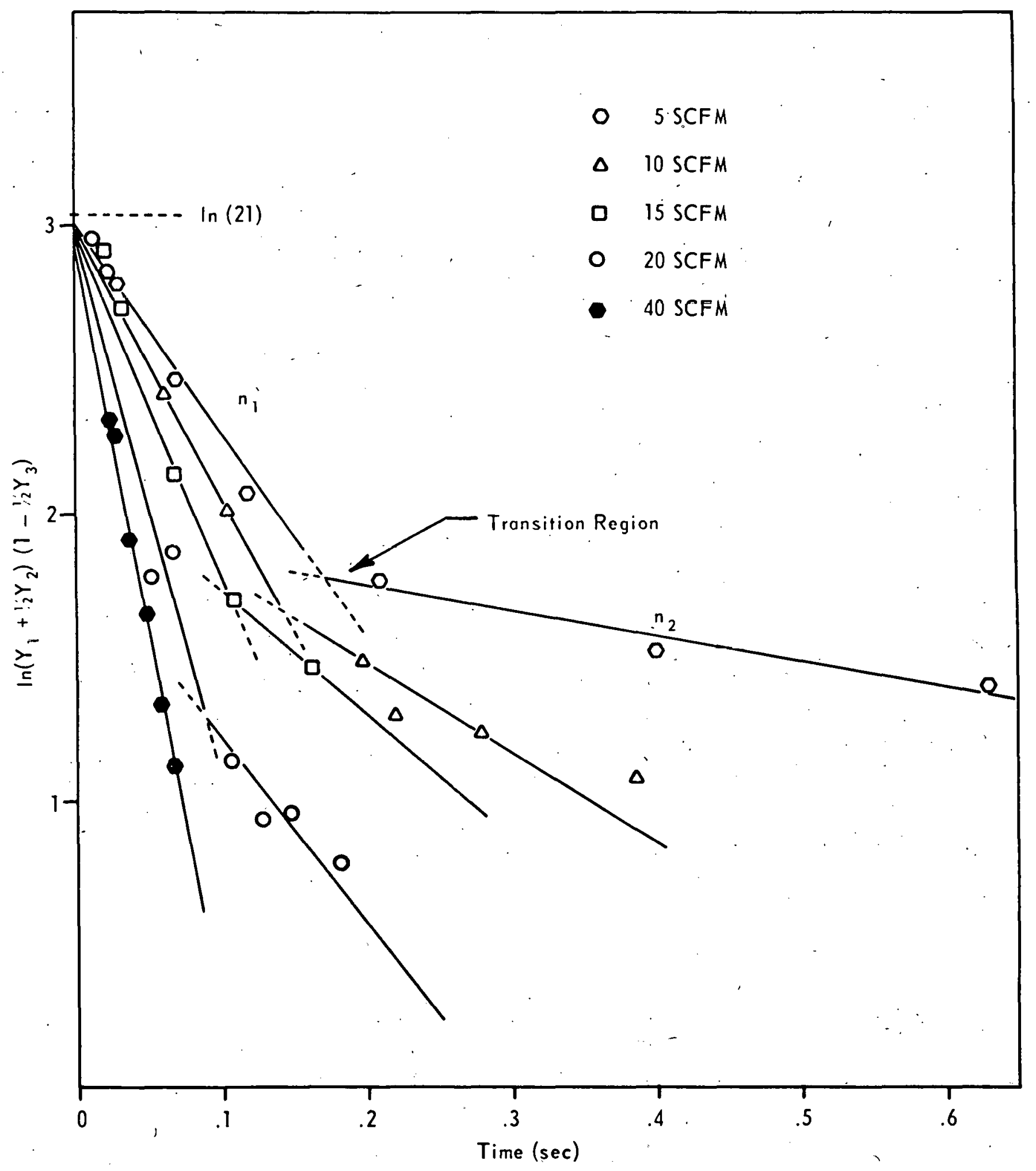

Figure 6. VARIATION OF $\ln \left(Y_{1}+1 / 2 Y_{2}\right) /\left(1-1 / 2 Y_{3}\right)$ WITH TIME FOR (0.75-1.25") SIZE COKE BED 
- five different flow rates $(5,10,15,20$, and 40 SCFM). A representative curve is approximated by two intersecting straight lines. All the curves originate at 21 percent on the ordinate as evidenced by the equation (at $t=0, Y_{2}=Y_{3}=0$, and $Y_{1}=Y_{1}{ }^{\circ}$, the initial percentage of oxygen). They decline with a'slope $n_{1}$ to the point where oxygen virtually vanishes. Beyond a narrow transition region they continue to decline with slope $n_{2}$ until the temperature is below the point where any further reduction of carbon dioxide to carbon monoxide is possible.

The values of $n_{1}$ and $n_{2}$ are found to increase with velocity and/or temperature. Interpreting $n_{1}$ as the mass transfer rate constant, a loglog plot of $n_{1}$ vs velocity gives a.straight line with slope 0.76 (Figure 7 ) This is in good agreement with the value 0.7 given in the literature.10

In addition, the Reynolds numbers through the bed pores are in the laminar range with highest values about 200 . These results support the diffusion dominance mechanism in the oxidation region of the combustion pot.

The transition to a second region of linear decline of in $\left(Y_{1},+\right.$ $\left.1 / 2 \gamma_{2}\right) /\left(1-1 / 2 Y_{3}\right)$ with time suggests a chemical kinetic dominance region. In that case a chemical rate constant $n_{2}$ is expected to depend more on temperature than on velocity, and the changes in slope may be attributed actually to temperature variations. (Of course the velocity and temperature are interdependent since burning rate, and hence the temperature of the bed, increases with velocity).

As reported in the second quarterly report the temperature measurements have been started (Figures 8 and 9 ). Over all experiments average temperatures ranged from $1200^{\circ} \mathrm{C}$ to $1500^{\circ} \mathrm{C}$. The temperature varied with porosity (particle size) and velocity; but in a given experiment temperature at any point varied little throughout the experimental run.(Figure 9). Furthermore, the temperature was approximately uniform throughout the bed, rising very rapidly in the first half to orie inch above the cold grate. There was a peak in most experiments about the middle of the oxygen depletion region, with temperature falling slightly toward the top of the bed, mostly by less than $250^{\circ} \mathrm{C}$.

\section{Conclusion}

The results obtained so far show support of a diffusion dominance mechanism in the oxidation region of a combustion pot and a chemical kinetic mechanism in the gasification region. Work is underway to study the influence of particle size and velocity and temperature on the diffusional rate. 
<smiles>C1C2CC12</smiles> 


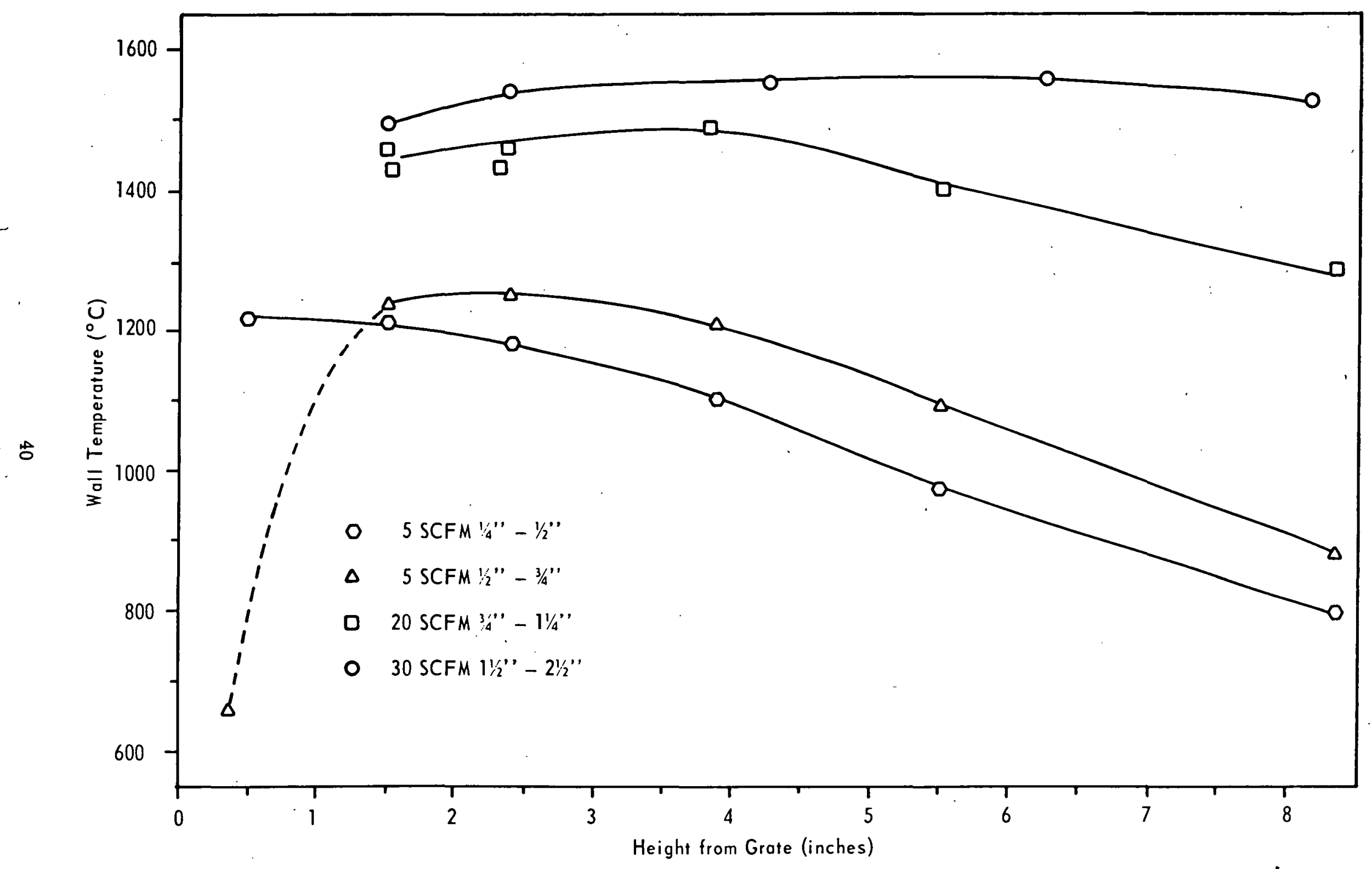

Figure 8. WALL TEMPERATURE VS HEIGHT FOR FOUR RUNS 


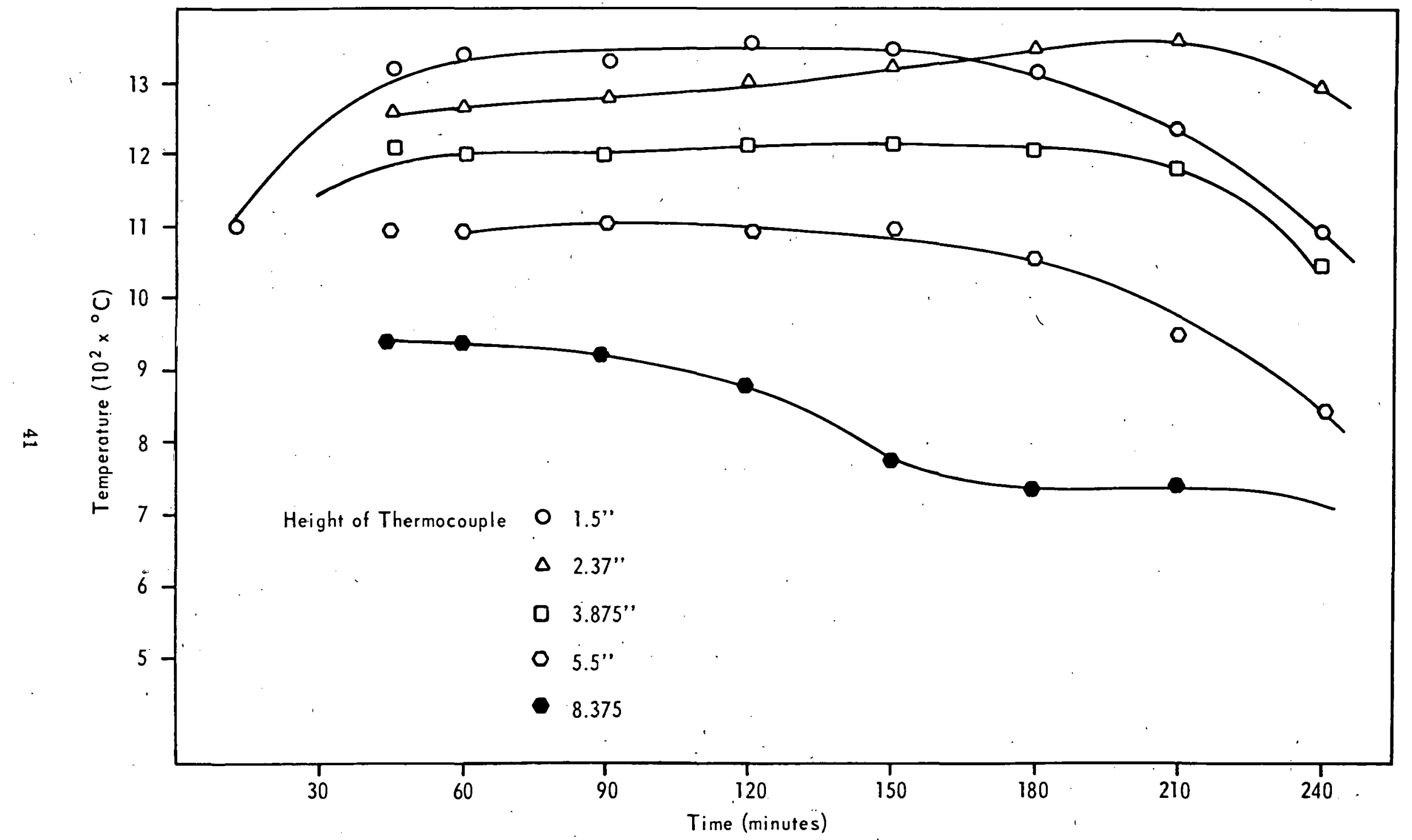

Figure 9. VARIATION OF TEMPERATURE OVER AN EXTENDED RUN (0.25-0.5" COKE AT 5 SCFM) 


\section{CHARACTERISTICS OF CHARS PROOUCED UPON RAPID DEVOLATILIZATION}

\section{OF NORTH DAKOTA LIGNITE}

\section{Introduction}

The first quarter of 1976 was devoted to three major research tasks. First a large amount of North Dakota lignite (PSOC-246) originally sizegraded to $140 \times 200$ mesh was devolatilized in a laminar flow reactor under the experimental conditions specified in the ERDA Quarterly Report of December 1975. The resulting char collected after a transit distance of $30.48 \mathrm{~cm}$ was subsequently recycled into the reaction zone. This recycling process was continued four times, giving a cumulative isothermal decomposition time of about one second.

Next, the extent of thermal decomposition (i.e. weight loss or simply volatile matter release) of the char before each recycling was determined, using ash as a tracer.

Finally, each of these chars was subjected to behavior characterization techniques, in order to determine its structure and physical properties (e.g. porosity, mercury and helium densities, nitrogen and carbon dioxide surface areas, etc.).

The results from these studies show that: (1) weight loss is a strong function of isothermal decomposition $\left(\tau_{i s o}\right),(2)$.physical properties such as nitrogen and carbon dioxide surface areas, mercury and helium 'densities, porosities, etc., also vary significantly with $\tau_{\text {iso' }}$ (3) weight loss contributes to the development of nitrogen and carbon dioxide surface areas, and (4) x-ray diffraction patterns show a rather sharp peak at $26.6^{\circ}$ in $2 \theta$ angles. It is believed that this peak is due to impure silicon dioxide $\left(\mathrm{SiO}_{2}\right)$, not to carbon.

\section{Experimental}

The cases under study are shown in Table 11, namely:

Case I is for the raw coal.

Case II is for char collected after a transit distance of $30.48 \mathrm{~cm}$.

Case III is for char recycled one time at a transit distance of $30.48 \mathrm{~cm}$. Case IV is for char recycled two times at a transit distance of $30.48 \mathrm{~cm}$. Case V:is for char recycled three times at a transit distance of $30.48 \mathrm{~cm}$. Case VI is for char recycled four times at a transit distance of $30.48 \mathrm{~cm}$.

The raw coal as well as all of the chars were subjected to studies for weight loss ánd characteristics as shown below. 
Table 11. Dependence of Weight Loss $(\Delta W)$ on Residence Time $(\tau)$ for PSOC-246 Originally Sized to $140 \times 200$ Mesh $(\bar{X}=86 \mu \mathrm{m})$

\begin{tabular}{ccccccc}
\hline & \multicolumn{2}{c}{ Residence Time $(\tau)$, sec } & & $\%$ Ash \\
Case & Heating & Isothermal & Total & (dry) & $\begin{array}{c}\Delta W \\
\text { of Original } \\
\text { daf coal) }\end{array}$ \\
\hline I & - & - & - & 7.29 & - \\
II & 0.095 & 0.205 & 0.300 & 9.56 & 25.18 \\
III & 0.190 & 0.410 & 0.600 & 10.32 & 31.67 \\
IV & 0.285 & 0.615 & 0.900 & 10.82 & 35.19 \\
V & 0.380 & 0.820 & 1.200 & 11.44 & 39.13 \\
VI & 0.475 & 1.025 & 1.500 & 11.99 & 42.28 \\
\hline
\end{tabular}

Weight loss $(\Delta W)$ was determined using ash as a tracer (as specified in the December 1975 ERDA Report). The data obtained from these determinations (Table 11), are used in plotting weight loss vs isothermal decomposition time (Figure 10). The solid curves in this figure are predicted by Badzioch and Hawksley equation. ${ }^{11}$ It is seen here that experimental results from the $140 \times 200$ mesh size grade deviate quite drastically at longer isothermal decomnnsition times. The deviations for the other two size grades ( $70 \times 100$ and $200 \times 270$ mesh) are less serious. Comparison between experimental and theoretical (i.e. predicted by the Badzioch and Hawksley, equation) results are better illustrated in Figure 11 . The deviation from the $140 \times 200$ mesh size fraction is again reflected in this figure.

The samples referred to in Table 11 have also been subjected to various characterization techniques (see report of January 1975). Due to the incompleteness of these studies, only a limited amount of data will be presented here.

Nitrogen and carbon dioxide surface area data (Table 12) are plotted vs isothermal decomposition time (Figure 12).

Appropriate data in Tables 12 and 13 are then used to correlate nitrogen and carbon dioxide surface areas with weight loss. The correlation shows (Figure 13) that volatile matter release during devolatilization contributes rather significantly to the development of nitrogen and carbon dioxide surface areas.

The samples in Table 11 and the other ones (Table 13) were subjected to $x$-ray diffraction studies. The aim was to see whether appreciable crystallinity of the materials develops under our devolatilization conditions, since coal devolatilization is indeed a graphitization process. 


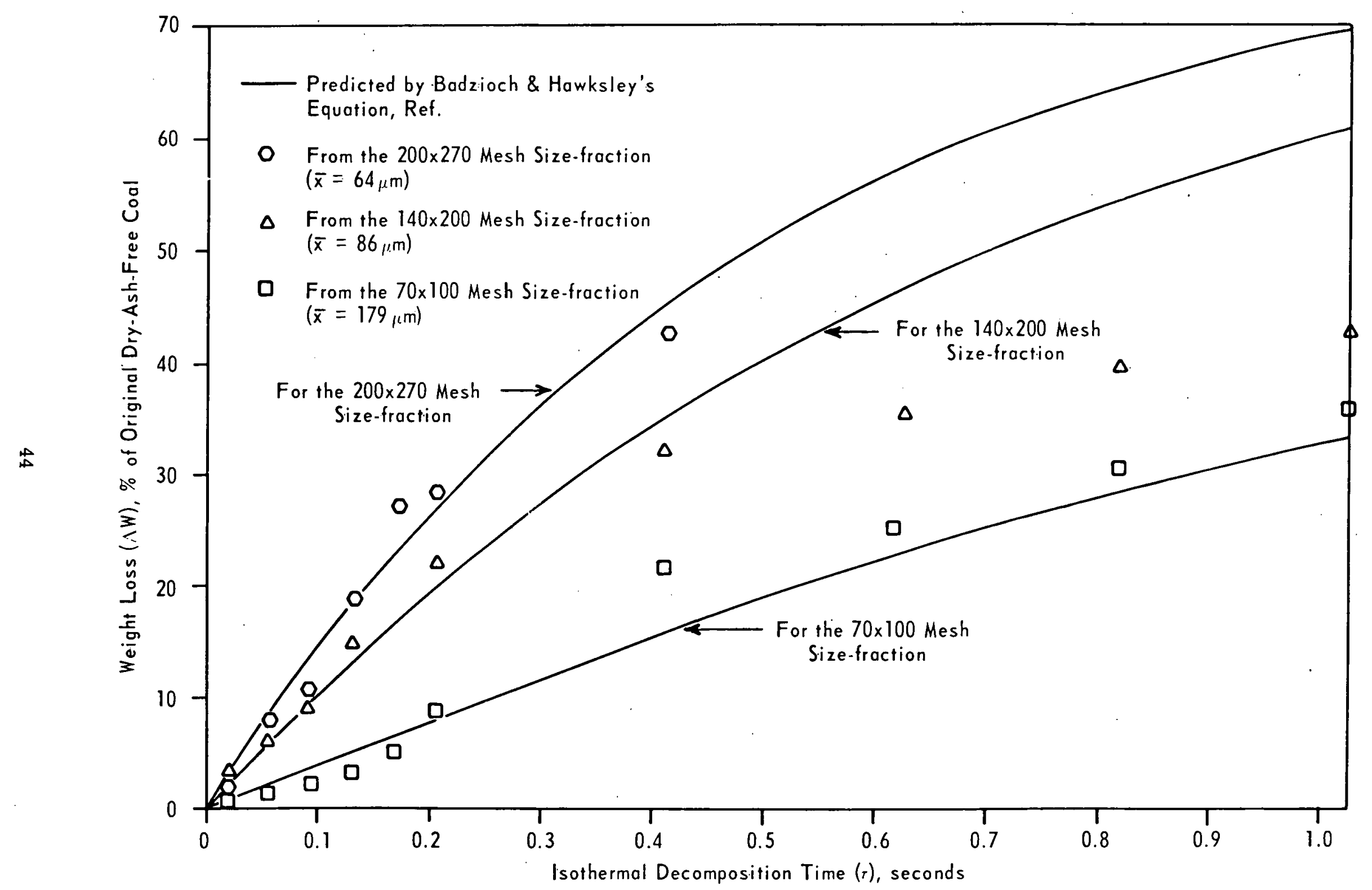

Figure 10. DEPENDENCE OF WEIGHT LOSS ON RESIDENCE TIME FOR PSOC-246 


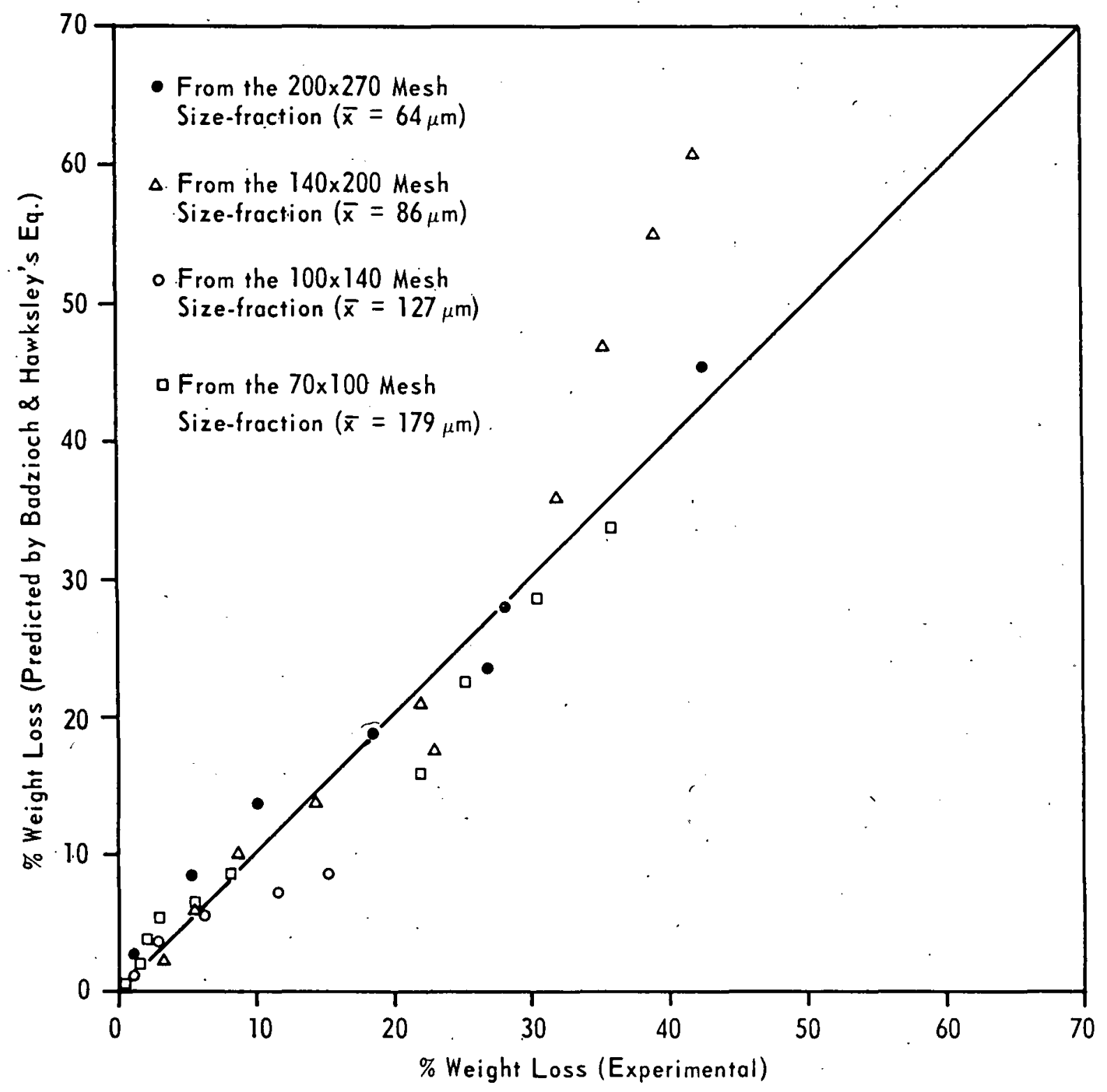

Figure 11. WEIGHT LOSS ( $\triangle W$ ): PREDICTED VS EXPERIMENTAL FOR PSOC-246 
Table 12. Dependence of Nitrogen and Carbon Dioxide Surface Areas on Residence Time $(\tau)$ for PSOC-246 Originally Sized to $140 \times 200$ Mesh $(\bar{X}=86 \mu \mathrm{m})$

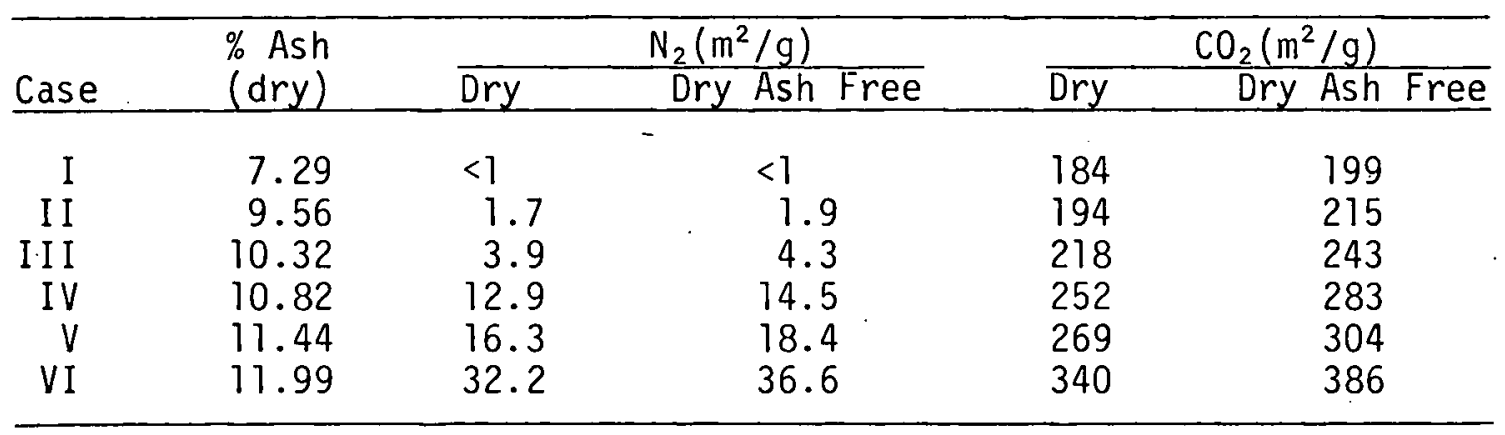

Table 13. X-ray Data

\begin{tabular}{|c|c|c|c|c|c|c|c|c|}
\hline \multirow[b]{2}{*}{ Case } & \multicolumn{2}{|c|}{$\begin{array}{l}70 \times 100 \text { mesh } \\
(\bar{X}=179 \mu \mathrm{m})\end{array}$} & \multicolumn{2}{|c|}{$\begin{array}{l}100 \times 140 \text { mesh } \\
(\bar{x}=127 \mu \mathrm{m})\end{array}$} & \multicolumn{2}{|c|}{$\begin{array}{c}140 \times 200 \text { mesh } \\
(\bar{X}=86 \mu \mathrm{m})\end{array}$} & \multicolumn{2}{|c|}{$\begin{array}{c}200 \times 270 \text { mesh } \\
(\bar{X}=64 \mu \mathrm{m})\end{array}$} \\
\hline & ${ }^{d}(101)$ & $L_{(101)}$ & ${ }^{d}(101)$ & $L_{(101)}$ & $\mathrm{d}(101)$ & $\mathrm{L}(101)$ & ${ }^{d}(101)$ & $\mathrm{L}(101)$ \\
\hline I & 3.36 & 241 & 3.36 & 241 & 3.36 & 241 & 3.36 & 241 \\
\hline I I & 3.36 & 28 & - & - & 3. & 2 & 3.3 & 2 \\
\hline I I I & 3.35 & 352 & - & - & 3.36 & 28 & 3.36 & 352 \\
\hline IV & 3.37 & 352 & - & - & 3.36 & $2 \varepsilon$ & 3.35 & 285 \\
\hline V & 3 & 35 & - & 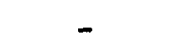 & 3.35 & 28 & 3.35 & 285 \\
\hline VI & & 44 & - & - & & 53 & 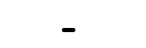 & 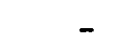 \\
\hline VII & 3.35 & 285 & 3.35 & 285 & 3.35 & 285 & 3.35 & 285 \\
\hline & 2.03 & 300 & 2.03 & 300 & 203 & 300 & 2.03 & 300 \\
\hline
\end{tabular}

Case VII is for chars obtained in a fluid bed.

The (002) reflection at $\sim 26.6^{\circ}$ in $2 \theta$ angles was scanned to characterize the carbon structure. The peak found in this region was generally sharper for chars than for raw lignite. The Bragg equation has been used to determine its interlayer spacing, i.e.

$$
d_{(n k 1)}=\frac{\lambda \text { CuK }_{\alpha}}{2 \sin 0(h k 1)}
$$




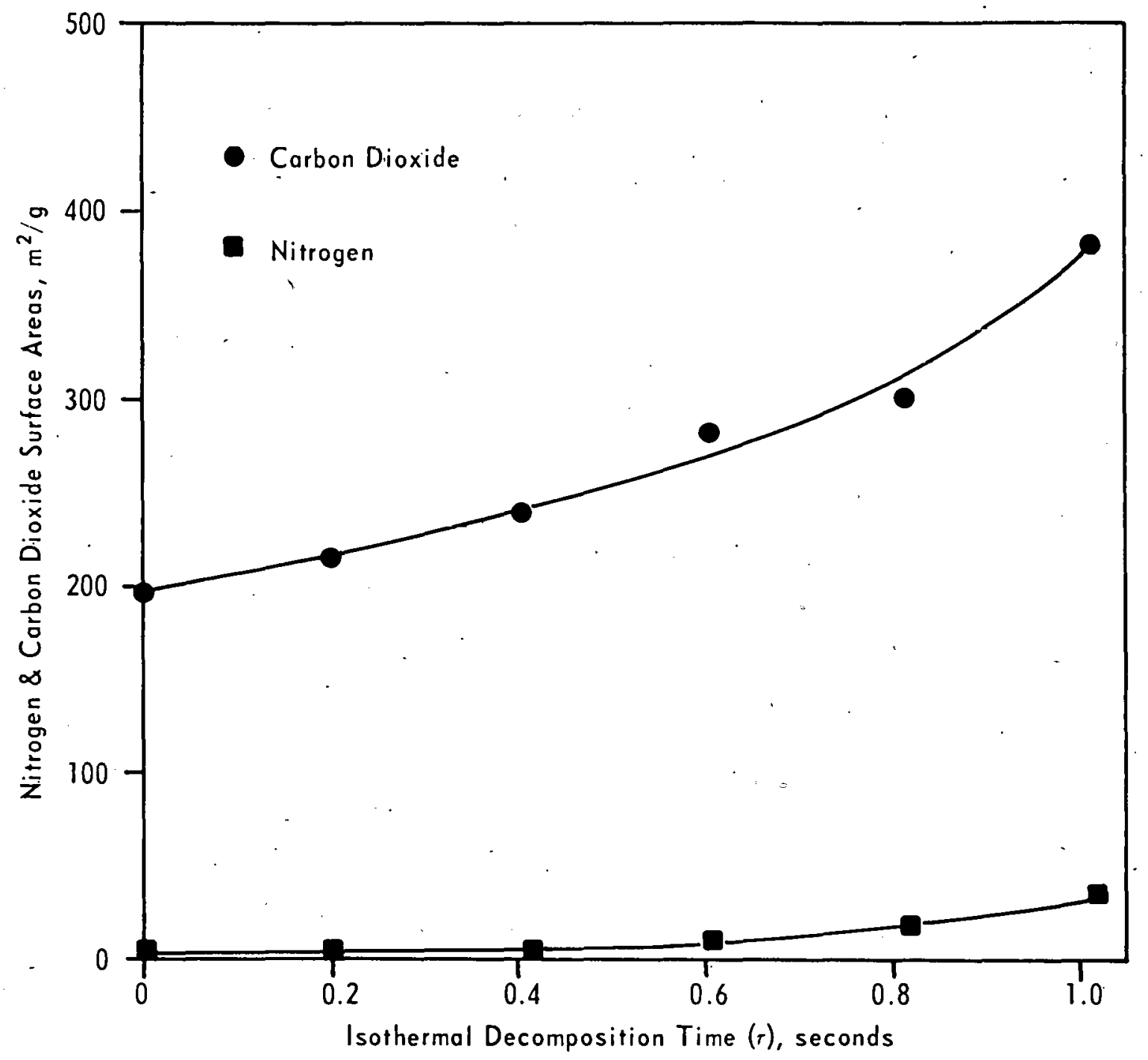

Figure 12. CHANGE OF SURFACE AREAS WITH ISOTHERMAL DECOMPOSITION TIME FOR PSOC-246 ORIGINALLY SIZED TO 140×200 MESH 


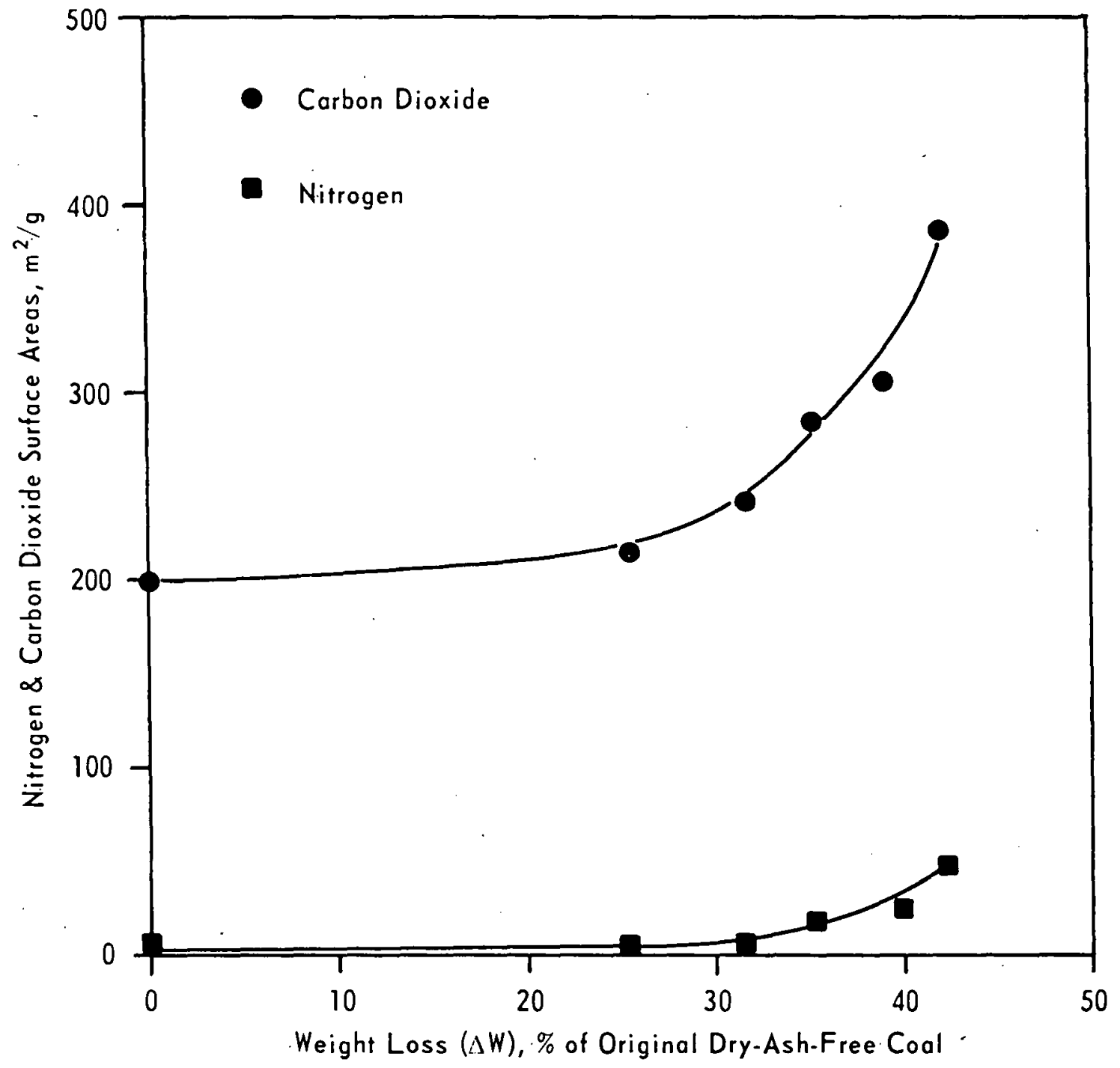

Figure 13. CORRELATION BETWEEN SURFACE AREAS AND WEIGHT LOSS FOR PSOC-246 ORIGINALLY SIZED TO 140X200 MESH 
where $d_{(h k l)}$ is the interlayer spacing and $\lambda \mathrm{CuK}_{\alpha}=1.54812 \mathrm{~A}$. The average d-spacing (Table 13) is about 3.36A. This value, coupled with the sharpness of the peak indicates that this peak was due to a mineral rather than to carbon. Demineralization of the raw sample and one of the chars (Case VI for the $140 \times 200$ mesh size grade) with hydrochloric acid and hydrofluoric acid caused complete disappearance of the peak, thus supporting our hypothesis. A survey of the ASTM data file narrowed the choices to $\alpha-$ quartz and impure silicon dioxide. Further evidence suggests that the peak is the result of a (101) reflection from impure silicon dioxide.

The other peak found in fluid bed chars only at $\sim 44.6^{\circ}$ in $2 \theta$ angles (i.e. $d_{(h k l)}=2.03 \mathrm{~A}$ ) is believed to be due to a yet unidentified mineral. An LTA sample is in the process of being submitted to the Mineral Constitution Laboratory of The Pennsylvania State University for major elements analysis.

The crystallite size was determined from Scherrer equation. ${ }^{22}$ In order to deterinine accurate crystallite size, two corrections are made: $\theta$ and instrument time broadening. Using a sodium chloride internal standard, we found that there was no need for $\theta$ correction. The correction for the time line broadening, $\beta$, due only to crystallite size was carried out using quartz as an internal standard. Next the method of Klug and Alexander ${ }^{13}$ was used to obtain the correct $\beta$ value in radians. This value was then substituted in the Scherrer equation: ${ }^{2}$

$$
L_{(101)}=\frac{{\mathrm{K} \lambda \mathrm{CuK}_{\alpha}}_{\beta \cos \theta}(101)}{\beta}
$$

where $L_{(101)}$ is the crystallite size and $K=$ shape factor $\simeq 1$. All $x$-ray data are given in Table 13.

Since devolatilization is also a decarboxylation process, it should be of interest to see whether our experimental conditions are such that the carboxylic groups of PSOC-246 are altered. In conjunction with this, a Fourier Transform Infra-red Spectroscopy (FTIR) study of some of the samples presented in Table 11 is underway. 
FACET IV-B: COKES AND CHARS

REACTIVITIES OF AMERICAN COAL CHARS IN AIR

Introduction

Reactivity of a char increases with increase in partial pressure of oxygen. Effect of particle size on char reactivity will be discussed.

Reactivity of the most reactive char (PSOC-91) has been studied at $405^{\circ} \mathrm{C}$ in different mixtures of oxygen and nitrogen. The char reactivity increases with increase in partial pressure of oxygen. Effect of particle size on char reactivity has been studied in the case of two chars: a low volatile bituminous char (.PSOC-127) and a lignite char (PSOC-87). Reduction in particle size increases the reactivity- of both raw and demineralized-PSOC-127 char. However,' in the case of raw and demineralized PSOC-87 chars reactivities are almost independent of particle size. Relative reactivities of various chars in air and carbon dioxide are the same.

\section{Experimental}

In the last ERDA Report, it was reported that reactivity of a char increases with increase in partial pressure in oxygen. "These reactivity runs were made at $500^{\circ} \mathrm{C}$. However, it was subsequently discovered that due to high exothermicity. of the carbon-oxygen reaction, char reactivities were not independent of bed height. Reactivities were found to be independent of bed height at $405^{\circ} \mathrm{C}$. Therefore, the effect of the partial pressure of oxygen on reactivity of PSOC-91 (the most reactive char) was studied at $405^{\circ} \mathrm{C}$. The results are listed in Table 14. It is significant to note that $R_{0}$ increases almost 4.6 fold upon increasing the proportion of oxygen from 2 to 21 percent with the reiationship $R_{0}$, proportional to (oxygen pressure) ${ }^{0.71}$ as seen in Figure 14. Partial pressure of oxygen also has a marked effect on reactivity profiles (Figure 15). It is noteworthy that all of the reactivity plots in Figure 15 coincide if the data are normalized (Figure 16). Normalization was done in the following manner. In each case, time corresponding to 50 percent burnoff was noted. These times were found to be in the ratio 1.45:1.0:0.34 for the reaction in oxygen-nitrogen mixtures containing 2, 4, and 21 percent oxygen, respectively. For normalizing the data, time corresponding to a given burn-off in the 2 and 21 percent runs was divided by 1.45 and 0.34 respectively. The norimalized curves plotted in Figure 16 suggest that although gasification rates increase with increase in partial pressure of oxygen; the mechanism of gasification of a given char in air is independent of the partial pressure of oxygen. 
Table 14. Influence of Oxygen Partial Pressure on Reactivity of PSOC-91 Char at $405^{\circ} \mathrm{C}$

\begin{tabular}{|c|c|}
\hline $\begin{array}{c}\mathrm{O}_{2} \text { in } \mathrm{O}_{2}-\mathrm{N}_{2} \text { Mixture } \\
(\%)\end{array}$ & $\begin{array}{l}\text { Reactivity }\left(R_{0}\right) \\
\left(m g h r^{-1} \mathrm{mg}^{-1}\right)\end{array}$ \\
\hline $\begin{array}{r}2 \\
4 \\
10 \\
15 \\
21\end{array}$ & $\begin{array}{l}0.60 \\
0.94 \\
1.9 \\
2.5 \\
2.7\end{array}$ \\
\hline
\end{tabular}

The effect of particle size on the reactivity of a lignite char (PSOC-87) and a low volatile bituminous char (PSOC-127) is illustrated by the data listed in Table 15 . An increase in reactivity upon reduction of particle size of a carbon indicates that gasification rate is partly diffusion-controlled. In the case of PSOC-87 raw char, reactivity decreases slightly upon particle size reduction from $40 \times 100$ to $100 \times 150$ mcsh and increases upon further reduction to $200 \times 325$ mesh. The decrease in reactivity with decrease in particle size is contrary tó expectations. It is suggested that the decrease is due to separation of beneficial catalytic mineral matter from the coal matrix during grinding or to different particle size fractions having different maceral composition. In this context, Davis and Reynolds ${ }^{14}$ have previously reported that different particle size cuts derived from the same coke had different mineral matter contents. Reactivities of various size fractions of the PSOC-87 demineralized char are about the same and are invariably less than those of the corresponding size fractions of the raw char.

A decrease in particle size of PSOC- 127 from $40 \times 100$ to $200 \times 325$ mesh leads to an increase in char reactivity of almost two-fold. This increase is significantly greater than that observed in the case of PSOC-87 raw char. This is presumably because of the lower nitrogen surface (feeder porosity) of the PSOC-127 char. It is noteworthy that, for each particle size, the reactivity of the PSOC-127 demineralized char is almost 10 times higher than that of the raw char. Such increases have previously been attributed to the opening of feeder pores; the increase in porosity resulting in a substantial decrease in mass transport control of gasification. ${ }^{15}$

It is significant that reactivities of the $200 \times 325$ mesh fractions of the PSOC-87 and 127 demineralized chars are about the same although reactivity of the former char is twice that of the latter for the $40 \times 100$ mesh fraction. 


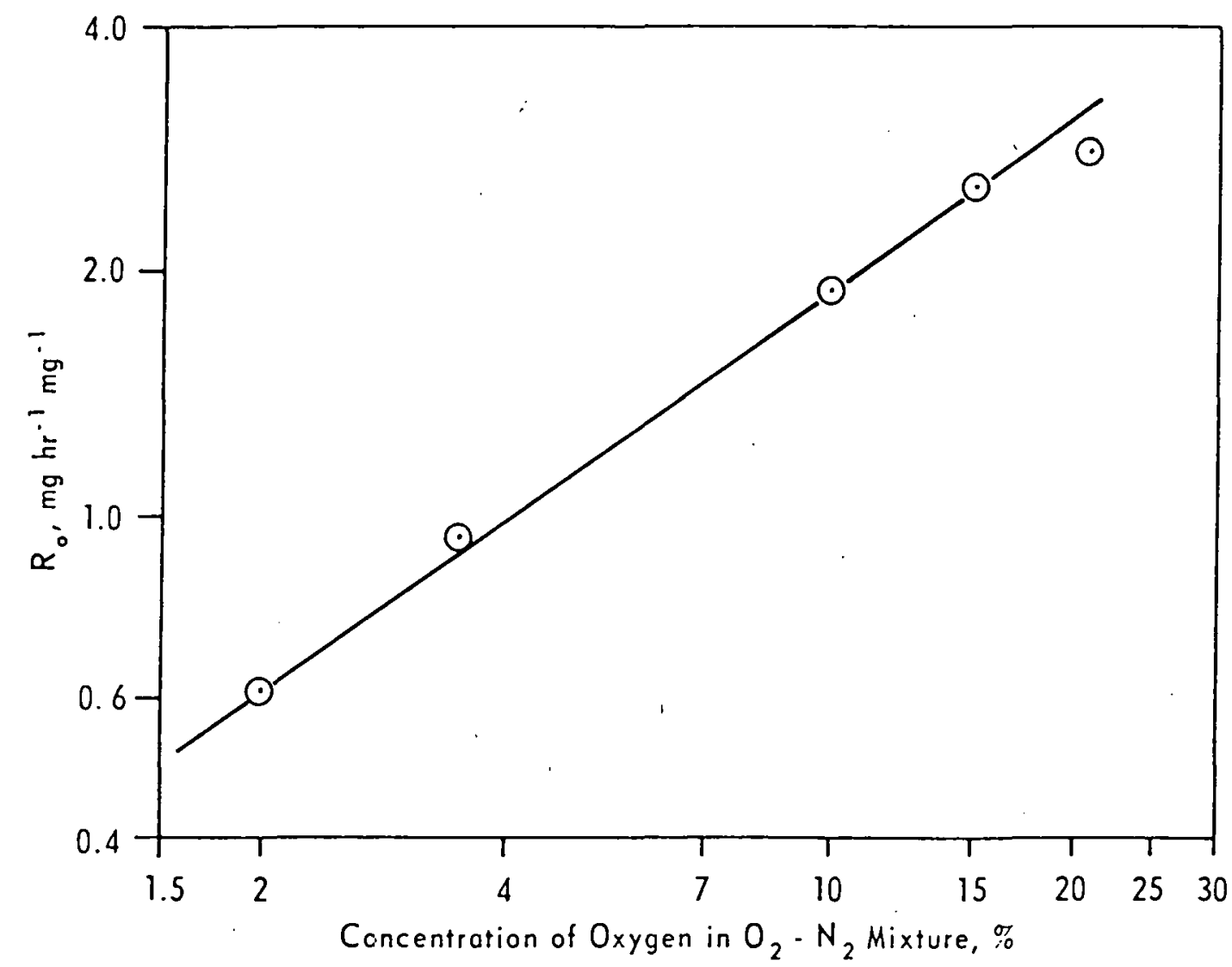

Figure 14. INFLUENCE OF OXYGEN PARTIAL PRESSURE (TOTAL PRESSURE 1 ATM) ON THE REACTIVITY OF PSOC-91 CHAR AT $405^{\circ} \mathrm{C}$ 


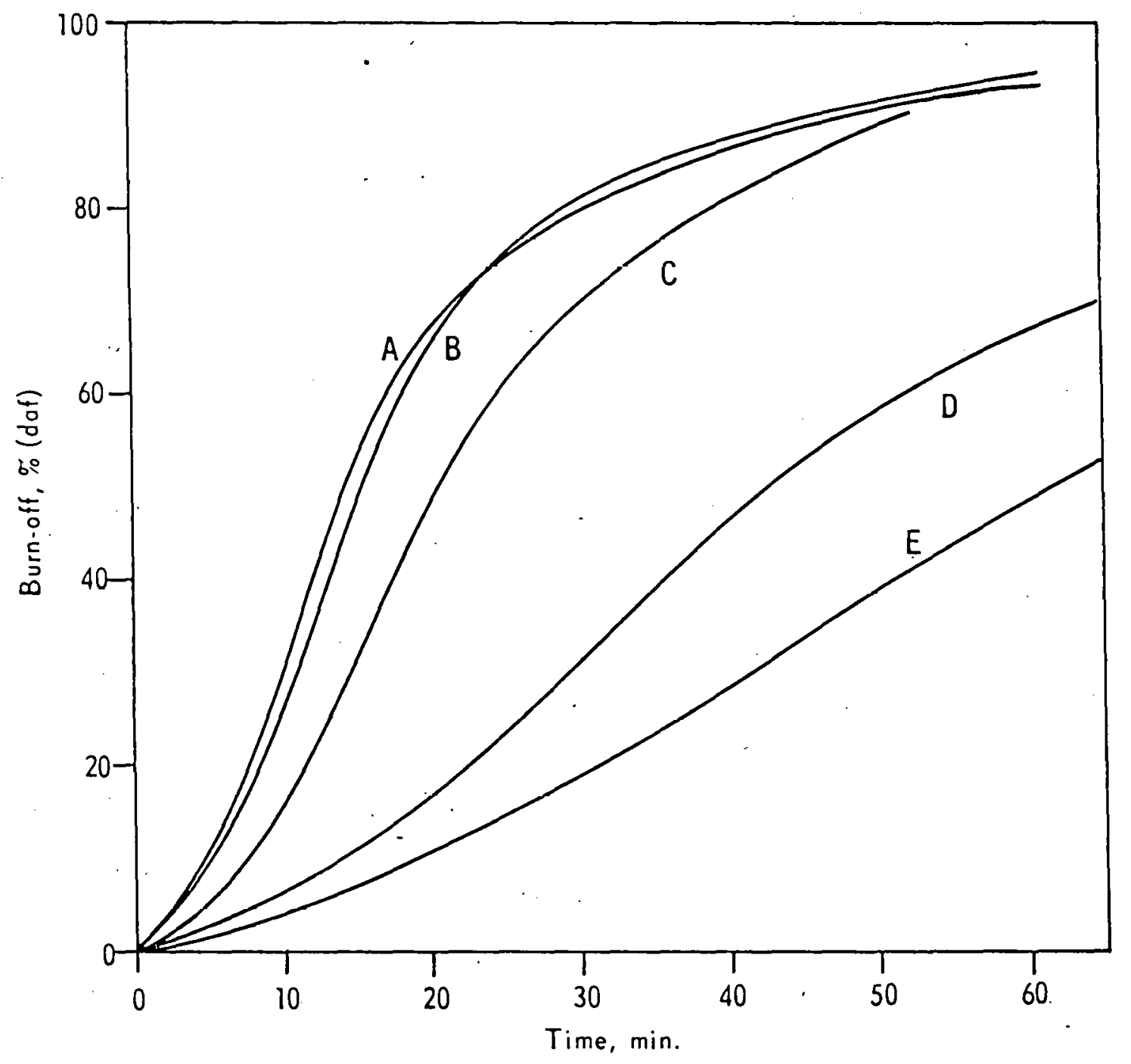

Figure 15. INFLUENCE OF OXYGEN CONCENTRATION ON REACTIVITY OF PSOC-91 CHAR AT $405^{\circ} \mathrm{C}$
A - $21 \% 0$
B. $15^{\circ} \circ \mathrm{O}_{2}^{2}$
C. $10 \% 0_{2}^{2}$
D - $4 \% \mathrm{O}_{2}^{2}$
E. $2 \% \mathrm{O}_{2}^{2}$ 


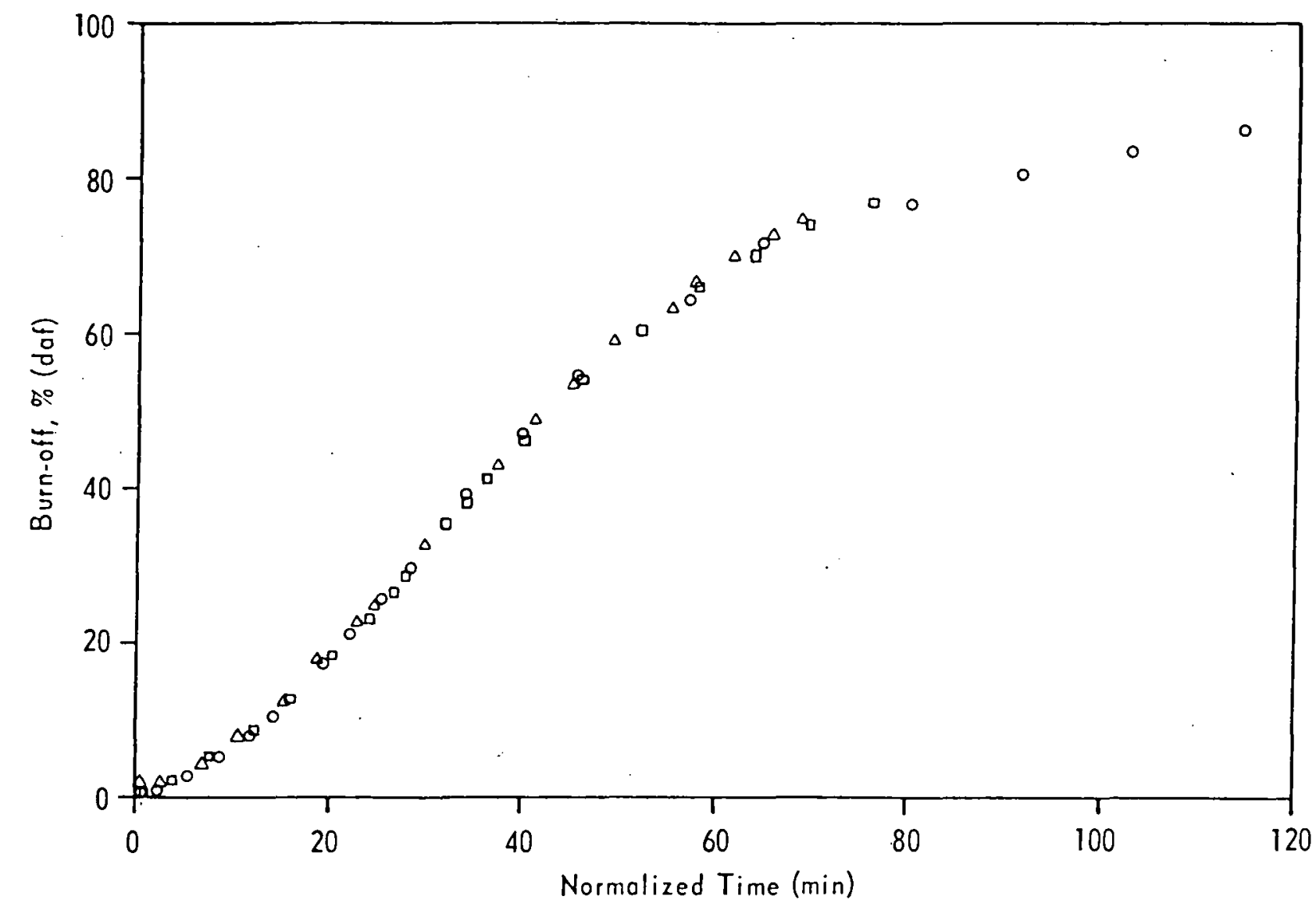

Figure 16. NORMALIZED BURN-OFF VS TIME PLOTS FOR DIFFERENT PARTIAL PRESSURES OF OXYGEN FOR PSOC- 91 CHAR AT $405^{\circ} \mathrm{C}$

- $21 \% \mathrm{O}_{2}$ in $\mathrm{N}_{2}$ (Times Multiplied by 2.86)

- $4 \% \mathrm{O}_{2}$ in $\mathrm{N}_{2}$ (Times os Such)

$\triangle \quad 2 \% \mathrm{O}_{2}$ in $\mathrm{N}_{2}$ (Times Multiplied by 0.68 ) 
Table 15. Influence of Particle Size on Reactivity of Chars

\begin{tabular}{|c|c|c|c|}
\hline \multirow{2}{*}{$\begin{array}{l}\text { Particle Size } \\
\text { Mesh }\end{array}$} & \multicolumn{3}{|c|}{ Reactivity (mg hr $\mathrm{m}^{-1} \mathrm{mg}^{-1}$ ) } \\
\hline & $\overline{R_{0}}$ & $\begin{array}{ll}R_{i} & R_{0}\end{array}$ & $R_{i}$ \\
\hline & \multicolumn{3}{|c|}{ PSOC-87 Char } \\
\hline & Raw & & Demineralized \\
\hline \multirow{4}{*}{$\begin{array}{r}40 \times 100 \\
100 \times 150 \\
200 \times 325\end{array}$} & 1.11. & 0.23 & 0.12 \\
\hline & 0.850 .8 & 0.25 & 0.23 \\
\hline & 1.21. & 0.24 & 0.21 \\
\hline & \multicolumn{3}{|c|}{ PSOC-127 Char } \\
\hline $40 \times 100$ & 0.016 & 0.0270 .11 & 0.025 \\
\hline $100 \times 150$ & 0.025 & $0.025 \quad 0.19$ & 0.06 \\
\hline $200 \times 325$ & 0.031 & 0.0310 .28 & 0.12 \\
\hline
\end{tabular}

Walker et az. ${ }^{15,16}$ have previously measured reactivities of several chars in air at $500^{\circ} \mathrm{C}$ and carbon dioxide at $900^{\circ} \mathrm{C}$. The chars studied were prepared from the same set of coals which were used for the preparation of chars in the present study.. These workers observed that reactivity of a given char in air at $500^{\circ} \mathrm{C}$ was essentially the same as in carbon dioxide at $900^{\circ} \mathrm{C}$. However, it was discussed in the earlier ERDA Reports that these results were not obtained in $1 \mathrm{~atm}$ of air and carbon dioxide. In the present study, reactivities of various chars in air at $405^{\circ} \mathrm{C}$ are compared with those in carbon dioxide at $900^{\circ} \mathrm{C}$ determined by Tomita, ${ }^{17}$ using an upward flow system (Table 16). Although absolute reactivity parameters for various chars determined in carbon dioxide are generally higher than those in air (Table 16), normalized reactivities are the same in carbon dioxide and air (Figure 17).

\section{REACTIVITIES OF AMERICAN COAL CHARS IN STEAM}

\section{Introduction}

Reactivities of American coal chars in steam are being studied. Preliminary results of these investigations are presented in this report.

Reactivities of chars in air and carbon dioxide have previously been shown to be predominantly determined by the nature of the present coal and mineral matter composition. In order to make a valid comparison of reactivities of chars in steam with those in air at $405^{\circ} \mathrm{C}$ and carbon 
Table 16. Compárison Between Air Reactivity at $405^{\circ} \mathrm{C}$, and Carbon Dioxide Reactivity at $900^{\circ} \mathrm{C}$ for American Coal Chars

\begin{tabular}{rcc}
\hline & $\begin{array}{c}\text { Reactivity } \mathrm{R}_{0} \text { in } \\
\mathrm{CO}_{2} \text { at } 900^{\circ} \mathrm{C}^{-1} \\
\mathrm{mg} \mathrm{hr} \mathrm{mg}^{-1}\end{array}$ & $\begin{array}{c}\text { Reactivity } \mathrm{R}_{0} \text { in } \\
\text { air at } 405^{\circ} \mathrm{C} \\
\mathrm{mg} \mathrm{hr} \mathrm{mg}^{-1}\end{array}$ \\
\hline 91 & 6.3 & 2.7 \\
87 & - & 1.07 \\
140 & 3.4 & 1.3 \\
138 & 1.9 & 0.53 \\
98 & 1.3 & 0.60 \\
101 & 4.6 & 1.84 \\
26 & 0.18 & 0.30 \\
22 & 0.59 & 0.34 \\
24 & 1.3 & 0.46 \\
67 & 0.15 & 0.27 \\
171 & 0.08 & 0.082 \\
4 & 0.20 & 0.26 \\
137 & 0.09 & 0.11 \\
114 & 0.07 & 0.016 \\
127 & 0.07 & 0.016 \\
81 & 0.13 & 0.11 \\
177 & 0.04 & 0.075 \\
\hline
\end{tabular}

dioxide at $900^{\circ} \mathrm{C}$, chars used in the air and carbon dioxide reactivity work have been used in the present work. Methods of preparation of chars have; been reported in earlier ERDA Progress Reports. However, it may be pertinent to briefly outline the experimental procedure. Various coals were charred at $1000^{\circ} \mathrm{C}$ in a nitrogen atmosphere; heating rate was $10^{\circ} \mathrm{C} / \mathrm{min}$ and soak time at $1000^{\circ} \mathrm{C}$ was $2 \mathrm{hr}$. In order to study the effect of mineral matter removal on reactivity, a few selected coals, prior to their carbonization, were acid-washed with hydrochloric acid-and/or demineralized hydrochloric-hydrofluoric acid mixture.

- The effect of particle size on reactivity is being studied for two chars, namely PSOC-127, a relatively unreactive low volatile bituminous char and PSOC-87, a highly reactive lignite char. Both chars were prepared from the parent raw coals. The demineralized coals are being studied also. Particle size fractions chosen for this study were $40 \times 100$, $100 \times 150$, and $200 \times 325$ mesh.

The Fisher Thermo Gravimetric Analyzer (TGA); Model 300, has been used for measurerients of reactivity. The TGA technique enables continuous weight measurement to be made on a sample while it undergoes thermal treatment in a flowing controlled atmosphere. 


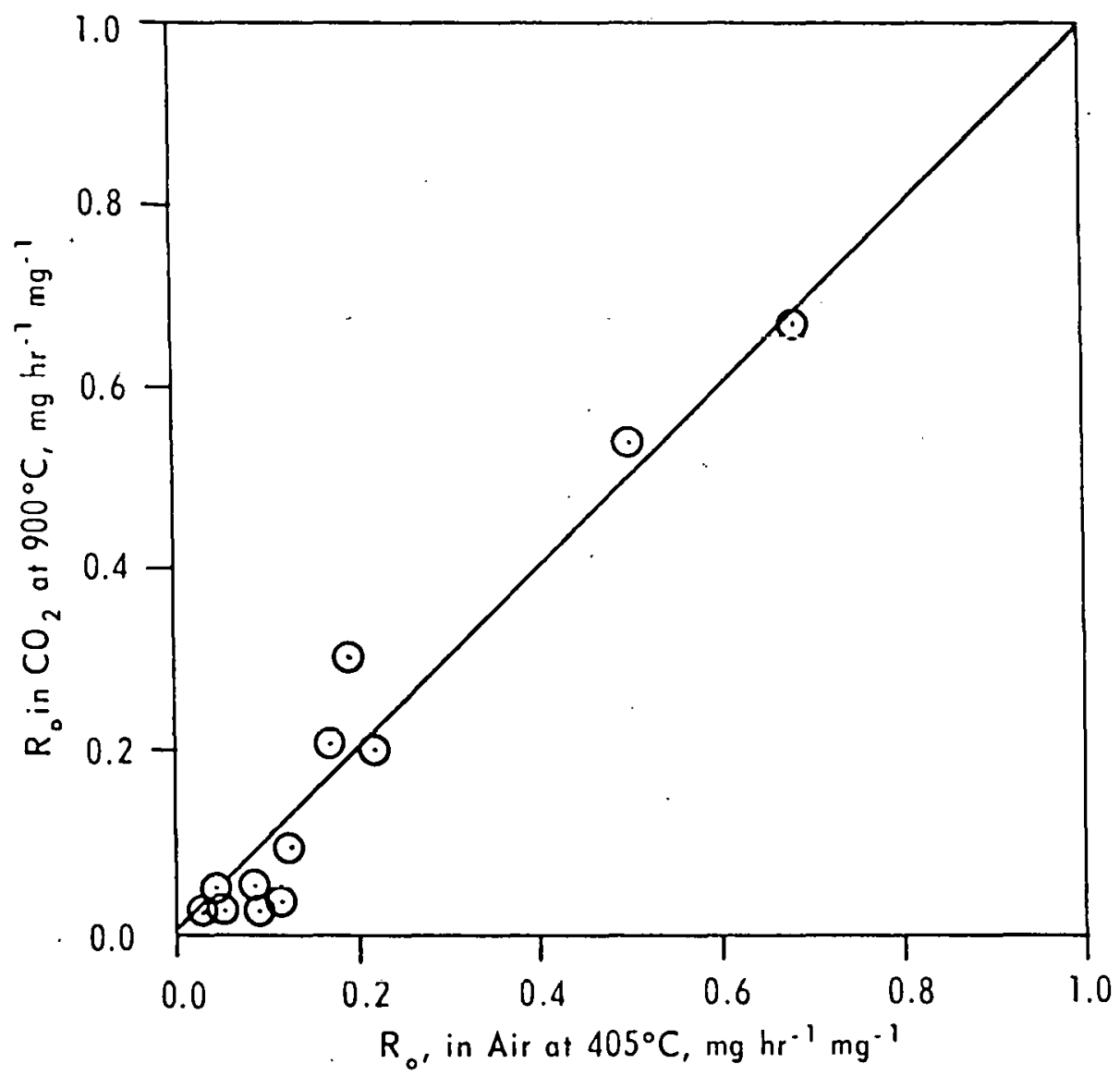

Figure 17. CORRELATION BETWEEN NORMALIZED VALUES OF RO FOR AIR AT $405^{\circ} \mathrm{C}$ AND $\mathrm{CO}_{2}$ AT $900^{\circ} \mathrm{C}$ 
The major difference in experimental operation from the previous studies is the change in the oxidant gas from air and carbon dioxide to steam and a consequent change in reaction temperature.

The sample temperature is measured by the TGA thermocouple. Before the TGA technique can be used to measure quantitatively the weight changes during reaction, it is imperative to measure accurately the sample temperature.

For calibration purposes, decomposition temperatures for calcium oxalate, corresponding to the following changes, were measured in a nitrogen flow $(60 \mathrm{cc} / \mathrm{min})$ using a heating rate of $10^{\circ} \mathrm{C} / \mathrm{min}$.

$$
\begin{aligned}
\mathrm{CaC}_{2} \mathrm{O}_{4} \cdot \mathrm{H}_{2} \mathrm{O} & \rightarrow \mathrm{CaC}_{2} \mathrm{O}_{4}+\mathrm{H}_{2} \mathrm{O} \\
\mathrm{CaC}_{2} \mathrm{O}_{4} & \rightarrow \mathrm{CaCO}_{3}+\mathrm{CO} \\
\mathrm{CaCO}_{3} & \rightarrow \mathrm{CaO}+\mathrm{CO}_{2}
\end{aligned}
$$

Temperatures corresponding to the maximum reaction rates for the above three reactions are given in Table 17. These temperatures are very close to those reported in the last ERDA Report.

Before reactivities of the chars could be studied, it was essential to decide on a suitable temperature for reactivity measurements. Since the carbon-steam reaction is a much slower reaction than the carbon-air reaction, it must be carried out at a much higher temperature to obtain the same reaction rate. A temperature of $910^{\circ} \mathrm{C}$ was selected at which the rate of reaction of the more reactive lignite, PSOC-9l (40x100 mesh), in steam corresponded closely to its reactivities in air at $405^{\circ} \mathrm{C}$ ( Table 18).

The chosen reaction temperature should be such that reactivity is independent of bed height. That is, there should be no resistance to diffusion of reactant molecules down through the bed.

To ensure that the effect of diffusion through the bed was negligible, a small weight of char was used. Table 19 lists char reactivities of $40 \times 100$ mesh PSOC-91 at various bed weights. For starting weights less than $3 \mathrm{mg}$ reactivity is almost constant. Therefore, in the present study reactivity measurements were made on $3 \mathrm{mg}$ weights of chars.

Reactivity measurements were made at $910^{\circ} \mathrm{C}$ in steam in the Fisher TGA unit. About $3 \mathrm{mg}$ of char contained in a platinum pan were heated in an upward nitrogen flow $(350 \mathrm{cc} / \mathrm{min})$ up to $1000^{\circ} \mathrm{C}$ at a heating rate of $20^{\circ} \mathrm{C} / \mathrm{min}$. Heating was continued until the char weight became constant. The sample was then cooled to the reaction temperature $\left(910^{\circ} \mathrm{C}\right)$ and held at this temperature for 20 min for temperature stabilization. After this, nitrogen was replaced by a nitrogen-water vapor mixture $(350 \mathrm{cc} / \mathrm{min})$. 
Table 17. Temperatures for the Decomposition of Calcium Oxalate

\begin{tabular}{|c|c|}
\hline & $\begin{array}{ll}\text { Sample wt } & =4 \mathrm{mg} \\
\text { Atmosphere } & =\mathrm{N}_{2}(60 \mathrm{cc} / \mathrm{min}) \\
\text { Heating Rate } & =10^{\circ} \mathrm{C} / \mathrm{min}\end{array}$ \\
\hline \multicolumn{2}{|c|}{ Decomposition Temperatures (maximum), ${ }^{\circ} \mathrm{C}$} \\
\hline lst reaction & 2nd reaction \\
\hline$\overline{\mathrm{CaC}_{2} \mathrm{O}_{4} \cdot \mathrm{H}_{2} \mathrm{O} \rightarrow \mathrm{CaC}_{2} \mathrm{O}_{4}+\mathrm{H}_{2} \mathrm{O}}$ & $\overline{\mathrm{CaC}_{2} \mathrm{O}_{4}} \rightarrow \mathrm{CaCO}_{3}+\mathrm{CO}$ \\
\hline 110 & 680 \\
\hline
\end{tabular}

Table 18. Reactivity of PSOC-91 Char in Steam at Different Temperatures

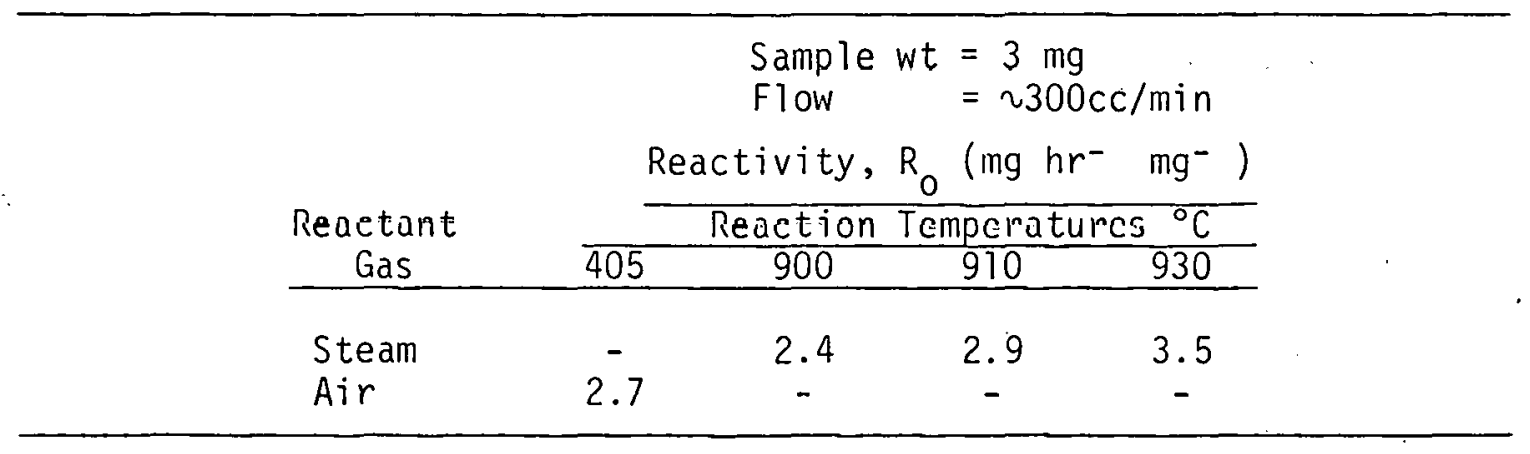

Table 19. Effect of Starting Bed Weight on Reactivity of PSOC-91 Char in Steam at $910^{\circ} \mathrm{C}$

\begin{tabular}{cc}
$\begin{array}{c}\text { Starting Weight } \\
(\mathrm{mg})\end{array}$ & $\begin{array}{c}\text { Reactivity, } \mathrm{R}_{\mathrm{O}} \\
\mathrm{mg} \mathrm{hr}^{-1} \mathrm{mg}^{-1} \mathrm{O}\end{array}$ \\
4.0 & 2.6 \\
3.5 & 2.7 \\
3.0 & 2.9 \\
2.5 & 2.9 \\
\hline
\end{tabular}


Partial pressure of the water vapor in the mixture was 17 torr. This pressure was generated by bubbling nitrogen through deaerated, demineralized water at $20^{\circ} \mathrm{C}$.

Reactivities of the chars were calculated by the following equation

$$
R_{0}=\frac{T}{W} \cdot \frac{d W}{d t}
$$

where $R_{0}$ is the reactivity of the char $\left(\mathrm{mg} \mathrm{hr} \mathrm{m}^{-1} \mathrm{mg}^{-1}\right) ; W$ is the weight of the initial char on a dry-ash-free basis (mg), and dW/dt is the change in

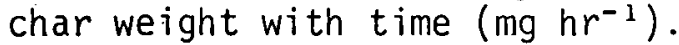

Figure 18 is a typical reactivity plot, where burn-off is calculated on a dry-ash-free basis. The reactivity plot has a rectilinear portion, in which maximum reactivity is observed and from which the reactivity parameter $\left(R_{0}\right)$ is calculated by equation (7).

Values of $\mathrm{R}_{0}$ obtained for various chars studied are listed in Table 20. The corresponding reactivities in air are also included in Table 20 for comparison. The data for the four char samples studied indicate that char reactivities in steam differ from those in air.

Char reactivity decreases with mineral matter removal, suggesting that mineral matter (some inorganic impurities) acts as gasification catalysts (Tab.le 21).

Future plans include determination in steam of reactivities of twenty chars prepared from coals of different rank. The effect of particle size and mineral matter. on char reactivity will also be investigated.

\section{REACTIVITY OF ION-EXCHANGED LIGNITE CHARS TO STEAM}

\section{Introduction}

Reactivities of variously treated chars made from PSOC-140, a Darco Texas lignite, have been measured at three reaction temperatures, $650^{\circ} \mathrm{C}$, $700^{\circ} \mathrm{C}$, and $750^{\circ} \mathrm{C}$. Preliminary results show that 1) reactivity decreases as heat treatment temperature increases, 2) raw coal chars are approximately ten times more reactive than the demineralized coal char for all reaction temperatures, and 3 ) reactivities of chars made-from demineralized coals, which had been ion exchanged with about 5 percent by weight calcium $^{++}$, were ten times greater than reactivities of raw coal char at a reaction temperature of $650^{\circ} \mathrm{C}$, but were only twice as great at a reaction temperature of $700^{\circ} \mathrm{C}$, and only slightly greater at a reaction temperature of $750^{\circ} \mathrm{C}$. 


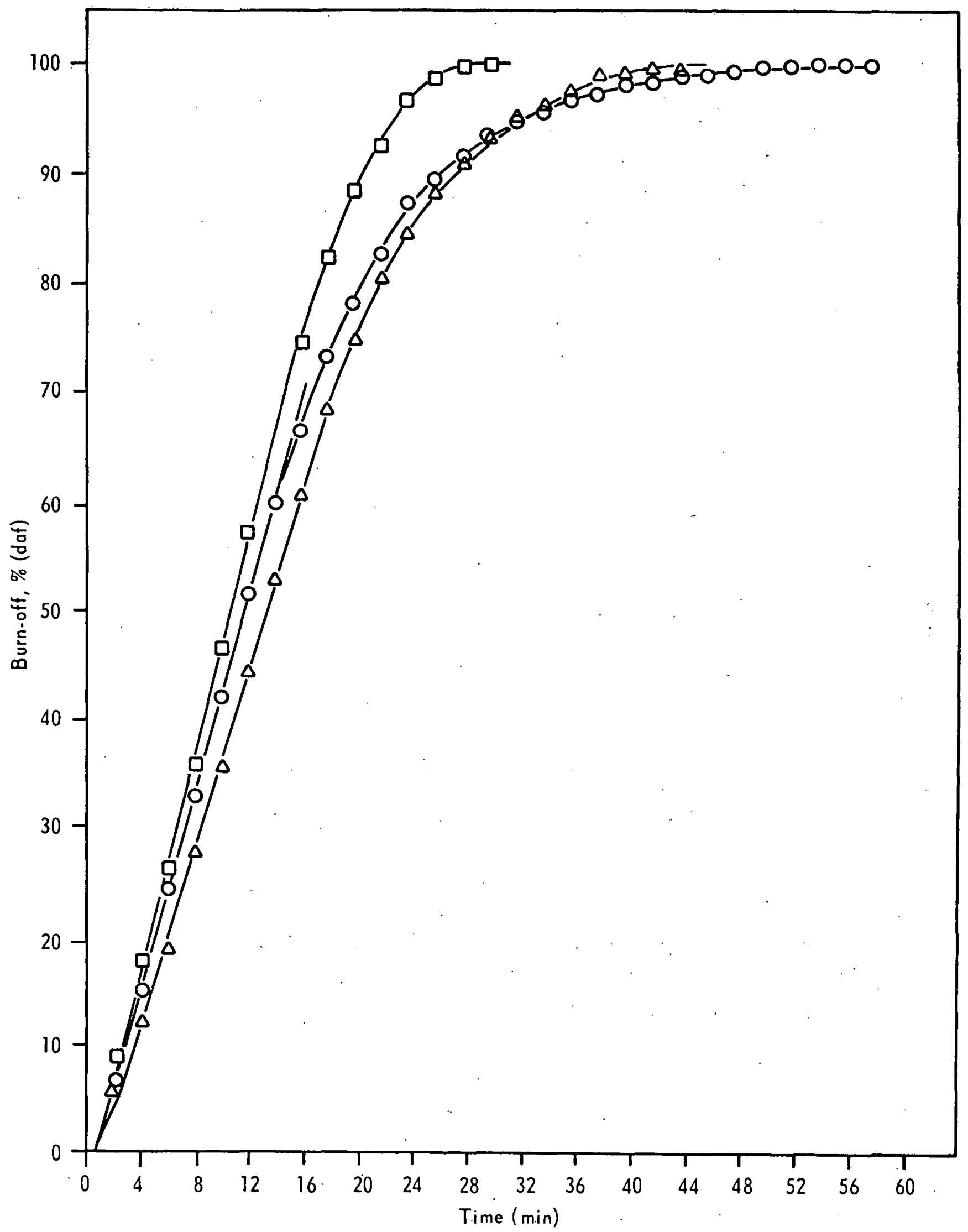

Figure 18. BURN-OFF CURVES (ON A DRY ASH-FREF BAS: 'N STEAM AT $910^{\circ} \mathrm{C}$ FOR $1000^{\circ} \mathrm{C}$ CHARS FROM PSOC-91(D), PSOC-87(O), AND PSOC-101(0) 
Table 20. Reactivity of Coal Chars in Steam at $910^{\circ} \mathrm{C}$.

\begin{tabular}{lcc}
\hline PSOC & \multicolumn{2}{c}{ Reactivity $\mathrm{R}_{\mathrm{O}}\left(\mathrm{mg} \mathrm{hr} \mathrm{hr}^{-1} \mathrm{mg}^{-1}\right)$} \\
\cline { 2 - 3 } Sample & Steam at $910^{\circ} \mathrm{C}$ & Air at $405^{\circ} \mathrm{C}$ \\
No. & 2.9 & 2.7 \\
91 & 2.8 & 1.7 \\
87 & 2.5 & 1.8 \\
101 & 1.5 & 1.3 \\
\hline
\end{tabular}

Table 21. Influence of Mineral Matter Removal on Reactivity of Chars

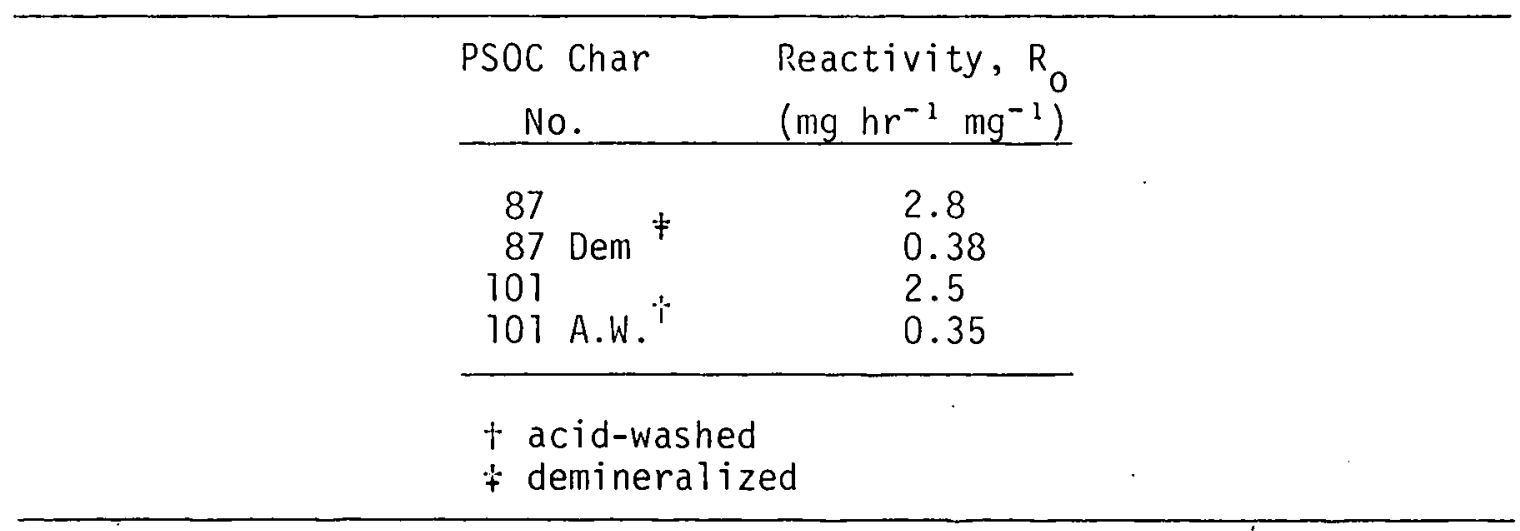

In addition to reactivities, helium densities, mercury densities, and carbon dioxide surface areas for some of the coals, chars, and reacted chars have been measured. Results show that helium densities in-, crease slowly as burn-off increases (more of the pore system is opened as burn-off is increased). Mercury densities decrease at a linear rate for a 10-55 percent burn-off range measured in one coal char. Carbon dioxide areas go through a maximum at 10 percent burn-off for that same char. Ash and moisture contents have been measured.

\section{Experimental}

The activation apparatus can be considered in three parts, a gas iniet, a gas outlet, and a reactor. The gas inlet streanl consists of a nitrogen line with monitoring accessories and a steam feed system. Helium is bubbled through the pressurized water feed tank to remove oxygen. The purified water is fed from the feed tank to the steam generator. The amount and pressure of the steam from the generator is controlled by 
limiting the power supply to the generator. From the steam generator gases flow through a preheater held at $600^{\circ} \mathrm{C}$, and on to the reactor inlet tube.

The reactor inlet tube, $7 \mathrm{~mm}$ diameter Vycor, is wrapped around the main body of the reactor, $35 \mathrm{~mm}$ diameter Vycor. Gas flows from the inlet tube through a fritted disk, which supports the bed of particles. A chromelalumel thermocouple, protected by a Vycor shield, measures temperature at the axial center of the bed about one $\mathrm{cm}$ from the fritted disk. The Vycor shield is attached to the reactor cap. Gases leave through the reactor cap and enter the gas outlet line.

The gases enter a condensor where most of the water is removed. The product gases and water pass a sampling port and are separated in a trap. The gases leave through the top of the trap and pass through a wet test meter and out to an exhaust fan. Carbon dioxide and carbon monoxide are analyzed in a Fisher bas partitioner and hydrogen is analyzed in a Hewlett-Packard chromatograph.

In the activation procedure, a weighed amount of char is placed in the reactor. The reactor and particle bed are purged for five minutes with nitrogen before the furnace preheater and steam generator are turned on. The reactor and bed of particles is brought to reaction temperature. After thermal equilibrium is achieved, nitrogen flow is stopped and steam is added. The volume of gas passing the wet test meter and time are recorded. Samples of gas are taken and analyzed for carbon monoxide, carbon dioxide, and hydrogen. Calculations of burn-offs are made by knowing total gas volume and the concentration of carbon monoxide and carbon dioxide. Burn-off percentages versus time are plotted for all runs. Reactivities are calculated from the burn-off curves. Reactivities of the chars were calculated using the following equation

$$
R=\frac{1}{W_{0}} \frac{d W}{d t}
$$

where $W_{0}$ equals the original weight on a dry-ash-free basis $(G), d W / d t$ equals the change in weight per unit time $\left(\mathrm{g} \mathrm{hr}^{-1}\right)$ and $R$ equals the reactivity $\left(g h r^{-1} g^{-1}\right)$.

Reactivities reported in Table 22 were calculated by drawing a tangent to the burn-off curves of the chars at 10 percent burn-off. Other methods of calculating reactivity will be explored and evaluated in the future.

The ion exchange procedure is outlined below.

1) Half of a 1 molar solution of calcium asetate (or other solution of interest) and $100 \mathrm{~g}$ of coal are placed in a one 1 plastic beaker. 
Table 22. Reactivity of Chars at 10\% Burn-off

\begin{tabular}{|c|c|c|c|c|c|}
\hline \multirow{2}{*}{$\begin{array}{c}\text { Heat } \\
\text { Treatment } \\
\text { Temperature, }{ }^{\circ} \mathrm{C}\end{array}$} & \multirow{2}{*}{$\begin{array}{l}\text { Mesh } \\
\text { Size }\end{array}$} & \multirow{2}{*}{$\begin{array}{c}\text { Reaction } \\
\text { Temperature, }{ }^{\circ} \mathrm{C} \\
\end{array}$} & \multicolumn{3}{|c|}{$\begin{array}{c}\text { Reactivity }(10 \% \text { Burn-off }) \\
\text { g } h^{-1} g^{-1},(\text { daf })\end{array}$} \\
\hline & & & Raw & Dem. & $5 \%$ Ca I.E. \\
\hline 700 & $28 \times 48$ & 650 & 0.057 & 0.0062 & 0.68 \\
\hline 800 & $28 \times 48$ & 650 & 0.050 & n.d: & 0.43 \\
\hline 800 & $28 \times 48$ & 700 & 0.352 & 0.032 & 0.85 \\
\hline 800 & $28 \times 48$ & 750 & 0.956 & 0.078 & 1.03 \\
\hline 900 & $28 \times 48$ & 650 & 0.020 & 0.0046 & n.d. \\
\hline 900 & $28 \times 48$ & 700 & 0.151 & 0.020 & 0.68 \\
\hline 900 & $28 \times 48$ & 750 & 0.456 & 0.038 & n.d. \\
\hline
\end{tabular}

2) A precalculated amount of standardized base (sodium hydroxide) is added to the mixture. The amount of base added is determined by the amount of calcium ${ }^{++}$desired to be exchanged on the coal.

3) The $\mathrm{pH}$ is monitored as a function of time.

4) The $\mathrm{pH}$ of the solution is allowed to adjust for one day at room temperature. If the $\mathrm{pH}$ does not reach 8.4 , the solution can be heated by placing a plastic beaker inside a glass beaker partially filled with water. The glass beaker is then placed on a hot plate. (At increased temperatures ion exchange is increased for a certain $\mathrm{pH}$ level.)

5) The solution is removed after $1 \mathrm{hr}$ and allowed to cool.

6) The $\mathrm{pH}$ is measured. If the $\mathrm{pH}$ is not lower than 8.4 the procedure is repeated. The calcium ion exchanged coal used in experiments this quarter was only adjusted to a $9.5 \mathrm{pH}$. A coal will be produced with a similar concentration of calcium at a pH of 8.4. Also, an attempt will be made to make a 5 percent calcium ion exchange char with an end point $\mathrm{pH}$ of about 11. The effect of end point $\mathrm{pH}$ on reactivity will be ex-. plored.

\section{Results and Discussion}

Reactivity has been studied for a wide range of chars for the carbon dioxide-carbon ${ }^{18}$ and oxygen-carbon ${ }^{15}$ reactions. The results indicate that chars made from lower rank coals are much more reactive. Comparatively little work has been done on the steam-carbon reaction, but probably the same factors will affect reactivity of chars to steall. Highly dispersed cations exchanged on the low rank coal are believed to cause the high reactivity. 
Reactivity measurements are usually limited to about $50^{\circ} \mathrm{C}$ below the highest temperature the char has seen. Limiting the temperature prevents change of the thermal structure of the char during reaction.

Two reactions are of primary concern in this study. They are the carbon-steam and water-gas shift reactions. The carbon-carbon dioxide reaction takes place but is slower and should not be important at the temperature studied. The carbon-hydrogen reaction is very slow under reaction conditions being studied. No evidence has been found which indicates methane formation.

Figure 19 is a typical burn-off curve for the reaction of a char made from PSOC- 140 in steam. It can be seen that a slow but steady decrease in rate occurs. This decrease may be the result of a slow deactivation of the catalysts in the char or a decrease in active surface available for the reaction.

Table 22 lists reactivities of chars made from raw, demineralized, and ion exchanged coals. Reactivities of chars made from all three types of coal decrease as heat treatment temperature increases even though ash concentration increases with heat treatment. The more concentrated catalysts in the char on a unit weight basis would be expected to increase reactivity. However, the catalysts may agglomerate at higher heat treatment temperatures and become less effective. In addition, a change in structure of the char as heat treatment temperature increases may also cause a decrease in reactivity. The two effects may also be of equal importance. Differences in burn-off due to particle size are small and ambiguous. Only the chars made from the raw coal have been reacted in the smaller particle sizes. Problems with heavy loss of fines for smaller particle size make reactivity measurements inaccurate. Activation energies - measured are a complex function of diffusion and catalytic effects. The activation energy for the gasification of $800^{\circ} \mathrm{C}$ char derived from the raw coal is about $55 \pm 10 \mathrm{kcal} / \mathrm{mole}$ of carbon on a daf basis. The activation energy for the gasification of the $800^{\circ} \mathrm{C}$ char derived from the ion exchange coal is about $20 \pm 10 \mathrm{kcal} / \mathrm{mole}$ on a daf bas is.

In general, helium densities increase and mercury densities decrease with burn-off. Carbon dioxide areas maximize and fall off slowly with burn-off. The calculations of the amount of calcium ion exchanged from $\mathrm{pH}$ readings and the calculated amount of calcium in the ash of the ion exchanged coal agree. The actual amount will be measured by atomic absorption.

Future plans include the study of:

1) Ion exchange of demineralized coal with calcium and other cations will continue.

2) Demineralization of a $900^{\circ} \mathrm{C}$ raw coal char made from the $28 \times 48$ mesh size fraction of the coal will be prepared. 


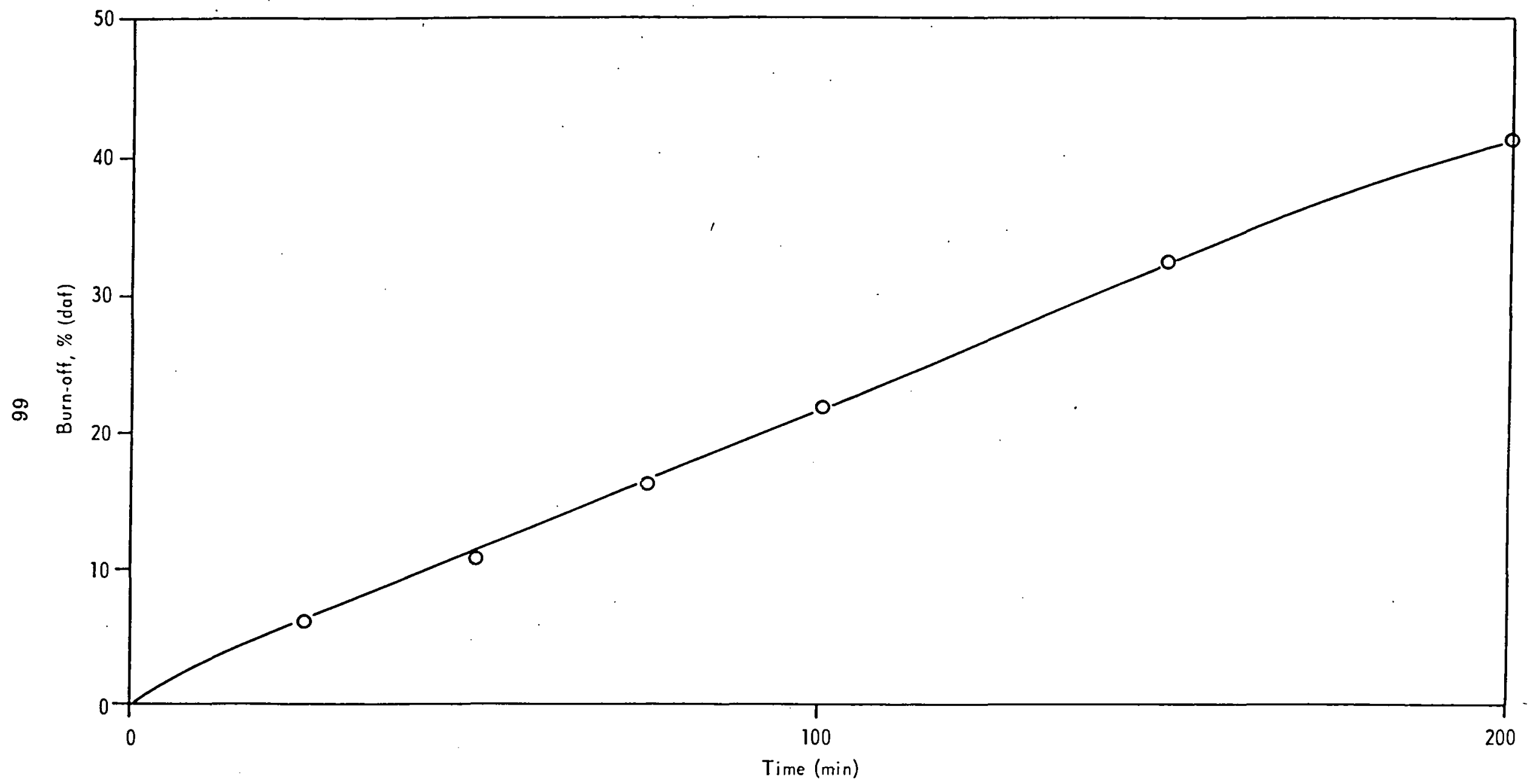

Figure 19. TYPICAL BURN-OFF CURVE FOR A $28 \times 48 \mathrm{MESH}$ CHAR REACTED AT $700^{\circ} \mathrm{C}$ 
3) More chars will be made from the ion exchange coals.

4) The $900^{\circ} \mathrm{C}$ char that was demineralized will be treated with nitric acid to add carboxyl groups destroyed by charring.

5) That char will be ion exchanged with calcium and a reaction of the ion exchanged calcium char with steam at several reaction temperatures below $900^{\circ} \mathrm{C}$ will be followed to determine the effect of reaction and heat treatment on calcium dispersal and its consequential effect on catalytic efficiency.

6) New samples will be characterized as required.

\section{EFFECT OF HEAT TREATMENT CONDITIONS ON}

REACTIVITY OF CHARS TO AIR

\section{Introduction}

The effect of various modes of heat treatment on char reactivity in air at $500^{\circ} \mathrm{C}$ has been studied. Reactivities have been shown to be maximized by keeping the maximum heat treatment temperature as low as possible, the heating rate as high as possible, and allowing no soak time at the maximum temperature. It has been observed that aging of chars in dry air has little or no effect on subsequent reactivity. Heat treatment of chars in different atmospheres (nitrogen, carbon dioxide, hydrogen) to the same temperature has no significant effect on subsequent char reactivity.

\section{Experimental}

In previous ERDA Reports, we reported the results of the effect of heat treatment temperature, soak time and aging in air on the reactivity of Exxon Wyodak, Exxon bituminous, and Bureau of Mines chars. The effect of heating rate and rapid devolatilization on char reactivity were reported for the Exxon chars only. In this report we are presenting results of the effect of heating rate and rapid devolatilization on the reactivity of the Bureau of Mines and the FMC (COED) chars. In addition to these, results are reported on the determination of temperature seen by the char during rapid devolatilization. Results on the effect of preheating in different atmospheres (nitrogen, carbon dioxide, and hydrogen) to the same temperature on subsequent reactivity of. Exxon Wyodak char in air are also presented. For the sake of comparison, results which were previously reported are included in this report.

Reactivity parameters reported here were reproducible within \pm 2 percent. 
The experimental procedure was the same as outlined in previous reports. Maximum reactivities of four commercial chars heat treated to different temperatures prior to measuring their reactivities to air at $500^{\circ} \mathrm{C}$ are 1 isted in Table 23 . In each case the reactivity decreases after a certain heat treatment temperature (HTT). The thermal history of a char, that is, heating rate, atmosphere, maximum temperature, and soak time at maximum temperature used during preparation of the char, profoundly affects its structure, porosity, and surface areas, and hence, its reactivity. When reactivity of a char, whose thermal history during preparation is not known, is studied as a function of HTT (prior to reactivity measurement), it is expected that the reactivity will remain constant up to the maximum HTT reached by the char during its preparation, and decrease thereafter. It can be concluded from Table 23 and Figure 20 that both Exxon Wyodak and Exxon bituminous chars had reached a temperature of $725^{\circ} \mathrm{C}$ during their preparation whereas the corresponding temperatures for the Bureau of Mines and FMC (COED) chars were $700^{\circ} \mathrm{C}$ and $750^{\circ} \mathrm{C}$, respectively.

For any HTT up to about $750^{\circ} \mathrm{C}$ reactivity of the Exxon Wyodak char is higher than that of any of the other three chars. It is suspected that Exxon Wyodak was prepared from a subbituminous coal, whereas the other chars were derived from bituminous coals. It has previously been reported by walker and co-workers that chars prepared from subbituminous coals are more reactive than those prepared from bituminous coals.

The effect of soak time at maximum HTT (above which char reactivity starts decreasing) on reaction rate in air at $500^{\circ} \mathrm{C}$ is shown by the data listed in Table 24. The results for Exxon Wyodak, Exxon bituminous, and Bureau of Mines chars were presented and discussed in the last report. In the case of the FMC (COED) char, soak time at maximum HTT appears to be about $20 \mathrm{~min}$. That is, reactivity falls off sharply for longer soak times.

Table 25 shows results for the effect of heating rate on reactivity. In each case reactivity increases with increase in heating rate.

In the last report results were presented for the Exxon Wyodak and Exxon bituminous chars. In this report we are presenting the results for the other two chars in Table 26. Reactivities of the rapidly devolatilized samples are appreciably higher than those of the samples which were heat treated at lower heating rates. The effect of rapid devolatilization was aiso examined in the case of PSOC-2.46 char. The raw coal was heated at a rate of $10^{\circ} \mathrm{C} / \mathrm{min}$ in a fluidized bed reactor up to $800^{\circ} \mathrm{C}$ with no soak time at this temperature. The resultant char was then rapidly devolatilized at $800^{\circ} \mathrm{C}$ in the isothermal reactor. The rapidly devolatilized char has a higher reactivity than the char prepared in the fluidized bed (Table 26).

During rapid devolatilization, chars were heated to $800^{\circ} \mathrm{C}$ at the rate of $10^{3 \circ} \mathrm{C} / \mathrm{sec}$. Residence time at $800^{\circ} \mathrm{C}$ was of the order of $200-300$ 


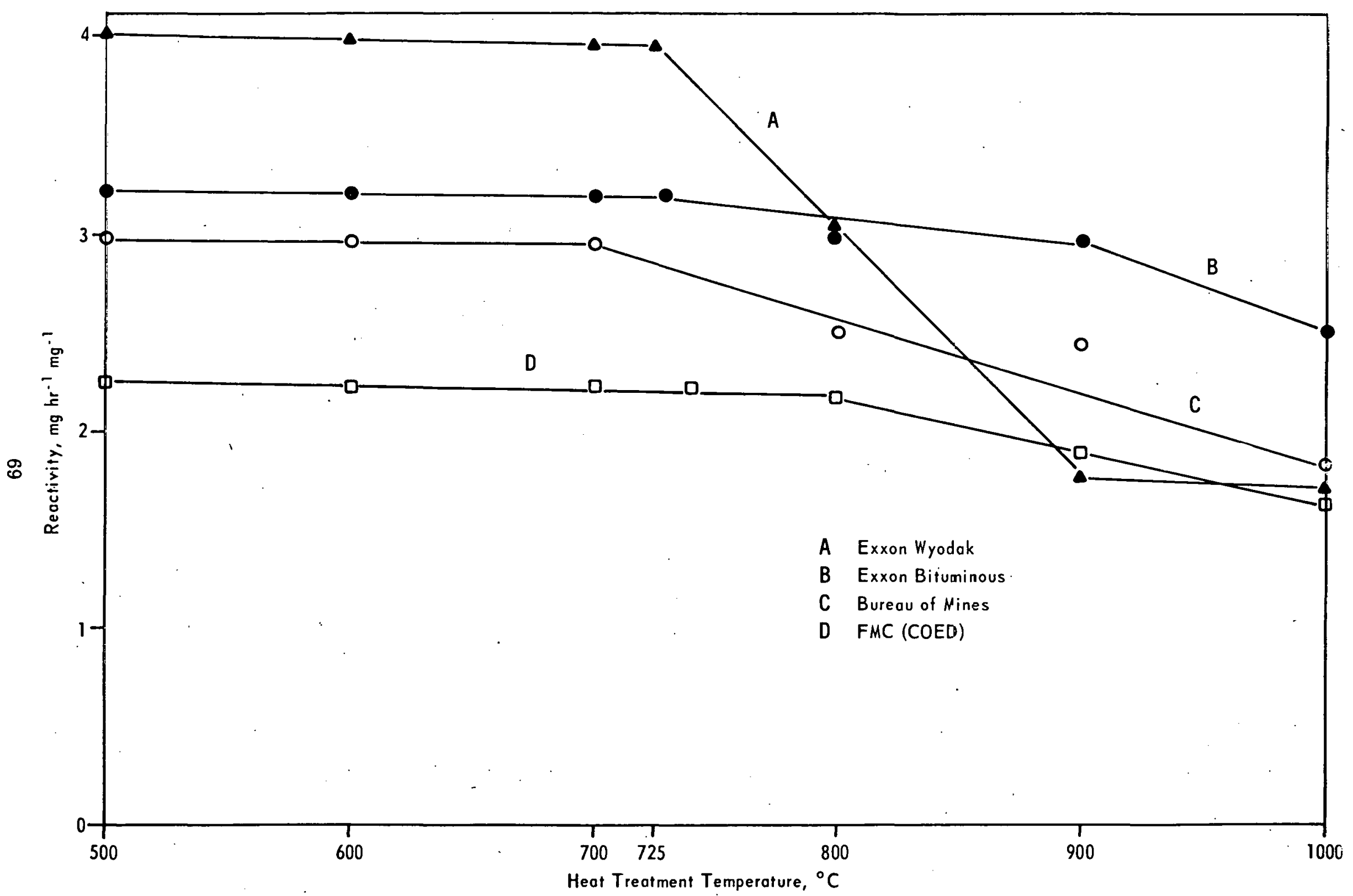

Figure 20. EFFECT OF HEAT TREATMENT TEMPERATURE ON CHAR REACTIVITY TO AIR AT $500^{\circ} \mathrm{C}$ 
Table 23. Effect of Heat Treatment Temperature on Reactivity of Chars

\begin{tabular}{rcccc}
\hline & \multicolumn{4}{c}{$\mathrm{R}_{\mathrm{T}}\left(\mathrm{mg} \mathrm{hr}^{-1} \mathrm{mg}^{-1}\right)$} \\
\cline { 2 - 5 } Temp. , ${ }^{\circ} \mathrm{C}$ & $\begin{array}{l}\text { Exxon } \\
\text { Wyodak }\end{array}$ & Exxon Bit. & $\begin{array}{c}\text { Bureau of } \\
\text { Mines }\end{array}$ & FMC (COED) \\
\hline 500 & 4.06 & 3.43 & 2.96 & 2.25 \\
600 & 3.95 & 3.39 & 2.97 & 2.20 \\
650 & - & - & 2.96 & - \\
675 & - & - & 2.96 & - \\
700 & 3.90 & 3.38 & 2.91 & 2.21 \\
725 & 3.90 & 3.37 & 2.80 & 2.20 \\
735 & 3.72 & 3.30 & - & 2.20 \\
750 & 3.69 & 3.14 & 2.71 & 1.90 \\
800 & 3.12 & 3.00 & 2.50 & - \\
870 & 2.46 & - & - & 1.80 \\
900 & 2.06 & 2.70 & 2.42 & 1.60 \\
1000 & 1.92 & 2.50 & 2.16 & \\
\hline
\end{tabular}

Table 24. Effect of Soak Time on Reactivity of Various Chars

\begin{tabular}{ccccc}
\hline & \multicolumn{4}{c}{$\mathrm{R}_{\mathrm{T}}\left(\mathrm{mg} \mathrm{hr^{-1 } \mathrm { mg } ^ { - 1 } )}\right.$} \\
\cline { 2 - 5 } $\begin{array}{c}\text { Soak Time } \\
\text { (min.) }\end{array}$ & $\begin{array}{l}\text { Exxon } \\
\text { Wyodak }\end{array}$ & Exxon Bit. & $\begin{array}{c}\text { Bureau of } \\
\text { Mines }\end{array}$ & FMC (COED) \\
\hline 0 & 3.95 & 3.39 & 2.96 & 2.20 \\
15 & 3.85 & 3.37 & 2.91 & 2.20 \\
20 & - & - & - & 2.00 \\
30 & 3.02 & 3.00 & 2.90 & 1.55 \\
60 & - & 3.00 & 2.04 & 1.53 \\
120 & 3.03 & 3.00 & 2.02 & 1.53 \\
\hline
\end{tabular}

In using such fast heating rates and low residence times, there may be significant temperature gradients between the surface and interior of the char particles. In order to see if such is the case, reactivity of the rapidly devolatilized Exxon Wyodak char was determined after heat treatiment in the TGA unit to different temperatures at the rate of $10^{\circ} \mathrm{C} / \mathrm{min}$. In each case, following heat treatment at a given temperature (no soak time) the sample was cooled in nitrogen to $500^{\circ} \mathrm{C}$ and its reactivity measured at $500^{\circ} \mathrm{C}$ in air. The relevant data are listed in Table 27; char reactivity starts decreasing. when HTT exceeds $780^{\circ} \mathrm{C}$. 
Table 25. Effect of Heating Rate on Reactivity of Chars*

\begin{tabular}{ccccc}
\hline & \multicolumn{4}{c}{$\mathrm{R}_{\mathrm{T}}\left(\mathrm{mg} \mathrm{hr}^{-1} \mathrm{mg}^{-1}\right)$} \\
\cline { 2 - 5 } $\begin{array}{c}\text { Heating Rate } \\
\left({ }^{\circ} \mathrm{C} / \mathrm{min}\right)\end{array}$ & $\begin{array}{l}\text { Exxon } \\
\text { Wyodak }\end{array}$ & Exxon Bit. & $\begin{array}{c}\text { Bureau of } \\
\text { Mines }\end{array}$ & FMC (COED) \\
\hline 5 & 3.68 & 3.25 & 2.65 & 2.11 \\
10 & 3.90 & 3.43 & 2.96 & 2.20 \\
20 & 4.12 & 3.50 & 3.10 & 2.30 \\
25 & 4.21 & 3.58 & 3.21 & 2.35
\end{tabular}

* Heat treatment temperature prior to reactivity measurement $=500^{\circ} \mathrm{C}$

Table 26. Effect of Rapid Devolatilization to $800^{\circ} \mathrm{C}$ on Reactivity

\begin{tabular}{lcc}
\hline \multirow{1}{c}{ Sample } & $\mathrm{R}_{\mathrm{T}}\left(\mathrm{mg} \mathrm{hr} \mathrm{m}^{-1} \mathrm{mg}^{-1}\right)$ & \\
\cline { 2 - 3 } STow Heating $\left(10^{\circ} \mathrm{C} / \mathrm{min}\right)$ & Rapid Devolatilization \\
\hline Exxon Wyodak & 3.12 & 5.68 \\
Exxon bituminous & 3.00 & 4.11 \\
Bureau of Mines & 2.50 & 3.67 \\
FMC (COED) & 1.90 & 3.08 \\
PSOC-246 char & 2.79 & 3.10 \\
\hline
\end{tabular}

Table 27. Determination of Maximum Temperature of Exxon Wyodak Char During Rapid Heating

\begin{tabular}{cc} 
Temp. ${ }^{\circ} \mathrm{C}$ & $\mathrm{R}_{\mathrm{T}}$ (mg hr-1 $\left.\mathrm{mg}^{-1}\right)$ \\
\hline 500 & 5.00 \\
600 & 5.00 \\
700 & 4.98 \\
750 & 4.98 \\
775 & 4.94 \\
780 & 4.93 \\
790 & 4.83 \\
800 & 4.80 \\
\hline
\end{tabular}


These results thus indicate that char particles during rapid devolatilization had reached a temperature of about $780^{\circ} \mathrm{C}$. This temperature is quite close to $792^{\circ} \mathrm{C}$, the figure calculated theoretically by Nsakala ya Nsakala. Thus, it can be concluded that during rapid heating the center of the char particle reaches essentially the same temperature as the surface of the particle.

It was thought of interest to study if the gaseous atmosphere used during heat treatment of chars has any effect "on subsequent reactivity in air. For this study Exxon Wyodak char was heated to $725^{\circ} \mathrm{C}$ at the rate of $10^{\circ} \mathrm{C} / \mathrm{min}$ in nitrogen, carbon dioxide, and hydrogen atmospheres. In each case, as soon as the temperature reached $725^{\circ} \mathrm{C}$, heating was stopped and the sample cooled to $500^{\circ} \mathrm{C}$ at the rate of $10^{\circ} \mathrm{C} / \mathrm{min}$. Its reactivity was then determined at $500^{\circ} \mathrm{C}$ in air. Data listed in Table 28 show that the reactivity values are essentially independent of the atmosphere used during heat treatment of the chars prior to reactivity measurements.

SMALL ANGLE X-RAY STUDIES ON COAL CHARS

\section{Introduction}

The prime objective of this study is to evaluate the applicability of small angle x-ray scattering (SAXS) in characterizing the pore structures of coal chars. Preliminary data indicates that such an approach shows promise. For a series of coals heated to $1050^{\circ} \mathrm{C}$ the primary SAXS structural parameter $\ell_{m}$ (range of inhomogeneity) varies systematically with the rank of the parent coal. From a knowledge of this primary parameter and the volume fraction of pores it is possible to evaluate a mean pore size (a dimension characterizing the length of the carbonaceous matrix between pores and the surface area). The most important advantage in using. SAXS is that it is not limited by closed porosity, but is a measure of the total porosity.

\section{Experimental}

In previous reports it was reported that raw SAXS data had been obtained for a series of coal chars. Figure 21 is a typical scattering curve obtained for a char prepared from a demineralized coal char (demineralized PSOC-213 heated to $1050^{\circ} \mathrm{C}$ ). This plot is of log $\mathrm{J}$ (intensity) versus $\log s(s=2 \theta / \lambda$, where $2 \theta$ is the scattering angle and $\lambda$ is the wavelength of $x$-radiation-Cuk ${ }_{\alpha}$ ). At very small angles the plot is a curve which at higher angles inflects and then follows a linear function. This linear portion should ideally have a -3 slope. Since it does not a correction needs to be made. The deviation from ideal behavior is due mainly to density fluctuations in the solid matrix (carbonaceous phase). 


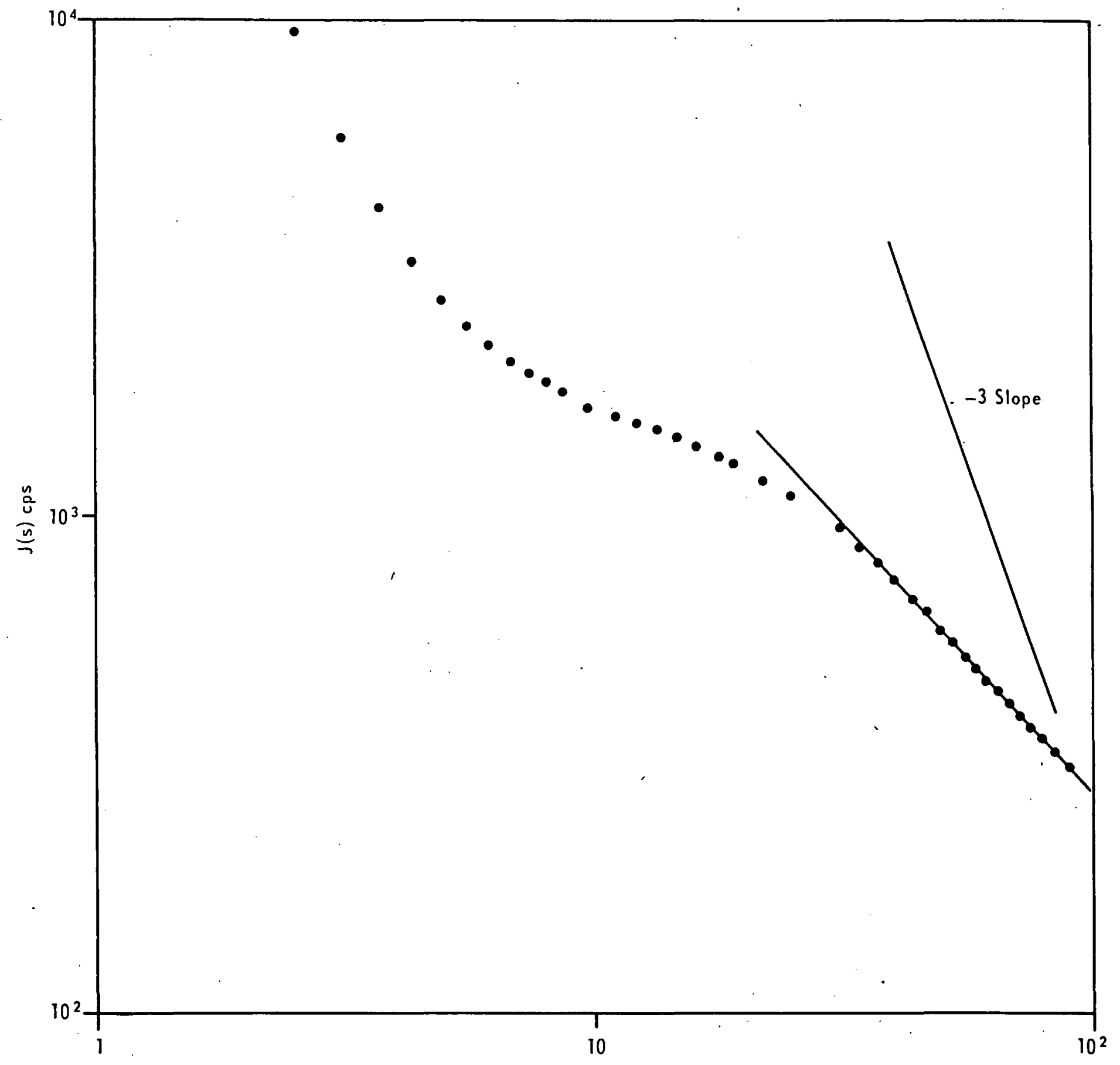

$S \times 10^{-3} \mathrm{~A}^{-1}(S=2 \theta / \lambda)$

Figure 21. SAXS CURVE FOR DEMINERALIZED PSOC-213 HEATED TO $1050^{\circ} \mathrm{C}$ 
Table 28. Effect of Gaseous Atmosphere During Heat Treatment of Exxon Wyodak Char on Subsequent Reactivity in Air at $500^{\circ} \mathrm{C}$

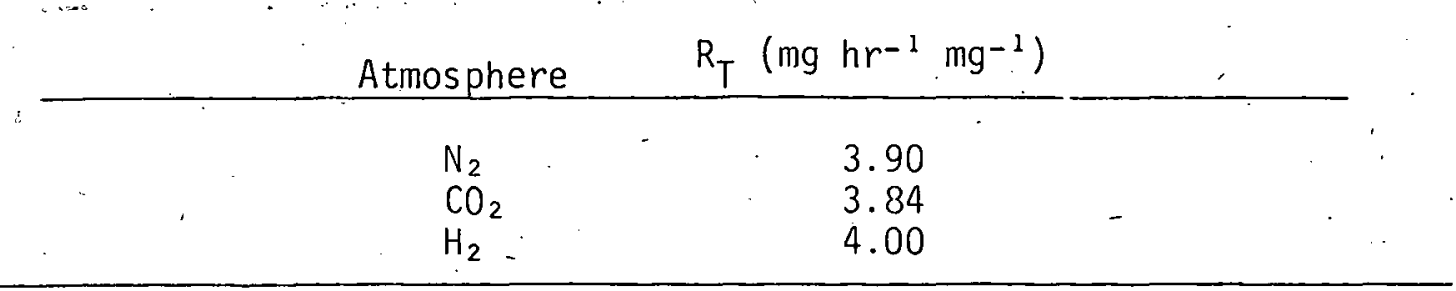

From the corrected data it is possible to calculate several structural parameters. However, it has been suggested ${ }^{16}$ that only one primary parameter $\left(l_{m}\right)$ can be considered as unambiguous for a dense system. For some of the other parameters the exact meaning in such a system is very much in question. The parameter ' $l_{\mathrm{m}}$ ' is very useful since there are three secondary parameters which can be estimated from it. The three secondary parameters are:

a) surface àrea

$$
S A=4 \times 10^{4} \mathrm{C}(1-\mathrm{C}) / \ell_{\mathrm{m}} \rho_{\mathrm{Hg}}, \mathrm{m}^{2} / \mathrm{gm}
$$

where $C$ is the volume fraction of pores, estimated from density measurements, and $\rho_{\mathrm{Hg}}$ is the density of the particles as measured in mercury. voids

b) $d_{\text {voids }}$, defined as the average dimension of segments in the

$$
d_{\text {voids }}=\ell_{m} /(1-C)
$$

c) $d_{\text {solid }}$, defined as a measure of the average distance between pore walls within the carbonacèous matrix

$$
\mathrm{d}_{\text {solid }}=\ell_{\dot{m}} / C
$$

In the last report we described how $l_{m}$ was evaluated. This has been completed for the samples listed in Table 29 . The values have been plotted versus percent carbon (daf) of the parent coal (Figure 22). All coals were demineralized prior to heat treatment. For the chars produced around $1050^{\circ} \mathrm{C}$ there is a systematic variation with rank of the parent coal. For the $1500^{\circ} \mathrm{C}$ chars the trend is somewhat different in that it increases with increasing rank, al though the values of $\ell_{\mathrm{m}}$ are all quite similar for this series of samp.les. The value of $\ell_{\text {ill }}$ for the only char produced at $1150^{\circ} \mathrm{C}$ falls between the two curves. It is interesting to note that further heat treatment temperature has had no effect on this parameter for charred PSOC-88. 


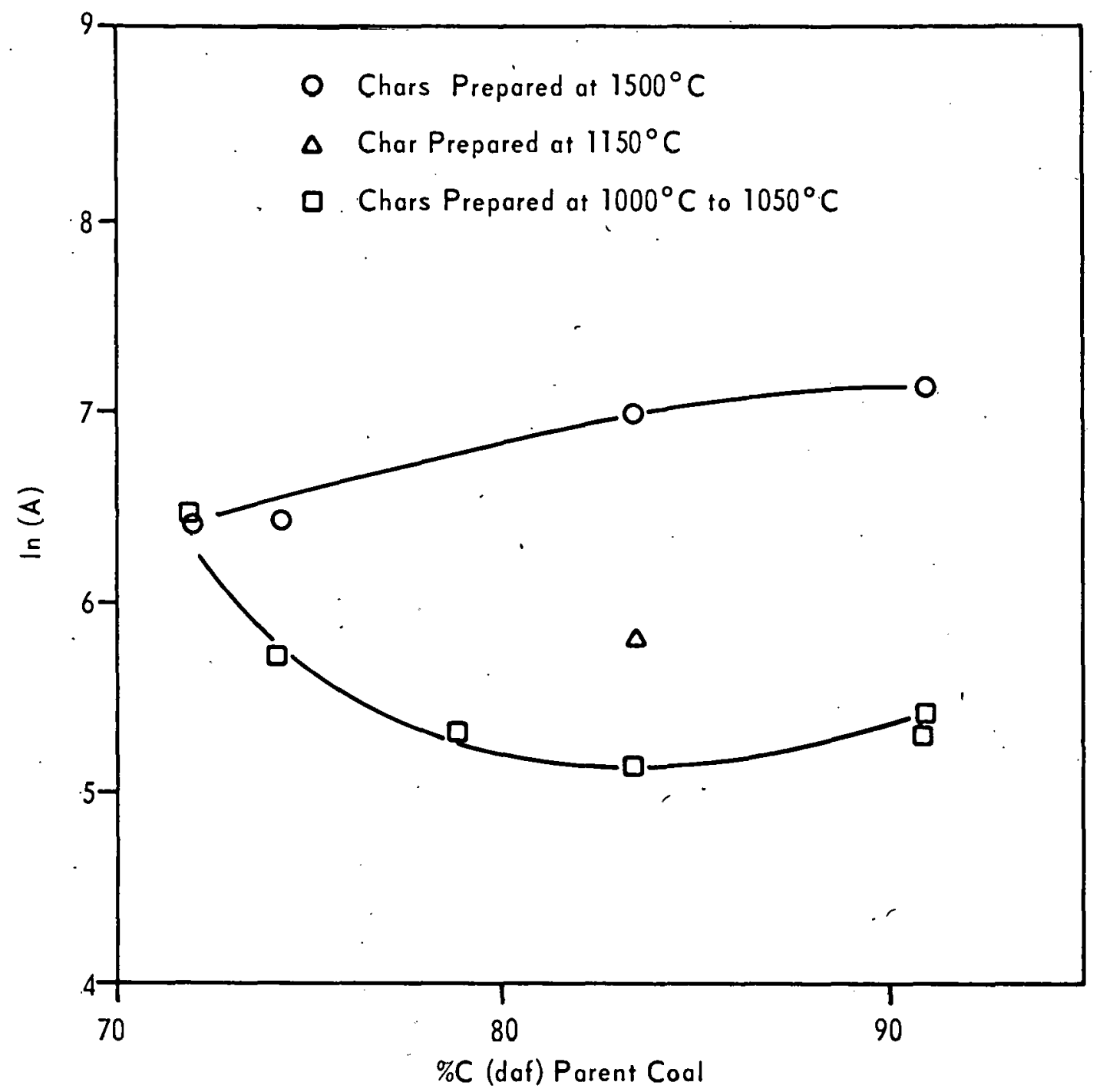

Figure 22. VARIATION OF In WITH CARBON CONTENT OF PARENT COAL 
Table 29. SAXS Paräneter $\ell_{m}$ for Chars Prepared at Various Heat Treatment Temperatures

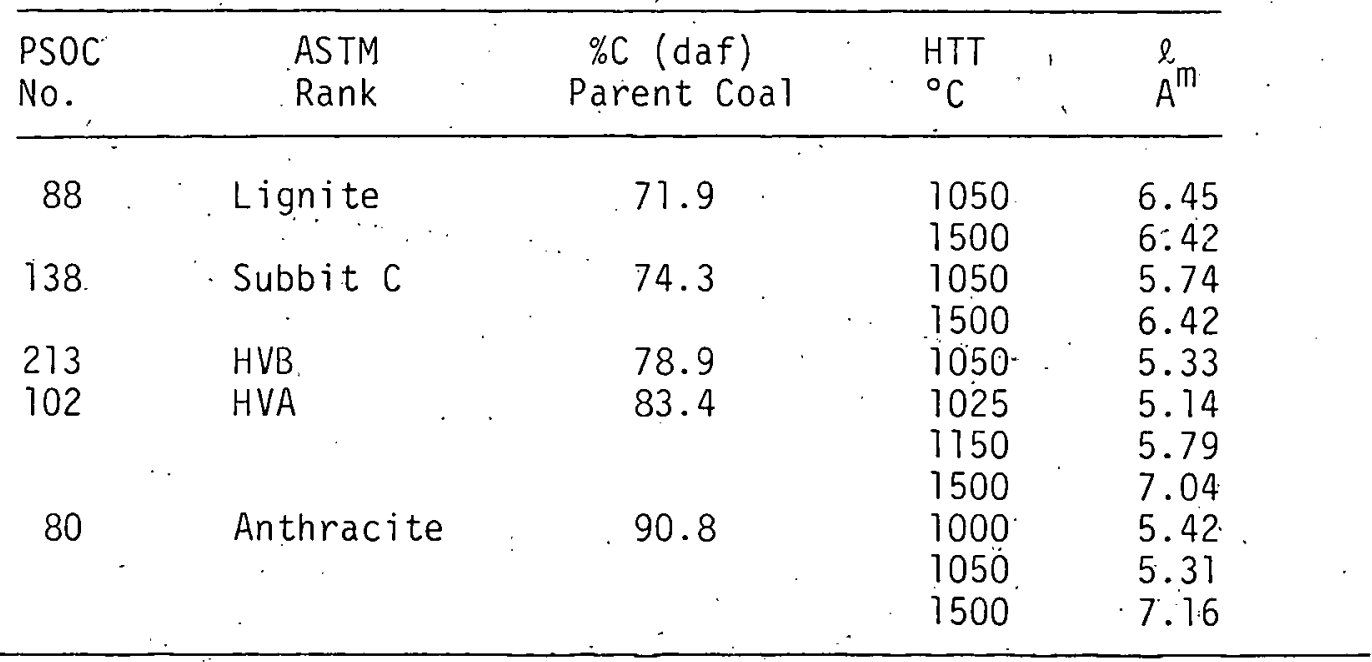

At the present time we are getting values for the volume fraction of pores so that we can calculate the secondary parameters described previously. In addition, the surface area of the chars are being measured by carbon dioxide adsorption so that comparisons can be made. 
FACET IV-F: DIFFERENTIAL SCANNING CALORIMETRY

DIFFERENT IAL SCANINING CALORIMETRY STUDIES ON COALS AND CHARS

\section{Introduction}

The DSC technique has been used to study the thermal effects involved during chemisorption of oxygen on Saran carbon. Saran carbon resembles coal chars but is of high purity. The existence of different kinetic stages corresponding to adsorption on different active sites is indicated. The rate of heat released during chemisorption is proportional to the square root of oxygen partial pressure.

\section{Experimental}

This report describes further studies on oxygen chemisorption on Saran carbon using the DSC technique. Experimental procedure and methods of calculation were described in the last ERDA Report. The Saran carbon sample used in the present work was hand-crushed in a lab mortar and a $150 \times 250$ mesh fraction was used for studying the thermal effects involved during rhemisnrption of oxyqen: The iron content of this sample was 14$22 \mathrm{ppm}$. The carbon sample was heated in the BSC cell up to bUU ${ }^{\circ} \mathrm{C}$ in the manner described in the last ERDA Report and then cooled to room temperature. After this, the sample was heated to the desired reaction temperature and held at this temperature for $30 \mathrm{~min}$ in a nitrogen $\mathrm{flow}(45 \mathrm{cc} / \mathrm{min})$. Air was then introduced to replace nitrogen and the DSC scan started. Values of $Q(\mathrm{cal} / \mathrm{g} \mathrm{C}$ ) were calculated from the thermograms at different time. intervals. The plots of $Q$ vs $\log t$ (Elovich plots) are shown in Figure 23. Below $202^{\circ} \mathrm{C}$, no significant thermal effects were observed. Therefore, in order to study the discontinuities in the Elovich plots at lower temperatures, an activated Saran carbon sample was used. The Saran carbon was activated in a fluid bed reactor in air at $425^{\circ} \mathrm{C}$ for $10 \mathrm{hr}$ to 63.8 percent carbon burn-off. The thermograms for the activated sample were obtained in the temperature range $100-202^{\circ} \mathrm{C}$. Plots $Q$ vs $\log t$ are shown in Figure 24 . These plots as well as those in Figure 23 are discontinuous straight lines. This behavior indicates the existence of different kinetic stages during chemisorption of oxygen. Eash of these stages corresponds to a different group of active sites. Increase in reaction temperature results in an earlier appearance of any one kinetic stage. At lower temperatures, the rate of heat released is slow and probably chemisorption occurs at the most active sites. As the temperature increases, chemisorption occurs on less active sites. With the DSC technique, it is difficult to detect thermal changes be $10 \mathrm{w} 100^{\circ} \mathrm{C}$. Attempts were made to examine variation in the activation energy $\left(E_{a}\right)$ for the chemisorption process as a function of Q. Figure 25 shows the Arrhenius plots obtained at different selected values of cor different 


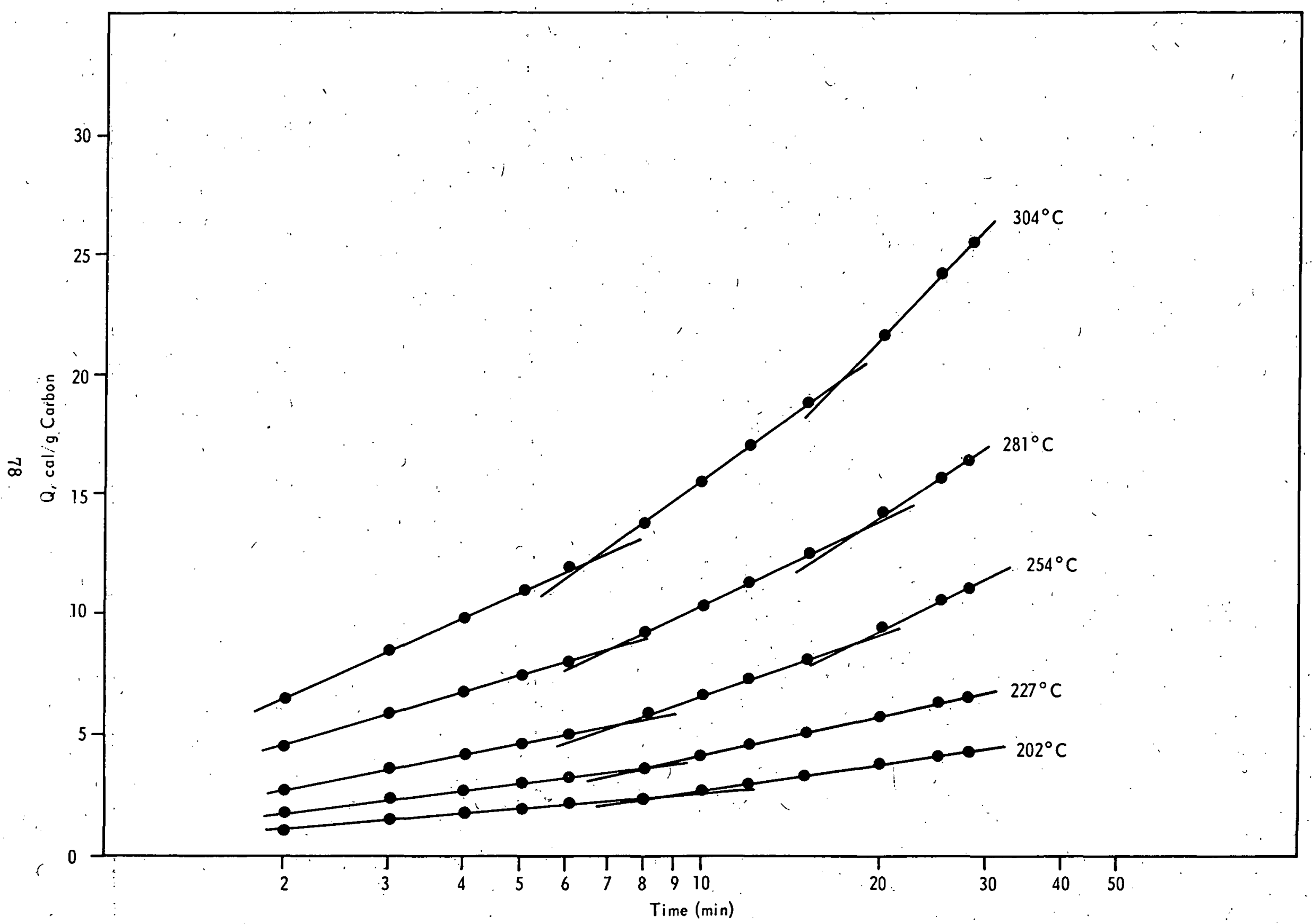

Figure 23. Q VS LOG T PLOTS FOR UNACTIVATED SARAN $(150 \times 250)$ 


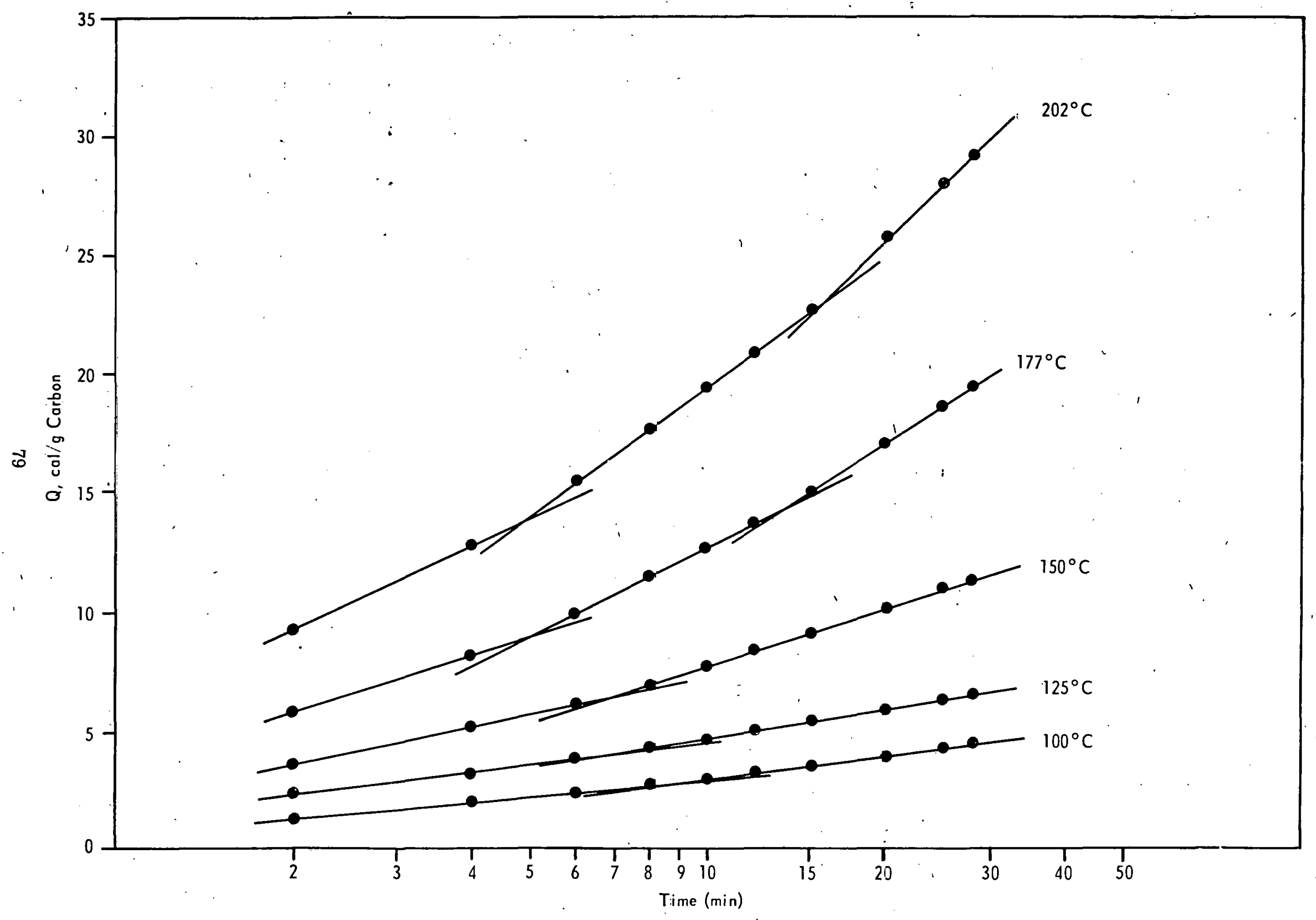

Figure 24. Q VS LOG T PLOTS FOR AIR-ACTIVATED SAF. (150 $\times$ 250) 


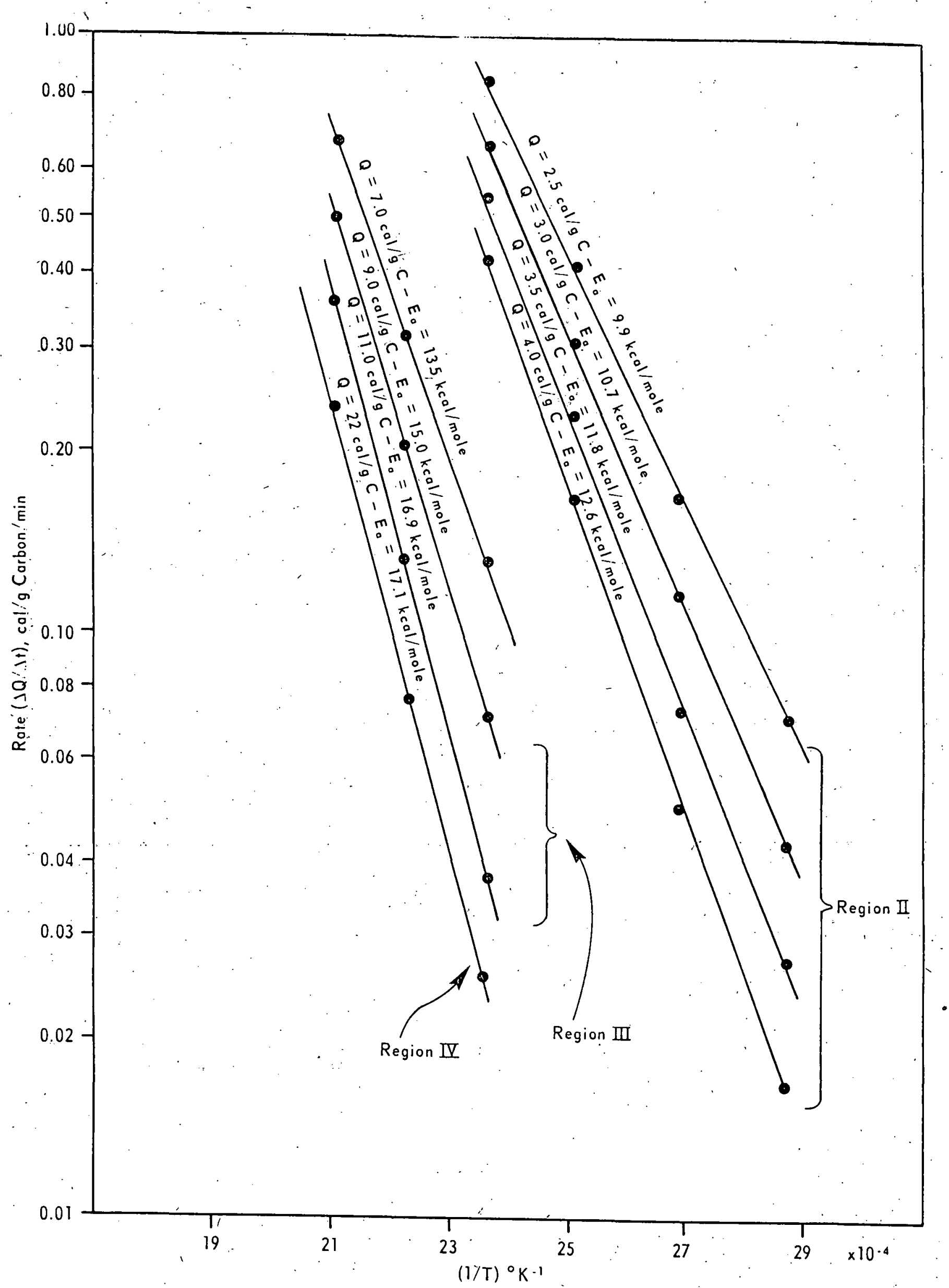

Figure 25. ARRHENIUS PLOTS FOR AIR ACTIVATED SARAN CARBON 
active sites. In the case of the activated Saran carbon, $E_{a}$ for chemisorption on the most active site is $5.6 \mathrm{kcal} / \mathrm{mole}$. This value increases with increase in $Q$ liberated, that is when chemisorption occurs at less active sites. Finally $E_{a}$ becomes constant at 16.9-17.1 kcal/mole for the least active sites. However, in the case of the unactivated sample, the value of $E_{a}$ remained almost constant $(16.2-18.7 \mathrm{kcal} / \mathrm{mole})$ and was independent of $Q$. It is probable that for the unactivated sample, although different active sites have the same value of $E_{a}$, they have different

values of heats of chemisorption. When this sample was activated to 63.8 percent burn-off, more active sites were created involving less activation energy during chemisorption of oxygen.

In studying the order of the chemisorption process with respect to partial pressure of oxygen, a few experiments were performed on the unactivated sample at $227^{\circ} \mathrm{C}$. For each run, a mixture of oxygen and nitrogen of different proportions was passed over the sample. The sum of flow rates of both gases was kept constant at $45 \mathrm{cc} / \mathrm{min}$. Partial pressure of oxygen in the mixture was calculated from the relative flow rates of the two gases. One additional run was made using air. The partial pressure of oxygen in various oxygen-nitrogen mixtures was varied from 0.1 to 1.0 atm. Differential and integral rates of heat released were calculated. The differential rates were calculated by dividing the increment of heat released by the corresponding time interval $(\Delta Q / \Delta t)$. The integral heat was calculated by dividing the total (cumulative) $Q$ released by time $t$ required to reach that value. Both rates were computed at $10,15,20$, and $25 \mathrm{~min}$. Plots of these rates vs partial pressure of oxygen are shown in Figure 26. The straight lines obtained have slopes ranging between 0.47-0.51 and are independent of time. This indicates that the order of chemisorption of oxygen on Saran carbon is a function of the square root of oxygen partial pressure.

Adsorption and desorption runs were next made to study the extent of surface coverage during chemisorption of oxygen at different temperatures. DSC scans were first obtained for chemisorption of oxygen at different temperatures. At the end of a given scan, the sample was heated to $600^{\circ} \mathrm{C}$ in a nitrogen flow and held at this temperature for $3-1 / 2 \mathrm{hr}$. This was followed by cooling the sample in a nitrogen atmosphere at the same flow rate. A second adsorption scan (resorption) was then obtained on the same sample at the same temperature as used in the first adsorption run. The amount of heat released $Q_{2}(\mathrm{cal} / \mathrm{g} \mathrm{C})$ during any resorption run was lower than that released during the first adsorption run. This indicates that when desorption is performed at $600^{\circ} \mathrm{C}$, only a part of the chemisorbed oxygen is desorbed,: so that a part of the chemisorbed oxygen is still retained on the surface- The ratio $\left[Q_{2} / Q_{1}\right]_{600}$ is defined here as the fraction of the surface regenerated after heating the sample at $600^{\circ} \mathrm{C}$ for $3-1 / 2 \mathrm{hr}$. Table 30 lists the values of $Q, Q_{2}$, and other relevant data. As the adsorption temperature increases, the 


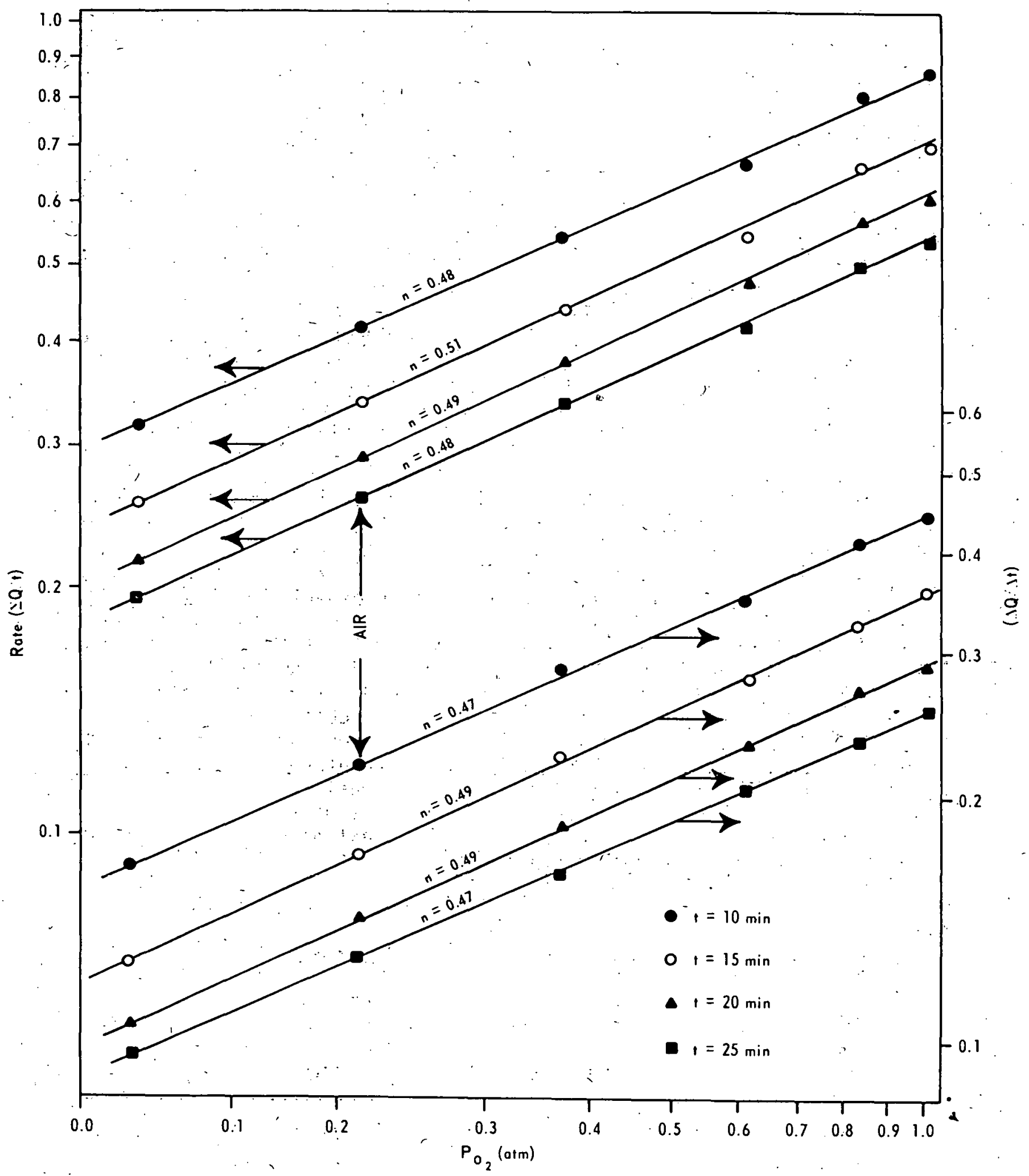

Figure 26. EFFECT OF PARTIAL PRESSURE OF $\mathrm{O}_{2}$ ON HEAT OF CHEMISORPTION 
Table 30. Thermal Effects Involved During Chemisorption of Oxygen

\begin{tabular}{lccccc}
\hline $\begin{array}{c}\text { Adsorption Temp. } \\
\left({ }^{\circ} \mathrm{C}\right)\end{array}$ & 177 & 202 & 227 & 254 & 281 \\
\hline$Q_{1}(\mathrm{cal} / \mathrm{g} \mathrm{C})$ & 6.25 & 10.45 & 17.27 & 25.38 & 41.14 \\
$Q_{2}(\mathrm{cal} / \mathrm{g} \mathrm{C})$ & 3.48 & 6.18 & 11.12 & 16.98 & 29.12 \\
{$\left[Q_{2} / Q_{1}\right]_{600}(\%)$} & 55.7 & 59.2 & 64.4 & 66.9 & 70.8 \\
$\left(Q_{1}-Q_{2}\right)(\mathrm{cal} / \mathrm{g} C)$ & 2.77 & 4.27 & 6.15 & 8.40 & 12.03 \\
\hline
\end{tabular}

value of $Q$ liberated is higher both for the first as well as the subsequent adsorption run. The fraction of the surface regenerated after desorption increases with increase in the adsorption temperature. Thus a surface which is initially covered with more oxygen would desorb more oxygen. This indicates that at elevated adsorption temperatures, most of the chemisorbed oxygen is attached to less active sites. On the other hand, at lower adsorption temperatures, oxygen is strongly attached to the surface, and consequently the fraction of surface regenerated during desorption is less.

The effect of desorption temperature on the regeneration of carbon surface was also investigated. An adsorption experiment was first done at $227^{\circ} \mathrm{C}$. This was followed by heating the carbon sample in nitrogen to a certain temperature in the range $450-600^{\circ} \mathrm{C}$. The sample was held at the chosen maximum temperature for $3-1 / 2 \mathrm{hr}$ and then cooled to room temperature. Resorption of oxygen was carried out on the sample at $227^{\circ} \mathrm{C}$ Table 31 lists the values of $Q_{1}, Q_{2}$, and $Q_{1} / Q_{2}$ obtained after desorption at $600,550,520,500$, and $450^{\circ} \mathrm{C}$. It can be seen that the reaction of surface regenerated at higher desorption temperatures is greater than that regenerated at lower temperatures. The ratio $Q_{2} / Q_{1}$ is constant at temperatures below $450^{\circ} \mathrm{C}$, showing that there is no significant effect of desorption temperature below $450^{\circ} \mathrm{C}$ on the extent of surface regenerated for subsequent oxygen chemisorption.

Table 31. Effect of Desorption Temperature on Heat of Chemisorption of Oxygen at $227^{\circ} \mathrm{C}$

\begin{tabular}{lccccc}
\hline $\begin{array}{c}\text { Desorption } \\
\text { Temp. }\left({ }^{\circ} \mathrm{C}\right)\end{array}$ & 600 & 550 & 520 & 500 & 450 \\
\hline$Q_{1},(\mathrm{cal} / \mathrm{g} \mathrm{C})$ & 17.27 & 17.48 & 17.39 & 17.38 & 17.32 \\
$Q_{2},(\mathrm{cal} / \mathrm{g} C)$ & 11.12 & 8.05 & 7.36 & 6.79 & 6.58 \\
$\left(Q_{2} / Q_{1}\right),(\mathrm{cal} / \mathrm{y} C)$ & 64.4 & 46.7 & 42.3 & 39.1 & 38.0 \\
$\left(Q_{1}-Q_{2}\right),(\mathrm{cal} / \mathrm{g} C)$ & 6.15 & 9.43 & 10.03 & 10.59 & 10.74 \\
\hline
\end{tabular}


FACET $V$-Á: COMBUSTION OF CHARS AND LOW VOLATILE FUELS

\author{
COAL COMBUSTION RESEARCH; \\ LOW VOLATILE FUELS--COMBUSTION OF CHAR AND \\ ANTHRACITE COAL IN LARGE UTILITY BOILERS
}

Introduction

Most of our work to date has been focused on the development of computer models to analyze and explain past experiments and to design future ones. A model which considers only the stable combustion of a pulverized char flame in an infinite parallel plane geometry (properties varying only along the direction of flow) is a logical and valid starting point toward further three dimensional modeling. The model does permit examination of the detailed structure of pulverized char flames simply, yet realistically:

\title{
Experimental
}

Presented in this section is a computer analys is of the ignition behavior of a pulverized char and air mixture when a hot wall ignition source is used. Using the infinite parallel plane computer model, the procedure was to fix the exit permeable wall at some temperature considerably above ambient, and to solve for the resulting combustor temperature profile from the entrance.through the "left" permeable.wall. (fixed at ambient temperature) to the exit or "right" permeable wall (fixed at elevated temperatures).

Points $A$ through $K$ of Figure 27 are the resulting completeness of combustion values plotted against the corresponding values of the constrained exit wall temperature. : Points $A$ through $C$ correspond to low exit wall temperatures and less than one percent combustion. As the exit wall temperature is elevated above $1400^{\circ} \mathrm{C}$, the completeness of combustion starts to rise appreciably until, near point $\dot{K}$; changes in the hot exit wall temperature of only several degrees varies the completeness of combustion by 5 or 6 percent. As the hot wall temperature increases toward $1558^{\circ} \mathrm{C}$, the completeness of combustion increases toward 75 percent ( -25 percent "excess" air condition). For wall temperatures in excess of $1558^{\circ} \mathrm{C}$, points such as point $M$ are typical, with combustion being nearly complete.

With the exit wall temperature reduced through $1558^{\circ} \mathrm{C}$, the conditions corresponding to points $N$ through $R$ are obtained, with completeness of combustion ranging just under 75 percent. With further reduction in exit wall temperature (below point $R$ value of $1227^{\circ} \mathrm{C}$ ), the only stable condition is one- of essentially zero combustion and. to the left of point $A$. The processes outlined above are ignition, stable (combustion) operation, and extinction in the context of a hot wall ignition source. Once the hot wall temperature exceeds around $1558^{\circ} \mathrm{C}$, the system has only one possible stable state (combustion), e.g., point $M$. Points $L$ through $R$ represent stable combustion 


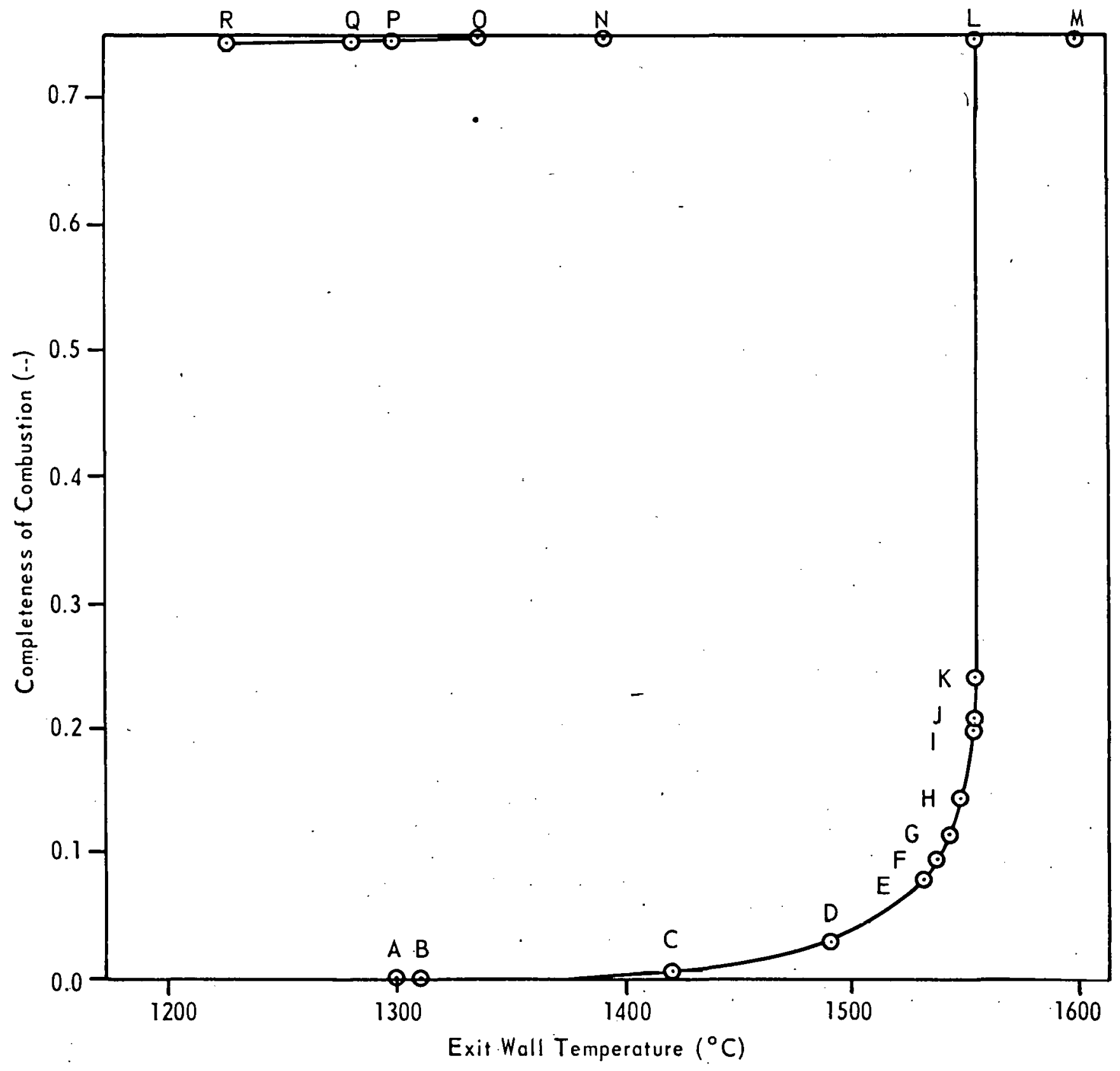

Figure 27. COMPLETENESS OF COMBUSTION VS EXIT WALL TEMPERATURE (Infinite Parallel Plane Model Results) 
(ignited) states, while points $A$ through $K$ represent stable slow oxidation (unignited) states. Thus, if the hot wall temperature is below $1227^{\circ} \mathrm{C}$, only one state exists; if the temperature is between $1227^{\circ} \mathrm{C}$ and $1558^{\circ} \mathrm{C}$, two states exist; and above $1558^{\circ} \mathrm{C}$ only one state exists again.

As an example of the two possible states for one set of boundary conditions, Figure 28 shows two combustor temperature profiles for exactly identical boundary and operating conditions. For both temperature profiles, the hot wall temperature is $1299^{\circ} \mathrm{C}$. The. ignited profile corresponds to point $P$ in Figure 27 (completeness of combustion 74.74 percent) and the unignited profile corresponds to point $A(0.04$ percent). The method of obtaining the ignited or unignited solution in the two-solution region is to use either high or low initial estimates for the iterative solution scheme.

Therefore, with respect to a hot wall ignition-source, ignition and extinction. (wall) temperatures can be defined, as well as the stable range of combustor performance. These temperatures are functions of fuel reactivity, inlet flow conditions, and stoichiometry.

With the submission of the second quarterly report the infinite parallel plane model was limited to equal nodal spacings of the distance between the two end walls and a constant cloud radiation absorption coefficient. A major revision has removed these restrictions. That these restrictions were of a serious nature can be seen in Figure 29 . The combustor temperature profiles are plotted versus distance from the entrance to exit permeable walls. The only variation in run conditions is that of the dust cloud radiation absorption coefficient. Unilike the study reported above, here the exit (hot) wall temperature is iteratively solved for by heat balance conditions. Profiles for absorption coefficients of $3.33 \mathrm{~m}^{-1}$ and $6.67 \mathrm{~m}^{-1}$ appear in Figure 29. The absorption coefficient does have an appreciable effect on the temperature profile.

In reaility, the dust cloud absorption coefficient should be directly proportional to the particle concentration and the square of the particle diameter according to the simple black geometric interceptor theory. For a system where gas temperatures vary from $300^{\circ} \mathrm{K}$ to about $2200^{\circ} \mathrm{K}$, the particle cloud concentration can vary by more than a factor of seven. Thus, a constant "mean" absorption coefficient is actually quite crude. At $300^{\circ} \mathrm{K}$, the cloud absorption coefficient could range from about $10 \mathrm{~m}^{-1}$ to as much as 30 to $40 \mathrm{~m}^{-1}$. depending on particle size, particle density, and fuel/air ratio. In the study plotted in Figure 29, when the absorption coefficient used exceeded $6.67 \mathrm{~m}^{-1}$ the program predicted only unignited solutions. Much below $3.33 \mathrm{~m}^{-1}$ the same sort of problem is present. It had been suspected for some time that the inability of the model to predict:fast temperature rises was due to the use of:a low uniform absorption coefficient. This suspicion has proven to be correct.

Another point can be seen from examining the $6.67 \mathrm{~m}^{-1}$ curve in Figure 29. . This fact is, as is true of the plane flame furnace experimental 


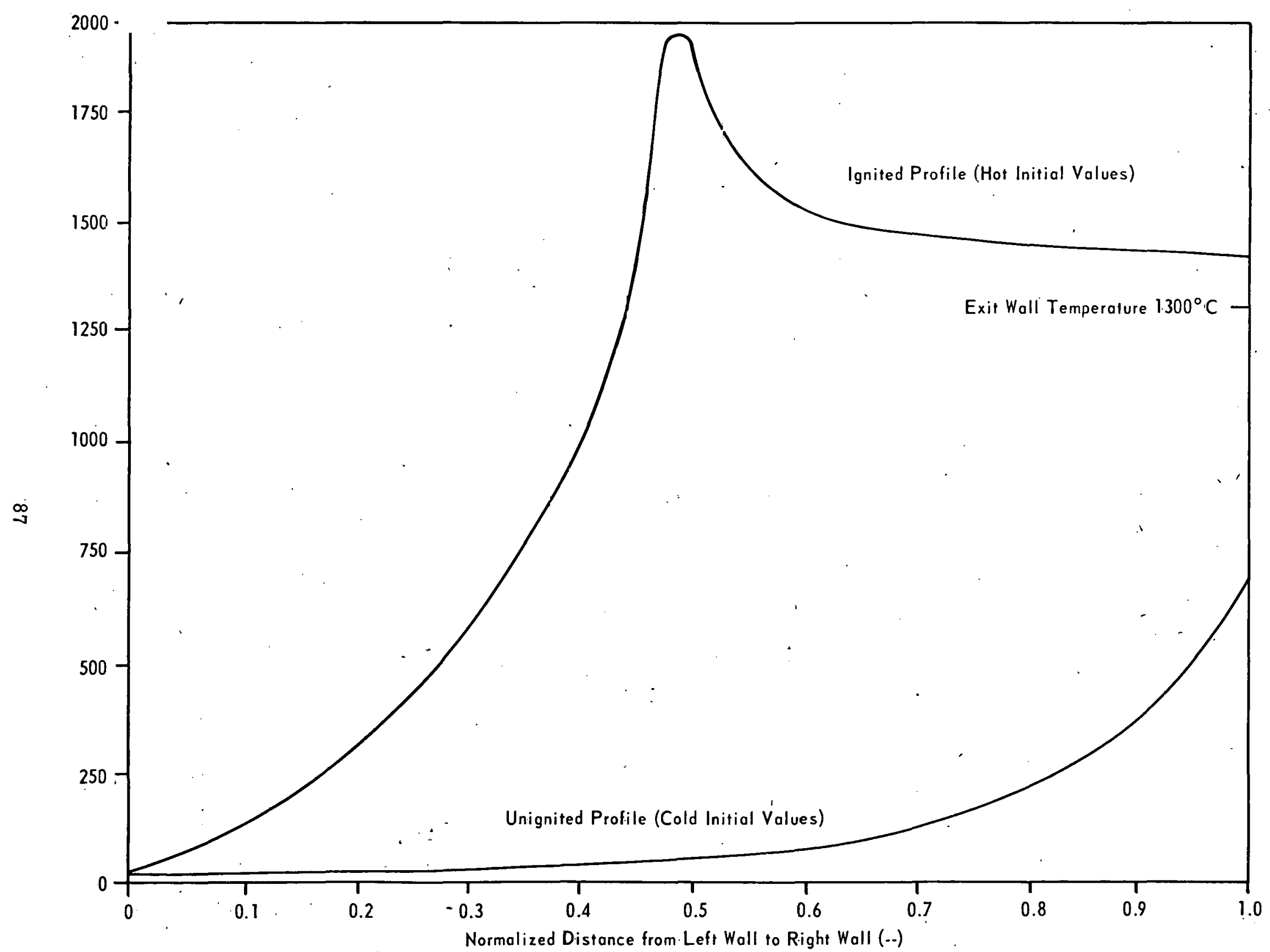

Figure 28. GAS TEMPERATURF. VS NORMALIZED DISTANCE FROM LEFT WALL TO RIGHT WALL' Actual Wall Separation: $75 \mathrm{~cm}$ 


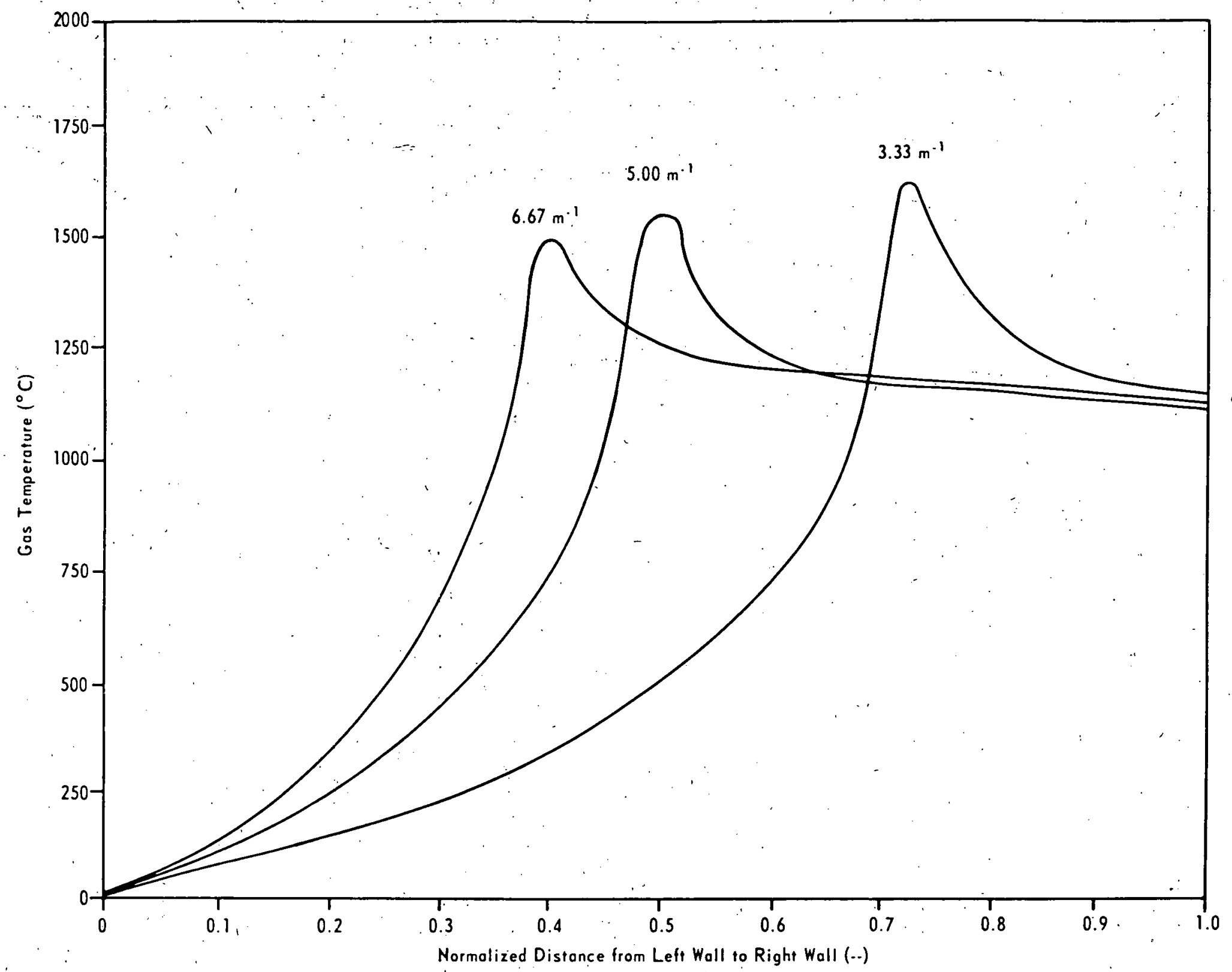

Figure 29. GAS TEMPERATURE VS DISTANCE FROM LEFT WALL DUST CLOUD RADIATION ABSORPTION COEFFICIENT VARIATION (Infinite Parallel Plone Model Results)

Actual Wall Separation: $75 \mathrm{~cm}$ 
results, that half, or more than half, of the chamber is essentially isothermal. Unequal nodal spacing would allow more "fine grained" detail in the flame front region, for equal computation times, if much larger nodal spacings were used in the isothermal "tail" region. Thus, both unequal nodal point spacings and variable absorption coefficient were incorporated into the infinite parallel plane model.

Figure 30 shows two temperature profiles plotted versus distance from the entrance wall to the exit wall for a rather high base value $\left(T=300^{\circ} \mathrm{K}\right.$, original $20 \mathrm{~m} \mu$ diameter) of absorption coefficient: $41.6 \mathrm{~m}^{-1}$. This high value was chosen because it simulates a char of extremely small density (abnormally macroporous), as the two Exxon chars are believed to be. The typically fast temperature rises attainable with this high absorption coefficient caused numerical instabilities earlier, when only uniform nodal spacing was available. The distance of the primary reaction zone from the cold inlet wall is seen as being about 10 percent of the $0.75 \mathrm{~m}$ total interwall distance, or about $7.5 \mathrm{~cm}$. This compares favorably with the distances found experimentally for the reactive chars at fuel rich conditions. The temperature profile was solved for iteratively with the absorption coefficient continualiy being updated during every other iteration for temperature and particle size effects (constant density burnoff assumed). After each complete absorption coefficient update, the radiative transfer matrix is also recalculated. A total of 76 nodal points were used for the calculation plotted in Figure 30. From node one (entrance) to node 41, a unit spacing was used; from node 41 to node 46 a spacing twice as large was used; and from node 46 to 76 three times the unit spacing was used. As stated above, the uneven nodal spacing allows a much finer detailed solution to be obtained in the regions of large temperature gradients. No instabilities occurred in the computational process, even though quite large temperature gradients were present. Therefore, the combination of variable absorption coefficient and uneven nodal spacing appears to function as desired.

For the same operating conditions as were used in the Figure 30 calculation, the char combustion kinetics of Field ${ }^{19}$ were employed to see if actually measured char kinetics would predict "reasonable" results for a reportedly high reactive char. Field's expressions for the surface reaction rate are

$$
\begin{gathered}
R_{S}=8710 \exp (-35,700 / R T) \frac{\mathrm{gm}}{\mathrm{cm}^{2} \mathrm{sec} \operatorname{atm} 0_{2}} \\
\text { for } T \leq 1277^{\circ} \mathrm{K},
\end{gathered}
$$

and

$$
\begin{gathered}
R_{S}=-0.09-1.26 \times 10^{-4} \mathrm{~T}+1.58 \times 10^{-7} \mathrm{~T}^{2} \frac{\mathrm{gm}}{\mathrm{cm}^{2} \mathrm{sec} \mathrm{atm} \cdot 0_{2}} \\
\text { for } \mathrm{T}>1277^{\circ} \mathrm{K}
\end{gathered}
$$

where $R_{S}$ is the rate of particle mass depletion per unit external surface 


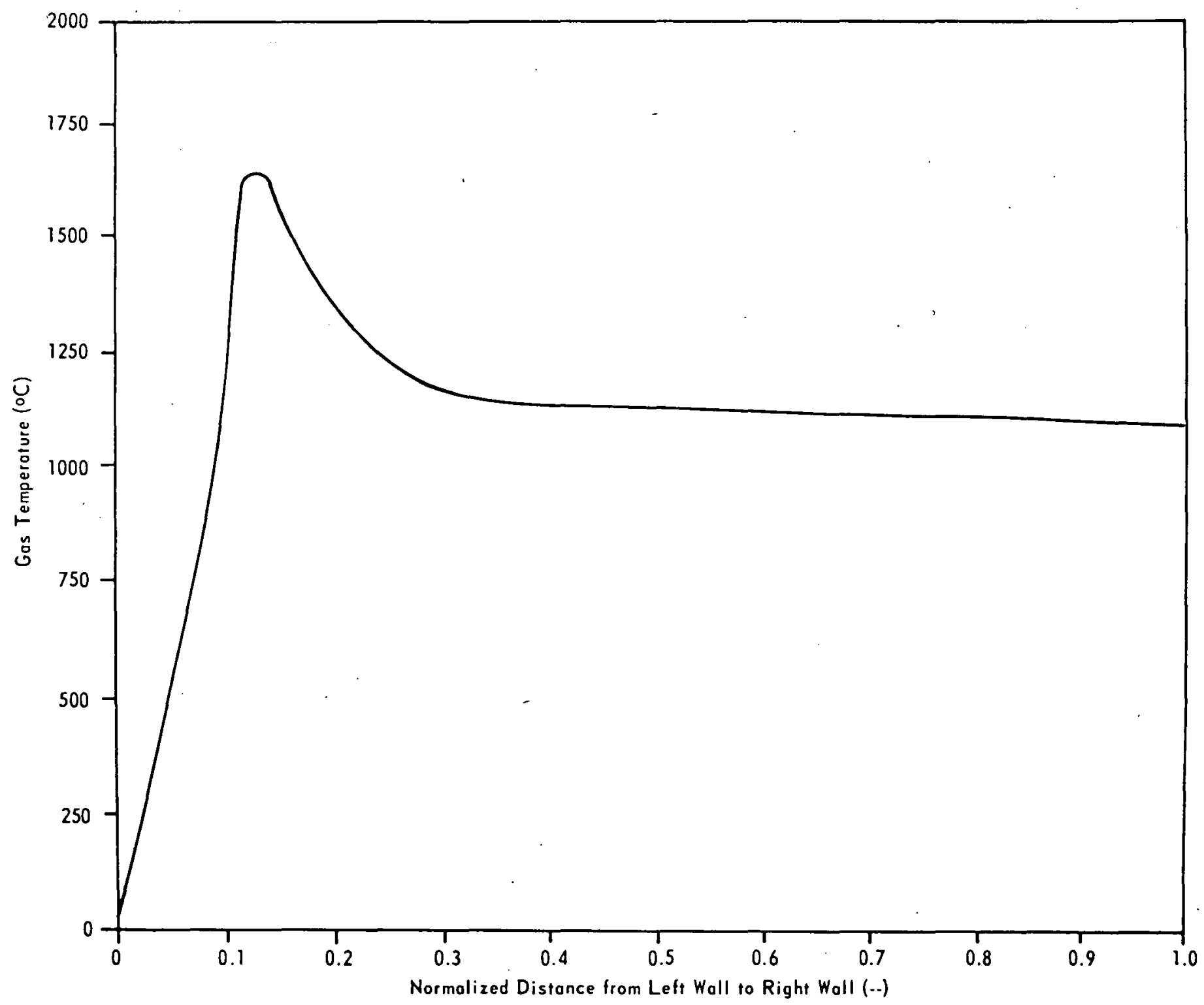

Figure 30. GAS TEMPERATURE VS DISTANCE FROM LEFT WALL BASE ABSORPTION COEFFICIENT $41.6 \mathrm{~m}^{-1}$

(Infinite Parallel Plone Model Results)

Actual Wall Separation: $75 \mathrm{~cm}$ 
area, per unit time and per unit atmosphere of oxygen (first order in oxygen assumed). The combustor temperature profile, using the above Field kinetics, is plotted versus distance from inlet wall to outlet wall in Figure 31. Here, again as in Figure 30, the base absorption coefficient is $41.6 \mathrm{~m}^{-1}$. This figure would be justified since Field's kinetics were obtained for a usually quite porous low rank char, and since fine grinds (normally 45 percent smaller than $44 \mathrm{~mm}$ by weight) are used in the plane flame furnace. It can be seen in Figure 31 that for a wall separation of $0.75 \mathrm{~m}$, the flame front would be somewhere around $6 \mathrm{~cm}$ or so from the coal inlet wall. The peak temperature obtained here is about $2040^{\circ} \mathrm{C}$ and the "tail" temperature is around $1420^{\circ} \mathrm{C}$, both reasonable enough figures considering that in the infinitc parallel plane model no heat can be lost in directions perpendicular to the direction of flow (normal to the walls). A nonuniform nodal spacing scheme and an absorption coefficient dependent on temperature and diameter were used here as in the Figure 30 calculation. Thus, a measured set of kinetics has yielded physically reasonably results in the infinite parallel plane model.

Work remaining to be done on the infinite parallel plane model includes the incorporation of a heat transfer equation to account for local particle/gas temperature differences, and the use of more detailed kinetics involving particulate physical structure (surface area, pore size distribution, etc.) and carbon monoxide/carbon dioxide conversion. During the next quarter, work on the three dimensional model will be revived to reach the ultimate modeling goals of this project. Samples of the Exxon, Illinois, and Wyodak chars, the FMC-COED char and the ultra-fine anthracite were sent to Micromeritics Corporation early in January, 1976 for complete particulate characterization analys is (surface areas, pore volumes, densities, pore size distributions, and particle size analysis). A report of these analyses will be forthcoming.

\section{Conclusions}

The following conclusions have been reached as a result of the work accomplished to date:

1. Low volatile chars and coals can be suitable fuels if adequate available internal surface area is present.

2. The low and high reactivity fuels show quite different combustion behavior in the plane flame furnace.

3. Computer modeling can predict combustion performance, "ignition" temperatures, and detailed heat transfer and chemical reaction couplings even with an infinite parallel plane model. 


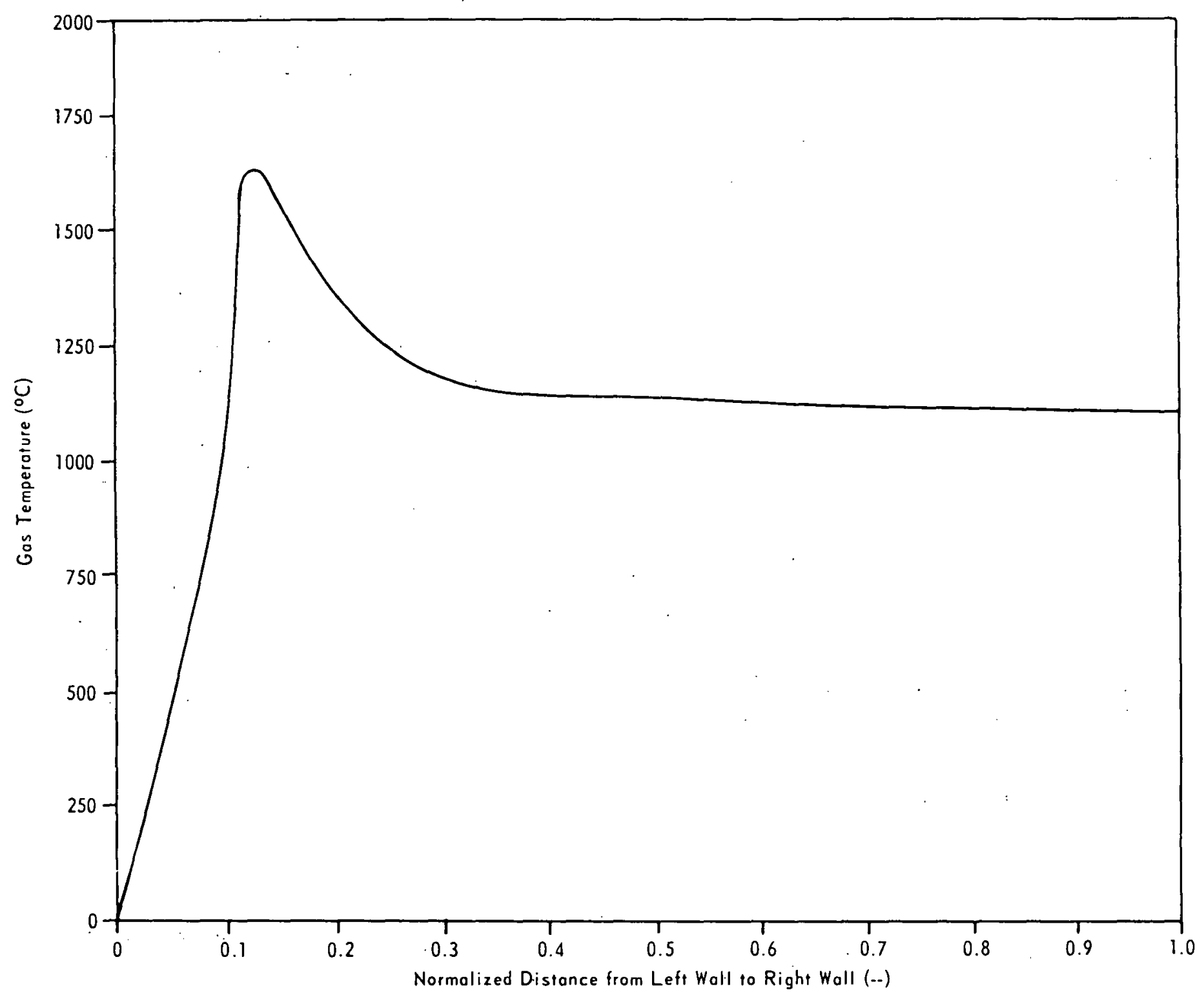

Figure 31. GAS TEMPERATURE VS DISTANCE FROM LEFT WALL

FIELD CHAR COMBUSTION KINETICS

(Infinite Parallel Plane Model Results)

Actual Wall Separation: $75 \mathrm{~cm}$ 


\title{
FACET V-B: COMBUSTION OF COAL-OIL EMULSIONS
}

\author{
COMBUSTION OF COAL-OIL EMULSTIONS
}

Introduction

This quarter work centered on the evaluation of data acquired since June, 1975 and the preparation of a paper for presentation at the Central States Section of the Combustion Institute at Batelle-Columbus Laboratories. Entitled "Smoke Point and Heat Transfer Characteristics of 0il/ Water/Air Emulsions Without and With Coal Addition in a Hot Wall Furnace", it is included as Appendix $B$ to this report. In addition to those investigators contractors by ERDA, the paper was co-authored by several "outside" scientists, since the research discussed is part of an on-going project which commenced prior to inception of the ERDA contract.

\section{Experimental}

The furnace was a refractory wall unit of internal dimensions $2 \mathrm{ft}$ $\times 2 \mathrm{ft} \times 10 \mathrm{ft}$ with 17 water-cooled tubes on $i$ ts floor to simulate the load of a continuous industrial thermal processing furnace. The burner was a split jet-can (perforated wall) type of combustor with air so supplied that it produced a double vortex mixing pattern. An impact atomizer with large clearances to accomodate the coal was used in the burner; flame stability and turn down were very good.

The main observations and conclusions reported within the paper deal with the applications of emulsions of oil/water/air mixtures. The analys is of the effects of coal additions from traces to only one percent has been included. In summary the emulsions without coal additions (Number 2 oil, water and air, generated by a Sebba (6) emulsifier, fired in a hot wall furnace at $1.25 \mathrm{million}$ BTU/hr) were found to reduce excess air requirements at the smoke point, to remove carbon buildup at the burner, and to reduce the flame emissivity (and, therefore, thermal efficiency). Flame emissivity was restored to its original value or better by addition of coal at concentrations ranging from traces to one percent or by addition of inert magnesia (or by permitting operation with medium to heavy smoke). The experiments suggest that the principal combustion reactions and the smoke formation reactions are effectively independent of each other, with smoke influenced by, and combustion uninfluenced by water. The reduced radiation with water suggests that these emulsions would be appropriate for substitution of gas by $0 i 1$ where oil radiation can cause problems of overheating and burn out, for example, in radiant tube furnaces.

Attention has also been given to the technical problem encountered in dispersing significantly greater amounts of coal into the emulsions. In addition the next quarter requires consideration of desig 'modifications for the burner atomizer to avoid fouling problems otherwize $\epsilon$ :pected when higher coal concentrations are used. 


\section{CONCLUSIONS}

1. Early comparisons indicate a mathematical relationship between average random reflectance as recorded by the Rapid Scan and the mean-maximum reflectance as obtained by standard reflectance. analys is.

2. The results obtained so far show support of a diffusion dominance mechanism in the oxidation region of a combustion pot and a chemical kinetic mechanism in the gasification region. Work is underway to study the influence of particle size and velocity and temperature on the diffusional rate.

3. Values of reaction rates in coke beds have been calculated from experiments with a fixed bed shaft gasifier (combustion pot), assuming diffusion dominated reaction in the oxidation region and chemical kinetic controlled reaction in the gasification region. The equation for the variation of gas composition with time in the bed is:

$$
\left.\left(Y_{1}+1 / 2 Y_{2}\right) / L-1 / 2 Y_{3}\right)=A e^{-n_{1} t}+B e^{-n_{2} t}+C
$$

where $Y_{1}, Y_{2}$ and $Y_{3}$ are mole fractions of $\mathrm{O}_{2}, \mathrm{CO}_{2}$ and $\mathrm{CO}$ respectively, $n_{1}$ and $n_{2}$ are modified rate constants for the two heterogeneous reactions and $A, B$, and $C$ are constants. The experimental results obtained are in support of the assumed mechanisms.

4. Devolatilization of a North Dakota lignite in a laminar flow reactor and subsequent treatment of the resulting char has shown that weight loss is strongly dependent upon the isothermal decomposition time $\left(\tau_{\text {iso }}\right)$. Physical properties such as nitrogen and carbon dioxide surface areas change appreciably with $\tau_{\text {iso }}$. Weight loss contributes to the development of nitrogen and carbon dioxide surface areas. The $x$-ray diffraction peak found at $226.6^{\circ} \mathrm{C}$ in $2 \theta$ angles is believed to be from a (101) reflection of impure silicon dioxide. The crystallite size of impure silicon dioxide is smaller for the raw coal than it is for the chars.

5. The reactivity of chars in air was found to increase with increase in oxygen pressure, with the relationship $R_{0}$ proportional to (oxygen pressure $)^{0.71}$. Burn-off versus time plots obtained for a given char in different oxygen-nitrogen mixtures can be normalized indicating that although gasification rates increase with increase in partial pressure of oxygen the mechanism for gasification of a given char is independent of partial pressure of oxygen. Normalized reactivities in air at $405^{\circ} \mathrm{C}$ of the seventeen American chars studied correlate with reactivities in carbon dioxide at $900^{\circ} \mathrm{C}$, determined previously. Reduction in particle size increased the reactivity in air of both raw and demineralized low volatile bituminous char (PSOC-127). In the case of demineralized lignite char (PSOC-87 Dem), reduction in particle size did not show any appreciable effect on reactivity. 
6. Preliminary studies on reactivities of chars in steam at $910^{\circ} \mathrm{C}$ have been reported. No significant conclusions can be drawn from the limited data presently available. However, the results indicated that reactivities of chars follow a different trend than that observed previously in air and carbon dioxide. Removal of mineral matter from coals prior to their carbonization decreases subsequent char reactivity. This indicates that mineral matter catalyzes the char gasification in steam.

7. Study of the reactivity of ion-exchanged lignite chars to steam shows that increased heat treatment decreases reactivity; ion exchange increases reactivity; particle size change between $28 \times 48$ and $60 \times 100$ mesh has only a small effect on reactivity; helium densities increase and mercury densities decrease during burn-off; and chars become more porous as burn-off increases.

8. Reactivities of four chars have been determined under different heat treatment conditions. Reactivity of a char is determined by heat treatment temperature, heating rate, soak time at maximum temperature, and is essentially independent of the gaseous atmosphere used during heat treatment. Reactivity of a char prepared by rapid devolatilization is appreciably higher than that prepared by heat treatment at lower heating rates.

9. Use of the DSC technique to study the thermal effects involved during chemisorption of oxygen on Saran carbon has yielded the results which follow.

In the temperature range $100-200^{\circ} \mathrm{C}$, the Saran carbon activated to 63.8 percent of carbon burn-off showed the existence of different groups of active sites. The unactivated sample showed similar behavior in the temperature range $202-208^{\circ} \mathrm{C}$. The activation energy $\left(E_{a}\right)$ for chemisorption of oxygen increases with increase in thermal effects involved at reaction temperatures up to $202^{\circ} \mathrm{C}$. Above this temperature, $E_{a}$ remains almost constant. The rate of heat released during chemisorption is proportional to square root of oxygen partial pressure. The fraction of carbon surface regenerated after desorption increases with increase in adsorption or desorption temperatures.

10. The use of SAXS to characterize heat treated coals shows much promise. Systematic variations of a primary structural parameter are noted with variations in heat treatment temperature and the rank of the parent coal.

11. Work on the infinite parallel plane char combustion computer model has determined that low volatile chars and coals can be suitable fuels if adequate available internal surface area is present. Low and high reactivity fuels show quite different combustion behavior in the plane flame furnace. Computer modeling can predict combustion performance, "ignition" temperatures, and detailed heat transfer and chemical reaction couplings even with an infinite parallel plane model. 


\section{REFERENCES}

1. Berry, W.F. Properties and Reactions Exhibited by Vitrinoid Macerals from Bituminous Coals. Preprints, Div. Gas and Fuel Chem., A.C.S., Boston, p. 29-49, 1959.

2. . The Thermal Behavior of Coal Constituents. Ph.D. Thes is, The Pennsylvania State University, 273 p., 1963.

3. Walsh, Jr., M., and R.R. Dutcher. Properties and Reactions Exhibited by Anthracite Lithotypes Under Thermal Stress. Min. Ind. Exp. Sta., College of Earth and Mineral Sciences, The Pennsylvania State University, Special Research Rept. No. SR-11, 15 p., 1959.

4. Dutcher, R.R. Physical, Chemical and Thermal Properties of Selected Vitrinitic Substances. Ph.D. Thesis, The Pennsylvania State University, p. 131-139, 1960.

5. Rau, E., and J.A. Robertson. The Use of the Hot-Stage Microscope in Coal Research. Preprints of Div. of Fuel Chem., A.C.S., v. 8, p. $105-117,1964$.

6. Nandi, B.N., and D.S. Montgomery. Nature and Thermal Behavior of Semi-Fusinite in Cretaceous Coal from Western Canada. Fuel, v. 54, p. 193-196, 1975.

7. International Committee for Coal Petrology. International Handbook of Coal Petrography. Supplement to the 2nd Edition, Paris, 1971.

8. Interim Research Reports 51 (December 1972), 52 (March 1973), 53 (June 1973), 54 (September 1973). OCR Contract No. 14-01-001-390. The Pennsylvania State University to the U.S. Office of Coal Research.

9. Stefanko, R., R.V. Ramani, and I.K. Chopra. The Influence of Mining Techniques on Size Consist and Washability Characteristics of Coal. Res. \& Dev. Rept. No. 61 and Interim Rept. No. 8. The Pennsylvania State University to the U.S. Office of Coal Research, August, 1973.

10. Thring, M.W. Physics of Fuel Bed Combustion. Fuel, v. 31, p. 355, 1952.

11. Badzioch, S., and P.G.W. Hawksley. Ind. Eng. Chem. Process Des. Develop., v. 9, p. 521, 1970.

12. Scherrer, P. Nachr. Gess. Wiss, Goettingen, v. 2, p. 98, 1915.

13. Klug, H.P., and L.E. Alexander. X-ray Diffraction Procedures. John Wiley and Sons, Inc., New York, Chap. 9, 1954. 
14. Davis, J.D., and D.A. Reynolds. Ind. Eng. Chem., v. 20, p. 617, 1928.

15. Hippo, E., and P.L. Walker, Jr. Fuel, v. 54, p. 245, 1975.

16. Jenkins, R.G., S.P. Nandi, and P.L. Walker, Jr. Fue , v. 52, p. 288, 1973.

17. Tomita, A. Unpublished results, The Pennsylvania State University, 1975.

18. Ruland, W. J. Appl. Cryst., v. 4, p. 70, 1971.

19. Field, M.A. Combustion and Fllame, v. 13, p. 237, 1969. 
The following individuals have made contributions to this report:

J.T. Ashu, R. Blackadar, J.C. Cogoli, C.P. Dolsen, T. Eapen, E.J. Hippo, D.S. Hoover, J.M. Hower, I.K. Ismail, R. Jenkins, A. Kokkinos, K.W. Kuehn, A. Linares, O.P. Mahajan, N.Y. Nsakala, H.E. Shull, L.E.B. Soledade, N.H. Suhr, and H.S. Zeiss. 


$$
=
$$


DATA POR - PRODUCT COAL

THIS FRACTION CONSTITUTES 66.9 PERCENT OP THE PEED.

\begin{tabular}{|c|c|c|c|c|c|c|c|c|c|c|c|c|c|}
\hline \multirow{2}{*}{\multicolumn{2}{|c|}{$\begin{array}{c}\text { SIZE } \\
\text { FRACTION }\end{array}$}} & - & IRECT $\nabla$ & UES - - - & -- & \multicolumn{2}{|l|}{-- CU } & \multicolumn{2}{|c|}{ RETAINED - } & \multicolumn{2}{|c|}{---- COMULATIVE } & \multicolumn{2}{|c|}{ PASSED-D.- } \\
\hline & & VEIGHT & A SH & SOIPOR & MOISTORE & WEIGHT & ASH & SOLFUR & MOISTURE & VEIGHT & A SH & SULFUR & MOIST \\
\hline PASSED & RETAINED & PERCENT & PERCENT & PERCENT & PERCENT & PERCENT & PERCENT & PERCENT & PERCENT & PERCENT & PERCENT & PERCENT & PERCENT \\
\hline $\begin{array}{r}30 \mathrm{M} \\
60 \mathrm{M} \\
100 \mathrm{M}\end{array}$ & $\begin{array}{r}30 \mathrm{M} \\
60 \mathrm{M} \\
100 \mathrm{M}\end{array}$ & $\begin{array}{r}0.60 \\
50.50 \\
24.70 \\
24.20\end{array}$ & $\begin{array}{r}6.60 \\
8.14 \\
9.56 \\
15.31\end{array}$ & $\begin{array}{l}1.04 \\
1.51 \\
2.46 \\
5.81\end{array}$ & $\begin{array}{l}0.75 \\
0.55 \\
0.60 \\
0.75\end{array}$ & $\begin{array}{r}0.60 \\
51.10 \\
75.80 \\
100.00\end{array}$ & $\begin{array}{r}6.60 \\
8.12 \\
8.59 \\
10.22\end{array}$ & $\begin{array}{l}1.04 \\
1.50 \\
1.82 \\
2.78\end{array}$ & $\begin{array}{l}0.55 \\
0.57 \\
0.61\end{array}$ & $\begin{array}{r}100.00 \\
99.40 \\
48.90 \\
24.20\end{array}$ & $\begin{array}{l}10.22 \\
10.24 \\
12.41 \\
15.31\end{array}$ & $\begin{array}{l}2.78 \\
2.79 \\
4.12 \\
5.81\end{array}$ & $\begin{array}{l}0.61 \\
0.61 \\
0.67 \\
0.75\end{array}$ \\
\hline
\end{tabular}

DATA FOR - MIDDLING COAI

THIS PRACTION CONSTITUTES 10.7 PERCENT OP THE PEED.

\begin{tabular}{|c|c|c|c|c|c|c|c|c|c|c|c|c|c|}
\hline \multirow{2}{*}{\multicolumn{2}{|c|}{$\begin{array}{c}\text { SIZE } \\
\text { PRACTION }\end{array}$}} & & & & & & & & \\
\hline & & $\begin{array}{l}\text { HEIGRT } \\
\text { PERCENT }\end{array}$ & $\begin{array}{c}\text { ASH } \\
\text { PRRCENT }\end{array}$ & $\begin{array}{l}\text { SUI PUR } \\
\text { PERCENT }\end{array}$ & $\begin{array}{l}\text { MOISTORE } \\
\text { PERCENT }\end{array}$ & $\begin{array}{l}\text { WEIGHT } \\
\text { PERCENT }\end{array}$ & $\begin{array}{c}\text { ASH } \\
\text { PERCENT }\end{array}$ & $\begin{array}{l}\text { SULPUR } \\
\text { PERCEN T }\end{array}$ & $\begin{array}{l}\text { MOISTITRE } \\
\text { PERCENT }\end{array}$ & $\begin{array}{l}\text { WEIGHT } \\
\text { PERCENT }\end{array}$ & $\begin{array}{c}\text { ASH } \\
\text { PERCENT }\end{array}$ & $\begin{array}{l}\text { SULPUR } \\
\text { PERCENT }\end{array}$ & $\begin{array}{l}\text { MOISTU } \\
\text { PERCEN }\end{array}$ \\
\hline $\begin{array}{r}30 \mathrm{H} \\
60 \mathrm{M} \\
100 \mathrm{H}\end{array}$ & $\begin{array}{r}30 \mathrm{H} \\
60 \mathrm{H} \\
100 \mathrm{H}\end{array}$ & $\begin{array}{r}7.50 \\
77.40 \\
12.00 \\
3.10\end{array}$ & $\begin{array}{l}10.97 \\
10.22 \\
29.49 \\
32.90\end{array}$ & $\begin{array}{r}2.21 \\
2.21 \\
7.30 \\
17.27\end{array}$ & $\begin{array}{l}0.60 \\
0.65 \\
0.65 \\
0.45\end{array}$ & $\begin{array}{r}7.50 \\
84.90 \\
96.90 \\
100.00\end{array}$ & $\begin{array}{l}10.97 \\
10.29 \\
11.67 \\
12.33\end{array}$ & $\begin{array}{l}2.21 \\
2.21 \\
2.84 \\
3.29\end{array}$ & $\begin{array}{l}0.60 \\
0.65 \\
0.65 \\
0.64\end{array}$ & $\begin{array}{r}100.00 \\
92.50 \\
15.10 \\
3.10\end{array}$ & $\begin{array}{l}12.33 \\
12.44 \\
23.83 \\
32.90\end{array}$ & $\begin{array}{r}3.29 \\
3.38 \\
9.35 \\
17.27\end{array}$ & $\begin{array}{l}0.64 \\
0.64 \\
0.61 \\
0.45\end{array}$ \\
\hline
\end{tabular}

DATA FOR - REPUSE COAL

THIS PRACTION CONSTITUTES 22.4 PERCENT OP THE PEED.

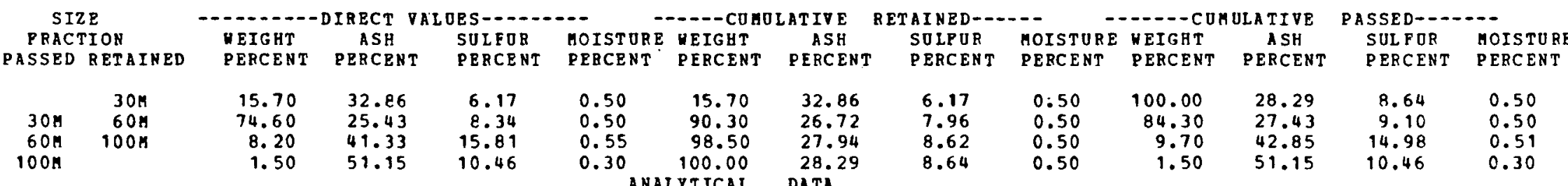

DATA FOR DRYPLO SEPARATION TEST 1

FIGURES PROA ELLIOT PEED SAHPLE.

DATA FOR -

* conposite**

THIS PRACTION CONSTITUTES 100.0 PERCENT OP THE PEED.

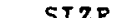
NEIGHT DIBECT PALUES ASH SUL SULFUR

\section{-D--CUMOLATIVE \\ ASH}

PASSED BETAIRED

$\begin{array}{rr}4.72 & 26.91 \\ 58.78 & 13.35 \\ 19.65 & 13.31\end{array}$

$\begin{array}{ll}30 \mathrm{O} & 6 \mathrm{H} \\ 60 \mathrm{OH} & 100 \mathrm{H}\end{array}$

19.65

16.86

13.31

16.37
5.06
3.55

4. 02

6.13
0.54
0.55
0.60
0.74
26.91
14.36

RET AI

SULP
PERC
5.06
3.6
3.7

4.72
63.50

83. 14

100.00
14.11

14.49

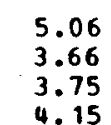

5.06
3.66
3.75
4.15
OTSTORE YRIGHT OLATIVE PERCENT PERCENT

$\begin{array}{rr}0.54 & 100.00 \\ 0.55 & 95.28\end{array}$

0.55

0.56
0.59
95.28
36.50
16.86 PERCENT

14.49
13.88

13.88
14.72

14.72
16.37
PASSED-- - - - SULFOR MOISTURE PERCENT PERCENT

$\begin{array}{ll}4.15 & 0.59 \\ 4.10 & 0.59 \\ 5.00 & 0.66 \\ 6.13 & 0.74\end{array}$


ANALYTICAL DATA

DATA POB DRYPLO SEPARATION TEST 2

DATA FOP - PRODUCT COAL.$$
S I Z E
$$

FRACTION

$\begin{array}{lr} & \\ \text { HEIGHT } & \text { ASH } \\ \text { PERCENT } & \text { PERCENT } \\ & \\ 1.20 & 10.05 \\ 51.90 & 8.84 \\ 26.00 & 10.56 \\ 20.90 & 14.84\end{array}$

$$
\text { ASH }
$$

SUIFOR PERCEN MOIST
PERCE
0.45

$$
\begin{aligned}
& 1.31 \\
& 1.67 \\
& 1.46
\end{aligned}
$$$$
0.45
$$$$
5.36
$$$$
0.60
$$

FIGORES PROH ELLIOT FEED SAMPLE.

THIS FRACTION CONSTITUTES 68.3 PERCENT OF THE PEED.
- O-CUHOLATIVE RETAI

EIGHT
PBCENT

ASH SULPOR MOISTU
PERCEN

REIGHT AOLATVE
PERCENT PERCENT

$$
\begin{array}{r}
1.20 \\
53.10 \\
79.10
\end{array}
$$

10.05

$$
\begin{aligned}
& 1.31 \\
& 1.66
\end{aligned}
$$$$
\begin{aligned}
& 1.31 \\
& 1.66 \\
& 2.38
\end{aligned}
$$

0.45
0.45
0.50

0.45
0.45
0.50

0.50
0.52
100.00
98.80

46.90

20.90

\subsection{56}

12.47 14.84 SULPUR MOISTURE PERCENT PERCENT

TAIS PRACTION CONSTITUTES 12.9 PERCENT OP THE PEED.

$\begin{array}{ll}2.38 & 0.52 \\ 2.40 & 0.52\end{array}$

$\begin{array}{ll}3.20 & 0.52 \\ 5.36 & 0.60\end{array}$

$\begin{array}{ll}3.20 & 0.60 \\ 5.36 & 0.60\end{array}$
DATA FOR - MIDDLING COAL

SIZE

$$
\text { FRACTION }
$$

PASSED RETAINED

P

$$
\text { HEIGHT DIRECT VAL ASH }
$$

EIG HT

ASH VALUES-

SOIFOR

MOTSTORE---CUMDLATIVE

RETAINED-...--

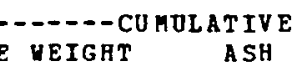

ASH
RCENT

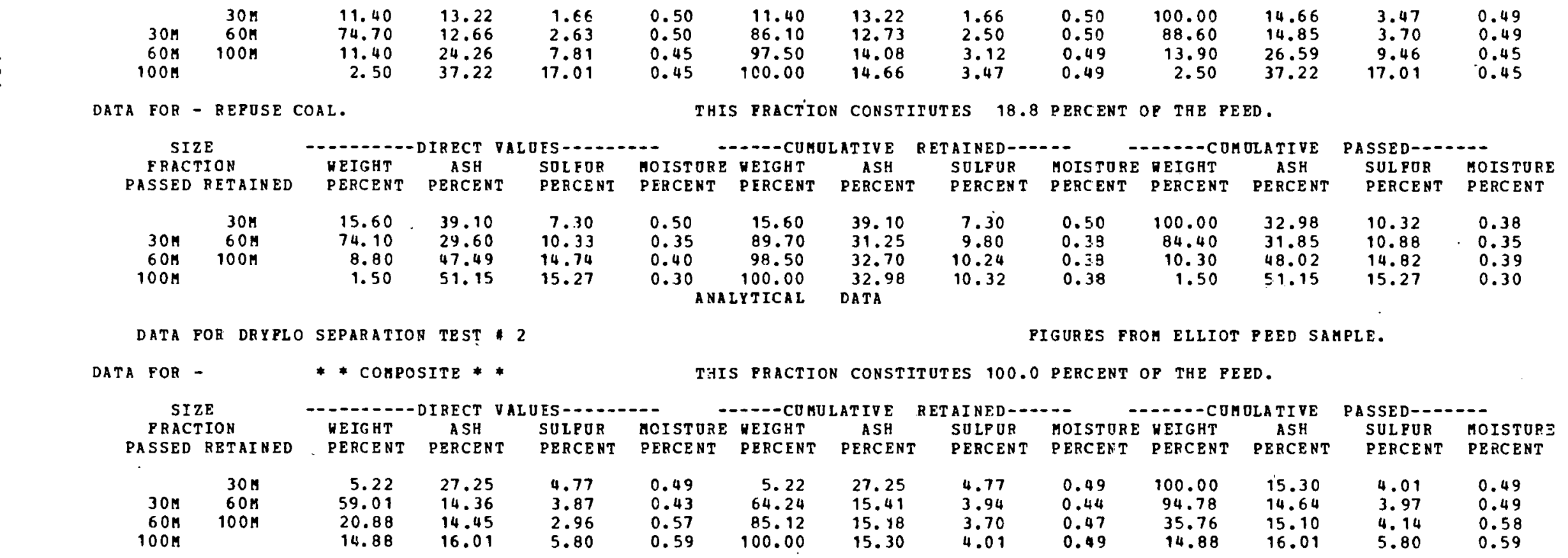


ANALYTICAL DATA

DATA POR DRYPLO SEPARATION TEST * 3

PIGURES FROH ELLIOT PEED SAMPLE.

DATA FOR - PRODUCT COAL

THIS PRACTION CONSTITUTES 57.3 PERCENT OP THE PEED.

\begin{tabular}{|c|c|c|c|c|c|c|c|c|c|c|c|c|c|}
\hline S.I2 & & $--1-2-1$ & IRECT VA & JES- - - & -. & $---\operatorname{con}$ & ATIVE & RETAINED - - & $=-$ & $---\operatorname{col}$ & JLATIVE & PASSED $-\cdots$ & $=-$ \\
\hline $\mathbf{F}$. & ION & NEIGHT & ASH & SULFOR & MOISTORE & WEIGHT & ASH & SULPUR & MOISTURE & REIGRT & A SH & SOLPOR & MOISTURE \\
\hline SSED & RETAINED & PERCENT & PERCENT & PERCENT & PERCENT & PERCENT & PERCENT & PERCENT & PERCENT & PERCENT & PERCENT & PERCENT & PERCENT \\
\hline $\begin{array}{r}30 \mathrm{M} \\
60 \mathrm{M} \\
.100 \mathrm{M}\end{array}$ & $\begin{array}{r}30 \mathrm{M} \\
60 \mathrm{M} \\
100 \mathrm{M}\end{array}$ & $\begin{array}{r}3.30 \\
59.70 \\
22.40 \\
14.60\end{array}$ & $\begin{array}{r}7.90 \\
7.69 \\
10.52 \\
14.62\end{array}$ & $\begin{array}{l}1.21 \\
1.60 \\
2.39 \\
5.68\end{array}$ & $\begin{array}{l}0.65 \\
0.55 \\
0.65 \\
0.45\end{array}$ & $\begin{array}{r}3.30 \\
63.00 \\
85.40 \\
100.00\end{array}$ & $\begin{array}{l}7.90 \\
7.70 \\
8.44 \\
9.34\end{array}$ & $\begin{array}{l}1.21 \\
1.58 \\
1.79 \\
2.36\end{array}$ & $\begin{array}{l}0.65 \\
0.56 \\
0.58 \\
0.56\end{array}$ & $\begin{array}{r}100.00 \\
96.70 \\
37.00 \\
14.60\end{array}$ & $\begin{array}{r}9.34 \\
9.39 \\
12.14 \\
14.62\end{array}$ & $\begin{array}{l}2.36 \\
2.40 \\
3.69 \\
5.68\end{array}$ & $\begin{array}{l}0.56 \\
0.56 \\
0.57 \\
0.45\end{array}$ \\
\hline
\end{tabular}

DATA POR - MIDDLING COAL

THIS PRACTION CONSTITOTES 21.9 PERCENT OP THE FERD.

\begin{tabular}{|c|c|c|c|c|c|c|c|c|c|c|c|c|c|}
\hline \multirow{2}{*}{\multicolumn{2}{|c|}{$\begin{array}{c}\text { SIZE } \\
\text { FRACTION }\end{array}$}} & \multicolumn{2}{|c|}{$\cdots-\infty$ DIRECT $v$} & \multicolumn{2}{|c|}{ VALOES - } & \multicolumn{2}{|c|}{--- CUMOLATIVI } & \multicolumn{2}{|c|}{ RETAINED - } & \multicolumn{2}{|c|}{$-\infty--$ CO HULAT IVE } & \multicolumn{2}{|c|}{ PASSED- } \\
\hline & & HEIG T T & A SH & SULFUR & MOISTURE & WEIGHT & AS H & SOLFOR & MOISTURE & WEIGHT & A SH & SOLFUR & MOISTO \\
\hline PASSED & RETAINED & PERCENT & PERCENT & PERCENT & PERCENT & PERCENT & PERCENT & PERCENT & PRRCENT & PERCENT & PERCENT & PERCENT & PERCEN \\
\hline $\begin{array}{r}30 \mathrm{M} \\
60 \mathrm{M} \\
100 \mathrm{H}\end{array}$ & $\begin{array}{r}30 M \\
60 M \\
100 M\end{array}$ & $\begin{array}{r}16.90 \\
66.20 \\
13.60 \\
3.30\end{array}$ & $\begin{array}{l}16.91 \\
13.73 \\
17.96 \\
35.94\end{array}$ & $\begin{array}{r}2.10 \\
2.91 \\
5.90 \\
20.19\end{array}$ & $\begin{array}{l}0.65 \\
0.55 \\
0.60 \\
0.40\end{array}$ & $\begin{array}{r}16.90 \\
83.10 \\
96.70 \\
100.00\end{array}$ & $\begin{array}{l}16.91 \\
14.38 \\
14.88 \\
15.58\end{array}$ & $\begin{array}{l}2.10 \\
2.75 \\
3.19 \\
3.75\end{array}$ & $\begin{array}{l}0.65 \\
0.57 \\
0.57 \\
0.57\end{array}$ & $\begin{array}{r}100.00 \\
83.10 \\
16.90 \\
3.30\end{array}$ & $\begin{array}{l}15.58 \\
15.30 \\
21.47 \\
35.94\end{array}$ & $\begin{array}{r}3.75 \\
4.09 \\
8.69 \\
20.19\end{array}$ & $\begin{array}{l}0.57 \\
0.55 \\
0.56 \\
0.40\end{array}$ \\
\hline
\end{tabular}

DATA FOR - REFUSE COAL

THIS RRACTION CONSTITUTES 20.8 PERCENT OF THE PEED.

\begin{tabular}{|c|c|c|c|c|c|c|c|c|c|c|c|c|c|}
\hline \multirow{2}{*}{\multicolumn{2}{|c|}{$\begin{array}{c}\text { SIZE } \\
\text { FRACTION }\end{array}$}} & \multicolumn{2}{|c|}{------- DIRECT } & JES--- - & \multicolumn{3}{|c|}{--- -CUMOLATIVE } & \multicolumn{2}{|c|}{ ETAINED - - - - } & \multicolumn{2}{|c|}{$-\infty-$ CUAULA } & \multicolumn{2}{|c|}{ PASSED- - - } \\
\hline & & $\begin{array}{l}\text { VEIGHT } \\
\text { PERCENT }\end{array}$ & $\begin{array}{c}\text { ASR } \\
\text { PERCENT }\end{array}$ & $\begin{array}{l}\text { SOLFUR } \\
\text { PERCENT }\end{array}$ & $\begin{array}{l}\text { MOIST ORE } \\
\text { PERCENT }\end{array}$ & $\begin{array}{l}\text { WEIGHT } \\
\text { PERCENT }\end{array}$ & $\begin{array}{c}\text { ASH } \\
\text { PERCENT }\end{array}$ & $\begin{array}{l}\text { SULPOR } \\
\text { PERCENT }\end{array}$ & $\begin{array}{l}\text { MOISTORE } \\
\text { PERCENT }\end{array}$ & $\begin{array}{l}\text { DEIGHT } \\
\text { PERCENT }\end{array}$ & $\begin{array}{c}\text { ASR } \\
\text { PERCENT }\end{array}$ & $\begin{array}{l}\text { SOLPOR } \\
\text { PERCE HT }\end{array}$ & $\begin{array}{l}\text { MOISTOI } \\
\text { PERCEN }\end{array}$ \\
\hline $\begin{array}{r}30 \mathrm{~A} \\
60 \mathrm{~A} \\
100 \mathrm{M}\end{array}$ & $\begin{array}{l}3 \mathrm{CH} \\
60 \mathrm{M} \\
100 \mathrm{~N}\end{array}$ & $\begin{array}{r}22.20 \\
65.90 \\
10.20 \\
1.70\end{array}$ & $\begin{array}{l}40.16 \\
27.90 \\
38.50 \\
50.80\end{array}$ & $\begin{array}{r}8.73 \\
9.30 \\
16.20 \\
19.89\end{array}$ & $\begin{array}{l}0.40 \\
0.25 \\
0.65 \\
0.40\end{array}$ & $\begin{array}{r}22.20 \\
88.10 \\
98.30 \\
100.00\end{array}$ & $\begin{array}{l}40.16 \\
30.32 \\
31.17 \\
31.50\end{array}$ & $\begin{array}{r}8.73 \\
9.16 \\
9.89 \\
10.06\end{array}$ & $\begin{array}{l}0.40 \\
0.29 \\
0.33 \\
0.33\end{array}$ & $\begin{array}{r}100.00 \\
77.80 \\
11.90 \\
1.70\end{array}$ & $\begin{array}{l}31.50 \\
29.03 \\
40.26 \\
50.80\end{array}$ & $\begin{array}{l}10.06 \\
10.44 \\
16.73 \\
19.89\end{array}$ & $\begin{array}{l}0.33 \\
0.31 \\
0.61 \\
0.40\end{array}$ \\
\hline
\end{tabular}

DATA POR DRYPLO SEPARATION TEST *3

PIGURES PROY ELLIOT PEED SAMPLE.

DATA POR -

* conposite *

THIS FRACTION CONSTITUTES 100.0 PERCENT OP THE PEED.

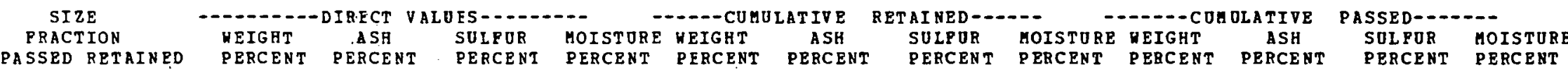

$\begin{array}{rrrrrrrrrrrrrr} & 30 \mathrm{M} & 10.21 & 25.76 & 4.93 & 0.54 & 10.21 & 25.76 & 4.93 & 0.54 & 100.00 & 15.32 & 4.27 & 0.51 \\ 30 \mathrm{M} & 60 \mathrm{M} & 62.41 & 13.33 & 3.60 & 0.48 & 72.62 & 15.08 & 3.78 & 0.49 & 89.79 & 14.13 & 4.19 & 0.51 \\ 60 \mathrm{M} & 100 \mathrm{M} & 17.94 & 15.67 & 4.61 & 0.64 & 90.56 & 15.08 & 3.95 & 0.52 & 27.38 & 15.94 & 5.54 & 0.57 \\ 100 \mathrm{M} & & 9.44 & 17.61 & 7.32 & 0.44 & 100.00 & 15.32 & 4.27 & 0.51 & 9.44 & 17.61 & 7.32 & 0.44\end{array}$


ANALYTICAL DATA

DATA POR DRYPIO SEPARATION TEST * 4 DATA POR - PRODUCT COAL
PIGURES PROM ELLIOT PEED SAMPLE.

THIS FRACTION CONSTITUTES 53.0 PERCFNT OP THE FEED.

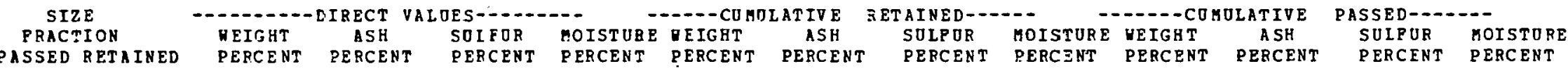

PASSED RETAINED PERCENT PERCENT PERCENT PERCENT PERCENT PERCENT PERCENT PERCENT PERCENT PERCENT

\begin{tabular}{|c|c|c|}
\hline $\begin{array}{l}30 \% \\
60 \% \\
100 \%\end{array}$ & $\begin{array}{r}30 M \\
60 M \\
100 M\end{array}$ & $\begin{array}{r}2.20 \\
50.80 \\
30.70 \\
16.30\end{array}$ \\
\hline
\end{tabular}

DATA FOR - MIDDLING COAL

\subsection{45}

0.45
0.60

\begin{abstract}
2.20
83.70
\end{abstract}

100.00

1.32
1.47
1.73

1.73
2.43
THIS FRACTION CONSTITUTES 20.9 PERCENT OF TRE PEED.

$\begin{array}{rrrrr}0.55 & 100.00 & 9.07 & 2.43 & 0.55 \\ 0.45 & 97.80 & 9.11 & 2.45 & 0.55 \\ 0.51 & 47.00 & 11.19 & 3.51 & 0.65\end{array}$

$\begin{array}{llll}0.51 & 47.00 & 11.19 & 3.5 \\ 0.55 & 16.30 & 14.46 & 6.04\end{array}$

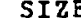

$$
\text { DEIGHT DIRECT VALUES-D }
$$

CUMJLATIVE RETAINED-

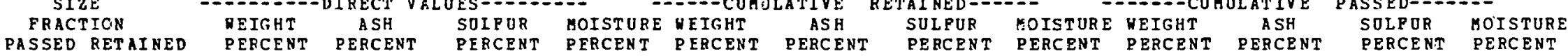

$\begin{array}{rrrrrr} & 30 \mathrm{M} & 14.80 & 13.73 & 1.62 & 0.55 \\ 30 \mathrm{M} & 60 \mathrm{M} & 69.90 & 11.73 & 2.22 & 0.70 \\ 60 \mathrm{M} & 100 \mathrm{M} & 12.60 & 18.57 & 5.69 & 0.65 \\ 100 \mathrm{M} & & 2.70 & 37.12 & 16.56 & 0.45\end{array}$

DATA FOR - REPOSE COAL

$\begin{array}{lrl}0.55 & 14.80 & 13.7 \\ 0.70 & 84.70 & 12.08 \\ 0.65 & 97.30 & 12.97 \\ 0.45 & 160.00 & 13.62\end{array}$

$\begin{array}{rrr}1.62 & 0.55 & 100.00 \\ 2.12 & 0.67 & 85.20 \\ 2.58 & 0.6 .7 & 15.30\end{array}$
13.62
13.61
22.17

22.17
37.12

2.96

3.19

16.51

0.66

0.68

0.61

THIS FEACTIJN CONSTITOTES 26.1 PERCENT OF THE PEED.

SIZE ---.----DIRECT VALOES-

PRACTION
PASSED RETAIN

PEIGHT ASH

----CUhDLATIVE RETAINED--

$\begin{array}{lll}30 M & 21.80 & 39.70\end{array}$

$\begin{array}{rrrr} & 30 M & 21.80 & 39.70 \\ 30 M & 60 M & 67.50 & 24.14 \\ 60 M & 100 M & 9.00 & 39.57 \\ 100 \mathrm{H} & & 1.70 & 52.38\end{array}$

7.46

MOISTURE WEIGHT

SULFUR
PBRCENI

- - -----CUNULATI

ATIVE. PASSE

SSED-- - - -

$\begin{array}{ll}\text { SULPUR } & \text { MOISTURE } \\ \text { PERCENT PERCENT }\end{array}$

$100 \mathrm{~A}$

$1.70 \quad 52.38$

8.10
17.65

17.16

$\begin{array}{rr}0.50 & 21.80 \\ 0.60 & 89.30 \\ 0.55 & 98.30 \\ 0.35 & 100.00\end{array}$

39.70

7.46

0.50

100.00
78.20
10.70
1.70

29.40

26.53

1.61
52.38

8.97

9.47
17.57

17.57

0.57

29.40

$8.97 \quad 0.57$

52.38

0.52

FIGURES PROM ELIIOT PEED SAIPLE.

DATA FOR -

* conposite * *

\begin{tabular}{|c|c|c|c|c|c|c|c|c|c|c|c|c|c|}
\hline \multirow{2}{*}{\multicolumn{2}{|c|}{$\begin{array}{c}\text { SIZE } \\
\text { PRACTION }\end{array}$}} & \multicolumn{2}{|c|}{------ DIRECT } & JES $-\cdots$ & -.- & \multicolumn{2}{|c|}{----- CU MOLATIVE } & \multicolumn{2}{|c|}{ RET ATNED------ } & \multicolumn{2}{|c|}{---- CUNOLATIVE } & \multicolumn{2}{|c|}{ PASSED--.--- } \\
\hline & & $\begin{array}{l}\text { YEIGHT } \\
\text { PERCENT }\end{array}$ & $\begin{array}{c}\text { ASH } \\
\text { PERCENT }\end{array}$ & $\begin{array}{l}\text { SOLPUR } \\
\text { PERCENT }\end{array}$ & $\begin{array}{l}\text { MOISTURE } \\
\text { PERCERT }\end{array}$ & $\begin{array}{l}\text { HEIGHT } \\
\text { PERCENT }\end{array}$ & $\begin{array}{c}\text { ASH } \\
\text { PERCENT }\end{array}$ & $\begin{array}{l}\text { SOLFOR } \\
\text { PERCENT }\end{array}$ & $\begin{array}{l}\text { MOISTORE } \\
\text { PERCPBT }\end{array}$ & $\begin{array}{l}\text { WEIGHT } \\
\text { PERCENT }\end{array}$ & $\begin{array}{c}\text { ASH } \\
\text { PERCENT }\end{array}$ & $\begin{array}{l}\text { SULPUR } \\
\text { PERCE AT }\end{array}$ & $\begin{array}{l}\text { MOISTORE } \\
\text { PERCENT }\end{array}$ \\
\hline $\begin{array}{r}301 \\
60 n \\
100 n\end{array}$ & $\begin{array}{r}30 \mathrm{~K} \\
60 \mathrm{H} \\
100 \mathrm{H}\end{array}$ & $\begin{array}{r}9.95 \\
59.15 \\
21.25 \\
9.65\end{array}$ & $\begin{array}{l}27.83 \\
13.36 \\
13.97 \\
17.53\end{array}$ & $\begin{array}{l}4.92 \\
3.63 \\
4.31 \\
7.17\end{array}$ & $\begin{array}{l}0.52 \\
0.56 \\
0.60 \\
0.71\end{array}$ & $\begin{array}{r}9.95 \\
69.10 \\
90.35 \\
100.00\end{array}$ & $\begin{array}{l}27.83 \\
15.44 \\
15.09 \\
15.33\end{array}$ & $\begin{array}{l}4.92 \\
3.82 \\
3.94 \\
4.25\end{array}$ & $\begin{array}{l}0.52 \\
0.55 \\
0.56 \\
0.58\end{array}$ & $\begin{array}{r}100.00 \\
90.05 \\
30.90 \\
9.65\end{array}$ & $\begin{array}{l}15.33 \\
13.95 \\
15.08 \\
17.53\end{array}$ & $\begin{array}{l}4.25 \\
4.17 \\
5.20 \\
7.17\end{array}$ & $\begin{array}{l}0.58 \\
0.58 \\
0.64 \\
0.71\end{array}$ \\
\hline
\end{tabular}

THIS PRACTION CONSTITUTES 100.0 PERCENT OP THE PEED. 
ANALTICAL DATA

DATA POR DRYFLO SEPARATION TEST 5.

PIGURES PROM PSOC 233 PEED SAMPLE.

DATA POR - PRODUCT COAL.

THIS FRACTION CONSTITUTES 68.5 PERCENT OP THE PEED.

\begin{tabular}{|c|c|c|c|c|c|c|c|c|c|c|c|c|c|}
\hline \multicolumn{2}{|c|}{ SIZE } & \multicolumn{2}{|c|}{$-\cdots---$ DIRECT } & UES - - - - & ..- & \multicolumn{2}{|l|}{.--- синu } & \multicolumn{2}{|c|}{ RETAINED - - } & \multicolumn{2}{|c|}{--..--CURULATIVE } & \multicolumn{2}{|c|}{ PASSED-..... } \\
\hline FPAC & TION & WEIGHT & ASH & SOLFUR & NOISTURE & HEIGHT & $\mathrm{ASH}$ & SULPUR & MOISTORE & REIGHT & A SH & SOLFUR & no \\
\hline SSED & RETAINED & PERCENT & PERCENT & PERCENT & PERCENT & PERCENT & PERCENT & PERCENT & PERCENT & PERCENT & PERCENT & PERCFNT & ER \\
\hline $\begin{array}{r}30 \mathrm{H} \\
60 \mathrm{H} \\
100 \mathrm{M}\end{array}$ & $\begin{array}{r}30 \mathrm{M} \\
60 \mathrm{M} \\
100 \mathrm{M}\end{array}$ & $\begin{array}{r}1.30 \\
46.30 \\
26.20 \\
26.20\end{array}$ & $\begin{array}{l}6.67 \\
6.60 \\
6.72 \\
8.35\end{array}$ & $\begin{array}{l}0.60 \\
0.55 \\
0.65 \\
0.64\end{array}$ & $\begin{array}{l}6.25 \\
6.80 \\
7.00 \\
6.60\end{array}$ & $\begin{array}{r}1.30 \\
47.60 \\
73.80 \\
100.00\end{array}$ & $\begin{array}{l}6.67 \\
6.60 \\
6.64 \\
7.09\end{array}$ & $\begin{array}{l}0.60 \\
0.55 \\
0.59 \\
0.60\end{array}$ & $\begin{array}{l}6.25 \\
6.78 \\
6.86 \\
6.79\end{array}$ & $\begin{array}{r}100.00 \\
98.70 \\
52.40 \\
26.20\end{array}$ & $\begin{array}{l}7.09 \\
7.10 \\
7.53 \\
8.35\end{array}$ & $\begin{array}{l}0.60 \\
0.60 \\
0.64 \\
0.64\end{array}$ & $\begin{array}{l}6.79 \\
6.80 \\
6.80 \\
6.60\end{array}$ \\
\hline
\end{tabular}

DATA FOR - MIDDLING COAL.

THIS PRACTION CONSTITUTES 19.0 PERCENT OP THE PEED.

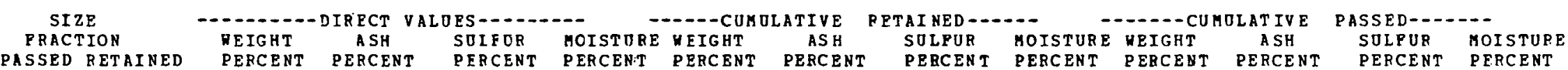

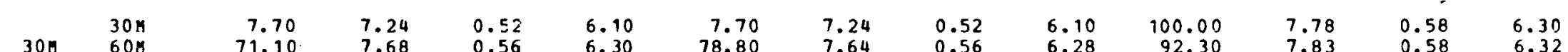

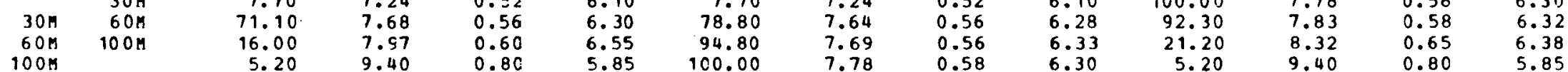

POR - REFUSE COAL.

THIS PRACTION CONSTITUTES 12.5 PERCENT OP THE PEED.

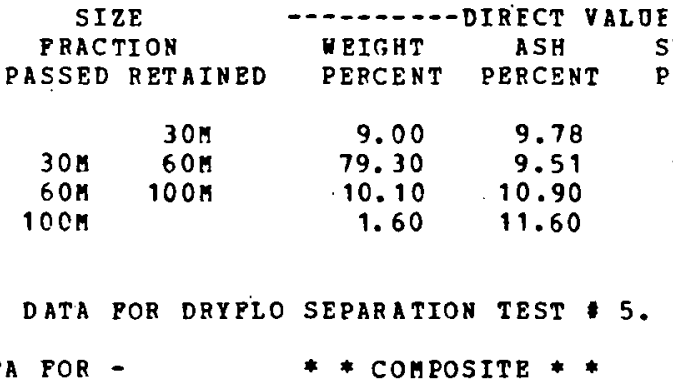

SIZE

PRACT IOH

PASSED RETAINED

\begin{tabular}{|c|c|c|c|c|c|c|c|c|c|c|c|c|c|}
\hline $\begin{array}{r}30 \mathrm{M} \\
60 \mathrm{H} \\
100 \mathrm{H}\end{array}$ & $\begin{array}{r}30 \mathrm{~B} \\
60 \mathrm{~B} \\
100 \mathrm{II}\end{array}$ & $\begin{array}{r}3.48 \\
55.14 \\
22.25 \\
19.13\end{array}$ & $\begin{array}{l}7.92 \\
7.39 \\
7.13 \\
8.44\end{array}$ & $\begin{array}{l}0.56 \\
0.56 \\
0.65 \\
0.66\end{array}$ & $\begin{array}{l}6.07 \\
6.52 \\
6.88 \\
6.55\end{array}$ & $\begin{array}{r}3.48 \\
58.62 \\
80.86 \\
100.00\end{array}$ & $\begin{array}{l}7.92 \\
7.42 \\
7.34 \\
7.55\end{array}$ & $\begin{array}{l}0.56 \\
0.56 \\
0.59 \\
0.60\end{array}$ & $\begin{array}{l}6.07 \\
6.49 \\
6.60 \\
6.59\end{array}$ & $\begin{array}{r}100.00 \\
96.52 \\
41.38 \\
19.13\end{array}$ & $\begin{array}{l}7.55 \\
7.54 \\
7.73 \\
8.44\end{array}$ & $\begin{array}{l}0.60 \\
0.60 \\
0.65 \\
0.66\end{array}$ & $\begin{array}{l}6.59 \\
6.69 \\
6.73 \\
6.55\end{array}$ \\
\hline
\end{tabular}


ANALYTICAL DATA

DATA POR DRYPLC SEPARATION TEST 6 DATA FOR - PRODUCT COAL.
PIGORES FROM PSOC 233.

THIS FRACTION CONSTITUTES 80.7 PERCENT OP THE PEED.

\begin{tabular}{|c|c|c|c|c|c|c|c|c|c|c|c|c|c|}
\hline \multicolumn{2}{|c|}{ SIZE } & 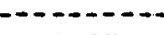 & IRECT V & UES---- & -- & \multicolumn{2}{|c|}{--- CUAOLATIVE } & \multicolumn{2}{|c|}{ RET A INED $\cdots-$} & \multicolumn{2}{|c|}{--- CU MULAT IVE } & \multicolumn{2}{|c|}{ PASSED- - - - } \\
\hline PRACI & ION & WEIGHT & ASH & SOLFOR & MOISTORE & KEIGHT & ASH & SOLPUR & MOISTURE & WEIGHT & A SH & SULPUR & MOISTUPE \\
\hline ASSED & RETAINED & PERCENT & PERCENT & PERCENT & PERCENT & PERCENT & PERCENT & PERCENT & PERCENT & PERCENT & PERCENT & PERCENT & PERCENT \\
\hline $\begin{array}{r}30 \mathrm{H} \\
60 \mathrm{~K} \\
100 \mathrm{M}\end{array}$ & $\begin{array}{r}30 \mathrm{H} \\
60 \mathrm{~N} \\
100 \mathrm{H}\end{array}$ & $\begin{array}{r}2.40 \\
54.70 \\
24.40 \\
18.50\end{array}$ & $\begin{array}{l}6.77 \\
6.95 \\
7.00 \\
8.18\end{array}$ & $\begin{array}{l}0.56 \\
0.57 \\
0.61 \\
0.58\end{array}$ & $\begin{array}{l}7.00 \\
7.25 \\
7.20 \\
7.10\end{array}$ & $\begin{array}{r}2.40 \\
57.10 \\
81.50 \\
100.00\end{array}$ & $\begin{array}{l}6.77 \\
6.94 \\
6.96 \\
7.19\end{array}$ & $\begin{array}{l}0.56 \\
0.57 \\
0.58 \\
0.58\end{array}$ & $\begin{array}{l}7.00 \\
7.24 \\
7.23 \\
7.20\end{array}$ & $\begin{array}{r}100.00 \\
97.60 \\
42.90 \\
18.50\end{array}$ & $\begin{array}{l}7.19 \\
7.20 \\
7.51 \\
8.18\end{array}$ & $\begin{array}{l}0.58 \\
0.58 \\
0.60 \\
0.58\end{array}$ & $\begin{array}{l}7.20 \\
7.21 \\
7.16 \\
7.10\end{array}$ \\
\hline
\end{tabular}

DATA POR - MIDDLING COAL. TRIS PRACTION CONSTITUTES 9.7 PERCENT OP THE PEED.

\begin{tabular}{|c|c|c|c|c|c|c|c|c|c|c|c|c|c|}
\hline \multirow{2}{*}{\multicolumn{2}{|c|}{$\begin{array}{c}\text { SIZE } \\
\text { PRACTION }\end{array}$}} & $\ldots$ & IRECT & $5-$ & - & $=0 n$ & ATIVE & CAI NED - & - & cur & JLATIVE & PASSED- & - \\
\hline & & $\begin{array}{l}\text { HETGHT } \\
\text { PEBC }\end{array}$ & $\begin{array}{c}\text { A SH } \\
\text { PERCENT }\end{array}$ & $\begin{array}{l}\text { SOIFOR } \\
\text { PERCE NT }\end{array}$ & $\begin{array}{l}\text { MOISTURE } \\
\text { PERCENT }\end{array}$ & $\begin{array}{l}\text { WEIGHT } \\
\text { PERCENT }\end{array}$ & $\begin{array}{c}\text { ASH } \\
\text { PERCENT }\end{array}$ & $\begin{array}{l}\text { SULFUR } \\
\text { PERCENT }\end{array}$ & $\begin{array}{l}\text { MOISTORE } \\
\text { PERCENT }\end{array}$ & $\begin{array}{l}\text { REIGHT } \\
\text { PERCENT }\end{array}$ & $\begin{array}{c}\text { ASH } \\
\text { PERCENT }\end{array}$ & $\begin{array}{l}\text { SULFUR } \\
\text { PERCENT }\end{array}$ & $\begin{array}{l}\text { MOISTUE } \\
\text { PERCENT }\end{array}$ \\
\hline $\begin{array}{r}30 \mathrm{~N} \\
60 \mathrm{H} \\
100 \mathrm{H}\end{array}$ & $\begin{array}{r}30 \mathrm{M} \\
60 \mathrm{M} \\
100 \mathrm{M}\end{array}$ & $\begin{array}{r}7.70 \\
69.60 \\
16.40 \\
6.30\end{array}$ & $\begin{array}{l}7.70 \\
7.90 \\
6.40 \\
8.97\end{array}$ & $\begin{array}{l}0.53 \\
0.55 \\
0.64 \\
0.84\end{array}$ & $\begin{array}{l}5.80 \\
6.30 \\
6.20 \\
5.75\end{array}$ & $\begin{array}{r}7.70 \\
77.30 \\
93.70 \\
100.00\end{array}$ & $\begin{array}{l}7.70 \\
7.88 \\
7.62 \\
7.71\end{array}$ & $\begin{array}{l}0.53 \\
0.55 \\
0.56 \\
0.58\end{array}$ & $\begin{array}{l}5.80 \\
6.25 \\
6.24 \\
6.21\end{array}$ & $\begin{array}{r}100.00 \\
92.30 \\
22.70 \\
6.30\end{array}$ & $\begin{array}{l}7.71 \\
7.71 \\
7.11 \\
8.97\end{array}$ & $\begin{array}{l}0.58 \\
0.59 \\
0.70 \\
0.84\end{array}$ & $\begin{array}{l}6.21 \\
6.24 \\
6.08 \\
5.75\end{array}$ \\
\hline
\end{tabular}

DATA FOR - REFOSE COAL.

THIS PRACTION CONSTITUTES 9.6 PERCENT OP THE PEED.

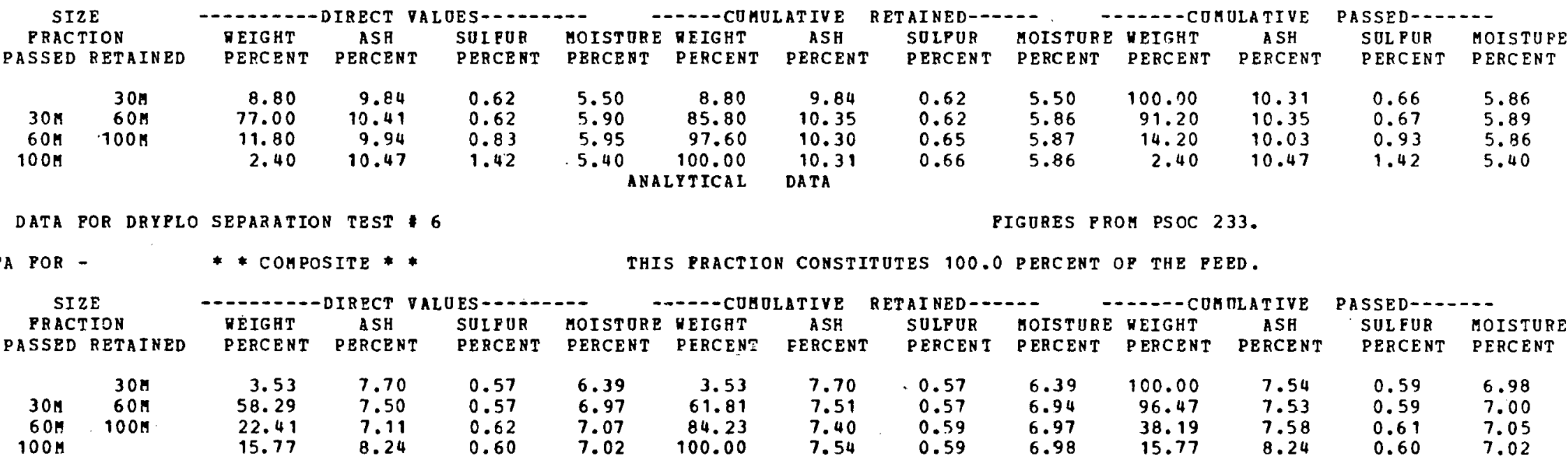


DATA POR DRTPLO SEPARATION TEST 7 * X-BAY SULPOR *

FIGURÉS PROA PSOC 233 PERD.

DATA POR - PRODUCT COAL.

THIS PRACTION CONSTITUTES $\mathbf{7 3 . 4}$ PERCENT OP THE PEED.

SIZE

PASSED RETAINED PERCENT PEPCENT PERCENT PERCENT PERCENT PERCENT PERCENT PERCENT PERCENT PERCENT PERCENT PERCENT

\begin{tabular}{|c|c|c|c|c|c|c|c|c|c|c|c|c|c|}
\hline $\begin{array}{r}30 \mathrm{H} \\
60 \mathrm{H} \\
100 \mathrm{H} \\
150 \mathrm{H} \\
200 \mathrm{M}\end{array}$ & $\begin{array}{l}30 \mathrm{H} \\
60 \mathrm{H} \\
100 \mathrm{H} \\
150 \mathrm{H} \\
200 \mathrm{H}\end{array}$ & $\begin{array}{r}2.30 \\
.56 .6 C \\
26.20 \\
10.50 \\
1.50 \\
2.90\end{array}$ & $\begin{array}{r}6.057 \\
7.08 \\
7.33 \\
7.35 \\
8.44 \\
12.06\end{array}$ & $\begin{array}{l}0.55 \\
0.50 \\
0.55 \\
0.60 \\
0.70 \\
0.60\end{array}$ & $\begin{array}{l}5.30 \\
5.40 \\
6.55 \\
5.40 \\
5.25 \\
5.05\end{array}$ & $\begin{array}{r}2.30 \\
58.90 \\
85.10 \\
95.60 \\
97.10 \\
100.00\end{array}$ & $\begin{array}{l}6.07 \\
7.08 \\
7.15 \\
7.18 \\
7.20 \\
7.34\end{array}$ & $\begin{array}{l}0.55 \\
0.50 \\
0.52 \\
0.53 \\
0.53 \\
0.53\end{array}$ & $\begin{array}{l}5.30 \\
5.40 \\
5.75 \\
5.71 \\
5.71 \\
5.69\end{array}$ & $\begin{array}{r}100.00 \\
97.70 \\
41.10 \\
14.90 \\
4.40 \\
2.90\end{array}$ & $\begin{array}{r}7.34 \\
7.34 \\
7.71 \\
8.38 \\
10.83 \\
12.06\end{array}$ & $\begin{array}{l}0.53 \\
0.53 \\
0.57 \\
0.61 \\
0.63\end{array}$ & $\begin{array}{l}5.69 \\
5.70 \\
6.10 \\
5.32 \\
5.12 \\
5.05\end{array}$ \\
\hline
\end{tabular}

DATA POR - MIDDLING COAL.

THIS PRACTION CONSTITUTES 19.0 PERCENT OP THE PEED.

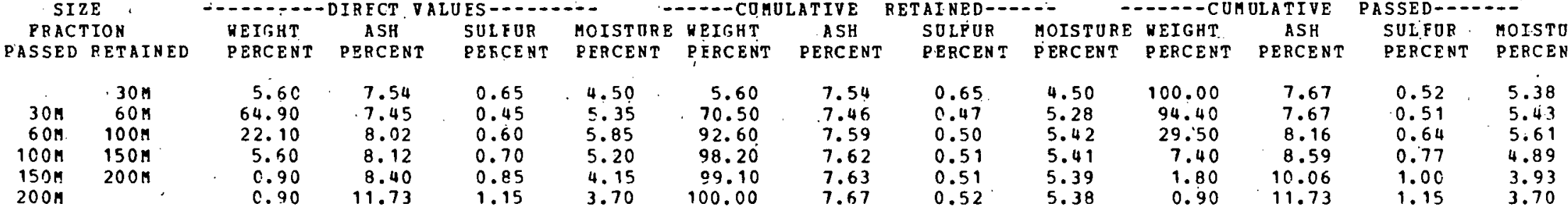

DATA FOR - REPUSE COAL.

TRIS FRACTION CONSTITUTES. 7.6 PERCENT OP THE PEED.

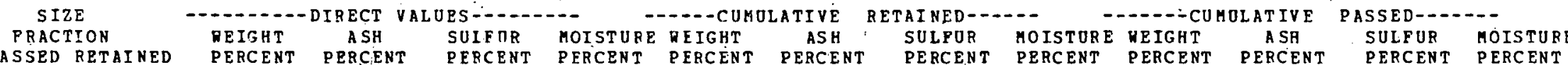

\begin{tabular}{|c|c|c|c|c|c|c|c|c|c|c|c|c|c|}
\hline $\begin{array}{r}30 \mathrm{M} \\
60 \mathrm{H} \\
100 \mathrm{H} \\
150 \mathrm{H} \\
200 \mathrm{H}\end{array}$ & $\begin{array}{r}30 \mathrm{H} \\
60 \mathrm{H} \\
100 \mathrm{~B} \\
150 \mathrm{H} \\
200 \mathrm{H}\end{array}$ & $\begin{array}{r}7.80 \\
76.00 \\
14.00 \\
1.40 \\
0.00 \\
0.80\end{array}$ & $\begin{array}{r}10.51 \\
9.51 \\
11.02 \\
11.01 \\
0.00 \\
11.13\end{array}$ & $\begin{array}{l}0.85 \\
0.50 \\
0.65 \\
1.15 \\
0.00 \\
1.30\end{array}$ & $\begin{array}{l}4.35 \\
5.10 \\
5.15 \\
3.80 \\
0.00 \\
3.00\end{array}$ & $\begin{array}{r}7.80 \\
83.80 \\
97.80 \\
99.20 \\
99.20 \\
100.00\end{array}$ & $\begin{array}{r}10.51 \\
9.97 \\
10.12 \\
10.13 \\
10.13 \\
10.14\end{array}$ & $\begin{array}{l}0.85 \\
0.53 \\
0.55 \\
0.56 \\
0.56 \\
0.56\end{array}$ & $\begin{array}{l}4.35 \\
5.03 \\
5.05 \\
5.03 \\
5.03 \\
5.01\end{array}$ & $\begin{array}{r}100.00 \\
92.20 \\
16.20 \\
2.20 \\
0.80 \\
0.80\end{array}$ & $\begin{array}{l}10.14 \\
10.11 \\
11.02 \\
11.05 \\
11.13 \\
11.13\end{array}$ & $\begin{array}{l}0.56 \\
0.54 \\
0.73 \\
1.20 \\
1.30 \\
1.30\end{array}$ & $\begin{array}{l}5.01 \\
5.07 \\
4.93 \\
3.51 \\
3.00 \\
3.00\end{array}$ \\
\hline
\end{tabular}

DATA POR DRYPLO SEPARATION TEST 7 * X-RAY SOLPUR *

PIGORES PROA PSOC 233 FEED.

DATA POR -

* conposite *

THIS. PRACTION CONSTITUTES 100.0 PERCENT OP THE PEED.

$S I Z E$

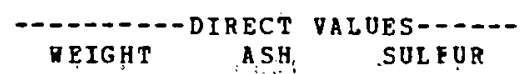
PASSED RETAINED PERCENT PERCENT SULEUR MOISTORE UEIGHT

TAINED-20-

$\begin{array}{rrrr} & 30 \mathrm{H} & 3.34 & 7.78^{3} \\ 30 \mathrm{~N} & 60 \mathrm{H} & 59.65 & 7.43 \\ 60 \mathrm{H} & 100 \mathrm{H} & 24.49 & 7.61 \\ 100 \mathrm{H} & 150 \mathrm{H} & 8.88 & 7.49 \\ 150 \mathrm{H} & 200 \mathrm{M} & 1.27 & 8.43 \\ 200 \mathrm{H} & & 2.36 & 12.01\end{array}$

$$
\begin{aligned}
& 0.63 \\
& 0.49 \\
& 0.56 \\
& 0.62 \\
& 0.72 \\
& 0.66
\end{aligned}
$$

PERCE
4.88
5.36
6.37
5.36
5.10
4.90

\section{ASH}

SULPUR

PERCEN

3.34
63.00
87.49
96.37
97.64
100.00

7.78
7.45
7.49
7.49
7.51
7.61

\subsection{3}

0.50

0.52

0.53

0.53
100.00

$$
\text { MOISTU }
$$

YEIGHT - CUMULATIVE A SH

PASSED--.-.-.
4.88
5.33
5.62
5.60
5.59
5.58

100.00
96.65
37.00
12.51
3.63
2.36

7.69
7.61
7.89
8.44
10.76
12.01

12.01
SULPUR MOISTURE

$0.53, \quad 5.58$

0.53

0.59

0.64

0.68

5.60
5.99

5.99
5.24.

4.97 
DATA FOR DRYFLO SEPARATION TEST 8 DATA FOR - PRODUCT COAL.
PIGURES FROA PSOC 233 PEED SAMPLE.

THIS PRACTION CONSTITUTES 73.1 PERCENT OP THE PERD.

\begin{tabular}{|c|c|c|c|c|c|c|c|c|c|c|c|c|c|}
\hline \multirow{2}{*}{\multicolumn{2}{|c|}{$\begin{array}{c}\text { SIZE } \\
\text { PRACTION }\end{array}$}} & \multicolumn{2}{|c|}{ V } & \multicolumn{2}{|c|}{ OES-D...... } & \multicolumn{2}{|c|}{----CUMOLATIVE } & \multicolumn{2}{|c|}{ RETAI NED- - - } & \multicolumn{2}{|c|}{--- COMOIATIVE } & \multicolumn{2}{|c|}{ PASSED-- - - } \\
\hline & & YEIGHT & ASH & SULEOR & MOISTORE & DEIGHT & $\triangle S H$ & SOLP OR & MOISTORE & WEIGHT & ASH & SOLFOR & HoIs \\
\hline PASSED & RETAINED & PERCENT & PERCENT & PERCENT & PERCENT & PERCENT & PERCENT & PERCEN T & PERCENT & PERCENT & PERCENT & PERCEAT & PERC \\
\hline $\begin{array}{r}30 \mathrm{H} \\
60 \mathrm{H} \\
100 \mathrm{H} \\
150 \mathrm{H} \\
20 \mathrm{CH}\end{array}$ & $\begin{array}{r}30 \mathrm{H} \\
60 \mathrm{H} \\
100 \mathrm{H} \\
150 \mathrm{H} \\
200 \mathrm{H}\end{array}$ & $\begin{array}{r}1.80 \\
49.50 \\
29.80 \\
12.20 \\
2.80 \\
3.90\end{array}$ & $\begin{array}{r}6.97 \\
6.62 \\
6.85 \\
7.15 \\
8.35 \\
10.99\end{array}$ & $\begin{array}{l}0.53 \\
0.56 \\
0.57 \\
0.61 \\
0.75 \\
1.04\end{array}$ & $\begin{array}{l}4.55 \\
5.55 \\
5.85 \\
5.60 \\
5.40 \\
5.40\end{array}$ & $\begin{array}{r}1.80 \\
51.30 \\
81.10 \\
93.30 \\
96.10 \\
100.00\end{array}$ & $\begin{array}{l}6.63 \\
6.71 \\
6.77 \\
6.82 \\
6.98\end{array}$ & $\begin{array}{l}0.53 \\
0.56 \\
0.56 \\
0.57 \\
0.57 \\
0.59\end{array}$ & $\begin{array}{l}4.55 \\
5.51 \\
5.64 \\
5.63 \\
5.63 \\
5.62\end{array}$ & $\begin{array}{r}100.00 \\
98.20 \\
48.70 \\
18.90 \\
6.70 \\
3.90\end{array}$ & $\begin{array}{r}6.98 \\
6.98 \\
7.34 \\
8.12 \\
9.89 \\
10.99\end{array}$ & $\begin{array}{l}0.59 \\
0.63 \\
0.72 \\
0.92 \\
1.04\end{array}$ & $\begin{array}{l}5.62 \\
5.64 \\
5.73 \\
5.53 \\
5.40 \\
5.40\end{array}$ \\
\hline
\end{tabular}

DATA POR - MIDDLING COAL.

THIS PRACTION CONSTITUTES 17.8 PERCENT OP THE FEED.

\begin{tabular}{|c|c|c|c|c|c|c|c|c|c|c|c|c|c|}
\hline \multicolumn{2}{|c|}{ SIZE } & \multicolumn{2}{|c|}{$\cdots-\cdots$ DIRECT $\nabla$} & \multicolumn{2}{|c|}{ VALOES - - } & \multicolumn{2}{|c|}{----COMULATIVE } & \multicolumn{2}{|c|}{ RETAI NED - - - } & \multicolumn{2}{|c|}{$-\cdots-$ CUMOLAT IVE } & \multicolumn{2}{|c|}{ PASSED- - - - - } \\
\hline PRAC & PION & WEIGHT & A SH & SULEUR & MOISTURE & NEIGHT & AS H & SULFUR & MOISTURE & WEIGHT & ASH & SOLPOR & Morstu \\
\hline PASSED & RET AINED & PERCENT & PERCENT & PERCENT & PERCENT & PERCENT & PERCENT & PERCENT & PERCEMT & PERCENT & PERCENT & PERCENT & $N$ \\
\hline $30 \mathrm{n}$ & $\begin{array}{l}30 \mathrm{H} \\
60 \mathrm{H}\end{array}$ & $\begin{array}{r}6.90 \\
65.80\end{array}$ & $\begin{array}{l}7.68 \\
7.62\end{array}$ & $\begin{array}{l}0.56 \\
0.58\end{array}$ & $\begin{array}{l}4.90 \\
5.50\end{array}$ & $\begin{array}{r}6.90 \\
72.70\end{array}$ & $\begin{array}{l}7.68 \\
7.63\end{array}$ & $\begin{array}{l}0.56 \\
0.58\end{array}$ & $\begin{array}{l}4.90 \\
5.44\end{array}$ & $\begin{array}{r}100.00 \\
93.10\end{array}$ & $\begin{array}{l}7.86 \\
7.87\end{array}$ & $\begin{array}{l}0.60 \\
0.61\end{array}$ & 5.3 \\
\hline $\begin{array}{r}60 \mathrm{O} \\
100 \mathrm{M}\end{array}$ & $100 \mathrm{~A}$ & $\begin{array}{r}19.90 \\
4.80\end{array}$ & $\begin{array}{l}8.15 \\
8.66\end{array}$ & $\begin{array}{l}0.62 \\
0.74\end{array}$ & $\begin{array}{l}5.50 \\
4.20\end{array}$ & $\begin{array}{l}92.60 \\
97.40\end{array}$ & $\begin{array}{l}7.74 \\
7.78\end{array}$ & $\begin{array}{l}0.59 \\
0.59\end{array}$ & $\begin{array}{l}5.46 \\
5.39\end{array}$ & $\begin{array}{r}27.30 \\
7.40\end{array}$ & 8.47 & $\begin{array}{l}0.67 \\
0.82\end{array}$ & 4.1 \\
\hline $\begin{array}{l}1 \mathrm{COA} \\
150 \mathrm{H}\end{array}$ & $200 \mathrm{M}$ & $\begin{array}{l}4.80 \\
0.90\end{array}$ & $\begin{array}{l}8.66 \\
8.77\end{array}$ & 0.44 & $\begin{array}{l}4.20 \\
3.65\end{array}$ & 98.30 & 7.79 & $\begin{array}{l}0.59 \\
0.59\end{array}$ & $\begin{array}{l}5.39 \\
5.38\end{array}$ & $\begin{array}{l}7.40 \\
2.60\end{array}$ & $\begin{array}{r}9.33 \\
10.57\end{array}$ & $\begin{array}{l}0.82 \\
0.96\end{array}$ & 4.1 \\
\hline OH & & 1.70 & 11.53 & 1.23 & 4.20 & 100.00 & 7.86 & 0.60 & 5.36 & 1.70 & & 1.23 & u \\
\hline
\end{tabular}

THIS FRACTION CONSTITOTES 9.1 PERCEN OP THE PEED.

DATA FOR - REPOSE COAL.

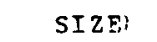

SIZE; $-1-2---D I R E C T$ VALUES

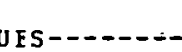
$\begin{array}{llll}\text { PASSED RETAINED } & \text { PEIGHT } & \text { ASH } & \text { SOLFOR } \\ \text { PASERT } & \text { PERCENT } & \text { PERCENT }\end{array}$

$\begin{array}{rrrrr} & 30 \mathrm{M} & 11.00 & 10.79 & 0.85 \\ 30 \mathrm{M} & 60 \mathrm{M} & 73.70 & 9.90 & 0.71 \\ 60 \mathrm{M} & 100 \mathrm{M} & 11.00 & 11.83 & \mathrm{C} .92 \\ 100 \mathrm{M} & 150 \mathrm{M} & 2.50 & 11.15 & 1.55 \\ 150 \mathrm{M} & 200 \mathrm{M} & 0.90 & 7.40 & 0.00 \\ 20 \mathrm{CM} & & 0.90 & 11.86 & 0.00\end{array}$

4.10
5.05
4.50
4.0
1.3
3.05

$$
\begin{aligned}
& 4.10 \\
& 5.05 \\
& 4.50 \\
& 4.00 \\
& 1.35 \\
& 3.05
\end{aligned}
$$

HALYTICAL

--.--CUMULATIVE RETAINH

SULPUR MOISTURE YEIGHT PRCENT P

DATA FOR DRYPLO SEPARATION TEST 8

$\begin{array}{rr}11.00 & 10.79 \\ 84.70 & 10.02 \\ 95.70 & 10.22 \\ 98.20 & 10.25 \\ 99.10 & 10.22 \\ 100.00 & 10.24\end{array}$

0.85
0.73
0.75
0.77
0.76
0.76$$
\begin{aligned}
& 4.10 \\
& 4.93
\end{aligned}
$$$$
4.88
$$$$
\begin{aligned}
& 4.86 \\
& 4.82
\end{aligned}
$$

4.82
4.81

100.00
89.00
15.30
4.30
1.80
0.90
PERCE NT

ASSED--

SULFOR MOISTORE PERCENT PERCENT

FIGURES PROA PSOC 233 PEED SAMPLE.

THIS FRACTION CONSTITUTES 100.0 PERC OP THE PEED.

$\begin{array}{rrr}10.24 & 0.76 & 4.81 \\ 10.17 & 0.75 & 4.89 \\ 11.46 & 0.91 & 4.15 \\ 10.51 & 0.90 & 3.25 \\ 9.63 & 0.00 & 2.20 \\ 11.86 & 0.00 & 3.05\end{array}$

.81
.89

.25

3.05
DATA FOR -

* * Conposite* *

SIZE FRACTION
PASSED RETAINED

$\begin{array}{rrrrrr} & 30 \mathrm{M} & 3.54 & 8.29 & 0.63 & 4.54 \\ 30 \mathrm{M} & 60 \mathrm{M} & 54.6 \mathrm{C} & 7.24 & 0.58 & 5.48 \\ 6 \mathrm{M} & 10 \mathrm{MM} & 26.33 & 7.21 & 0.59 & 5.75 \\ 10 \mathrm{M} & 150 \mathrm{M} & 10.00 & 7.37 & 0.64 & 5.44 \\ 150 \mathrm{M} & 200 \mathrm{M} & 2.29 & 8.35 & 0.70 & 5.13 \\ 20 \mathrm{M} & & 3.24 & 11.06 & 1.03 & 5.23\end{array}$

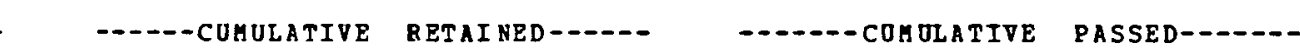

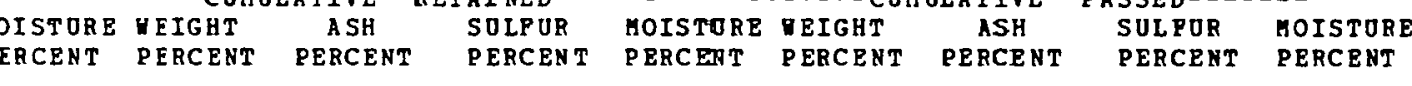

$\begin{array}{rrrr}.54 & 3.54 & 8.29 & 0.63\end{array}$

$\begin{array}{rrr}3.54 & 8.29 & 0.63 \\ 58.15 & 7.30 & 0.59 \\ 84.48 & 7.27 & 0.59 \\ 94.48 & 7.28 & 0.59 \\ 96.76 & 7.31 & 0.60 \\ 100.00 & 7.43 & 0.61\end{array}$

4.54

100.00

5.42
5.52

5.52
5.52

5.51

5.50

41.85

41.85
15.52

5.52

7.43
7.40
7.61
8.28
9.94
1.06

0.6

$\begin{array}{ll}0.64 & 5.60 \\ 0.73 & 5.35\end{array}$

$0.89 \quad 5.19$

$1.03 \quad 5.23$ 
ANALYTICAL DATA

DATA FOR DRYPLO SEPARATION TEST: *

DÁTA POR - PRODUCT COAL.
FIGURES FROM PSOC 233 PEED SAMPLE.

THIS PRACTION CONSTITUTES 83.9 PERCENT OP THE PEED.

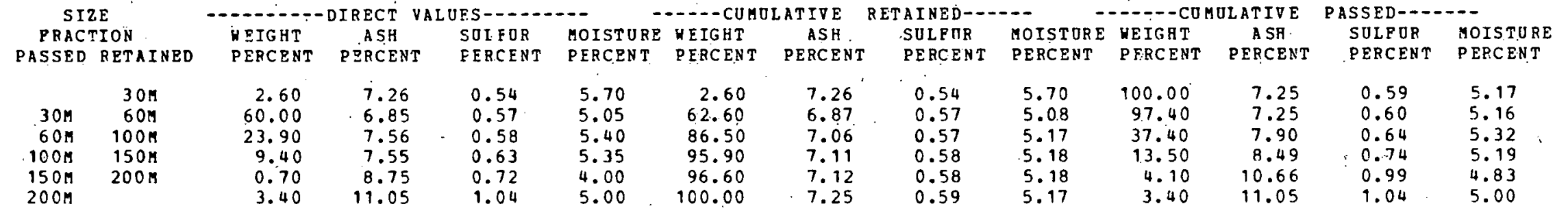

DATA FOR - MIODLING COAL.

THIS FRACTION CONSTITUTES 8.1 PERCENT OP THE PEED.

$\begin{array}{ccccc}\text { SIZE } & & & \\ \text { PRACTION } & \text { HEIGHT } & \text { ASH } & \text { SOLF } \\ \text { PASSED RETAINED } & \text { PERCENT } & \text { PERCENT } & \text { PERC } \\ & & & & \\ 30 M & 60 \mathrm{M} & 6.10 & 8.20 & 0.5 \\ 60 \mathrm{M} & 100 \mathrm{M} & 64.60 & 7.86 & 0.5 \\ 100 \mathrm{M} & 150 \mathrm{M} & 20.80 & 8.25 & 0.6 \\ 150 \mathrm{M} & 20 \mathrm{M} & 5.40 & 8.66 & 0.7 \\ 200 \mathrm{M} & & 0.80 & 8.25 & 0.0 \\ & & 2.30 & 11.88 & 1.4\end{array}$

DATA FOR - REPUSE COAL.

FUR MOISTURE DEIGET ASH SULPUR MOISTURE VEIGHT ASH SOLPOR MOISTURE

TIVE RETAINED--..-

- - CUMOLATTIVE

T.VE PASSED-.....

$-$

$\begin{array}{llllllllll}0.58 & 3.60 & 6.10 & .8 .20 & 0.58 & 3.60 & 100.00 & 8.10 & 0.61 & 4.56\end{array}$

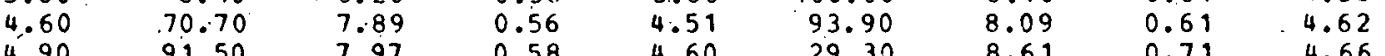

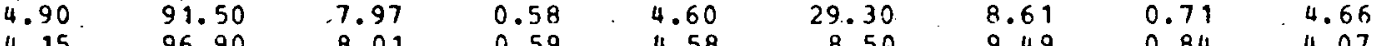

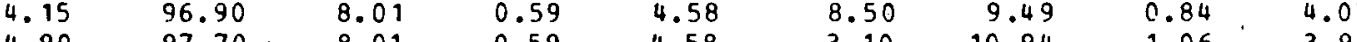

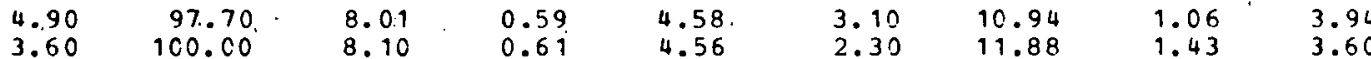

' THIS PBACTION CONSTITOTES 8.0 PERCENT OF THE PEED.

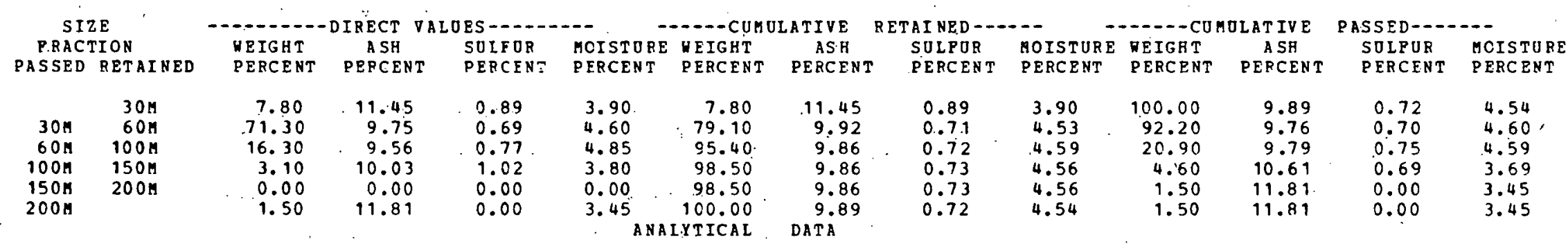

DATA FOB DRTFlo SEPARATION TEST DATA POR -

* composite

PIGORES PROR PSOC 233 FEED SAMPLE.

THIS PRACTION CONSTITUTES 100.0 PERCENT OP.THE PEED.

\begin{tabular}{|c|c|c|c|c|c|c|c|c|c|c|c|c|c|}
\hline \multirow{2}{*}{\multicolumn{2}{|c|}{$\begin{array}{l}\text { SIZE } \\
\text { FRACTION }\end{array}$}} & \multicolumn{2}{|c|}{$\cdots-1-1$ DIRECT } & \multicolumn{2}{|c|}{ PALOES- } & \multicolumn{2}{|c|}{--- CU MULATIVE } & \multicolumn{2}{|c|}{ RETAINED- - - } & \multicolumn{2}{|c|}{$-\cdots-$ COMULAT IV́E } & \multicolumn{2}{|c|}{ PASSED- - - } \\
\hline & & VEIGHT & A SH & SUIFOR & MOISTURE & HEIGHT & ASH & SULPOR. & MOISTORE & DEIGHT & A.SH & SULFOR & MOISTURE \\
\hline SSED & RETAINED & & $\mathrm{NT}$ & & & & NT & IT & & & & & \\
\hline $\begin{array}{r}30 \mathrm{M} \\
60 \mathrm{H} \\
100 \mathrm{M} \\
150 \mathrm{H} \\
200 \mathrm{O}\end{array}$ & $\begin{array}{r}30 \mathrm{H} \\
60 \mathrm{~N} \\
100 \mathrm{~K} \\
150 \mathrm{~N} \\
200 \mathrm{~N}\end{array}$ & $\begin{array}{r}3.30 \\
61.28 \\
23.04 \\
8.57 \\
0.65 \\
3.16\end{array}$ & $\begin{array}{r}8.19 \\
7.21 \\
7.72 \\
7.68 \\
8.70 \\
11.13\end{array}$ & $\begin{array}{l}0.61 \\
0.58 \\
0.60 \\
0.65 \\
0.65 \\
1.02\end{array}$ & $\begin{array}{l}5.05 \\
4.97 \\
5.33 \\
5.24 \\
4.09 \\
4.86\end{array}$ & $\begin{array}{r}3.30 \\
64.58 \\
87.62 \\
96.19 \\
96.84 \\
100.00\end{array}$ & $\begin{array}{l}8.19 \\
7.26 \\
7.38 \\
7.41 \\
7.41 \\
7.53\end{array}$ & $\begin{array}{l}0.61 \\
0.58 \\
0.59 \\
0.59 \\
0.59 \\
0.61\end{array}$ & $\begin{array}{l}5.05 \\
4.97 \\
5.07 \\
5.08 \\
5.08 \\
5.07\end{array}$ & $\begin{array}{r}100.00 \\
96.70 \\
35.42 \\
12.38 \\
3.81 \\
3.16\end{array}$ & $\begin{array}{r}7.53 \\
7.51 \\
8.03 \\
8.61 \\
10.71 \\
11.13\end{array}$ & $\begin{array}{l}0.61 \\
0.60 \\
0.65 \\
0.74 \\
0.96 \\
1.02\end{array}$ & $\begin{array}{l}5.07 \\
5.07 \\
5.25 \\
5.08 \\
4.73 \\
4.86\end{array}$ \\
\hline
\end{tabular}


DATA FOR DRYFLO SEPARATION TEST * 10

DATA POR - PRODUCT COAL.
SIZP

PRACTION

PASSED RETAINED

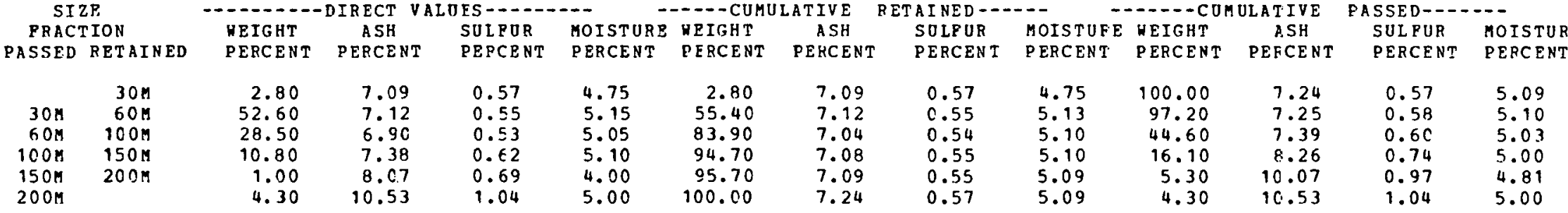

FIGURES PROM PSOC 233 PEED SAMPLE.

THIS FRACTION CONSTITUTES 84.8 PERCENT OP THE FEED.

DATA FOR - MIDDLING COAL.

THIS PRACTION CONSTITUTES 7.8 PERCENT OF THE FEED.

SIZE
PRACTION

REIGAT ASH SUIFUR MCISTURE MEIGHT ASH RETAINED

SSED RETAINED PERCENT PERCENT

$\begin{array}{rrrr}30 \mathrm{M} & 30 \mathrm{M} & 6.30 & 8.29 \\ 60 \mathrm{M} & 60 \mathrm{M} & 65.00 & 7.76 \\ 100 \mathrm{M} & 150 \mathrm{M} & 21.70 & 8.01 \\ 150 \mathrm{M} & 200 \mathrm{M} & 4.90 & 9.08 \\ 200 \mathrm{M} & & 0.00 & 0.00 \\ & & 2.10 & 11.96\end{array}$

PERCENT PER

DATA FOR - REPUSE COAL.$$
\operatorname{SIZE}
$$$$
\text { FRACTIOU }
$$

$\begin{array}{rrrrr} & 30 \mathrm{M} & 6.60 & 10.86 & 1.0 \\ 30 \mathrm{M} & 60 \mathrm{M} & 70.80 & 9.32 & 0.7 \\ 60 \mathrm{M} & 100 \mathrm{M} & 17.50 & 9.59 & 0.7 \\ 100 \mathrm{M} & 150 \mathrm{M} & 3.60 & 10.56 & 1.0 \\ 150 \mathrm{M} & 200 \mathrm{M} & 0.00 & 0.00 & 0.00 \\ 20 \mathrm{M} & & 1.50 & 12.93 & 0.0\end{array}$

DATA FOR DRYPLO SEPARATION TEST 10 $L_{i i}$ i $P O R$ -

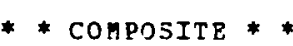

0.59
0.60
0.59
0.74
$0.0 C$
1.34

$\begin{array}{rr}3.55 & 6.30 \\ 4.60 & 71.30 \\ 4.45 & 93.00 \\ 3.10 & 97.90 \\ 0.00 & 97.90 \\ 3.05 & 100.00\end{array}$

8.29
7.81
7.85
7.92
7.92
8.00

\subsection{9}$$
\begin{aligned}
& 0.60 \\
& 0.60
\end{aligned}
$$$$
0.60
$$$$
0.60
$$

0.60
0.62

ThIS PRACTION CONSTITUTES 7.4 PERCENT OP THE FEED.

$\begin{array}{rrrrr} & & & & \\ 3.55 & 100.00 & 8.00 & 0.62 & 4.40 \\ 4.51 & 93.70 & 7.98 & 0.62 & 4.45 \\ 4.49 & 28.70 & 8.48 & 0.67 & 4.12 \\ 4.42 & 7.00 & 9.94 & 0.92 & 3.09 \\ 4.42 & 2.10 & 11.96 & 1.34 & 3.05 \\ 4.40 & 2.10 & 11.96 & 1.34 & 3.05\end{array}$

-- ----COLULATIVE RETAINED---$-----C U R U L A T$ PERCENT PERC

1.05
0.70
0.75
1.01
0.00
0.00

3.30

3.30
4.50
4.10
3.85

3.85
0.00

3.00
3.30

100.00

SULPUR
PERCENT
NAIYTICAL

$\begin{array}{rr}6.60 & 10.86 \\ 77.40 & 9.45 \\ 94.90 & 9.48 \\ 98.50 & 9.52 \\ 98.50 & 9.52 \\ 100.00 & 9.57\end{array}$

DATA

\begin{abstract}
1.05
\end{abstract}
1.05
0.73
0.73

0.73
0.74

0.74

0.74
0.73

0.73

\section{FIGURES PROM PSOC 23
0.0 PERCENT OF THE PEED.}

THIS PRACTION CONSTITUTES 100.0 PERCENT OF THE PEED.

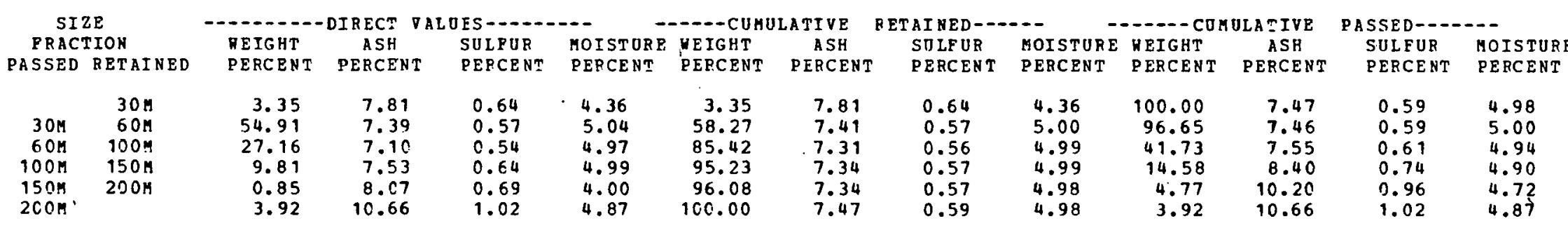


DATA POR DRYPLO SEPARATION TEST 11 DATA POR - PRODUCT COAL.
PIGURES FROM PSOC 233 FEED SAMPLF.

THIS FRACTION CONSTITUTES 70.4 PRRCENT OP THE FEED.

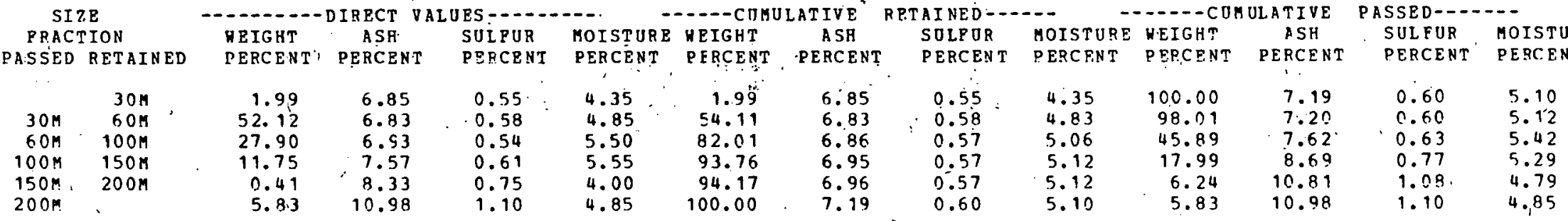

DATA FOR - MIDDLING COAL.

THIS PRACTION CONSTITUTES 19.6 PRRCENT OP THE PEED.

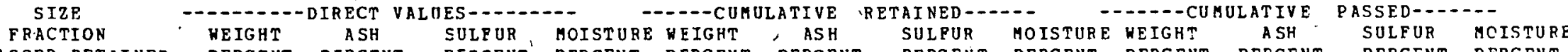

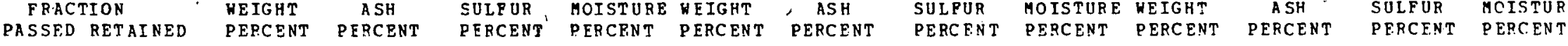

\begin{tabular}{|c|c|c|c|c|c|c|c|c|c|c|c|c|}
\hline $\begin{array}{l}30 M \\
60 \mathrm{M} \\
100 \mathrm{M} \\
150 \mathrm{M} \\
200 \mathrm{H}\end{array}$ & $\begin{array}{r}4.95 \\
61.83 \\
22.94 \\
6.79 \\
0.37 \\
3.12\end{array}$ & $\begin{array}{r}7.62 \\
7.24 \\
7.72 \\
8.46 \\
7.96 \\
10.93\end{array}$ & $\begin{array}{l}0.56 \\
0.55 \\
0.58 \\
0.69 \\
0.00 \\
1.24\end{array}$ & $\begin{array}{l}4.85 \\
5.45 \\
5.40 \\
4.90 \\
3.85 \\
4.85\end{array}$ & $\begin{array}{r}4.95 \\
66.78 \\
89.72 \\
96.51 \\
96.88 \\
100.00\end{array}$ & $\begin{array}{l}7.62 \\
7.27 \\
7.38 \\
7.46 \\
7.166 \\
7.57\end{array}$ & $\begin{array}{l}0.56 \\
0.55 \\
0.56 \\
0.57 \\
0.57 \\
0.59\end{array}$ & $\begin{array}{l}4.85 \\
5.49 \\
5.40 \\
5.37 \\
5.36 \\
5.35\end{array}$ & $\begin{array}{r}100.00 \\
95.05 \\
33.22 \\
10.28 \\
3.49 \\
3.12\end{array}$ & $\begin{array}{r}7.57 \\
7.57 \\
8.18 \\
9.19 \\
10.62 \\
10.93\end{array}$ & $\begin{array}{l}0.59 \\
0.59 \\
0.66 \\
0.83 \\
1.11 \\
1.24\end{array}$ & $\begin{array}{l}5.35 \\
5.37 \\
5.23 \\
4.85 \\
4.74 \\
4.85\end{array}$ \\
\hline
\end{tabular}

DATA FOR - REFUSE COAL.

THIS PRACTION CONSTITUTES 10.0 PERCENT OP THE FEED.

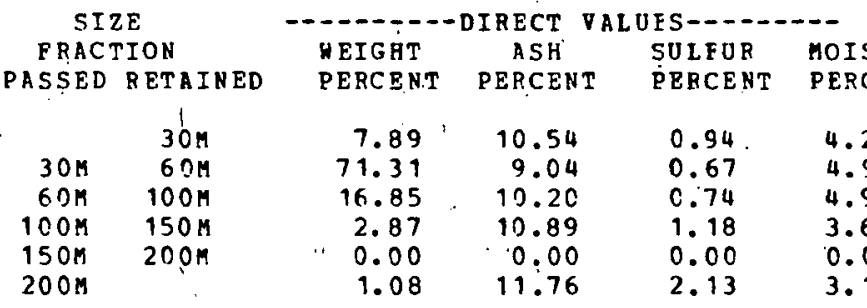

DATA FOR DRYFLO SEPARATION TEST 11
DATA FOR - * COHPOSITE * *

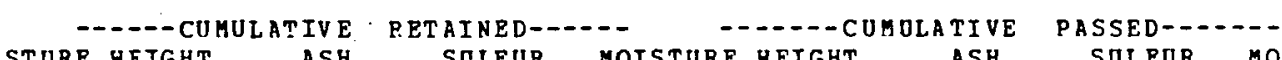

$\begin{array}{lcc}\text { ISTURE } & \text { WEIGHT } & \text { ASH } \\ \text { RCENT } & \text { PERCENT } & \text { PERCENT } \\ .20 & 7.89 & 10.54 \\ .90 & 79.20 & 9.19\end{array}$

SILFUR MOISTURE MEIGHT ATE ASH PASED-
SOLPOR MOISTURE

PERCENT PERCENT PERCENT PERCENT PERCENT PERCENT

$\begin{array}{rrrr}20 & 7.89 & 10.54 & 0.94 \\ 90 & 79.20 & 9.19 & 0.70\end{array}$

$.90 \quad 96.05 \quad 9.37$
.60

$\begin{array}{lll}.60 & 98.92 & 9.41 \\ .00 & 98.92 & 9.41\end{array}$

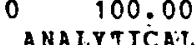

9.44

DATA

0.70
0.72

$4.20 \quad 100.00$

4.83

92.11
20.80

9.44
9.34

$\begin{array}{lll}4.81 & 3.95 & 11.13\end{array}$

0.72

4.79

1.08

$11: 76$
11.76

0.73
0.72

0.72
0.87

0.87
1.44

4.63

0.73

PIgures Fron PSOC * 233 PEED SAMPLE.

\begin{tabular}{|c|c|c|c|c|c|c|c|c|c|c|c|c|c|}
\hline \multirow{2}{*}{\multicolumn{2}{|c|}{$\begin{array}{c}\text { SIZF } \\
\text { PRACTION }\end{array}$}} & \multicolumn{2}{|c|}{$-\cdots-D$ DIRECT } & $45 S_{----}$ & - & \multicolumn{2}{|c|}{--- CUMULATIVE } & \multicolumn{2}{|c|}{ RETAINED - } & \multicolumn{2}{|c|}{$-\cos \theta$} & \multicolumn{2}{|c|}{ PA'SSED- } \\
\hline & & NEIGRT & A SH & SOLPOR & MOIST URE & WEIGHT & A SH & SOLP OR & MOISTURE & WEIGHT & ASH & SOLFOR & MOISTURE \\
\hline PASSED & RETAINED & PEBCENT & PERCENT & PERCENT & PERCP.NT & PERCENT & PERCENT & PERCENT & PERCENT & PERCENT & PERCENT & PERCENT & PERCENT \\
\hline $\begin{array}{l}30 \mathrm{M} . \\
60 \mathrm{M} \\
100 \mathrm{M} \\
150 \mathrm{M} \\
200 \mathrm{H}\end{array}$ & $\begin{array}{l}30 \mathrm{M} \\
60 \mathrm{M} \\
100 \mathrm{M} \\
150 \mathrm{H} \\
200 \mathrm{~N}\end{array}$ & $\begin{array}{r}3.16 \\
55.94 \\
25.82 \\
9.89 \\
0.36 \\
4.82\end{array}$ & $\begin{array}{r}8.01 \\
7.20 \\
7.28 \\
7.79 \\
8.26 \\
10.99\end{array}$ & $\begin{array}{l}0.65 \\
0.58 \\
0.56 \\
0.64 \\
0.60 \\
1.14\end{array}$ & $\begin{array}{l}4.47 \\
4.99 \\
5.44 \\
5.41 \\
3.97 \\
4.81\end{array}$ & $\begin{array}{r}3.16 \\
59.10 \\
84.93 \\
94.81 \\
95.18 \\
100.00\end{array}$ & $\begin{array}{l}8.01 \\
7.24 . \\
7.26 \\
7.31 \\
7.31 \\
7.49\end{array}$ & $\begin{array}{l}0.65 \\
0.59 \\
0.58 \\
0.59 \\
0.59 \\
0.61\end{array}$ & $\begin{array}{l}4.47 \\
4.96 \\
5.11 \\
5.14 \\
5.13 \\
5.12\end{array}$ & $\begin{array}{r}100.00 \\
96.84 \\
40.90 \\
15.07 \\
5.18 \\
4.82\end{array}$ & $\begin{array}{r}7.49 \\
7.47 \\
7.85 \\
8.82 \\
10.80 \\
10.99\end{array}$ & $\begin{array}{l}0.6: 1 \\
0.61 \\
0.65 \\
0.80 \\
1.10 \\
1.14\end{array}$ & $\begin{array}{l}5.12 \\
5.14 \\
5.35 \\
5.18 \\
4.75 \\
4.89\end{array}$ \\
\hline
\end{tabular}


AHALYTICAL DATA

DATA POR DRYPLC SEPARATION TEST 12

DATA POR - PRODUCT COAL.
FIGURES FROM PSOC 233 PEED SAMPLE.

THIS FPACTION CONSTITOTES $\mathbf{7 2 . 4}$ PERCENT OP THE PEED,

\begin{tabular}{|c|c|c|c|c|c|c|c|c|c|c|c|c|c|}
\hline & & & & & & & & & & & & & \\
\hline $\begin{array}{r}\text { PRAC } \\
\text { PASSRD }\end{array}$ & $\begin{array}{l}\text { ION } \\
\text { RETAINED }\end{array}$ & $\begin{array}{l}\text { NEIGHT } \\
\text { PERCENT }\end{array}$ & $\begin{array}{c}\text { ASH } \\
\text { PERCENI }\end{array}$ & $\begin{array}{l}\text { SOIPOR } \\
\text { PERCENT }\end{array}$ & $\begin{array}{l}\text { MOISTURE } \\
\text { PERCENT }\end{array}$ & $\begin{array}{l}\text { WEIGHT } \\
\text { PERCENT }\end{array}$ & $\begin{array}{c}\text { ASH } \\
\text { PERCENT }\end{array}$ & $\begin{array}{l}\text { SOLPOR } \\
\text { PERCENT }\end{array}$ & $\begin{array}{l}\text { MOISTORE } \\
\text { PERCENT }\end{array}$ & $\begin{array}{l}\text { NEIGUT } \\
\text { PERCENT }\end{array}$ & $\begin{array}{c}\text { A SH } \\
\text { PERCPNT }\end{array}$ & $\begin{array}{l}\text { SULPDR } \\
\text { PERCENT }\end{array}$ & $\begin{array}{l}\text { MOIST } \\
\text { PERCEI }\end{array}$ \\
\hline $\begin{array}{l}30 \mathrm{M} \\
60 \mathrm{M} \\
100 \mathrm{M} \\
150 \mathrm{M} \\
200 \mathrm{M}\end{array}$ & $\begin{array}{l}30 M \\
60 M \\
100 M \\
150 M \\
200 M\end{array}$ & $\begin{array}{r}2.00 \\
53.20 \\
26.30 \\
12.50 \\
0.20 \\
5.80\end{array}$ & $\begin{array}{r}7.05 \\
7.23 \\
7.03 \\
7.31 \\
7.61 \\
10.71\end{array}$ & $\begin{array}{l}0.57 \\
0.56 \\
0.57 \\
0.63 \\
0.69 \\
1.11\end{array}$ & $\begin{array}{l}4.95 \\
5.20 \\
5.35 \\
4.95 \\
3.45 \\
4.75\end{array}$ & $\begin{array}{r}2.00 \\
55.20 \\
81.50 \\
94.00 \\
94.20 \\
100.00\end{array}$ & $\begin{array}{l}7.05 \\
7.22 \\
7.16 \\
7.18 \\
7.18 \\
7.39\end{array}$ & $\begin{array}{l}0.57 \\
0.56 \\
0.56 \\
0.57 \\
0.57 \\
0.60\end{array}$ & $\begin{array}{l}4.95 \\
5.19 \\
5.24 \\
5.20 \\
5.20 \\
5.17\end{array}$ & $\begin{array}{r}100.00 \\
98.00 \\
44.80 \\
18.50 \\
6.00 \\
5.80\end{array}$ & $\begin{array}{r}7.39 \\
7.39 \\
7.59 \\
8.38 \\
10.61 \\
10.71\end{array}$ & $\begin{array}{l}0.60 \\
0.60 \\
0.66 \\
0.78 \\
1.10 \\
1.11\end{array}$ & $\begin{array}{l}5.18 \\
5.15 \\
4.87 \\
4.71 \\
4.75\end{array}$ \\
\hline
\end{tabular}

DATA FOR - MIDDLING COAL.

THIS PEACTION CONSTITUTES 17.7 PERCENT OP THE PEED.

\begin{tabular}{|c|c|c|c|c|}
\hline \multirow{2}{*}{\multicolumn{2}{|c|}{$\begin{array}{l}\text { SIZE } \\
\text { FRACTION }\end{array}$}} & \\
\hline & & MEIGHT & ASH & SULEU \\
\hline PASSED & RETAINED & PEPCENT & PERCENT & PEFC \\
\hline & $30 \mathrm{M}$ & 4.90 & 7.55 & 0 . \\
\hline $30 \mathrm{M}$ & $60 \mathrm{M}$ & 59.90 & 7.4 & 0.6 \\
\hline $60 \mathrm{~m}$ & $100 \mathrm{M}$ & 24.00 & 7.63 & 0.6 \\
\hline $10 \mathrm{CM}$ & $150 M$ & 7.80 & 8.30 & 0. \\
\hline $150 \mathrm{M}$ & $200 \mathrm{n}$ & 0.00 & 0.00 & 0.0 \\
\hline $200 \mathrm{M}$ & & 3.40 & 11.22 & 1.3 \\
\hline
\end{tabular}

DATA FOR - REFUSE COAL.

----COMULATIVE RETAINED-

SINED $-1-2$
SUIPUR

ASH

$\begin{array}{rrrr}0.59 & 4.60 & 100.00 & 7.72 \\ 0.60 & 5.20 & 95.10 & 7.73\end{array}$

0.60

4.60
5.25

5.60

4. 85

0.00

4.90
64.80

64.80
88.80

88.80
96.60

56.60

100.00

7.49

7.59

0.60

0.61
0.61

7.59

0.63

5.20
5.31

5.31
5.27

5.27
5.27

5.25
95.10
35.20
11.20
3.40
3.40
7.72
7.73
8.13
8.13
9.19
11.22

11.22

THIS FRACTION CONSTItUTES 9.9 PERCENT OP THE PEED.

SIZE

FRACTION

PASSED RETAINED REIGHT DIRECT ASH VALOES-1-2.-SULFUR OISTURE HEIGHT
PRCENT PERCENT

\section{TIVE RETAINED -} PERCE MOIST

\section{- - - - CIJMULAT IVE}

TIVE PASSED-

$\begin{array}{lll}4.05 & 7.50 \quad 10.58\end{array}$

PERCE

$$
\begin{aligned}
& 1.66 \\
& 0.68 \\
& 0.83 \\
& 1.15 \\
& 0.00 \\
& 1.66
\end{aligned}
$$

$60 \mathrm{M} \quad 10 \mathrm{OM}$

$100 \mathrm{M} \quad 150 \mathrm{M}$

$200 M$

17.20
3.70

3.70
0.00

9.48

0.00

DATA FOR DRYFLO SEPARATION TEST 12 DATA FOR -

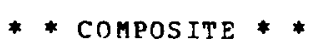

4.05

4.55

4.45

0.00
3.20

$20 \quad 100.00$

$9.6 ?$

1.06
0.72
0.74

0.72

0.75

0.75

9.66
9.69

DATA

0.77

4.05
4.82
4.77
4.76
4.76
4.74

4.05
4.82
4.77
4.76
4.76
4.74

100.00
92.50
22.30
5.10
1.40
1.40

PERCENT

9.69
9.62

9.62

10.08
11.83

11.83
11.83

PIGURES PROA PSOC 233 FEED SAMPLE.

THIS PRACTION CONSTITOTES 100.0 PERCFNT OP THE PEED. 0.77 0.74 0.94 1.29 1.66
1.66 MOISTMRE

SIZE

FRACTION -

PASSED RETAINED SULFUR MOIST ORE WEIGHT - COROLATIVE TAINED--
SULFUR MOISTUR

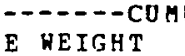
ATIVE SH 4.74 4.45 4.45 4.11
3.21 3.20

$\begin{array}{rrrrrr} & 30 \mathrm{M} & 3.06 & 8.05 & 0.69 & 4.63 \\ 30 \mathrm{M} & 60 \mathrm{M} & 56.07 & 7.58 & 0.58 & 5.17 \\ 60 \mathrm{M} & 100 \mathrm{M} & 24.99 & 7.30 & 0.59 & 5.34 \\ 100 \mathrm{M} & 150 \mathrm{M} & 10.80 & 7.51 & 0.66 & 4.92 \\ 150 \mathrm{M} & 200 \mathrm{M} & 0.14 & 7.51 & 0.69 & 3.45 \\ 200 \mathrm{M} & & 4.94 & 10.80 & 1.15 & 4.69\end{array}$

3.06
59.13
84.12
94.92
95.06
100.00
PERCENT PERCEN

$$
\begin{aligned}
& 8.05 \\
& 7.60 \\
& 7.51 \\
& 7.51 \\
& 7.51 \\
& 7.67
\end{aligned}
$$$$
0.69
$$$$
\begin{aligned}
& 0.69 \\
& 0.59 \\
& 0.59
\end{aligned}
$$$$
\begin{aligned}
& 0.59 \\
& 0.60
\end{aligned}
$$$$
0.60
$$$$
\begin{aligned}
& 4.63 \\
& 5.14 \\
& 5.20 \\
& 5.17 \\
& 5.17 \\
& 5.14
\end{aligned}
$$$$
\begin{array}{r}
100.00 \\
96.94 \\
40.87 \\
15.88 \\
5.08 \\
4.94
\end{array}
$$
PERCENT SULFUR MOISTURE PERCENT PERCENT

0.63

5.14

4.94

7.67
7.66
7.78
8.53
10.77
10.80

0.63
0.62

0.68

0.68
0.81

0.81
1.14

1.15

5.14

5.14

5.14
4.83

4.65

4.69 
DATA FOR DRYPLO SEPARATION TEST 13

DATA FOR - PRODUCT COAL.
PIGURES FROM PSOC 85 (ANTHRACITE) PEED.

THIS FRACTION CONSTITOTES 86.9 PERCENT OF THE PEED.

PRACTION

DETGHT-DIRECT VALUES

PASSED RETAINED

AEIGHT ASH

OISTORE REIGHT ASH RETA

SULFUR MOI

MOISTURE UEIGHT

ATIVE PASSED-1.-

$\begin{array}{rrrrrr} & 30 M & 5.10 & 7.46 & 1.40 & 0.80 \\ 30 M & 60 M & 47.30 & 8.32 & 1.35 & 0.80 \\ 60 M & 100 M & 24.30 & 8.93 & 1.50 & 0.95 \\ 100 M & 150 M & 10.40 & 9.89 & 1.60 & 0.90 \\ 150 M & 200 M & 0.90 & 11.30 & 1.60 & 0.90 \\ 200 M & & 12.00 & 14.81 & 1.45 & 1.05\end{array}$

.80
.80
0.95
.90
.90
.05

5.10
52.40
76.70
87.10
88.00
100.00

$\begin{array}{ll}7.46 & 1.40 \\ 8.24 & 1.35 \\ 8.46 & 1.40 \\ 8.63 & 1.42 \\ 8.65 & 1.43 \\ 9.39 & 1.43\end{array}$

0.80

$0.80 \quad 100.00$

0.85

94.90

9.39

9.50
10.67

$\begin{array}{lll}0.85 & 23.30 & 12.48\end{array}$

$0.85-12.90$

0.88

12.00

14.57

14.81

THIS PRACTION CONSTITUTES 4.4 PERCENT OP THE FEED.

DATA POR - MIDDLING COAL.

SIZE

FRACTION

$\begin{array}{cc} & \\ \text { WEIGHT } & \text { ASH } \\ \text { PERCENT } & \text { PERCENT } \\ & \\ 14.40 & 11.58 \\ 68.50 & 16.78 \\ 13.60 & 16.16 \\ 1.70 & 0.00 \\ 0.00 & 0.00 \\ 1.70 & 0.00\end{array}$

$$
\text { JUES- }-2-1-2
$$

REIGHT

\title{
RETAINED----
}

$\begin{array}{lll} & \\ \text { SULPUR } & \text { MOISTORE HEIGH } & \text { ASH } \\ \text { PERCENT } & \text { PERCENT PERCENT PERCEN }\end{array}$

E
38
38

PASSED-- - - -

SULPOR MOISTURE

1.20

0.70

\begin{abstract}
14.40
\end{abstract}
11.58

1.20

0.70

100.00

15. 38

1.28
1.31
1.32

1.30
1.45

1.45
2.20

0.80
0.65
0.00

83.00
96.60

15.88
15.92

0.00
2.15

0.00

98.30

15.64

1.32

0.78
0.76
0.75

85.60

0.75

17.00
3.40

16.01
12.93

98.30
100.00

15.64
15.38

1.32
1.34

0.75
0.74

3.40
1.70

12.93
0.00

0.00
0.00

0.00
0.00

1.34

1.36

1.59

2.17
2.15

2.15
2.15

0.88

THIS FRACTION CONSTITUTES 8.7 PERCENT OP THE PERD.

DATA POR - REPUSE COAL.

- - - - CUMULATIVE RETAINED-- -

\begin{tabular}{|c|c|c|c|c|}
\hline & & - - - & DIRECT & L. O \\
\hline $\begin{array}{r}\text { FRAC } \\
\text { PASSED }\end{array}$ & $\begin{array}{l}\text { ION } \\
\text { RETAINED }\end{array}$ & $\begin{array}{l}\text { HEIGHT } \\
\text { PERC\&NT }\end{array}$ & $\begin{array}{c}\text { ASH } \\
\text { PERCENT }\end{array}$ & $\begin{array}{l}\text { SUL } \\
\text { PER }\end{array}$ \\
\hline $30 M$ & $\begin{array}{l}30 M \\
60 M\end{array}$ & $\begin{array}{l}16.20 \\
74.40\end{array}$ & $\begin{array}{l}19.38 \\
21.14\end{array}$ & \\
\hline $60 \mathrm{M}$ & $100 \mathrm{M}$ & 8.10 & 23.44 & \\
\hline $100 \mathrm{M}$ & $15 \mathrm{~cm}$ & 0.90 & 0.00 & \\
\hline $150 M$ & $200 \mathrm{~N}$ & 0.00 & 0.00 & \\
\hline $200 \mathrm{M}$ & & 0.40 & 000 & \\
\hline
\end{tabular}

DATA FOR DRYFLO SEPARATION TEST 13 $\begin{array}{lll} & \\ \text { MOISTURE WEIGHT } & \text { ASH } \\ \text { PECENT } & \text { PERCENT PERCENT PERCENT }\end{array}$ SULPUR MOISTURE UEIGHT TIVE
ASH PASSED--.--SULFOR MOISTURE $1.10 \quad 0.65$

$\begin{array}{lr}0.65 & 16.20 \\ 0.65 & 90.60 \\ 0.60 & 98.70 \\ 0.00 & 99.60 \\ 0.00 & 99.60 \\ 0.00 & 100.00\end{array}$

19.38
20.83

20.83
21.04 PERCENT PERCENT WEIGHT PERCENT PERCENT PERCENT

AOR -

* * composite**

$$
\begin{aligned}
& 1.10 \\
& 1.10 \\
& 1.17 \\
& 1.19 \\
& 1.19 \\
& 1.2
\end{aligned}
$$

0.65
0.65

0.65

0.64

0.64
0.64
100.00
83.80
9.40
1.30
0.40
0.40

20.77
21.03
20.20
0.00
0.00
0.00

1.21
1.23

2.22

4.24

4.10
4.10

0.64
0.64

20.85
20.77

DATA

FIGURES PROH PSOC *85 (ANTHRACITE) PEFD.

THIS PRACTICN CONSTTtUTES 100.0 PERCENT OP THE PEED.

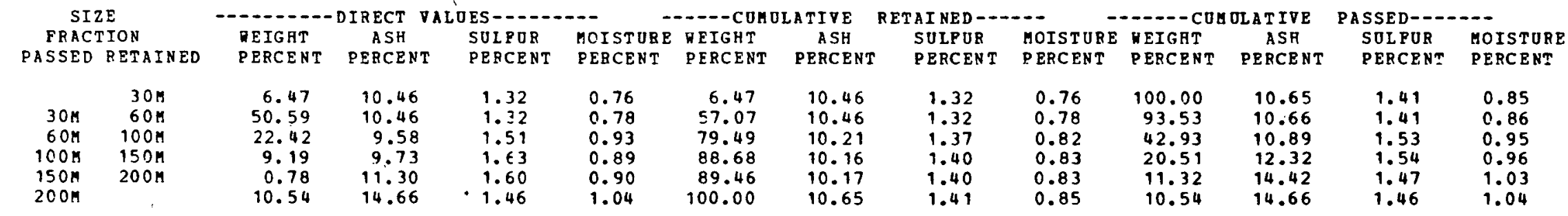


ANALYTICAL DATA

DATA FOR DRYPLO SEPARATION TEST 14

DATA FOR - PRODUCT COAL.
PIGCRES PROA PSOC BS (ANTHRACITE) PEED.

THIS FRACTION CONSTITUTES 88.2 PERCENT OP TRE PEED.

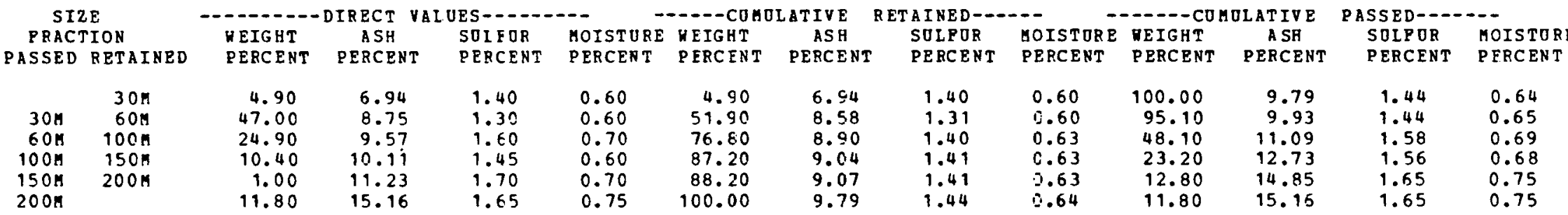

DATA POR - MIDDLING COAL.

THIS PRACTION CONSTITUTES 3.9 PERCENT OP THE PEED.

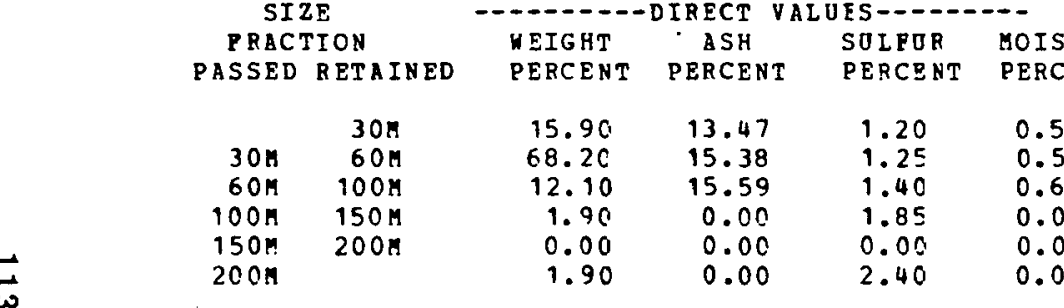

DATA POR - REFOSE COAL. ISTORE WEIGHT
ASH

SIZE

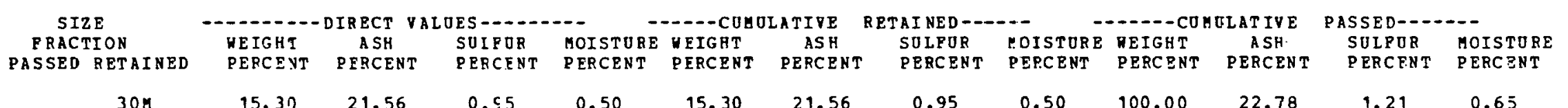

\begin{tabular}{|c|c|c|c|c|c|c|c|c|c|c|c|c|c|}
\hline $\begin{array}{l}30 \mathrm{H} \\
60 \mathrm{H} \\
100 \mathrm{H} \\
150 \mathrm{H} \\
200 \mathrm{n}\end{array}$ & $\begin{array}{r}30 \mathrm{M} \\
60 \mathrm{H} \\
100 \mathrm{H} \\
150 \mathrm{H} \\
200 \mathrm{H}\end{array}$ & $\begin{array}{r}15.30 \\
75.00 \\
8.30 \\
0.90 \\
0.00 \\
0.50\end{array}$ & $\begin{array}{r}21.56 \\
22.90 \\
27.73 \\
0.00 \\
0.00 \\
0.00\end{array}$ & $\begin{array}{l}0.55 \\
1.10 \\
2.05 \\
5.30 \\
0.00 \\
5.30\end{array}$ & $\begin{array}{l}0.50 \\
0.65 \\
1.00 \\
0.00 \\
0.00 \\
0.00\end{array}$ & $\begin{array}{r}15.30 \\
90.30 \\
98.60 \\
99.50 \\
99.50 \\
100.00\end{array}$ & $\begin{array}{l}21.56 \\
22.67 \\
23.10 \\
22.89 \\
22.89 \\
22.78\end{array}$ & $\begin{array}{l}0.95 \\
1.07 \\
1.16 \\
1.19 \\
1.19 \\
1.21\end{array}$ & $\begin{array}{l}0.50 \\
0.62 \\
0.66 \\
0.65 \\
0.65 \\
0.65\end{array}$ & $\begin{array}{r}100.00 \\
84.70 \\
9.70 \\
1.40 \\
0.50 \\
0.50\end{array}$ & $\begin{array}{r}22.78 \\
22.99 \\
23.73 \\
0.00 \\
0.00 \\
0.00\end{array}$ & $\begin{array}{l}1.21 \\
1.26 \\
2.52 \\
5.30 \\
5.30 \\
5.30\end{array}$ & $\begin{array}{l}0.65 \\
0.67 \\
0.85 \\
0.00 \\
0.00 \\
0.00\end{array}$ \\
\hline
\end{tabular}

DATA POR DRYPLO SEPARATION TEST 14

PIGURES FROM PSOC 85 (ANTHRACITE) FEED. DATA POR -

- conposite* *

THIS PRACTION CONSTITUTES 100.0 PERCENT OP THE FEED.

\begin{tabular}{|c|c|c|c|c|c|c|c|c|c|c|c|c|c|}
\hline \multirow{2}{*}{\multicolumn{2}{|c|}{$\begin{array}{c}\text { SIZE } \\
\text { PRACIION }\end{array}$}} & \multicolumn{2}{|c|}{$--10-1$ DIRECT } & \multicolumn{2}{|c|}{ VALOES- - } & \multicolumn{2}{|c|}{--- CONOLAT IVE } & \multicolumn{2}{|c|}{ RETAINED-- - - } & \multicolumn{2}{|c|}{$\cdots-\infty$ CUMOLATIVE } & \multicolumn{2}{|c|}{ PASSED-.-- } \\
\hline & & $\begin{array}{l}\text { WEIGHT } \\
\text { PERCENT }\end{array}$ & $\begin{array}{c}\text { ASH } \\
\text { PERCENT }\end{array}$ & $\begin{array}{l}\text { SOLFOR } \\
\text { PERCENT }\end{array}$ & $\begin{array}{l}\text { MOISTORE } \\
\text { PERCENT }\end{array}$ & $\begin{array}{l}\text { WEIGHT } \\
\text { PERCENT }\end{array}$ & $\begin{array}{c}\text { ASH } \\
\text { PERCENT }\end{array}$ & $\begin{array}{l}\text { SULPUR } \\
\text { PERCENT }\end{array}$ & $\begin{array}{l}\text { MOISTURE } \\
\text { PERCENT }\end{array}$ & $\begin{array}{l}\text { DEIGHT } \\
\text { PEBCENT }\end{array}$ & $\begin{array}{c}\text { ASH } \\
\text { PERCENT }\end{array}$ & $\begin{array}{l}\text { SOIFOR } \\
\text { PERCENT }\end{array}$ & $\begin{array}{l}\text { MOISTURE } \\
\text { PERCENT }\end{array}$ \\
\hline $\begin{array}{r}30 \mathrm{H} \\
60 \mathrm{H} \\
100 \mathrm{H} \\
150 \mathrm{M} \\
200 \mathrm{H}\end{array}$ & $\begin{array}{l}30 \mathrm{H} \\
60 \mathrm{M} \\
100 \mathrm{M} \\
150 \mathrm{H} \\
20 \mathrm{OH}\end{array}$ & $\begin{array}{r}6.15 \\
50.04 \\
23.0 .9 \\
9.32 \\
0.88 \\
10.52\end{array}$ & $\begin{array}{r}10.47 \\
10.78 \\
10.21 \\
9.55 \\
11.23 \\
15.00\end{array}$ & $\begin{array}{l}1.29 \\
1.27 \\
1.61 \\
1.48 \\
1.70 \\
1.67\end{array}$ & $\begin{array}{l}0.58 \\
0.60 \\
0.71 \\
0.59 \\
0.70 \\
0.74\end{array}$ & $\begin{array}{r}6.15 \\
56.19 \\
79.28 \\
88.60 \\
89.48 \\
100.00\end{array}$ & $\begin{array}{l}10.47 \\
10.74 \\
10.59 \\
10.52 \\
10.53 \\
11.00\end{array}$ & $\begin{array}{l}1.29 \\
1.28 \\
1.37 \\
1.38 \\
1.39 \\
1.42\end{array}$ & $\begin{array}{l}0.58 \\
0.60 \\
0.63 \\
0.63 \\
0.63 \\
0.64\end{array}$ & $\begin{array}{r}100.00 \\
93.85 \\
43.81 \\
20.72 \\
11.40 \\
10.52\end{array}$ & $\begin{array}{l}11.03 \\
11.32 \\
12.57 \\
14.71 \\
15.00\end{array}$ & $\begin{array}{l}1.42 \\
1.43 \\
1.60 \\
1.59 \\
1.67 \\
1.67\end{array}$ & $\begin{array}{l}0.64 \\
0.64 \\
0.69 \\
0.67 \\
0.74 \\
0.74\end{array}$ \\
\hline
\end{tabular}


ANALYTICAL DATA

DATA POR DRYPLO SEPARATION. TEST 15 DATA FOR - PRODUCT COAL.
FIGORES PROM PSOC 102 FEED SAMPLE.

THIS PRACTION CONSTITOTES 88.2 PERCENT OP THE PERD

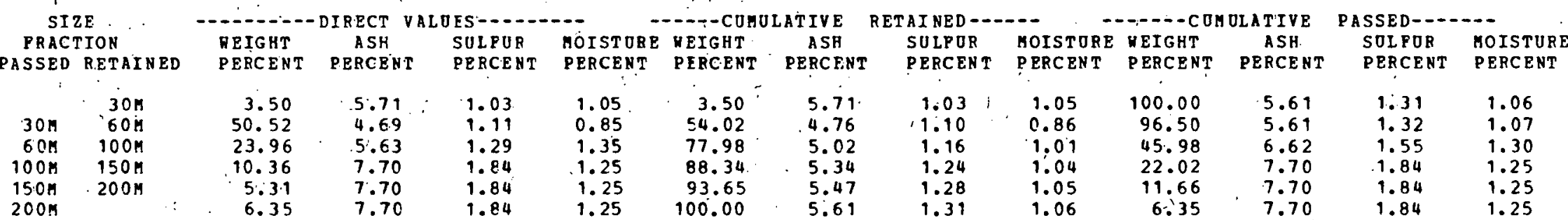

DATA FOR - MIDDLING COAL

THIS FRACTION COHSTITUTES 5.3 PERCENT OP THE PEED.

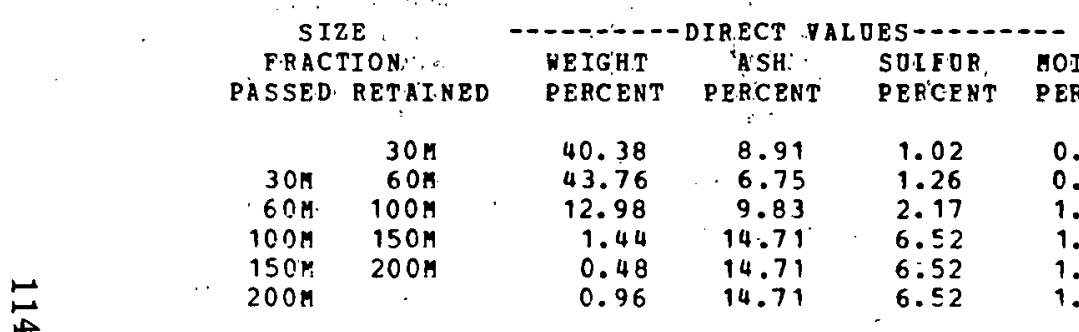

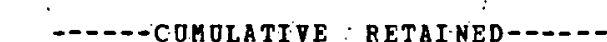

DATA POR - REFUSE COAL.

PERCENT PERCENT PERCPNT
PEE

PERCE

MOISTORE MEIGHT AUT

ASH
PERCENT

PASSED-- - - :

SDLPUR MOISTURE

$\begin{array}{lll}0.70 & 40.38 & 8.91\end{array}$

$1.02 \quad 0.70$

$\begin{array}{ll}0.70 \quad 100.00 \\ 0.75 & 59.62\end{array}$

100.00
59.62
15.86
2.88

8.25
7.81

7.81
10.72
14.71

14.71

14.71
14.71

1.43

1.7 .1
2.96

2.96

6.52
6.52

0.84

$\begin{array}{llllll}1.40 & 98.56 & 8.16 & 1.28 & 0.83 & 15.83 \\ 1.40 & 99.04 & 8.19 & 1.38 & 0.83 & 2.88\end{array}$

$\begin{array}{rrrrr}90.04 & 8.19 & 1.38 & 0.84 & 1.44 \\ 100.00 & 8.25 & 1.43 & 0.84 & 0.96\end{array}$

THIS PRACTION CONSTITUTES 6.5 PERCENT OP THE PEED.

\begin{tabular}{|c|c|c|c|c|c|}
\hline & $\mathrm{ZE}$ & & -1 & & \\
\hline FRAC & TION & & MEIGHT & ASH & \\
\hline PASSEI & RET & A IN ED & PERCENT & PERCEH T & \\
\hline & & On & 18.97 & 22.93 & \\
\hline $3 \mathrm{CH}$ & & OM & 74.69 & 11.5 & \\
\hline $60 \mathrm{M}$ & & OM & 5.14 & 16.48 & \\
\hline $10 \mathrm{CH}$ & & OM & 0.40 & 29.04 & \\
\hline $150 \mathrm{H}$ & & On & 0.40 & 21.04 & \\
\hline & & & & & \\
\hline & & 1 & 、 & - & \\
\hline DATA & POR & DRY FLO & SEPARATION & TEST & 15 \\
\hline
\end{tabular}

- - - CURULATIVE RETAINED--.--

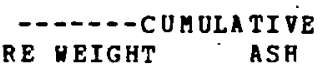

1.40

TA FOR

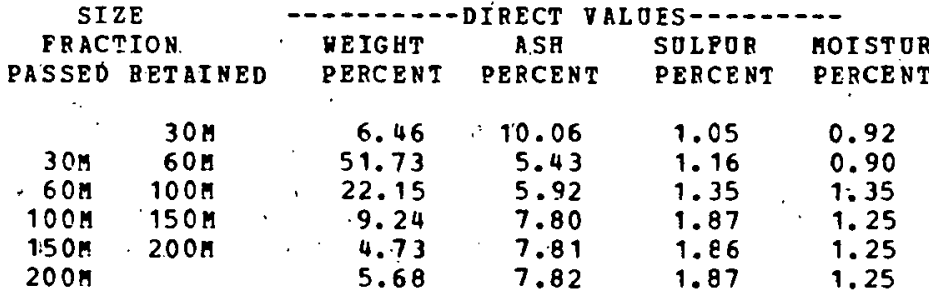

ASH

SOLPOR.

\section{MOIST}

PASSED-.---

$\begin{array}{rrrr}1.17 & 1.00 & 18.97 & 22.93 \\ 1.57 & 1.40 & 93.66 & 13.86 \\ 3.63 & 1.40 & 98.80 & 14.00 \\ 0.00 & 1.85 & 99.20 & 14.03 \\ 0.00 & 1.85 & 99.60 & 14.06 \\ 0.00 & 1.85 & 100.00 & 14.08 \\ & & \end{array}$

1.17
1.49
1.60
1.59
1.59
1.58

1.00
1.32
1.32
1.33
1.33
1.33

100.00
81.03
6.34
1.20
0.80
0.40

14.08

12.01

17.34
21.04

21.04
21.04

21.04

SOLPUR MOISTURE

PERCENT PERCENT

PIGURES PROA PSOC 102 PEED SAMPLE.

THIS PRACTION CONSTITUTES 100.0 PERCENT OP THE PEED.

$\begin{array}{ll}1.58 & 1.33 \\ 1.68 & 1.41 \\ 2.94 & 1.49 \\ 0.00 & 1.85 \\ 0.00 & 1.85 \\ 0.00 & 1.85\end{array}$

\section{EIGHT - CURULATIVE RETATNED-C-
ASH SOLPOR \\ - - - - - COHOLATIVE \\ MOISTORE HEIGHT}

PASSED--.-.--

PERCENT PERCENT

SOLPOR

ASH

SOLPUR. MOISTURE

6.46
58.19

10.06

1.05

$\begin{array}{cc}\text { PERCENT } \\ 0.92 & 100.00^{\circ}\end{array}$

6.30

PERCENT PISTURE

58.19
80.35

89.59

94.32

5.94
5.94

6.13
6.21

1.15
1.20

1.150 .90

1.27

1.30
1.34

1.03
1.05

1.05
1.06

93.54

41.81
19.65

6.04
6.81
7.81

6.30

$1.07 \quad 5.68$

7.82

$\begin{array}{ll}1.34 & 1.07 \\ 1.35 & 1.08 \\ 1.60 & 1.30 \\ 1.87 & 1.25 \\ 1.87 & 1.25 \\ 1.87 & 1.25\end{array}$


ANALYTICAL DATA

DATA POR DRYPLO SEPARATION TEST: 16. DATA POR - PRODUCT COAL.
FIGURES FROM PSOC \# 102 PEED SAMPLE.

THIS PRACTION CONSTITUTES 89.8 PERCENT OF THE PEED.

\begin{tabular}{|c|c|c|c|c|c|c|c|c|c|c|c|c|c|}
\hline \multirow{2}{*}{\multicolumn{2}{|c|}{$\begin{array}{l}\text { SIZE } \\
\text { PRACTION }\end{array}$}} & --- - - & RECT V & ES - - & - & $-\cos$ & CATIVE & RETAINED - & - & $----\mathrm{Cl}$ & DLATIVE & PASSED-- & - \\
\hline & & $\begin{array}{l}\text { HEIGHT } \\
\text { PERCENT }\end{array}$ & $\begin{array}{c}\text { ASH } \\
\text { PERCENT }\end{array}$ & $\begin{array}{l}\text { SUIEUR } \\
\text { PERCENT }\end{array}$ & $\begin{array}{l}\text { MOISTURE } \\
\text { PERCENT }\end{array}$ & $\begin{array}{l}\text { HEIGHT } \\
\text { PERCENT }\end{array}$ & $\begin{array}{c}\text { ASH } \\
\text { PERCENT }\end{array}$ & $\begin{array}{l}\text { SULPUR } \\
\text { PERCENT }\end{array}$ & $\begin{array}{l}\text { MOISTURE } \\
\text { PERCENT }\end{array}$ & $\begin{array}{l}\text { VEIGHT } \\
\text { PERCENT }\end{array}$ & $\begin{array}{c}\text { ASH } \\
\text { PERCENT }\end{array}$ & $\begin{array}{l}\text { SULPOR } \\
\text { PERCENT }\end{array}$ & $\begin{array}{l}\text { MOISTURE } \\
\text { PERCENTT }\end{array}$ \\
\hline $\begin{array}{r}30 \mathrm{H} \\
60 \mathrm{M} \\
100 \mathrm{O} \\
150 \mathrm{OM} \\
20 \mathrm{OM}\end{array}$ & $\begin{array}{r}30 \mathrm{M} \\
60 \mathrm{M} \\
100 \mathrm{M} \\
150 \mathrm{M} \\
200 \mathrm{M}\end{array}$ & $\begin{array}{r}5.36 \\
55.36 \\
21.68 \\
9.18 \\
4.21 \\
4.21\end{array}$ & $\begin{array}{l}6.27 \\
4.86 \\
5.38 \\
7.50 \\
7.50 \\
7.50\end{array}$ & $\begin{array}{l}0.99 \\
1.13 \\
1.35 \\
1.93 \\
1.93 \\
1.93\end{array}$ & $\begin{array}{l}1.15 \\
1.30 \\
1.40 \\
1.35 \\
1.35 \\
1.35\end{array}$ & $\begin{array}{r}5.36 \\
60.72 \\
82.40 \\
91.58 \\
95.79 \\
100.00\end{array}$ & $\begin{array}{l}6.27 \\
4.98 \\
5.09 \\
5.33 \\
5.43 \\
5.51\end{array}$ & $\begin{array}{l}0.99 \\
1.12 \\
1.18 \\
1.25 \\
1.28 \\
1.31\end{array}$ & $\begin{array}{l}1.15 \\
1.29 \\
1.32 \\
1.32 \\
1.32 \\
1.32\end{array}$ & $\begin{array}{r}100.00 \\
94.64 \\
39.28 \\
17.60 \\
8.42 \\
4.21\end{array}$ & $\begin{array}{l}5.51 \\
5.47 \\
6.33 \\
7.50 \\
7.50 \\
7.50\end{array}$ & $\begin{array}{l}1.31 \\
1.33 \\
1.61 \\
1.93 \\
1.93 \\
1.93\end{array}$ & $\begin{array}{l}1.32 \\
1.33 \\
1.38 \\
1.35 \\
1.35 \\
1.35\end{array}$ \\
\hline
\end{tabular}

DATA POR - MIDDLING COAL.

this PRACtion Constitutes 4.9 percent of the peEd.

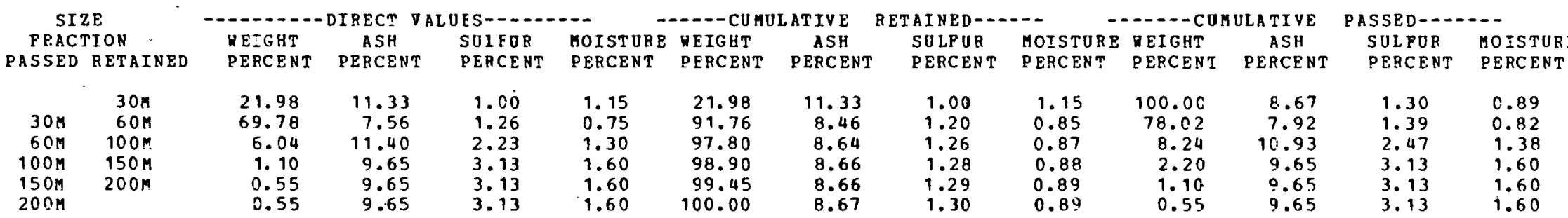

DATA POR - REPUSE COAL.

ThIS PRACTION CONStitutes 5.3 PERCENT OP THE FEed.

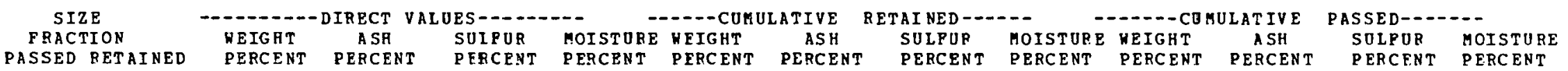

\begin{tabular}{|c|c|c|c|c|c|c|c|c|c|c|c|c|c|}
\hline $\begin{array}{r}30 \mathrm{M} \\
60 \mathrm{M} \\
100 \mathrm{M} \\
150 \mathrm{M} \\
200 \mathrm{M}\end{array}$ & $\begin{array}{r}30 \mathrm{M} \\
60 \mathrm{M} \\
100 \mathrm{M} \\
150 \mathrm{M} \\
200 \mathrm{M}\end{array}$ & $\begin{array}{r}22.34 \\
73.10 \\
3.55 \\
0.51 \\
0.00 \\
0.50\end{array}$ & $\begin{array}{l}24.77 \\
13.13 \\
24.38 \\
24.60 \\
24.60 \\
24.60\end{array}$ & $\begin{array}{l}1.24 \\
1.63 \\
3.49 \\
5.84 \\
5.84 \\
5.84\end{array}$ & $\begin{array}{l}0.70 \\
1.10 \\
1.35 \\
1.35 \\
1.35 \\
1.35\end{array}$ & $\begin{array}{r}22.34 \\
95.44 \\
98.99 \\
99.50 \\
99.50 \\
100.00\end{array}$ & $\begin{array}{l}24.77 \\
15.85 \\
16.16 \\
16.20 \\
16.20 \\
16.25\end{array}$ & $\begin{array}{l}1.24 \\
1.54 \\
1.61 \\
1.63 \\
1.63 \\
1.65\end{array}$ & $\begin{array}{l}0.70 \\
1.01 \\
1.02 \\
1.02 \\
1.02 \\
1.02\end{array}$ & $\begin{array}{c}100.00 \\
77.66 \\
4.55 \\
1.01 \\
0.50 \\
0.50\end{array}$ & $\begin{array}{l}16.25 \\
13.79 \\
24.43 \\
24.60 \\
24.60 \\
24.60\end{array}$ & $\begin{array}{l}1.65 \\
1.77 \\
4.01 \\
5.84 \\
5.84 \\
5.84\end{array}$ & $\begin{array}{l}1.02 \\
1.11 \\
1.35 \\
1.35 \\
1.35 \\
1.35\end{array}$ \\
\hline
\end{tabular}

DATA POR DRYFLO SEPARATION TEST 16.

PIGURES PROM PSOC 102 PEEd SAMPLE.

DATA FOR -

* composite**

THIS PRACTION CONSTITUTES 100.0 PERCENT OP THE PEED.

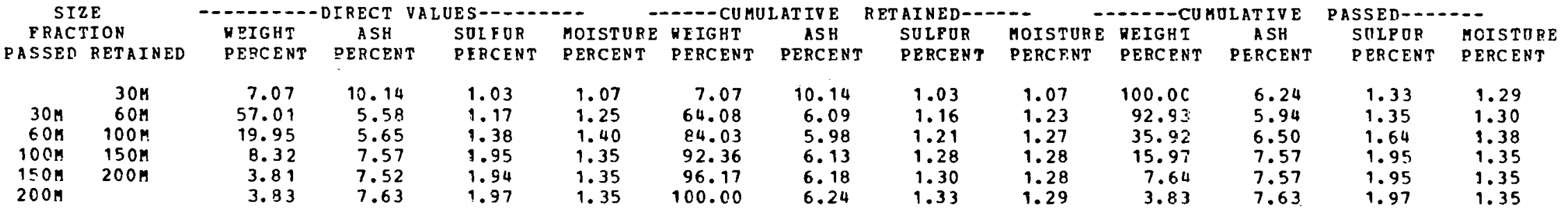


ANALYTICAL DATA

DATA POR DRYPLO SEPARATION TEST 17

DATA FOR - PRODUCT COAL.

THIS PRACTION CONSTITUTES 69.1 PERCENT OP THE PEED. ARET TALOES
ASH SUIPUR - ----COHOLATIVE SI NED - - - -

PRACTION QREIGHT ASH

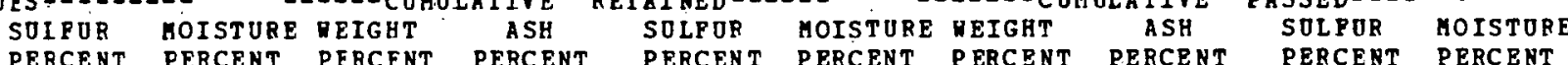
ATIVE PASSED----- -

$\begin{array}{rrrrr} & 30 \mathrm{M} & 10.30 & 6.84 & 1.21 \\ 30 \mathrm{M} & 60 \mathrm{M} & 57.40 & 5.02 & 1.06 \\ 60 \mathrm{M} & 100 \mathrm{M} & 19.40 & 6.58 & 1.25 \\ 100 \mathrm{M} & & 12.90 & 7.59 & 1.80\end{array}$

$\begin{array}{rr}1.16 & 10.30 \\ 1.20 & 67.70 \\ 1.30 & 87.10\end{array}$

$\begin{array}{ll}6.84 & 1.21 \\ 5.30 & 1.08 \\ 5.58 & 1.12\end{array}$

1.16

100.00
89.70
32.30

$5: 84$
5.73

PERCENT PERCENT

$100 \mathrm{M}$

12.90

1.30

87.10
100.00

5.58
5.84

1.21

1.22

12.90

6.98

1.22

1.2 .101 .24

TRIS PRACTION CONSTITUTES 22.4 PERCENT OP THE PEED.

DATA POB - MIDDLING COAL.

. THIS PRACTION CONSTITUTES 22.4 PERCENT OP THE PEED.

SIZE
FRACTION MEIGHT DIRECT VALOES OES - - - - PASSED RETAINED PERCENT PERCENT
PERT

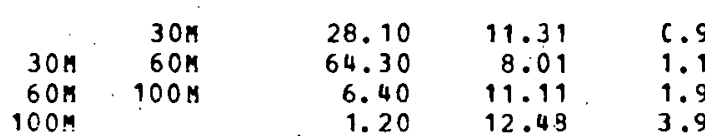

DATA FOR - REPUSE COAL.

TOUR MOISTORE REIGRT

LAT IVE

AINED--
SULFUR

SULFUR
PERCEN

MOIST URE NEIGHT

OLAT IVE
ASH ASH
PERCENT

PASSED----SULFOR MOISTORE PERCENT PERCENT

\section{10 \\ 1.10
1.16
1.24}

28.10

28.10
92.40

$0.96 \quad 1.10$

100.00

71.90

9.19

8.36
11.33

11.33
12.48

1.19
1.28

1.28

1.14

$100.00 \quad 9.15$

$\begin{array}{ll}1.16 & 1.15 \\ 1.19 & 1.14\end{array}$

1.20

HIS PRACTION CONSTITUTES 8.5 PERCENT OP THE PEED.

0.67
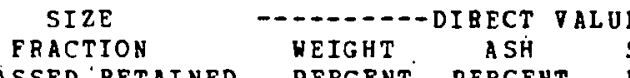

\section{$8.5 \mathrm{PE}$}

- - - - CUMULAT IVE

PASSED RETAINED

$\begin{array}{rrrrr} & 30 \mathrm{M} & 28.50 & 24.15 & 1.08 \\ 30 \mathrm{M} & 60 \mathrm{M} & 66.50 & 14.95 & 1.43 \\ 60 \mathrm{M} & 100 \mathrm{M} & 4.20 & 16.56 & 3.67 \\ 100 \mathrm{M} & & 0.80 & -0.00 & 0.00\end{array}$

DATA FOR DRYPLO SEPARATION TEST 17 DATA FOR -

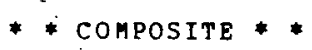

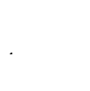

SIZE

PRACTION

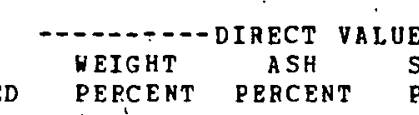

$\begin{array}{rr}30 M \\ 30 M & 60 M \\ 60 M & 100 M\end{array}$

$\begin{array}{rr}15.83 & 11.27 \\ 59.72 & 6.68 \\ 15.20 & 7.24 \\ 9.25 & 7.68\end{array}$

$\begin{array}{rrrr}1.08 & 1.04 & 100.00 & 17.53 \\ 1.32 & 1.12 & 71.50 & 14.89 \\ 1.42 & 1.13 & 5.00 & 13.91 \\ 1.41 & 1.13 & 0.80 & 0.00\end{array}$
PERCE

MOISTOR

-PIGURES FROM PSOC 102 HAMGER MIIL PEED

THIS PRACTION CONSTITOTES 100.0 PERCENT OP THP PEED.

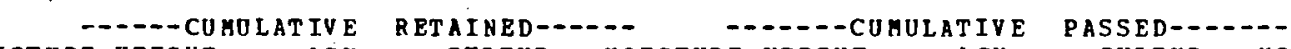

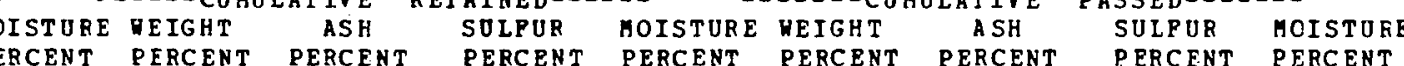
ERCENT PERCENT PERCENT

$$
\begin{aligned}
& 1.09 \\
& 1.12 \\
& 1.37 \\
& 1.85
\end{aligned}
$$

1.12

1.12
1.19
1.30

15.83
75.55

75.55
90.75

11.27
7.64
7.58

1.09
1.12
1.16

1.12
1.17
1.19

100.00
84.17
24.45
9.25

7.58

6.89

7.41
7.68

$\begin{array}{ll}1.22 & 1.21 \\ 1.25 & 1.22 \\ 1.55 & 1.31 \\ 1.85 & 1.33\end{array}$


QHALTICAL DATA.

DATA FOR DRYFLO SEPARATION TEST 18 DATA FOR - PRODUCT COAL.
FIGURES PROA PSOC 102 ROLL AILL PEED.

THIS FRACTION CONSTITOTES 76.1 PERCEHT OP THE PEED.

SIZE

FRACTION REIGHT DIRECT VALUES ASH

PEIGHT TENT PER

ASH

SUIPOR

OISTORE IEIGH

TIVE RETAINED-2.--

OISTURE VEIGHT COHOLATIVE PAS

SSED-- - - -

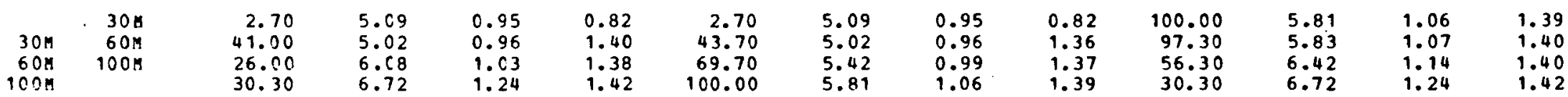

DATA FOR - MIDDLING COAL.

THIS PRACTION CONSTITUTES 14.9 PERCERT OP TRE PEED.

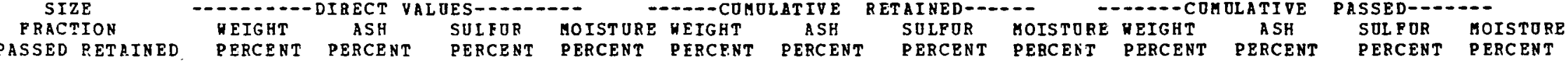

\begin{tabular}{|c|c|c|c|c|}
\hline $\begin{array}{l}30 \mathrm{~N} \\
60 \mathrm{~N}\end{array}$ & $\begin{array}{r}30 \mathrm{O} \\
6 \mathrm{CM} \\
10 \mathrm{CM}\end{array}$ & $\begin{array}{r}13.70 \\
73.90 \\
10.50\end{array}$ & $\begin{array}{r}7.42 \\
8.05 \\
11.01 \\
10.5 ?\end{array}$ & $\begin{array}{l}0.98 \\
1.03 \\
1.29\end{array}$ \\
\hline
\end{tabular}

$\begin{array}{rrr}1.30 & 13.70 & 7.42 \\ 1.38 & 87.60 & 7.95 \\ 1.40 & 98.10 & 8.28 \\ 0.85 & 100.00 & 8.32\end{array}$

$\begin{array}{lrr}0.98 & 1.30 & 100.00 \\ 1.02 & 1.37 & 86.30 \\ 1.05 & 1.37 & 12.40 \\ 1.08 & 1.36 & 1.90\end{array}$

8.32
8.46
10.93

1.08

1.37

THIS FRACTION CONSTITUTES 9.0 PERCEH OP THE PEED.

DATA FOR - REFOSE COAL.

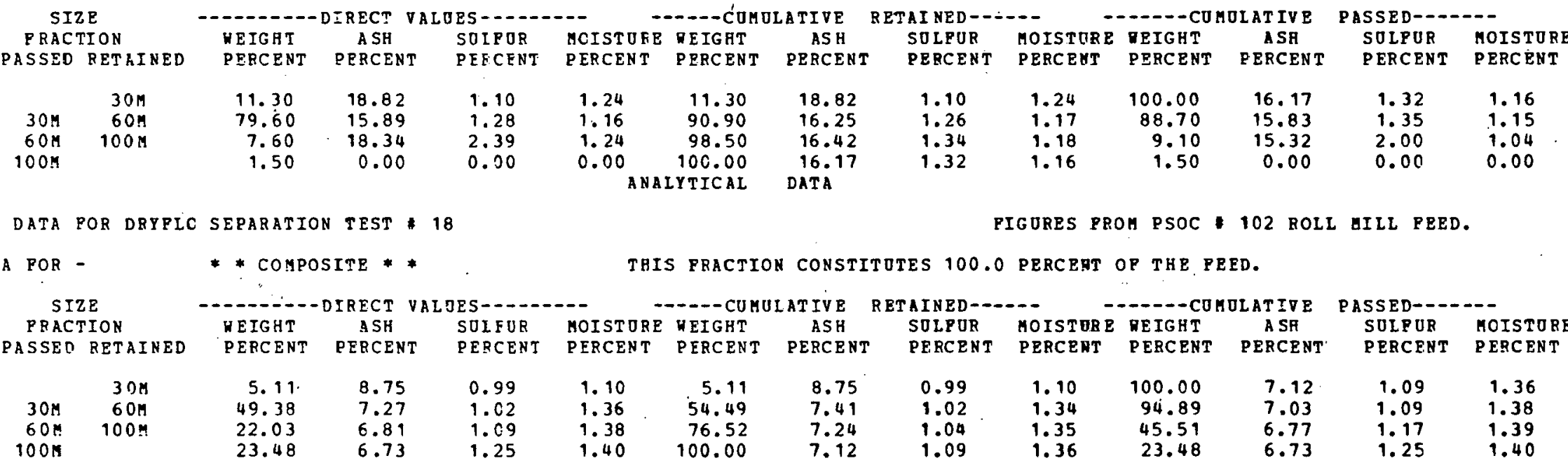


ANALTTCAL DATA

PIGURES FROA PSOC 102 ROLL MILL PEED.

DATA FOR DRYPLO SEPARATION TEST $19^{\circ}$

THIS PRACTION CONSTITOTES 89.2 PERCENT OF THE PEED.

DATA FOR - PRODUCT CONL.

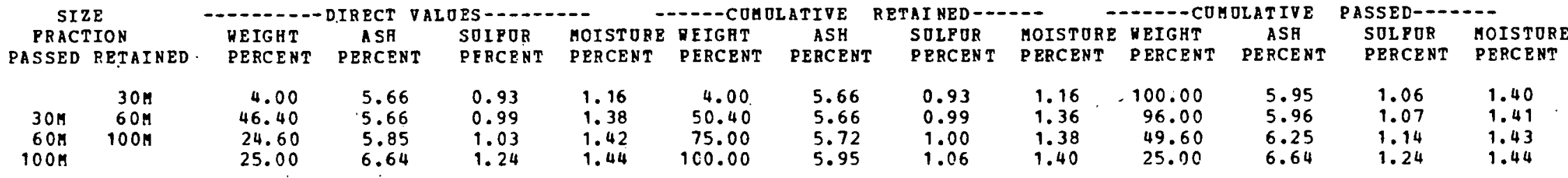

DATA FOR - VIDDLING COAL.

TEIS PRACTION CONSTITOTES 5.2 PERCENT OP THE PEED.

\begin{tabular}{|c|c|c|c|c|c|c|c|c|c|c|c|c|c|}
\hline & & $-\ldots$ & DIRECT $\nabla$ & ES-- & $\cdots$ & $-\cdots$ & ATIVE & INE & - & $\cdots-c$ & OLAT: & PASSED - & - \\
\hline FRAC & ION & WEIGHT & $\begin{array}{c}\text { ASH } \\
\text { PERCENT }\end{array}$ & $\begin{array}{l}\text { SOIFOR } \\
\text { PPRCENT }\end{array}$ & MOISTURE & DPIGHT & ASH & SOIFOR & MOISTURE & WEIGHT & A SH & SUL POR & MOIST \\
\hline $\begin{array}{r}30 \mathrm{M} \\
60 \mathrm{M} \\
100 \mathrm{M}\end{array}$ & $\begin{array}{r}30 \mathrm{H} \\
60 \mathrm{H} \\
100 \mathrm{H}\end{array}$ & $\begin{array}{r}15.90 \\
72.30 \\
9.20 \\
2.60\end{array}$ & $\begin{array}{r}9.93 \\
9.97 \\
10.58 \\
7.91\end{array}$ & $\begin{array}{l}1.00 \\
1.67 \\
1.47 \\
1.83\end{array}$ & $\begin{array}{l}1.26 \\
1.34 \\
1.26 \\
0.59\end{array}$ & $\begin{array}{r}15.90 \\
88.20 \\
97.40 \\
100.00\end{array}$ & $\begin{array}{r}9.93 \\
9.96 \\
10.02 \\
9.97\end{array}$ & $\begin{array}{l}1.00 \\
1.06 \\
1.10 \\
1.12\end{array}$ & $\begin{array}{l}1.26 \\
1.33 \\
1.32 \\
1.30\end{array}$ & $\begin{array}{r}100.00 \\
84.10 \\
11.80 \\
2.60\end{array}$ & $\begin{array}{l}9.97 \\
9.97 \\
9.99 \\
7.91\end{array}$ & $\begin{array}{l}1.12 \\
1.14 \\
1.55 \\
1.83\end{array}$ & $\begin{array}{l}1.30 \\
1.31 \\
1.91 \\
0.59\end{array}$ \\
\hline
\end{tabular}

DATA FOR - REFUSE COAL.

THIS PRACTION CONSTITUTES 5.6 PERCENT OF THE PEED.

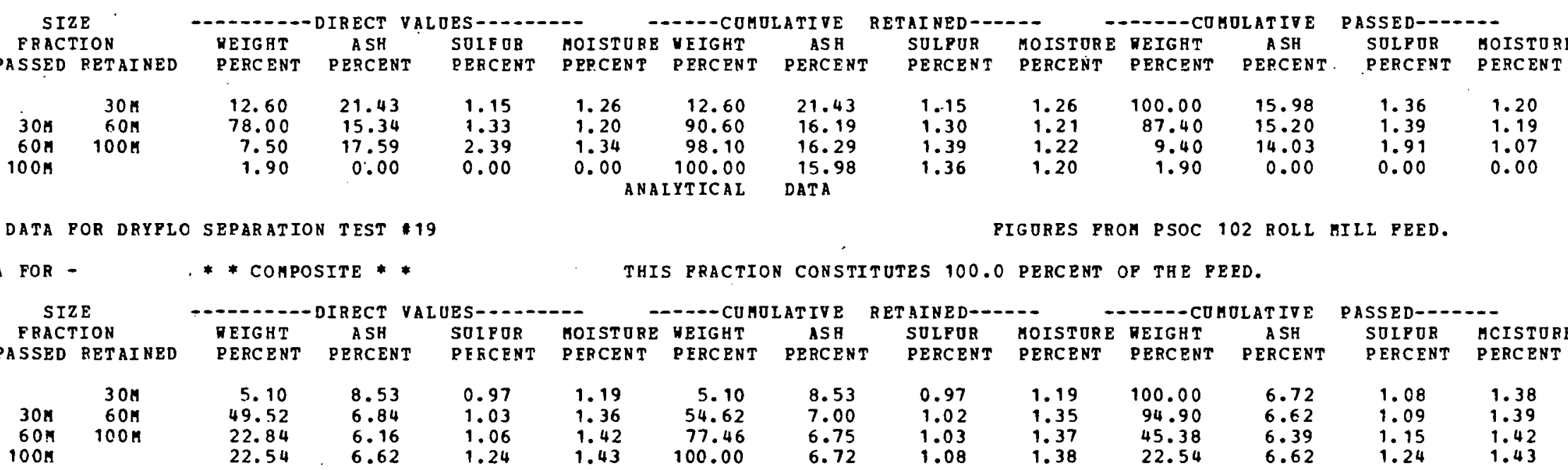




\section{ANALYTICAL DATA}

PIGURES PROM PSOC 102 ROLL MILL PEED.

DATA FOR DRYPLO SEPARATION TEST * 20

THIS PRACTION CONSTITOTES 91.0 PERCENT OP THE PEED.

DATA FOR - PRODUCT COAL

\begin{tabular}{|c|c|c|c|c|c|c|c|c|c|c|c|c|c|}
\hline \multirow{2}{*}{\multicolumn{2}{|c|}{$\begin{array}{c}\text { SIZE } \\
\text { FRACTION }\end{array}$}} & \multicolumn{2}{|c|}{$--1-1-$ DIRECT } & \multicolumn{2}{|c|}{ VALUES $-\cdots$} & \multicolumn{2}{|c|}{----CUhULATIVE } & \multicolumn{2}{|c|}{ RETAINED - - - } & \multicolumn{2}{|c|}{$\cdots-$ CUMDLATIVE } & \multicolumn{2}{|c|}{ PASSED $\cdots$} \\
\hline & & HEIGYT & ASH & SUIFUR & MOISTURE & HEIGHT & ASH & SOLPOR & MOISTORE & NEIGHT & ASH & SULPUR & MOISTO \\
\hline PASSED & RET AINED & PERCENT & PERCENT & PERCENT & PERCENT & PERCENT & PERCENT & PERCENT T & PERCENT & PERCENT & PERCENT & PERCENT & PERCENT \\
\hline $\begin{array}{r}30 M \\
60 M \\
100 M\end{array}$ & $\begin{array}{r}30 M \\
60 M \\
100 M\end{array}$ & $\begin{array}{r}4.30 \\
49.40 \\
22.70 \\
23.60\end{array}$ & $\begin{array}{l}5.48 \\
5.65 \\
5.92 \\
6.29\end{array}$ & $\begin{array}{l}0.98 \\
1.02 \\
1.06 \\
1.31\end{array}$ & $\begin{array}{l}1.30 \\
1.32 \\
1.44 \\
1.28\end{array}$ & $\begin{array}{r}4.30 \\
53.70 \\
76.40 \\
100.00\end{array}$ & $\begin{array}{l}5.48 \\
5.64 \\
5.72 \\
5.86\end{array}$ & $\begin{array}{l}0.98 \\
1.02 \\
1.03 \\
1.10\end{array}$ & $\begin{array}{l}1.30 \\
1.32 \\
1.35 \\
1.34\end{array}$ & $\begin{array}{r}100.00 \\
95.70 \\
46.30 \\
23.60\end{array}$ & $\begin{array}{l}5.86 \\
5.87 \\
6.11 \\
6.29\end{array}$ & $\begin{array}{l}1.10 \\
1.10 \\
1.19 \\
1.31\end{array}$ & $\begin{array}{l}1.34 \\
1.34 \\
1.36 \\
1.28\end{array}$ \\
\hline
\end{tabular}

DATA FOR - YIDDLING COAL.

THIS PRACTION CONSTITUTES 3.8 PERCENT OF THE PEED.

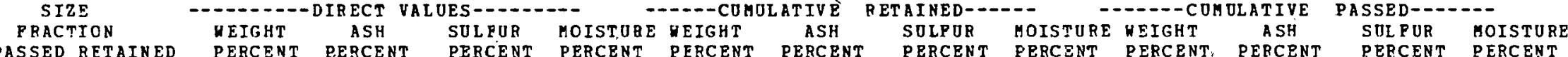

PASSED RETAINED PERCENT PERCENT PERCENT PERCENT PERCENT PERCENT PERCENT PERCENT PERCENT, PERCENT PERCENT PERCENT

$\begin{array}{rrrrrrrrrrrrrrr} & 30 \mathrm{M} & 16.80 & 9.96 & 1.03 & 1.34 & 16.80 & 9.96 & 1.03 & 1.34 & 100.00 & 9.08 & 1.18 & 1.34 \\ 30 \mathrm{M} & 60 \mathrm{OM} & 72.10 & 8.72 & 1.14 & 1.36 & 88.90 & 8.95 & 1.12 & 1.36 & 83.20 & 8.90 & 1.21 & 1.34 \\ 604 & 100 \mathrm{M} & 8.10 & 11.19 & 1.70 & 1.36 & 97.00 & 9.14 & 1.17 & 1.36 & 11.10 & 10.08 & 1.70 & 1.22\end{array}$

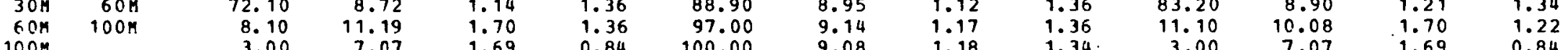

DATA POR - FEPUSE COAL.

THIS PRACTION CONSTITUTES 5.2 PERCENT OP THE PEED.

\begin{tabular}{|c|c|c|c|c|c|c|c|c|c|c|c|c|c|}
\hline \multicolumn{2}{|c|}{ SIZE } & \multicolumn{2}{|c|}{$-1-1-1$ DIRECT } & \multicolumn{2}{|c|}{ FALDES - - - - } & \multicolumn{2}{|c|}{ - - - CUMOLATIVE } & \multicolumn{2}{|c|}{ RETAI NED - - - - } & \multicolumn{2}{|c|}{----- CO RULAT IVE } & \multicolumn{2}{|c|}{ PASSED- - - - } \\
\hline PRAC & IION & WEIGHT & A SH & SUIFOR & MOISTURE & WEIGHT & AS H & SOLPOR & MOISTURE & WEIGHT & ASA & SULPUR & MOIS \\
\hline SSE & RETAINED & PERCENT & PERCENT & PERCENT & PERCENT & PERCENT & PERCENT & PERCENT & PERCENT & PEF & PERCENT & PERCENT & $2 \pi$ \\
\hline $\begin{array}{r}30 M \\
60 M \\
100 M\end{array}$ & $\begin{array}{r}30 M \\
60 M \\
100 M\end{array}$ & $\begin{array}{r}15.80 \\
77.20 \\
5.50 \\
1.50\end{array}$ & $\begin{array}{r}18.21 \\
16.48 \\
15.59 \\
0.00\end{array}$ & $\begin{array}{l}1.13 \\
1.46 \\
2.75 \\
0.00\end{array}$ & $\begin{array}{l}1.36 \\
1.40 \\
1.40 \\
0.00\end{array}$ & $\begin{array}{r}15.80 \\
93.00 \\
98.50 \\
100.00\end{array}$ & $\begin{array}{l}18.21 \\
16.77 \\
16.71 \\
16.46\end{array}$ & $\begin{array}{l}1.13 \\
1.40 \\
1.48 \\
1.46\end{array}$ & $\begin{array}{l}1.36 \\
1.39 \\
1.39 \\
1.37\end{array}$ & $\begin{array}{r}100.00 \\
84.20 \\
7.00 \\
1.50\end{array}$ & $\begin{array}{r}16.46 \\
16.13 \\
12.25 \\
0.00\end{array}$ & $\begin{array}{l}1.46 \\
1.52 \\
2.16 \\
0.00\end{array}$ & $\begin{array}{l}1.37 \\
1.38 \\
1.10 \\
0.00\end{array}$ \\
\hline
\end{tabular}

DATA FOR DRYFLC SEPAFATION TEST 20

FIGURES PROH PSOC 102 BOLL MILL PEED.

DATA POR -

* conposite *

THIS FRACTION CONSTITUTES 100.0 PERCENT OP THE PEED.

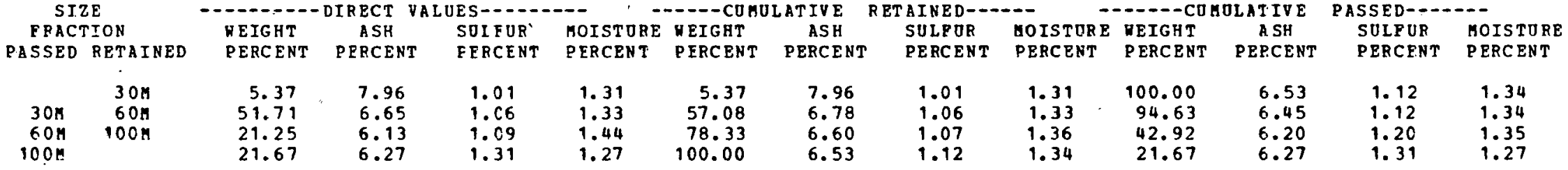


ANALTICAL DATA

DATA POR DRTELO SEPARATION TEST 21 DATA FOR - PRODUCT COAL.
PIGURES PROA ELLIOT PEED - 100 MESH.

THIS PRACTION CONSTITUTES 61.7 PERCENT OP THE PEED.

\begin{tabular}{|c|c|c|c|c|c|c|c|c|c|c|c|c|c|}
\hline \multirow{2}{*}{\multicolumn{2}{|c|}{$\begin{array}{c}\text { SIZE } \\
\text { PRACTION }\end{array}$}} & \multicolumn{2}{|c|}{------ DIBECT $\nabla$} & DES $\cdots \cdots$ & -- & \multicolumn{2}{|c|}{ - ---CUMOLATIVE } & \multicolumn{2}{|c|}{ RETAINED-D. } & \multicolumn{2}{|c|}{---- CU BULAT IVE } & \multicolumn{2}{|c|}{ PASSED- - } \\
\hline & & WEIGHT & A SH & SULFOR & HOISTURE & VEIGHT & ASH & SULFOR & MOISTUPE & WEIGRT & A SH & SOLPUR & MOIST \\
\hline PASSED & RETAINED & PERCENT & PERCENT & PERCENT & PERCENT & PERCENT & PERCENT & PERCENT & PERCENT & PERCENT & PERCENT & PERCENT & PERCENT \\
\hline $\begin{array}{r}30 \mathrm{H} \\
60 \mathrm{M} \\
100 \mathrm{~N} \\
150 \mathrm{M}\end{array}$ & $\begin{array}{r}30 \mathrm{H} \\
60 \mathrm{H} \\
100 \mathrm{~K} \\
150 \mathrm{H}\end{array}$ & $\begin{array}{r}0.30 \\
1.20 \\
38.70 \\
17.90 \\
41.90\end{array}$ & $\begin{array}{r}0.00 \\
6.88 \\
10.39 \\
11.03 \\
13.42\end{array}$ & $\begin{array}{l}0.00 \\
1.65 \\
3.8 .2 \\
4.59 \\
5.92\end{array}$ & $\begin{array}{l}0.00 \\
0.33 \\
0.94 \\
0.80 \\
0.98\end{array}$ & $\begin{array}{r}0.30 \\
1.50 \\
40.20 \\
58.10 \\
100.00\end{array}$ & $\begin{array}{r}0.00 \\
5.50 \\
10.21 \\
10.46 \\
11.70\end{array}$ & $\begin{array}{l}0.00 \\
1.32 \\
3.73 \\
3.99 \\
4.80\end{array}$ & $\begin{array}{l}0.00 \\
0.26 \\
0.91 \\
0.88 \\
0.92\end{array}$ & $\begin{array}{r}100.00 \\
99.70 \\
98.50 \\
59.80 \\
49.90\end{array}$ & $\begin{array}{l}11.70 \\
11.74 \\
11.80 \\
12.70 \\
13.42\end{array}$ & $\begin{array}{l}4.80 \\
4.81 \\
4.85 \\
5.52 \\
5.92\end{array}$ & $\begin{array}{l}0.92 \\
0.92 \\
0.93 \\
0.93 \\
0.98\end{array}$ \\
\hline
\end{tabular}

DATA POR - REPUSE COAL.

THIS FRACTION CONSTITOTES 38.3 PERCENT OF THE PEED. 
DATA POR DBYPLO SEPARATION TEST 22 DATA FOR - PRODUCT COAL.

AHALTICAL DATA

PIGURES FROA ELLIOT FEED - 100 MESH.

THIS PRACTION CONSTITUTES 30.6 PERCENT OP THE PEED.

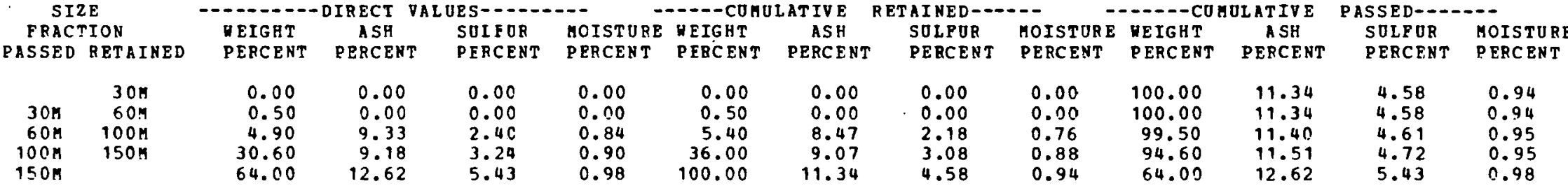

DATA POR - REPUSE COAL.

IHIS PRACTION CONSTITDTES 69.4 PERCENT OP THE PEED.

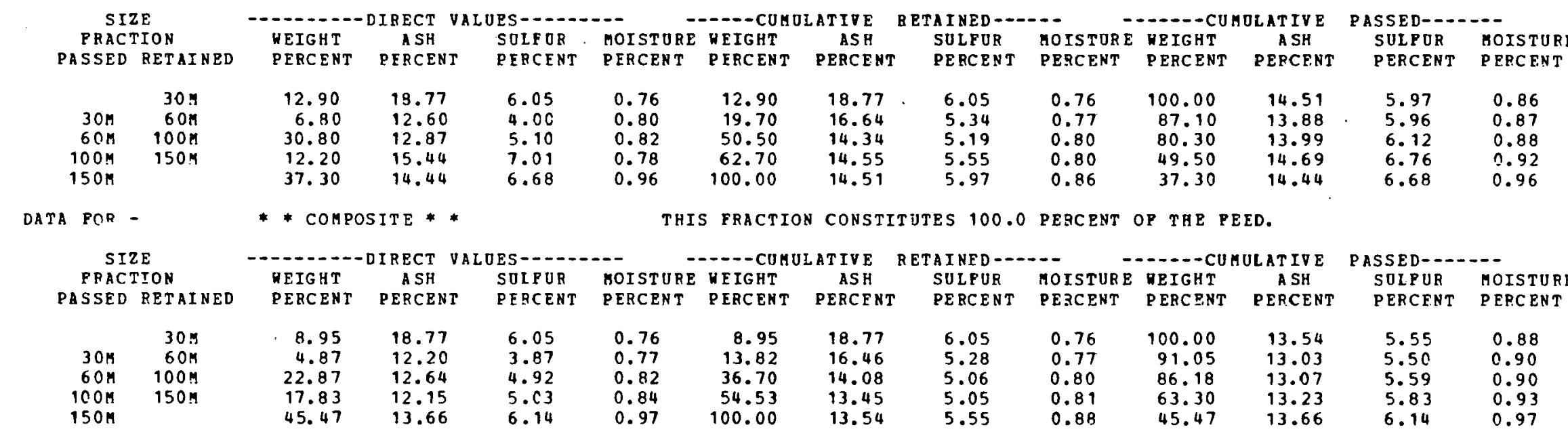

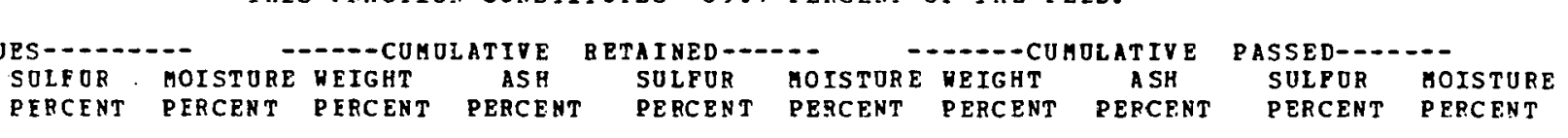


ANALYTICAL DATA

DATA POR DRYFLC SEPARATION TEST 23 DATA POR - PEOPOCT COAL.
PIGURES PROA PSOC 5 ROLL MILL PEED.

THIS PRACTION CONSTITUTES 48.5 PERCENT OP TRE PEED.

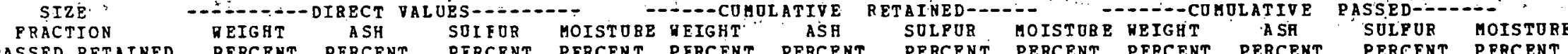

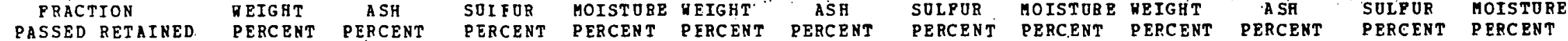

$\begin{array}{rrrrrr} & 30 \mathrm{M} & 3.20 & 3.14 & 1.06 & 1.08 \\ 30 \mathrm{M} & 60 \mathrm{M} & 38.30 & 2.54 & 1.08 & 1.16 \\ 60 \mathrm{OM} & 100 \mathrm{M} & 26.30 & 2.98 & 1.17 & 1.20 \\ 100 \mathrm{OM} & 150 \mathrm{M} & 1.3 .50 & 3.25 & 1.37 & 1.40 \\ 150 \mathrm{OM} & . & 18.70 & 4.80 & 1.88 & 1.40\end{array}$

DATA FOR - MIDDLING COAL.

$\begin{array}{rr}3.20 & 3.14 \\ 41.50 & 2.96 \\ 67.80 & 2.96 \\ 81.30 & 3.01 \\ 100.00 & 3.35\end{array}$
1.06
1.08

1.16

1.08
1.15
1.17
1.21
100.00
96.80
96.80

58.50
32.20

3.35
3.35
3.62
4.15
4.80

1.29

1.30

1.44

1.25

1.25

HIS PRACTION CONSTITUTES 26.5 PERCENT OP THE PEED.

1.40
1.40

$$
S I Z E
$$

FRACTION

$\begin{array}{cc} & \\ \text { HEIGHT } & \text { ASH } \\ \text { PERCENT } & \text { PERCENT } \\ & \\ 20.40 & 3.32 \\ 64.30 & 3.51 \\ 12.50 & 4.30 \\ 1.60 & 0.00 \\ 1.20 & 0.00\end{array}$

------COLOLATIVE RETAINBD--.-STIFUR MOIST MOTSTORE REIGRT

ATIVE RETA
ASH
PERCENT

SOLPUR
SOLPUR MOISTURE - DE---CUMULATIVE

$1.13 \quad 1.18$ $\begin{array}{ll}20.40 & 3.32\end{array}$

1.13

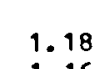

1.18
1.16

3.46
3.57

1.27

1.88

1.16
1.44
0.00

84.70
97.20

97.20
98.80

98.80
100.00

$3.51 \quad 1.32$

1.16
.79 .60

1.20
1.18

1.18 .
$1.17-80$

1. 20

THIS PRACTION CONSTITOTES 25.0 PERCENT OP THE PEED.

DATA POB - REFUSE COAL.

\section{- - COMOLATIVE RETAINED-- -} $\begin{array}{cl}\text { FRACTION } & \text { REIGHT } \\ \text { PASSED RETAINED PERCENT PERCENT }\end{array}$

$\begin{array}{rrrrrr} & 30 \mathrm{M} & 21.30 & 5.12 & 1.85 & 1.04 \\ 30 \mathrm{M} & 60 \mathrm{M} & 68.80 & 5.82 & 2.49 & 1.04 \\ 60 \mathrm{M} & 10 \mathrm{M} & 8.70 & 6.51 & 4.29 & 1.40 \\ 100 \mathrm{M} & 150 \mathrm{M} & .0 .40 & 0.00 & 0.00 & 0.00 \\ 150 \mathrm{M} & & 0.80 & 0.00 & 0.00 & 0.00\end{array}$

DATA POR DRYFLO SEPARATION TEST 23 DATA FOR -

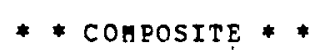


ANALYTICAL DATA

PIGERES PROH PSOC 5 P.OLL HILI PEED.

DATA POB DRTPLO SEPABATION TEST 24 DATA FOP - PRODUCT COAL.

TRIS PRACTION CONSTITUTES 32.0 PERCENT OP THE PEED.

\begin{tabular}{|c|c|c|c|c|c|c|c|c|c|c|c|c|c|}
\hline \multirow{2}{*}{\multicolumn{2}{|c|}{$\begin{array}{c}\text { SIZE } \\
\text { PRACTION }\end{array}$}} & \multicolumn{2}{|c|}{$\cdots-\cdots$ DIBECT } & \multicolumn{2}{|c|}{ IOES---- } & \multicolumn{2}{|c|}{-- COGOLATIVE } & \multicolumn{2}{|c|}{ RETAI NED - } & \multicolumn{2}{|c|}{$-\infty--$ CUAULATIVE } & \multicolumn{2}{|c|}{ PASSED- } \\
\hline & & $\begin{array}{l}\text { DEIGHT } \\
\text { PERCENT }\end{array}$ & $\begin{array}{c}\text { ASH } \\
\text { PERCENT }\end{array}$ & $\begin{array}{l}\text { SOLPOR } \\
\text { PERCENT }\end{array}$ & $\begin{array}{l}\text { MOISTURE } \\
\text { PERCENT }\end{array}$ & $\begin{array}{l}\text { REIGHT } \\
\text { PERCENT }\end{array}$ & $\begin{array}{c}\text { ASH } \\
\text { PERCENT }\end{array}$ & $\begin{array}{l}\text { SOLPUR } \\
\text { PERCENT }\end{array}$ & $\begin{array}{l}\text { MOISTORE } \\
\text { PERCENT }\end{array}$ & $\begin{array}{l}\text { DEIGHT } \\
\text { PERCENT }\end{array}$ & $\begin{array}{c}\text { ASH } \\
\text { PERCE NT }\end{array}$ & $\begin{array}{l}\text { SOLPOR } \\
\text { PERCENT }\end{array}$ & $\begin{array}{l}\text { MOISTORE } \\
\text { PERCENT }\end{array}$ \\
\hline $\begin{array}{r}30 \mathrm{M} \\
60 \mathrm{M} \\
100 \mathrm{M} \\
150 \mathrm{M}\end{array}$ & $\begin{array}{l}30 \% \\
60 M \\
100 M \\
150 \%\end{array}$ & $\begin{array}{r}0.80 \\
31.50 \\
30.40 \\
15.30 \\
22.00\end{array}$ & $\begin{array}{l}2.81 \\
2.86 \\
3.30 \\
4.62\end{array}$ & $\begin{array}{l}1.03 \\
1.15 \\
1.29 \\
1.73\end{array}$ & $\begin{array}{l}1.00 \\
1.24 \\
1.22 \\
1.26\end{array}$ & $\begin{array}{r}0.80 \\
32.30 \\
62.70 \\
78.00 \\
100.00\end{array}$ & $\begin{array}{l}2.81 \\
2.83 \\
2.93 \\
3.30\end{array}$ & $\begin{array}{l}1.03 \\
1.09 \\
1.13 \\
1.26\end{array}$ & $\begin{array}{l}1.00 \\
1.12 \\
1.14 \\
1.16\end{array}$ & $\begin{array}{r}100.00 \\
99.20 \\
67.70 \\
37.30 \\
22.00\end{array}$ & $\begin{array}{l}3.30 \\
3.30 \\
3.53 \\
4.08 \\
4.62\end{array}$ & $\begin{array}{l}1.26 \\
1.37 \\
1.55 \\
1.73\end{array}$ & $\begin{array}{l}1.16 \\
1.17 \\
1.24 \\
1.24 \\
1.26\end{array}$ \\
\hline
\end{tabular}

DATA POR - MIDDLING COAL.

THIS PRACTION CONSTITUTES 45.8 PERCENT OP THE PEED.

\begin{tabular}{|c|c|c|c|c|c|c|c|c|c|c|c|c|c|}
\hline \multicolumn{2}{|c|}{ SIZE } & \multicolumn{2}{|c|}{$------D$ DIRECT } & OES $-\cdots$ & -- & \multicolumn{2}{|c|}{----- COROLATIVE } & \multicolumn{2}{|c|}{ RETAINED- - - } & \multicolumn{2}{|c|}{----- CUR OLA TIVE } & \multicolumn{2}{|c|}{ PASSED- } \\
\hline $\begin{array}{r}\text { PRAC } \\
\text { PASSED }\end{array}$ & $\begin{array}{l}\text { ION } \\
\text { RETAINED }\end{array}$ & $\begin{array}{l}\text { WEIGHT } \\
\text { PERCENT }\end{array}$ & $\begin{array}{c}\text { A SH } \\
\text { PERCENT }\end{array}$ & $\begin{array}{l}\text { SOIPOR } \\
\text { PERCENT }\end{array}$ & $\begin{array}{l}\text { MOISTURE } \\
\text { PERCENT }\end{array}$ & $\begin{array}{l}\text { WEIGHT } \\
\text { PERCENT }\end{array}$ & $\begin{array}{c}\text { ASH } \\
\text { PERCENT }\end{array}$ & $\begin{array}{l}\text { SULPUR } \\
\text { PERCEN T }\end{array}$ & $\begin{array}{l}\text { MOISTORE } \\
\text { P RRCENT }\end{array}$ & $\begin{array}{l}\text { DEIGHT } \\
\text { PERCENT }\end{array}$ & $\begin{array}{c}\text { ASH } \\
\text { PERCEAT }\end{array}$ & $\begin{array}{l}\text { SOLPOR } \\
\text { PERCENT }\end{array}$ & $\begin{array}{l}\text { MOISTJRE } \\
\text { PERCENT }\end{array}$ \\
\hline $\begin{array}{r}30 \mathrm{M} \\
60 \mathrm{M} \\
100 \mathrm{M} \\
150 \mathrm{M}\end{array}$ & $\begin{array}{l}30 \mathrm{H} \\
60 \mathrm{H} \\
100 \mathrm{H} \\
150 \mathrm{H}\end{array}$ & $\begin{array}{r}11.90 \\
70.60 \\
14.50 \\
1.90 \\
1.10\end{array}$ & $\begin{array}{l}3.09 \\
3.37 \\
3.85 \\
6.68 \\
7.84\end{array}$ & $\begin{array}{l}1.03 \\
1.09 \\
1.69 \\
3.01 \\
3.23\end{array}$ & $\begin{array}{l}0.98 \\
0.96 \\
1.32 \\
1.50 \\
0.95\end{array}$ & $\begin{array}{r}11.90 \\
82.50 \\
97.00 \\
98.90 \\
100.00\end{array}$ & $\begin{array}{l}3.09 \\
3.33 \\
3.41 \\
3.47 \\
3.52\end{array}$ & $\begin{array}{l}7.03 \\
1.08 \\
1.17 \\
1.21 \\
1.23\end{array}$ & $\begin{array}{l}0.98 \\
0.96 \\
1.02 \\
1.03 \\
1.02\end{array}$ & $\begin{array}{r}100.00 \\
88.10 \\
17.50 \\
3.00 \\
1.10\end{array}$ & $\begin{array}{l}3.52 \\
3.58 \\
4.41 \\
7.11 \\
7.84\end{array}$ & $\begin{array}{l}1.23 \\
1.26 \\
1.93 \\
3.09 \\
3.23\end{array}$ & $\begin{array}{l}1.02 \\
1.03 \\
1.32 \\
1.30 \\
0.95\end{array}$ \\
\hline
\end{tabular}

-----CONOLATIVE RETAINED--.---

DATA FOR - REPUSE COAL.

THIS FRACTION CONSTITUTES 22.2 PERCENT OP THE PEED.

\begin{tabular}{|c|c|c|c|}
\hline \multirow{2}{*}{\multicolumn{2}{|c|}{$\begin{array}{c}\text { SIZE } \\
\text { FRACTION }\end{array}$}} & \multicolumn{2}{|c|}{ - DIRECT } \\
\hline & & HEIGHT & A SH \\
\hline PASSED & RETAINED & PERCENT & PERCENT \\
\hline & $30 \mathrm{H}$ & 20.60 & 4.76 \\
\hline $30 \mathrm{M}$ & 608 & 71.00 & 5.64 \\
\hline $\begin{array}{r}60 \% \\
1004\end{array}$ & $100 \mathrm{n}$ & $\begin{array}{l}7.50 \\
0.30\end{array}$ & 9.35 \\
\hline $150 \mathrm{M}$ & & 0.60 & 0.00 \\
\hline
\end{tabular}

DATA POR DRYPIO SEPARATION TEST 24

$$
\text { UES - }
$$

SES
PERCENT P

----COROLATIVE RETAINED--..

$\begin{array}{lccc} & & \\ 1.54 & 1.24 & 20.60 & 4.76\end{array}$

$\begin{array}{rrrr}1.54 & 1.24 & 20.60 & 4.76 \\ 2.17 & 1.36 & 99.60 & 5.44 \\ 5.99 & 1.64 & 99.10 & 5.74 \\ 0.00 & 0.00 & 99.40 & 5.72 \\ 0.00 & 0.00 \quad 100.00 & 5.69 \\ & & \\ & & \end{array}$

SOLFUR PERCENT

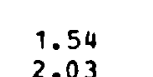

1.54
2.03
2.33

2.32

2.31 DTSTORE NEIGHT

$\begin{array}{rr}1.24 & 100.00 \\ 1.33 & 79.40 \\ 1.36 & 8.40 \\ 1.35 & 0.90 \\ 1.34 & 0.60\end{array}$
$\begin{array}{ccc}\text { OLATIVE } & \text { PASSED- } & - \\ \text { ASH } & \text { SOLPUR } & \text { MOISTURE } \\ \text { PERCENT } & \text { PERCENT } & \text { PERCENT }\end{array}$

5.69
5.93
8.35
0.00
0.00

2.39 2.51 5.35 0.00 1.34 1.37
1.46 1.46
0.00 0.00

FIGORES PROA PSOC 5 ROIL HILL PEED. DATA FOR -

* conposite * *

THIS PRACTION CONSTITUTES 100.0 PERCENT OP THE PEED.

\begin{tabular}{|c|c|c|c|c|c|c|c|c|c|c|c|c|c|}
\hline \multirow{2}{*}{\multicolumn{2}{|c|}{$\begin{array}{c}\text { SIZE } \\
\text { FRACTION }\end{array}$}} & \multicolumn{2}{|c|}{$-\cdots---D$ DIRECT } & \multicolumn{2}{|c|}{ VALUES $\cdots$} & \multicolumn{2}{|c|}{ - - - COLULATIVE } & \multicolumn{2}{|c|}{ RETAINED - - } & \multicolumn{2}{|c|}{---- COMOLAT IVE } & \multicolumn{2}{|c|}{ PASSED } \\
\hline & & $\begin{array}{l}\text { DEIGHT } \\
\text { PERCED? }\end{array}$ & $\begin{array}{c}\text { ASH } \\
\text { PERCENT }\end{array}$ & $\begin{array}{l}\text { SOLFUR } \\
\text { PERCENT }\end{array}$ & $\begin{array}{l}\text { MOIST ORE } \\
\text { PERCENI }\end{array}$ & $\begin{array}{l}\text { DEIGHT } \\
\text { PERCENT }\end{array}$ & $\begin{array}{c}\text { ASH } \\
\text { PERCENT }\end{array}$ & $\begin{array}{l}\text { SOLEOR } \\
\text { PERCENT }\end{array}$ & $\begin{array}{l}\text { MOISTORE } \\
\text { PERCENT }\end{array}$ & $\begin{array}{l}\text { MEIGHT } \\
\text { PERCENT }\end{array}$ & $\begin{array}{c}\text { A SH } \\
\text { PERCENT }\end{array}$ & $\begin{array}{l}\text { SULPUR } \\
\text { PERCENT }\end{array}$ & $\begin{array}{l}\text { MCISTORE } \\
\text { PERCENT }\end{array}$ \\
\hline $\begin{array}{l}30 \mathrm{H} \\
60 \mathrm{n} \\
100 \mathrm{H} \\
150 \mathrm{H}\end{array}$ & $\begin{array}{l}30 \mathrm{~K} \\
60 \mathrm{H} \\
100 \mathrm{H} \\
150 \mathrm{H}\end{array}$ & $\begin{array}{r}10.28 \\
58.18 \\
18.03 \\
5.83 \\
7.68\end{array}$ & $\begin{array}{l}3.83 \\
3.89 \\
3.82 \\
3.77 \\
4.75\end{array}$ & $\begin{array}{l}1.26 \\
1.37 \\
1.80 \\
1.53 \\
1.80\end{array}$ & $\begin{array}{l}1.09 \\
1.08 \\
1.31 \\
1.25 \\
1.22\end{array}$ & $\begin{array}{r}10.28 \\
68.46 \\
86.49 \\
92.32 \\
100.00\end{array}$ & $\begin{array}{l}3.83 \\
3.88 \\
3.87 \\
3.86 \\
3.93\end{array}$ & $\begin{array}{l}1.26 \\
1.36 \\
1.45 \\
1.45 \\
1.48\end{array}$ & $\begin{array}{l}1.09 \\
1.08 \\
1.13 \\
1.13 \\
1.14\end{array}$ & $\begin{array}{r}100.00 \\
89.72 \\
31.54 \\
13.51 \\
7.68\end{array}$ & $\begin{array}{l}3.93 \\
3.94 \\
4.04 \\
4.33 \\
4.75\end{array}$ & $\begin{array}{l}1.48 \\
1.50 \\
1.75 \\
1.68 \\
1.80\end{array}$ & $\begin{array}{l}1.14 \\
1.15 \\
1.27 \\
1.23 \\
1.22\end{array}$ \\
\hline
\end{tabular}


ANALTtical DATA

DATA POR.DRYPLO SEPARATION TEST 25 DATA POR - PRODDCT COAL.

PIGORES FROH. PSOC 5 ROLL AILL PEED.

THIS PRACTION CONSTITUTES 67.4 PERCENT OP THE PEED.

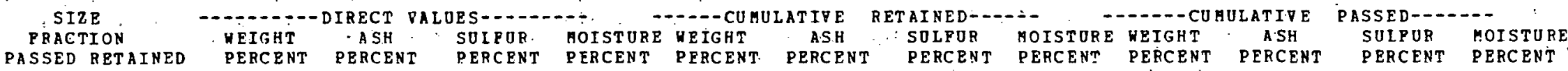

\begin{tabular}{|c|c|c|c|c|c|c|c|c|c|c|c|c|c|}
\hline $\begin{array}{l}30 \mathrm{M} \\
60 \mathrm{M} \\
100 \mathrm{H}\end{array}$ & $\begin{array}{l}30 M \\
60 M \\
100 M \\
150 M\end{array}$ & $\begin{array}{r}5.30 \\
43.50 \\
24.80 \\
11.40 \\
15.00\end{array}$ & $\begin{array}{l}3.30 \\
3.11 \\
3.02 \\
3.33 \\
4.79\end{array}$ & $\begin{array}{l}1.03 \\
1.13 \\
1.31 \\
1.37 \\
1.76\end{array}$ & $\begin{array}{l}1.20 \\
1.24 \\
1.56 \\
1.58 \\
1.50\end{array}$ & $\begin{array}{r}5.30 \\
48.80 \\
73.60 \\
85.00\end{array}$ & $\begin{array}{l}3.30 \\
3.13 \\
3.09 \\
3.13\end{array}$ & $\begin{array}{l}1.03 \\
1.12 \\
1.18 \\
1.21\end{array}$ & $\begin{array}{l}1.20 \\
1.24 \\
1.34 \\
1.38\end{array}$ & $\begin{array}{r}100.00 \\
94.70 \\
51.20 \\
26.40\end{array}$ & $\begin{array}{l}3.37 \\
3.38 \\
3.61 \\
4.16\end{array}$ & $\begin{array}{l}1.29 \\
1.31 \\
1.46 \\
1.59\end{array}$ & $\begin{array}{l}1.41 \\
1.42 \\
1.58 \\
1.59\end{array}$ \\
\hline
\end{tabular}

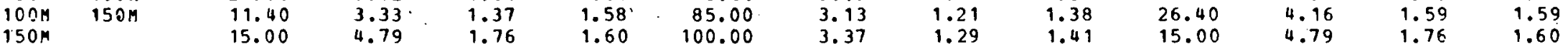

DATA FOR - MIDDLING COAL. THIS PRACTION CONSTITUTES. 4.7 PERCENT OP THE PEED.

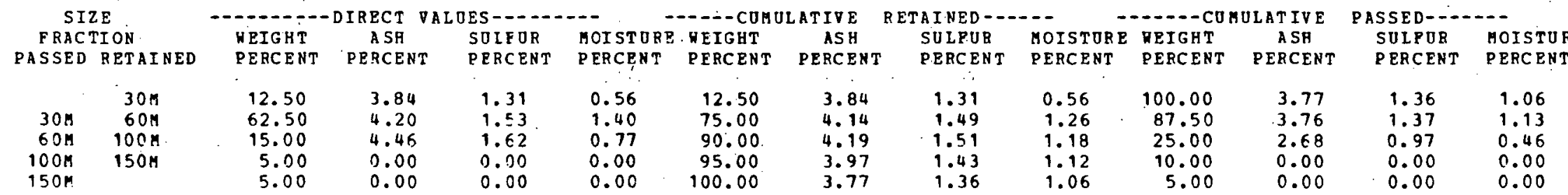

DATA POP - REPUSE COAL.

THIS PRACTION CONSTITUTES 27.9 PERCENT OF THE PEED.

\begin{tabular}{|c|c|c|c|c|}
\hline & & & & \\
\hline F RA & IION & REIGHT & A SH & \\
\hline A SSED & RET AINED & PERCENT & PERCENT & PE \\
\hline & 30 & 15. & 5.24 & \\
\hline & $60 \mathrm{M}$ & 69.20 & 5.55 & \\
\hline $60 \mathrm{M}$ & 1004 & 11.80 & $6 \cdot 16$ & \\
\hline $150 M$ & $150 \mathrm{~m}$ & $\begin{array}{l}2.10 \\
1.70\end{array}$ & $\begin{array}{l}1.44 \\
0.00\end{array}$ & \\
\hline
\end{tabular}

DATA POR DRYPLO SEPARATION TEST 25
* * Compostte** MOISTURE SULFOR MOTSTURE- MEIGHT ASH A SH OLPUR MOISTORE PERCENT PERCENT PERCENT

$\begin{array}{rrr}1.42 & 15.20 & 5.24 \\ 1.44 & 84.40 & 5.82 \\ 1.52 & 96.20 & 5.86 \\ 0.82 & 98.30 & 5.90 \\ 0.00 & 100.00 & 5.80\end{array}$
ANALYTICAL DATA

$\begin{array}{llr}1.76 & 1.42 & 100.00 \\ 2.15 & 1.44 & 84.80 \\ 2.14 & 1.45 & 15.60 \\ 2.17 & 1.43 & 3.80 \\ 2.13 & 1.41 & 1.70\end{array}$

5.80
5.90
5.66
4.11
0.00

2.13 2.19 1.99 0.00

PIGURES PROM PSOC 5 ROLL MILL PEED. THIS PRACTION CONSTITUTES 100.0 PERCENT OP THE PEED.

FPACTION NEIGHT - DIRECT - - - - CUhOLATIPE RETAINED-- - - - -COHULATIVE PASSED--

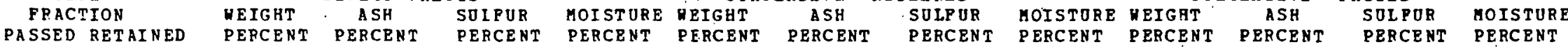

\begin{tabular}{|c|c|c|c|c|c|c|c|c|c|c|c|c|c|}
\hline $\begin{array}{r}30 M \\
60 M \\
100 M \\
150 M\end{array}$ & $\begin{array}{l}30 M \\
60 M \\
100 M \\
150 M\end{array}$ & $\begin{array}{r}8.40 \\
51.56 \\
20.71 \\
8.50 \\
10.82\end{array}$ & $\begin{array}{l}4.32 \\
4.24 \\
3.57 \\
3.52 \\
4.48\end{array}$ & $\begin{array}{l}1.42 \\
1.57 \\
1.44 \\
1.46 \\
1.64\end{array}$ & $\begin{array}{l}1.27 \\
1.32 \\
1.53 \\
1.48 \\
1.50\end{array}$ & $\begin{array}{r}8.40 \\
59.96 \\
80.68 \\
89.18 \\
100.00\end{array}$ & $\begin{array}{l}4.32 \\
4.25 \\
4.07 \\
4.02 \\
4.07\end{array}$ & $\begin{array}{l}1.42 \\
1.55 \\
1.52 \\
1.51 \\
1.53\end{array}$ & $\begin{array}{l}1.27 \\
1.32 \\
1.37 \\
1.38 \\
1.39\end{array}$ & $\begin{array}{l}100.00 \\
.91 .60 \\
40.04 \\
19.32 \\
10.82\end{array}$ & $\begin{array}{l}4.07 \\
4.05 \\
3.80 \\
4.06 \\
4.48\end{array}$ & $\begin{array}{l}1.53 \\
1.54 \\
1.50 \\
1.56 \\
1.64\end{array}$ & $\begin{array}{l}1.39 \\
1.40 \\
1.51 \\
1.49 \\
1.50\end{array}$ \\
\hline
\end{tabular}


BNALYTCAL DATA

DATA POR DRYPLO SEPARATION TEST 26

DATA FOR - PRODOCT COAL.
FIGURES PROA PSOC 5 ROLL MILL PEED.

THIS PRACTIOA CONSTITUTES 47.5 PERCENT OP THE PEED.

\begin{tabular}{|c|c|c|c|c|c|c|c|c|c|c|c|c|c|}
\hline \multirow{2}{*}{\multicolumn{2}{|c|}{$\begin{array}{c}\text { SIZE } \\
\text { FRACTION }\end{array}$}} & \multicolumn{2}{|c|}{$------D$ DIRECT } & \multicolumn{2}{|c|}{ VALOES- - - } & \multicolumn{2}{|c|}{--CUMULATIVE } & \multicolumn{2}{|c|}{ RETAINED- } & \multicolumn{2}{|c|}{---- CUMULATIVE } & \multicolumn{2}{|c|}{ PASSED $-\cdots-\cdots$} \\
\hline & & WEIGHT & ASH & SULPUR & MOISTORE & HEIGHT & ASH & SOLPUR & MOISTURE & WEIGHT & ASH & SULPUR & MOIST \\
\hline & RETAINED & PERCENT & PERCENT & PERCENT & PERCENT & PERCENT & PERCENT & PERCENT & PERCENT & PERCENT & PERCENT & PERCENT & PERCENT \\
\hline $\begin{array}{r}30 M \\
60 M \\
100 M \\
150 M\end{array}$ & $\begin{array}{r}30 M \\
60 M \\
100 M \\
150 M\end{array}$ & $\begin{array}{r}3.50 \\
44.70 \\
26.70 \\
10.80 \\
14.30\end{array}$ & $\begin{array}{l}2.91 \\
3.06 \\
3.44 \\
3.69 \\
4.97\end{array}$ & $\begin{array}{l}1.09 \\
1.09 \\
1.20 \\
1.50 \\
1.87\end{array}$ & $\begin{array}{l}1.36 \\
1.40 \\
1.60 \\
1.40 \\
1.60\end{array}$ & $\begin{array}{r}3.50 \\
48.20 \\
74.90 \\
85.70 \\
160.00\end{array}$ & $\begin{array}{l}2.91 \\
3.05 \\
3.19 \\
3.25 \\
3.50\end{array}$ & $\begin{array}{l}1.0 .9 \\
1.09 \\
1.13 \\
1.18 \\
1.28\end{array}$ & $\begin{array}{l}1.36 \\
1.40 \\
1.47 \\
1.46 \\
1.48\end{array}$ & $\begin{array}{r}100.00 \\
96.50 \\
51.80 \\
25.10 \\
14.30\end{array}$ & $\begin{array}{l}3.50 \\
3.52 \\
3.91 \\
4.42 \\
4.97\end{array}$ & $\begin{array}{l}1.28 \\
1.28 \\
1.45 \\
1.71 \\
1.87\end{array}$ & $\begin{array}{l}1.48 \\
1.48 \\
1.56 \\
1.51 \\
1.60\end{array}$ \\
\hline
\end{tabular}

TATA FOR - MIDDLING COAL.

THIS PRACTION CONSTIIUTES 28.0 PERCENT OF THF. PEED.

SIZE
FRACTIO PASSFD RETAINED

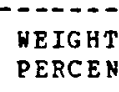
PERCENT

$$
\text { I AECT }
$$
CT VAL
SH
CENT SULFUR PERCE

\section{$--10---c 0$}

\section{IVE RETAINED-} SULPUR MOIST - - - - - COMOLATI ATIVE ASH PASSED--...-.SULFUR MOISTURE PERCENT PERCENT

$\begin{array}{rrr} & 30 M & 14.70 \\ 30 M & 60 M & 65.70 \\ 60 M & 100 M & 15.30 \\ 100 M & 150 M & 2.30 \\ 150 M & & 2.00\end{array}$

$$
\begin{aligned}
& 3.57 \\
& 3.61 \\
& 4.75 \\
& 5.77 \\
& 6.92
\end{aligned}
$$$$
\begin{array}{ll}
3.61 & 1.37
\end{array}
$$

$$
\begin{aligned}
& 1.28 \\
& 1.36 \\
& 1.58 \\
& 0.49
\end{aligned}
$$$$
80.40
$$$$
\begin{array}{ll}
1.58 & 95.70 \\
0.49 & 98.00
\end{array}
$$$$
\begin{array}{rr}
0.74 \quad 100.00
\end{array}
$$

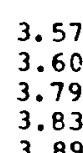

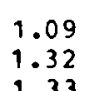

1.33

1.37
1.28
1.35
$1.3 E$
1.36

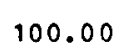

85.30

19.60

4.30
3.89
3.95
5.09
6.3 $\begin{array}{ll}1.39 & 1.35 \\ 1.44 & 1.36\end{array}$

$\begin{array}{ll}1.44 & 1.36 \\ 1.66 & 1.37\end{array}$
$2.52 \quad 0.61$

$2.18 \quad 0.74$

DATA FOR - REFUSE COAL.

THIS PRACTION CONSTITUTES 24.5 PERCENT OP THE FEED.

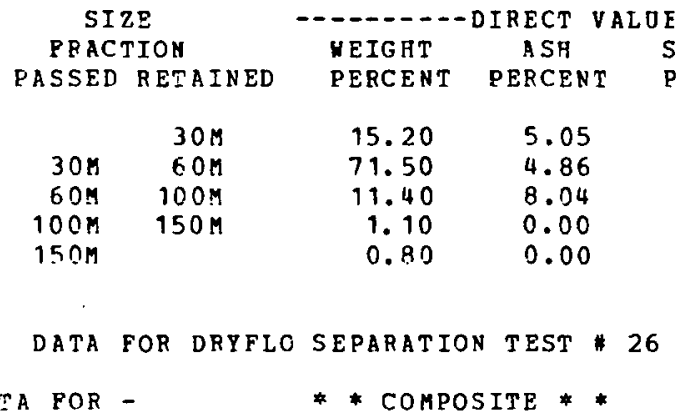

4PA FOR - * COMPOSITE**

FRACTION HETGHT DIRECT VALUES--.--

SOLPOR MOISTORE RETA SINED - - D.- - - - COMOLATIVE

PASSED-.-.-. PELPOR MONT PERC

1.65
2.14
2.65
0.00
0.00
ISTORE REIGHT PERCENT SULPOR MOISTORE HEIGAT ASH SULPUR MOISTURE

$\begin{array}{lrr}1.32 & 15.20 & 5.05 \\ 1.38 & 86.70 & 4.89 \\ 1.50 & 98.10 & 5.26 \\ 0.00 & 99.20 & 5.20 \\ 0.00 & 100.00 & 5.16\end{array}$

1.65
2.05
2.12
2.10
2.08

$$
\begin{aligned}
& 1.32 \\
& 1.37 \\
& 1.38 \\
& 1.37
\end{aligned}
$$
PERCENT PEPCENT SULPUR DATA

2.08

$$
1.36
$$$$
\begin{array}{r}
100.00 \\
84.80 \\
13.30 \\
1.90
\end{array}
$$$$
\begin{aligned}
& 5.16 \\
& 5.18
\end{aligned}
$$$$
\begin{aligned}
& 5.18 \\
& 6.89
\end{aligned}
$$$$
\begin{aligned}
& 6.89 \\
& 0.00
\end{aligned}
$$

2.08

2.08
2.16
2.27

2.27
0.00

1.36

0.80

0.00

0.00

1.29
0.00

PIG ORES PROA PSOC 5 ROLI HILL PEED.

THIS PRACTION CONSTITUTES 100.0 PERCENT OP THE PEED. NEIGHT ASH SUIFUR MOISTUAE HEIGHT ASH SUIRUR - - - - -CUNULATIVE ATIVE
ASH
PRCENT SSED--.--SULPOR MOISTURE

$\begin{array}{rrr} & 30 \mathrm{M} & 9.50 \\ 30 \mathrm{M} & 60 \mathrm{M} & 57.15 \\ 60 \mathrm{M} & 100 \mathrm{M} & 19.76 \\ 100 \mathrm{M} & 150 \mathrm{M} & 6.04 \\ 150 \mathrm{M} & & 7.55\end{array}$

$\begin{array}{lll}4.03 & 1.31 & 1.31 \\ 3.79 & 1.50 & 1.38 \\ 4.37 & 1.45 & 1.58 \\ 3.75 & 1.57 & 1.24 \\ 4.99 & 1.84 & 1.49\end{array}$

9.50
66.65
86.41
92.45
100.00

4.03
3.82
3.95
3.94
4.02

PERCEN

\section{OISTORE MEIGHT}

$\begin{array}{ll}1.31 & 100.00\end{array}$

$\begin{array}{ll}1.31 & 100.00 \\ 1.37 & 90.50 \\ 1.42 & 33.35 \\ 1.41 & 13.59\end{array}$

$\begin{array}{rr}1.41 & 13.59 \\ 1.41 & 7.55\end{array}$
4.02
4.01
4.40
4.43
4.99
1.50

1.50
1.52

1.56

1.72
1.84
OISTURE

1.41

1.42

1.50

1.38
1.49 
ANALYTICAL DATA

DATA POR DRYPLO SEPARATION TEST 27

DATA POR - PRODUCT COAL.
FIGURES PROA PSOC 5 ROLL AILL PEED.

THIS PRACTION CONSTITUTES 53.9 PERCENT OP THE PEED.

\begin{tabular}{|c|c|c|c|c|c|c|c|c|c|c|c|c|c|}
\hline \multirow{2}{*}{\multicolumn{2}{|c|}{$\begin{array}{c}\text { SIZE } \\
\text { PRACTION }\end{array}$}} & \multicolumn{2}{|c|}{$\cdots-\infty,-$ DIRECT } & \multicolumn{2}{|l|}{ UES - - } & \multicolumn{2}{|c|}{-----COAULATIVE } & \multicolumn{2}{|c|}{ RETAINED } & \multicolumn{2}{|c|}{-COROLATIVE } & \multicolumn{2}{|c|}{ PASSED- $-\cdots$} \\
\hline & & DEIGHT & A SH & SUIFOR & MOISTURE & MEIGHT & ASH & SULPOR & HOISTURE & VEIGRT & A SH & SOLF UR & MOISTURE \\
\hline & RETAINED & PERCENT & PERCENT & PERCENT & PERCENT T & PERCENT & PERCENT & PERCENT. & PERCENT & PERCENT & PERCENT & PERCENT & PERCENT \\
\hline $\begin{array}{r}30 M \\
60 \mathrm{H} \\
100 \mathrm{M} \\
150 \mathrm{M}\end{array}$ & $\begin{array}{l}30 \mathrm{H} \\
60 \mathrm{M} \\
100 \mathrm{M} \\
150 \mathrm{M}\end{array}$ & $\begin{array}{r}4.00 \\
46.80 \\
26.40 \\
10.80 \\
12.00\end{array}$ & $\begin{array}{l}2.86 \\
2.92 \\
3.13 \\
3.44 \\
4.87\end{array}$ & $\begin{array}{l}1.03 \\
1.04 \\
1.02 \\
1.33 \\
1.96\end{array}$ & $\begin{array}{l}1.24 \\
1.38 \\
1.78 \\
1.64 \\
1.80\end{array}$ & $\begin{array}{r}4.00 \\
50.80 \\
77.20 \\
88.00 \\
100.00\end{array}$ & $\begin{array}{l}2.86 \\
2.92 \\
2.99 \\
3.04 \\
3.26\end{array}$ & $\begin{array}{l}1.03 \\
1.04 \\
1.03 \\
1.07 \\
1.18\end{array}$ & $\begin{array}{l}1.24 \\
1.37 \\
1.51 \\
1.53 \\
1.56\end{array}$ & $\begin{array}{r}100.00 \\
96.00 \\
49.20 \\
22.80 \\
12.00\end{array}$ & $\begin{array}{l}3.26 \\
3.28 \\
3.62 \\
4.19 \\
4.87\end{array}$ & $\begin{array}{l}1.18 \\
1.18 \\
1.32 . \\
1.66 \\
1.96\end{array}$ & $\begin{array}{l}1.56 \\
1.57 \\
1.75 \\
1.72 \\
1.80\end{array}$ \\
\hline
\end{tabular}

DATA POR - MIDDLING COAL.

THIS PRACTION CONSTITUTES 18.4 PERCENT OP THE PEED.

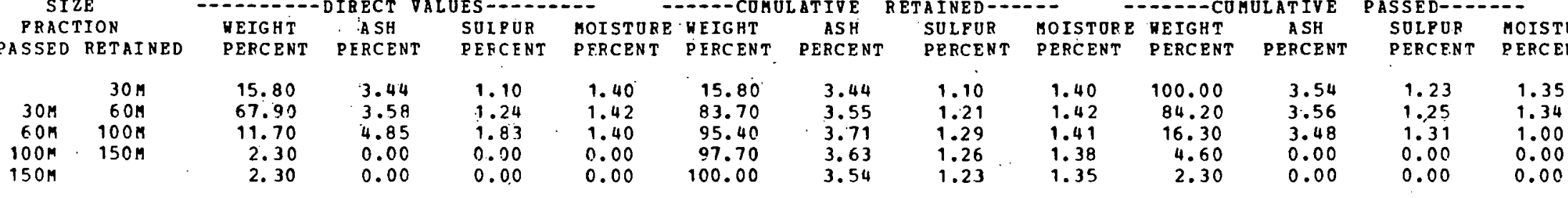

DATA POR - REPUSE CCAL:

THIS PRACTION CONSTITUTES 27.7 PERCENT OP THE PEED.

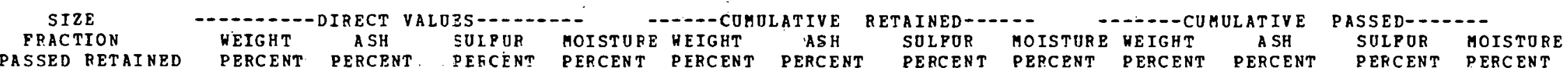
PASSED RETAINED PERCENT PERCENT. PEFCENT PERCENT PERCENT PERCENT PERCENT PERCENT PERCENT PERCENT PEFCENT PERCENT

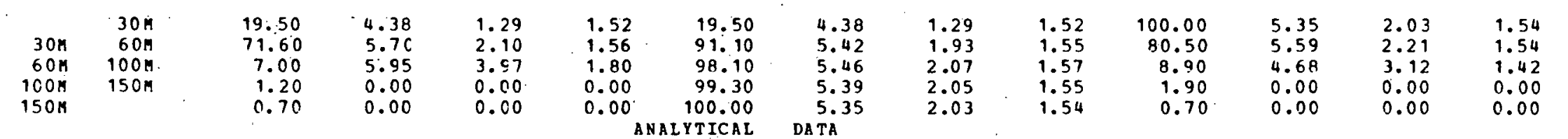

DATA POR DRYPLO SEPARATION TEST $\# 27$ DATA POR --

* * conposite * *

FIGURES PROM PSOC 5. ROLL MILL FEED.

THIS PRACTICN CONSTITUTES 100.0 PERCENT OP THE PEED.

\begin{tabular}{|c|c|c|c|c|c|c|c|c|c|c|c|c|c|}
\hline \multirow{2}{*}{\multicolumn{2}{|c|}{$\begin{array}{c}\text { SIZE } \\
\text { PRACTION }\end{array}$}} & \multicolumn{2}{|c|}{$-1-1-1$ DIRECT $\nabla$} & \multicolumn{2}{|c|}{ ALUES - - . } & \multicolumn{2}{|c|}{-- - CUMOLATIVE } & \multicolumn{2}{|c|}{ RETAINED $\cdots-$} & \multicolumn{2}{|c|}{$-\ldots$ CORULATIVE } & \multicolumn{2}{|c|}{ PASSED- - - } \\
\hline & & DEIGHT & ASH & SULFUR & MOISTURE & REIGHT & $\mathrm{ASH}$ & SOLPUR & MOISTURE & WEIGHT & ASH & SULPOR & MOISTORE \\
\hline ASSED & RETAINED & PEPCENT & PERCENT & PERCENT & PERCENT & PERCENT & FERCENT & PERCENT & PERCENT & PERCENT & PERCENT & PERCENT & PERCENT \\
\hline $\begin{array}{r}30 M \\
601 \\
100 M \\
150 M\end{array}$ & $\begin{array}{r}30 \mathrm{M} \\
60 \mathrm{M} \\
100 \mathrm{M} \\
150 \mathrm{M}\end{array}$ & $\begin{array}{r}10.46 \\
57.55 \\
18.32 \\
6.58 \\
7.09\end{array}$ & $\begin{array}{l}3.81 \\
4.02 \\
3.63 \\
3.04 \\
4.45\end{array}$ & $\begin{array}{l}1.18 \\
1.45 \\
1.43 \\
1.18 \\
1.79\end{array}$ & $\begin{array}{l}1.43 \\
1.45 \\
1.74 \\
1.45 \\
1.64\end{array}$ & $\begin{array}{r}10.46 \\
68.02 \\
86.34 \\
92.91 \\
100.00\end{array}$ & $\begin{array}{l}3.81 \\
3.99 \\
3.91 \\
3.85 \\
3.89\end{array}$ & $\begin{array}{l}1.18 \\
1.41 \\
1.41 \\
1.40 \\
1.42\end{array}$ & $\begin{array}{l}1.43 \\
1.45 \\
1.51 \\
1.50 \\
1.51\end{array}$ & $\begin{array}{r}100.00 \\
89.54 \\
31.98 \\
13.66 \\
7.09\end{array}$ & $\begin{array}{l}3.89 \\
3.90 \\
3.69 \\
3.77 \\
4.45\end{array}$ & $\begin{array}{l}1.42 \\
1.45 \\
1.46 \\
1.49 \\
1.79\end{array}$ & $\begin{array}{l}1.51 \\
1.52 \\
1.66 \\
1.55 \\
1.64\end{array}$ \\
\hline
\end{tabular}




\section{ANALYTICAL DATA}

DATA FOR DRYPLO SEPARATIOH TEST 28. DATA POR - PRODOCT COAL.
PIGURES FROM PSOC 105 PEED SAMPLE.

TAIS FRACTICN CONSTITUTES 56.4 PERCENT OP THE PEED.

\begin{tabular}{|c|c|c|c|c|c|c|c|c|c|c|c|c|c|}
\hline \multirow{2}{*}{\multicolumn{2}{|c|}{$\begin{array}{c}\text { SIZE } \\
\text { PRACTION }\end{array}$}} & - & CRECT & $s=--$ & 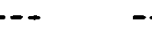 & $--\operatorname{con} 0$ & I IVE & I NED - & - & $----\infty \mathrm{cou}$ & LATIVE & PASSED- & $=-$ \\
\hline & & $\begin{array}{l}\text { NEIGHT } \\
\text { PERCENT }\end{array}$ & $\begin{array}{c}\text { ASH } \\
\text { PERCENT }\end{array}$ & $\begin{array}{l}\text { SOLPOR } \\
\text { FERCENT }\end{array}$ & $\begin{array}{l}\text { MOISTURE } \\
\text { PERCENT }\end{array}$ & $\begin{array}{l}\text { NEIGHT } \\
\text { PERCENT }\end{array}$ & $\begin{array}{c}\text { ASR } \\
\text { FERCENT }\end{array}$ & $\begin{array}{l}\text { SULPOR } \\
\text { PERCENT }\end{array}$ & $\begin{array}{l}\text { MOISTURE } \\
\text { PERCENT }\end{array}$ & $\begin{array}{l}\text { WEIGHT } \\
\text { PERCENT }\end{array}$ & $\begin{array}{c}\text { ASH } \\
\text { PERCENT }\end{array}$ & $\begin{array}{l}\text { SULFUR } \\
\text { PERCENT }\end{array}$ & $\begin{array}{l}\text { MOISTURE } \\
\text { PERCENT }\end{array}$ \\
\hline $\begin{array}{r}30 M \\
60 M \\
100 M \\
150 M\end{array}$ & $\begin{array}{r}30 \mathrm{H} \\
60 \mathrm{H} \\
100 \mathrm{M} \\
150 \mathrm{H}\end{array}$ & $\begin{array}{r}29.90 \\
34.40 \\
17.70 \\
9.00 \\
17.00\end{array}$ & $\begin{array}{l}7.77 \\
8.03 \\
8.19 \\
8.80 \\
9.63\end{array}$ & $\begin{array}{l}1.66 \\
1.77 \\
1.91 \\
2.05 \\
2.82\end{array}$ & $\begin{array}{l}5.00 \\
6.00 \\
5.00 \\
5.65 \\
3.95\end{array}$ & $\begin{array}{r}21.90 \\
56.30 \\
74.00 \\
83.00 \\
100.00\end{array}$ & $\begin{array}{l}7.77 \\
7.93 \\
7.99 \\
8.08 \\
8.34\end{array}$ & $\begin{array}{l}1.66 \\
1.73 \\
1.77 \\
1.80 \\
1.97\end{array}$ & $\begin{array}{l}6.00 \\
6.00 \\
6.00 \\
5.96 \\
5.62\end{array}$ & $\begin{array}{r}100.00 \\
78.10 \\
43.70 \\
26.00 \\
17.00\end{array}$ & $\begin{array}{l}8.34 \\
8.50 \\
8.88 \\
9.34 \\
9.63\end{array}$ & $\begin{array}{l}1.97 \\
2.06 \\
2.29 \\
2.55 \\
2.82\end{array}$ & $\begin{array}{l}5.62 \\
5.51 \\
5.13 \\
4.54 \\
3.95\end{array}$ \\
\hline
\end{tabular}

DATA FOR - RECYCLE TO TEST $\$ 54$.

THIS FRACTION CONSTIIOTES 43.6 PERCENT OP THE PEED.

\begin{tabular}{|c|c|c|c|c|c|}
\hline & & & & \\
\hline FRAC & ION & WEIG AT & A SH & SUIPUR & \\
\hline ASSED & RETAINED & PERCENT & PERCENT & FERCENT & \\
\hline & $30 \mathrm{~m}$ & 57.40 & 9.74 & 2.00 & \\
\hline$O A$ & $60 \mathrm{M}$ & 38.40 & 9.20 & 2.08 & \\
\hline OM & $100 M$ & 3.60 & $12: 49$ & 3.33 & \\
\hline $100 \mathrm{M}$ & $150 \mathrm{M}$ & 0.30 & 24.15 & 4.53 & \\
\hline $15 \mathrm{CM}$ & & 0.30 & 21.40 & 5.36 & \\
\hline
\end{tabular}

----DUMCLATIVE EETAINED--

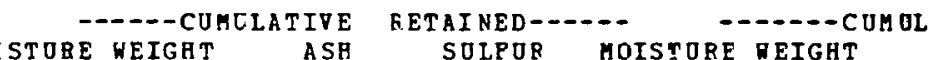
TIVE PASSED-- - - 作

$\begin{array}{lll}5.50 & 57.40 & 9.74\end{array}$

2.00

$5.50 \quad 100.00$

$$
9.71
$$

2.10

99.40

9.52
9.63

9.63
9.67

2.03

5.50
5.68
5.67

42.60

$42.60 \quad 9.67$
$4.20 \quad 13.96$

$\begin{array}{ll}4.20 & 13.96\end{array}$

$\begin{array}{ll}0.60 & 22.77 \\ 0.30 & 29.40\end{array}$

2.23

3.56

4.94
5.36

5.65

1.70

2.09
2.10

5.66
5.65

5.86

TFIS PRACTION CONSTITUTES 100.0 PERCENT OF THE PEED.

DATA FOR -

* *ompostte * *

-.---COHULATIVE RETAINED----

SIZE PASSED RETAINED - - - - - IIRECT VALUES--- - - WEIGHT AIRECT VALUES SIFUR MOISTURE REIGHT ASH SULPUR norstobe

OLATIV

PASSED-2.-.PERCENT PERCENT PEFCENT PERCENT PERCENT PERCENT PERCENT PERCENT PERCBNT

ASH
PERCENT SULFUR PERCBNT MOISTURE

$\begin{array}{rrr} & 30 \mathrm{M} & 37.38 \\ 30 \mathrm{M} & 60 \mathrm{M} & 36.14 \\ 60 \mathrm{M} & 100 \mathrm{M} & 11.55 \\ 100 \mathrm{M} & 150 \mathrm{M} & 5.21 \\ 150 \mathrm{M} & & 9.72\end{array}$

$\begin{array}{ll}9.09 & 1.89 \\ 8.57 & 1.91 \\ 8.77 & 2.10 \\ 9.19 & 2.11 \\ 9.79 & 2.85\end{array}$

5.67
5.98
5.93
5.57
3.92

37.38
73.52
85.07
90.28
100.00

9.09
8.83

8.83
8.83

8.83

1.89
1.90

1.90
1.93

$5.67 \quad 100.00$

100.00
62.62

5.83

26.48

3.94
8.85

8.85
9.23

$8.94 \quad 2.03$

$5.63 \quad 9.72$

9.58

9.79

2.03
2.11
2.38
2.60
2.85

5.63

5.62

5.12
4.50

3.92 


\section{ANALYTICAL DATA}

DATA FOR DRYPLO SEPARATION TEST $\$ 29$. DATA FOR - PRODOCT COAL.

THIS FRACTION CONSTITUTES 85.8 PERCENT OP THE PEED.

\begin{tabular}{|c|c|c|c|c|c|c|c|c|c|c|c|c|c|}
\hline \multirow{2}{*}{\multicolumn{2}{|c|}{$\begin{array}{c}\text { SIZE. } \\
\text { FRACTION }\end{array}$}} & \multicolumn{2}{|c|}{$--1-1-D$ DIRECT } & JES $=-$. & - & \multicolumn{2}{|c|}{--- CORULATIVE } & \multicolumn{2}{|c|}{ RETAI NED - - - - } & \multicolumn{2}{|c|}{$\ldots$ CUVOLATIVE } & \multicolumn{2}{|c|}{ PASSED } \\
\hline & & HEIGHT & ASH & SOIPOR & MOISTURE & REIGH T & ASH & SOLFOR & MOISTORE & REIGHT & ASH & SUIFOR & MOISTURE \\
\hline ASSED & RETAINED & PERCENT & PERCENT & PERCENT & PERCENT & PERCENT & FERCENT & PERCENT & PERCENT & P.ERCENT & PERCENT & PERCENT & PERCENT \\
\hline $\begin{array}{r}1 / 4 " i \\
84 \\
16 \%\end{array}$ & $\begin{array}{r}1 / 4 " \\
8 H \\
16 H\end{array}$ & $\begin{array}{r}0.20 \\
31.50 \\
46.20 \\
22.10\end{array}$ & $\begin{array}{r}7.55 \\
8.51 \\
10.25 \\
10.26\end{array}$ & $\begin{array}{l}0.87 \\
1.70 \\
1.60 \\
1.56\end{array}$ & $\begin{array}{l}2.60 \\
3.05 \\
3.40 \\
2.55\end{array}$ & $\begin{array}{r}0.20 \\
31.70 \\
77.90 \\
100.00\end{array}$ & $\begin{array}{l}7.55 \\
8.50 \\
9.54 \\
9.70\end{array}$ & $\begin{array}{l}0.87 \\
1.69 \\
1.64 \\
1.62\end{array}$ & $\begin{array}{l}2.60 \\
3.05 \\
3.26 \\
3.10\end{array}$ & $\begin{array}{r}100.00 \\
99.80 \\
68.30 \\
22.10\end{array}$ & $\begin{array}{r}9.70 \\
9.70 \\
10.25 \\
10.26\end{array}$ & $\begin{array}{l}1.62 \\
1.62 \\
1.59 \\
1.56\end{array}$ & $\begin{array}{l}3.10 \\
3.10 \\
3.12 \\
2.55\end{array}$ \\
\hline
\end{tabular}

DATA FOR - MIDDLING COAL.

THIS PRACTION CONSTITUTES 5.6 PERCENT OP THE FEED.

\begin{tabular}{|c|c|c|c|c|c|c|c|c|c|c|c|c|c|}
\hline \multirow{2}{*}{\multicolumn{2}{|c|}{$\begin{array}{c}\text { SIZE } \\
\text { FRACTION }\end{array}$}} & -- & IRECT & ES - & - & $-\operatorname{cono}$ & ATIVE & I NED - & - & $\mathrm{col}$ & ILATIVE & PASSED-- & - \\
\hline & & $\begin{array}{l}\text { NEIGHT } \\
\text { PERCENT }\end{array}$ & $\begin{array}{c}\text { ASH } \\
\text { PERCENT }\end{array}$ & $\begin{array}{l}\text { SOLFOR } \\
\text { PERCENT }\end{array}$ & $\begin{array}{l}\text { MOISTORE } \\
\text { PERCENTT }\end{array}$ & $\begin{array}{l}\text { DEIGHT } \\
\text { PERCENT }\end{array}$ & $\begin{array}{c}\text { ASH } \\
\text { PERCENT }\end{array}$ & $\begin{array}{l}\text { SOLPUR } \\
\text { PERCENT }\end{array}$ & $\begin{array}{l}\text { MOISTORE } \\
\text { PERCENT }\end{array}$ & $\begin{array}{l}\text { REIGHT } \\
\text { PERCENT }\end{array}$ & $\begin{array}{c}\text { A SH } \\
\text { PERCENT }\end{array}$ & $\begin{array}{l}\text { SUIFOR } \\
\text { PERCENT }\end{array}$ & $\begin{array}{l}\text { MCISTURE } \\
\text { PERCENT }\end{array}$ \\
\hline $\begin{array}{r}1 / 4 n \\
8 \mathrm{H} \\
16 \mathrm{M}\end{array}$ & $\begin{array}{r}1 / 40 \\
8 \mathrm{H} \\
16 \mathrm{H}\end{array}$ & $\begin{array}{r}0.00 \\
22.70 \\
51.50 \\
25.80\end{array}$ & $\begin{array}{r}0.6 C \\
16.41 \\
12.64 \\
11.99\end{array}$ & $\begin{array}{r}0.00 \\
4.39 \\
r 2.12 \\
1.90\end{array}$ & $\begin{array}{l}0.00 \\
1.25 \\
2.10 \\
2.00\end{array}$ & $\begin{array}{r}0.00 \\
22.70 \\
74.20 \\
100.00\end{array}$ & $\begin{array}{r}0.00 \\
16.41 \\
13.79 \\
13.33\end{array}$ & $\begin{array}{l}0.00 \\
4.39 \\
2.81 \\
2.58\end{array}$ & $\begin{array}{l}0.00 \\
1.25 \\
1.84 \\
1.88\end{array}$ & $\begin{array}{r}100.00 \\
100.00 \\
77.30 \\
25.80\end{array}$ & $\begin{array}{l}13.33 \\
13.33 \\
12.42 \\
11.99\end{array}$ & $\begin{array}{l}2.58 \\
2.58 \\
2.05 \\
1.90\end{array}$ & $\begin{array}{l}1.88 \\
1.88 \\
2.07 \\
2.00\end{array}$ \\
\hline
\end{tabular}

DATA FOR - REPOSE COAL.

TRIS PRACTION CONSTITUTES 8.6 PERCENT OF THE PEED.

\begin{tabular}{|c|c|c|c|c|c|c|c|c|c|c|c|c|c|}
\hline \multirow{2}{*}{\multicolumn{2}{|c|}{$\begin{array}{c}\text { SIZE } \\
\text { PRACTION }\end{array}$}} & \multicolumn{2}{|c|}{$--1-1$ DIRECT } & UES - - & - & \multicolumn{2}{|c|}{$\cdots--$ COBULATIVP } & \multicolumn{2}{|c|}{ RETAINED----- } & \multicolumn{2}{|c|}{---- COMOL AT IVE } & \multicolumn{2}{|c|}{ PASSED- - - } \\
\hline & & WEIGHT & A SH & SOIFUR & MOISTORE & WEIGHT & AS H & SUIFUR & MOISTORE & WEIGHT & AS & so & URE \\
\hline SSED & RETAINED & PEPCENT & PERCENT & PERCENT & PERCENT & PERCENT & PERCENT & PE RCENT & PERCENT & PERCENT & PERCENT & PERCENT & PERCENT \\
\hline $\begin{array}{r}1 / 4 " \\
8 M \\
16 M\end{array}$ & $\begin{array}{r}1 / 4 " \\
8 \mathrm{M} \\
16 \mathrm{M}\end{array}$ & $\begin{array}{r}0.00 \\
20.80 \\
54.40 \\
24.80\end{array}$ & $\begin{array}{r}0.00 \\
11.62 \\
14.20 \\
13.55\end{array}$ & $\begin{array}{l}0.00 \\
1.90 \\
2.08 \\
2.31\end{array}$ & $\begin{array}{l}2.35 \\
2.10 \\
2.25\end{array}$ & $\begin{array}{r}0.00 \\
20.80 \\
75.20 \\
100.00\end{array}$ & $\begin{array}{r}0.00 \\
11.62 \\
13.49 \\
13.50\end{array}$ & $\begin{array}{l}0.00 \\
1.90 \\
2.03 \\
2.10\end{array}$ & $\begin{array}{l}2.35 \\
2.17 \\
2.19\end{array}$ & $\begin{array}{r}100.00 \\
100.00 \\
79.20 \\
24.80\end{array}$ & $\begin{array}{l}13.50 \\
13.50 \\
14.00 \\
13.55\end{array}$ & $\begin{array}{l}2.10 \\
2.15 \\
2.31\end{array}$ & $\begin{array}{l}2.19 \\
2.15 \\
2.25\end{array}$ \\
\hline
\end{tabular}

DATA FOR DRY.PLO SEPABATION TEST * 29 .

FIGURES PROM PSOC 105 FEED SAMPLE.

DATA FOR -

* * compositr * *

THIS FRACTION CONSTITUTES 100.0 PERCENT OF THE PEED.

\begin{tabular}{|c|c|c|c|c|c|c|c|c|c|c|c|c|c|}
\hline \multirow{2}{*}{\multicolumn{2}{|c|}{$\begin{array}{c}\text { SIZE } \\
\text { FRACTION }\end{array}$}} & \multicolumn{2}{|c|}{$--1-1$-DIRECT $\nabla$} & \multicolumn{2}{|c|}{ VALUES $-\cdots+\cdots$} & \multicolumn{2}{|c|}{$-\ldots$ COnOLATIVE } & \multicolumn{2}{|c|}{ RETAINED- } & \multicolumn{2}{|c|}{---- -CUMULATIVE } & \multicolumn{2}{|c|}{ PASSED-D.-.- } \\
\hline & & WEIGHT & A SH & SULPUR & MOISTURE & DEIGHT & ASH & SULPUB & MOISTURE & WEIGHT & A SH & SULPOR & MOIS \\
\hline ASSED & RETAINED & PEBCENT & PERCENT & PEBCENT & PERCENT & PERCENT & PERCENT & PERCENT & PERCENT & PERCENT & PERCENT & PERCENT & PERCENT \\
\hline $\begin{array}{r}1 / 4 n \\
8 n \\
16 n\end{array}$ & $\begin{array}{r}1 / 4 " \\
8 M \\
164\end{array}$ & $\begin{array}{r}0.17 \\
30.09 \\
47.20 \\
22.54\end{array}$ & $\begin{array}{r}7.55 \\
9.03 \\
10.79 \\
10.68\end{array}$ & $\begin{array}{l}0.87 \\
1.83 \\
1.68 \\
1.65\end{array}$ & $\begin{array}{l}2.60 \\
2.93 \\
3.19 \\
2.49\end{array}$ & $\begin{array}{r}0.17 \\
30.26 \\
77.46 \\
100.00\end{array}$ & $\begin{array}{r}7.55 \\
9.02 \\
10.10 \\
10.23\end{array}$ & $\begin{array}{l}0.87 \\
1.82 \\
1.73 \\
1.72\end{array}$ & $\begin{array}{l}2.60 \\
2.93 \\
3.09 \\
2.95\end{array}$ & $\begin{array}{r}100.00 \\
99.83 \\
69.74 \\
22.54\end{array}$ & $\begin{array}{l}10.23 \\
10.23 \\
10.75 \\
10.68\end{array}$ & $\begin{array}{l}1.72 \\
1.72 \\
1.67 \\
1.65\end{array}$ & $\begin{array}{l}2.95 \\
2.95 \\
2.96 \\
2.49\end{array}$ \\
\hline
\end{tabular}


ANALTICAL DATA

DATA FOR DRYPLO SEPARATION TEST 30.

FIGURES FROM PSOC 105 PEED SAMPLE.

DATA FOR - PRODUCT COAL.

THIS FRACTION COASTITUTES 66.9 PERCENT OP THE PEED.

\begin{tabular}{|c|c|c|c|c|c|c|c|c|c|c|c|c|c|}
\hline \multirow{2}{*}{\multicolumn{2}{|c|}{$\begin{array}{c}\text { SIZE } \\
\text { PRACTION }\end{array}$}} & \multicolumn{2}{|c|}{-1} & \multicolumn{2}{|c|}{ VALUES } & \multicolumn{2}{|c|}{--- COBULATIVE } & \multicolumn{2}{|c|}{ RETAI NED - } & \multicolumn{2}{|c|}{$\ldots$ CUMOLATIVE } & \multicolumn{2}{|c|}{ PASSED- $-\cdots$} \\
\hline & & WEIGHT & A SH & SOLFOR & MOIST ORE & DEIGHT & ASH & SULFUR & MOISTURE & WEIGHT & ASH & SULPUR & JRE \\
\hline ISSED & RETAINED & PERCENT & PERCENT & PER & PERCBNT & PERCENT & PERCENT & PERCENT & CENT & PE: & PERCENT & PERCENT & NT \\
\hline $\begin{array}{r}8 M \\
16 n\end{array}$ & $\begin{array}{r}8 M \\
16 M\end{array}$ & $\begin{array}{l}26.40 \\
48.60 \\
25.00\end{array}$ & $\begin{array}{r}8.48 \\
9.77 \\
10.16\end{array}$ & $\begin{array}{r}1.55 \\
1.59 \\
1.59\end{array}$ & $\begin{array}{l}2.90 \\
2.96 \\
1.92\end{array}$ & $\begin{array}{r}26.40 \\
75.00 \\
100.00\end{array}$ & $\begin{array}{l}9.32 \\
9.53\end{array}$ & $\begin{array}{l}1.53 \\
1.58 \\
1.58\end{array}$ & $\begin{array}{l}2.97 \\
2.71\end{array}$ & $\begin{array}{r}100.00 \\
73.60 \\
25.00\end{array}$ & $\begin{array}{r}9.53 \\
9.90 \\
10.16\end{array}$ & $\begin{array}{r}1.59 \\
1.59\end{array}$ & $\begin{array}{l}2.61 \\
1.92\end{array}$ \\
\hline
\end{tabular}

DATA FOR - MIDDLING COAL. THIS PRACTION CONSTITUTES 22.0 PERC3NT OP THE PEED.

\begin{tabular}{|c|c|c|c|c|c|c|c|c|c|c|c|c|c|}
\hline \multicolumn{2}{|c|}{ SIZE } & \multicolumn{2}{|c|}{$--1-1-$ DIRECT } & JES-- & - & \multicolumn{2}{|c|}{--- CUHULAT } & \multicolumn{2}{|c|}{ RETAI NED - - - - } & \multicolumn{2}{|c|}{$-\infty-$ CUMOLAT IVE } & \multicolumn{2}{|c|}{ PASSED $\cdots$} \\
\hline $\begin{array}{r}\text { FRAC } \\
\text { PASSED }\end{array}$ & $\begin{array}{l}\text { IOB } \\
\text { RET AINED }\end{array}$ & $\begin{array}{l}\text { MEIGHT } \\
\text { PERCENT }\end{array}$ & $\begin{array}{c}\text { A SH } \\
\text { PERCENT }\end{array}$ & $\begin{array}{l}\text { SUIFOR } \\
\text { PERCENT }\end{array}$ & $\begin{array}{l}\text { MOISTURE } \\
\text { PEPCENT }\end{array}$ & $\begin{array}{l}\text { VEIGHT } \\
\text { PERCENT }\end{array}$ & $\begin{array}{c}\text { AS H } \\
\text { PERCENT }\end{array}$ & $\begin{array}{l}\text { SULPUR } \\
\text { PERCENT }\end{array}$ & $\begin{array}{l}\text { MOISTOPE } \\
\text { PERCENT }\end{array}$ & $\begin{array}{l}\text { DEIGHT } \\
\text { PERCENT }\end{array}$ & $\begin{array}{c}\text { ASH } \\
\text { PERCENT }\end{array}$ & $\begin{array}{l}\text { SUIPUR } \\
\text { PERCENT }\end{array}$ & $\begin{array}{l}\text { MOISTURE } \\
\text { PERCENT }\end{array}$ \\
\hline $\begin{array}{r}84 \\
164\end{array}$ & $\begin{array}{r}8 M \\
16 M\end{array}$ & $\begin{array}{l}33.00 \\
46.60 \\
20.40\end{array}$ & $\begin{array}{l}13.17 \\
11.96 \\
11.56\end{array}$ & $\begin{array}{l}3.22 \\
1.68 \\
1.81\end{array}$ & $\begin{array}{l}3.00 \\
2.80 \\
2.58\end{array}$ & $\begin{array}{r}33.00 \\
79.60 \\
100.00\end{array}$ & $\begin{array}{l}13.17 \\
12.46 \\
12.28\end{array}$ & $\begin{array}{l}3.22 \\
2.32 \\
2.21\end{array}$ & $\begin{array}{l}3.00 \\
2.88 \\
2.82\end{array}$ & $\begin{array}{r}100.00 \\
67.00 \\
20.40\end{array}$ & & $\begin{array}{l}2.21 \\
1.72 \\
1.81\end{array}$ & $\begin{array}{l}2.82 \\
2.73 \\
2.58\end{array}$ \\
\hline
\end{tabular}

DATA FOP - REPUSE COAL.

THIS PRACTICN CONSTITOTES 11.1 PERCENT OP THE PEED.

\begin{tabular}{|c|c|c|c|c|c|c|c|c|c|c|c|c|c|}
\hline \multirow{2}{*}{\multicolumn{2}{|c|}{$\begin{array}{l}\text { SIZE } \\
\text { FRACTION }\end{array}$}} & \multicolumn{2}{|c|}{$\cdots---1$ DIRECT V } & \multicolumn{2}{|c|}{ VALUES $\cdots \cdots$} & \multicolumn{2}{|c|}{---- CUMULATIVE } & \multicolumn{2}{|c|}{ RET AINED----- } & \multicolumn{2}{|c|}{----- CU MULATIVE } & \multicolumn{2}{|c|}{ PASSED--- - - - } \\
\hline & & HEIGGT & ASH & SOLFOR & MOISTORE & REIGHT & ASH & SULPUR & MOISTURE & HEIGHT & A SH & SULPUR & MOISTO \\
\hline$E D$ & RETAINED & PERCENT & PERCENT & PEBCENT & PERCENT & PERCENT & PERCENT & PERCENT & PERCEN? & PERCENT & PERCENT & PERCENT & RC \\
\hline $\begin{array}{r}8 \% \\
164\end{array}$ & $\begin{array}{r}8 H \\
16 M\end{array}$ & $\begin{array}{l}23.80 \\
53.60 \\
22.60\end{array}$ & $\begin{array}{l}14.72 \\
14 . C 8 \\
14.96\end{array}$ & $\begin{array}{l}2.89 \\
2.76 \\
3.08\end{array}$ & $\begin{array}{l}3.00 \\
2.78 \\
2.60\end{array}$ & $\begin{array}{r}23.80 \\
77.40 \\
100.00\end{array}$ & $\begin{array}{l}14.72 \\
14.28 \\
14.43\end{array}$ & $\begin{array}{l}2.89 \\
2.80 \\
2.86\end{array}$ & $\begin{array}{l}3.00 \\
2.85 \\
2.79\end{array}$ & $\begin{array}{r}100.00 \\
76.20 \\
22.60\end{array}$ & $\begin{array}{l}14.43 \\
14.34 \\
14.96\end{array}$ & $\begin{array}{l}2.86 \\
2.85 \\
3.08\end{array}$ & $\begin{array}{l}2.79 \\
2.73 \\
2.60\end{array}$ \\
\hline
\end{tabular}

DATA FOB DRYPLO SEPARATION TEST 30.

PIGURES PROM PSOC 105 PEED SAMPLE.

DATA FOR -

* conposite **

THIS FRACTION CONSTITOTES 100.0 PERCENT OP THE PERD.

\begin{tabular}{|c|c|c|c|c|c|c|c|c|c|c|c|c|c|}
\hline \multirow{2}{*}{\multicolumn{2}{|c|}{$\begin{array}{c}\text { SIZE } \\
\text { FRACTION }\end{array}$}} & \multicolumn{2}{|c|}{-} & \multicolumn{2}{|c|}{ VAL DES $\cdots$} & \multicolumn{2}{|c|}{--- CUAULATIVE } & \multicolumn{2}{|c|}{ RETAINED - - - } & \multicolumn{2}{|c|}{---- CO HOLATIVE } & \multicolumn{2}{|c|}{ PASSED- } \\
\hline & & YEIGHT & ASH & SULFOR & MOISTURE & WEIGHT & $\mathrm{ASH}$ & SULPOR & MOISTURE & DEIGHT & A SH & SOLPOR & no \\
\hline ASSED & RETAINED & PERCENT & PERCENT & EERCENT & PERCENT & PERCENT & PERCENT & PERCENT & PERCENT & NT & PEQCENT & PERCENT & CENT \\
\hline $\begin{array}{r}8 n \\
16 n\end{array}$ & $\begin{array}{r}8 M \\
16 M\end{array}$ & $\begin{array}{l}48.71 \\
23.72\end{array}$ & $\begin{array}{l}10.31 \\
10.76 \\
10.93\end{array}$ & $\begin{array}{l}2.12 \\
1.75 \\
1.79\end{array}$ & $\begin{array}{l}2.99 \\
2.90 \\
2.12\end{array}$ & $\begin{array}{r}27.56 \\
76.28 \\
100.00\end{array}$ & $\begin{array}{l}10.31 \\
10.60 \\
10.68\end{array}$ & $\begin{array}{l}2.12 \\
1.88 \\
1.86\end{array}$ & $\begin{array}{l}2.99 \\
2.93 \\
2.74\end{array}$ & $\begin{array}{r}100.00 \\
72.44 \\
23.72\end{array}$ & $\begin{array}{l}10.68 \\
10.81 \\
10.93\end{array}$ & $\begin{array}{l}1.86 \\
1.76 \\
1.79\end{array}$ & $\begin{array}{l}2.74 \\
2.65 \\
2.12\end{array}$ \\
\hline
\end{tabular}


ANALYTICAL DATA.

DATA FOR DRYFLO SEPABATION TEST * 31. DATA FOR - PRODUCT COAL.
FIGURES PROU PSOC 105 PEED SAMPLE.

THIS FRACTION CONSTITUTES 71.3 PERCENT OP THE PEED.

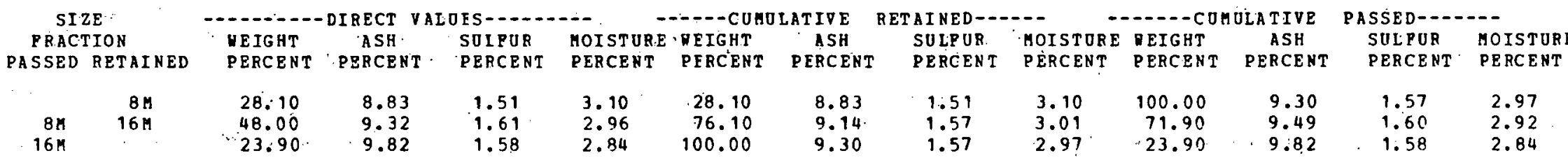

DATA FOR - MIDDLING COAL.

$\therefore$ THIS PRACTION CONSTITUTES 18.7 PERCENT OF THE PEED.

\begin{tabular}{|c|c|c|c|c|c|c|c|c|c|c|c|c|}
\hline SIZE & $-\cdots---$ & DIRECT & UES - - - & -- & $----2 c$ & LAT I & RETAI NED - & $\because-{ }_{-} \quad>$ & --- & AT IV B & PASSEL- & $\because-$ \\
\hline IION & VEIGHT & ASH & SUIPUR & MOISTORE & HEIGHT & ASH & SULPUR & MOISTURE & WEIGHT & ASH & SOLPUR & MOISTURE \\
\hline E PETAINED & PERCENT & PERCENT & PERCENT & PERCEN T & PERCENT & PERCENT & PERCENT & PERCENT & PERCENT & PRRCENT & PERCENT & PERCENT \\
\hline
\end{tabular}

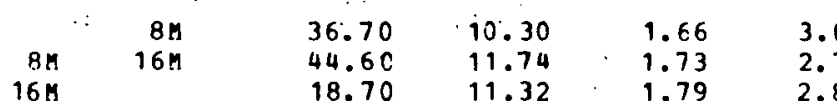

3.00
2.7 .8
2.80

$\begin{array}{rrr}36.70 & 10.30 & 1.66 \\ 81.30 & 11.09 & 1.70\end{array}$

$\begin{array}{rr}3.00 & -100.00 \\ 2.88 & 63.30\end{array}$

11.13 PERCENT PERCENT

TA FOR - REPUSE COAL.

THIS PRACTION CONSTITOTES 10.0 PERCENT OP THE PEED.

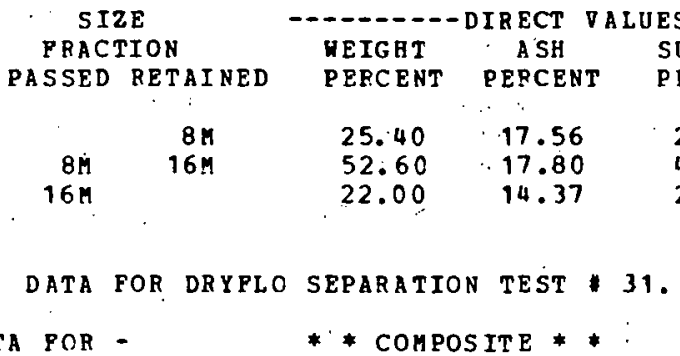

THIS PRACTION CONSTITUTES 10.0 PERCENT OP THE PEED.

ES- - - - -

-- --CUMULATIVE RETAINED-- - - - - SOLPUR MOISTURE HEIGAT ASH SULPUR MOISTURE:HEIGHT ASH STLPOR MOISTORE ERCENT PERCENT PERCENT PERCENT PRRCENT PERCFNT. PERCENT PERCENT PERCENT PERCENT

TA FOR -

* * conposite** :

$\begin{array}{llrrrrrrrr}2.43 & 2.80 & 25.40 & 17.56 & 2.43 & 2.80 & 100.00 & 16.98 & 3.50 & 2.69 \\ 4.23 & 2.60 & 78.00 & 17.72 & 3.64 & 2.67 & 74.60 & 16.79 & 3.86 & 2.65 \\ 2.98 & 2.76 & 100.00 & 16.98 & 3.50 & 2.69 & 22.00 & 14.37 & 2.98 & 2.76\end{array}$

ANALYTICAL DATA

PIG̈URES PROA PSOC 105 .PEED SAMPLE.

THIS FRACTION CONSTITOTES 100.0 PERCENT OF THE PEED.

\begin{tabular}{|c|c|c|c|c|c|c|c|c|c|c|c|c|c|}
\hline \multirow{2}{*}{\multicolumn{2}{|c|}{$\begin{array}{c}\text { SIZE } \\
\text { FRACTION } \\
\text { PASSED RETAINED }\end{array}$}} & \multicolumn{2}{|c|}{$\cdots-D$ DIRECT } & \multicolumn{2}{|c|}{ ALUES $\cdots$} & \multicolumn{2}{|c|}{-----CURULATIVE } & \multicolumn{2}{|c|}{ RETAI NED - - - } & \multicolumn{2}{|c|}{---- COROLAT IVE } & \multicolumn{2}{|c|}{ PASSED- } \\
\hline & & $\begin{array}{l}\text { WEIGHT } \\
\text { PERCENT }\end{array}$ & $\begin{array}{l}\text { ASH } \\
\text { PERCEN I }\end{array}$ & $\begin{array}{l}\text { SULPUR } \\
\text { PERCENT }\end{array}$ & $\begin{array}{l}\text { MOISTURE } \\
\text { PERCENT }\end{array}$ & $\begin{array}{l}\text { WEIGRT } \\
\text { PERCENT }\end{array}$ & $\begin{array}{c}\text { ASH } \\
\text { FERCENT }\end{array}$ & $\begin{array}{l}\text { SULPOR } \\
\text { PERCENT }\end{array}$ & $\begin{array}{l}\text { BOISTURE } \\
\text { PERCENT }\end{array}$ & $\begin{array}{l}\text { WEIGHT } \\
\text { PERCENT }\end{array}$ & $\begin{array}{c}\text { ASH } \\
\text { PERCENT }\end{array}$ & $\begin{array}{l}\text { SOLPUR } \\
\text { PERCENT }\end{array}$ & $\begin{array}{l}\text { MOISTURE } \\
\text { PERCENT }\end{array}$ \\
\hline $\begin{array}{r}84 \\
164\end{array}$ & $\begin{array}{r}8 n \\
16 n\end{array}$ & $\begin{array}{l}29.44 \\
47.82 \\
22.74\end{array}$ & $\begin{array}{r}9.93 \\
10.67 \\
10.49\end{array}$ & $\begin{array}{l}1.62 \\
1.92 \\
1.75\end{array}$ & $\begin{array}{l}3.05 \\
2.89 \\
2.83\end{array}$ & $\begin{array}{r}29.44 \\
77.26 \\
100.00\end{array}$ & $\begin{array}{r}9.93 \\
10.39 \\
10.49\end{array}$ & $\begin{array}{l}1.62 \\
1.81 \\
1.79\end{array}$ & $\begin{array}{l}2.95 \\
2.92\end{array}$ & $\begin{array}{r}100.00 \\
70.56 \\
22.74\end{array}$ & $\begin{array}{l}10.41 \\
10.62 \\
10.49\end{array}$ & & \\
\hline
\end{tabular}


ANALTICAL JATA

DATA FOR DRYPLC SEPABATION TEST 32.

PIGURES PROA PSOC 105 PEED SAMPLE.

DATA FOR - PRODUCT COAL。

THIS PRACTION CONSTITUTES 87.5 PERCENT OP THE PERD.

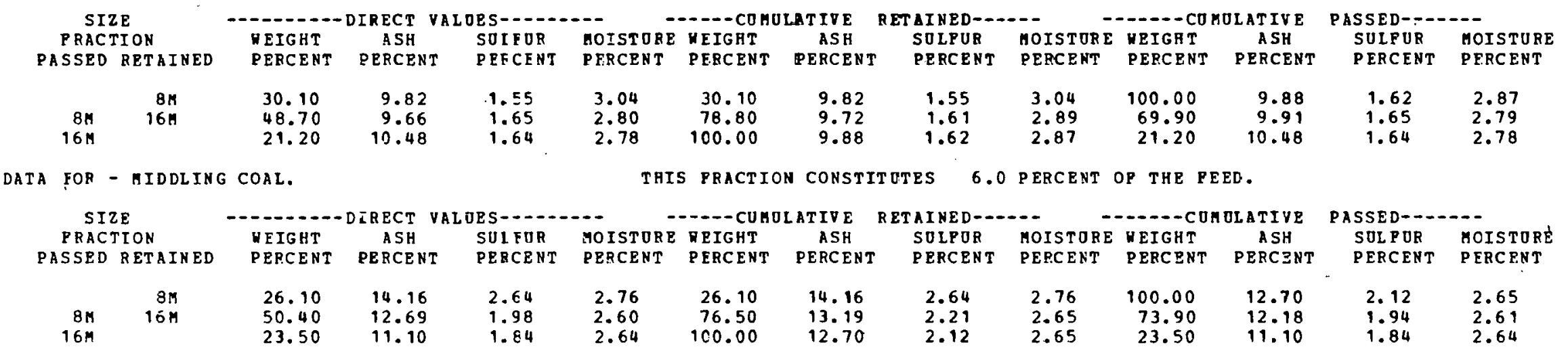

DATA FOR - REPUSE COAL.

THIS PRACTIOL CONSTITUTES 6.5 PERCENT OP THE PEED.

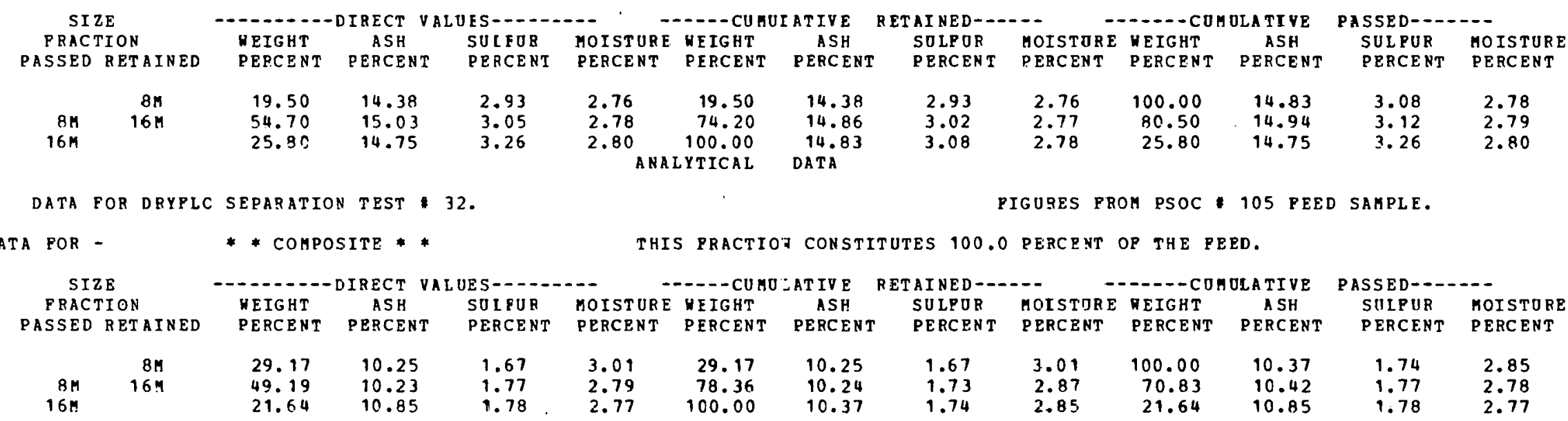




\section{AHALTTICAL DATA}

DATA FOB DRYPLO SEPARATIOH TEST 33. DATA FOR - PRODUCT COAL.
FIGURES PROM PSOC 208 PEED SAMPLE.

THIS FRACTION CONSTITUTES 63.9 PERCENT OF THE PEED.

\begin{tabular}{|c|c|c|c|c|c|c|c|c|c|c|c|c|c|}
\hline \multirow{2}{*}{\multicolumn{2}{|c|}{$\begin{array}{c}\text { SIZE } \\
\text { FRACTIOON }\end{array}$}} & \multicolumn{2}{|c|}{$---1-$ D IRECT } & \multicolumn{2}{|c|}{ VALUES $-\cdots$} & \multicolumn{2}{|c|}{--- -CUROLATIVE } & \multicolumn{2}{|c|}{ RETAI NED - } & \multicolumn{2}{|c|}{$-\ldots$ CUM OLATIVE } & \multicolumn{2}{|c|}{ PASSED $\cdots$} \\
\hline & & HEIGHT & ASH & SOLPOR & MOISTORE & DEIGHT & ASH & SOLPOR & MOISTORE & MEIGHT & ASH & SULFOR & MOISTORE \\
\hline & RETAINED & PERCENT & PERCENTT & PERCENT & PERCENT & PEBCENT & PERCENT & PERCENT & ENT & $\mathrm{PE}$ & PERCENT & PERCENT & PERCENT \\
\hline $\begin{array}{r}8 M \\
16 M\end{array}$ & $\begin{array}{r}8 M \\
16 \mathrm{H}\end{array}$ & $\begin{array}{r}6.50 \\
64.30 \\
29.20\end{array}$ & $\begin{array}{l}6.80 \\
5.94 \\
5.67\end{array}$ & $\begin{array}{l}2.03 \\
2.02 \\
2.18\end{array}$ & $\begin{array}{l}3.20 \\
3.40 \\
3.58\end{array}$ & $\begin{array}{r}6.50 \\
70.80 \\
100.00\end{array}$ & $\begin{array}{l}6.02 \\
6.00\end{array}$ & $\begin{array}{l}2.03 \\
2.02 \\
2.07\end{array}$ & $\begin{array}{l}3.20 \\
3.38 \\
3.44\end{array}$ & $\begin{array}{r}100.00 \\
.93 .50 \\
29.20\end{array}$ & $\begin{array}{l}5.95 \\
5.97\end{array}$ & $\begin{array}{l}2.07 \\
2.18\end{array}$ & $\begin{array}{l}3.46 \\
3.58\end{array}$ \\
\hline
\end{tabular}

DATA POR - MIDDLING COAL.

THIS PRACTION CONSTITUTES 26.7 PERCENT OF THE PEED.

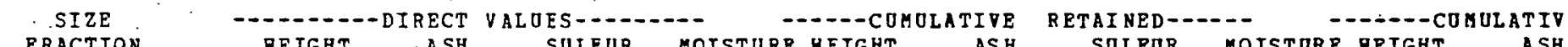

DEIGAT ASH SUIFUB MOISTURE WEIGHT ASH SULPOR MOISTURE TEIGHT

PASSED RET AINED PERCENT PERCENT SUIEUQ

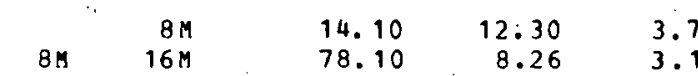

DATA FOR - REPUSE COAL.

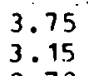

3.15
2.78 $\begin{array}{lr}3.00 & 14.10 \\ 3.38 & 92.20 \\ 3.36 & 100.00\end{array}$

12.30
8.88
8.81

3.75
3.24
3.21

3.00

3.32
3.32

100.00
85.90

85.90
7.80

8.81
8.24

8.24
8.05

THIS FRACTION CONSTITOTES 9.4 PERCENT OP THE PEED.

\begin{tabular}{|c|c|c|c|c|c|c|c|c|c|c|c|c|c|}
\hline \multicolumn{2}{|c|}{$\begin{array}{c}\text { SIZE } \\
\text { FRACTION }\end{array}$} & ----- & IRECT $V$ & JES - - & -- & $-\operatorname{con} c$ & ATIVE & rAI NED - & - & UI & JLATIVE & PASSED $-\cdots$ & - \\
\hline $\begin{array}{l}\text { FRAC } \\
\text { SSED }\end{array}$ & $\begin{array}{l}\text { RION } \\
\text { RETAINED }\end{array}$ & $\begin{array}{l}\text { HEIGHT } \\
\text { PEPCENT }\end{array}$ & $\begin{array}{c}\text { A SH } \\
\text { PERCEN? }\end{array}$ & $\begin{array}{l}\text { SUIPUR } \\
\text { PERCENT }\end{array}$ & $\begin{array}{l}\text { MCISTURE } \\
\text { PERCENT }\end{array}$ & $\begin{array}{l}\text { MEIGHT } \\
\text { PERCENT }\end{array}$ & $\begin{array}{c}\text { ASH } \\
\text { PERCENT }\end{array}$ & $\begin{array}{l}\text { SULPUR } \\
\text { PBRCENT }\end{array}$ & $\begin{array}{l}\text { MOISTORE } \\
\text { PERCENT }\end{array}$ & $\begin{array}{l}\text { NEIGHT } \\
\text { PERCENT }\end{array}$ & $\begin{array}{c}\text { ASH } \\
\text { PERCENT }\end{array}$ & $\begin{array}{l}\text { SOLPDR } \\
\text { PERCENT }\end{array}$ & $\begin{array}{l}\text { YOISTORE } \\
\text { PERCENT }\end{array}$ \\
\hline $\begin{array}{r}8 M \\
16 M\end{array}$ & $\begin{array}{r}8 \mathrm{M} \\
16 \mathrm{~m}\end{array}$ & $\begin{array}{r}7.70 \\
69.10 \\
23.20\end{array}$ & $\begin{array}{l}31.74 \\
22.00 \\
16.64\end{array}$ & $\begin{array}{r}10.28 \\
7.91 \\
5.94\end{array}$ & $\begin{array}{l}2.60 \\
3.04 \\
2.60\end{array}$ & $\begin{array}{r}7.70 \\
76.80 \\
100.00\end{array}$ & $\begin{array}{l}31.74 \\
22.98 \\
21.51\end{array}$ & $\begin{array}{r}10.28 \\
8.15 \\
7.61\end{array}$ & $\begin{array}{l}2.60 \\
3.00 \\
2.90\end{array}$ & $\begin{array}{r}100.00 \\
92.30 \\
23.20\end{array}$ & $\begin{array}{l}29.51 \\
20.65 \\
16.64\end{array}$ & $\begin{array}{l}7.61 \\
7.39 \\
5.84\end{array}$ & $\begin{array}{l}2.90 \\
2.93 \\
2.60\end{array}$ \\
\hline
\end{tabular}

DATA POR DRYPLO SEPARATION TEST $\$ 33$.

PIGURES PROA PSOC * 208 PEED SAMPLE. DATA POR -

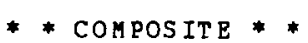

SIZE FRACTION

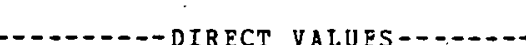

PASSED RETAINED -----COMOLATIVE RETAINPD - -

$$
\begin{array}{r}
8 \mathrm{H} \\
16 \mathrm{M}
\end{array}
$$$$
\begin{array}{r}
8 M \\
16 M
\end{array}
$$
PERCENT PEBCENT SUIPUR
PERCENT

$$
\text { ASH }
$$$$
\text { TAI NED - }
$$
MOISTURE UEIGHT SULPUR MOISTURE UEIGHT ASH ASH PASSED-- - - SULPOR MOISTURE $\begin{array}{lll}8.64 & 11.28 & 3.47\end{array}$

$8 \mathrm{H}$
$16 \mathrm{M}$

68.44

8.17
.7 .17

3.92
2.58

3.06
3.36
3.47

8.64
77.08
100.00

11.28
8.52

3.47

3.0 .6

100.00

8.21

8.21

2.89

3.36

22.92

7.17

2.89
2.84

2.84
2.58

3.36 3.47 
ANALYTICAL DATA

DATA FOR DPYPLO SEPARATION TEST * 34. DATA. FOR - PRODUCT COAL.

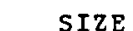$$
\text { SIZE }
$$
PRACTION
PIZE HEIGHT DIRECT VAL ASH
PERCENT EERCENT

$8 \mathrm{M}$

$8 M \quad 16 n$

7.90
64.80
27.30

8.36
6.32
6.29

27.30

THIS PRACTION CONSTITUTES 61.8 PERCERT OP THE PEED.

SUIFOR
PRRCENT
2.42

MOISTURE DEIGHT CULATIVE RETAIKED-
SOLFOR

SOLFOR MOISTORE HEIGHT ASH

A SH
PERCENT

PASSED--.-.-

SULPUR MOISTURE

$2.18 \quad 7.90$

8.36

2.42

PERCENT PERCENT

PERCENT PERCENT

72.70

6.54
6.47

2.33

$\begin{array}{rr}2.18 & 100.00 \\ 2.23 & 92.10\end{array}$

$\begin{array}{lll}6.47 & 2.28 & 2.21 \\ 6.31 & 2.27 & 2.22\end{array}$

DATA POR - MIDDLING COAL.

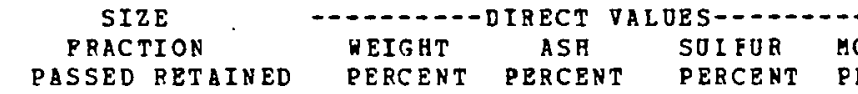

PASSED RETAINED

$\begin{array}{rrrrrr} & 8 M & 12.80 & 19.43 & 3.16 & 2.04 \\ 8 K & 16 M & 65.40 & 9.74 & 3.78 & 2.20 \\ 16 M & & 21.80 & 7.36 & 2.67 & 2 .\end{array}$

DATA POR - REFUSE COAL.

2.16

THIS PRACTION CONSTITUTES 26.5 PERCEHT OP THE PEED.

$$
\text { SIZE }
$$
FRACTION
PASSED RETAINED

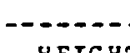

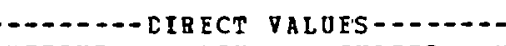

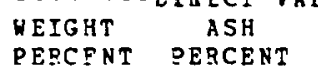
SULFOR SULFOR

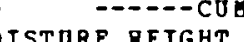
ATIVE RETAINED--
ASH
SOLPUB - ----- CUROLAT 6.292 .14

$\begin{array}{rrrrrrrrrrrrrrr} & 8 M & 7.80 & 26.91 & 9.01 & 1.76 & 7.80 & 26.91 & 9.01 & 1.76 & 100.00 & 24.06 & 9.48 & 1.87 \\ 8 M & 16 M & 68.90 & 26.80 & 10.57 & 1.84 & 76.70 & 26.81 & 10.41 & 1.83 & 92.20 & 23.82 & 9.52 & 1.88 \\ 16 M & & 23.30 & 15.00 & 6.40 & 2.00 & 100.00 & 24.06 & 9.48 & 1.87 & 23.30 & 15.00 & 6.40 & 2.00\end{array}$

DATA FOR DRYPLC SEPARATION TEST * 34.

FIGURES PROM PSOC 208 PEED SAMPLE.

DATA FOR -

* *onposite* *

\begin{tabular}{|c|c|c|c|c|c|c|c|c|c|c|c|c|c|}
\hline \multirow{2}{*}{\multicolumn{2}{|c|}{$\begin{array}{c}\text { SIZE } \\
\text { FRACTION }\end{array}$}} & \multicolumn{2}{|c|}{$\cdots-\cdots$ DIRECT } & \multicolumn{2}{|c|}{ PALUES- } & \multicolumn{2}{|c|}{--- CUMULATIVE } & \multicolumn{2}{|c|}{ RETAINED-D } & \multicolumn{2}{|c|}{$----C D$ COLATIVE } & \multicolumn{2}{|c|}{ PASSED- } \\
\hline & & WEIGHT & ASH & SOLEOR & DOISTURE & DEIGHT & $\mathrm{ASH}$ & SOLFOR & MOISTURE & NEIGHT & $\mathbf{A} \mathbf{S H}$ & SULFOR & MCISTURE \\
\hline ASSED & RET AINED & PERCENT & PERCENT & PERCBNT & PERCENT & PERCENT & PERCENT & PERCENT & PERCENT & PERCENT & PERCENT & PERCENT & PERCENT \\
\hline $\begin{array}{r}8 \% \\
16 \%\end{array}$ & $\begin{array}{r}8 M \\
16 n\end{array}$ & $\begin{array}{r}9.19 \\
65.44 \\
25.37\end{array}$ & $\begin{array}{r}11.34 \\
9.75 \\
7.47\end{array}$ & $\begin{array}{l}3.35 \\
3.72 \\
2.72\end{array}$ & $\begin{array}{l}2.09 \\
2.18 \\
2.15\end{array}$ & $\begin{array}{r}9.19 \\
74.63 \\
100.00\end{array}$ & $\begin{array}{r}11.34 \\
9.94 \\
9.32\end{array}$ & $\begin{array}{l}3.35 \\
3.68 \\
3.43\end{array}$ & $\begin{array}{l}2.09 \\
2.17 \\
2.15\end{array}$ & $\begin{array}{r}100.00 \\
90.81 \\
25.37\end{array}$ & $\begin{array}{l}9.32 \\
9.11 \\
7.47\end{array}$ & $\begin{array}{l}3.43 \\
3.44 \\
2.72\end{array}$ & $\begin{array}{l}2.16 \\
2.17 \\
2.15\end{array}$ \\
\hline
\end{tabular}

THIS FRACTION CONSTITUTES 100.0 PERCENT OP THE PEED. 
ANALYTCAL DATA

DATA FOR DRYPLO SEPARATION TEST 35

DATA FOR - PRODUCT COAL.

PSOC 208 PLUS MAGMETITE PEED.

TRIS PRACTION CONSTITUTES 80.9 PERCENT OP THE PEED.

\begin{tabular}{|c|c|c|c|c|c|c|c|c|c|c|c|c|c|}
\hline \multirow{2}{*}{\multicolumn{2}{|c|}{$\begin{array}{c}\text { SIZE } \\
\text { FRACTION }\end{array}$}} & 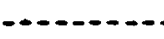 & DIRECT $v$ & UES - & - & \multicolumn{2}{|c|}{---- -CUMULATIVE } & \multicolumn{2}{|c|}{ RETAINED - } & \multicolumn{2}{|c|}{---- COHOLATIVE } & \multicolumn{2}{|c|}{ PASSED- - - - } \\
\hline & & VEIGHT & ASH & SUIFOR & KOIST URE & WEIGHT & ASH & SULF OR & MOISTURE & VEIGHT & ASH & SOLPOR & MOISTURE \\
\hline & RETAINED & NT & 'ERCENT & PERCENT & PERCENT & PERCENT & PERCENT & PERCENT & PERCENT & PERCENT & PERCENT & PERCENT & PERCENT \\
\hline $\begin{array}{r}1 / 4 \mathrm{H} \\
8 \mathrm{H} \\
16 \mathrm{M}\end{array}$ & $\begin{array}{r}8 M \\
16 M\end{array}$ & $\begin{array}{r}9.30 \\
65.40 \\
25.30\end{array}$ & $\begin{array}{l}9.73 \\
8.04 \\
7.43\end{array}$ & $\begin{array}{l}2.99 \\
2.48 \\
2.51\end{array}$ & $\begin{array}{l}3.60 \\
3.76 \\
3.88\end{array}$ & $\begin{array}{r}9.30 \\
74.70 \\
100.00\end{array}$ & $\begin{array}{l}9.73 \\
8.25 \\
8.04\end{array}$ & $\begin{array}{l}2.99 \\
2.54 \\
2.54\end{array}$ & $\begin{array}{l}3.60 \\
3.74 \\
3.78\end{array}$ & $\begin{array}{r}100.00 \\
90.70 \\
25.30\end{array}$ & $\begin{array}{r}8.04 \\
.7 .87 \\
7.43\end{array}$ & $\begin{array}{l}2.54 \\
2.49 \\
2.51\end{array}$ & $\begin{array}{l}3.78 \\
3.79 \\
3.88\end{array}$ \\
\hline
\end{tabular}

DATA FOR - MIDDLING COAL: : THIS PRACTION CONSTITUTES 10.3 PERCËT OP THE FEED.

\begin{tabular}{|c|c|c|c|c|c|c|c|c|c|c|c|c|c|}
\hline \multirow{2}{*}{\multicolumn{2}{|c|}{$\begin{array}{c}\text { SIZE } \\
\text { FRACTION }\end{array}$}} & \multicolumn{2}{|r|}{ IRECT $V$} & \multicolumn{2}{|l|}{ UES $=-\ldots$} & \multicolumn{2}{|c|}{---- CUMOLATIVE } & \multicolumn{2}{|c|}{ RETAINED - } & \multicolumn{2}{|c|}{$-\ldots-C$ COMOLAT IVE } & \multicolumn{2}{|c|}{ PASSED $\cdots-\cdots$} \\
\hline & & WEIGHT & ÄSH & SUIFUR & MOISTURE & VEIGHT & AS H H & SULFOR & MOISTDRE & REIGHT. & AS & SULPUR & \\
\hline ASSED & RETAINED & PERCENT & PERCENT & PERCENT & PERCENT & PERCENT & PERCENT & PERCENT & PERCENT & PERCENT & PERCENT & PERCENT & PERCE \\
\hline $\begin{array}{r}1 / 4 n \\
8 m \\
16 M\end{array}$ & $\begin{array}{r}8 M \\
16 M\end{array}$ & $\begin{array}{r}9.90 \\
67.00 \\
23.10\end{array}$ & $\begin{array}{r}17.76 \\
15.28 \\
9.83\end{array}$ & $\begin{array}{l}5.14 \\
5.02 \\
3.59\end{array}$ & $\begin{array}{l}3.48 \\
3.49 \\
3.79\end{array}$ & $\begin{array}{r}9.90 \\
76.90 \\
100.00\end{array}$ & $\begin{array}{l}17.76 \\
15.60 \\
14.27\end{array}$ & $\begin{array}{l}5.14 \\
5.04 \\
4.70\end{array}$ & $\begin{array}{l}3.48 \\
3.49 \\
3.56\end{array}$ & $\begin{array}{r}100.90 \\
90.10 \\
23.10\end{array}$ & $\begin{array}{r}14.27 \\
13.88 \\
9.83\end{array}$ & $\begin{array}{l}4.65 \\
3.59\end{array}$ & $\begin{array}{l}3.56 \\
3.57 \\
3.79\end{array}$ \\
\hline
\end{tabular}

DATA POR - REPUSE COAL.

THIS PRACTION CONSTITUTES 8.8 PERCENT OP THE PEED.

\begin{tabular}{|c|c|c|c|c|c|c|c|c|c|c|c|c|c|}
\hline \multirow{2}{*}{\multicolumn{2}{|c|}{$\begin{array}{c}\text { SIZE } \\
\text { FRACTION }\end{array}$}} & \multicolumn{6}{|c|}{ - DIRECT $:$ VALUES -1} & \multicolumn{2}{|c|}{ RETAI RED-- - - } & \multicolumn{2}{|c|}{ - - - CUAOLAT IVE } & \multicolumn{2}{|c|}{ PASSED- - - - : } \\
\hline & & $\begin{array}{l}\text { NEIGHT } \\
\text { PERC.ENT }\end{array}$ & $\begin{array}{c}\text { ASH } \\
\text { PERCENT }\end{array}$ & $\begin{array}{l}\text { SOIFOF } \\
\text { PEFCENT }\end{array}$ & $\begin{array}{l}\text { MOISTORE } \\
\text { PERCENT }\end{array}$ & $\begin{array}{l}\text { WEIGHT } \\
\text { PERCENTT }\end{array}$ & $\begin{array}{c}\text { ASH } \\
\text { PERCENT }\end{array}$ & $\begin{array}{l}\text { SOLFOR } \\
\text { PERCENT }\end{array}$ & $\begin{array}{l}\text { MOISTURE } \\
\text { PERCENT }\end{array}$ & $\begin{array}{l}\text { REIGHT } \\
\text { PERCENT }\end{array}$ & $\begin{array}{c}\text { A SH } \\
\text { PERCENT }\end{array}$ & $\begin{array}{l}\text { SOLFUR } \\
\text { PERCENT }\end{array}$ & $\begin{array}{l}\text { MOISTURE } \\
\text { PRRCENT }\end{array}$ \\
\hline $\begin{array}{r}1 / 4 " \\
8 M \\
16 M\end{array}$ & $\begin{array}{r}8 M \\
16 n\end{array}$ & $\begin{array}{r}6.60 \\
66.50 \\
26.90\end{array}$ & $\begin{array}{l}30.56 \\
20.84 \\
14.55\end{array}$ & $\begin{array}{r}10.58 \\
9.12 \\
7.05\end{array}$ & $\begin{array}{l}3.60 \\
3.32 \\
3.58\end{array}$ & $\begin{array}{r}6.60 \\
73.10 \\
100.00\end{array}$ & $\begin{array}{l}30.56 \\
21.72 \\
19.79\end{array}$ & $\begin{array}{r}10.58 \\
9.25 \\
8.66\end{array}$ & $\begin{array}{l}3.60 \\
3.35 \\
3.41\end{array}$ & $\begin{array}{r}100.00 \\
93.40 \\
26.90\end{array}$ & $\begin{array}{l}19.79 \\
19.03 \\
14.55\end{array}$ & $\begin{array}{l}8.66 \\
8.52 \\
7.05\end{array}$ & $\begin{array}{l}3.41 \\
3.39 \\
3.58\end{array}$ \\
\hline
\end{tabular}

DATA FOR DRYFLO SEPARATION TEST 35

PSOC 208 PLUS MAGNETTE PEED.

DATA POR -

* * conposite * *

THIS PRACTION CONSTITOTES 100.0 PERCENT OP THE PEED.

\begin{tabular}{|c|c|c|c|c|c|c|c|c|c|c|c|c|c|}
\hline \multirow{2}{*}{\multicolumn{2}{|c|}{$\begin{array}{c}\text { SIZE } \\
\text { FRACTION }\end{array}$}} & $----n--2$ & $\mathrm{ECT}$ & UES-- - - & - & \multicolumn{2}{|c|}{------CURULATIVE } & \multicolumn{2}{|c|}{ RETAY NED----- } & \multicolumn{2}{|c|}{----- CURULAT IVE } & \multicolumn{2}{|l|}{ PAS } \\
\hline & & $\begin{array}{l}\text { WEIGHT } \\
\text { PERCENT }\end{array}$ & $\begin{array}{c}\text { ASH } \\
\text { PERCENT }\end{array}$ & $\begin{array}{l}\text { SOIEOR } \\
\text { PERCENT }\end{array}$ & $\begin{array}{l}\text { MOIST ORE } \\
\text { PERCENT }\end{array}$ & $\begin{array}{l}\text { QEIGHT } \\
\text { PERCENT }\end{array}$ & $\begin{array}{c}\text { ASH } \\
\text { PERCENT }\end{array}$ & $\begin{array}{l}\text { SULPUR } \\
\text { PERCENT }\end{array}$ & $\begin{array}{l}\text { MOISTORE } \\
\text { PERCENT }\end{array}$ & $\begin{array}{l}\text { NEIGHT } \\
\text { PERCENT }\end{array}$ & $\begin{array}{c}\text { ASH } \\
\text { PERCENT }\end{array}$ & $\begin{array}{l}\text { SULFUR } \\
\text { PERCENT }\end{array}$ & $\begin{array}{l}\text { MOISTURE } \\
\text { PERCENT }\end{array}$ \\
\hline $\begin{array}{r}1 / 4 n \\
8 \% \\
16 \mathrm{H}\end{array}$ & $\begin{array}{r}8 M \\
16 M\end{array}$ & $\begin{array}{r}9.12 \\
65.66 \\
25.21\end{array}$ & $\begin{array}{r}11.95 \\
9.94 \\
8.32\end{array}$ & $\begin{array}{l}3.71 \\
3.34 \\
3.04\end{array}$ & $\begin{array}{l}3.59 \\
3.69 \\
3.84\end{array}$ & $\begin{array}{r}9.12 \\
74.79 \\
100.00\end{array}$ & $\begin{array}{r}10.19 \\
9.72\end{array}$ & $\begin{array}{l}3.71 \\
3.38 \\
3.30\end{array}$ & & $\begin{array}{r}100.00 \\
90.88 \\
25.21\end{array}$ & & $\begin{array}{l}3.30 \\
3.26 \\
3.04\end{array}$ & \\
\hline
\end{tabular}




\section{ANALYTICAL DATA}

DATA FOR DRYPLO SEPARATION TEST $\$ 36$

DATA POR - PRODOCT COAL.
PSOC 208 PLUS MAGNETITE PEED.

THIS PRACTIOA CONSTITDTES 82.8 PERCENT OP THE PEED.

\begin{tabular}{|c|c|c|c|c|c|c|c|c|c|c|c|c|c|}
\hline \multirow{2}{*}{\multicolumn{2}{|c|}{$\begin{array}{c}\text { SIZE } \\
\text { PRACTION }\end{array}$}} & \multicolumn{2}{|c|}{$\cdots---$ DIRECT } & 2 & - & \multicolumn{2}{|c|}{-----CUHU二ATIVE } & \multicolumn{2}{|c|}{ RETAINED--.-- } & \multicolumn{2}{|r|}{ HTI } & \multicolumn{2}{|c|}{ PASSED- } \\
\hline & & HEIGHT & A SH & SULPOR & MOISTURE & HEIGHT & ASH & SULI & MOISTJRE & NEIGHT & ASH & SUI & MOISTUP \\
\hline PASSED & KET AI NED & PERCENT & PERCENT & PERCENT & PERCENT & PERCENT & PERCENT & PERCEN T & PERCENT & PERCENT & PERCENT & PERCENT & PERCENT \\
\hline $\begin{array}{r}1 / 4 " \\
8 M \\
16 M\end{array}$ & $\begin{array}{r}84 \\
164\end{array}$ & $\begin{array}{l}10.00 \\
65.70 \\
24.30\end{array}$ & $\begin{array}{l}7.58 \\
6.71\end{array}$ & $\begin{array}{l}2.64 \\
2.22\end{array}$ & $\begin{array}{l}3.02 \\
3.50 \\
3.60\end{array}$ & $\begin{array}{r}10.00 \\
75.70 \\
100.00\end{array}$ & $\begin{array}{l}7.96 \\
7.66\end{array}$ & $\begin{array}{l}2.64 \\
2.54\end{array}$ & $\begin{array}{l}3.02 \\
3.44 \\
3.48\end{array}$ & $\begin{array}{r}100.00 \\
90.00 \\
24.30\end{array}$ & & & $\begin{array}{l}3.48 \\
3.53 \\
3.60\end{array}$ \\
\hline
\end{tabular}

DATA FOR - MIDDLING COAL.

THIS PRACTION CONSTITUTES 9.1 PERCENT OP THE PEED.

\begin{tabular}{|c|c|c|c|c|c|c|c|c|c|c|c|c|c|}
\hline \multicolumn{2}{|c|}{ SIZE } & 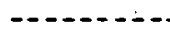 & DIRECT $V$ & JES $\cdots$ & -- & $\ldots$ CUn & ATIVE & RETAINED - & -- & $-\cdots--c 0$ & ULATIVE & PASSED- & -- \\
\hline FRAC & IION & WEIGHT & A SH & SULFOR & MOISTUR3 & NEIGHT & AS H & SULPUR & MOISTURE & WEIGHT & ASH & SUL & MOISTURE \\
\hline ASSED & RETAINED & PERCENT & PERCENT & PERCENT & PERCENT & PERCENT & PERCENT & PERCENT & P PRCENT & PERCENT & PERCENT & PERCENT & PERCENT \\
\hline $\begin{array}{r}1 / 4 n \\
8 m \\
16 m\end{array}$ & $\begin{array}{r}8 M \\
16 M\end{array}$ & $\begin{array}{r}9.60 \\
66.70 \\
23.70\end{array}$ & $\begin{array}{r}16.80 \\
13.77 \\
9.23\end{array}$ & $\begin{array}{l}5.41 \\
4.67 \\
3.18\end{array}$ & $\begin{array}{l}3.12 \\
3.30 \\
3.38\end{array}$ & $\begin{array}{r}9.60 \\
76.30 \\
100.00\end{array}$ & $\begin{array}{l}16.80 \\
14.15 \\
12.98\end{array}$ & $\begin{array}{l}5.41 \\
4.76 \\
4.39\end{array}$ & $\begin{array}{l}3.12 \\
3.28 \\
3.30\end{array}$ & $\begin{array}{r}100.00 \\
90.40 \\
23.70\end{array}$ & $\begin{array}{r}12.98 \\
12.58 \\
9.23\end{array}$ & $\begin{array}{l}4.39 \\
4.28 \\
3.18\end{array}$ & $\begin{array}{l}3.30 \\
3.32 \\
3.38\end{array}$ \\
\hline
\end{tabular}

DATA FOP - REFUSE COAL.

THIS FRACTION CONSTITOTES 8.1 PERCENT OF THE PEED.

\begin{tabular}{|c|c|c|c|c|c|c|c|c|c|c|c|c|c|}
\hline \multirow{2}{*}{\multicolumn{2}{|c|}{$\begin{array}{c}\text { SIZE } \\
\text { FRACTION }\end{array}$}} & \multicolumn{2}{|c|}{$\cdots$ DIRECT V } & \multicolumn{2}{|c|}{ ALOES } & \multicolumn{2}{|c|}{---- CUMULATIVE } & \multicolumn{2}{|c|}{ RETAINED - . } & \multicolumn{2}{|c|}{$-\cdots-$ CUMULAT IVE } & \multicolumn{2}{|c|}{ PASSED- } \\
\hline & & HEIGHT & A SH & SULPOR & MOISTURE & WEIGHT & AS H & SULPUR & MOISTURE & WEIGHT & A SH & SULPUR & \\
\hline PASSED & RETAINED & PERCENT & PRRCENT & PERCENT & PERCENT & PERCENT & PEPCENT & PERCENT & PERCENT & PERCENT & PEFCENT & PEPCENT & PERC \\
\hline $\begin{array}{r}1 / 4 " \\
84 \\
164\end{array}$ & $\begin{array}{r}8 M \\
16 M\end{array}$ & $\begin{array}{r}5.80 \\
67.70 \\
26.50\end{array}$ & $\begin{array}{l}33.04 \\
23.84 \\
15.56\end{array}$ & $\begin{array}{l}9.59 \\
8.14 \\
5.63\end{array}$ & $\begin{array}{l}2.69 \\
2.98 \\
3.35\end{array}$ & $\begin{array}{r}5.80 \\
73.50 \\
100.00\end{array}$ & $\begin{array}{l}33.04 \\
24.57 \\
22.18\end{array}$ & $\begin{array}{l}9.59 \\
8.25 \\
7.56\end{array}$ & $\begin{array}{l}2.69 \\
2.96 \\
3.06\end{array}$ & $\begin{array}{r}100.00 \\
94.20 \\
26.50\end{array}$ & $\begin{array}{l}22.18 \\
21.51 \\
15.56\end{array}$ & $\begin{array}{l}7.56 \\
7.43 \\
5.63\end{array}$ & $\begin{array}{l}3.06 \\
3.08 \\
3.35\end{array}$ \\
\hline
\end{tabular}

DATA POR DRYFLO SEPARATION TEST: 36

PSOC 2 C8 plus magetite peEd.

DATA FOR -

* * composit E * *

THIS FRACTION CONSTITOTES 100.0 PERCENT OP THE PEED.

TIZE WEIGHT DIRECT VALOES-

- - CUMULATIVE RETAINED-_...-

- - - - - COMULATIVE

FRACTION

WEIGHT ASH

SOLPOR

MOISTURE WEIGHT

AS H

SOLPOR

OISTURE HEIGHT

BSH

NT

$-1$

\begin{tabular}{|c|c|c|c|c|c|c|c|c|c|c|c|c|c|}
\hline $\begin{array}{r}1 / 4 M \\
8 M \\
16 M\end{array}$ & $\begin{array}{r}8 M \\
16 M\end{array}$ & $\begin{array}{r}9.62 \\
65.95 \\
24.42\end{array}$ & $\begin{array}{r}12.16 \\
9.50 \\
7.71\end{array}$ & $\begin{array}{l}3.21 \\
3.28 \\
2.60\end{array}$ & $\begin{array}{l}3.01 \\
3.44 \\
3.56\end{array}$ & $\begin{array}{r}9.62 \\
75.58 \\
100.00\end{array}$ & $\begin{array}{r}12.16 \\
9.84 \\
9.32\end{array}$ & $\begin{array}{l}3.21 \\
3.28 \\
3.11\end{array}$ & $\begin{array}{l}3.01 \\
3.38 \\
3.43\end{array}$ & $\begin{array}{r}100.00 \\
90.38 \\
24.42\end{array}$ & $\begin{array}{l}9.32 \\
9.02 \\
7.71\end{array}$ & $\begin{array}{l}3.11 \\
3.10 \\
2.60\end{array}$ & $\begin{array}{l}3.43 \\
3.47 \\
3.56\end{array}$ \\
\hline
\end{tabular}




\section{ANALYTICAL DATA}

DATA FOR DRYPLO SEPARATION TEST * 37 DATA POR - PRODUCT COAL.

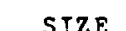
PASSED RETAINED

MEIGHT DIRECT VALOES ASH
PERCENT PERCENT

LOBSSOLBOR SULPOR

$\begin{array}{ll}11.80 & 7.87 \\ 64.90 & 8.37\end{array}$

$$
\begin{aligned}
& 0.50 \\
& 0.57 \\
& 0.58
\end{aligned}
$$

$16 n$ 8.57

PSOC 86 PLUS HAGNETITE PEED.

THIS PRACTION CONSTITUTES 79.6 PERCENT OF THE PEED.

DATA FOR - MIDDLING COAL.

10.50
10.
10.78

10.80
10.78

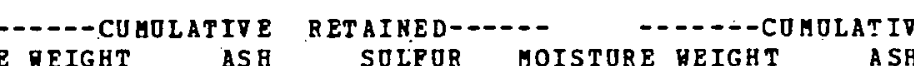
SOLPOR MOISTORE HEIGHT ASH ASH
PERCENT

ASSED-D.-.-SULPUR MOISTORE PERCENT PERCENT

11.8 .0
76.70

7.87
8.29

$$
0.50
$$

10.50

PERCENT

8.36
8.42

$\begin{array}{ll}0.56 & 10.77\end{array}$

100.00

8.36

0.56

10.77

88.20

$\begin{array}{lll}8.57 & 0.58 & 10.81 \\ 8.58 & 10.78\end{array}$

\begin{tabular}{|c|c|c|c|c|c|c|c|c|c|c|c|c|c|}
\hline $\begin{array}{l}\text { PBACT } \\
\text { PASSED }\end{array}$ & $\begin{array}{l}E \\
\text { RION } \\
\text { RETAINED }\end{array}$ & $\begin{array}{l}\text { REIGRT } \\
\text { PERCENT }\end{array}$ & $\begin{array}{c}\text { ASH } \\
\text { PEQCENT }\end{array}$ & $\begin{array}{l}\text { SULEUR } \\
\text { PERCENT }\end{array}$ & $\begin{array}{l}\text { MOISTORE } \\
\text { PERCENT }\end{array}$ & $\begin{array}{l}\text { WEIGHT } \\
\text { PERCENT }\end{array}$ & $\begin{array}{c}\text { ASH } \\
\text { PERCENT }\end{array}$ & $\begin{array}{l}\text { SULPOR } \\
\text { PERCENT }\end{array}$ & $\begin{array}{l}\text { MOISTORE } \\
\text { PERCENT }\end{array}$ & $\begin{array}{l}\text { WEIGHT } \\
\text { PERCENT }\end{array}$ & $\begin{array}{c}\text { ASH } \\
\text { PERCENT }\end{array}$ & $\begin{array}{l}\text { SULFOR } \\
\text { PERCENT }\end{array}$ & $\begin{array}{l}\text { MOISTORE } \\
\text { PERCENT }\end{array}$ \\
\hline $\begin{array}{r}1 / 4 " \\
8 m \\
16 M\end{array}$ & $\begin{array}{r}8 M \\
16 M\end{array}$ & $\begin{array}{l}11.00 \\
6.6 .70 \\
22.30\end{array}$ & $\begin{array}{r}10.72 \\
8.95 \\
9.12\end{array}$ & $\begin{array}{l}1.16 \\
0.67 \\
0.68\end{array}$ & $\begin{array}{l}10.28 \\
10.42 \\
10.50\end{array}$ & $\begin{array}{r}11.00 \\
77.70 \\
100.00\end{array}$ & $\begin{array}{r}10.72 \\
9.20 \\
9.18\end{array}$ & $\begin{array}{l}1.16 \\
0.74 \\
0.73\end{array}$ & $\begin{array}{l}10.28 \\
10.40 \\
10.42\end{array}$ & $\begin{array}{r}100.00 \\
89.00 \\
22.30\end{array}$ & $\begin{array}{l}9.18 \\
8.99 \\
9.12\end{array}$ & $\begin{array}{l}0.73 \\
0.67 \\
0.68\end{array}$ & $\begin{array}{l}10.42 \\
10.44 \\
10.50\end{array}$ \\
\hline
\end{tabular}

THIS PRACTION CONSTITUTES 12.2 PERCENT OP THE PEED.

DATA FOR - REPOSE COAL.

\begin{tabular}{|c|c|c|c|c|c|c|c|c|c|c|c|c|c|}
\hline \multicolumn{2}{|c|}{ SIZF } & \multicolumn{2}{|c|}{------ DIRECT $\nabla$} & VALOES $=\cdots$ & -- & \multicolumn{2}{|c|}{-CUnOLATIVE } & \multicolumn{2}{|c|}{ RETAINED - } & \multicolumn{2}{|c|}{$\cdots-\cdots$ COMOLATIVE } & \multicolumn{2}{|c|}{ PASSED- $-\cdots$} \\
\hline $\begin{array}{r}\text { FRAC } \\
\text { PASSED }\end{array}$ & TION & WEIGHT & $\begin{array}{l}\text { ASH } \\
\text { PERCENT }\end{array}$ & SULEUR & MOISTURE & प्रEIGHT & $\begin{array}{c}\text { ASH } \\
\text { PERCENT }\end{array}$ & SOLPOR & MOISTURE & HEIGHT & $\begin{array}{c}\text { ASR } \\
\text { PEBCENT }\end{array}$ & $\begin{array}{l}\text { SULFOR } \\
\text { PFRCENT }\end{array}$ & $\begin{array}{l}\text { MOISTURE } \\
\text { PERCENT }\end{array}$ \\
\hline $\begin{array}{r}1 / 4 M \\
8 M \\
16 M\end{array}$ & $\begin{array}{r}8 M \\
16 M\end{array}$ & $\begin{array}{r}5.60 \\
66.20 \\
28.20\end{array}$ & $\begin{array}{l}16.67 \\
12.53 \\
10.79\end{array}$ & $\begin{array}{l}2.91 \\
1.87 \\
1.12\end{array}$ & $\begin{array}{r}9.29 \\
10.09 \\
10.12 \text { AXAL }\end{array}$ & $\begin{array}{r}5.60 \\
71.80 \\
100.00 \\
\text { YTICCAL }\end{array}$ & $\begin{array}{r}16.67 \\
12.85 \\
12.27 \\
\text { DATA }\end{array}$ & $\begin{array}{l}2.91 \\
1.95 \\
1.72\end{array}$ & $\begin{array}{r}9.29 \\
10.03 \\
10.05\end{array}$ & $\begin{array}{r}100.00 \\
94.40 \\
28.20\end{array}$ & $\begin{array}{l}12.27 \\
12.01 \\
10.79\end{array}$ & $\begin{array}{l}1.72 \\
1.65 \\
1.12\end{array}$ & $\begin{array}{l}10.05 \\
10.10 \\
10.12\end{array}$ \\
\hline DATA & FOR DRYPLC & SEPARATION & TEST & * 37 & & & & & $50 \mathrm{~S} \cdot 86$ & PLUS MAGI & ET IT E & ED. & \\
\hline FOR & - & * compos & ITE * * & & THIS & S PRACTION & CONSTIT & TUTES 100.0 & PERCENT & OP THE PI & $\bullet$ & & \\
\hline SI & $\mathrm{ZE}$ & 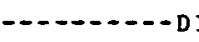 & IRECT $\nabla$ & VALUES - . - . & - & -.--CUAOL & LATIVE & RET AINED--- & - &.$---C D !$ & DLATIVE & PASSED $=-$ & -.- \\
\hline $\begin{array}{r}\text { PRAC } \\
\text { PASSED }\end{array}$ & $\begin{array}{l}\text { TION } \\
\text { BETAINED }\end{array}$ & $\begin{array}{l}\text { WFIGHT } \\
\text { PERCENT }\end{array}$ & $\begin{array}{c}\text { ASH } \\
\text { PERCENT }\end{array}$ & $\begin{array}{l}\text { SULFUR } \\
\text { PERCENT }\end{array}$ & $\begin{array}{l}\text { MOISTURE } \\
\text { PERCENT }\end{array}$ & $\begin{array}{l}\text { WEIGHT } \\
\text { PERCENT }\end{array}$ & $\begin{array}{c}\text { ASH } \\
\text { PERCENT }\end{array}$ & $\begin{array}{l}\text { SULEUR } \\
\text { PERCENT }\end{array}$ & $\begin{array}{l}\text { MOISTURE } \\
\text { PERCENT }\end{array}$ & $\begin{array}{l}\text { DEIGKT } \\
\text { PERCENT }\end{array}$ & $\begin{array}{c}\text { A SH } \\
\text { PERCENT }\end{array}$ & $\begin{array}{l}\text { SULFOR } \\
\text { PERCENT }\end{array}$ & $\begin{array}{l}\text { MOISTURE } \\
\text { PERCENT }\end{array}$ \\
\hline $\begin{array}{r}1 / 4 " 1 \\
84 \\
164\end{array}$ & $\begin{array}{r}8 M \\
16 M\end{array}$ & $\begin{array}{l}11.19 \\
65.23 \\
23.58\end{array}$ & $\begin{array}{l}8.57 \\
8.79 \\
8.85\end{array}$ & $\begin{array}{l}0.68 \\
0.69 \\
0.64\end{array}$ & $\begin{array}{l}10.42 \\
10.71 \\
10.68\end{array}$ & $\begin{array}{r}11.19 \\
76: 42 \\
100.00\end{array}$ & $\begin{array}{l}8.57 \\
8.76 \\
8.78\end{array}$ & $\begin{array}{l}0.68 \\
0.69 \\
0.68\end{array}$ & $\begin{array}{l}10.42 \\
10.67 \\
10.67\end{array}$ & $\begin{array}{r}100.00 \\
88.81 \\
23.58\end{array}$ & $\begin{array}{l}8.78 \\
8.81 \\
8.85\end{array}$ & $\begin{array}{l}0.68 \\
0.68 \\
0.64\end{array}$ & $\begin{array}{l}10.67 \\
10.70 \\
10.68\end{array}$ \\
\hline
\end{tabular}

THIS PRACTION CONSTITOTES 8.2 PERCRNT OP THE FEED. 


\section{ANALTTICAL DATA}

DATA FOB DRYPLO SEPARATION TEST 38

DATA FOR - PRODUCT COAL.

\begin{tabular}{|c|c|c|c|c|c|c|c|c|c|c|c|c|c|}
\hline \multirow{2}{*}{\multicolumn{2}{|c|}{$\begin{array}{c}\text { SIZE } \\
\text { FRACTION }\end{array}$}} & \multicolumn{2}{|c|}{$-\cdots-1-1$ DIRECT } & \multicolumn{2}{|c|}{ ALOES $\ldots \ldots$} & \multicolumn{2}{|c|}{-----CUMOLATIVE } & \multicolumn{2}{|c|}{ RETAI NED - } & \multicolumn{2}{|c|}{$-\because--$ COM OLATIVE } & \multicolumn{2}{|c|}{ PASSED $\cdots$} \\
\hline & & REIGHT & $\triangle S B$ & SUIFU & MOISTURE & NEIGHT & A SR & SOLFOR & MOISTMRE & HEIGHT & A SR & SOLPOR & MOISTORE \\
\hline PASSED & RETAINED & PEPCENT & PERCENT & PERCENT & PERCENT & PERCENT & PERCENT & PERCEN T & PERCENT & PERCENT & PERCENT & PERCENT & PERCENT \\
\hline $\begin{array}{r}1 / 4 " \\
8 M \\
16 M\end{array}$ & $\begin{array}{r}81 \\
16 \pi\end{array}$ & $\begin{array}{r}9.30 \\
63.80 \\
26.90\end{array}$ & $\begin{array}{l}7.31 \\
7.91 \\
8.53\end{array}$ & $\begin{array}{l}0.47 \\
0.52 \\
0.53\end{array}$ & $\begin{array}{l}10.58 \\
10.96 \\
10.90\end{array}$ & $\begin{array}{r}9.30 \\
73.10 \\
100.00\end{array}$ & $\begin{array}{l}7.31 \\
7.83 \\
8.02\end{array}$ & $\begin{array}{l}0.47 \\
0.51 \\
0.52\end{array}$ & $\begin{array}{l}10.58 \\
10.91 \\
10.91\end{array}$ & $\begin{array}{r}100.00 \\
90.70 \\
26.90\end{array}$ & $\begin{array}{l}8.02 \\
8.09 \\
8.53\end{array}$ & $\begin{array}{l}0.52 \\
0.52 \\
0.53\end{array}$ & $\begin{array}{l}10.91 \\
10.94 \\
10.90\end{array}$ \\
\hline
\end{tabular}

DATA FOR - MIDDIING COAL.

THIS FRACTION CONSTITUTES 28.9 PERCENT OP THE PEED.
PSOC * 86 PLOS MAGNTITE FEED.

THIS PRACTION CONSTITOTES 60.5 PERCENT OP THE PEED.

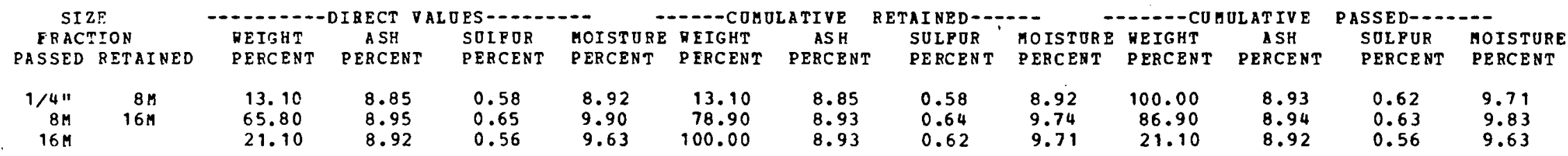

DATA FOR - REFUSE COAL.

THIS PRACTION CONSTITUTES 10.6 PERCENT OF THE PEED.

\begin{tabular}{|c|c|c|c|c|c|c|c|c|c|c|c|c|c|}
\hline SI & & 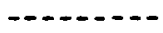 & IRECT VA & JES - & $=-$ & $-\infty-$ CUH & ATIVE & RETAINED - & $\cdots$ & $----c u$ & JLATIVE & PASSED- - & - \\
\hline P RAC & TION & WEIGHT & A SH & SUIROR & MOISTURE & MEIGHT & $\mathrm{ASH}$ & SULPOR & MOISTURE & DEIGHT & $\triangle \mathrm{SH}$ & SULFOR & MOISTURE \\
\hline$S F$ & RETAINED & PERCENT & PERCENT & PEBCENT & P ERCENT & PERCENT & PERCENT & PERCENT & DERCENT & PERCENT & PERCENT & PERCENT & PERCENT \\
\hline $\begin{array}{r}1 / 4 " \\
8 M \\
16 M\end{array}$ & $\begin{array}{r}8 M \\
16 M\end{array}$ & $\begin{array}{r}7.00 \\
66.70 \\
26.30\end{array}$ & $\begin{array}{l}14.50 \\
12.88 \\
10.55\end{array}$ & $\begin{array}{l}2.30 \\
1.81 \\
1.09\end{array}$ & $\begin{array}{r}8.60 \\
10.10 \\
10.20\end{array}$ & $\begin{array}{r}7.00 \\
73.70 \\
100.00\end{array}$ & $\begin{array}{l}14.50 \\
13.03 \\
12.38\end{array}$ & $\begin{array}{l}2.30 \\
1.86 \\
1.65\end{array}$ & $\begin{array}{r}8.60 \\
9.96 \\
10.02\end{array}$ & $\begin{array}{r}100.00 \\
93.00 \\
26.30\end{array}$ & $\begin{array}{l}12.38 \\
12.22 \\
10.55\end{array}$ & $\begin{array}{l}1.65 \\
1.61 \\
1.09\end{array}$ & $\begin{array}{l}10.02 \\
10.13 \\
10.20\end{array}$ \\
\hline
\end{tabular}

DATA FOR DRYFLC SEPARATION TEST 38

PSOC 86 PLUS MAGETITE PEED.

DATA FOR -

* * conpostte**

THIS FRACTION CONSTITUTES 100.0 PERCENT OP THE FEED.

\begin{tabular}{|c|c|c|c|c|c|c|c|c|c|c|c|c|c|}
\hline \multirow{2}{*}{\multicolumn{2}{|c|}{$\begin{array}{c}\text { SIZE } \\
\text { FPACTION }\end{array}$}} & \multicolumn{2}{|c|}{$\cdots$ DIRECT } & JES & $=-$ & \multicolumn{2}{|c|}{ - - - CUMULATIVE } & \multicolumn{2}{|c|}{ RETAINED-.... } & \multicolumn{2}{|c|}{--} & \multicolumn{2}{|c|}{ PASSED--..- } \\
\hline & & DEIGHT & A SH & SOIFOR & MOISTORE & WEIGHT & ASH & sol & MOISTURE & WE & ASH & so & \\
\hline ASSED & RETAINED & PERCENT & PERCENT & PERCENT & PERCENT & PERCENT & PERCENT & PERCEN T & PERCENT & PERCENT & PERCENT & PERCENT & PERCENT \\
\hline $\begin{array}{r}1 / 4 " 1 \\
8 M \\
16 n\end{array}$ & $\begin{array}{r}8 M \\
16 M\end{array}$ & $\begin{array}{l}10.15 \\
64.69 \\
25.16\end{array}$ & $\begin{array}{l}8.41 \\
8.76 \\
8.85\end{array}$ & $\begin{array}{l}0.64 \\
0.70 \\
0.60\end{array}$ & $\begin{array}{r}9.82 \\
10.55 \\
10.51\end{array}$ & $\begin{array}{r}10.15 \\
74.84 \\
100.00\end{array}$ & $\begin{array}{l}8.41 \\
8.71 \\
8.75\end{array}$ & $\begin{array}{l}0.64 \\
0.69 \\
0.67\end{array}$ & $\begin{array}{r}9.82 \\
10.45 \\
10.47\end{array}$ & $\begin{array}{r}100.00 \\
89.85 \\
25.16\end{array}$ & $\begin{array}{l}8.75 \\
8.78 \\
8.85\end{array}$ & $\begin{array}{l}0.67 \\
0.67 \\
0.60\end{array}$ & $\begin{array}{l}10.47 \\
10.54 \\
10.51\end{array}$ \\
\hline
\end{tabular}


- ANALYTICAL Data

DATA FOR DRYFLO SEPARATION TEST 39

DATA FOR - PRODUCT COAL.

SIZE

PRACTION

PASSED RETAINED

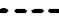

NEIGHT

DIRECT VALUES-

$\begin{array}{cl}\text { ASR } & \text { SUIPUR } \\ \text { PERCENT } & \text { FERCENT }\end{array}$

HOTST ORT UETG CUVOLATIVE

THIS PRACTION CONSTITUTES

ELLIOT PLUS MAGETITE PEED.

2.8 PERCENT OP TRE PEED.

SUINED--.---

$\begin{array}{rrrrr}1 / 41 & 8 M & 2.40 & 16.06 & 2.1 \\ 8 M & 16 M & 75.10 & 14.69 & 2.60 \\ 16 M & & 22.50 & 12.38 & 2.4\end{array}$

DATA POR - MIDDLING COAL.

2.16
2.60
2.49

\section{OISTORE NEIGHT}

PERCENT

SULPUR
PERCENT

0.89
0.88

0.88
0.90

2.40
77.50

16.06

$\begin{array}{ll}16.06 & 2.16 \\ 14.73 & 2.59\end{array}$

2.16
2.59
2.56

HIS PRACTION CONSTITOTES 22.6 PERCENT OP THE PEED.

\begin{tabular}{|c|c|c|c|c|}
\hline \multirow{2}{*}{\multicolumn{2}{|c|}{$\begin{array}{c}\text { SIZE } \\
\text { PPACTION }\end{array}$}} & 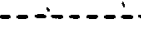 & I RECT & UES - - \\
\hline & & HEIGH & ASH & SULFUR \\
\hline ASSE & RETAINED & PERCENT & PERCENT & PEPCENT \\
\hline $\begin{array}{r}1 / 4 " \\
8 M \\
16 m\end{array}$ & $\begin{array}{r}8 M \\
16 n\end{array}$ & $\begin{array}{r}5.30 \\
79.10 \\
15.60\end{array}$ & $\begin{array}{r}31.37 \\
21.15 \\
18.70\end{array}$ & $\begin{array}{l}6.77 \\
3.71 \\
3.98\end{array}$ \\
\hline
\end{tabular}

DATA POR - REFUSE COAL.

\section{MOISTURB} TIVE RETAINED-...TAINED-
SULFOR
PERCENT PERCENT

0.69
$\begin{array}{rr}0.69 & 5.30 \\ 0.80 & 84.40\end{array}$ 31.37
21.79 6.77
3.90 3.97
3.91

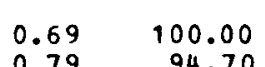

$0.79 \quad 94.70$

THIS PRACTION CONSTITOTES 14.6 PERCENT OP THE PEED.

$\begin{array}{lll}21.31 & 3.91 & 0.80 \\ 20.75 & 3.75 & 0.81 \\ 18.70 & 3.98 & 0.84\end{array}$

\begin{tabular}{|c|c|c|c|c|}
\hline \multicolumn{2}{|c|}{ SIZE } & $----\infty---$ & IRECT & FSS--- \\
\hline $\begin{array}{r}\text { FRAC } \\
\text { PASSED }\end{array}$ & $\begin{array}{l}\text { ION } \\
\text { RETAINED }\end{array}$ & $\begin{array}{l}\text { NEITHT } \\
\text { PERCENTT }\end{array}$ & $\begin{array}{c}\text { ASH } \\
\text { PERCENT }\end{array}$ & $\begin{array}{l}\text { SULEOR } \\
\text { PERCENT }\end{array}$ \\
\hline $\begin{array}{r}1 / 4 " \\
8 M \\
164\end{array}$ & $\begin{array}{r}84 \\
16 M\end{array}$ & $\begin{array}{r}5.40 \\
78.80 \\
15.80\end{array}$ & $\begin{array}{l}59.50 \\
47.43 \\
35.62\end{array}$ & $\begin{array}{r}29.19 \\
16.73 \\
11.92\end{array}$ \\
\hline
\end{tabular}

DATA FOR DRTFLO SEPARATION TEST * 39

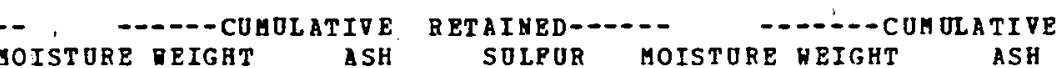

PERCENT PERCENT PERCENT
PERT

SOLPOR

SULPUR

MOISTORE

0.40
0.59
0.78

100.00

ANALYTICAL

48.20
46.22

29.19
17.53

17.53
16.64

0.40
0.58

0.58
0.61

100.00
94.60
15.80

94.60
15.80

ASH
PERCENT
46.22

45.46
35.62

$35.62 \quad 15.93$

ELLIOT PLOS MAGNETITE PEED.

THIS PRACTION CONSTITUTES 100.0 PERCENT OP THE PEED.

$\begin{array}{ll}16: 64 & 0.61 \\ 15.93 & 0.62 \\ 11.92 & 0.78\end{array}$

* * conposite * *
DAT,A FOR -

SIZE PRIZE
PASSED RETAINED

HEIGRT
PERCENT PERCENT PERTERT

$1 / 4 n \quad 8 M$

$1 / 4 n$
$8 n$
$16 n$

$8 M$
$16 n$

3.49
7.6 .54

PERCENT

7.6 .54
-19.96

31.11
21.12
16.18

9.84
4.98
3.84

DOESTO
PEBCEN
0.71
0.82
0.88

$---C U H O L A T I V E$
PEIGHT R ASH
PERCENT PERCENT

ETAINED---.-

- ---DCU DUL

\author{
PED
}

ASSED--..--

SULPOR MOISTURE PERCENT PERCENT

0.62
0.78 
ANALTICAL DATA

DATA FOR DBYPLO SEPARATION TEST 40 DATA POR - PRODUCT COAL.
ELLiOT PLUS hagNeTtTE PEED.

THIS PRACTICH CONSTITUTES 68.2 PERCENT OP TRE PERD.

\begin{tabular}{|c|c|c|c|c|}
\hline & \multirow{3}{*}{$\begin{array}{l}\text { REIGAT } \\
\text { PERC } \because N T\end{array}$} & \multirow{3}{*}{$\begin{array}{c}\text { ASH } \\
\text { PERCENT }\end{array}$} & \\
\hline \multicolumn{2}{|c|}{ FRACTION } & & & \\
\hline PASSED & RETAINED & & & \\
\hline $1 / 4 "$ & 81 & 3.20 & 26.54 & \\
\hline $\begin{array}{r}8 M \\
16 . M\end{array}$ & $16 \mathrm{H}$ & $\begin{array}{l}75.80 \\
21.00\end{array}$ & $\begin{array}{l}17.26 \\
13.23\end{array}$ & \\
\hline
\end{tabular}

DATA PGR - MIDDLING COAL.$$
\text { POR - MIDDLING CORL. }
$$

Pent

PASSED RETAINED

PEIGET DIRECT VALUES
PERCENT PERCENT
$-1$ CURCLATIVE RETAINED------

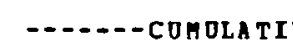

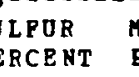
ISTORE WEIGHT ASH SULPOR MOISTURE WEIGRT ASH PERCENT PERCENT PERCENT PERCENT PASSED---.-.ULPOR HOISTURE \begin{tabular}{llllllll}
\hline .09 & 0.80 & 3.20 & 26.54 & 5.09 & 0.80 & 100.00 & 16.71
\end{tabular} 3.09 0.80
0.80
0.96 3.20
79.00 26.54
17.64 5.09
3.17
3.08 0.80
0.80 100.00
96.80 16.71
16.39 16.39 PERCENT PERCENT

THIS PRACTION CONSTITUTES 14.6 PERCENT OP THE PEED.

$\begin{array}{rrrrrrrrrrrrrr}1 / 41 & 8 M & 6.10 & 51.81 & 20.01 & 0.50 & 6.10 & 51.81 & 20.01 & 0.50 & 100.00 & 33.91 & 10.27 & 0.72 \\ 8 M & 16 \mathrm{M} & 77.20 & 34.89 & 10.43 & 0.72 & 83.30 & 36.13 & 11.13 & 0.70 & 93.90 & 32.75 & 9.64 & 0.73 \\ 16 M & & 16.70 & 22.85 & 5.99 & 0.79 & 100.00 & 33.91 & 10.27 & 0.72 & 16.70 & 22.85 & 5.99 & 0.79\end{array}$

DATA FOR - REPUSE COAL.

THIS PRACTIO CONSTITOTES 17.2 PERCENT OP THE PEED.

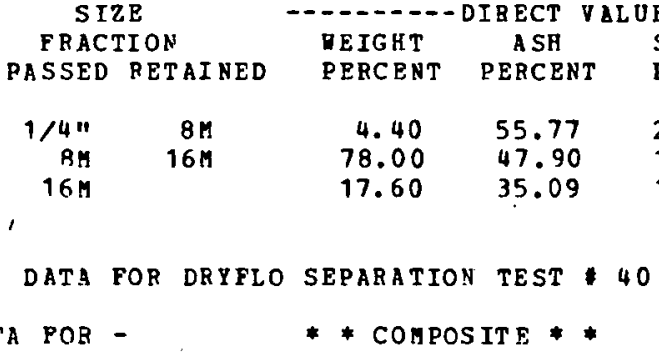

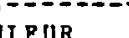
SUIPUR MOISTURE DEIGHT ASH SULPOR SULPOR HOTSTURE UEIGHT 3.08 0.83 3.01 0.83 $2.72 \quad 0.96$
23. $18 \quad 0.40$

23.18
18.58

11.77 $\begin{array}{lr}0.40 & 4.40 \\ 0.59 & 82.40 \\ 0.68 & 100.00\end{array}$

ANLLTTICAL
55.77
48.32
45.99

DATA
23.18

23.18
18.83

18.83
17.58
0.40
0.58

0.58
0.60

95.60
17.60

ELLTOT PLUS MAGNTITE FEED. THIS FRACTIOE CONSTITOTES 100.0 PERCENT OP THE PEED.
TA POR -

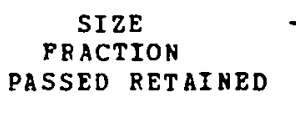

$\begin{array}{rr}1 / 4 " & 8 M \\ 8 M & 16 M\end{array}$

THIS $\begin{array}{lclll}\text { NEIGHT } & \text { ASH } & \text { SOIFUR } & \text { MOISTORE REIGHT } & \text { ASH } \\ \text { PERCENT } & \text { PERCENT } & \text { PERCENT } & \text { PERCENT PERCENT } & \text { PERCENT }\end{array}$ SULPUR
PERCENT

$\begin{array}{rrrr}3.83 & 38.19 & 12.13 & 0.65 \\ 76.38 & 25.24 & 6.89 & 0.75 \\ 19.79 & 17.76 & 4.51 & 0.90\end{array}$

3.83
80.21

38.19

12.13 MOISTURE MEIGHT OLATIVE
PERCE ACET SOLPC----SOLPUR HOISTURE $0.90 \quad 100.00 \quad 24.26$

0.65
0.75

0.75
0.78
24.26
23.70

17.76

\section{$6.62 \quad 0.78$}

$6.40 \quad 0.78$ 
ANALTICAL DATA

PIGORES PRON PSOC 86 PEED SAMPLE.

DATA POR DRYPLO SEPARATION TEST 41

TRIS PRACTION CONSTITOTES 47.4 PERCENT OP THE PEED.

DATA POR - PRODUCT COAL.

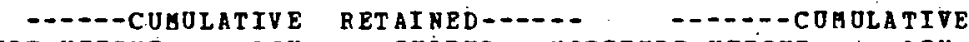

\begin{tabular}{|c|c|c|c|c|c|c|c|c|c|c|c|c|c|}
\hline \multirow{2}{*}{\multicolumn{2}{|c|}{$\begin{array}{c}\text { SIZE } \\
\text { PRACTION }\end{array}$}} & $--\cdots$ & I RECT & $s-$ & & $----c u$ & ATIVE & I $\mathbf{N}$ & & $-\cdots--c 0$ & OLA & $\triangle S S E D-$ & -- \\
\hline & & $\begin{array}{l}\text { DEIGHT } \\
\text { PERCENT }\end{array}$ & $\begin{array}{c}\text { ASH } \\
\text { PERCENT }\end{array}$ & $\begin{array}{l}\text { SULPUR } \\
\text { 2ERCENT }\end{array}$ & $\begin{array}{l}\text { MOISTURE } \\
\text { PERCENT }\end{array}$ & $\begin{array}{l}\text { NEIGHT } \\
\text { PERCENT }\end{array}$ & $\begin{array}{c}\text { ASH } \\
\text { PERCENT }\end{array}$ & $\begin{array}{l}\text { SOLPOR } \\
\text { PERCENT }\end{array}$ & $\begin{array}{l}\text { MOISTURE } \\
\text { PERCENT }\end{array}$ & $\begin{array}{l}\text { HEIGHT } \\
\text { PERCENT }\end{array}$ & $\begin{array}{c}\text { ASH } \\
\text { PERCENT }\end{array}$ & $\begin{array}{l}\text { SULPOR } \\
\text { PERCE NT }\end{array}$ & $\begin{array}{l}\text { MOISTUR } \\
\text { PERCENT }\end{array}$ \\
\hline $\begin{array}{l}30 M \\
60 M \\
100 M \\
150 M\end{array}$ & $\begin{array}{l}30 \mathrm{M} \\
60 \mathrm{O} \\
100 \mathrm{H} \\
150 \mathrm{M}\end{array}$ & $\begin{array}{l}15.00 \\
34.40 \\
24.60 \\
13.70 \\
12.30\end{array}$ & $\begin{array}{r}8.04 \\
8.39 \\
9.82 \\
11.48 \\
16.23\end{array}$ & $\begin{array}{l}0.55 \\
0.62 \\
0.76 \\
0.96 \\
1.69\end{array}$ & $\begin{array}{l}10.45 \\
10.60 \\
10.90 \\
11.55 \\
11.25\end{array}$ & $\begin{array}{r}15.00 \\
49.40 \\
74.00 \\
87.70 \\
100.00\end{array}$ & $\begin{array}{r}8.04 \\
8.28 \\
8.79 \\
9.21 \\
1.0 .08\end{array}$ & $\begin{array}{l}0.60 \\
0.65 \\
0.70 \\
0.82\end{array}$ & $\begin{array}{l}10.45 \\
10.55 \\
10.67 \\
10.81 \\
10.86\end{array}$ & $\begin{array}{r}100.00 \\
85.00 \\
50.60 \\
26.00 \\
12.30\end{array}$ & $\begin{array}{l}10.08 \\
10.44 \\
19.83 \\
13.73 \\
16.23\end{array}$ & $\begin{array}{l}0.82 \\
0.87 \\
1.04 \\
1.31 \\
1.69\end{array}$ & $\begin{array}{l}10.93 \\
11.16 \\
11.41 \\
11.25\end{array}$ \\
\hline
\end{tabular}

DATA FOR - MIDDLING COAL.

THIS PRACTION CONSTITOTES 35.9 PERCENT OP THE PEED.

SIZE

PRACTION
PASSED RETAINED

$\begin{array}{rrr} & 30 M & 49.80 \\ 30 M & 60 M & 41.50 \\ 60 M & 100 M & 7.10 \\ 100 M & 150 M & 0.80\end{array}$

- - - CUNULATIVE RETAINED--

SUIFOB

MOISTURE HEIGHT

ASH

SULPOR

\section{MOIST}

- - - - COMOLATIVE

PASSE

SSED--.-...

SULPUR MOISTURE

\section{PERCENT}

$0.68 \quad 10.45$

100.00

THIS PRACTION CONSTITUTES

DATA FOR - REPOSE COAL.

SIZE
FRACTION

$\begin{array}{cc}\text { HEIGHT } & \text { DISE VA } \\ \text { PERCENT } & \text { PERCENT } \\ & \\ 55.30 & 10.08 \\ 40.60 & 10.47 \\ 3.30 & 18.75 \\ 0.30 & 32.17 \\ 0.50 & 28.94\end{array}$

$$
\text { JES- - - - }
$$
SOIPOR
PERCENT

PASSED RETAINED

$\begin{array}{rrrr} & 30 M & 55.30 & 10.08 \\ 30 M & 60 M & 40.60 & 10.47 \\ 60 M & 100 M & 3.30 & 18.75 \\ 100 \mathrm{M} & 150 \mathrm{M} & 0.30 & 32.17 \\ 150 \mathrm{M} & & 0.50 & 28.94\end{array}$

$\begin{array}{rr}0.94 & 9.20 \\ 0.93 & 9.30 \\ 2.37 & 10.40 \\ 0.00 & 10.25 \\ 5.67 & 10.00\end{array}$

5. $67 \quad 10.00$

$10.00 \quad 100.00$

DATA FOR DRYFLO SEPARATION TEST 41 DATA FOR -

THIS PRACTION CONSTITUTES 100.0 PERCENT OP THE PEED.

8.43
8.83

8.43
8.83
9.11
9.21

\subsection{0}

$\begin{array}{ll}0.68 & 10.45 \\ 0.71 & 10.52\end{array}$

$0.73 \quad 10.52$

10.52

100.00
50.20
8.70
1.60

$9.32 \quad 0.75$

16.7 PERCENT OP THE PEED.

PERCENT

SULFOR

AOISTURE NEIGHT ASH

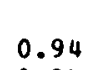

$$
\begin{aligned}
& 0.94 \\
& 0.94 \\
& 0.98
\end{aligned}
$$$$
0.98
$$

0.98
1.00

10.59
10.69

10.69 PERCENT

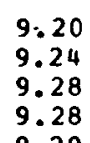

9.24
9.28
9.28

44.70

4.10

0.50

PERCENT

PERCENT PERCENT

PIGORES PROA PSOC 86 PEED SAMPLE.

$\begin{array}{rrr}9.32 & 0.75 & 10.52\end{array}$

$14.37 \quad 0.90 \quad 10.59$

$\begin{array}{lll}21.99 & 3.22 & 10.45 \\ 22.58 & 3.18 & 10.10\end{array}$ $\begin{array}{lll}14.37 & 9.51 & 11.27\end{array}$
* * Conpostte * * PRACTION MEIGHT TASH
PERCENT PERCENT OES--...... PASSED RETAINED SUIFOB MOISTORE DEIGHT $-2-$ COMOLATIVE RET
DEIGTT ASH

$30 \mathrm{H} \quad 30 \mathrm{OH}$

$\begin{array}{rr}30 \mathrm{M} & 60 \mathrm{M} \\ 60 \mathrm{M} & 100 \mathrm{M} \\ 100 \mathrm{H} & 150 \mathrm{H}\end{array}$

$150 \mathrm{H}$

$\begin{array}{rr}34.22 & 6.79 \\ 37.98 & 9.13 \\ 14.76 & 10.64 \\ 6.83 & 12.05 \\ 6.20 & 16.70\end{array}$

$\begin{array}{rr}34.22 & 8.79 \\ 72.21 & 8.97 \\ 86.97 & 9.25 \\ 93.80 & 9.46 \\ 100.00 & -9.91\end{array}$

$\begin{array}{ll}0.68 & 10.11 \\ 0.73 & 10.31 \\ 0.88 & 10.98 \\ 1.05 & 19.51 \\ 1.80 & 11.18\end{array}$


DATA POR DRYPLO SEPARATION TEST 42 DATA FOR - PEODUCT COAL.
PIGURES PROA PSOC * 86 PEEd SAMPLE.

THIS PRACTION CONSTITOTES 46.1 PERCENT OP THE PEED.
SIZE PRACTION PASSED RETAIVED

$\begin{array}{rrr} & 30 \mathrm{M} & 8.70 \\ 30 \mathrm{M} & 6 \mathrm{OH} & 32.70 \\ 60 \mathrm{M} & 10 \mathrm{OH} & 28.70 \\ 100 \mathrm{M} & 150 \mathrm{M} & 16.00 \\ 150 \mathrm{M} & & 13.90\end{array}$

DATA FOR - MIDDLING COAL.

\begin{tabular}{rr} 
HEIGHT & \multicolumn{1}{c}{ ASH } \\
PERCENT & PERCEN \\
& \\
8.70 & 7.87 \\
32.70 & 7.32 \\
28.70 & 9.72 \\
16.00 & 11.49 \\
13.90 & 16.70
\end{tabular}

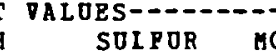
PERCENT

$\begin{array}{ll}0.51 & 10.45 \\ 0.59 & 10.50\end{array}$

$0.76 \quad 11.50$

$0.99 \quad 11.20$

\section{-----CUHOLATIVE RETAINED---- -}

STURE HEIGHT

AS B
PEBCENT

SOLPOR

-

- - - - CONOLAT IVE

DEIGHT

8.70
$41.40 \quad 7.87$
70.10

41.40
70.10

7.87
7.44
8.37

7.44
8.37
8.95

$\begin{array}{ll}0.51 & 10.45 \\ 0.57 & 10.49\end{array}$

0.51
0.57
0.65
0.71

$0.65 \quad 10.90$

$\begin{array}{ll}0.65 & 10.96 \\ 0.86 & 10.94\end{array}$

100.00

10.03

13.90

100.00
91.30
58.60
29.90
13.90

A SH
PEBCENT

SULPUR MOISTURE

PULRERT PERCENT
PERT

THIS PRACTION CONSTITUTES 38.6 PERCENT OP THE PERD.

$\begin{array}{lll}10.03 & 0.86 & 10.94 \\ 10.23 & 0.90 & 10.98 \\ 11.86 & 1.07 & 11.25 \\ 13.91 & 1.37 & 11.01 \\ 16.70 & 1.80 & 10.80\end{array}$

SIZE PRACTION
PASSED RETAINED

DEIGGT DIRECT VALUES-D--

-....--CUMULATIV PERCENT PERC

PASSED RET

$\begin{array}{lc}\text { DEIGHT } & \text { ASH } \\ \text { PERCENT } & \text { PERCENT }\end{array}$

$\begin{array}{rrrr} & 30 M & 44.00 & 8.68 \\ 30 M & 60 M & 45.50 & 9.35 \\ 60 \mathrm{M} & 100 \mathrm{M} & 9.00 & 13.45 \\ 100 \mathrm{M} & 150 \mathrm{M} & 0.90 & 24.47 \\ 150 \mathrm{M} & & 0.60 & 27.10\end{array}$

$\begin{array}{rrr}0.62 & 10.70 & 44.00 \\ 0.76 & 10.65 & 89.50 \\ 1.30 & 11.55 & 98.50 \\ 3.15 & 10.50 & 99.40 \\ 4.14 & 9.60 & 100.00\end{array}$

PERCEN

MOISTOB

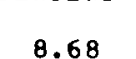

8.68
9.02
9.43
9.56

0.62

0.69

10.70
10.67
10.75

10.67
10.75

9.56

0.75
0.77
0.79

10.75
10.75

THIS FRACTION CONSTITUTES 15.3 PERCENT OP THE PEED.

DATA POR - REPUSE COAL.

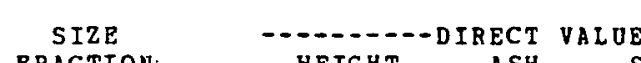

SIZE

$\begin{array}{lll}\text { PASSED RETAINED } & \text { NEIGHT } & \text { ASH } \\ \text { PERCENT } & \text { PERCENT }\end{array}$

$\begin{array}{rrrr} & 30 \mathrm{M} & 35.00 & 9.29 \\ 30 \mathrm{M} & 60 \mathrm{M} & 58.10 & 9.57 \\ 60 \mathrm{M} & 100 \mathrm{M} & 5.30 & 19.64 \\ 100 \mathrm{M} & 150 \mathrm{M} & 0.60 & 32.82 \\ 150 \mathrm{M} & & 1.00 & 29.18\end{array}$
$\begin{array}{ll}\text { SOLPUR } & \text { MOISTURE UEIGRT } \\ \text { PERCENT } & \text { PERCENT } \\ \end{array}$ ASE RETAI SULPUR MOIS

$$
0.72
$$

0.72
0.89

1.94
6.54

$\begin{array}{ll}9.55 & 35.00 \\ 9.70 & 93.10\end{array}$

$\begin{array}{rr}9.70 & 93.10 \\ 10.15 & 98.40 \\ 9.20 & 99.00\end{array}$

PERCENT

MOISTOAE VEIGHT

A SH

$$
\begin{array}{r}
9.29 \\
9.71 \\
10.25 \\
10.39 \\
10.57
\end{array}
$$

0.72
0.83

0.83
0.89

4.80

$9.70 \quad 100.00$

0.92
0.96

DATA

PERCENT PERCENT

$$
\begin{aligned}
& 9.55 \\
& 9.64 \\
& 9.67 \\
& 9.67 \\
& 9.67
\end{aligned}
$$

100.00
65.00
6.90

65.00
6.90

10.57

11.26

$1.60 \quad 30.54$

30.54
29.18

PIGURES FROM PSOC 86 PEED SAMPLE.

DATA FOR DRYFLO SEPARATION TEST \# 42 DATA FOR -

THIS PRACTICN CONSTITUTES 100.0 PERCENT OP THE PEED.

* * composite * *

$$
\begin{gathered}
\text { SIZE } \\
\text { FRACTION }
\end{gathered}
$$

PASSED RETAINED

$$
\text { HEIGHT }
$$

$$
\text { RECT VALUES- }
$$

SUIFUR

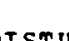

----CUROLATIVE

\section{RETAINED-----}

PERCENT PERCENT

$\begin{array}{rrr} & 30 M & 26.35 \\ 30 M & 60 M & 41.53 \\ 60 M & 100 M & 17.52 \\ 100 M & 150 M & 7.82 \\ 150 M & & 6.79\end{array}$

8.68
8.75
10.92
12.32
17.34

$\begin{array}{ll}0.62 & 10.43 \\ 0.73 & 10.39 \\ 0.92 & 11.45 \\ 1.15 & 11.15\end{array}$

$\begin{array}{lll}17.34 & 1.95 & 11.15 \\ & 1.95 & 10.73\end{array}$

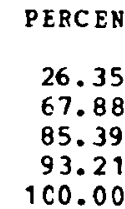

A SH

SOLFOR

MOISTUBE REIGHT ASH

$8.68 \quad 0.62 \quad 10.43 \quad 100.00,9.97$

8.68
8.72
9.17
9.44

0.62

0.69
0.73

0.73
0.77

9.97

0.85

10.43
10.41
10.62
10.66

10.67

100.00
73.65
32.12
14.61
6.79

9.97
10.43
12.62
14.65

17.34
PASSED--.--

SULPUR MOISTURE PERCENT PERCENT

$0.85 \quad 10.67$

$0.93 \quad 10.75$

$1.19 \quad 11.22$

$\begin{array}{ll}1.52 & 10.95 \\ 1.95 & 10.73\end{array}$ 
ANALYTICAL DATA

DATA FOR DRYPLO SEPARATION TEST \# 43

DATA POR - PRODUCT COAL.
PIGURES PROA PSOC 86 FEED SAMPLE.

THIS PRACTION CONSTITUTES 52.1 PERCENT OP THE PEED.
SIZE

FRACTION

PASSED RETAINED

HEIGHT DIRECT VALOES

-----CUMULATIVE RETAINED-----

$\begin{array}{rrrr} & 30 M & 8.50 & 7.78 \\ 30 M & 60 M & 31.80 & 8.10 \\ 60 M & 100 M & 28.20 & 9.55 \\ 100 M & 150 M & 15.30 & 10.67 \\ 150 M & & 16.20 & 14.76\end{array}$

$\begin{array}{lll}150 \mathrm{M} & 16.20 & 14.76\end{array}$

DATA FOR - MIDDLING COAL.

ASH VALOES-D.--

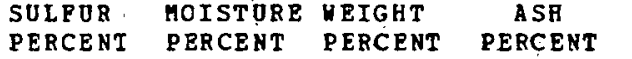

SOLPTR MOISTORE REIGHT

HOISTURE REIGHT ASH

TIVE
ASH

ASSED--D-- - -

SOLFOR, MOISTORE

$0.49 \quad 10.05$

8.50

7.78
8.03

0.49

$10.05 \quad 100.00$

$\begin{array}{lll}0.55 & 10.37 & 91.50\end{array}$

9.95

10.16

11.25

$0.73 \quad 10.50$

68.50

8.66

100.00

9.02
9.95

0.67

10.42

10.44
10.40

59.70
31.50

31.50
16.20

12.77
14.76

14.76

THIS FRACTION CONSTITOTES 24.5 PERCENT OF THE PEED. FRACTION

$\begin{array}{cccc}\text { FRACTION } & \text { MEIGHT } & \text { ASH } & \text { SUL } \\ \text { PASSED RETAINED } & \text { PERCENT } & \text { PERCENT } \\ & \text { POM: } & 49.60 & 8.24\end{array}$

DEIGHT DIRECT VALUES-

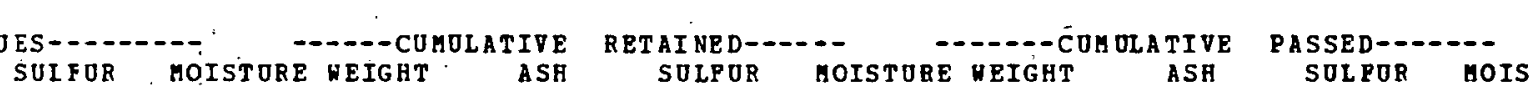

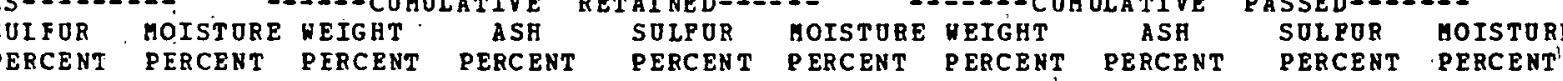

$\begin{array}{rrrr} & 30 M & 41.60 & 8.24 \\ 30 M & 60 M & 47.80 & 9.04 \\ 60 M & 100 M & 9.00 & 12.91 \\ 100 M & 150 M & 0.80 & 26.18 \\ 150 M & & 0.80 & 24.90\end{array}$

DATA POR - REPUSE COAL.

$\begin{array}{rrrr}0.55 & 10.20 & 41.60 & 8.24 \\ 0.69 & 10.40 & 89.40 & 8.67 \\ 1.25 & 10.55 & 98.40 & 9.06 \\ 4.88 & 10.05 & 99.20 & 9.19\end{array}$

$\begin{array}{llr}0.55 & 10.20 & 100.00 \\ 0.62 & 10.31 & 58.40 \\ 0.68 & 10.33 & 10.60 \\ 0.72 & 10.33 & 1.60 \\ 0.74 & 10.32 & 0.80\end{array}$
9.32
10.09
14.82

14.82
25.54

$0.74 \quad 10.32$

$0.88 \quad 10.41$

$1.72, \quad 10.46$
$4.39, \quad 9.95$

THIS PRACTION CONSTITUTES. 23.4 PERCENT OP THE PERD.

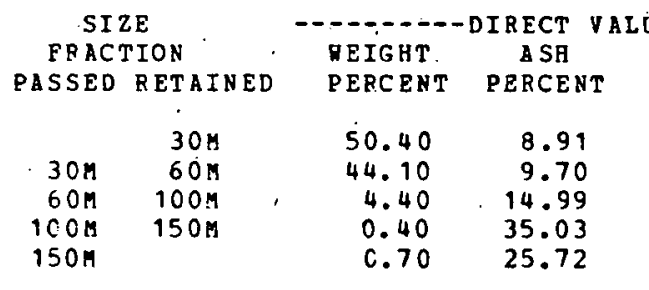

DATA FOR DRYFLO SEPARATION TEST * 43

DATA FOR -

* * conposite **

SULPUR MOISTORE REIGHT

TIVE RETAI
ASH

SAI NED --
SOIPUR

MOISTORE MEIGHT COLATIVE

$4.39,9.95$
$3.90 \quad 9.85$

. SIZE

--2--DIRECT VALOES

$\begin{array}{rrrr}0.68 & 9.65 & 50.40 & 8.91 \\ 0.79 & 9.75 & 94.50 & 9.28 \\ 1.86 & 10.25 & 9.8 .90 & 9.53 \\ 8.68 & 9.80 & 99.30 & 9.64 \\ 4.29 & 10.20 & 100.00 & 9.75 \\ & & \end{array}$

PERCEN T

TIVE PASSED-......

SULPOR HOISTURE

$\begin{array}{rrrrrr}0.68 & 9.65 & 100.00 & 9.75 & 0.84 & 9.72 \\ 0.73 & 9.70 & 49.60 & 10.60 & 1.00 & 9.80\end{array}$

$\begin{array}{rrrrrr}0.73 & 9.70 & 49.60 & 10.60 & 1.00 & 9.80 \\ 0.78 & 9.72 & 5.50 & 17.81 & 2.67 & 10.21\end{array}$

$\begin{array}{llllll}0.78 & 9.72 & 5.50 & 17.81 & 2.67 & 10.21 \\ 0.81 & 9.72 & 1.10 & 29.11 & 5.89 & 10.05\end{array}$

$\begin{array}{llllll}0.81 & 9.72 & 1.10 & 29.11 & 5.89 & 10.05\end{array}$

ANAITTICAL DATa

PIGURES PROA PSOC 86 PEED SAMPLE.

THIS PRACTION CONSTITUTES 100.0 PERCENT OP THE PEED.

FRACTION

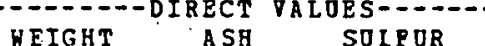

PASSED RETAINED

PERCENT PERCENT

-

MOISTURE AEIG CULULATIV

TIVE . PASSED--

$\begin{array}{rrrr} & 30 M & 26.41 & 8.46 \\ 30 \mathrm{H} & 60 \mathrm{OH} & 38.60 & 8.81 \\ 60 \mathrm{H} & 100 \mathrm{OH} & 17.93 & 10.28 \\ 100 \mathrm{OH} & 150 \mathrm{H} & 8.26 & 11.31\end{array}$

$\begin{array}{rr}0.60 & 9.93 \\ 0.66 & 10.25\end{array}$

$\begin{array}{ll}0.66 & 10.25 \\ 0.86 & 10.49\end{array}$

1. $17 \quad 10.48$

26.41

26.41
65.01

65.01
82.94

15.19

1.65

$\begin{array}{rr}10.48 & 91.20 \\ 10.19 & 100.00\end{array}$

8.46
8.67
9.02
9.23
9.75

PERCEN

PERCENT

SULFUR MOISTORE

PERCET PERCENT

8.80

0.64
0.68

0.72

9.93
10.12

10.12

10.20
10.22

100.00

73.59

34.99

$\begin{array}{rr}10.22 & 17.06 \\ & 8.80\end{array}$

9.75
10.21

10.21

11.76

13.31
15.19

0.80

$0.80 \quad 10.22$

$0.87 \quad 10.33$

$\begin{array}{ll}1.11 & 10.41 \\ 1.37 & 10.33\end{array}$

$\begin{array}{ll}1.37 & 10.33 \\ 1.65 & 10.19\end{array}$ 
DATA FOR DRYFLO SEPARATION TEST $\$ 44$ DATA POR - PRODUCT COAL.
PIGURES PROA PSOC 86 PEED SAMPLE.

TRIS PRACTION CONSTITUTES 64.1 PERCENT OP THE PEED.

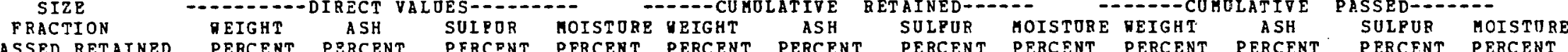

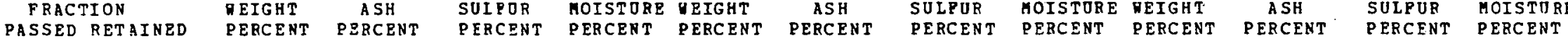

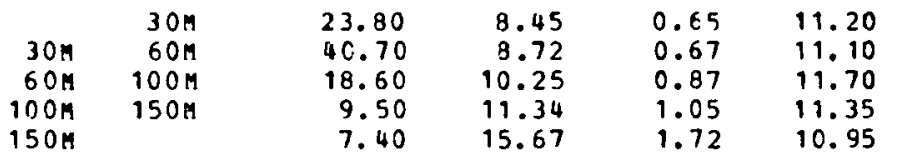

$\begin{array}{rl}23.80 & 8.45 \\ 64.50 & 8.62 \\ 83.10 & 8.99 \\ 92.60 & 9.23 \\ 90.00 & 9.70\end{array}$

0.65
0.66
0.71

11.20

100.00

9.70

0.82

11.25

100.00

9.70

0.71

11.26

35.50

16.90

11.67

13.24

11.45

THIS PRACTION CONSTITUTES 20.7 PERCENT OF THE PEED.

DATA FOR - MIDDLING COAL.

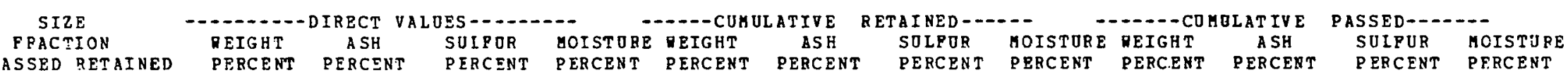

PASSED RET

$\begin{array}{rr}30 M & 30 M \\ 60 M & 6 O M \\ 10 O M & 10 C M \\ 150 M & 150 \mathrm{M}\end{array}$

61.20
35.80
2.20
0.30
0.50

9.14
10.35

19.14

0.69

10.30

61.20

ERCENT

PERCENT

gRCE

$2.70 \quad 10.65$

10.65
9.25

97.00
99.20

99.50

0.73

9.80

0.77

23.80

2.98

$10.10 \quad 100.00$

$9.95 \quad 0.78$

10.24

10.25

100.00

38.80
3.00

11.24
21.81

10.25

$0.50 \quad 23.80$

$\begin{array}{ll}0.78 & 10.25 \\ 0.93 & 10.17\end{array}$

$2.48 \quad 10.42$

$1.86 \quad 9.78$

THIS PRACTION CONSTITOTES 15.2 PERCENT OP THE PEED.

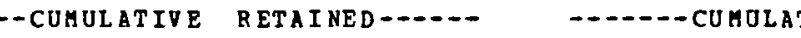

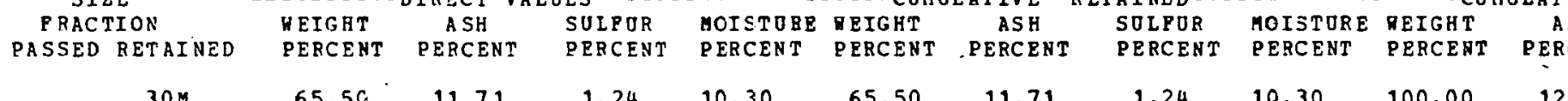

\begin{tabular}{|c|c|c|c|c|c|c|c|c|c|c|c|c|c|}
\hline $\begin{array}{l}30 M \\
60 H \\
100 M \\
15 O M\end{array}$ & $\begin{array}{l}30 \mathrm{M} \\
60 \mathrm{M} \\
100 \mathrm{M} \\
150 \mathrm{M}\end{array}$ & $\begin{array}{r}65.50 \\
32.70 \\
0.90 \\
0.20 \\
0.70\end{array}$ & $\begin{array}{l}11.71 \\
11.83 \\
27.47 \\
45.77 \\
22.20\end{array}$ & $\begin{array}{l}1.24 \\
1.23 \\
5.85 \\
0.00 \\
3.66\end{array}$ & $\begin{array}{r}10.30 \\
10.40 \\
9.35 \\
10.40 \\
9.90\end{array}$ & $\begin{array}{r}65.50 \\
98.20 \\
99.10 \\
99.30 \\
100.00\end{array}$ & $\begin{array}{l}11.71 \\
11.75 \\
11.89 \\
11.96 \\
12.03\end{array}$ & $\begin{array}{l}1.24 \\
1.24 \\
1.28 \\
1.28 \\
1.29\end{array}$ & $\begin{array}{l}10.30 \\
10.33 \\
10.32 \\
10.32 \\
10.32\end{array}$ & $\begin{array}{r}100.00 \\
34.50 \\
1.80 \\
0.90 \\
0.70\end{array}$ & $\begin{array}{l}12.03 \\
12.65 \\
27.45 \\
27.44 \\
22.20\end{array}$ & $\begin{array}{l}1.29 \\
1.39 \\
4.35 \\
2.85 \\
3.66\end{array}$ & $\begin{array}{r}10.32 \\
10.36 \\
9.68 \\
10.01 \\
9.90\end{array}$ \\
\hline
\end{tabular}

DATA POR DRYPLO SEPARATION TEST * 44 ANALYTICAL DATA

PIGURES PROM PSOC 86 FEED SAMPLE.

DATA FOR -

* * cogposite * *

THIS PRACTION CONSTITOTES 100.0 PERCENT OF THE PEED.

SIZE -DIRECT VALUES -

FRACTION

PASSED RETAIYED

HEIGHT ASH SOLPOR AOT

- - - - CUN OLATIVE

SOLPUR MOISTURE HEIGHT ASH SULPUR MOISTOPE

$\begin{array}{rrrrrr} & 30 M & 37.88 & 9.54 & 0.82 & 10.66 \\ 30 M & 60 M & 38.47 & 9.8 .4 & 0.77 & 10.83 \\ 60 \mathrm{M} & 10 \mathrm{MM} & 12.51 & 10.78 & 0.99 & 11.64 \\ 100 \mathrm{M} & 150 \mathrm{M} & 6.18 & 11.38 & 1.03 & 11.32 \\ 150 \mathrm{M} & & 4.95 & 15.98 & 1.79 & 10.91\end{array}$

37.88
76.35
88.86
95.05
100.00

PERCENT

9.54
9.49
9.67
9.80

0.82

0.82
0.79
0.82
0.83

10.66

100.00

10.11

PERCENT PERCENT

10.11

0.88

10.75

10.87

10.90
10.90

62.12

12.12

$4.95 \quad 13.65$

15.98

$\begin{array}{ll}0.88 & 10.90 \\ 0.92 & 11.05\end{array}$

$0.92 \quad 11.05$

$\begin{array}{ll}1.17 & 11.4 \mathrm{C} \\ 1.37 & 11.14\end{array}$

$\begin{array}{ll}1.37 & 11.14 \\ 1.79 & 10.91\end{array}$ 
ANALYTICAL DATA

DATA FOR DRYFLO SEPARATION TRST \# 45 DATA FOR - PRODUCT. COAL.
PIGURES FROM PSOC 86 PEED SAMPLE.

TEIS PRACTION CONSTITOTES 66.1 PERCENT OP THE PEED.

\begin{tabular}{|c|c|c|c|c|c|c|c|c|c|c|c|c|c|}
\hline \multirow{2}{*}{\multicolumn{2}{|c|}{$\begin{array}{c}\text { SIZE } \\
\text { FRACTION }\end{array}$}} & \multicolumn{2}{|c|}{$-\cdots-$ DIRECT V } & \multicolumn{2}{|c|}{ VALUES - - - - - } & \multicolumn{2}{|c|}{ - - - CUHULATIVE } & \multicolumn{2}{|c|}{ RETAINED - . . } & \multicolumn{2}{|c|}{--- CUMULATIVE } & \multicolumn{2}{|c|}{ PASSED-- - - - } \\
\hline & & HEIGHT & ASH & SULPOR & MOISTURB & DEIGHT & ASH & SOLFUR & MOISTURE & WEIGHT & ASH & SULPUR & MOISTU \\
\hline PASSED & RPTAINED & PERCENT & PERCENT & PERCENT & PERCENT & PERCENT & PERCENT. & PERCENT & PERCENT & PERCENT & PERCENT & PERCENT & PERCENT \\
\hline $\begin{array}{l}30 \mathrm{M} \\
60 \mathrm{OM} \\
100 \mathrm{M} \\
150 \mathrm{M}\end{array}$ & $\begin{array}{r}30 M \\
60 M \\
100 M \\
150 M\end{array}$ & $\begin{array}{r}25.40 \\
40.10 \\
18.40 \\
9.40 \\
6.70\end{array}$ & $\begin{array}{r}8.72 \\
8.89 \\
10.42 \\
11.25 \\
15.87\end{array}$ & $\begin{array}{l}0.66 \\
0.64 \\
0.82 . \\
0.97 \\
1.64\end{array}$ & $\begin{array}{l}11.10 \\
11.15 \\
1.1 .75 \\
11.55 \\
1.0 .85\end{array}$ & $\begin{array}{r}25.40 \\
65.50 \\
83.90 \\
93.30 \\
100.00\end{array}$ & $\begin{array}{l}8.72 \\
8.82 \\
9.17 \\
9.38 \\
9.82\end{array}$ & $\begin{array}{l}0.66 \\
0.65 \\
0.69 \\
0.71 \\
0.78\end{array}$ & $\begin{array}{l}11.10 \\
11.13 \\
11.27 \\
11.30 \\
11.27\end{array}$ & $\begin{array}{r}100.00 \\
74.60 \\
34.50 \\
16.10 \\
6.70\end{array}$ & $\begin{array}{r}9.82 \\
10.19 \\
11.70 \\
13.17 \\
15.87\end{array}$ & $\begin{array}{l}0.78 \\
0.82 \\
1.02 \\
1.25 \\
1.64\end{array}$ & $\begin{array}{l}11.27 \\
11.32 \\
11.52 \\
11.26 \\
10.85\end{array}$ \\
\hline
\end{tabular}

DATA FOR - MIDDLING COAL.

THIS PRACTION CONSTITUTES 24.3 PERCENT OP THE PEED.

SIZE

FEACTION
PASSED RETAINED

$\begin{array}{rr} & 30 M \\ 30 M & 60 M \\ 60 M & 100 M \\ 10 O M & 150 M\end{array}$$$
\text { NEIGHT }
$$

-DIRECT VALUES

CT VALUES -

-..--COHULATIVE RETAINED-.....

- - - - CUNOLATIVE OISTORE UEIGHT

ASH RTAT

SOIPOR
PERCENT

MOISTORE WEIGHT ASH

PASSED'-...-

SULFUR MOISTURE

$61.40 \quad 9.99$

$\begin{array}{rr}61.40 & 9.99 \\ 35.80 & 10.76 \\ 2.10 & 17.21 \\ 0.30 & 33.41 \\ 0.40 & 21.23\end{array}$

0.73

0.99
2.42

11.45
$10.8 \mathrm{C}$

$10.8 \mathrm{C}$
11.10

$6.67 \quad 9.30$
4.189 .30

61.40
97.20

97.20
99.30

9.99
10.27
10.42
10.49

0.73

0.73
0.83

0.83
0.86

11.45
11.21

11.21
11.21

99.60
100.00

10.53

$0.89 \quad 11.20$

100.00
38.60
2.80
0.70
0.40

10.53

11.40

19.52

26.45
21.23

PEPCENT

THIS PRACTION CONSTITUTES 9.6 PERCENT OF THE PEED.

DATA FOR - REPUSE COAL.

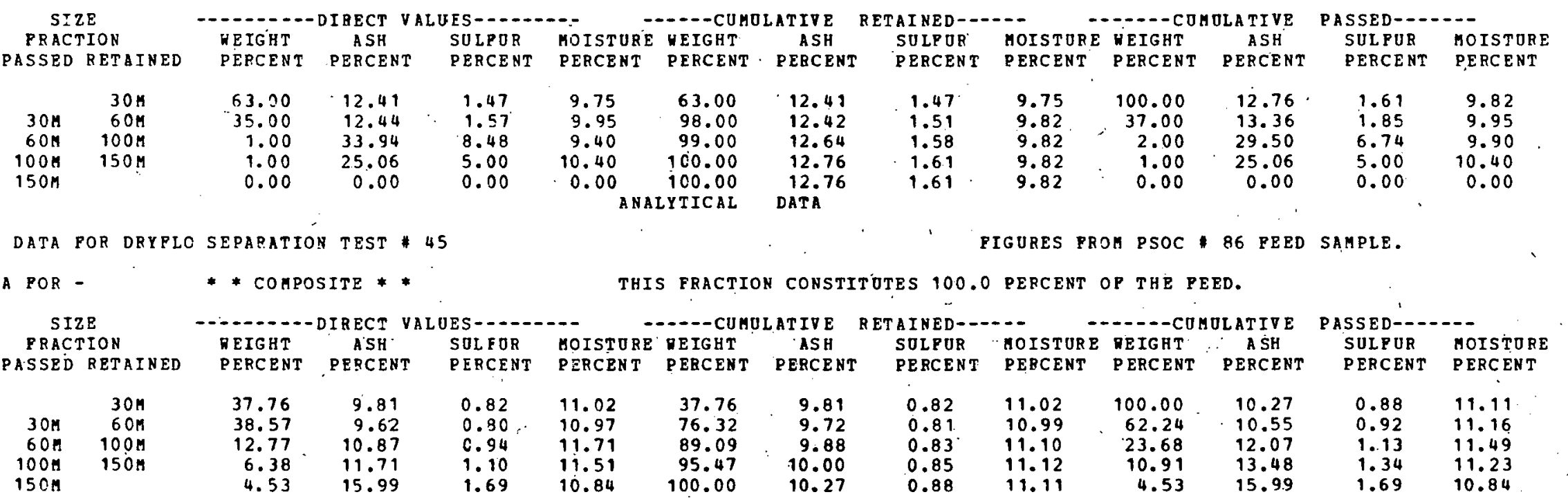


ANALYTICAL DATA

DATA POR DRYPLO SEPAPATION TEST $\$ 46$ DATA FOR - PRCDUCT COAL.
FIGURES PFOA PSOC 208 FEED SAMPLE.

THIS PRACTION CONSTITUTES 54.4 PERCEHT OP THE PEED.
SIZE FRACTION PASSED RETAINED

$\begin{array}{rrrr} & 30 M & 16.30 & 5.16 \\ 30 M & 60 M & 32.60 & 5.58 \\ 60 M & 100 M & 22.70 & 7.38 \\ 100 M & 150 \mathrm{M} & 11.40 & 9.65 \\ 150 \mathrm{M} & & 17.00 & 16.54\end{array}$

DATA FOR - MIDDLING COAL.$$
\text { SIZE }
$$$$
\text { FPACTION }
$$

PASSEDION PEIGHT

DITECT $\nabla$ ALOES -

SOIPOR

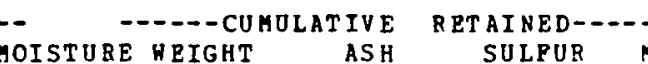

PE

$\begin{array}{rrr}1.73 & 2.20 & 16.30 \\ 1.91 & 3.15 & 48.90 \\ 2.34 & 3.80 & 71.60 \\ 3.15 & 3.60 & 83.00 \\ 5.10 & 3.85 & 100.00\end{array}$

$\begin{array}{ll}5.16 & 1.73 \\ 5.44 & 1.85 \\ 6.06 & 2.01 \\ 6.55 & 2.16 \\ 8.25 & 2.66\end{array}$

THIS PRACTION CONSTITOTES 33.7 PERCERT OP THE PEED.

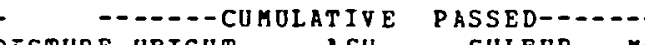
IVE PASSED-D MOISTURE

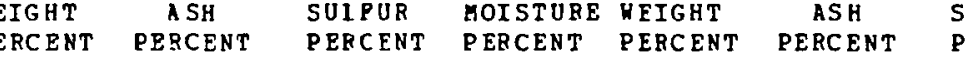

$\begin{array}{rrrr} & 30 M & 51.40 & 6.85 \\ 30 M & 60 M & 39.10 & 7 . C 5 \\ 60 M & 100 M & 7.40 & 11.53 \\ 100 M & 150 M & 1.30 & 22.29 \\ 150 M & & 0.80 & 31.45\end{array}$

$\begin{array}{rr}2.53 & 2.85 \\ 2.77 & 2.90 \\ 3.88 & 3.70 \\ 9.97 & 3.10 \\ 14.28 & 3.50\end{array}$

51.40
90.50
97.90
99.20
100.00

6.85
6.94
7.28
7.48
7.67

2.91

THIS PRACTION CONSTITUTES

A I NED - - . PERCE

2.53
2.63
2.73
2.82
2.91
HOTSTURE WEIGHT ASB $\begin{array}{ccc} & \text { PERCENT } & \text { PERCENT } \\ 2.85 & 100.00 & 7.67\end{array}$

$\begin{array}{rrr}2.85 & 100.00 & 7.67 \\ 2.87 & 48.60 & 8.54 \\ 2.93 & 9.50 & 14.68 \\ 2.94 & 2.10 & 25.78\end{array}$

$\begin{array}{lll}2.94 & 2.10 & 25.78 \\ 2.94 & 0.80 & 31.45\end{array}$

DATA FOR - REFUSE COAL

$\begin{array}{rrrrr}2.20 & 100.00 & 8.25 & 2.66 & 3.31 \\ 2.83 & 83.70 & 8.85 & 2.84 & 3.53 \\ 3.14 & 51.10 & 10.93 & 3.44 & 3.77 \\ 3.20 & 28.40 & 13.77 & 4.32 & 3.75 \\ 3.31 & 17.00 & 16.54 & 5.10 & 3.85\end{array}$

3.31
3.53

.77 3.85

$\begin{array}{ll}\text { SULPUR } & \text { MOISTURE } \\ \text { PERCENT } & \text { PERCENT }\end{array}$

$\begin{array}{rr}2.91 & 2.94 \\ 3.32 & 3.04 \\ 5.59 & 3.60 \\ 11.61 & 3.25 \\ 14.28 & 3.50\end{array}$

$\begin{array}{ll}11.61 & 3.25 \\ 14.28 & 3.50\end{array}$
11 PERCENT PERCENT DATA FOR -

\begin{tabular}{|c|c|c|c|c|c|}
\hline \multirow{2}{*}{\multicolumn{2}{|c|}{$\begin{array}{c}\text { SIZE } \\
\text { FRACTION }\end{array}$}} & \multicolumn{4}{|c|}{$\ldots-\ldots$ DIRECT VALUES $\cdots$} \\
\hline & & HEIGHT & A SH & SUIPUR & \\
\hline PASSED & RETAINED & PERCENT & PERCENT & PERCENT & PE \\
\hline & $30 \mathrm{M}$ & $\begin{array}{l}55.60 \\
39.30\end{array}$ & $\begin{array}{l}9.72 \\
9.84\end{array}$ & 3.75 & \\
\hline $60 \mathrm{M}$ & $\begin{aligned} 604 \\
1034\end{aligned}$ & 4.10 & 19.73 & 6.90 & \\
\hline $100 \mathrm{M}$ & 1508 & 0.50 & 42.13 & 20.01 & \\
\hline $150 \mathrm{M}$ & & 0.50 & 34.90 & 16.25 & \\
\hline
\end{tabular}

DATA POR DRYFLO SEPARATION TEST *46

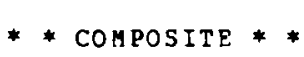

ASH
PERCENT

\section{STZE}

PRACTION

PASSED RETAINED

$$
\text { WEIGHT ASH AT }
$$

ASH VALUES---.--

SULPUR

MOISTURE

RE UEIGHT

-

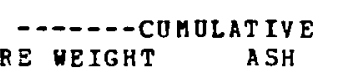

$\begin{array}{lll}.75 & 55.60 & 9.72 \\ & 95 & 9.77\end{array}$

9.72
9.77
10.18
10.34

3.75
3.73

3.73
3.86
3.95

10.47

4.01

PERCEST

2.75
2.83

2.83
2.85

2.85
2.84

2.85

100.00

44.40
5.10

5.10
1.00

0.50

PERCENT

FIGURES PROM PSOC 208 FEED SAMPLE.

THIS PRACTION CONSTITOTES 100.0 PERCENT OF THE PEED.

----CUMULATIVE RETAINED----

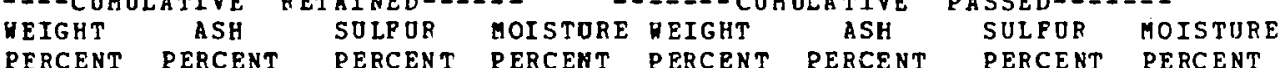

RCENT PERCENT PERCENT

$\begin{array}{rrrrrr} & & & & \\ 30 M & 60 M & 32.81 & 6.57 & 2.56 & 2.65 \\ 60 M & 100 M & 35.59 & 6.68 & 2.46 & 3.03 \\ 100 M & 150 M & 6.73 & 8.45 & 2.74 & 3.7 \\ 150 M & & 9.58 & 10.77 & 3.75 & 3.55 \\ 1507 & & 9.07 & 5.43 & 3.84\end{array}$


ANALYTICAL DATA

DATA POR DRYPLO SEPARATION TEST 47

FIGURES FROM PSOC 208 PEED SAMPLE.

DATA POR:- PRODUCT COAL.

THIS PRACTION CONSTITUTES 59.9 PERCENT OP THE PEED.

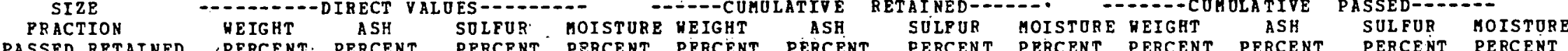

PASSED RETAINED , PERCENT. PERCENT PERCENT PERCENT PRRCENT PERCENT PERCENT PERCENT PERCENT PERCENT PERCEAT PERCENT

\begin{tabular}{|c|c|c|c|c|c|c|c|c|c|c|c|c|c|}
\hline $\begin{array}{l}30 \mathrm{H} \\
60 \mathrm{M} \\
10.0 \mathrm{M} \\
150 \mathrm{H}\end{array}$ & $\begin{array}{l}30 M \\
60 M \\
100 M \\
150 M\end{array}$ & $\begin{array}{l}18.90 \\
32.90 \\
21.70 \\
11.10 \\
15.40\end{array}$ & $\begin{array}{r}5.84 \\
5.31 \\
7.31 \\
10.37 \\
16.01\end{array}$ & $\begin{array}{l}1.88 \\
2.07 \\
2.35 \\
3.36 \\
4.90\end{array}$ & $\begin{array}{l}3.20 \\
3.05 \\
3.60 \\
3.55 \\
3.20\end{array}$ & $\begin{array}{r}18.90 \\
51.80 \\
73.50 \\
84.60 \\
100.00\end{array}$ & $\begin{array}{l}5.84 \\
5.50 \\
6.04 \\
6.61 \\
8.05\end{array}$ & $\begin{array}{l}1.88 \\
2.00 \\
2.10 \\
2.27 \\
2.67\end{array}$ & $\begin{array}{l}3.20 \\
3.10 \\
3.25 \\
3.29 \\
3.28\end{array}$ & $\begin{array}{r}100.00 \\
81.10 \\
48.20 \\
26.50 \\
15.40\end{array}$ & $\begin{array}{r}8.05 \\
8.57 \\
10.79 \\
13.65 \\
16.01\end{array}$ & $\begin{array}{l}2.67 \\
2.86 \\
3.40 \\
4.25 \\
4.90\end{array}$ & $\begin{array}{l}3.28 \\
3.29 \\
3.46\end{array}$ \\
\hline
\end{tabular}

DATA FOR - MIDDLING COAL.

THIS PRACTION CONSTITUTES 14.0 PERCENT OF THE PEED.

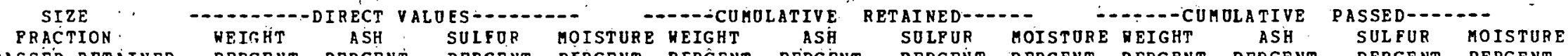

PASSED RETAINED PERCENT PERCENT PERCENT PERCENT PERCENT PERCENT PERCENT PERCENT PERCENT PERCENT. PERCENT PERCENT

\begin{tabular}{|c|c|c|c|c|c|c|c|c|c|c|c|c|}
\hline 1007 & $\begin{array}{r}30 M \\
60 M \\
100 M \\
150 M\end{array}$ & $\begin{array}{r}47.60 \\
40.30 \\
9.40 \\
1.60 \\
1.10\end{array}$ & $\begin{array}{r}5.99 \\
6.92 \\
10.08 \\
19.77 \\
29.37\end{array}$ & $\begin{array}{l}2.17 \\
2.65 \\
3.51 \\
7.79\end{array}$ & $\begin{array}{l}3.15 \\
3.20 \\
3.30 \\
2.65\end{array}$ & $\begin{array}{r}47.60 \\
87.90 \\
97.30 \\
98.90\end{array}$ & $\begin{array}{l}5.99 \\
6.42 \\
6.77 \\
6.98\end{array}$ & $\begin{array}{l}2.17 \\
2.39 \\
2.50 \\
2.58\end{array}$ & $\begin{array}{l}3.15 \\
3.17 \\
3.19 \\
3.18\end{array}$ & $\begin{array}{r}100.00 \\
52.40 \\
12.10 \\
2.70\end{array}$ & $\begin{array}{r}7.23 \\
8.35 \\
13.11 \\
23.68\end{array}$ & $\begin{array}{r}2.69 \\
3.17 \\
4.89 \\
9.68\end{array}$ \\
\hline
\end{tabular}

DATA FOR - REFUSE COAL.

THIS PRACTION CONSTITUTES 26.1 PERCENT OP THE PEED.

PRACTION

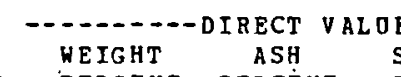

1

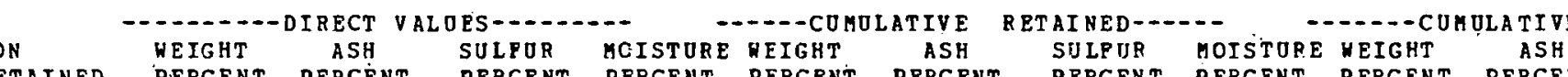

\begin{tabular}{|c|c|c|c|}
\hline $\begin{array}{r}30 \mathrm{M} \\
60 \mathrm{M} \\
100 \mathrm{M} \\
150 \mathrm{M}\end{array}$ & $\begin{array}{r}30 M \\
60 \mathrm{M} \\
100 \mathrm{M} \\
150 \mathrm{M}\end{array}$ & $\begin{array}{r}55.20 \\
38.50 \\
5.30 \\
0.60 \\
0.40\end{array}$ & $\begin{array}{r}8.41 \\
8.76 \\
16.03 \\
33.50 \\
32.99\end{array}$ \\
\hline
\end{tabular}

DATA POR DRYFLO SEPARATION TEST \$47

DATA FOR -

* *omposite * *

PERCENT PERCENT PERCENT

SASSED-- - -

$\begin{array}{lllll}3.02 & 1.95 & 55.20 & \mathbf{8 . 4 1} & \mathbf{3} .02\end{array}$

$1.95 \quad 100.00$

ERCENT

PERCENT PERCENT

- SIZE

PRACTION

- - - - DIRECT VALUES- - - - -

$\begin{array}{ll}2.35 & 93.70 \\ 3.30 & 99.00\end{array}$

8.55

3.17

2.11

44.80
6.30

9.20
10.17

3.41
3.89

$3.60 \quad 100.00$

$9.10 \quad 3.36$

2.18

1.00

18.77

33.30

6.93

2.47

ANALYTICAL

DATA

3.36
3.41

2.18

0.40

32.99

15.04

3. 20

PIGURES FRO'M PSOC * 208 FEED SAMPLE.

THIS FRACTION CONSTITUTES 100.0 PERCENT OP THE PEED.

DEIGHT ASH

SOIFOR

--.--COUOLATIVE RETAINED-...- - - COROLATIVE PAS

$\begin{array}{rrr}30 \mathrm{M} & 30 \mathrm{M} & 32.39 \\ 60 \mathrm{M} & 60 \mathrm{M} & 35.40 \\ 100 \mathrm{M} & 100 \mathrm{M} & 15.70 \\ 150 \mathrm{M} & 150 \mathrm{M} & 7.03 \\ 150 & 9.48\end{array}$

$\begin{array}{rrr}7.01 & 2.45 & 2.63 \\ 6.55 & 2.54 & 2.88 \\ 8.31 & 2.72 & 3.55 \\ 11.18 & 3.75 & 3.49 \\ 16.41 & 5.13 & 3.20\end{array}$

$\begin{array}{rr}32.39 & 7.01 \\ 67.79 & 6.77 \\ 83.49 & 7.06 \\ 90.52 & 7.38 \\ 100.00 & 8.24\end{array}$

SOLPOR

MOISTURE

$$
\text { WEIGHT }
$$

ASH

PASSED-...-.

SULPUR MOISTURE

PERCENT PERCENT

$\rightarrow$

16.41

5.13

2.45
2.49
2.54
2.63
2.87

2.63

2.76

2.91

100.00

67.61

32.21

16.51
9.48

8.24
8.82
11.32

2:.87

3.07

$5.13 \cdot 3.20$ 
ANALYTICAL DATA

DATA POR DRYPLO SEPARATION TEST \# 48

DATA FOR - PFODUCT COAL.
PIGURES PROA PSOC * 208 FEED SAMPLE.

THIS FRACTION CONSTITUTES 60.2 PERCENT OP THE PEED.

\begin{tabular}{|c|c|c|c|c|c|c|c|c|c|c|c|c|c|}
\hline \multicolumn{2}{|c|}{ SIZE } & \multicolumn{2}{|c|}{ - DIRECT } & \multicolumn{2}{|c|}{ VALUES $-\cdots$} & \multicolumn{2}{|c|}{--- CUMULATIVE } & \multicolumn{2}{|c|}{ RETAINED-- - - } & \multicolumn{2}{|c|}{$--\cdots--$ COAOLATIVE } & \multicolumn{2}{|c|}{ PASSED - } \\
\hline $\begin{array}{r}\text { FRAC } \\
\text { PASSED }\end{array}$ & $\begin{array}{l}\text { RION } \\
\text { RETAINED }\end{array}$ & $\begin{array}{l}\text { NEIGET } \\
\text { PERCENT }\end{array}$ & $\begin{array}{c}\text { A SH } \\
\text { PERCENT }\end{array}$ & $\begin{array}{l}\text { SUIFCR } \\
\text { PERCENT }\end{array}$ & $\begin{array}{l}\text { MOIST URE } \\
\text { PERCENT }\end{array}$ & $\begin{array}{l}\text { YEIGHT } \\
\text { PERCENT }\end{array}$ & $\begin{array}{l}\text { AS H } \\
\text { PERCENT }\end{array}$ & $\begin{array}{l}\text { SOLPUR } \\
\text { PERCENT }\end{array}$ & $\begin{array}{l}\text { MOISTURE } \\
\text { PERCENT }\end{array}$ & $\begin{array}{l}\text { NEIGHT } \\
\text { PERCENT }\end{array}$ & $\begin{array}{c}\text { A SH } \\
\text { PERCENT }\end{array}$ & $\begin{array}{l}\text { SULPOR } \\
\text { PERCENT }\end{array}$ & $\begin{array}{l}\text { MOISTO } \\
\text { PERCEN }\end{array}$ \\
\hline $\begin{array}{l}30 \% \\
60 \% \\
100 \% \\
150 M\end{array}$ & $\begin{array}{r}30 M \\
60 M \\
100 M \\
150 M\end{array}$ & $\begin{array}{l}20.60 \\
32.80 \\
19.20 \\
15.10 \\
12.30\end{array}$ & $\begin{array}{r}5.15 \\
5.78 \\
7.52 \\
10.21 \\
16.19\end{array}$ & $\begin{array}{l}1.91 \\
2.07 \\
2.38 \\
3.36 \\
5.08\end{array}$ & $\begin{array}{l}3.00 \\
3.05 \\
3.55 \\
3.55 \\
3.35\end{array}$ & $\begin{array}{r}20.60 \\
53.40 \\
72.60 \\
87.70 \\
100.00\end{array}$ & $\begin{array}{l}5.15 \\
5.54 \\
6.06 \\
6.78 \\
7.93\end{array}$ & $\begin{array}{l}1.91 \\
2.01 \\
2.11 \\
2.32 \\
2.66\end{array}$ & $\begin{array}{l}3.00 \\
3.03 \\
3.17 \\
3.23 \\
3.25\end{array}$ & $\begin{array}{r}100.00 \\
79.40 \\
46.60 \\
27.40 \\
12.30\end{array}$ & $\begin{array}{r}7.93 \\
8.66 \\
10.68 \\
12.89 \\
16.19\end{array}$ & $\begin{array}{l}2.66 \\
2.86 \\
3.41 \\
4.13 \\
5.08\end{array}$ & $\begin{array}{l}3.25 \\
3.31 \\
3.50 \\
3.46 \\
3.35\end{array}$ \\
\hline
\end{tabular}

DATA. FOR - MIDDLING COAL.

THIS PRACTION CONSTITOTES 19.6 FERCENT OP THE PEED.

\begin{tabular}{|c|c|c|c|c|c|c|c|c|c|c|c|c|c|}
\hline \multirow{2}{*}{\multicolumn{2}{|c|}{$\begin{array}{l}\text { SIZE } \\
\text { FPACTION }\end{array}$}} & \multicolumn{2}{|c|}{$---1---$ DIRECT V } & \multicolumn{2}{|c|}{ VALUES } & \multicolumn{2}{|c|}{--- CUNOLATIVE } & \multicolumn{2}{|c|}{ RETAINED - } & \multicolumn{2}{|c|}{-- CUMULAT IVE } & \multicolumn{2}{|c|}{ PASSED- } \\
\hline & & WEIGET & A SH & SULF OR & MOISTURE & VEIGAT & ASH & SULPOR & MOISTORE & HEIGRT & A SH & SULF OR & MOIS \\
\hline PASSED & RETAI UED & PERCENT & PERCENT & PERCEN: & PERCENT & PERCENT & PERCENT & PERCENT & EERCENT & PERCENT & PERCENT & PERCENT & 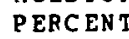 \\
\hline $\begin{array}{r}30 \mathrm{M} \\
60 \mathrm{~B} \\
100 \mathrm{M} \\
150 \mathrm{M}\end{array}$ & $\begin{array}{r}30 M \\
60 M \\
100 M \\
150 M\end{array}$ & $\begin{array}{r}51.10 \\
39.50 \\
7.50 \\
1.10 \\
0.83\end{array}$ & $\begin{array}{r}7.05 \\
7.75 \\
10.93 \\
21.69 \\
32.30\end{array}$ & $\begin{array}{r}2.48 \\
2.87 \\
4.00 \\
8.87 \\
14.41\end{array}$ & $\begin{array}{l}3.60 \\
3.25 \\
3.45 \\
2.95 \\
3.25\end{array}$ & $\begin{array}{r}51.10 \\
90.60 \\
98.10 \\
99.20 \\
100.00\end{array}$ & $\begin{array}{l}7.05 \\
7.36 \\
7.63 \\
7.78 \\
7.98\end{array}$ & $\begin{array}{l}2.48 \\
2.65 \\
2.75 \\
2.82 \\
2.91\end{array}$ & $\begin{array}{l}3.60 \\
3.45 \\
3.45 \\
3.44 \\
3.44\end{array}$ & $\begin{array}{r}100.00 \\
48.90 \\
9.40 \\
1.90 \\
0.80\end{array}$ & $\begin{array}{r}7.98 \\
8.95 \\
14.01 \\
26.16 \\
32.30\end{array}$ & $\begin{array}{r}2.91 \\
3.37 \\
5.46 \\
11.20 \\
14.41\end{array}$ & $\begin{array}{l}3.44 \\
3.27 \\
3.37 \\
3.08 \\
3.25\end{array}$ \\
\hline
\end{tabular}

DATA FOR - REFUSE COAL.

ThIS FRACTION CONSTItUTES 20.2 PERCENT OF THE PEED.

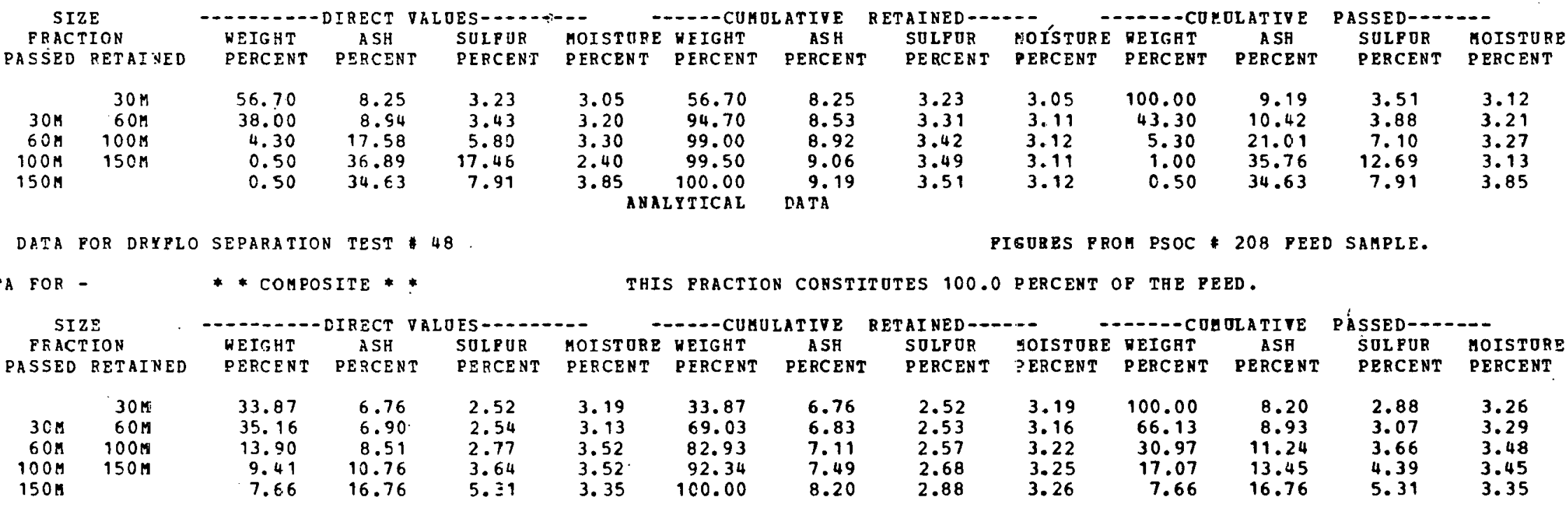


ANALYTICAL: DATA

PIGORES PROA PSOC 208 PEED SAMPLE.

DATA FOR DRYFLO SEPARATION TEST 49

DATA POR - PRODUCT COAL.

THIS PRACTION CONSTITUTES 56.2 PERCENT OP THE PEED.

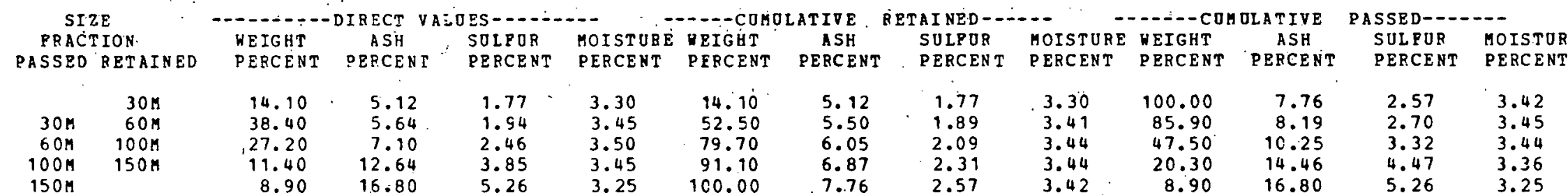

DATA FOR - MIDDLING COAL.

THIS FRACTION CONSTITUTES 20.3 PERCENT OP THE PEED.

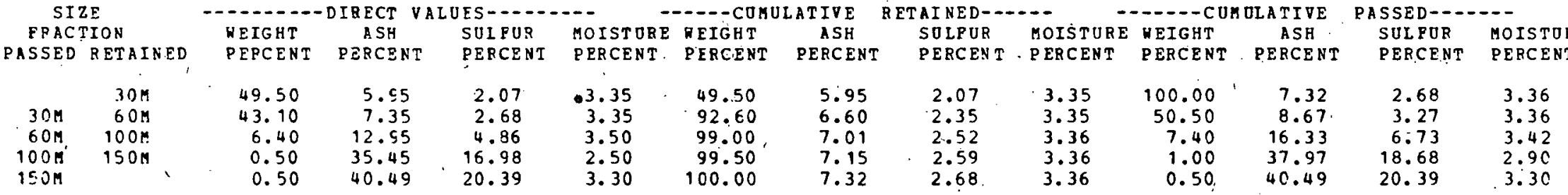

DATA FOR - REFUSE COAL.

TAIS FRACTION CONSTITOTES, 23.5 PERCENT OP THE PEED.

- SIZE

FRACTION
PASSED.RETAINED

$\begin{array}{rrrr} & 30 M & 58.50 & 8.15 \\ 30 M & 60 M & 37.90 & 8.72 \\ 60 M & 100 M & 3.00 & 23.83 \\ 160 M & 150 M & 0.60 & 40.50 \\ 150 M & & 0.00 & 0.00\end{array}$

DATA FOR DRYFLO SEPARATION TEST * 49 DATA FOR -

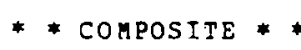

--2-CUGULATIVE RETAINED-- OES SULFUR

PERCENT

3.03
3.58
9.55
21.87

$$
\begin{aligned}
& \text { PERCE } \\
& 3.10 \\
& 3.05 \\
& 3.05 \\
& 3.70 \\
& 0.00
\end{aligned}
$$$$
\text { MOIST ORE UEIGHT }
$$

RE NEIGHT.

ASH

SOLFUR

PERCEN

\begin{abstract}
8.15 3.03
\end{abstract}
8.15
8.37

$8.37-3.25$

8.84
9.03
ISTURE VEIGHT

TH DLATIVE ATIVE

9.03

DATA
3.03
3.25
3.44
3.55
3.55
3.10

3.08

3.08
3.08
100.00
41.50
3.60
0.60
0.00
PERCENT

9.03
10.27
26.61
40.50
0.00

FIGURES PROM PSOC 208 PEED SAMPLE. TEIS FRACTION CONSTITOTES 100.0 PERCENT OP TYE FEED.

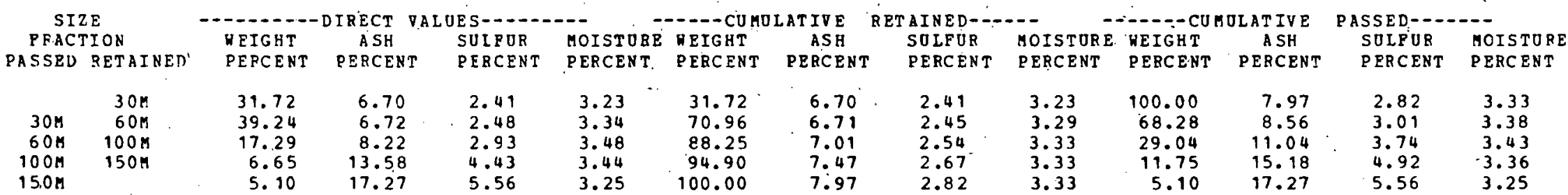


ANALYTICAL DATa

DATA FOR DRYPLO SEPARATION TEST 50 DATA POR - PRODUCT COAL.
PIGURES PROA PSOC 208 PEED SAMPLF.

THIS PRACTIO CONSTITUTES 63.0 PERCENT OP THE PEBD.

\begin{tabular}{|c|c|c|c|c|c|c|c|c|c|c|c|c|c|}
\hline \multirow{2}{*}{\multicolumn{2}{|c|}{$\begin{array}{c}\text { SIZE } \\
\text { PRACTION }\end{array}$}} & \multicolumn{2}{|c|}{$-\cdots-1-D$ DIRECT } & JES - & $\cdots$ & \multicolumn{2}{|c|}{$-\cdots-\infty$ COMÜATIVB } & \multicolumn{2}{|c|}{ BETAINED - - - - } & \multicolumn{2}{|c|}{$\cdots--$ COHULAT IVE } & \multicolumn{2}{|c|}{ PASSED-..... } \\
\hline & & NEIGHT & A SH & SULFOR & MOISTURE & WEIGHT & AS H & SOLFOR & MOISTURE & DEIGHT & A SH & SULFUR & MOIST \\
\hline PASSED & RETAINED & PERCENT & PERCENT & PERCENT & PERCENT & PERCENT & PERCENT & PERCENT & PERCENT & PERCENT & PERCENT & PERCENT & PERCENT \\
\hline $\begin{array}{r}304 \\
60 K \\
1004 \\
150 \%\end{array}$ & $\begin{array}{l}30 \mathrm{H} \\
60 \mathrm{H} \\
100 \mathrm{M} \\
150 \mathrm{H}\end{array}$ & $\begin{array}{r}17.80 \\
43.20 \\
23.90 \\
9.60 \\
5.50\end{array}$ & $\begin{array}{r}5.11 \\
5.95 \\
8.79 \\
14.77 \\
18.18\end{array}$ & $\begin{array}{l}1.74 \\
2.12 \\
2.88 \\
4.93 \\
5.98\end{array}$ & $\begin{array}{l}3.20 \\
3.40 \\
3.35 \\
3.15 \\
3.20\end{array}$ & $\begin{array}{r}17.80 \\
61.00 \\
84.90 \\
94.50 \\
100.00\end{array}$ & $\begin{array}{l}5.11 \\
5.70 \\
6.57 \\
7.41 \\
8.00\end{array}$ & $\begin{array}{l}1.74 \\
2.01 \\
2.25 \\
2.53 \\
2.72\end{array}$ & $\begin{array}{l}3.20 \\
3.34 \\
3.34 \\
3.32 \\
3.32\end{array}$ & $\begin{array}{r}100.00 \\
82.20 \\
39.00 \\
15.10 \\
5.50\end{array}$ & $\begin{array}{r}8.00 \\
8.62 \\
11.59 \\
16.01 \\
18.18\end{array}$ & $\begin{array}{l}2.72 \\
2.93 \\
3.82 \\
5.31 \\
5.98\end{array}$ & $\begin{array}{l}3.32 \\
3.34 \\
3.28 \\
3.17 \\
3.20\end{array}$ \\
\hline
\end{tabular}

DATA FOR - MIDDLING COAL.

THIS PRACTIOI CONSTITUTES 17.7 PERCENT OF THE PEED.

\begin{tabular}{|c|c|c|c|c|c|c|c|c|c|c|c|c|c|}
\hline \multirow{2}{*}{\multicolumn{2}{|c|}{$\begin{array}{c}\text { SIZE } \\
\text { RACTION }\end{array}$}} & $\cdots-\infty-\infty-\infty$ & IRECT $\nabla$ & UES - - - & - & $--\operatorname{COH}$ & LATIVE & RETA I NED - - & - & $----\mathrm{CU}$ & ULATIVE & PASSED - - & -- \\
\hline & & DEIGHT & $\mathrm{ASH}$ & SUIEUR & MCISTOBE & MEIGHT & $\mathrm{ASH}$ & SULFUR & MOISTORE & WEIGHT & A SR & POR & MOIS? \\
\hline ASSED & RETAINED & PERCENT & PERCENT & PERCENT & PERCEHT & PERCENT & PERCENT & PERCENT & PE & PER & PERCENT & RCENT & \\
\hline $\begin{array}{l}30 M \\
60 \mathrm{H} \\
100 \mathrm{H} \\
150 \mathrm{H}\end{array}$ & $\begin{array}{r}30 \mathrm{M} \\
60 \mathrm{M} \\
100 \mathrm{O} \\
150 \mathrm{M}\end{array}$ & $\begin{array}{r}56.90 \\
38.80 \\
3.50 \\
0.80 \\
0.00\end{array}$ & $\begin{array}{r}6.10 \\
7.95 \\
17.91 \\
33.02 \\
0.00\end{array}$ & $\begin{array}{r}2.18 \\
2.55 \\
7.74 \\
13.61 \\
0.00\end{array}$ & $\begin{array}{l}3.20 \\
3.20 \\
3.10 \\
2.80 \\
0.00\end{array}$ & $\begin{array}{r}56.90 \\
95.70 \\
99.20 \\
100.00 \\
100.00\end{array}$ & $\begin{array}{l}6.10 \\
6.85 \\
7.24 \\
7.45 \\
7.45\end{array}$ & $\begin{array}{l}2.18 \\
2.49 \\
2.68 \\
2.76 \\
2.76\end{array}$ & $\begin{array}{l}3.20 \\
3.20 \\
3.20 \\
3.19 \\
3.19\end{array}$ & $\begin{array}{r}100.00 \\
43.10 \\
4.30 \\
0.80 \\
0.00\end{array}$ & $\begin{array}{r}7.45 \\
9.22 \\
20.72 \\
33.02 \\
0.00\end{array}$ & $\begin{array}{r}2.76 \\
3.54 \\
8.83 \\
13.61 \\
0.00\end{array}$ & $\begin{array}{l}3.19 \\
3.18 \\
3.04 \\
2.80 \\
0.00\end{array}$ \\
\hline
\end{tabular}

DATA FOR - REPUSE COAL.

THIS FRACTIOE CONSTITUTES 19.3 PERCENT OP THE PEED.

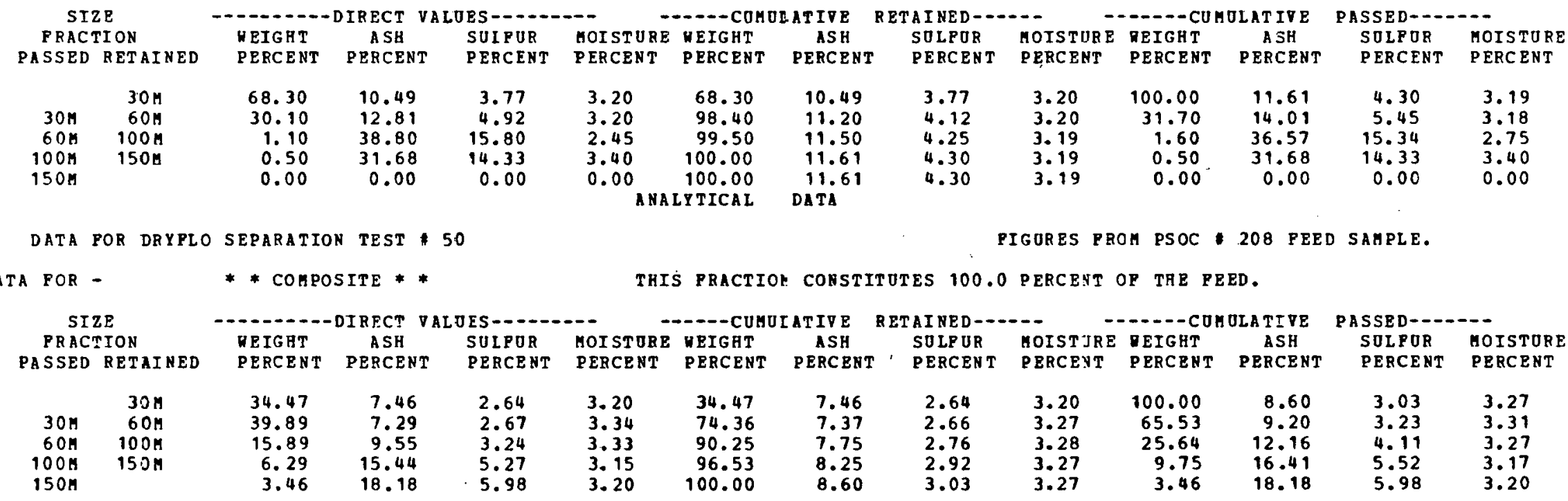


ANALYTICAL DATA

DATA FOR DRYPLO SEPARATION TEST 51

FIGURES PROA, ELLIOT PEED SAMPLE.

DATA POR - PRODUCT COAL.

THIS PRACTION CONSTITUTES 39.0 PERCENT OP THE PEED.

SIZE

FRACTION

- - C CUMULATIVE RETAINED-----

PASSED RETAINED

NEIGHT DIRECT VAL ASH
SUI PERC BNT PERCENT

IVE
ASET
PERCENT

SULPOR
MOISTUREं NEIGRT AULATIVE ATIVE
ASH
PERCENT SULPUR MOISTURE

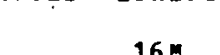

$\begin{array}{rrr}7.00 & 7.00 & 1.36 \\ 14.40 & 6.95 & 1.41 \\ 27.30 & 7.43 & 1.68 \\ 24.90 & 8.34 & 2.28 \\ 10.10 & 10.75 & 3.66 \\ 16.30 & 15.69 & 5.72\end{array}$

0.70
0.70
0.40
0.45
0.50
0.60

7.00
21.40
48.70
73.60
83.70
100.00

7.00
6.97
7.23
7.60
7.98
9.24

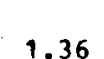

$$
\begin{aligned}
& 1.36 \\
& 1.39 \\
& 1.55 \\
& 1.80 \\
& 2.02 \\
& 2.63
\end{aligned}
$$

$\begin{array}{rr}0.70 & 100.00 \\ 0.70 & 93.00 \\ 0.53 & 78.60 \\ 0.50 & 51.30 \\ 0.50 & 26.40 \\ 0.52 & 16.30\end{array}$
9.24
9.91
9.86
11.15
13.80
15.69

$\{2.63$

2.63
2.72

2.96

2.96
3.64
4.9 .3

4.9 .3
5.72

0.52

0.51

0.59

THIS PRACTION CONSTITUTES 28.3 PERCENT OP THE PEED.

DATA POR - MIDDLING COAL.

' ITIS PRACTION CONSTTVUES 28.3 pencenT OP THE PEBD.

SIZE $\begin{array}{lll}\text { PRACTION } & \text { WEIGHT } & \text { ASH A SUIFUR } \\ \text { PASSED RETAINED } & \text { PERCENT, PERCENT PERCENT }\end{array}$

PASSED RETAINED

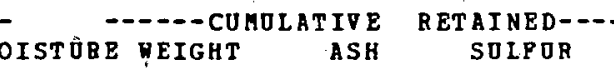

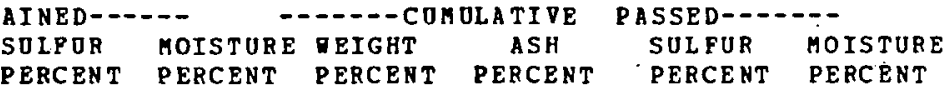

$\begin{array}{rrrr} & 16 \mathrm{H} & 25.40 & 12.85 \\ 16 \mathrm{M} & 30 \mathrm{M} & 32.30 & 12.03 \\ 30 \mathrm{H} & 60 \mathrm{M} & 29.70 & 10.74 \\ 60 \mathrm{M} & 100 \mathrm{H} & 8.70 & 12.01 \\ 10 \mathrm{MH} & 150 \mathrm{M} & 1.80 & 18.31 \\ 150 \mathrm{M} & & 2.10 & 16.30\end{array}$

1.77
2.34
2.77
3.23
8.91
8.33

DATA FOR - REPUSE COAL.

$\begin{array}{rrr}0.40 & 25.40 & 12.85 \\ 0.35 & 57.70 & 12.39 \\ 0.40 & 87.40 & 11.83 \\ 0.50 & 96.10 & 11.85 \\ 0.60 & 97.90 & 11.97 \\ 0.60 & 100.00 & 12.06\end{array}$

$$
\begin{aligned}
& 1.77 \\
& 2.09 \\
& 2.32 \\
& 2.40 \\
& 2.52
\end{aligned}
$$$$
\begin{aligned}
& 0.4 \\
& 0.37 \\
& 0.38 \\
& 0.39 \\
& 0.4 \\
& 0.40
\end{aligned}
$$

0.40
0.37
0.38
0.39
0.40
0.40

100.00

74.60
42.30

12.60

12.06

11.79

11.60
13.62

\begin{tabular}{|c|c|c|c|c|}
\hline \multirow{2}{*}{\multicolumn{2}{|c|}{$\begin{array}{c}\text { SIZE } \\
\text { FRACTION }\end{array}$}} & \multicolumn{3}{|c|}{ VALUES $-\ldots$} \\
\hline & & MEIGHT & A SH & SOIFUR \\
\hline PASSED & RETAI I NED & PERCENT & PERCENT & PERCENT \\
\hline & $16 \mathrm{M}$ & 26.60 & 25.72 & 4.98 \\
\hline $16 \mathrm{H}$ & $30 \mathrm{M}$ & 35.60 & 16.15 & 4.12 \\
\hline $30 \mathrm{n}$ & $60 \mathrm{M}$ & 28.60 & 11.53 & 3.29 \\
\hline $60 \mathrm{n}$ & $100 \mathrm{H}$ & 5.80 & 14.49 & 4.48 \\
\hline $100 \mathrm{n}$ & $150 \mathrm{M}$ & 3.40 & 16.28 & 7.84 \\
\hline $150 \mathrm{H}$ & & 0.00 & 0.00 & 0.00 \\
\hline
\end{tabular}

2.64
2.94

2.94

4.89

0.51
0.56

0.56
0.60

DATA POR DRYPLO SEPARATION TEST
* conpositz * $\begin{array}{llll}2.52 & 0.40 & 3.90 & 17.23 \\ 2.64 & 0.40 & 2.10 & 16.30\end{array}$

$\begin{array}{ll}4.89 & 0.53 \\ 8.60 & 0.60 \\ 8.33 & 0.60\end{array}$

THIS PRACTION CONSTITOTES 32.7 PERCENT OP THE PEED.

-----CUMULATIVE RETAIXED---- - - - - - - - CUMULAT IV

PASSED-...-.

DATA FOR -

STZE
FRACTION

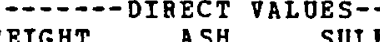

$\begin{array}{lll}\text { PERCENT } & \text { PERCENT PEBCENT }\end{array}$

SULPOR
PEBCENT PERT

0.30

0.30
0.65

0.55
0.50
0.00

26.60

62.20

25.72

20.24

$\begin{array}{rr}90.80 & 17.50\end{array}$

100.00

100.00

ANALYTICAL

17.32
17.28

17.28
17.28

4.98

$4.49 \quad 0.35$

4.11

4.13
4.26

4.26
4.26

0.32

0.31
0.33

0.34
0.34

DATA.

0.34

PERCENT

ASH

\begin{tabular}{|c|c|c|c|c|c|c|c|c|}
\hline & $-\operatorname{con} 0$ & IIVE & RET AINED & $=$ & $-----c \sigma^{\circ}$ & JLATIVE & PASSED $=-$ & - \\
\hline $\begin{array}{l}\text { MOISTURE } \\
\text { PERCENT }\end{array}$ & $\begin{array}{l}\text { DEIGHT } \\
\text { PERCENT }\end{array}$ & $\begin{array}{c}\text { ASH } \\
\text { PERCENT }\end{array}$ & $\begin{array}{l}\text { SOLPOR } \\
\text { PE GCENT }\end{array}$ & $\begin{array}{l}\text { MOISTORE } \\
\text { PERCENT }\end{array}$ & $\begin{array}{l}\text { NEIGBT } \\
\text { PERCENT. }\end{array}$ & $\begin{array}{c}\text { ASH } \\
\text { PERCENT }\end{array}$ & $\begin{array}{l}\text { SULPUR } \\
\text { PERCENT }\end{array}$ & $\begin{array}{l}\text { MOISTURE } \\
\text { PERCENT }\end{array}$ \\
\hline $\begin{array}{l}0.42 \\
0.40 \\
0.37 \\
0.49 \\
0.51 \\
0.60\end{array}$ & $\begin{array}{r}18.62 \\
45.01 \\
73.42 \\
87.49 \\
93.05 \\
100.00\end{array}$ & $\begin{array}{l}18.01 \\
14.93 \\
12.93 \\
12.43 \\
12.44 \\
12.67\end{array}$ & $\begin{array}{l}3.21 \\
3.04 \\
2.85 \\
2.83 \\
2.96 \\
3.17\end{array}$ & $\begin{array}{l}0.42 \\
0.41 \\
0.39 \\
0.41 \\
0.41 \\
0.43\end{array}$ & $\begin{array}{r}100.00 \\
81.38 \\
54.99 \\
26.58 \\
12.51 \\
6.95\end{array}$ & $\begin{array}{l}12.67 \\
11.45 \\
10.81 \\
11.93 \\
14.32 \\
15.74\end{array}$ & $\begin{array}{l}3.17 \\
3.16 \\
3.26 \\
4.05 \\
5.51 \\
5.94\end{array}$ & $\begin{array}{l}0.43 \\
0.43 \\
0.44 \\
0.52 \\
0.56 \\
0.5\end{array}$ \\
\hline
\end{tabular}

FIGURES PROA ELLIOT FEED SAMPLE.

PASSED RETAINED

$\begin{array}{rrrr} & 16 \mathrm{M} & 18.62 & 18.01 \\ 16 \mathrm{H} & .30 \mathrm{M} & 26.40 & 12.77 \\ 30 \mathrm{M} & 60 \mathrm{M} & 28.40 & 9.76 \\ 6 \mathrm{MH} & 10 \mathrm{OH} & 14.07 & 9.81 \\ 10 \mathrm{H} & 150 \mathrm{M} & 5.56 & 12.55 \\ 1 & & 6.95 & 15.74\end{array}$

.
SULPOR MOISTURE
PERCENT PERCENT 
ANALYTICAL

DATA

DATA POR DRYPLO SEPARATION TEST 52

PIGUEES BASED ON ELLIOT PEED SAMPLE.

DATA FOR - PRODUCT COAL.

THIS PRACTION CONSTITUTES 51.0 PERCEAT OP THE PEED.

\begin{tabular}{|c|c|c|c|c|c|c|c|c|c|c|c|c|c|}
\hline & \multicolumn{2}{|c|}{$\because-\because-O-D$ DIRECT } & \multicolumn{2}{|c|}{ LURS $\ldots . . . . . . .}$. & \multicolumn{2}{|c|}{$\rightarrow--$ CUYOLATIVE } & \multicolumn{2}{|c|}{ RETAI NED - - - } & \multicolumn{2}{|c|}{ - COKOLATIVE } & \multicolumn{2}{|c|}{ PASSED-D-C.- } \\
\hline $\begin{array}{r}\text { FRAC } \\
\text { ASSED }\end{array}$ & $\begin{array}{l}\text { IION } \\
\text { RETAINED }\end{array}$ & $\begin{array}{l}\text { WEIGHT } \\
\text { PERCENT }\end{array}$ & $\begin{array}{c}\text { ASH } \\
\text { PERCENT }\end{array}$ & $\begin{array}{l}\text { SOLPOB } \\
\text { PERCENZ }\end{array}$ & $\begin{array}{l}\text { MOISTORE } \\
\text { PERCENT }\end{array}$ & $\begin{array}{l}\text { WEIGHT } \\
\text { PERCENTT }\end{array}$ & $\begin{array}{c}\text { ASH } \\
\text { PERCENT }\end{array}$ & $\begin{array}{l}\text { SULPUR } \\
\text { PERCENT }\end{array}$ & $\begin{array}{l}\text { MOISTORE } \\
\text { PEPCEYT }\end{array}$ & $\begin{array}{l}\text { DEIGHT } \\
\text { PERCENT }\end{array}$ & $\begin{array}{c}\text { ASH } \\
\text { PERCENT }\end{array}$ & $\begin{array}{l}\text { SOLPOR } \\
\text { PERCENT }\end{array}$ & $\begin{array}{l}\text { MOISTURE } \\
\text { PERCENT }\end{array}$ \\
\hline $\begin{array}{l}16 \mathrm{H} \\
30 \mathrm{H} \\
60 \mathrm{~N} \\
100 \mathrm{M} \\
150 \mathrm{MI}\end{array}$ & $\begin{array}{r}16 \mathrm{H} \\
30 \mathrm{H} \\
60 \mathrm{H} \\
100 \mathrm{H} \\
150 \mathrm{M}\end{array}$ & $\begin{array}{r}8.90 \\
19.50 \\
32.60 \\
20.30 \\
9.00 \\
9.70\end{array}$ & $\begin{array}{r}8.84 \\
9.19 \\
8.94 \\
9.97 \\
12.37 \\
14.34\end{array}$ & $\begin{array}{l}1.38 \\
1.78 \\
2.18 \\
2.84 \\
4.66 \\
6.06\end{array}$ & $\begin{array}{l}0.50 \\
0.40 \\
0.40 \\
0.70 \\
0.60 \\
0.65\end{array}$ & $\begin{array}{r}8.90 \\
28.40 \\
61.00 \\
81.30 \\
90.30 \\
100.00\end{array}$ & $\begin{array}{r}8.84 \\
9.08 \\
9.01 \\
9.25 \\
9.56 \\
10.02\end{array}$ & $\begin{array}{l}1.38 \\
1.65 \\
1.94 \\
2.16 \\
2.41 \\
2.76\end{array}$ & $\begin{array}{l}0.50 \\
0.43 \\
0.41 \\
0.49 \\
0.50 \\
0.51\end{array}$ & $\begin{array}{r}100.00 \\
91.10 \\
71.60 \\
39.00 \\
18.70 \\
9.70\end{array}$ & $\begin{array}{l}10.02 \\
10.14 \\
10.39 \\
11.61 \\
13.39 \\
14.34\end{array}$ & $\begin{array}{l}2.76 \\
2.90 \\
3.20 \\
4.06 \\
5.39 \\
6.06\end{array}$ & $\begin{array}{l}0.51 \\
0.51 \\
0.54 \\
0.66 \\
0.63 \\
0.65\end{array}$ \\
\hline
\end{tabular}

DATA POR - MIDDLIUG COAL.

THIS PRACTION CONSTITUTES 22.6 PERCENT OP THE PEED.

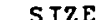

FPACTION

$\begin{array}{cccc}\text { SIZE } & & \\ \text { FRACTION } & \text { VEIGHT } & \text { A ASH } \\ \text { PASSED RETAINED } & \text { PERCENT } & \text { PERCENT } \\ & & & \\ 16 \mathrm{M} & 16 \mathrm{M} & 0.00 & 15.98 \\ 30 \mathrm{M} & 60 \mathrm{M} & 28.70 & 13.47 \\ 60 \mathrm{M} & 100 \mathrm{M} & 35.30 & 11.76 \\ 100 \mathrm{M} & 150 \mathrm{M} & 28.80 & 17.24 \\ 150 \mathrm{M} & & 5.00 & 19.41 \\ & & 2.20 & 19.41\end{array}$

PASSED RETAINEO

PALUES

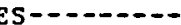

-----COMOLATIVE RETAINED-

SOLPOR HOTSTORE REIGHT

SUIPOR

SUIPUR HOISTORE VEIGHT ASH

PERCENT PER

2.08
3.06
3.33
6.91
9.51
9.51

0.50

0.50
0.50

0.50

0.55

9.51

0.55

PERCENT PERCENT

$\begin{array}{rr}0.00 & 0.00 \\ 28.70 & , 13.47 \\ 64.00 & 12.53 \\ 92.80 & 13.99 \\ 97.80 & 14.27 \\ 100.00 & 14.38\end{array}$

0.00

0.00
3.06
3.21

3.21
4.36

4.36
4.62

4.73

0.00
0.50
0.50
0.50
0.50
0.50

rHIS

IS PRACTION CONSTITUTES 26.4 PERCERT OP THE PEED.

DATA FOR - REPUSE COAL.

\begin{abstract}
-DIRECT VALTES
\end{abstract}
FIIZE WEIGHT DIRECT PALTE ASH
PERCENT PERCENT SUIFUR MOISTURE REIGHT

TIVE RETAINED-...-

$\begin{array}{rr}100.00 & 14.38 \\ 100.00 & 14.38 \\ 71.30 & 14.75 \\ 36.00 & 17.67 \\ 7.20 & 19.41\end{array}$
14.38 PASSED
SULPUR MOISTORE $\begin{array}{ll}\text { SULPUR } & \text { MOISTORE } \\ \text { PERCENT } & \text { PERCENT }\end{array}$ PASSED BETAINED

$\begin{array}{rr}0.00 & 25.55 \\ 31.50 & 15.46 \\ 38.10 & 15.33 \\ 25.90 & 20.83 \\ 3.10 & 19.80 \\ 1.40 & 19.80\end{array}$

6.07
3.70
4.57
9.16
9.86
9.86

0.60
0.40
0.50
0.40
0.50
0.50

0.60
0.40 PERCENI

PBRCENT

4.73

4.73
5.40

5.40
7.43

9.51

0.50

0.50

0.51
0.51

0.51
0.55

ANALYTICAL

17.00
DATA

DATA FOR DRYPLO SEPARATION TEST 52 DATA FOR -

* conposite** THIS PRACTION CONSTITUTES 100.0 PERCENT OP THE PEED.

SIZE
PRACTION PASSED RETAINED

$\begin{array}{rrrr} & 16 \mathrm{M} & 4.54 & 8.84 \\ 16 \mathrm{H} & 30 \mathrm{M} & 24.75 & 12.42 \\ 30 \mathrm{M} & 60 \mathrm{M} & 34.66 & 11.44 \\ 60 \mathrm{M} & 100 \mathrm{M} & 23.70 & 15.10 \\ 10 \mathrm{MM} & 150 \mathrm{M} & 6.54 & 14.52 \\ 150 \mathrm{O} & & 5.81 & 15.12\end{array}$

\begin{tabular}{lcrr} 
SOLPUR & MOISTORE & & \\
PERCENG & PERCENT & PERCENT & \multicolumn{1}{c}{ PSH } \\
& PERCENT \\
1.38 & 0.50 & 4.54 & 8.84 \\
2.76 & 0.43 & 29.29 & 11.86 \\
3.14 & 0.45 & 63.95 & 11.64 \\
5.78 & 0.56 & 87.65 & 12.57 \\
6.15 & 0.58 & 94.19 & 12.71 \\
6.60 & 0.63 & 100.00 & 12.85
\end{tabular}

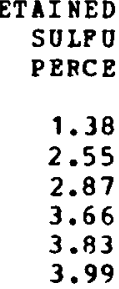

SULPOR - - - - COHOLATIVE SULPOR MOISTORE HEIGHT SULPOR HOISTORE WEIGH

$$
0.00
$$

\section{$0.00 \quad 100.00$}

$\begin{array}{ll}0.00 & 100.00 \\ 0.40 & 100.00 \\ 0.45 & 68.50\end{array}$

3.70

4.18

5.53
5.66

0.45

0.44

0.44
0.44

68.50
30.40

30.40
4.50

1.40

PERCEN

17.00
17.00

17.70

17.70
20.68
19.80

19.80

FIGURES BASED OR ELLIOT PEED SAMPLE.

$$
\text { MOTSTOR }
$$
MOISTORE

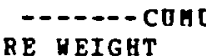

$\begin{array}{ccccc}\text { PERCET } & \text { PERCENT } & \text { PERCENT } & \text { SULPUR } & \text { MOISTURE } \\ \text { PERCENT } & \text { PERCENT } \\ 0.50 & 100.00 & 12.85 & 3.99 & 0.49\end{array}$

$\begin{array}{lrrrr}0.50 & 100.00 & 12.85 & 3.99 & 0.49 \\ 0.44 & 95.46 & 13.04 & 4.11 & 0.49 \\ 0.45 & 70.71 & 13.26 & 4.59 & 0.51 \\ 0.48 & 36.05 & 15.00 & 5.98 & 0.57 \\ 0.48 & 12.35 & 14.80 & 6.36 & 0.60 \\ 0.49 & 5.81 & 15.12 & 6.60 & 0.63\end{array}$

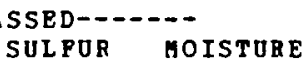
PERCENT PERCEN

$5.72 \quad 0.44$

$\begin{array}{ll}5.72 & 0.44 \\ 6.65 & 0.46\end{array}$

$9.65 \quad 0.46$

$9.26 \quad 0.41$

$\begin{array}{ll}9.86 & 0.50 \\ 9.86 & 0.50\end{array}$ 
ANALYTICAL DATA

DATA POR DRYFLO SEPARATION TEST 53. DATA FOR - PRODUCT COAL.
PIGORES PROA RLLIOT PEED SA MPLE.

THIS FRACTION CONSTITUTES 60.6 PERCENT OP THE PEED.

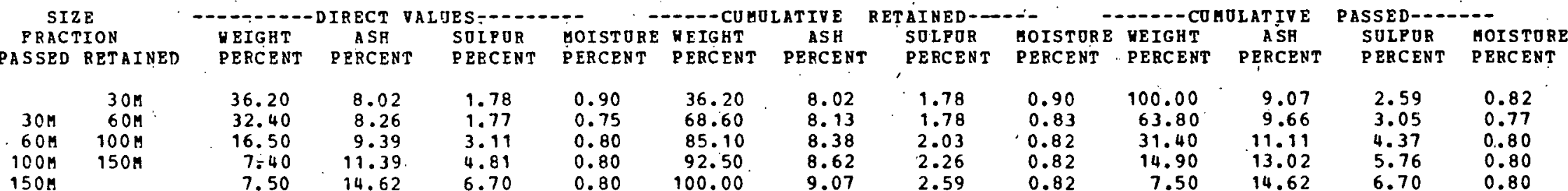

DATA FOR - MIDDLING COAL.

THIS FRACTION CONSTITUTES 23.6 PERCENT OP THE PEED.

\begin{tabular}{|c|c|c|c|c|c|c|c|c|c|c|c|c|c|}
\hline \multirow{2}{*}{\multicolumn{2}{|c|}{$\begin{array}{c}\text { SIZE } \\
\text { FRACTION }\end{array}$}} & \multicolumn{2}{|c|}{------- DIRBCT } & \multicolumn{2}{|c|}{ LUES - } & \multicolumn{2}{|c|}{ - - - CUMOLATIVE } & \multicolumn{2}{|c|}{ RETAINED - } & \multicolumn{2}{|c|}{--- CUHOLAT IVE } & \multicolumn{2}{|c|}{ PASSED $\ldots$} \\
\hline & & WEIGHT & A SH & SUIPOR & MOISTORE & DEIGHT & ASH & SOLPUR & MOISTURE & NEIGRT & $\mathrm{ASH}$ & SOLFOR & $P P P C F$ \\
\hline SSED & RETAINED & PERCENT & PERCENT & PERCENT & PERCENT & PERCENT & PERCENT & PERCENT & PERCENT & PERCENT & PERCENT & PERCENT & PERCE \\
\hline $\begin{array}{r}30 \mathrm{~N} \\
6 \mathrm{CM} \\
100 \mathrm{M} \\
1.50 \mathrm{M}\end{array}$ & $\begin{array}{l}30 \mathrm{M} \\
60 \mathrm{M} \\
100 \mathrm{M} \\
150 \mathrm{H}\end{array}$ & $\begin{array}{r}70.80 \\
25.30 \\
2.70 \\
0.60 \\
0.60\end{array}$ & $\begin{array}{l}15.33 \\
12.34 \\
21.23 \\
22.85 \\
16.82\end{array}$ & $\begin{array}{r}2.65 \\
3.48 \\
10.80 \\
12.61 \\
7.30\end{array}$ & $\begin{array}{l}0.55 \\
0.75 \\
0.60 \\
0.45 \\
0.70\end{array}$ & $\begin{array}{r}70.80 \\
96.10 \\
98.80 \\
99.40 \\
100.00\end{array}$ & $\begin{array}{l}15.33 \\
14.54 \\
14.73 \\
14.77 \\
11.79\end{array}$ & $\begin{array}{r}2.65 \\
2.87 \\
3.09 \\
3.14 \\
3.17\end{array}$ & $\begin{array}{l}0.55 \\
0.60 \\
0.60 \\
0.60 \\
0.60\end{array}$ & $\begin{array}{r}100.00 \\
29.20 \\
3.90 \\
1.20 \\
0.60\end{array}$ & $\begin{array}{l}14.79 \\
1.3 .47 \\
20.80 \\
19.83 \\
16.82\end{array}$ & $\begin{array}{r}3.17 \\
4.42 \\
10.54 \\
9.96 \\
7.30\end{array}$ & $\begin{array}{l}0.60 \\
0.73 \\
0.59 \\
0.57 \\
0.70\end{array}$ \\
\hline
\end{tabular}

DATA FOR - REPUSE COAL.

THIS PRACTION CONSTITUTES. 15.8 PERCENT OP THE PEED.

RACTICN

ThE

-DDIRECT VALOES-

-

$\begin{array}{rrrrr} & 30 \mathrm{M} & 76.30 & 21.81 & 5.47 \\ 30 \mathrm{M} & 60 \mathrm{M} & 21.20 & 16.36 & 5.53 \\ 60 \mathrm{M} & 100 \mathrm{M} & 1.50 & 26.80 & 11.74 \\ 100 \mathrm{M} & 150 \mathrm{M} & 0.50 & 23.56 & 11.18 \\ 150 \mathrm{M} & & 0.50 & 16.05 & 6.55\end{array}$

DATA FOR. DRYFLO SEPARATION TEST \#53.

DATA FOR -

* conposite * *

MOISTORE PEIGHT

RIVE RAINED--
SOLPUR

- - - - - CUROLATIVE PASSED-.--

$\begin{array}{lcc} & \text { PERCENT } & \text { PERCENT } \\ 0.50 & 76.30 & 21.81\end{array}$

$\begin{array}{rrr}0.50 & 76.30 & 21.81 \\ 0.65 & 97.50 & 20.62 \\ 0.55 & 99.00 & 20.72 \\ 0.45 & 99.50 & 20.73 \\ 0.65 & 100.00 & 20.71\end{array}$

ANALYTICAL

20.71
DATA

$\begin{array}{rrr}5.47 & 0.50 & 100.00 \\ 5.48 & 0.53 & 23.70 \\ 5.58 & 0.53 & 2.50 \\ 5.61 & 0.53 & 1.00 \\ 5.61 & 0.53 & 0.50\end{array}$

PEBCEN T

SULER

SULEUR MOISTURE

$\begin{array}{lll}20.71 & 5.61 & 0.53\end{array}$

$\begin{array}{rrr}17.17 & 6.06 & 0.64\end{array}$

$\begin{array}{rrr}24.00 & 10.59 & 0.55 \\ 19.80 & 8.86 & 0.55\end{array}$

$\begin{array}{lll}19.80 & 8.86 & 0.55\end{array}$

FIGURES PROA ELLIOT PEED SAMPLE.

ThIS PRACTION CONSTITTTES 100.0 PERCEHT OP THE PEED.

SIZE - - - - DIRECT VALOES- - - - - -

FRACTION. HEIGHT ASH SULPUR MOIS

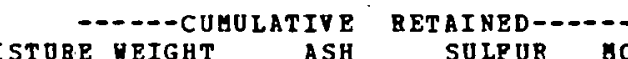

$\begin{array}{llll} & \\ \text { MOISTORE REIGHT } & \text { ASH } & \text { SULPUR } & \text { MOISTURE } \\ \text { PERCENT } & \text { PERCENT PERCENT PERCENT PERCET }\end{array}$ PASSED RETAINED

50.70 PERCENT

$\begin{array}{rr}30 M & 30 M \\ 60 M & 60 M \\ 100 M & 150 M \\ 150 M & \end{array}$

$\begin{array}{rr}50.70 & 13.71 \\ 28.95 & 10.04 \\ 10.87 & 10.46 \\ 4.70 & 11.94 \\ 4.77 & 14.71\end{array}$

2.94
2.56
3.75
5.15
6.72

PEIGHT

ASH

SULPUR

50.70

13.71
12.37

2.94

79.66

90.53

12.14

95.23
100.00

12.13

2.80

2.92

3.03
3.20

0.69

100.00

0.71
0.72

0.72

0.72
0.72

49.30
20.34

20.34
9.47

12.26
10.77

10.77

11.80
13.33

3.20

3.47
4.77

4.77

5.94
6.72

0.72

0.76
0.79

0.79
0.79

0.79 
ANALITICAL DATA

DATA POR DRYFLO SEPARATIOH TEST 54.

PIGORES FROE TBST 28 RECYCLE

DATA POR - PRODUCT COAL.

THIS PRACTION CONSTITOTES 44.3 PERCENT OP THB PEED.

\begin{tabular}{|c|c|c|c|c|c|c|c|c|c|c|c|c|c|}
\hline \multirow{2}{*}{\multicolumn{2}{|c|}{$\begin{array}{c}\text { SIZE } \\
\text { PRACTION }\end{array}$}} & \multicolumn{2}{|c|}{$\cdots--1$-DIRECT $v$} & \multicolumn{2}{|c|}{ LUES - - - } & \multicolumn{2}{|c|}{-----CUROLATIVE } & \multicolumn{2}{|c|}{ RETAINED - } & \multicolumn{2}{|c|}{$\cdots-\cdots$ CUMOLATIVE } & \multicolumn{2}{|c|}{ PASSED- } \\
\hline & & $\begin{array}{l}\text { WEIGRT } \\
\text { PERCENT }\end{array}$ & $\begin{array}{c}\text { ASH } \\
\text { PERCENT }\end{array}$ & $\begin{array}{l}\text { SULFOR } \\
\text { PERCENT }\end{array}$ & $\begin{array}{l}\text { MOISTURE } \\
\text { PERCENT }\end{array}$ & $\begin{array}{l}\text { DEIGHT } \\
\text { PERCENT }\end{array}$ & $\begin{array}{c}\text { ASH } \\
\text { PERCENT }\end{array}$ & $\begin{array}{l}\text { SULPUR } \\
\text { PERCENT }\end{array}$ & $\begin{array}{l}\text { MOISTORE } \\
\text { PERCENT }\end{array}$ & $\begin{array}{l}\text { WEIGHT } \\
\text { PERCENT }\end{array}$ & $\begin{array}{c}\text { ASH } \\
\text { PERCENT }\end{array}$ & $\begin{array}{l}\text { SOLFOR } \\
\text { PERCENT }\end{array}$ & $\begin{array}{l}\text { MOISTURE } \\
\text { PERCENT }\end{array}$ \\
\hline $\begin{array}{l}301 \\
601 \\
1004 \\
15011\end{array}$ & $\begin{array}{r}30 n \\
60 n \\
100 n \\
1504\end{array}$ & $\begin{array}{r}37.30 \\
52.90 \\
8.60 \\
0.70 \\
0.50\end{array}$ & $\begin{array}{r}8.05 \\
7.92 \\
10.03 \\
21.13 \\
26.33\end{array}$ & $\begin{array}{r}1.60 \\
1.73 \\
2.25 \\
7.50 \\
19.29\end{array}$ & $\begin{array}{l}5.60 \\
5.90 \\
5.30 \\
3.70 \\
1.45\end{array}$ & $\begin{array}{r}37.30 \\
90.20 \\
98.80 \\
99.50 \\
100.00\end{array}$ & $\begin{array}{l}8.05 \\
7.97 \\
8.15 \\
8.24 \\
8.33\end{array}$ & $\begin{array}{l}1.60 \\
1.68 \\
1.73 \\
1.77 \\
1.81\end{array}$ & $\begin{array}{l}5.60 \\
5.78 \\
5.73 \\
5.72 \\
5.70\end{array}$ & $\begin{array}{r}100.00 \\
62.70 \\
9.80 \\
1.20 \\
0.50\end{array}$ & $\begin{array}{r}8.33 \\
8.50 \\
11.6 .5 \\
23.30 \\
26.33\end{array}$ & $\begin{array}{r}1.81 \\
1.94 \\
3.09 \\
9.08 \\
19.29\end{array}$ & $\begin{array}{l}5.70 \\
5.76 \\
4.99 \\
2.76 \\
1.45\end{array}$ \\
\hline
\end{tabular}

DATA POR - AIDDLING COAL.

THIS FRACTION CONSTITUTES 39.4 PERCENT OF THE PEED.

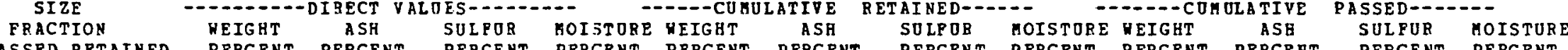

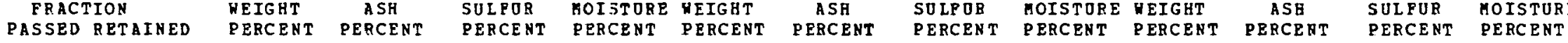

\begin{tabular}{|c|c|c|c|c|c|c|c|c|c|c|c|c|}
\hline $\begin{array}{l}30 \mathrm{H} \\
60 \mathrm{H} \\
100 \mathrm{OH} \\
150 \mathrm{~N}\end{array}$ & $\begin{array}{r}30 \mathrm{M} \\
60 \mathrm{M} \\
100.9 \\
150.9\end{array}$ & $\begin{array}{r}65.90 \\
32.50 \\
1.20 \\
0.10\end{array}$ & $\begin{array}{r}9.39 \\
12.67 \\
24.35 \\
56.78 \\
23.04\end{array}$ & $\begin{array}{r}1.82 \\
3.66 \\
10.83 \\
35.67 \\
11.03\end{array}$ & $\begin{array}{l}5.25 \\
4.50 \\
3.90 \\
0.35 \\
1.25\end{array}$ & $\begin{array}{r}65.90 \\
98.40 \\
99.60 \\
99.70 \\
100.00\end{array}$ & $\begin{array}{r}9.39 \\
10.47 \\
10.64 . \\
10.69 \\
10.72\end{array}$ & $\begin{array}{l}1.82 \\
2.43 \\
2.53 \\
2.56 \\
2.59\end{array}$ & $\begin{array}{l}5.25 \\
5.00 \\
4.99 \\
4.98 \\
4.97\end{array}$ & $\begin{array}{r}100.00 \\
34.10 \\
1.60 \\
0.40 \\
0.30\end{array}$ & $\begin{array}{l}10.72 \\
13.30 \\
26.13 \\
31.47 \\
23.04\end{array}$ & $\begin{array}{r}2.59 \\
4.07 \\
12.47 \\
17.19 \\
11.03\end{array}$ \\
\hline
\end{tabular}

DATA FOR - REPDSE COAL.

THIS PRACTION CONSTITUTES 16.3 PERCENT OP TRE PEED.

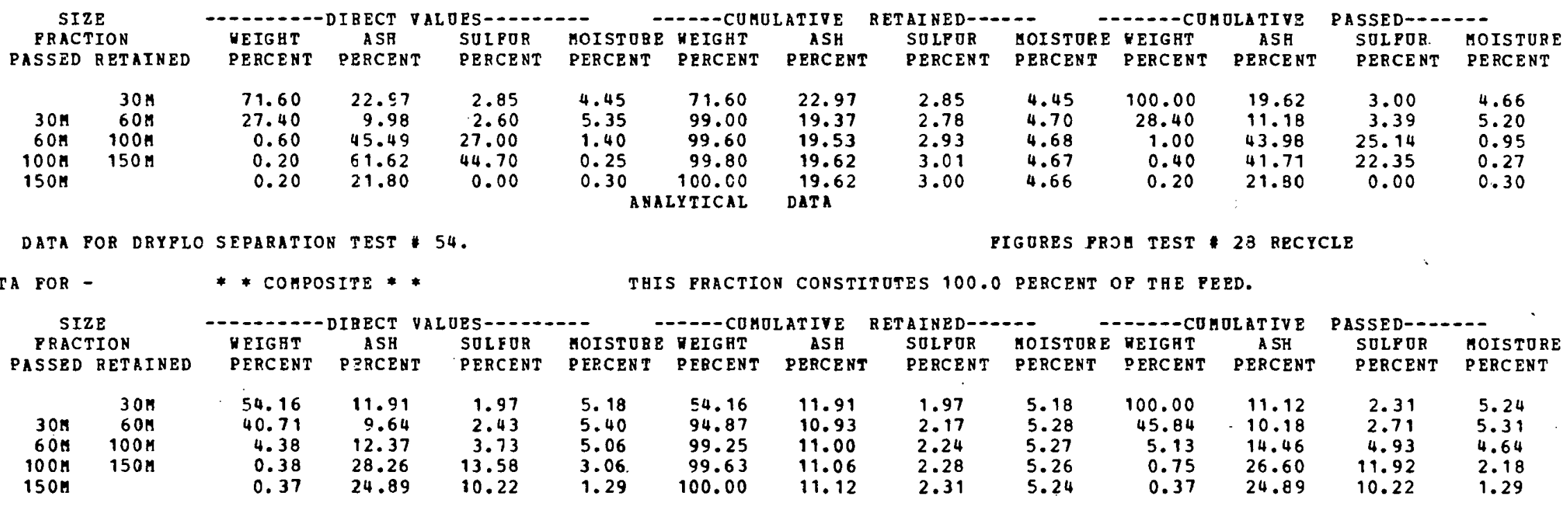


ANALYTCAL DATA

DATA FOR DRIPLO SEPARATION TEST 55. DATA FOR - PRODUCT COAL.
FIGORES PROM TEST 28 RECYCLE.

TAIS PRACTION CONSTITUTES 65.0 PERCENT OP THE PEED.

\begin{tabular}{|c|c|c|c|c|c|c|c|c|c|c|c|c|c|}
\hline \multirow{2}{*}{\multicolumn{2}{|c|}{$\begin{array}{c}\text { SIZE } \\
\text { PRACTION }\end{array}$}} & \multicolumn{2}{|c|}{$\cdots-\cdots-\cdots$ DIRECT } & \multicolumn{2}{|c|}{ VALUES $-\ldots$} & \multicolumn{2}{|c|}{ - - CUMULATIVE } & \multicolumn{2}{|c|}{ RETAINED $\cdots$} & \multicolumn{2}{|c|}{ - - - COHOLATIVE } & \multicolumn{2}{|c|}{ PASSED-D-D. } \\
\hline & $\begin{array}{l}\text { ION } \\
\text { RETAINED }\end{array}$ & $\begin{array}{l}\text { DEIGHT } \\
\text { PERCENT }\end{array}$ & $\begin{array}{c}\text { ASH } \\
\text { PEQCENT }\end{array}$ & $\begin{array}{l}\text { SOLFOR } \\
\text { PERCENT }\end{array}$ & $\begin{array}{l}\text { MOISTURE } \\
\text { PERCENT }\end{array}$ & $\begin{array}{l}\text { WEIGHT } \\
\text { PERCENT }\end{array}$ & $\begin{array}{c}\text { ASH } \\
\text { PERCENT }\end{array}$ & $\begin{array}{l}\text { SULPUR } \\
\text { PERCENT }\end{array}$ & $\begin{array}{l}\text { MOISTURE } \\
\text { PERCENT }\end{array}$ & $\begin{array}{l}\text { DEIGBT } \\
\text { PERCENT }\end{array}$ & $\begin{array}{c}\text { A SH } \\
\text { PERCENT }\end{array}$ & $\begin{array}{l}\text { SULPOR } \\
\text { PERCENT }\end{array}$ & $\begin{array}{l}\text { MOISTORE } \\
\text { PERCENT }\end{array}$ \\
\hline $\begin{array}{r}30 \mathrm{H} \\
60 \mathrm{H} \\
100 \mathrm{H} \\
150 \mathrm{O}\end{array}$ & $\begin{array}{r}30 M \\
60 M \\
100 M \\
150 M\end{array}$ & $\begin{array}{r}46.50 \\
47.00 \\
5.70 \\
0.50 \\
0.30\end{array}$ & $\begin{array}{r}8.25 \\
8.21 \\
11.59 \\
22.15 \\
30.38\end{array}$ & $\begin{array}{r}1.72 \\
1.83 \\
2.64 \\
8.92 \\
12.67\end{array}$ & $\begin{array}{l}5.50 \\
5.60 \\
5.05 \\
3.15 \\
1.40\end{array}$ & $\begin{array}{r}46.50 \\
93.50 \\
99.20 \\
99.70 \\
100.00\end{array}$ & $\begin{array}{l}8.25 \\
8.23 \\
8.42 \\
8.49 \\
8.56\end{array}$ & $\begin{array}{l}1.72 \\
1.78 \\
1.82 \\
1.86 \\
1.89\end{array}$ & $\begin{array}{l}5.50 \\
5.55 \\
5.52 \\
5.51 \\
5.50\end{array}$ & $\begin{array}{r}100.00 \\
53.50 \\
6.50 \\
0.80 \\
0.30\end{array}$ & $\begin{array}{r}8.56 \\
8.82 \\
13.27 \\
25.24 \\
30.38\end{array}$ & $\begin{array}{r}1.89 \\
2.04 \\
3.59 \\
10.33 \\
12.67\end{array}$ & $\begin{array}{l}5.50 \\
5.49 \\
4.74 \\
2.49 \\
1.40\end{array}$ \\
\hline
\end{tabular}

DATA POR - MIDDLING COAL.

THIS PRACTION CONSTITUTES 24.8 PERCENT OP THE PEED.

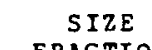

FRACTION

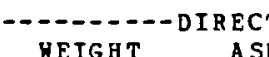

$0.30 \quad 30.38$

12.67

SUEPUR
PEPCENT PER

$$
\begin{array}{r}
1.92 \\
2.41 \\
19.43 \\
0.00 \\
0.00
\end{array}
$$

DOISTURE HETGHT

ATIVE

\section{ETAI NED--}

MOISTORE REIGHT

TIFE
A SR

$$
\begin{array}{ll}
6.30 & 74.00 \\
5.30 & 99.40
\end{array}
$$

PERCENT$$
1.92
$$

10.67
10.79

10.84

$0.10 \quad 99.90$

10.85

2.05

2.11
2.11

2.11

THIS FRACTION CONSTITUTES 10.2 PERCENT OP THE PEED.

DATA POR - REPUSE COAL.

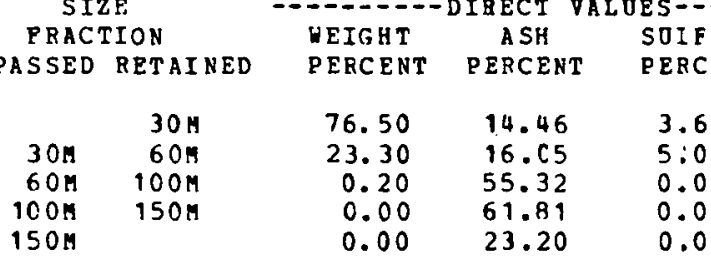

DATA FOR DRYFLO SEPARATION TEST 55 .

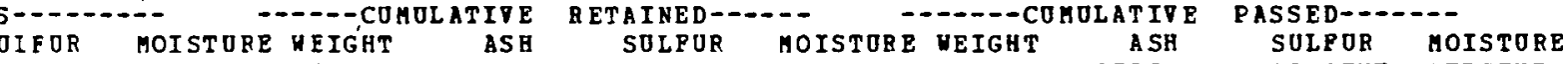
PERCENT PERCENT PERCENT PEBCENT PERCENT PERCEHT PERCENT PERCENT PERCENT

$\begin{array}{rrrrrrrrrr}3.69 & 2.50 & 76.50 & 14.46 & 3.69 & 2.50 & 100.00 & 14.91 & 3.99 & 2.71 \\ 5.02 & 3.40 & 99.80 & 14.83 & 4.00 & 2.71 & 23.50 & 16.38 & 4.98 & 3.38 \\ 0.00 & 0.55 & 100.00 & 14.91 & 3.99 & 2.71 & 0.20 & 55.32 & 0.00 & 0.55 \\ 0.00 & 0.20 & 100.00 & 14.91 & 3.99 & 2.71 & 0.00 & 0.00 & 0.00 & 0.00 \\ 0.00 & 0.40 & 100.00 & 14.91 & 3.99 & 2.71 & 0.00 & 0.00 & 0.00 & 0.00\end{array}$

PIGURES PROK TEST 28 RECYCLE. DATA FOR -

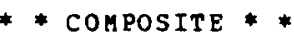

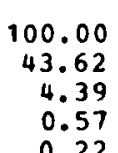

0.00
4.62
4.39
0.57
0.22

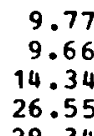

9.77
9.66
14.34

14.34
26.55

29.34 
ANRLYTICAL DATA

DATA FOR DRYPLO SEPARATION TEST 56 DATA FOR - PEODDCT COAL.
PIGURES PROM PSOC 105 FEED SAMPLE

THIS PRACTION CONSTITOTES 71.9 PERCENT OP THE PEED.

\begin{tabular}{|c|c|c|c|c|c|c|c|c|c|c|c|c|c|}
\hline \multirow{2}{*}{\multicolumn{2}{|c|}{$\begin{array}{c}\text { SIZE } \\
\text { PRACTION }\end{array}$}} & \multicolumn{2}{|c|}{$-\infty-1-1-$ DIRECT } & JES - . - & & \multicolumn{2}{|c|}{---- CUHOLATIVE } & \multicolumn{2}{|c|}{ RETAINED - ..... } & \multicolumn{2}{|r|}{ OLAT } & \multicolumn{2}{|c|}{ PASSED-..-.- } \\
\hline & & VEIGET & ASB & SULPUR & MOISTURZ & NEIGHT & ASH & SULF UR & MOISTURE & VEIGRT & $\mathrm{ASH}$ & SOLFUR & MOISTURE \\
\hline & RETAINED & PERCENT & PERCENT & PERCENT & FERCENT & PERCENT & PERCENT & PERCENT & PERCENT & PERCENT & PERCENT & PERCENT & PERCENT \\
\hline $\begin{array}{r}30 \mathrm{M} \\
60 \mathrm{M} \\
100 \mathrm{M} \\
150 \mathrm{M}\end{array}$ & $\begin{array}{r}30 M \\
60 M \\
100 M \\
150 M\end{array}$ & $\begin{array}{r}45.60 \\
48.50 \\
5.30 \\
0.40 \\
0.20\end{array}$ & $\begin{array}{r}8.34 \\
7.80 \\
11.49 \\
28.29 \\
28.62\end{array}$ & $\begin{array}{r}1.52 \\
1.88 \\
2.03 \\
12.51 \\
14.46\end{array}$ & $\begin{array}{l}5.30 \\
5.50 \\
5.15 \\
2.10 \\
1.30\end{array}$ & $\begin{array}{r}45.60 \\
94.10 \\
99.40 \\
99.80 \\
100.00\end{array}$ & $\begin{array}{l}8.34 \\
8.06 \\
8.24 \\
8.32 \\
8.37\end{array}$ & $\begin{array}{l}1.52 \\
1.71 \\
1.72 \\
1.77 \\
1.79\end{array}$ & $\begin{array}{l}5.30 \\
5.40 \\
5.39 \\
5.38 \\
5.37\end{array}$ & $\begin{array}{r}100.00 \\
54.40 \\
5.90 \\
0.60 \\
0.20\end{array}$ & $\begin{array}{r}8.37 \\
8.39 \\
13.21 \\
28.40 \\
28.62\end{array}$ & $\begin{array}{r}1.79 \\
2.02 \\
3.16 \\
13.16 \\
14.46\end{array}$ & $\begin{array}{l}5.37 \\
5.43 \\
4.81 \\
1.83 \\
1.30\end{array}$ \\
\hline
\end{tabular}

DATA PCR - MIDDLING COAL.

THIS PRACTION CONSTITUTES 19.2 PERCENT OP THE PEED.

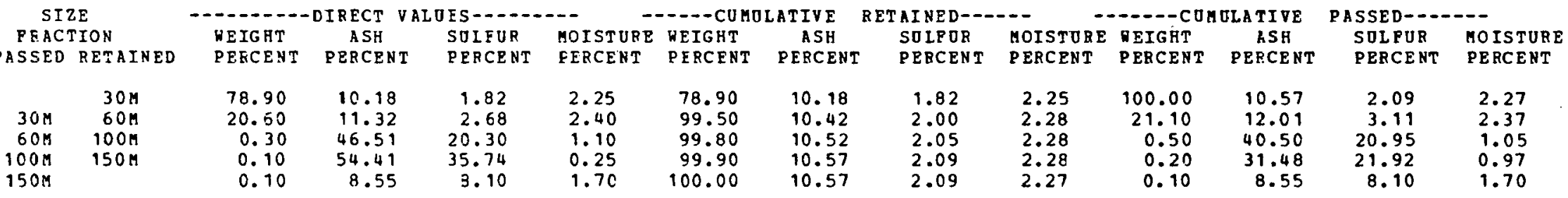

DATA FOR - REPUSE COAL.

THIS PRACTION CONSTITUTES B. 9 PERCENT OF THE PEED.

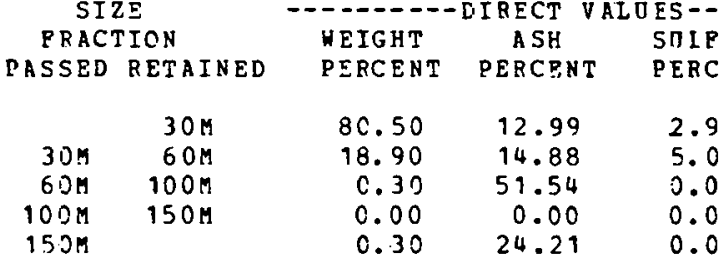

DATA POE DRYPLO SEPARATION TEST $\$ 56$
* * compositz **
- - - COMOLATIVE BETAINED----

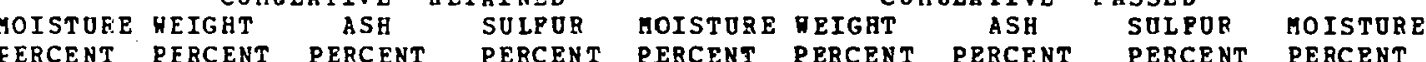
ERCENT PERCENT PERCENT

$\begin{array}{rrrr}2.25 & 80.50 & 12.99 & 2.97 \\ 2.20 & 99.40 & 13.35 & 3.36 \\ 0.60 & 99.70 & 13.46 & 3.35 \\ 0.00 & 99.70 & 13.46 & 3.35 \\ 0.70 & 100.00 & 13.50 & 3.34\end{array}$
APAYTICAL DATA

$\begin{array}{rrr}2.25 & 100.00 & 13.50 \\ 2.24 & 19.50 & 15.59 \\ 2.24 & 0.60 & 37.87 \\ 2.24 & 0.30 & 24.21\end{array}$

2.23

24.21
PERCE

3.34

4.88

0.00

0.00
0.00

2.23

2.15

0.65

0.70
0.70
DATA FOR -

$$
\begin{aligned}
& \text { SIZE } \\
& \text { FRACTION }
\end{aligned}
$$
PASSED RETAINED

$\begin{array}{rr}30 M & 30 M \\ 60 M & 60 M \\ 100 M & 150 M \\ 150 M & \end{array}$

$150 \mathrm{M}$ 150

$\begin{array}{lccc}\text { VEIGHT } & \text { ASH } & \text { SOLEOR } & \text { MOIST } \\ \text { PERCENT } & \text { PERCENT } & \text { ERRCENT } & \text { PERCE } \\ & & & \\ 55.10 & 9.45 & 1.79 & 4.06 \\ 40.51 & 8.44 & 2.09 & 5.06 \\ 3.89 & 12.28 & 2.29 & 5.06 \\ 0.31 & 29.92 & 13.96 & 1.98 \\ \text { C. } 19 & 25.97 & 11.78 & 1.26\end{array}$

11.78

1.26

THIS PRACTION CONSTITUTES 100.0 PEBCENT OP THE PEED.

\section{----CUHUL ATIVE} STUBE HEIGAT

ATIVE RETAIN
ASH TERT
PERCENT

\section{SOLPU} PERCEN

55.10
95.61
99.50
99.81
100.00

9.45
9.02
9.15
9.21
PERCE PERENT

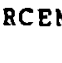

100

DEIGHT
PERCENT

\section{PEED SAMPLE}


ANALYTICAL DATA

DATA POR DRYPLO SEPARATION TEST 57.

DATA FOR - PRODUCT COAL.
PIGURES PROA BRADPORD PEED SALPLE.

THIS FRACTION CONSTITUTES 87.4 PERCENT OP THE PEED.

\begin{tabular}{|c|c|c|c|c|c|c|c|c|c|c|c|c|c|}
\hline \multirow{2}{*}{\multicolumn{2}{|c|}{$\begin{array}{c}\text { SIZE } \\
\text { PRACTION }\end{array}$}} & \multicolumn{2}{|c|}{$-\cdots-D$ DIRECT } & \multicolumn{2}{|c|}{ VALIJES-- } & \multicolumn{2}{|c|}{---CUAULATIVE } & \multicolumn{2}{|c|}{ RETAINED-- - - } & \multicolumn{2}{|c|}{--- CUMULATIVE } & \multicolumn{2}{|c|}{ PASSED----- } \\
\hline & & WEIGH & A SH & SOLEUR & MOISTORE & VEIGHT & AS H & SULPUR & MOISTURE & HEIGHT & A SH & SULFOR & MOIS \\
\hline ASSED & RETA INED & PERCENT & PERCENT & PERCENT & PERCENT & PERCPNT & PERCENT & PERCENT & PEBCENT & PERCENT & PERCENT & PERCENT & PERCENT \\
\hline $\begin{array}{r}1 / 4 " \\
8 \mathrm{M} \\
16 \mathrm{M}\end{array}$ & $\begin{array}{r}8 m \\
16 m\end{array}$ & $\begin{array}{r}63.1 .4 \\
29.16 \\
7.70\end{array}$ & $\begin{array}{r}11.39 \\
9.33 \\
8.99\end{array}$ & $\begin{array}{l}3.72 \\
2.88 \\
2.92\end{array}$ & $\begin{array}{l}0.35 \\
0.35 \\
0.40\end{array}$ & $\begin{array}{r}63.14 \\
92.30 \\
100.00\end{array}$ & $\begin{array}{l}10.74 \\
10.60\end{array}$ & $\begin{array}{l}3.45 \\
3.41\end{array}$ & $\begin{array}{l}0.35 \\
0.35\end{array}$ & $\begin{array}{r}100.00 \\
36.86 \\
7.70\end{array}$ & $\begin{array}{r}10.60 \\
9.26 \\
8.99\end{array}$ & $\begin{array}{l}3.41 \\
2.89 \\
2.92\end{array}$ & $\begin{array}{l}0.36 \\
0.40\end{array}$ \\
\hline
\end{tabular}

DATA FOR - MIDDLING COAL.

THIS PRACTION CONSTITUTES 6.2 PERCENT OP THE PEED.

\begin{tabular}{|c|c|c|c|c|c|c|c|c|c|c|c|c|c|}
\hline \multicolumn{2}{|c|}{ SIZE } & \multicolumn{2}{|c|}{$\cdots-\cdots$ DIRECT } & \multicolumn{2}{|c|}{ VALDES } & \multicolumn{2}{|c|}{$\cdots--$ CU UULATIVE } & \multicolumn{2}{|c|}{ RETAINED - } & \multicolumn{2}{|c|}{--- CUM OLATIVE } & \multicolumn{2}{|c|}{ PASSED- - } \\
\hline FRAC & TION & WEIGHT & ASH & SU L E OR R & MOISTORE & WEIGHT & ASH & SULFUR & MOISTURE & WEIGHT & ASH & SOLFUR & MOIS \\
\hline SS & RETAINED & PERCENT & PERCENT & PERCENT & PERCENT & PERCENT & PERCENT & PERCENT & PERCENT & PERCENT & PERCENT & PERCENT & PFRCENT \\
\hline $\begin{array}{r}1 / 4 " \\
8 M \\
16 M\end{array}$ & $\begin{array}{r}8 M \\
16 M\end{array}$ & $\begin{array}{r}57.90 \\
34.90 \\
7.20\end{array}$ & $\begin{array}{l}26.03 \\
19.46 \\
15.36\end{array}$ & $\begin{array}{l}9.94 \\
6.71 \\
5.15\end{array}$ & $\begin{array}{l}0.30 \\
0.30 \\
0.40\end{array}$ & $\begin{array}{r}57.90 \\
92.80 \\
100.00\end{array}$ & $\begin{array}{l}23.56 \\
22.97\end{array}$ & $\begin{array}{l}9.94 \\
8.73 \\
8.47\end{array}$ & $\begin{array}{l}0.30 \\
0.30 \\
0.31\end{array}$ & $\begin{array}{r}100.00 \\
42.10 \\
7.20\end{array}$ & $\begin{array}{l}22.97 \\
18.76 \\
15.36\end{array}$ & $\begin{array}{l}8.47 \\
6.44 \\
5.15\end{array}$ & $\begin{array}{l}0.32 \\
0.40\end{array}$ \\
\hline
\end{tabular}

DATA POR - REFUSE COAL.

THIS PRACTION CONSTITOTES 6.4 PERCENT OP THE PEED..

\begin{tabular}{|c|c|c|c|c|c|c|c|c|c|c|c|c|c|}
\hline \multirow{2}{*}{\multicolumn{2}{|c|}{$\begin{array}{l}\text { SIZE } \\
\text { FRACTION }\end{array}$}} & \multicolumn{2}{|c|}{------ DIRECT $v$} & \multicolumn{2}{|c|}{ VALUES - - } & \multicolumn{2}{|c|}{--- CUMULATIVE } & \multicolumn{2}{|c|}{ RETAINED- } & \multicolumn{2}{|c|}{---- COMULATIVE } & \multicolumn{2}{|c|}{ PASSED $-\cdots$} \\
\hline & & $\begin{array}{l}\text { WEIGHT } \\
\text { PEPCENT }\end{array}$ & $\begin{array}{c}\text { ASH } \\
\text { PERCENT }\end{array}$ & $\begin{array}{l}\text { SULPUR } \\
\text { PEFCENT }\end{array}$ & $\begin{array}{l}\text { MOISTURE } \\
\text { PERCENT }\end{array}$ & $\begin{array}{l}\text { WEIGHT } \\
\text { PEBCENT }\end{array}$ & $\begin{array}{c}\text { ASH } \\
\text { PERCENT }\end{array}$ & $\begin{array}{l}\text { SULPOR } \\
\text { PERCENT }\end{array}$ & $\begin{array}{l}\text { MOISTURE } \\
\text { PERCENTT }\end{array}$ & $\begin{array}{l}\text { VEIGHT } \\
\text { PERCENT }\end{array}$ & $\begin{array}{c}\text { ASH } \\
\text { PERCENT }\end{array}$ & $\begin{array}{l}\text { SULFUR } \\
\text { PERCENT }\end{array}$ & $\begin{array}{l}\text { MOISTURE } \\
\text { PERCENT }\end{array}$ \\
\hline $\begin{array}{r}1 / 4 " \\
8 n \\
16 n\end{array}$ & $\begin{array}{r}8 M \\
16 M\end{array}$ & $\begin{array}{r}45.50 \\
45.10 \\
9.40\end{array}$ & $\begin{array}{l}36.01 \\
26.74 \\
22.42\end{array}$ & $\begin{array}{r}10.01 \\
9.97 \\
9.02\end{array}$ & $\begin{array}{l}0.30 \\
0.35 \\
0.30\end{array}$ & $\begin{array}{r}45.50 \\
90.60 \\
100.00\end{array}$ & $\begin{array}{l}36.01 \\
31.40 \\
30.55\end{array}$ & $\begin{array}{r}10.01 \\
9.99 \\
9.90\end{array}$ & $\begin{array}{l}0.30 \\
0.32 \\
0.32\end{array}$ & $\begin{array}{r}100.00 \\
54.50 \\
9.40\end{array}$ & $\begin{array}{l}30.55 \\
25.99 \\
22.42\end{array}$ & $\begin{array}{l}9.90 \\
9.81 \\
9.02\end{array}$ & $\begin{array}{l}0.32 \\
0.34 \\
0.30\end{array}$ \\
\hline
\end{tabular}

DATA FOR DRYFLC SEPARATION TEST * 57.

FIGURES PROH BRADPORD PEED SAMPLE.

DATA FOR -

* * composite * *

THIS FRACTION CONSTITUTES 100.0 PERCENT OP THE PEED.

\begin{tabular}{|c|c|c|c|c|c|c|c|c|c|c|c|c|c|}
\hline \multirow{2}{*}{\multicolumn{2}{|c|}{$\begin{array}{l}\text { SIZE } \\
\text { FRACTION }\end{array}$}} & - & ECT $v$ & $85-$ & & U H & IVE & AINED & $=-$ & $\mathrm{Cu}$ & ILATIVE & PASSED-- & - \\
\hline & & $\begin{array}{l}\text { WEISHT } \\
\text { PERCENT }\end{array}$ & $\begin{array}{c}\text { ASH } \\
\text { PERCENT }\end{array}$ & $\begin{array}{l}\text { SUIFUR } \\
\text { PERCENTT }\end{array}$ & $\begin{array}{l}\text { MOISTURE } \\
\text { PERCENT }\end{array}$ & $\begin{array}{l}\text { WEIGHT } \\
\text { PERCENT }\end{array}$ & $\begin{array}{c}\text { ASH } \\
\text { PERCENT }\end{array}$ & $\begin{array}{l}\text { SULFUR } \\
\text { PERCENT }\end{array}$ & $\begin{array}{l}\text { MOISTURE } \\
\text { PERCENT }\end{array}$ & $\begin{array}{l}\text { NEIGHT } \\
\text { PERCENT }\end{array}$ & $\begin{array}{c}\text { A SR } \\
\text { PERCENT }\end{array}$ & $\begin{array}{l}\text { SULFUR } \\
\text { PERCENT }\end{array}$ & $\begin{array}{l}\text { MOISTURE } \\
\text { PERCENT }\end{array}$ \\
\hline $\begin{array}{r}1 / 4 n \\
8 n \\
16 n\end{array}$ & $\begin{array}{r}84 \\
164\end{array}$ & $\begin{array}{r}61.69 \\
30.54 \\
7.78\end{array}$ & $\begin{array}{l}13.40 \\
11.69 \\
10.39\end{array}$ & $\begin{array}{l}4.38 \\
3.82 \\
3.52\end{array}$ & $\begin{array}{l}0.34 \\
0.35 \\
0.39\end{array}$ & $\begin{array}{r}61.69 \\
92.22 \\
100.00\end{array}$ & $\begin{array}{l}13.40 \\
12.84 \\
12.65\end{array}$ & $\begin{array}{l}4.38 \\
4.19 \\
4.14\end{array}$ & $\begin{array}{l}0.34 \\
0.35 \\
0.35\end{array}$ & $\begin{array}{r}100.00 \\
38.31 \\
7.78\end{array}$ & $\begin{array}{l}12.65 \\
11.43 \\
10.39\end{array}$ & $\begin{array}{l}4.14 \\
3.76 \\
3.52\end{array}$ & $\begin{array}{l}0.35 \\
0.36 \\
0.39\end{array}$ \\
\hline
\end{tabular}


ANALYTICAL DATA

DATA POR DRYFLO SEPARATION TEST 58 DATA FOR - PRODUCT COAL.
FIGURES FROM BRADPORD FEED SAMPLE.

THIS, PRACTION CONSTITUTES 72.4 PERCENT OP THE FERD.

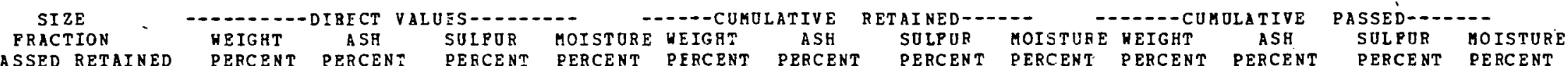

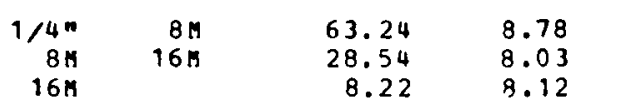

2.63
2.67

$$
0.30 \quad 63.24
$$

$$
\begin{array}{ll}
8.78 & 2.63 \\
8.55 & 2.64
\end{array}
$$$$
\begin{array}{rr}
0.30 \quad 100.00 \\
0.33
\end{array}
$$$$
\begin{array}{r}
100.00 \\
36.76
\end{array}
$$

8.51

DATA FOR - MIDDLING COAL.

THIS PRACTION CONSTItUTES 16.1 PERCENT OF THE PEED.

SIZE

$$
\text { FRACTION }
$$$$
\text { - }
$$

- ---CUMULATIVE RETAINED-..--

- DO-CUMULATIVE PASS

PASSED RETAINED PERCENT PERCENT PERCENT PER

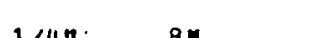

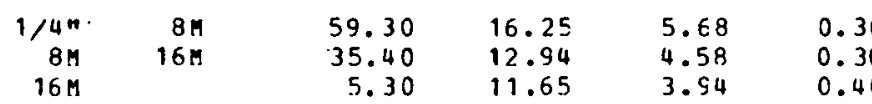

DATA FOR - REPUSE COAL.

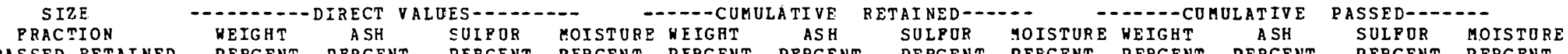

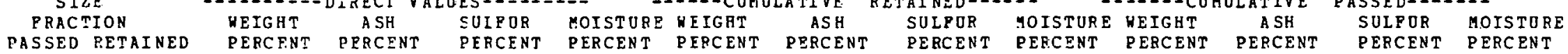

$\begin{array}{rrrrrrrrrrrrrrr}1 / 41 & 8 M & 58.30 & 35.51 & 10.13 & 0.30 & 58.30 & 35.51 & 10.13 & 0.30 & 100.00 & 31.70 & 10.02 & 0.32 \\ 8 M & 16 \mathrm{M} & 35.60 & 26.94 & 9.97 & 0.35 & 93.90 & 32.26 & 10.07 & 0.32 & 41.70 & 26.37 & 9.88 & 0.34 . \\ 16 \mathrm{M} & & 6.10 & 23.02 & 9.33 & 0.30 & 100.00 & 31.70 & 10.02 & 0.32 & 6.10 & 23.02 & 9.33 & 0.30 & \end{array}$

DATA FOR DRYFLO SEPARATION TEST \#58.

\begin{tabular}{|c|c|c|c|c|c|c|c|c|c|c|c|c|c|}
\hline \multirow{2}{*}{\multicolumn{2}{|c|}{$\begin{array}{l}\text { SIZE } \\
\text { FRACTION }\end{array}$}} & \multicolumn{2}{|c|}{$-\cdots---D$ DRECT $\nabla$} & DES - - & -- & \multicolumn{2}{|c|}{-..--Cunulative } & \multicolumn{2}{|c|}{ RETAI NED-- - } & \multicolumn{2}{|c|}{$-\infty--$ CUMULATIVE } & \multicolumn{2}{|c|}{ PASSED- - - - } \\
\hline & & WEIGHT & A SH & SOIFUR & MOISTURE & $\nabla E I G H T$ & ASH & SULPUR & MOISTORE & WEIGHT & ASH & SULPOR & MOISTURE \\
\hline PASSED & RETAINED & PERCENT & PERCENT & PERCENT & PERCENT & PERCELT & PERCENT & PERCENT & PERCENT & PERCENT & PERCENT & PERCENT: & PERCENT \\
\hline $\begin{array}{r}1 / 4 n \\
8 \% \\
16 n\end{array}$ & $\begin{array}{r}8 n \\
16 M\end{array}$ & $\begin{array}{r}62.04 \\
30.46 \\
7.51\end{array}$ & $\begin{array}{r}12.82 \\
11.49 \\
9.91\end{array}$ & $\begin{array}{l}3.91 \\
4.01 \\
3.34\end{array}$ & $\begin{array}{l}0.30 \\
0.37 \\
0.23\end{array}$ & $\begin{array}{r}62.04 \\
92.49 \\
100.00\end{array}$ & $\begin{array}{l}12.82 \\
12.38 \\
12.20\end{array}$ & $\begin{array}{l}3.91 \\
3.94 \\
3.90\end{array}$ & $\begin{array}{l}0.30 \\
0.32 \\
0.32\end{array}$ & $\begin{array}{r}100.00 \\
37.96 \\
7.51\end{array}$ & $\begin{array}{r}12.20 \\
11.18 \\
9.91\end{array}$ & $\begin{array}{l}3.9 C \\
3.88 \\
3.34\end{array}$ & $\begin{array}{l}0.32 \\
0.35 \\
0.23\end{array}$ \\
\hline
\end{tabular}

PIGURES FROM BRADPORD PEED SAMPLE.

ITA FOR -

* * conposite * * 
APPENDIX B

SMOKE POINT AND HEAT TRANSFER CHARACTERISTICS OF OIL/WATER/AIR EMULSIONS WITHOUT AND WITH COAL ADDITION IN A HOT WALL FURNACE 


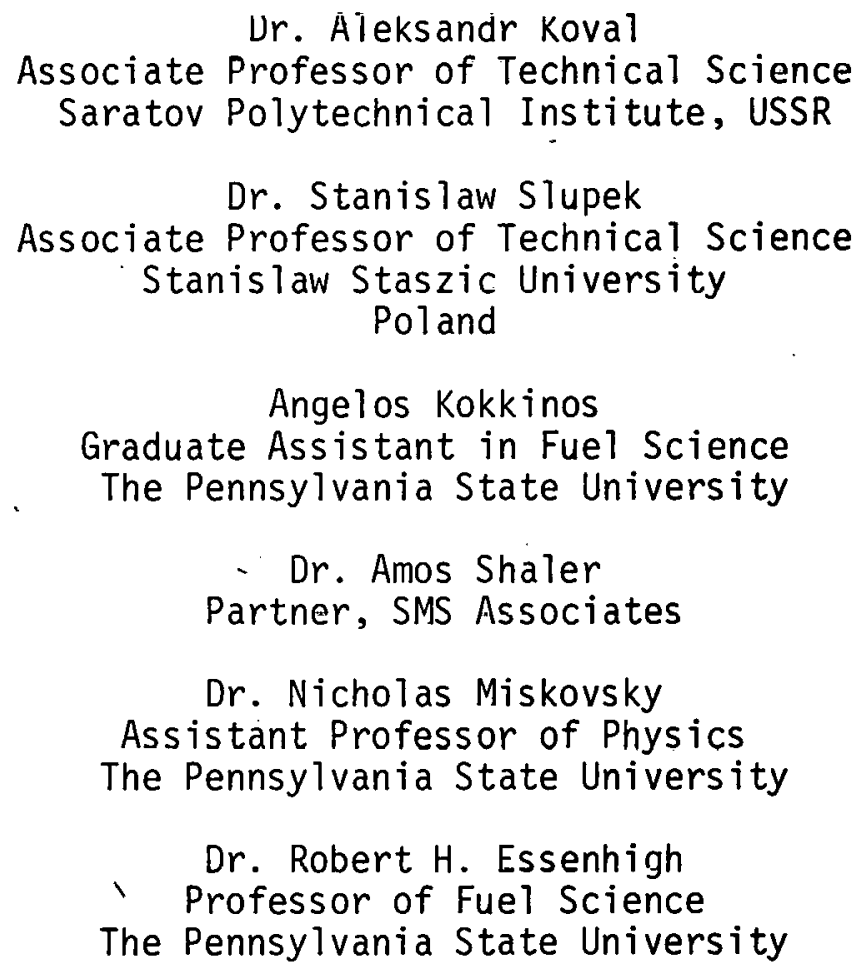

for

The Central States Section Meeting

of

The Combustion Institute

Columbus, Ohio 
Emulsions of Number 2 oil, water and alr, generated by a Sebba (6) emulsifter, fired in a hot wall furnace at 1.25 million Btu/hr, were found: to reduce the flame emissivity; and to remove carbon bulld-up on the burner. Excess afr at the smoke point was unchanged; however, smoke level at a given excess $a 1 r$, and soot concentration at a given smoke level, were generally reduced by the water addition. On account to reduced emissivity, thermal efficiency also dropped, by about 5 percentage pcints at effictencles in the region of 20 to $25 \%$. Flame emissivity was restored to 1ts original value or better by addition of coal at concentrations ranging from traces to $1 \%$, or by addition of Inert magnesia (or by permitting operation with medium to heavy smoke). The furnace was a refractory wall unit of internal dimensions $2^{\prime} \times 2^{\prime} \times 10^{\prime}$ with 17 water-cooled tubes on 1ts floor to simulate the load of a continuous Industrial thermal processing furnace. The burner supplied that it produced a double vortex mixing pattem. An 1mpact atomizer with large clearances to accomodate the coal was used in the burner. Flame stability and turn down were very good. In additional results, carbon monoxide levels were substantially independent of water content, with co not appearing unt1l smoke was at the 10 to $15 \%$ level, and therefore at a lower excess alt level than required for onset of smoke. It is therefore suggested that the principal combustion reactions and the smoke formation reactions are effectively independent of each other, with smoke somewhat influenced by, and combustion largely uninfluenced by added water. The reduced radiation with added water suggests that emulsions would be appropriate for substitution of gas by ofl where ofl radiation can cause problems of overheating and burn-out, for example, in radiant tube furnaces. Field tests on such a furnace are now providing support for this conclusion.

\section{INTRODUCTION}

The addition of water to ofl during combustion is a practice with a history of about 25 years in the case of mixtures or emulsions, and a history of 40 years or more for water added by separate injectors. The combustion systems involved have included reciprocating engines, gas turbines, and steam bollers (but not, 1t would appear, Industrial furnaces of the hot wall type used for thermal processing). Advantages claimed have been equally varied depending on the system, the objectives current at the time (e.g. reducing $\mathrm{No}_{x}$ ), the types of emulsion, and so forth. Included as advantages (some inter-related) one can find: increased power from engines, decreased engine cooling requirements, elimination of hard knock, increased thermal efficlency, increased combustion efficiency, reduced excess-air requirements, reduced flame length, faster burning, Improved atomization, reduced $\mathrm{NO}_{\mathrm{x}}$ emissions, reduced $\mathrm{SO}_{3}$ production from $\mathrm{SO}_{2}$, lower combustion nolse, less carbon bulld up, and reduced smoke or combustible particulate emissions. Much of this is covered in three recent reviews (1-3). To the extent that the clalms are substantlated, water addition is clearly advantageous, although supporting data are still not fully in evidence.

It is by no means clear what the most significant scientific issues and problems really are on which pertinent fundamental programs can properly be based.

Our own reasons for engaging in the experiments reported depended on the chance fuxtaposition of two otherwise Independent items of information. The first was that a number of companies faced with tight oil supplies two to three years ago had experienced burner problems, such as flame instability, flame-out, excessive smoke production, and so forth, 
when they changed ofl suppliers, even if the oil number was the same (with the exception of number 2). Inspection of the oll specifications shows that there is sufficient latitude in viscosity and similar requirements that variations in the 011 characteristics allowed within the spec1fications were projably the source of the combustion problems. A closely related problem that was faced but not solved generally derived from the purchase of oils that were different from those already in use by the company, which purchases were made on the assumption that anything available was better than nothing.

It occured to us in examining this problem of oil varlability that emulsifying the ofl might provide the answer if the emulsion properties over-rode the oll properties, and were reasonably consistent for a narrow or wide range of different olls. This would perwit change

or re-set the burter. A disadvantage m1ght be that many water-in-o1l emulsions have higher viscosities than tbe original oils, and this in turn can lead to larger drop size on atonization (4), which 1s clearly potentially detrinental and undesirable in combustion. A possible solution to this problem, however, was provided by the second chance 1 tem of information, that a new method of manufacturing emulsions $(5,6)$ was capable in some instances of generating eaulsions in which the viscosity was no greater than and sometimes less than that of the original fluid (7). If this potential for reducing viscosity could be realized it would not only be advantageous in maintaining or reducing the atomized drop size from the burner, but it also opened up the possibility of emulsifying heavy fuel oils that might then continue to flow (due to the viscosity reduction) without steam tracing when this 1 normally necessary.

This could also be relevant in due course to use of fuel liquids from coal. Such liquids as are already avallable tend to be on the heavy side, with SRC coal in perticular existing as a liquid when heated but as a pitch-like solid at normal temperatures. It can also be foreseen that the problem of maintaining fuel oil specifications will be a particularly difficult task for ofls derived from coal in view of the wide variation in coal properties from a single wine or even from a single seam. If specification margins for the product ofls could be relaxed by the use of emulsions, the advantages in reducing the plant complexity and costs̄ of manufacture are obvious. Another area of application might be to coal/oil dispersions, which have a history of exper1ment dating back to at least 1913, and for which a very good case can currently be made (8). In the interests jointly of saving. oll by coal replacement and of 1mproring the handleability and usability in combustio of coal, the objective is to use mixtures as rich in coal as possible. Jiscosity of the mixture, however, increáses both with increased solids concentration (with a practical limit at present in the region of 50z) and with reduced particle size (with very significant increases as partic: size drops below 2 to 3 microns, $[9,10])$. If there 18 a drop in viscosi of the mixture on emulsification, the coal loading can be increased, as desired.

We have not yet addressed experimentally the viscosity problem: it was, however, central to the conclusions that there could be further scope for the use of emulsions, and to the choice of emulsifier. We considered it necessary first to Investigate the behavior of the emulsions 1n combustion, before embarking on an investigation of the viscostity problem, partiy on accout of some apparent inconsistencies in previously 
reported work, but principally because we had selected an emulsion with

a new type of structure, and 1ts combustion behavior could not be assumed necessarily to parallel that of other emulsions. Unlike most other emulsions, these contain finely divided air as well as water, and to which the name microgas dispersions has been applied. Generally a comblation of emulsifying agents, in ppm concentrations, is required, but with some ofls, no agent is needed at all.

The experiments described in this paper have been carried out In a hot-wall furnace with water cooled floor pipes that simulates certain types of small industrial furnaces. (There seems to be only one previously recorded instance of similar experiments, 11). We were also interested in the heat balance, and more particularly in the heat flux profile, which appears to have been measured previously only by Moses, in a jet engine

providing the supporting test data. In the experiments described here, the principal measurements were the smoke profile and smoke point, the heat dellvered to the load, the thermal efficlency, and the heat-flux profile for the different emulsions or dispersion mixtures. Most of our experiments were done with No. 2 o11, some being with additions of coal or magnesla. An emulsion with No. 4 oll has also been satisfactorily fired.

\section{EXPER IMENTAL}

2.1 Furnace - The furnace, 11lustrated in F1g. 1, 1s a rectangular refractory box, of square cross-section, of internal dimensions $2^{\prime} \times 2^{\prime} \times 10$ long $(0.61 \mathrm{~m} \times 0.61 \mathrm{~m} \times 3.05 \mathrm{~m})$, g1ving a working volume of $40 \mathrm{cu} . \mathrm{ft} .(1.13$ cu.m.) of combustion space. Walls, roof, and base are $9 "(0.23 \mathrm{~m})$ thick, with outside metal cladding, of super duty firebrick for the floor and wa1ls, and roof of high temperature castable. The total weight of material

1s about 12 tons, which is a factor of importance in determining some aspects of experimental procedures. On the floor are 17 brass watercooled tubes of 1-1/4" (0.032m) o.d., with factlity for measurement of water flow rate and temperature rise. The spacing between tubes is mostly 6" $(0.015 \mathrm{~m})$. The exact spacing is indicated in F1g. 1. The tubes are fed from a single manifold, but discharge individually into a water trough: this is so that the flows can be individually observed at any time for safety reasons. The roof is also fitted down the centerline with 24 thermocouples in wells with their tips set flush with the inside surface of the roof. Spacings vary: the first 14 are $3^{\prime \prime}$ apart $(0.08 \mathrm{~m})$; the next 5 are $6 "$ apart $(0.15 \mathrm{~m})$; and the last 5 are $7.9^{\prime \prime}$ apart $(0.2 \mathrm{~m})$. The positions are as illustrated in Fig. 1. In both sides of the side wall at the burner end (see Fig. 1) are two slots, 4'.6" Iong (1.37m) and 12" high (0.3a). Each slot is closed by castable refractory covers S" thick $(0.15 \mathrm{~m})$ cast in metal cases and slung on rollers from a rail so that the cover can be slid open for inspection of the flame or other sultable purposes. Two ports with screw o! covers pierce these refractory blocks. These can be used for insertion of probes; the design permits 3-dimensional probing of the flame. The ports have been used to a 11 mited extent for this purpose in the present experiments, but the results are too 11 mited as yet to be of value and they will not be reported in this paper. Two other observation/probe ports exist in the side walls on the center 1ine, $75^{\prime \prime}(1.9 \mathrm{~m})$ and $45^{\prime \prime}(115 \mathrm{~m})$ from the exhaust end of the furnace, as Indicated on Fig. 1. Two other ports are set through the corners of the furnace at the burner end, angling in for a line of sight intersection on the geometrical axis $30 "(0.76 \mathrm{~m})$ from the burner end. 
2.2 Burner and Atonizer - The burner is illustrated in Fig. 2. 1t

consists essentially of two concentric tubes, each 11 " long $(0.28 \mathrm{~m})$, and of diameters respectively $7.5 "(0.19 \mathrm{~m})$ and $15^{\prime \prime}(0.38 \mathrm{~m})$, thus forming a 3.5" $(0.09 \pi)$ annulus between the tubes. The inner tube is perforated with $3 / 4^{\prime \prime} \mathrm{dia}$. holes $(0.02 \mathrm{~m})$. One end of the assembly is closed by a metal plate that also carries the atomizer. The other end of the annular space is also closed. There is also a divider half way down the annulus splitting it into two. Combustion air is supplied to the annulus through $2^{\mathrm{n}}$ dia tubes $(0.05 \mathrm{~m})$ with elbows on the their ends so that the air is forced to rotate as it emerges from the annulus into the inner (combustion) tubes, thus generating a vortex. The air is arranged to rotate in opposite directions in the two halves (upstream and downstream) of the annulus so that the flow pattern in the combuscion tute consists of two vortices rotating in opposite senses. As found in a number of previous cold model (13) and combustion experiments (14), mlxing by such a double vortex is irtense, and combustion tends to be very stable with high intensity at maximum firing rate, and with good turn down. As shown 1n Fig. 2, the burner penetrates $5.5^{\prime \prime}(0.14 \mathrm{~m})$ into the wall with the final aperture shaped with a flare out (of refractory) into the furnace. The flare out plays no part in the flame stabilization. The gases emerge in horizontal flow with no residual rotation for test performance.

The atomizer 1s 1llustráted in Fig. 3. This uses an 1mpact plate for atomization, which is normally good. As 1llustrated, atomizing alr, normally at $80 \mathrm{psig}\left(56000 \mathrm{~N} / \mathrm{m}^{2}\right)$ is supplied up the center tube in the atomizer block. This tube converges to a ventur1 throat about 0.5 " $(0.013 \mathrm{~m})$ from the end of the block. O11 or the emulsion is supplled from a small ring main through four tubes in the block to the throat of the venturi. The mixture 1s carried to the end of the block where 1 t strikes an 1mpact plate of about the diameter of the exit port. An Impact plate any larger than this tends to make the oil splash back onto the face of the block where $1 t$ condenses and runs down. The dimensions of the varlous ports are as, given in the figure. The block also carries six gas ports that run to the end of the block, ar.gling out as indicated at an angle of $30^{\circ}$. This is necessary to arold destroying the backmix pattern that exists on the combustion tube axis some inches downstrean from the atomizer (see Refs. 13).

The design directs the fuel (oil or gas) to the wall of the combustor tube; it is braght back from there by the mixing behavior of the air pattern. Alr 1s' generally used for atomizing; however, pressure gas is just as good, and provides easier 1ight-off. This atomizer has also been successfuli:y used in incineration tests of a chlorinated hydrocarbon in water (1\%). with the liquid for incineration supplied in place of the o1l, and with the gas ports used to supply the sustaining fuel for the incineration flaxe. The successful incineration of the chlorinated hydrocarbon testified to the excellent mixdng pattem obtained without by-pass in the combustion tube. In less suscessful tests, the same waste liquid in ethancl (5\%) was incinerated using the ethanol for the incineration flame. This rilxture was too rich in chlorine and much carbon was produced though this was greatly reduced by diluting the wixture with additional water.

2.3 Emulsifler - The device used to make the emulsions was developed by SMS Associates from the Sebba design (6) and is 11lustrated in Fig. 4.

The heart of the unit is a venturi section, as illustrated, in a closed loop, with air suppiled in the form of a conical sheet to the throat of the venturi (and with supply lines for oll, surfactant, and water to the loop and. a delivery Hne tapping of $f$ from the loop to the burner). The elements of the design have a strong simflarity to the atomizer except that the roles 
played by the liquids and the gas are reversed. A surfactant stabilizing agent is generally used. Classifying emulsifiers as: (1) mechanical; (2) chemical; and (3) other; this device is classified in category 3, but it has aspects of both mechanical and chemical emulsifiers. The design, however, permits use of lower pressures than are required for other mechanical atomizers -- typically in the range 10 to $50 \mathrm{psig}(70,000$ to $\left.350,000 \mathrm{~N} / \mathrm{m}^{2}\right)$-- and the use of much lower quantities of surfactant -typlcally in the region of $500 \mathrm{ppm}$, compared with 1 to $10 \%$ for a purely chemically formed emulsion.

The structure and properties of the emulsion, to the extent that these have been 1dentified, are also somewhat-to-substantially different from those of other emulsions (7). Photomicrographs show the emulsion to have something of a concentric bubble structure, with discrete (gized gas bubles (generally 1 to $10 \mathrm{microns}$ ) dispersed in a continuous water phase that in turn 1s permeated by a continuous of 1 phase. This is 1llustrated schematically in F1g. S. One can 1magine this as a porous mass of frog spawn, with the pores all connecting and permeated by ofl as the first (and main) continuous phase: the eggs then represent the discrete gas bubbles'surrounded by the containing gel, also as a continuous phase, representing the water. A mlxture of both water soluble and ofl soluble surfactants 18 used, when stabilizers are required (substances with partial solubility in both oil and water, such as organic acids, may also be used). Because of this structure, the tendency of the gas bubbles to coalesce is hindered by the surrounding water phase, and synergistically, the tendency of the connecting water layers on the bubbles to grow into one another and separate out from the o11 is hindered by the gas bubbles. An additional consequence of this

structure is that the emuision is compressible. Properties of the emulsions are still under investigation, but one additional characteristic of considerable relevance is that they evidently behave as Newtonian fluids (6), unlike most or all other emulsions which are non-Newtonian (4).

2.4 Sampling and Instrumentation - Measurements of interest include both overa11 heat and material balances, and also internal profiles. The only internal profiles so far measured are the heat flux profiles by the water pipes on the floor of the furnace, as described above, and the centerline roof temperature profiles, as also described above. As mentioned, provision exists for three-dimensional sampling from the burner exit to about half way down the furnace, and at two further stations downstream, but the few measurements of gas compositions and temperatures so far made will not be reported in this paper.

Principal other measurements so far have been gas exit temperatures, gas analyses, particulate loads, and smoke number. Probe stations for these measurements are located at the furnace extc or in the flue pass leading to the stack. The first section of flue pass from the furnace exit is a horizontal refractory lined tunnel of 1 'x 1 ' (internal) square cross-section $(0.30 \mathrm{~m} \times 0.30 \mathrm{~m})$ as indicated $1 \mathrm{n} F \mathrm{Fig}$. 1 . At the end of this section, which is $4^{\prime}(1.22 \mathrm{~m})$ long, the flue pass turns vertically upwards into a steel, unlined section. This section carries a 11ght obscuration smoke meter (Balley Type U5000 A) arbitrarily calibrated in percentage obscuration by Ringelmann grids. Downstream of that is an atmospheric damper to maintaln draft at the required level. The furnace was mostly operated at balanced draft to ellminate air Inleakage (and gas exleakage), the draft point being in the horizontal flue pass, on the level of the geometric axis of the furnace as indicated in Fig. 1. Read out was by a Bristol 24-hour draft meter 
Model D $40 \mathrm{M}$ with full scale readings of $0.05 "(0.0013 \mathrm{~m})$ w.c. pressure to $0.15 "(0.0038 \mathrm{~m})$ w.c. draft. Reading accuracy sensitivity was to $0.001 "(0.0003 \mathrm{~m})$ w.c. The meter was Installed with balanced 11nes. During operation, the furnace was also sealed to the extent possible with molstened asbestos tape squeezed into possible cracks.

Gases were sampled through a conventional water-cooled probe, passed through a wash bottle, dried, and collected in batch sampling bottles for batch analysis, by chromatogrephy for $\mathrm{O}_{2}, \mathrm{CO}_{2}, \mathrm{CO}$,

$\mathrm{N}_{2}$, and $\mathrm{CH}_{4}$. Excess-air percent was calculated from the gas analyses, and compared with the values determined from air and fuel flow rates.

Exhaust-gas temperatures were measured just ahead of the gas sampling point using a laboratory-built suction pyrometer of conventional. design. to a small external cyclone for principal capture of the solids, followed by a $2 "(0.05 \mathrm{~m})$ dia filter paper supported on a.wire mesh to capture the fines leaving the cylone. The transit istance from probe entry to cyclone $1 s 42^{\prime \prime}(1.1 \mathrm{~m})$. The sampling rate $1 \mathrm{~s} 2 \mathrm{cfm}(\operatorname{cold})\left(0.001 \mathrm{~m}^{3} / \mathrm{sec}\right)$, so that the transit time between entry and capture is $0.07 \mathrm{sec}$.

other instrumentation includes: 24-point read-out for the roof temperatures on an $\mathrm{L} \& \mathrm{~N}$ potentiometric multipoint recorder; smoke level read-out on a circular scale $(24 \mathrm{hr})$ calibrated in percentage obscuration of the light; direct reading flow meters (rotameter type) for water to the emulstfier (range $0-2.0 \mathrm{gph} ; 0-0.0000021 \mathrm{~m}^{3} / \mathrm{sec}$ ); for ofl (range $0-26 \mathrm{gph}$; $0-0.000027 \mathrm{~m}^{3} / \mathrm{sec}$ ); and for the atomizing a1r (or gas) (range $0-10 \mathrm{cfm}$; $\left.0-0.005 \mathrm{~m}^{3} / \mathrm{sec}\right)$; combustion air flow by a directly callbrated inclined gage connected to an Annubar element tr: the air 11ne (range $0-230 \mathrm{cfm}$; $\left.0-0.11 \mathrm{~m}^{3} / \mathrm{sec}\right)$.

2.5 Ancillaries - Otier equipment included the following. Combustion atr Is supplied from a Pyronics $24 \mathrm{oz} .\left(10,400 \mathrm{~N} / \mathrm{m}^{2}\right)$ blower with a free alr capacity of $430 \mathrm{cfm}\left(9.20 \mathrm{~m}^{3} / \mathrm{sec}\right)$. Atomization air is supplied from the University compresses alr line system, at $60 \mathrm{ps} 1 \mathrm{~g}\left(400,000 \mathrm{~N} / \mathrm{m}^{2}\right)$. Necessary water is avallable at $80 \mathrm{psig}\left(550,000 \mathrm{~N} / \mathrm{m}^{2}\right)$. 011 storage is in two $225 \mathrm{gal} .\left(0.85 \mathrm{~m}^{3}\right.$ ) capacity tanks (for No. 2), with feed to the furnace or enulstfier through a $15 \mathrm{gph}\left(0.000016 \mathrm{~m}^{3} / \mathrm{sec}\right)$ capacity pump, delivering at $100 \mathrm{psig}\left(700,000 \mathrm{~N} / \mathrm{m}^{2}\right)$. Where lower pressure is needed, It 1 s reduced accordingly. Some few experiments were carried out with Number $4 \mathrm{oll}$, and for these an auxiliary drum of $30 \mathrm{gal} .\left(0.000115 \mathrm{~m}^{3}\right)$ capacity was used. Light-off was usually started with (natural) gas which is avallable at $15 \mathrm{psig}\left(100,000 \mathrm{~N} / \mathrm{m}^{2}\right)$ to a line capacity of $500 \mathrm{cfh}\left(0.004 \mathrm{~m}^{3} / \mathrm{sec}\right)$. This fuel has also been used in comparative experiments. Susticn for the probes is provided efther by a suction pump or by a water cr alr ejector.

\section{RESULTS}

3.1 Scope of Experinents and Exper1mental Procedure - All except the comparative experiments with gas were carrled out at $1.25 \pm 0.05$ million Btu per hour -- $300,000 \pm 10,000 \mathrm{kcal} / \mathrm{hr}(1.30 \pm 0.05 \mathrm{GJ} / \mathrm{hr}$ or $0.35 \pm 0.01 \mathrm{MW})$. In the experiments viti gas, they were carried out at the line capacity of 0.5 million etu per hour $(125,000 \mathrm{kcal} / \mathrm{hr}, 0.53 \mathrm{GJ} / \mathrm{kr}$, or $0.15 \mathrm{MW})$. Experiments were carried out with gas, pure ofl (o. 2), with emulsions containing $10 \%, 12 \frac{2}{2}, 20 \%, 25 \%, 30 \%, 37 \frac{2}{2} \%, 40 \%$, and $50 \%$ water by weight (generally with 350 ?pm surfactant), and with emulsions at $12.5 \%$ by weight of water and containing 7 different levels of coal (from approximate1y $0.02 \%$ to $1.5 \%$ by weight. 
The fuel oil analysis and calorific values are given in Table 1.

Ail experiments were carried out with the furnace preheated up to the operating, temperature. This generally meant preheating on high fire (at about 2 to $2.5 \mathrm{milliton} \mathrm{But} / \mathrm{hr})(500000$ to $625000 \mathrm{k} \mathrm{cal} / \mathrm{hr}, 2.12$ to $2.65 \mathrm{GJ} / \mathrm{hr}, 0.6$ to $0.75 \mathrm{MW}$ ) for 4 to 6 hours. An experinent would be started by setting the air, o11, and water supplies to the emulsifier at the required rates, and feeding, the-mixture to the preheated furnace for a period for a final.stabilization of, conditions, ., At this starting point, the combustion air was set at a (measured) level high enough to prevent smoke. Stability of conditions could be checked by monitoring the gas. analyses and rise of water temperature in the floor tubes. When conditions.were steady, the measurements were re-checked, additional samples (e.g. particulates).' were drawn, 'and additional/measurements (e.g. smoke) were. made and recorded. With all measurements completed and samples drawn, the a1r rate was dropped, in a step equal to something between $1 \%$ and $10 \%$ change in the excess air, the magnitude of the step depending on the mixture involved and the position on the smoke curve. After a period for-re-stabilization, all new measurements were recorded and samples drawn, and the sequence was repeated again. The procedure was repeated until the light obscuration by smoke was at or near $100 \%$; this generally occurred between stoich10metric and $10 \%$ alr deficiency. In a period of three to six hours it. was possible to obtain about half a dozen measurements at different levels of excess air. The set constituted one complete run, In all, the results reported here are based on about 75 runs representing different conditions of experiment with 1 to 5 repeațs of each condition.
3.2 General Behavior - In a typical run with low to zero smoke, the furnace viewed through an observation' port at the end of the flue pass on the center line would appear clear or slightly hazy, except for the flame in the combustion can and its projection into the furnace, which was yellow and opaque. As air level was reduced, the haziness increased until at about $50 \%$ obscuration (Ringelmann 2 to 3 ), visibility in the furnace was reduced to zero.

The flame itself was contained only partly in the combustion can: the flame projected from two to four feet into the furnace in a flame brush or plume that approximated to a tapered cylinder of diameter 12" to $15 "(0.3$ to $0.38 \mathrm{~m})$. About 60 to $85 \%$ of the flame volume was therefore inside the furnace; at the same time, it is estimated that $50 \%$ or more of the combustion occurred inside the can. The flame volume in the furnace was at a11 times less than $10 \%$ of the furnace volume, down to $1 \%$ when firing gas. These are typical numbers for many industrial furnaces. $\therefore$ The flame length tended to increase with progresstve reduction. of the air rate, but the extent of the extension was soon obscured as the smoke level in the furnace rose.

In all experiments, both the roof temperatures and the heatflux profiles showed lowest values at the stations closest to the burner and the exit, with peaks roughly three feet (one meter) 'from' the burner. These are 1llustrated and discussed more fully below.

3. 3 Smoke Profiles - F1gure 6 11lustrates the smoke profiles, plotted as percentage obscuration against excess alr percent. Included on this graph are the curves for pure oil, for a chemical emulsion containing $12 \frac{1}{2} \%$ water and $7 \%$ emulsifier but no alr, and for three 011/water/air emulsions at $12.5 \%, 25 \%$ and $37 \% \%$ water. As shown, all curves have the 
same general shape, being sigmoids varying from zero smoke to high smoke as the excess air drops. As the curves show, the smoke point in all cases is at about $10 z$ excess air, and is not evidently affected by the emulsification. This seems to be contrary to all previous results (see Reviews, 1-3). As the curves also show, however, emulsification does clearly reduce the smoke level, at the same excess air level, for excess afr less than that at the smoke point. Evidently, there is some interference with the smoke forming reactions.

In assessing the results, it is possible to summarize as follows. The smoke point, or excess air percent at smoke onset, shows no detectable reduction by the use of emulsions. Belng contrary to previous reports, this may represent inherently good smoke control by good burner design. This itself could be a conclusion of practical significance that could become 1mportant if more furnaces are run near the smoke pcint to save fuel. The use of the microgas emulsion seems so be a lit:le tetter than the chemical emulsion, rinuigh whether tha dxffarens is reelly significant is open to argument. There is in general, a significant redüition in smoke level with the emulsions, with the effect increasing as the excess atr drops. This is a result of no practical value for burrers such as the one in use where h1gh smoke levels can not be permitted and there is no provision for final burn up, but it might have some practical significance for staged burners. The theoretical significance of the result in relation to understanding the mechanism of smoke formation may be greater significance in due course.

Supplementary to the above results, Fig. 7 is a plot of particulate concentration, Identiffed as soot, against the percent obscuration Ringelmann number. This brings out another point. It shows that at the same Ringelmann number, the welght of soot collected drops with increasing water in the emulsion. A replot of Fig. 6 with weight of soot in place of Ringelmann number would show an even greater effect of the emulsions.

Figure 7 contains the additional 1mplication of importance that lower soot concentration. for the same Ringelmann number requires smaller particle size. Such a result is in line with previous findings (1-3); the particle size of our samples is under examination at the moment but the results are not yet available.

3.4 Carbon Monoxide Profiles - The carbon monoxide profiles are similar in shape to the smoke profiles, but with certain differences that may be of fundamental importance. The profiles are 1llustrated in Fig. 8. As this shows, the analyses for the emulsions fall on a common line, unlike the smoke profiles, with the pure oil data possibly represented by a separate line (although this could be statistical scatter on the margin of the common line). This was a most unexpected result: it was assumed a prior1 that the co profiles, like the smoke profiles, would also be sensitive to water content on the argument that co appearance could be expected to correlate closely with smoke onset or smoke density. These results suggest that this is not the case. A possible interpretation of the results is that smoke formation and combustion take place by two independent reaction paths, the first, of course, being indexed by smoke, and the second being indexed by $C 0$. If this is a valid conclusion $1 t$ also then follows that water interferes with the smoke forming reaction bit not, or not sigaficantly, with the principal combustion reactions. Trils is a point that is not known to have been made before.

A further conclusion is that smoke onset occurs before, or significantly before, co enset. This is not too evident from Fig. 8; 1t. 1s much clearer in Fig, 9 which shows, the correlation of $C O$ with smoke level. This makes it quite clear that the smoke reaches $10 \%$ or more before the $\mathrm{C} 0$ concentration starts to rise. Th1s displacement 
appears to be substantially independent of water percentaze.

3.5 Heat Flux and Roof Temperature Profiles - Figure 10 1llustrates the typical scatter plot profile obtained for the quantity of heat absorbed In each tube on the floor of the furnace. F1gure 11 is the roof temperature profile for the same set of conditions. The interesting point about the profiles is that the gases can be expected to be at their highest temperature emerging from the combustor can, as observed experimentally in a smaller hot wall furnace that is a reasonable simulation of this present furnace (15). Such a peak in heat flux 1 of often referred to in industrial practices as a "hot spot", and it is a common assumption that the hot spot position is controlled by the flame temperature and emlssivity. As these results show, however, the hot spot is about three emissivity.

The reason for the displacement is provided by theoretical calculations in the previous paper (15). Those calculations show that in hot wall furnaces of this type, particularly with relatively small flame volumes as percentages of the furnace volume, anything from half to three quarters of the heat to the load (the floor tubes) is provided by radiation from the walls and roof. A detalled integration of heat supplied from the walls and roof will then generate a flux profile that w11l reflect the wall and roof temperature profiles, not forgetting that the wall-to-wall re-radiation tends to eliminate major asymetries of differences in temperature (15). The wall and roof temperature profiles are therefore determined as much by their local losses through the walls as by the pattern of radiant flux directly from the flame. Since the

wall loss is largest at the corners, a furnace with a completely symmetrical heat supply (for example, if it was perfectly stirred to produce completely uniform gas temperatures and emissivities) would still have peaking temperature profiles, but they would be completely symmetrical. Heat flux from the walls and roof to the cooled floor must then reflect to some degree the wall and roof temperature profiles. The product would be a symmetrically peaked profile of heat flux to the load, i.e. with a hot spot, in spite of the uniform gas temperatures and emissivities. In this present case, since the furnace length is about $10 \mathrm{ft}(3 \mathrm{~m})$, a symmetrical profile would place the hot spot $5 \mathrm{ft}(1.5 \mathrm{~m})$ from the burner. We therefore regard the hot spot, or peak flux position, as having been moved from the center to a point $1.5 \mathrm{ft}^{3}(0.5 \mathrm{~m})$ upstream from the center due to the asymetry of the heat supply.

3.6 Influence of Water Percent on Heat Flux Profiles - To compare the effect of water on the heat flux profiles, the average heat absorbed at each station was calculated in order to construct the comparative plot of Fig. 12. This is at the minimum excess air for zero smoke in each case. The trend is unmistakable: with increasing water in the emulsion, the peak heat flux drops, although heat flux in the downstream section of the furnace may rise. According to the argument of $\mathrm{Sec}$. 3.5, this must reflect changes in wall and roof temperatures. Figure 13 is a plot of the center line roof temperatures, and as expected, they drop steadily with rise in water percent. With less heat leaving the furnace through the walls and into the water tubes, there must be more In the stack exhaust, and a check of the gas exit temperatures showed that this was indeed the case (F1g. 14). 
With reduction in both wall temperatures and in heat flux to the tubes, it is clear that the heat transfer from the flame gases must also be reduced. Since radiation is well recognized to be the main mode of heat transfer from flame gases, the choices to explain the reduced heat transfer are: reduced gas temperatures, or reduced gas emissivities, or both. However, if more heat is left in the flame gases, the temperatures must be $h 1$ gher all the way along the flame. Just as they are at the furnace exit, as measured. Consequently, the effect of the water nust be to

- reduce the gas emissivities. This opens up a fundamental question that is discussed to some greater extent below.

3.6 Effect of Particles on Heat Transfer - As a further check on the conclusion that the reduced heat transfer was due to reduced radiation, the effect of particles added in varlous ways was investigated. In all cases the heat flux was increased. The simplest way of adding acditional radiative material was to operate the furnace fuel-rich. Follcwing that test, small quantities of coal were addes. In the final experiments, finely dispersed magnesia was used (Phtlips Milk of Magnesia).

The effect of the smoke showed a most interesting pactern. As smoke increased for the $0 \%, 12.5 \%$, and $25 \%$ water in the emulsion, the centerline roof temperatures rose steadily, up to the highest smoke level examined, of $94 \%$, with the peaks remaining at the same poir.t. It should be noted: that level of smoke would correspond to less then $1 \%$ heat loss by unburned sollds, though heat loss by unburned gases might be higher. Likewise, the flux profile to the water tubes alsc increased with increasing smoke, but only for the pure 011 case; and above $30 \%$ smoke, the further effect of smoke on the displacement of the curves was minor. With the emulsions, there was an initial rise, until the smoke reached 50 to $60 \%$, after which the flux fell again (the peaking point was uncertain).
The explanation for this behavior appears to be as follows. Increased power of the radiative souzces by way of increased roof and wall temperatures is available. Fo: an unchanged optical thickness of the gases in the furnace, the increased roof and wall radiation would increase the heat transfer to the tubes. However, the increasing smoke would increase the optical thickness, and the extra attenuation would modify the simple picture. We may conclude that in the case of the pure ofl, the increased radiant flux is almost exactly balanced by the 1ncreased optical thickness due to the smoke above $30 \%$ smoke. In the case of the emulsions, notir.g first that a given smoke level represents substantially different excess air levels (see Fig. 6), we may conclude that, Inttially, the Increased radiant flux from the walls exceeds the ef zect of the increased optical thickness, but as the smoke level rises, the effects reverse. At high smoke levels, an increasing fraction of the radiation in transit from the walls to the tubes is absorbed by the smoke.

hdditior: of coal provides a means of increasing the flame emissivity (and the gases absorptivity) with small to negligible addition to the thermal input at low coal loadings. To 1nvestigate the effects, coal was added to $12.5 \%$ water emulstons. The coal loadings were taken from a trace (at ppm concentration) up to 1.5 weight percent (about $1 \%$ thermal addition). The mean flux curves (Fig. 15) show an unexpected variation. As would be expected, the initial curves show increased heat transier to the tubes (at trace concentration, $0.02+0.01$ wt.\%, $0.175+0.75$ wt. $\%)$. In the next concentration range $(0.5 \mathrm{wt} . \%)$, the flux dropped, to rise somewhat at higher concentrations again (1.1+0.4 wt.\%). The pattern is otscurely regular. Nevertheless, it is clear from the 
results that trace,additions of coal can increase heat transfer by a measurable amount. The magnitude of the effect is most easily seen from the efficiency plots (below).

Finally, in these experfments on particle additions, a dispersion of fine magnesia particles was added to the $12.5 \%$ water emulsion. As these particles do not burn, they can be expected to malntain their radiant additive contribution to the end of the furnace, so their effect . might be expected to be greater than that of the coal additions. The magnesia line is included on Fig. 15. As can be seen, it is essentially indiștinguishable from the coal lines. The possible significance of this is discussed below.

3.7. Thermal Efficiency - The thermal efficienćy of the furnace is defined as the ratio of the heat absorbed by the water tubes to the heat input in the fuel. As a check on the accuracy of the figures, a closed heat balance was made for all runs at zero smoke: To do this, the stack enthalpy loss rate was calculated from the exhaust temperatures and the stack gas analyses; and wall losses were estimated from the inside roof temperatures and from a number of outside wall temperatures taken during the experiments. Of 60 definttive runs made, without coal, about 15 were found to have such disagreement between the excess air calculated fron the fuel/air rates and from the stack analyses that they were considered unrellable and discarded. (These were obtained using an early model of the emulsiffer.) of the remaining 45 runs, about 25 showed heat balance closures to better than $10 \%$. For the balance ( 20 runs), the closures were good to 10 to $50 \%$. As the closure balance deterlorated, less confidence was placed in the results. [About 15 runs were made with coal additionl.
Figure 16 shows the variation of thermal efficiency with water percent in the emulsions. As can be seen, and in agreement with expectation from the reduced heat flux curves, there is a relatively small decline in efficiency with increase in water content of the emulsions. However, the effect is relatively smail, and the drop in effictency is reacily restored by addition of a relatively small quantity of coal.

\section{DISCUSSION AND CONCLUSIONS}

In evaluating the above results we have addressed ourselves to two points: (1) the meaning and fundamental 1mpifcations of the results; and (2) the relevance of the results to our objectives of using emulsions for the reasons given in the Introduction.

(1) Sumarizing first the salient results of this study: the only clearly beneficial effect of the use of emulsions was the ability to reduce carbon bulld up: In fact, where carbon may have bullt up efther from the smoke experiments (rapid) or from normal firing of unwatered ofl (much slower), the switch to the emulsions resulted in gasification of any previously formed carbon deposits. Otherwise, the excess air at the smoke point was unaffected; flame emissivity and thermal efficlency were both reduced. of the above four findings, the first has been, generally reported (1-3; also see Introduction). The third (reduced heat transfer) has been

reported only by Moses (12). The second and last (unchanged smoke point and reduced efficiency) are contrary to effectively all other findings (Moses actually reported minimal drop in efficiency and rise in combustion temperature -- the minimal trend is in line with our results). Of the other advantages of exulstons 1isted'in the Introduction, engine operation was Irrelevant here, and other factors such as flame length, burning time, atomization, and so forth have not yet been investigated by us. 
The principal differences between our findings and other work are, therefore, the influence on smoke point and efficiency. This may be the difference between hot wall and cold (mostly water) wall operation, but it could be due to something more fundamental. It is now well known fror studies by Cooper et al (16) and others (see Review, 17) that swoke can be controlled or ellminated by recirculation of flue gases, and it has also been found that the "active principle" appears to be nothing more than dilution. The effect can be obtained by the addition of cylinder nitrogen, or $\mathrm{CC}_{2}$, or water. It is also well known that further dilution will result in the flame turning blue (the basis of blue flame burner designs). Indeed, we have performed this experiment ourselves, in the present furnace, using cylinder nitrogen, producing snoke-free, blue (or rather purple) flames even when operating fuel-rich (with $8 \% \mathrm{CO}$ in the stack gas). When the blue flames are formed, the switch from the usual yellow is quite sudden. This is not a dilution effect: the boundary in Cooper's results (16) between blue and yellow was found by us to be a line of approximately constant oxygen concentration (16 to $17 \%$ ) in terms of original mixture dilution.

It is common to interpret these dilution results as being due

to interference with the smoke forming reactions which are assumed to be an alternate, parallel reaction path to the normal combustion reactions. As outlined briefly in Sec. 3.4, and amplified here, two parallel reaction paths to the final combustion produsts are postulated. The firse is a very rapid breakdown of the fuel molecule as proposed, for example, In the Edelman and Fortune (18) Quas1-Global reaction scheme in which. $\mathrm{CO}$ and $\mathrm{H}_{2}$ are very rapidiy formed. If this is rapid enough, intermecilate products in the breakdown w1ll always be at too low concentrations to show their presence by significant radiation. Flame color in combustion by this sequence would therefore be blue. In parallel, we may suppose, following Echigo et al (19), that reaction proceeds through a path that Includes a "soot precursor". This soot precurscr was found to be the source of the yellow radiation commonly (and wrongly, according to Echigo et a1) attributed to solid particles of carbon. The well-known difficulty of burning up flame-formed carbon supports their view. In th1s soot precursor scheme, reaction of the precursor has two further parallel alternatives: efther total reaction proceeding to the usual end products of $\mathrm{CO}_{2}$ and water vapor; or it continues to soot, as the end product, by some suci path as that discussed by Palmer (20). The circumstances that result in the choice of the path to soot, rather than to $\mathrm{CO}_{2}$ and water vapor, are obscure. These alternate paths are illustrated in schematic summary in Fig. 17.

We can now see that interference with the path to soot (evidently by dilution to reduce the flame cemperature) will reduce or eliminate this branch of the reaction sequence. Further dilution to reduce the oxygen concentratior. would then eliminate the other branch of the reaction sequence, presumably by eliminating production of the soot precursor. As the soot precursor is the yellow radiating component, and since the only path to complete combustion left is the first path discussed which is blue flame combustion (as the combustion of essentially $\mathrm{CO}$ and $\mathrm{H}_{2}$ ), we should find that the flame should turn from yellow to blue. If we now suppose that before the soot-precursor reaction path is eliminated by the progressive dilution, its rate is so azfected that the soot precursor concentration 1 s progressively reduced (which seem reasonable), the outcome would be progressive reduction in flame emissivity, which, of course, is in line with our experimental findings, and those of Moses (12). We could also expect that this mechanism should hold universally. 
If this is a valid argument 1 t becomes somewhat difficult to understand the claims, as reported in the Reviews (1-3), for 1ncreased effictency by the use of emulsions. Evaluation of the clalms is difficult because the conditions of experiment were not always too fully specified; in particular, it is not clear that the role of excess ait was fully accounted for. It has indeed been suggested, particularly by Iammartino (1) that the efficlency gains were due to reduction in excess a1r, not to better heat transfer. This is most 11kely, in our opinion, to be the case although it ralses a further difficulty. Addition of water provides an increased thermal load in the flame that, other things being equal, would reduce thermal efficiency. Increased thermal efficlency therefore requires a better than one-to-one trade off by reduced excess alr, or else it requires increased heat transfer by increased temperature and/or emissivity. The one-to-one trade-off between the two can be approximately calculated. The results, expressed as percentage point drop in excess afr against the water/fuel weight rat1o, is 1llustrated 1n Fig. 18. As shown, it also depends on the exhaust gas temperature. For a given temperature, the plot shows that for a selected water/fuel ratio, the excess air percentage points must drop by at least the amount on the relevant line to break even. Thus, at $10 \%$ water, the excess air must drop by 2 to 3.5 percentage points for exhaust temperatures in the range $800^{\circ}$ to $2000^{\circ} \mathrm{C}$, and $1 \mathrm{t}$ must exceed $5 \%$ drop if the temperazure 18 down to $400^{\circ} \mathrm{C}$. In our experiments, stack temperatures were in the resion of $800^{\circ} \mathrm{C}$, and we would therefore have required a drop in excess atr of 5 to 15 percentage points to obtain an even trade off. In the case of cold wall bollers of high efficiency, exhaust temperatures would be $400^{\circ} \mathrm{C}$ or lower, and in the range $10 \%$ to $30 \%$ water in the oil, the excess atr percentage point drop would have to be in the range 5 to $25 \%$, to break even, and greater still to gain in efficiency.
Noting that Coopers experiments (16) showed a smoke point at $50 \%$ excess air, the existence of high excess air systems for zero smoke is demonstrated. Noting also the relatively low excess afr at the smoke point in our own experiments (10 to 15\%); the existence of low excess air burners at the smoke point is also demonstrated. It is suggested, therefor, that where the efficiency gains from emulsions have been reported, the best explanation for the improvement could be that the emulsions are dcing what could equally well be done by better atomizer/mixer design. We are faced otherwise with an incompatibility in the numbers for the thermal balances that is rendered worse if we then take into account the possibility of reduced flame emissivity in the emulsions.

Alternative explanations for improved efficiency focus on the possibility of improved atomization, but here again there are problems. With a well designed, maintalned, and operated burner, the combustion efficiency should be in the region of $99+\%$ at excess atr levels above, the sroke point. The scope for gain in combustion efficiency by improved atomization, at the same excess air point, is marginal to zero. Where improved combustion efficiency is reported it must mean that the burner was being operated away from its design point (gas turbines for jet engines operated at the equivalent to take off power would be an exception). Alternatively, better atomization can mean faster burning, which meanś a more compact, and therefore hotter flame. Even with a lower exhaust temperature, the overall or mean temperature can be higher, resulting in increased heat transfer and higher effictency, so there is scope for Improvement on that score.

Improved atomization; however, has not yet been demonstrated. The probleal of possibly increased viscosity that may increase drop size from the atomizer was mentioned in the Introduction; the point bears closer examination. Alternatively, it has been suggested that the 
phenomenon of "microexplosions" described by Ivanov et ai (21) will improve atomization. Photographs show that the oil drops may be ruptured as they heat up, the rupturing being attributed to the water droplets as they flash into steam. This has also been a common explanation for behavior of oll drops contalning a range of bolling points. To the extent that this occurs in flames, it would of fset any adverse effecis of poorer atomization from increased viscosity, if this is a factor. In sumnary, therefore, best available evidence would suggest the following. Addition of water will tend to reduce emlssivity by interfering with formation of some radiating specte (describable as the soot precursor). Addition of water must at least be of fset by reduced excess air, and this requires very substantial reductions at high water content of the emulsions, in the region of 10 to $25 \%$ excess air poitits for $30 \%$ water, depending on exhaust temperature. If there is scope fo: such reductions without going fuel rich, either the system is being operated at unnecessarily high levels of excess air, so that considerable savings would be possible without going to emulsions, or else the burner (atonizer/mixing) fattern is of poor design and needs replacing. The vi scosity of the enulston may be higher than that of the pure oil, and atomization will correspondingly suffer. This could be offset by "selfa: mization" due to vaporization of the water (microexplosions). Better atomization should lead to faster burning, and this could give higher peak flame temperazures. If the outcome is indeed better heat transfer and higher thermal efficiency, it is concluded, therefore, that most protably it has to be due to higher peak flame temperatures. This idertifies a critical point for future investigation in those systems in which higher thermal effictency is clatmed. Little improvement in combustion efficiency can be expected; elimination of even heavy smoke generally represents only a fraction of oxe percent lmprovenent in combustion efficiency.

(2) From these results it appears that there can be good reasons for using emulsions in certain circunstances. The most adverse condition would be use of an emulsion in place of pure oil where there are no particular objections to using ofl without treatment. There could be a small thermal efficiency penalty. An acceptable trade-of $f$ for this could be the tendency to control or eliminate carbon build-up, which might pay of $f$ in reduced maintenance.

A postivive reason for adopting emulsions in place of pure ofl would be a case where the ofl flame characteristics are undesirable in some respect. Such is the case for replacement of natural gas by ofl in firing radiant tubes iri metallurgical and other furnaces. With many burners, oil tends to produce local hot spots in the tube close to the burner which burns out the tube. In field tests currently in progress by SMS Associates, using an emulsifier of the same design as that described in this paper (built by Chemcut Corporation of State College, Pa.), a single unit was found to be capable of firing four radiant tubes (of 90,000 Btu/hr demand each) in the same furnace in heat treatment of small alloysteel parts. Operation was on-off, and on the basis of tests so far completed, seems to be satisfactory without evidence of hot spot destruction of the tubes.

With a trace of solids, notably coal, in the emulsion, the reduced emissivity can be restored. Efficiency rises to match the reduced emissivity. This suggest that one of the chief advantages of emulsions may be the flexibility in the use of coal and ofl, and the potential for talloring the flame characteristics to suit requirements. It encourages us therefore, to Investigate further the additional flame characteristics of the emulsions 
with other grades of fuel o11, and with heavier loadings of coal, together with a detalled examination of the viscosity characteristics of the different possible emulsions, fuels, and other mixtures as detalled in the Introduction.

\section{ACKNOWLEDGEMENTS}

The work described in this paper was carried out in the Combustion Laboratory of The Pennsylvania State University supported initially by the Combustion Laboratory Cooperative Fund (contributors: ALCOA, CE, Exxon, GE, G.M., Gulf 011, Mob11 011, PPG Industries, and Wingaersheek), and for the coal addition work by ERDA under contract No. E(49-18)-2030. We also appreciatively acknowledge contributions from IREX for support of Dr. A. Koval, visiting Scholar from Saratov (USSR); from Kojclusko Foundation for support of Dr. S. Slupek, visiting Scholar from Poland; from the Pẹn State Intercampus program, for support of Dr. N. Miskovsky; and for constructional work, technical assistance, and participation in the data collection from Mr. Robert A. Frank (Research Alde) and Mr. Carl J. Martin (Machinist).

\section{REFERENCES}

1. Lammartino, N.R., "Can Water Help Fuel Burn?" Chem. Engrg. p. 84, Nov. 11,1974

2. Dryer, F.L., "Fundamental Concepts on the Use of Emulsions as. Fuels", Aerospace and Mechanical Sciences Report No. 1224. Guggenheim Labor-

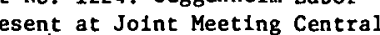
and Western States Sections of Comb. Inst., San Antonio, Texas. Ap1. 1975.

3. Dooher, J., Ginberg, R., Lippman, R., Morrone, T., Moon, S., Wright, D. Emuslions as Fuels. Am. Soc. Mech. Engrs. Fu/WA75.

4. Ford, R.E. \& Furmidge, C.G.L., "The Formation of Drops for Viscous Water-1n-0il Emulsions Sprayed through Fan-Jet Nozzles", Brit. J. App1.
Phys. 18, 491-501 (1967).

5. Sebba, F:

Patent appl. Serial No. 38,347. May 18, 1970.

6. Sebba, F., "Microgas Emulstons and Method of Forming Same", U.S. Patent No. $3,900,420$. Aug. 19,1975 .

$7 \because$ Sebba, F. "Microfoams; An Unexplotted Colloid System", J. Colloid \& Interface Sc1. 35 (4), 645 (1971).

8. Essenhigh, R.H., Testimony to the Subcommittee on Energy Research, Development, and Demonstration (Fossil Fuels) of the Committee on Science and Technology, U.S. House of Representatives. July 31, 1975: Jan. 26, 1976.

9. Jonnard, A1mison, "Collotdal Fuel Development for Industrial Use" Kansas State College Bulletin vo. XXX No. 2, Jan. 15, 1946.

10. Rudzk1, E.M., Pease, B.K., \& Weldner, T.H., "Use of Coal-in-0il Mixtures to Improve Open-Hearth Furnace Performance", J. Inst. Fuel $38,156-165 .,(1965)$.

11. Toussaint, M. \& Heap, M.P., "Formation des oxides d'azote et des particules dans une Clamne d'emulsion fuel lourd/eau", Committee Meeting of the Chemistry Section of the IFRF. Oct. 1974.

12. Moses, C.A., "Reduction of Exhaust Smoke from Gas-Turbine Engines by Using Fuel Emulsions", presented at Meeting of the Western States

13. Rao, S.T.R., Kuo, T., \& Essenhigh, R.H., Proc. 4th Nat. Incin. Conf. pp. 314-326 ASME N.Y. (1970); Rao, S.T.R. \& Essenh1gh, R. H., Proc. 13th P1ttsburgh, Pa. (1971); Zeinalov, M.A.O. Kuwata, M. \& Essenhigh, R.H. Proc. 14th Symp. (Internat) on Combustion: pp. 575-583. The Combustion Institute, Pittsburgh, Pa.(1973). 
14. E1swas, B.K. \& Essenh1gh, R.H. Comb \& F1ame 15, 93 (1970); B1swas, 3.K., Kuo, T. E Essenh1gh, R.H., Proc. 4th Nat. Inc1n. Conf. pp. 304-314. ASME W.Y. (1970); Sh1eh, W.S. \& Essenhigh, R.H. Proc. 4th Mid Atlant1c Industr. Conf $120-124$, E. Symp. Ser1es, Ho 126, vol. 63, p. 207, A I Chem E, N.Y. (1972); Kuwata, M \& Essenhigh, R.H. Proc. 2nd AGA - IGT Conf. on lat. Gas Res. \& Technal. (Atlanta, Ga.) Paper No. IV. 3 AGA - IGT (June 1972); also Comb. \&lame 20 , 37-439 (1973); also AIAA Paper No. 75-1267: AIAA/SAE 1l th Prop. Conf. knaheim Ca11f (1975).

15. Enomoto, H., Tsa1, Y., \& Essenhigh, R.H. "Heat Transfer in a Continuous Model Furnace: A Comparison of Theory and Experiment". Heat Transfer Conf. Paper No. 75-HT-5. San Francisco, Aug. 1975.

16. Cooper, P.W., Kamo, W.R., Marek, C.T., and Solbrig, C.W. "Recirculation and Fuel Air Mixing as Related to Oil-Burner Design". Am. Petroleum Inst. Publ. No. 1723 (May 1964)

17. Monaghan, M.T. \& McGrath, I.A. The Influence of Flue Gas Recirculation on the Combustion of Fuel 011. J. Inst. Petroleum 55, 303-321 (1969).

18. Edelman, R. For:une, 0. A Quasi-Global Chemical Kinetic Model for the Pinite Rate Combustion of Hydrocarbon Fuels. AIAA Paper 69-86.

19. Echigo, R., Nishiwaki, N., \& Hirata, M. A Study on the Eadiation of Luminous Flames. 11th Symposium (International) on Combustion pp. 331-389. The Combustion Institute Pittsburgt, Pa. (1967).

20. Palmer, H.B. Chemistry of Pollutant Formation 1n Flames. Am. Rev. Phys. Chem. 24, 235-262 (1973).

21. Ivanov, V.M., Kantrovich, B.V., Rapiovets, L.S., \& Khotuntsev, L.L. Fuel Emulstons for Combustion and Gasification. J. Acad. Se1. USSR Pp. 56-59 May (1957); Ivanov, V.M., \& Nefedov, P.I. "Expezimental investigation of the Combustion Process of Natural and Emu-sified fuels. Trudy Instituta Goryachikh Iskopayenylh
TTF - 258, Jan. 1965.

Table 1

Analysis and Calorific Value of No. 2 Fuel 011

\section{Elemental Anaiysis}

Carbon

Hydrogen

Oxyen

Nitrogen

Sulfur

$12.52 \%$

$0.117 \%$

$0.003 \%$

None Found

\section{Calorific Value}

$\begin{array}{lr}\text { Btu/1b } & 19,336 \text { (Gross) } \\ \text { Btu/1b } & 18,176 \text { (Net) } \\ \text { Btu/gal } & 133,232 \text { (Gross) } \\ \text { Btu/gal } & 121,727 \text { (Net) } \\ \text { Sp.Gr. } & 0.835\end{array}$

Source: P1ttsburgh Testing laboratory, P1ttsburgh, Pa. 


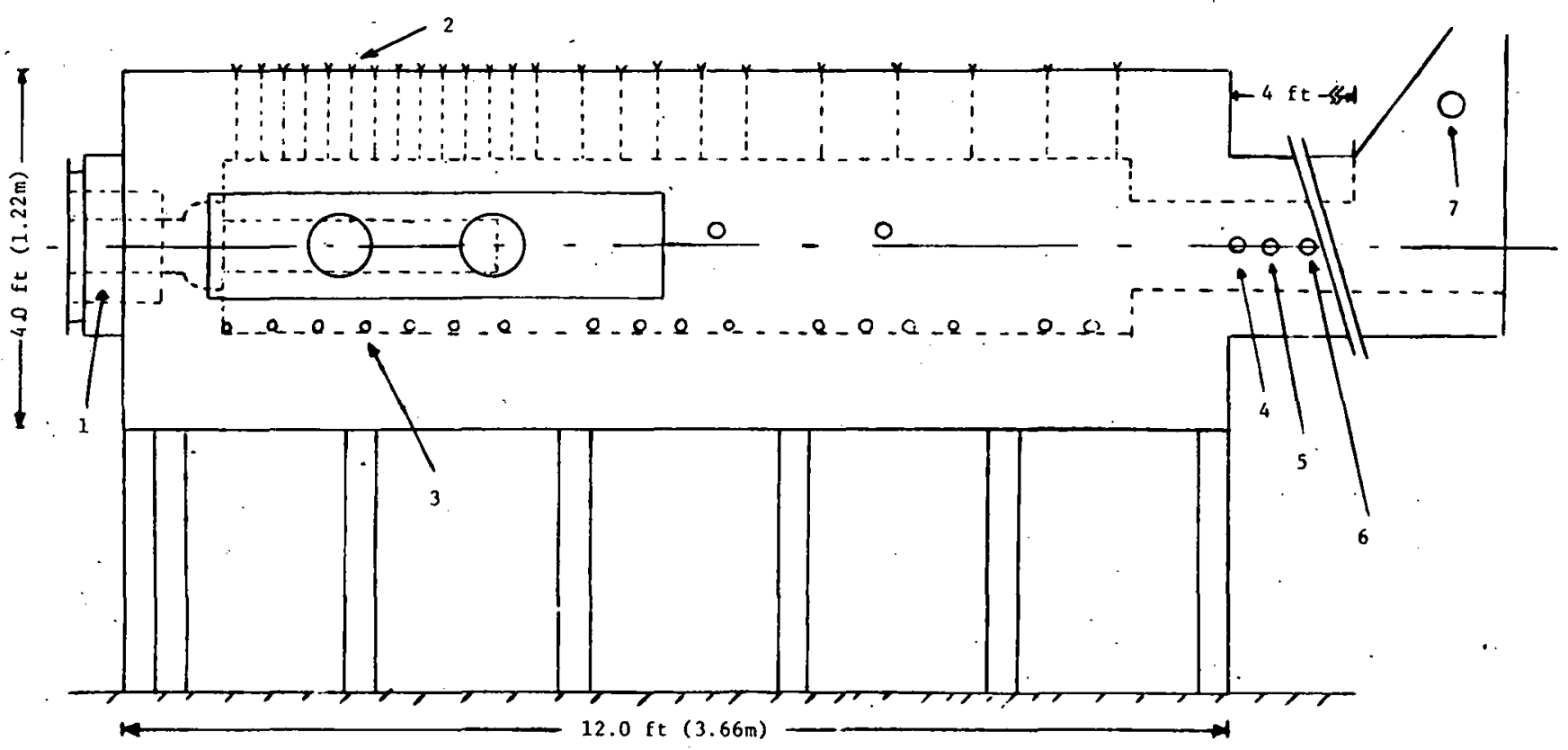

Fig. 1 - Schematic Diagram of Furnace (scale: half Inch equals 10")

1. Burner

2. 1 to 24 roof thermocouples

3. 1 to 17 water cooled tubes

4. Gas sampling probe

5. Suction pyrometer

6. Particulate collector

7. Obscuration meter (smoke meter)

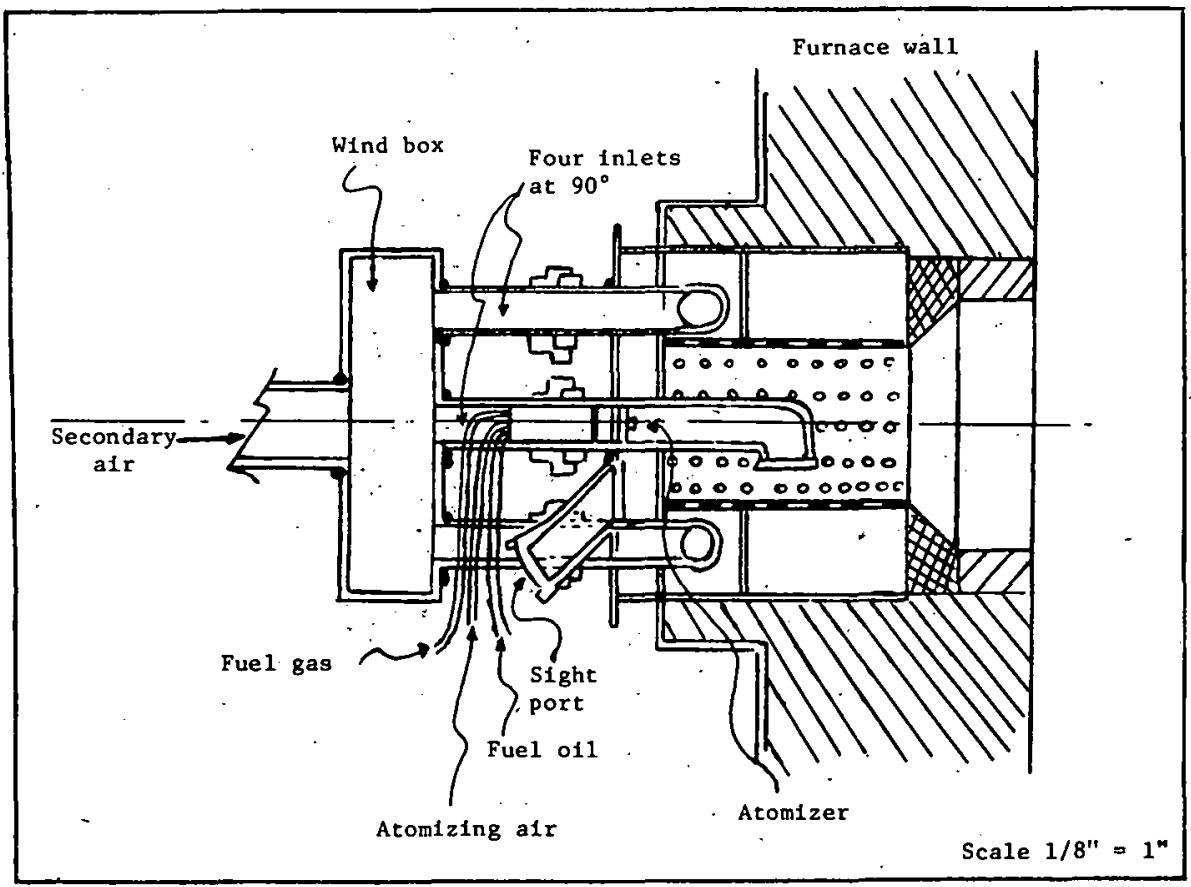

F18. 2 - Double Vortex Burner 


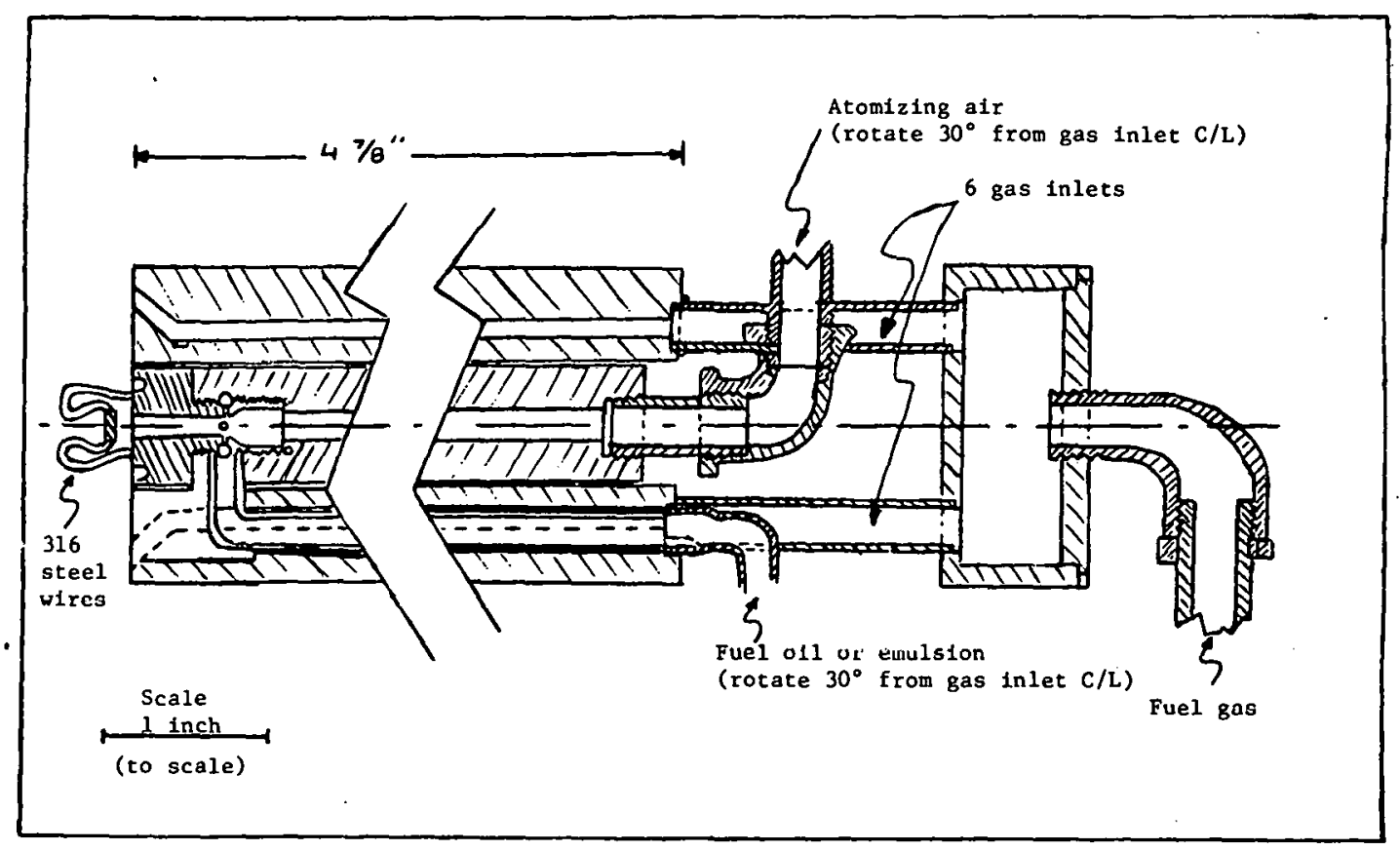

Fig. 3 - Fuel Atomizer (011/emulsion supply holes at throat of venturf pick-up: four at 0.040" dia)

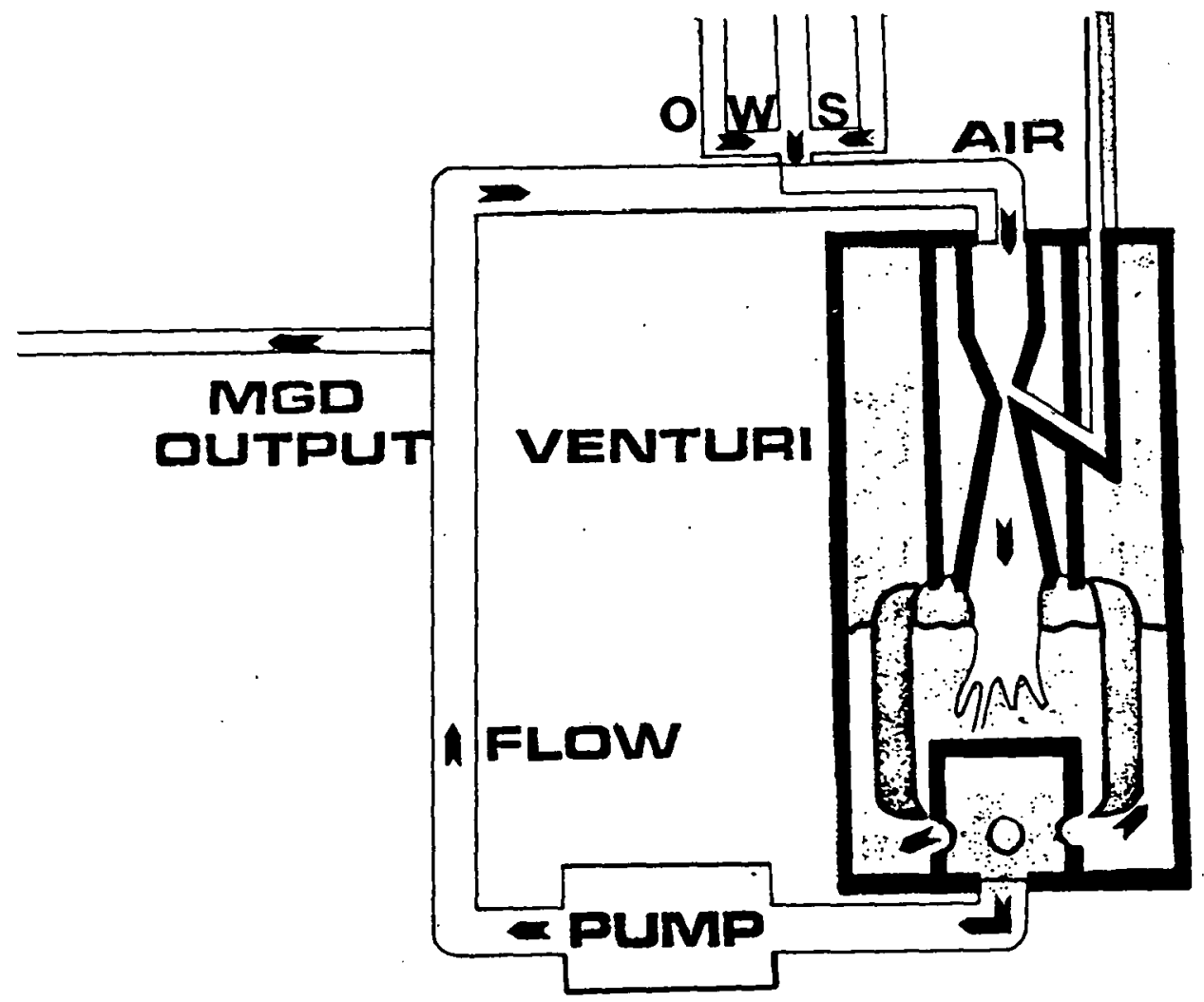

F1g. 4 - Microgas Dispersion Generator (SMS Associates) 


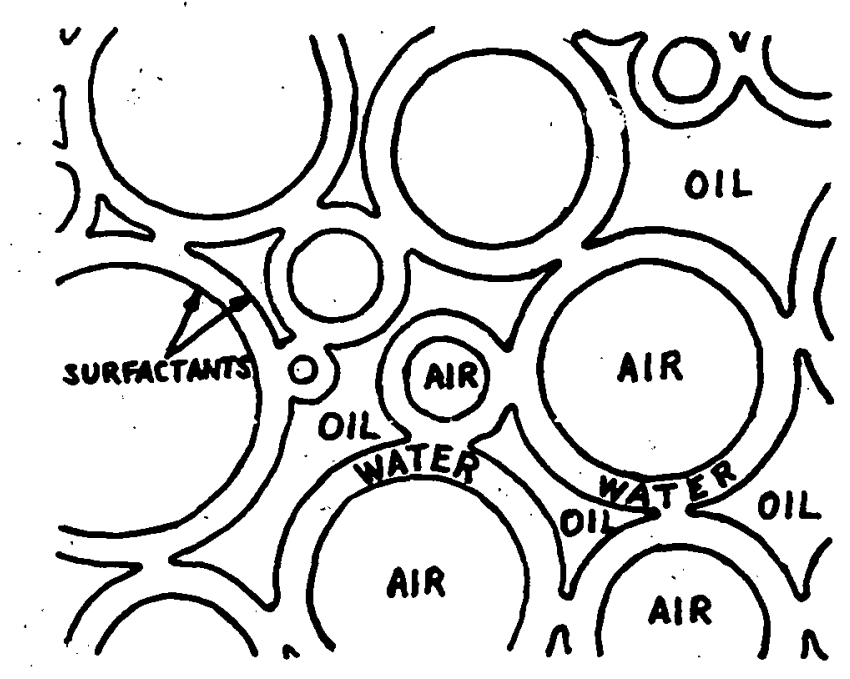
Fig. 5. - Schematic of the Structure of a Microgas
Dispersion of Colloidal Gas Bubbles in Separate Water and Oil Phases.

Note: Water and 011 Are Both Continous Phascs:'

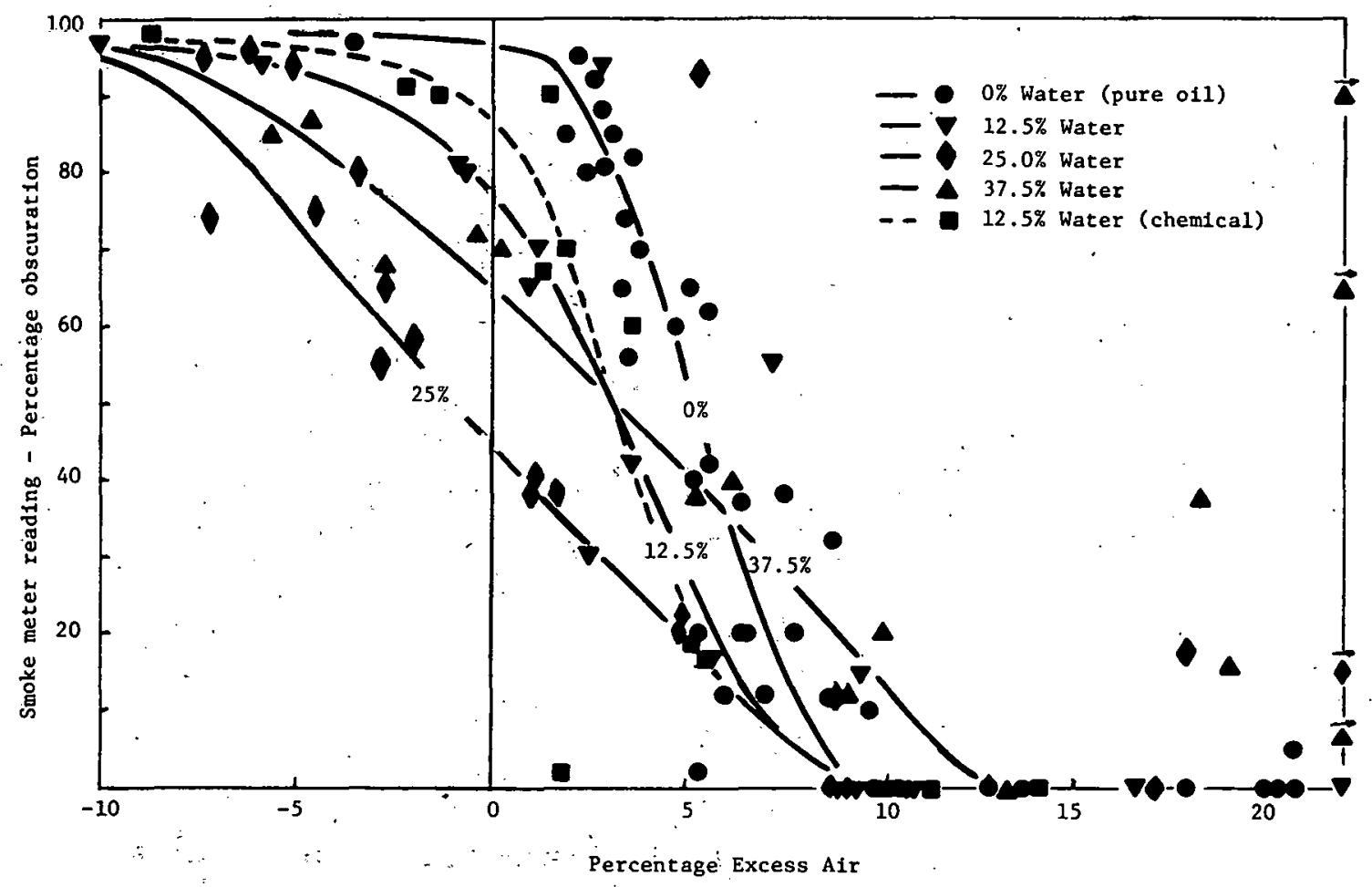

Fig. 6 - Variation of Smoke Meter Reading (Percent Obscuration) with Excess Air for O11, Emulsions at $12.5 \%, 25 \%$, and $37.5 \%$ Water, and a Chem1cal Emulsion 


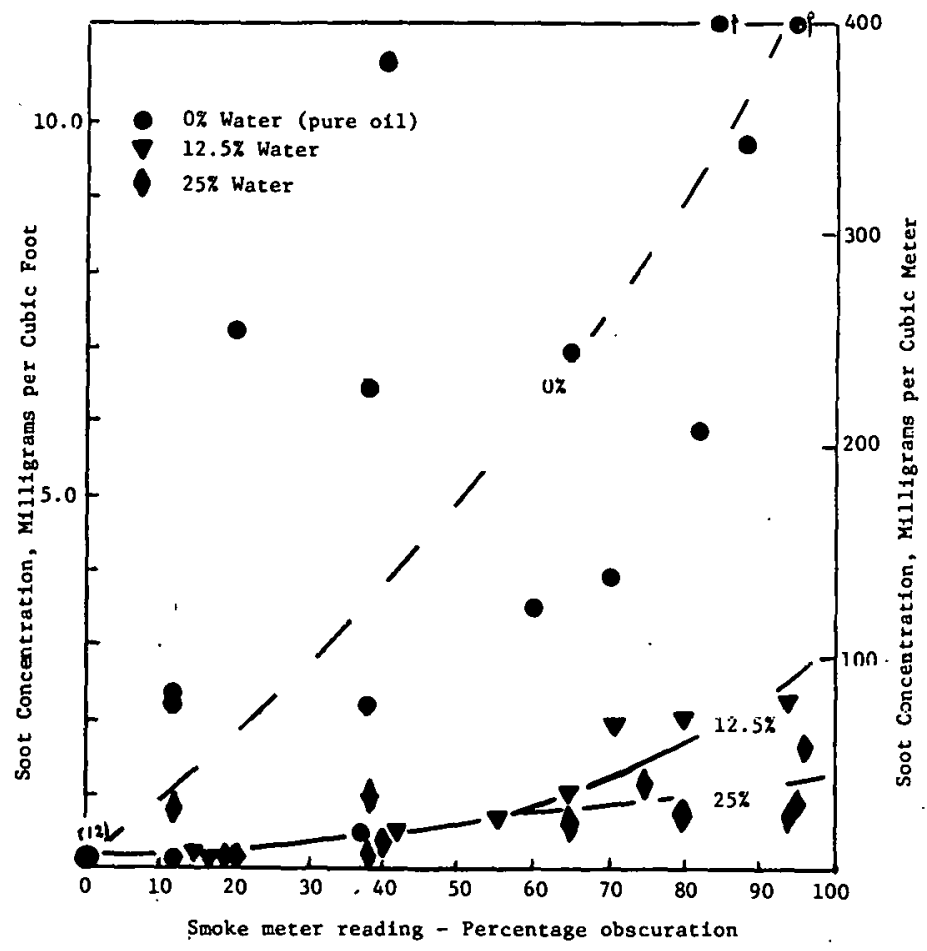

F18. 7 - Variation of Soot Concentration with Smoke Meter Reading (Percentage Obscuration) for 011 and Emulsions at $12.5 \%$ and $25 \%$ Water

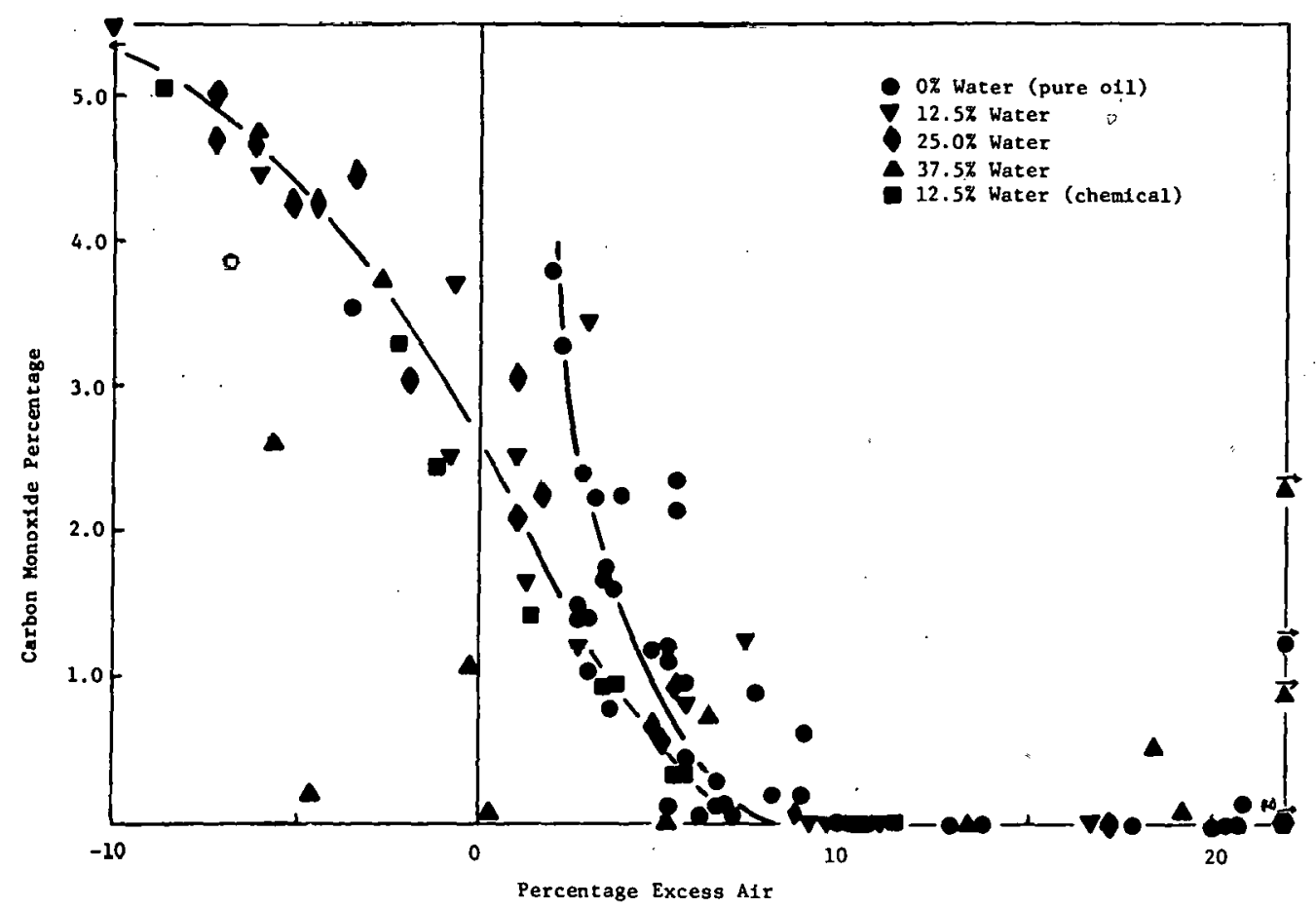

F18. 8 - Vartation of Carbon Monoxide Emitted as a Function of Excess A1r for Pure 011, Three Levels of Water Percent in the Emulsions, and the Chemical Eimulsion 


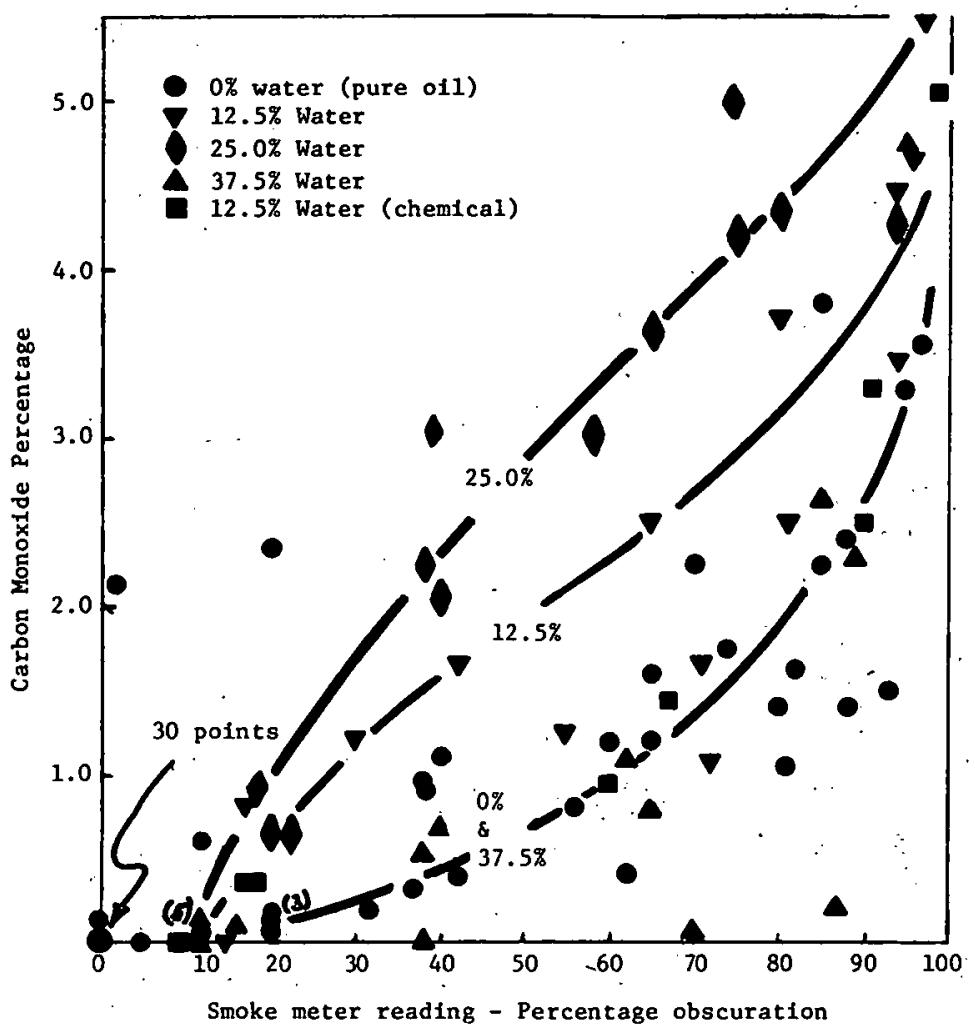

Fig. 9 - Variation of Carbon Monoxide Enitted as a Function of Smoke Meter Reading (Percent Obscuration)

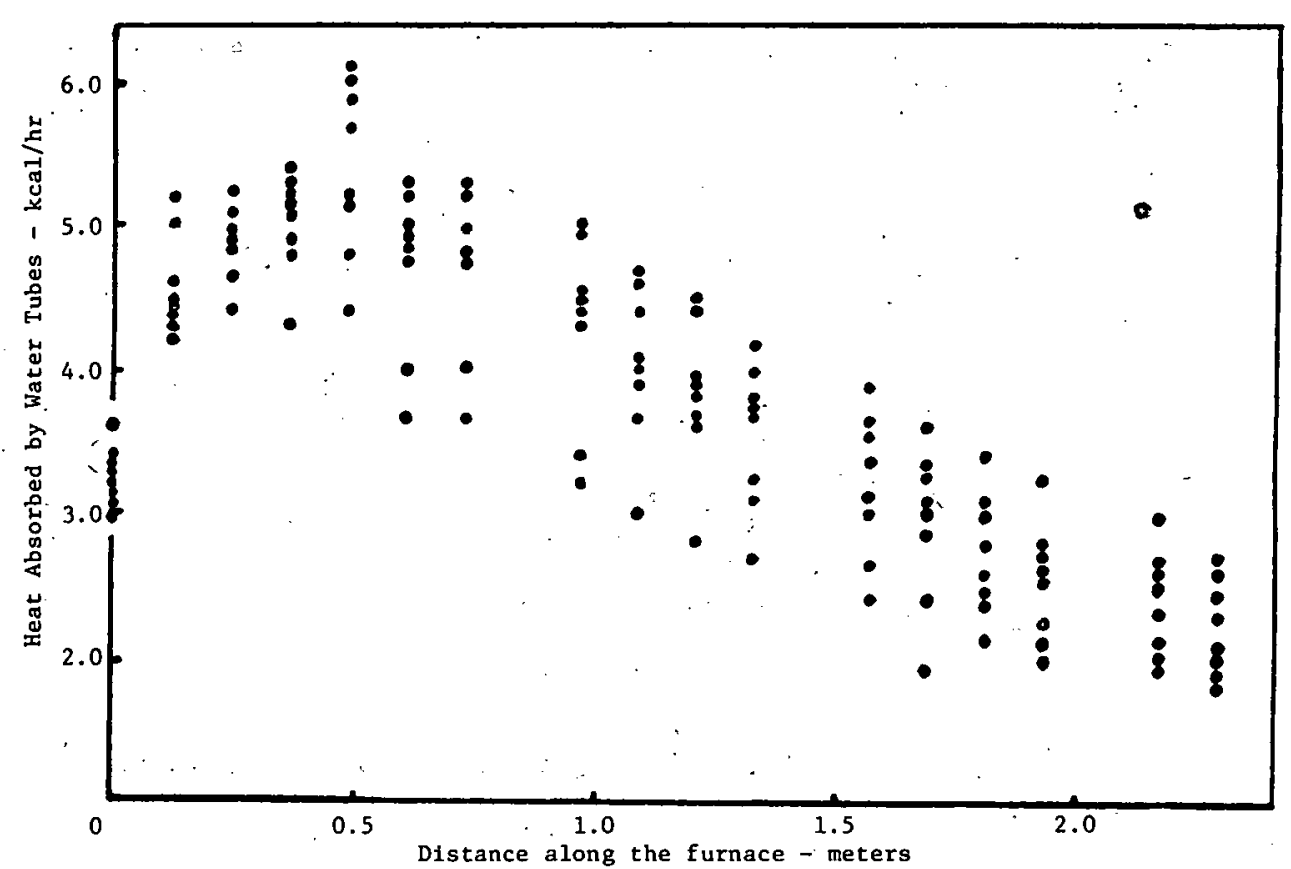

Fig. 10 - Variation of Heat Absorbed by Each Water Tube on the Furnace Floor, for All Runs at $12.5 \%$ Water in Emulsion (Scatter Plot) 


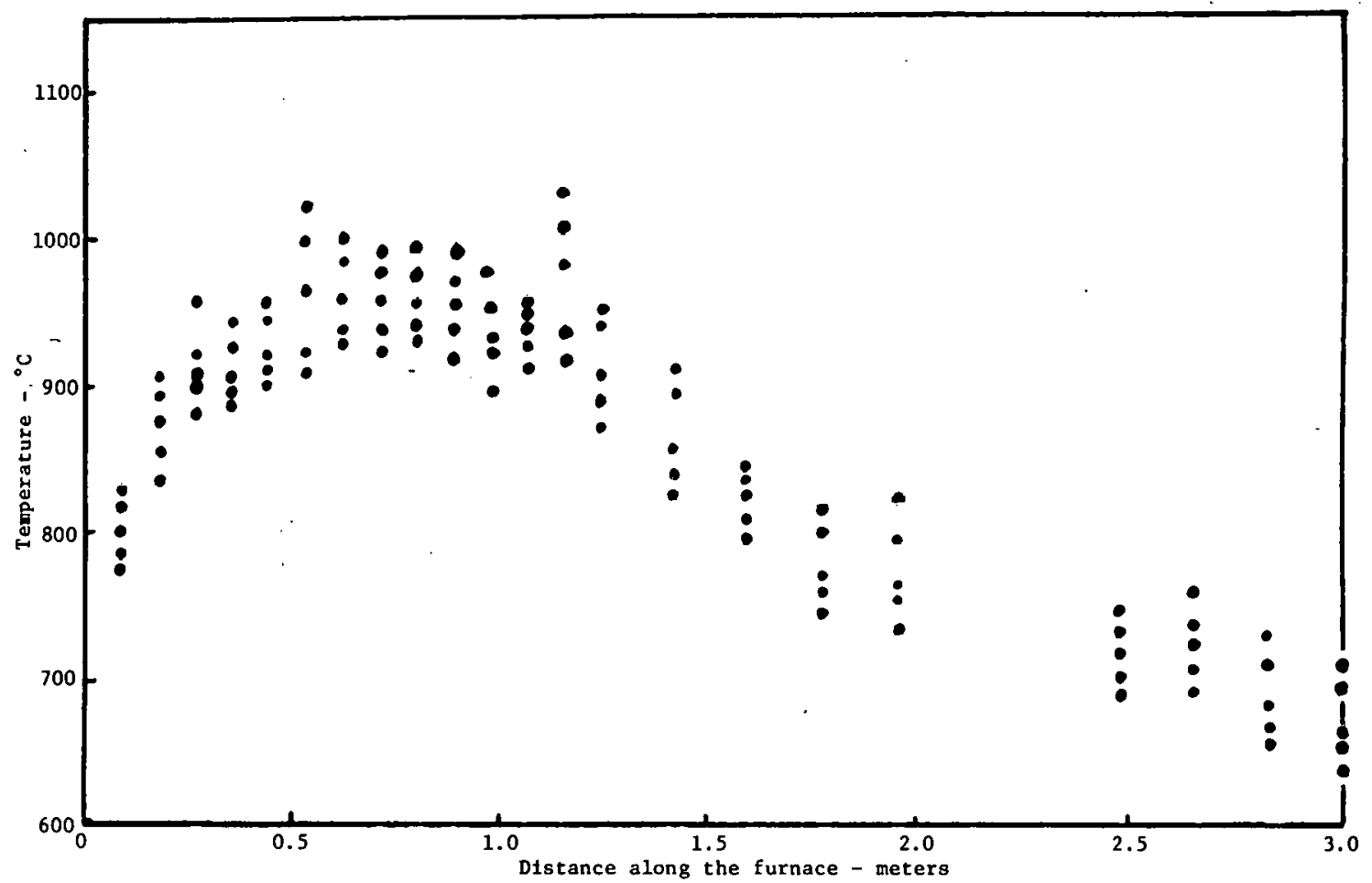

F1g. 11 - Variation of Roof Temperature with Distance Along the Furnace, for Five $12.5 \%$ Water in Emulsion (Scatter Plot)

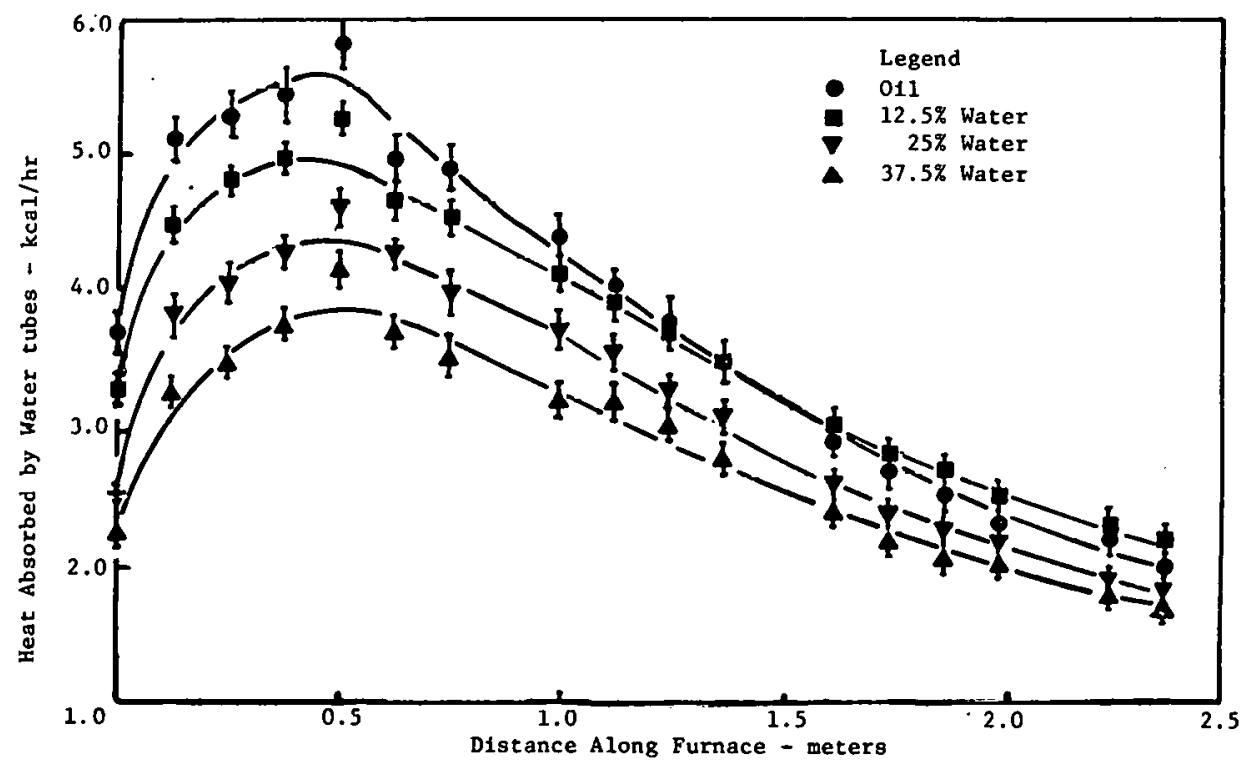

Fig. 12A - Effect of Water Content of Emulsions on Varlation of Heat Flux to Water Tubes with Distapce Along Furnace for Pure 011, and Three Levels of Water Percentage at $1.25 \times 10^{6} \mathrm{Btu} / \mathrm{hr}$ Thermal Input [Error bars denote standard error] 


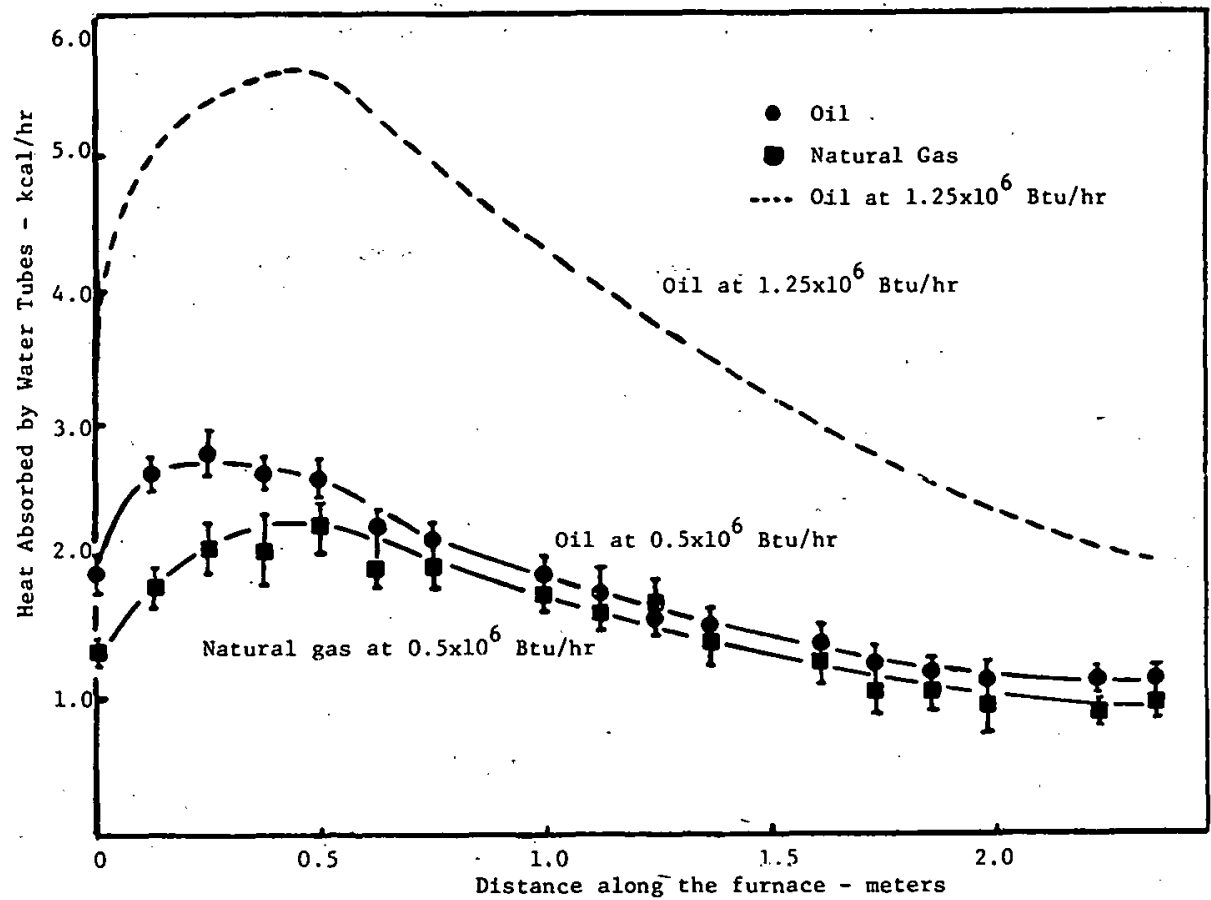

Fig. 12B - Comparison of Heat Flux Profiles for Oil and Natural Gas at 500,000 Btu/hr (and for ofl at $0.5 \times 10^{6}$ and $1.25 \times 10^{6} \mathrm{Btu} / \mathrm{hr}$ ) [Error bars denote standard error]

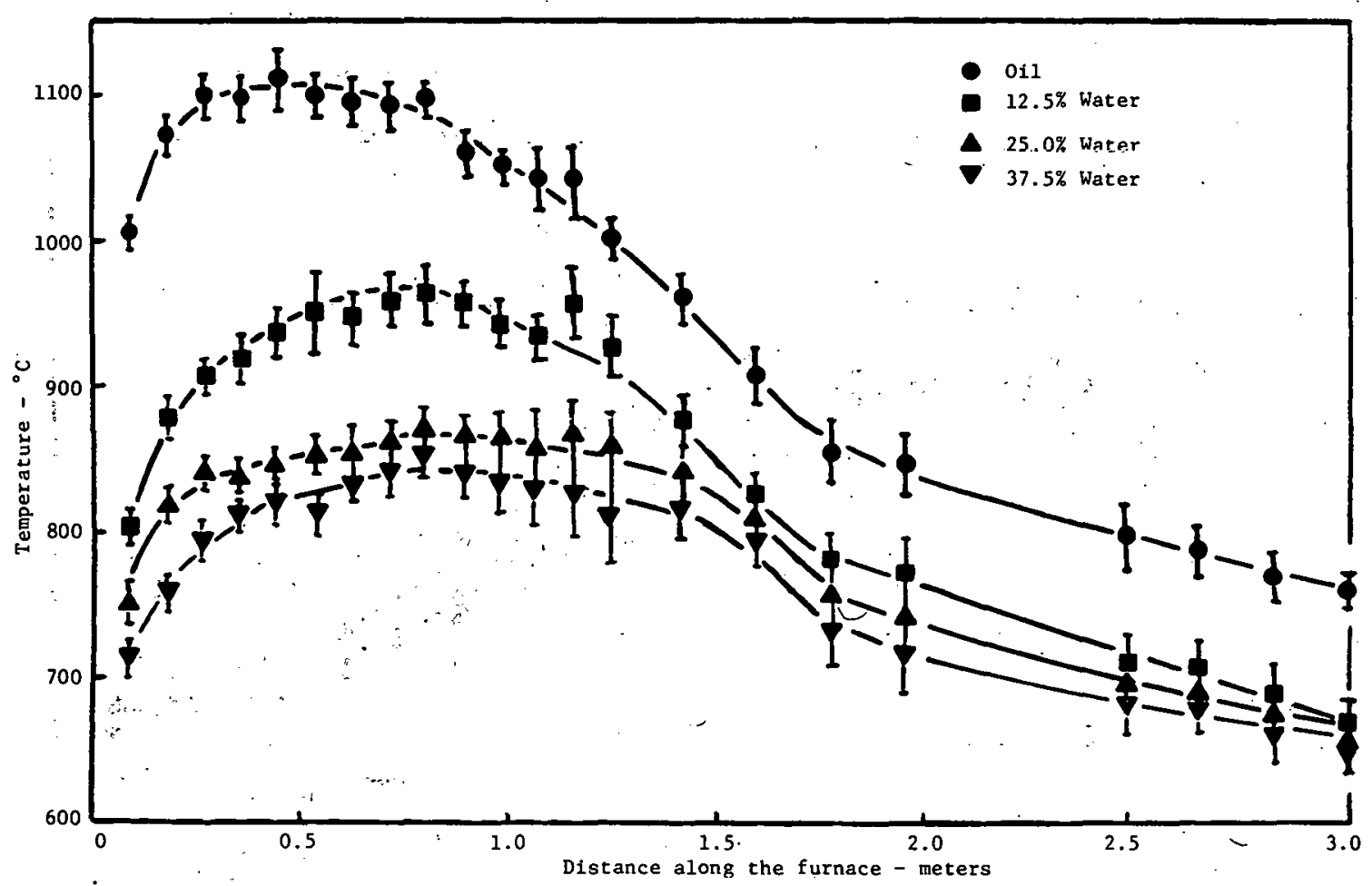

Fig. 13 - Variation of Center Line Roof Temperature with Distance Along the Furnace for 011 and Water Emulsion [Error bars denote standard error] 


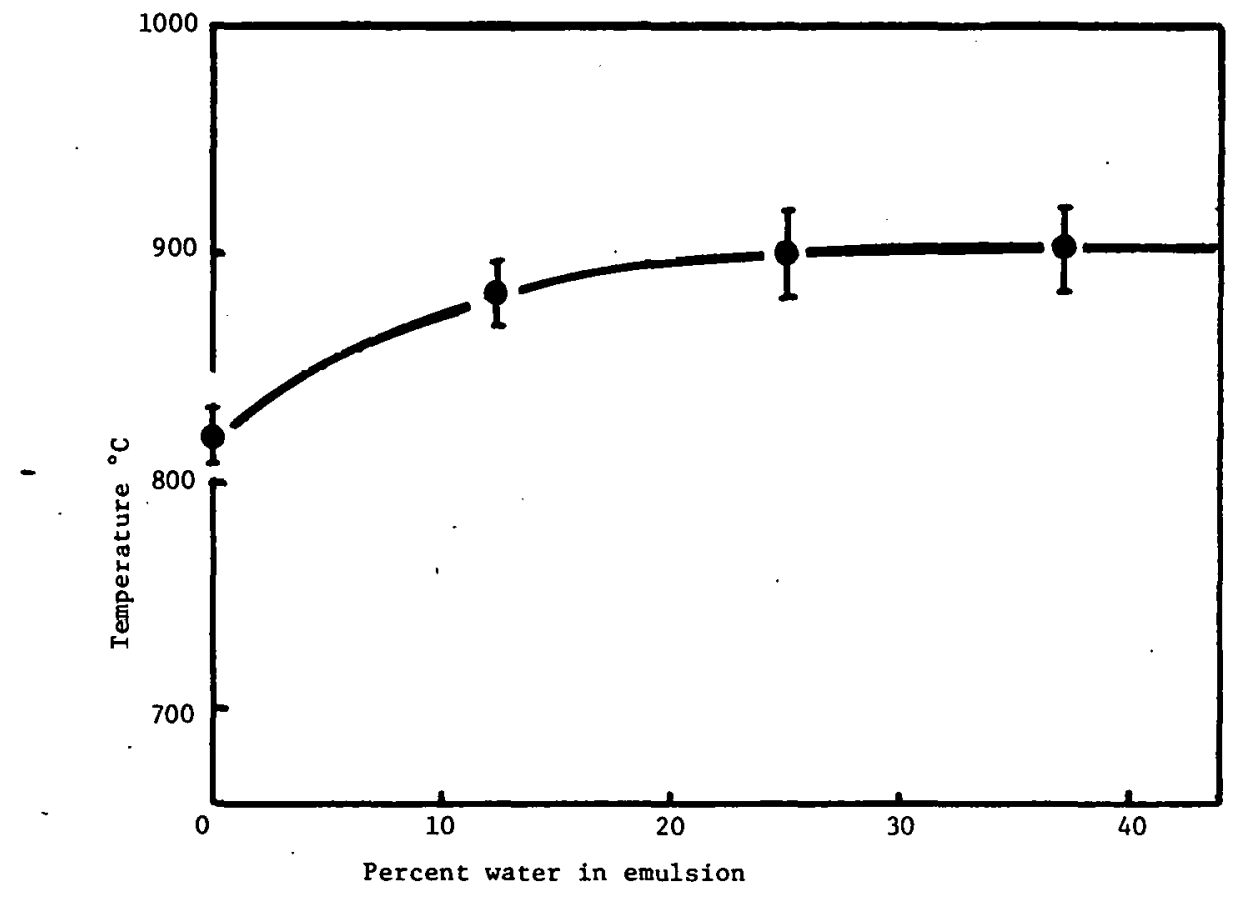

Fig. 14 - Variation of Exhaust Gas Temperature with Water Percentage in Emulsion [Etror bars denote standard error]

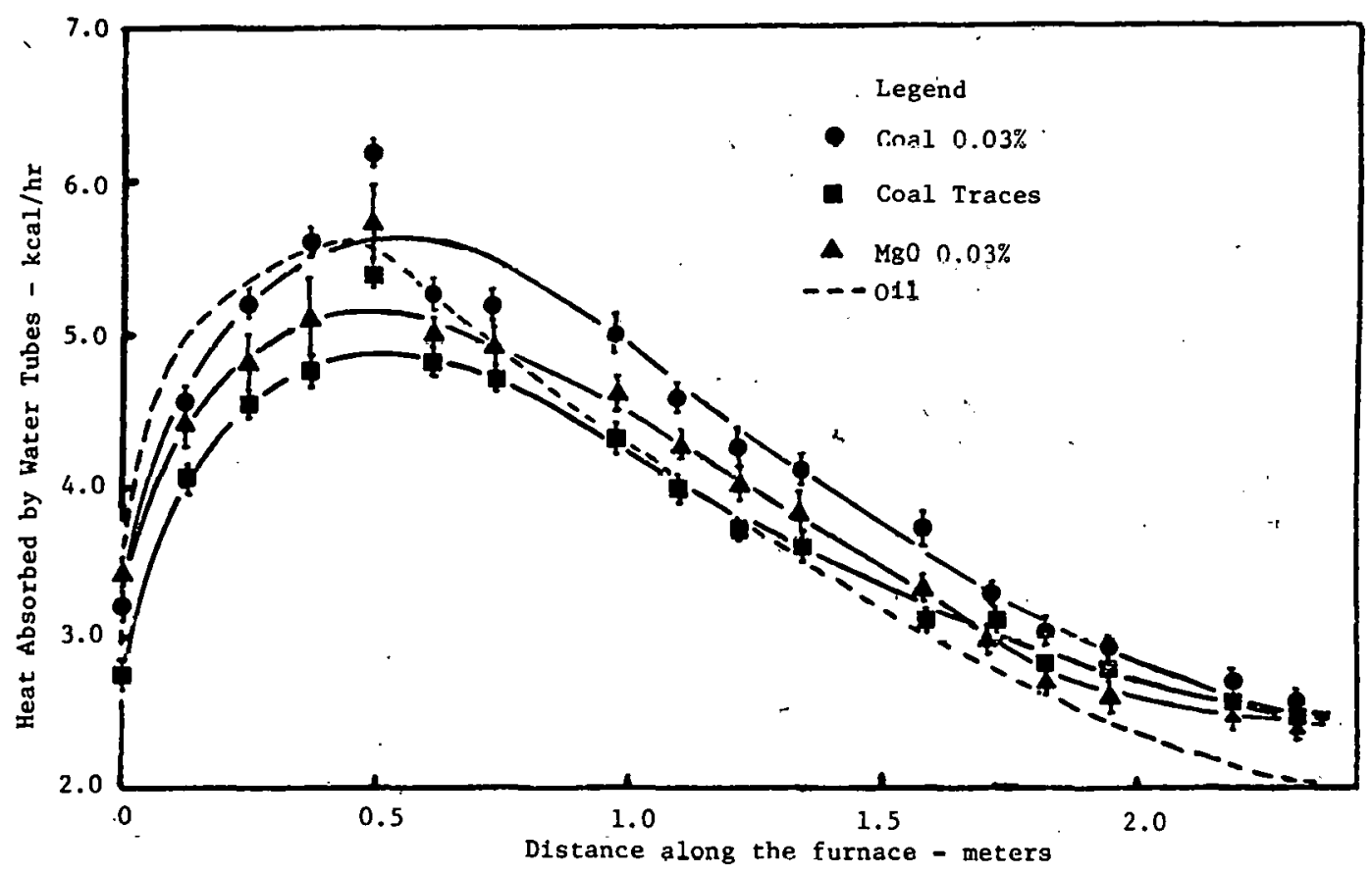

F1g. 15A - Variation of Effect of Coal (and Mg0) Addition to Heat Flux Profile Along Furnace (at two levels of coal: for effect of higher levels see Fig. 15B) [Error bars denote standard error] 


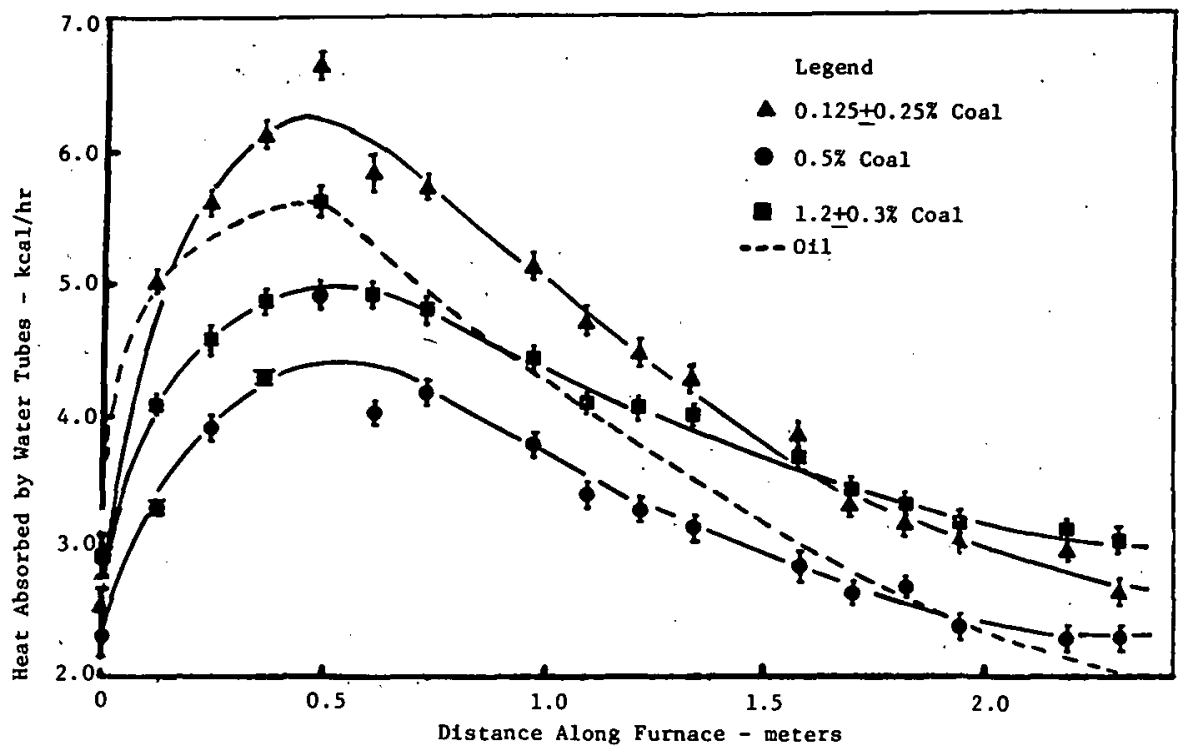

F18. 15B - Variation of Effect of Cól Addition to Heat Flux Profile Along Furnace at Three Levels of Coal Addition to Emulsion with $12.5 \%$. Water [Error bars denote standard error]

$\begin{array}{lrrrrrrrrr}\text { Water \% } & 0 & 10 & 12.5 & 20 & 25 & 30 & 37.5 & 40 & 50 \\ \begin{array}{l}\text { Number of } \\ \text { Runs }\end{array} & 8 & 1 & 9 & 2 & 6 & 1 & 4 & 1 & 1\end{array}$

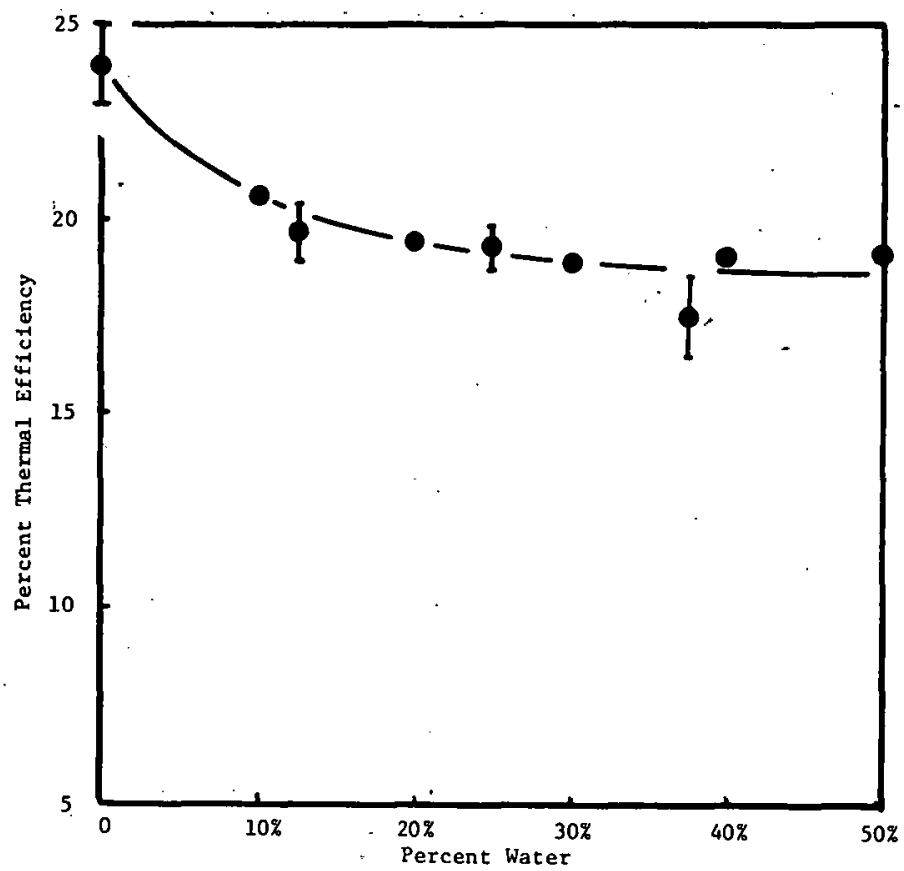

F1g. 16 - Variation of Thermal Efficiency with Percent Water in Emulsion [Error bars denote standard error] 


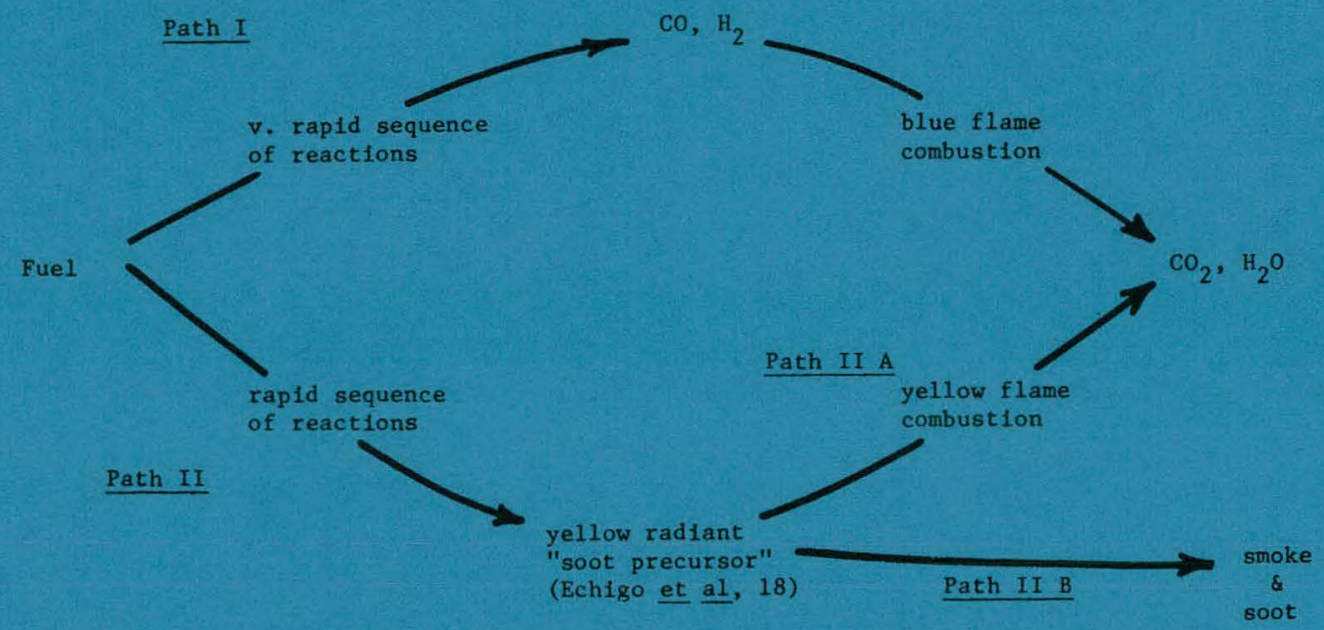

Fig. 17 - Suggested schematic of alternate reaction paths (I and IIA) to yield combustion products by blue flame and/or yellow flame combustion, or reaction path (IIB) to smoke and soot. Path II B is controlled by dilution (presumably temperature control); Path II A is controllec by oxygen concentration ( $<17 \%$ ) (see text).

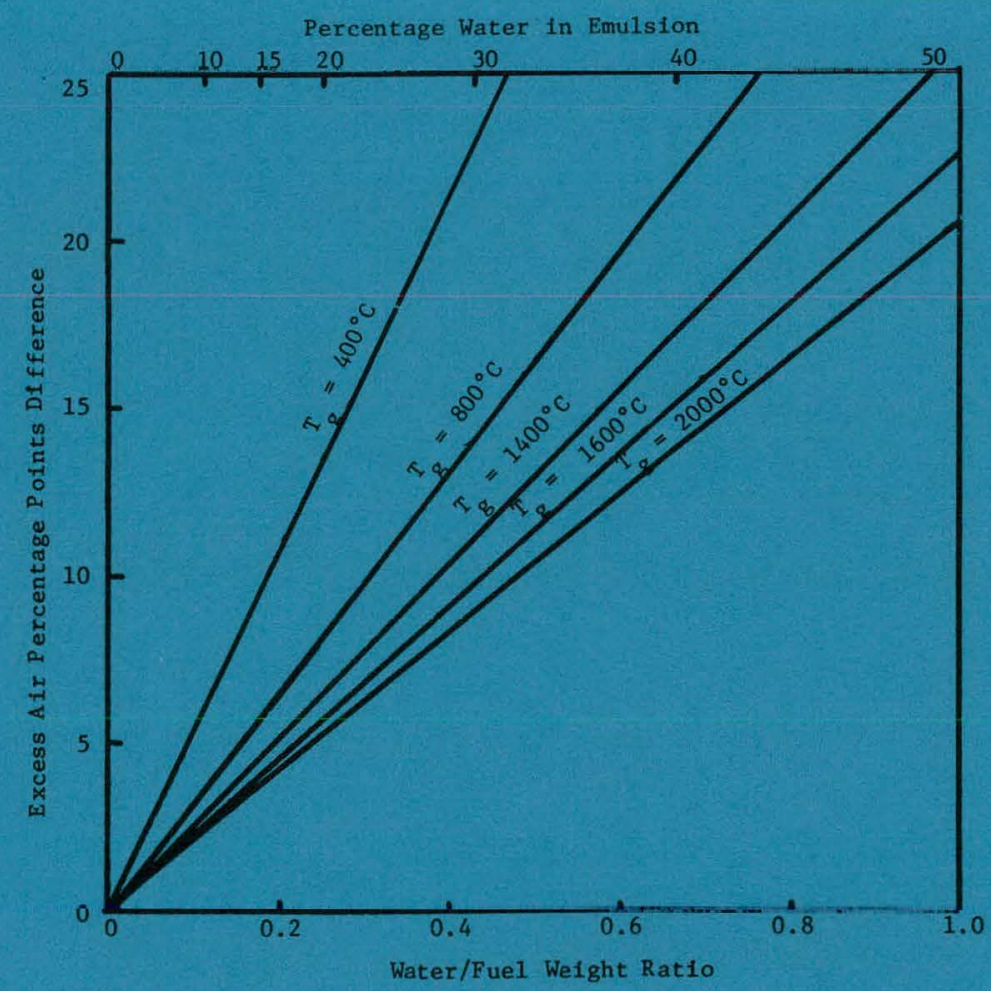

Fig. 18 - Required Percentage Point Drop in Excess Air to of fset Extra Thermal Loading of Water in Emulsions

$\mathrm{T}_{\mathrm{g}}$ : Exit Gas Temperature 